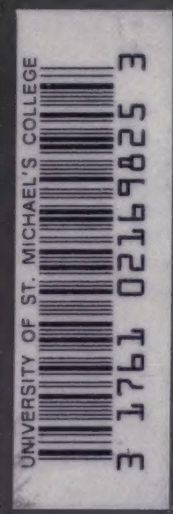




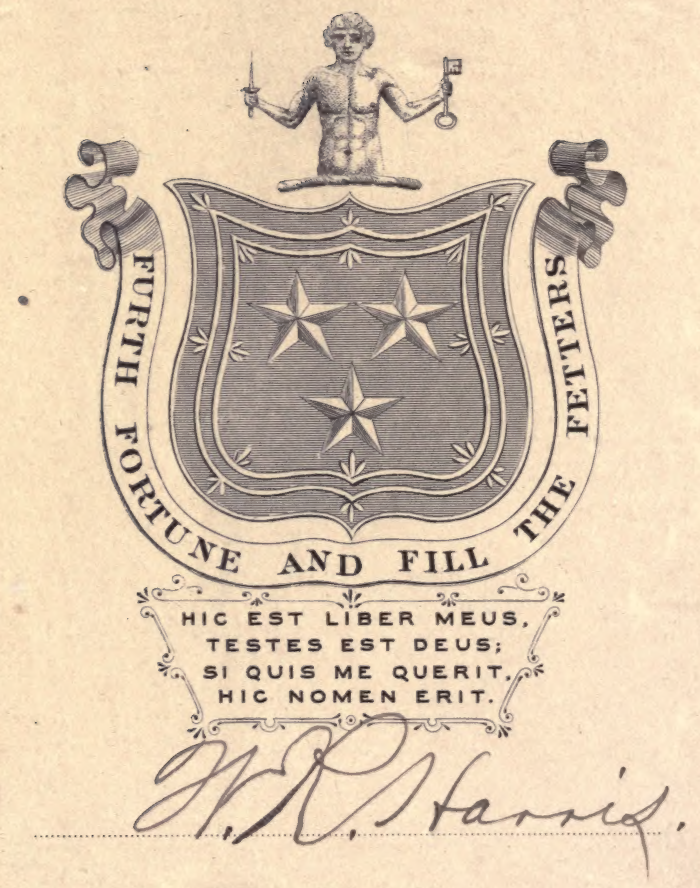


.

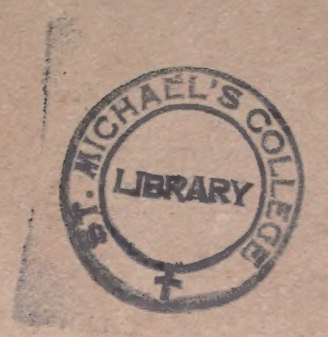


Digitized by the Internet Archive in 2007 with funding from Microsoft Corporation 


\section{DISTRIBUTION AND ORIGIN OF LIFE IN AMERICA}





\section{DISTRIBUTION AND \\ ORIGIN OF LIFE IN AMERICA}

\section{ar \\ ROBERT FRANCIS SCHARFF \\ Ph.D., B.Sc.}

Author of "European Animals, their Geological History and Geographical Distribution."

Corresponding Member of the Academy of Natural Sciences, Philadelphia;

of the Senckenberg Natural History Society, Frankfurt a/Main.

of the Linnean Society of Bordeaux; and of the

Anthropological Society of Paris

LONDON

CONSTABLE \& COMPANY LTD

10 ORANGE STREET LEICESTER SQUARE WC 



\section{PREFACE}

This volume is the outeome of the second series of "Swiney Lectures" on Geology which I delivered at the Victoria and Albert Museum in London in 1908. The subject chosen for these lectures was the "Geological History of the American Fauna." Instead of publishing the lectures, like the previous ones on the "European Fauna," with little alteration, I decided to amplify and rewrite them completely. In doing so I was enabled to bring out more clearly certain points in the geological history of the American animals which seemed to me of general interest.

It is always difficult to choose a suitable title for a work of this kind. The one I have selected is brief yet comprehensive. At the same time, it may be urged that the origin and distribution of Man might reasonably be expected from the title, whereas it has been omitted in the text. This omission is mainly due to the fact that the literature dealing with the subject, exclusive of Man, is very extensive, while the origin and distribution of human races in America is treated in quite a distinct set of periodicals and books.

An important feature of my researches is the elucidation of some of the problems connected with the cause and nature of the "Ice Age" or " Glacial Epoch." There is a considerable amount of faunistic evidence that both the Atlantic and the Pacific oceans were closed simultaneously in the north, resulting in a higher temperature of these oceans and a greater snowfall in the countries surrounding them in the north. Similarly, if the Glacial Epoch had been due to a closing of the Arctic Ocean, the higher temperature prevailing in the Arctic 
area during early Tertiary times must have been caused by a more abundant supply of warm currents in the Arctic Ocean at that time. Consequently North America would probably have been more isolated in the north than it is now, for the currents must have had ample facilities for passing freely into the Arctic Ocean. Palaeontological evidence, however, points to an intimate union of North America and the Old World during the greater part of the Tertiary Era. There are thus a number of interesting problems, all of which are fully discussed in this volume, quite apart from many other important theories arising out of the subject of the origin and distribution of life in North America. In this connection the testimony of fossil animals, and that of the marine fauna, has been largely availed of. To a certain degree the distribution of plants has also been included.

I have endeavoured, as far as possible, to quote all the more noteworthy works and papers dealing with the subject under consideration. Nevertheless I am conscious of having possibly overlooked a few important contributions ; and I only hope my colleagues will be good enough to draw myattention to anyomissions that they may notice, so as to enable me to add them in case a second edition of this book should be called for. I can lay no claim to having made careful studies of the literature dealing with the Geology or Botany of the American continents. The works cited are those that I happened to be acquainted with, and no doubt many gaps might be filled by those more conversant with these sciences than I am.

I have hesitated for some time before actually illustrating my views as to the former changes of land and water. Some geologists consider it inadvisable to publish palaeogeographical maps founded on zoogeographical data, since such maps are very liable to revision according to the constantly advancing state of our knowledge. The latter are also apt to lead to a good deal of adverse criticism, for one map can only represent a single short phase of a long series of geological ages during which repeated changes of land and water probably took place. In spite of these objections I have ventured to construct a few of these ideal maps of ancient geography as a 
general illustration of my views. I have felt that although I am open to criticism, my views will be more easily understood, and we shall eventually make more rapid progress in arriving at the correct conclusions as to the alterations in the configuration of the oceans and continents that actually occurred in the past than if such maps were altogether omitted.

The immense advance that has been made in the United States in the study of zoology has greatly facilitated my work. And everywhere in America I found willing helpers ready to impart information. My thanks are particularly due in this respect to Prof. H. F. Osborn, Dr. Matthew and Dr. Hornaday of New York, to Prof. Morse and Mr. John Ritchie of Boston, to Dr. Henry B. Bigelow and Mr. T. Barbour of Harvard University, to the late Dr. A. E. Brown and Mr. Witmer Stone of Philadelphia, to Dr. Dall, Dr. T. W. Vaughan, Dr. Stejneger and Miss Richardson of Washington, to the late Prof. Packard of Providence, to Dr. Ortmann of Pittsburg, to Dr. Van Denburgh of San Francisco and to Dr. Ruthven of Ann Arbor. Several of my European friends also aided me in many ways. Among them particularly the following members of the staff of the British Museum : Dr. Smith Woodward, who was good enough to look through the proofs and to draw my attention to several errors, Dr. Andrews, Dr. Boulenger, Mr. Regan, Mr. Pycraft and Mr. B. B. Woodward. Prof. Hull, Dr. Bruce and Dr. Stapf kindly pointed out to me various valuable sources of information. My most grateful acknowledgment, moreover, is due to the guardians of the Great Libraries, without whose ready assistance I should never have succeeded in accomplishing this work. The most generous facilities for study were given me by my friends Mr. Lyster of the National Library of Ireland, Mr. Praeger of the Royal Irish Academy Library and Dr. Foord of the Royal Dublin Society's Library. I am indebted, too, for many services to Mr. Kappel, the Librarian of the Linnean Society, to Mr. Jones, Librarian of the Geological Society, Mr. Waterhouse of the Zoological Society of London, and Mr. Hinch of the National Library of Ireland.

I am under a great obligation to Messrs. Meiklejohn \& Son 
for allowing me to reproduce two of their beautiful oroscopic maps, while the council of the Royal Irish Academy, Prof. Osborn, Dr. von Thering, Dr. Ortmann, Mr. Thompson Seton, Dr. True and Dr. Hornaday were good enough to give me permission to copy maps illustrating their works.

I can scarcely hope that all the conclusions I have arrived at in this book will be readily accepted, but I trust to have succeeded in impressing those who have not made a serious study of the science of geographical distribution of animals with the profound importance of the subject as an aid to palaeogeographical researches.

R. F. S.

Tudor House,

Dundrum, Co. Dublin,

November 27th, 1911. 


\section{CONTENTS}

\section{CHAPTER I}

\section{THE FAUNA OF GREENLAND}

Description of Greenland-The reindeer and its origin-The Arctic musk ox-The lemming and Aretic hare-On the ancient land connections between Greenland and the adjoining continents - On the cause of the Ice Age-The marine fauna of the North Atlantic cited as evidence in favour of a northern land connection-Did the fauna of Greenland survive the Ice Age in the country?-The snails of Greenland quoted in support of this theory-On the supposed polar origin of life-General faunistic affinities of Greenland with other northern countries . 1-25

\section{CHAPTER II}

\section{THE FAUNA OF NORTH-EASTERN NORTH AMERICA}

Description of the general features of Labrador and its fauna-The voles and jumping mice-On some northern frogs - The origin and distribution of the moose deer-The fauna of the White Mountains and its origin-Pre-Glacial relict colonies in the North-East-Supposed effect of the Ice Age on the fauna-Were the animals driven south by the cold? - On mild interglacial phases of the Glacial Epoch-Foraminifera in the Glacial drift deposits-The relict fauna of the Great Lakes-The fishes of the Great Lakes and their origin-Distribution and geological history of the fresh-water mussel Margaritana-The past history of the Great Lakes-The fauna of Newfoundland 26-57

\section{CHAPTER III}

\section{THE ANIMALS OF THE CANADIAN NORTH-WEST}

The Mackenzie basin and its fauna-The lemmings and gophers -On American ptarmigans-The past history of the bison and its gradual destruction-On the distribution and origin of the wapiti deer-The Canadian tree-porcupine-On the molluscan fauna of the north-west and its relationship . 


\section{CHAPTER IV}

THE FAUNA OF ALASKA

On the general features of Alaska, its glaciers, volcanoes and floraConditions of Alaska during the Glacial Epoch-On the evidences derived from the fossil mammals as to the former climate of the country-Evidences of an Asiatic invasion of animals into Alaska-The faunistic affinities of Alaska--On the former presence of the mammoth in Alaska-The fresh-water fishes of Alaska-The distribution and origin of the butterflies belonging to the genus Parnassius---On the mammals peculiar to AlaskaOn the relationship of the marine mollusks of the northern Pacific in recent and past times-Evidences of a former land bridge near Bering Strait . . . . . . . 74-100

\section{CHAPTER V}

THE ROCKY MOUNTAINS AND THEIR INHABITANTS

The region of the Great Salt Lake-Distribution and origin of the mountain sheep and Rocky Mountain goat-On the geological history of the American deer tribe-the prong-horn antelope and its origin-On the Rocky Mountain flora-Accidental distribution as applied to butterflies-Description of the American game preserves-The great Tertiary deposits and their contents

\section{CHAPTER VI}

THE ANIMALS OF THE EASTERN STATES

On the poverty of lizards in this region-The snakes of the eastern states and their affinities-The origin and distribution of the garter snakes--Rattlesnakes and their range-On American tortoises and turtles-The giant salamanders of America and Asia--On newts and their allies-The relationship of the Eastern plants-The pine-barren flora-The range of the star-nosed mole . . . . . . . . . . 123-143

\section{CHAPTER VII}

\section{THE FAUNA OF THE CONTINENTAL BASIN}

Description of the prairie region and its inhabitants-On the extinction of the horse in America and the geological history of the horse tribe-Prairie dogs and their distribution-On the origin and past history of the raccoon-On caves and their contents as illustrating the geological history of the fauna-The former 
presence of the reindeer south of its existing range-Evidences of a southern fauna in the north and of its gradual southward retreat-Helicina-Turkeys and the Florida parrot-On the dispersal of fresh-water mussels-Relicts of the past-Bony-pike

\section{CHAPTER VIII}

\section{THE SOUTH-EASTERN STATES AND BERMUDA}

On the vegetation and general features of Florida-The geological history of Florida-On the reptiles and amphibians of the southeast-The south-east as a centre of dispersal-The terrestrial mollusks of Florida-On scorpions and dragon-flies-Alligators and crocodiles, their origin and past history-The fauna of Bermuda island-The geology and flora of Bermuda-The birds and their origin-Terrestrial isopods, spiders and the land nemertean worm Geonemertes-On the snails of Bermuda and. their ancestors-The origin of the Bermudan fauna . 167-195

\section{CHAPTER IX}

\section{SOUTH-WESTERN NORTH AMERICA AND ITS FAUNA}

On the so-called "Sonoran Region"-The palaeogeography of California and the adjoining States-On the western insectivores-On horned toads and burrowing lizards-Discontinuous distribution of some western toads-The snails of CaliforniaThe fauna of lower California and its Cape region-On the European element of the Californian fauna as illustrated by the mollusks, butterflies and ants-The crayfishes of the southwest and their origin-Various faunistic problems-On mammalian affinities-The American rabbits and their relationsThe former Atlantic land connections between the New World and the Old, supported by the evidence derived from Tertiary mammals-Conclusions

\section{CHAPTER $\mathbf{X}$}

\section{THE FAUNA OF CENTRAL AMERICA}

The fishes of Central America and their origin-On the geology and palaeogeography of Central America-Importance of determining the age of Central America-Evidence derived from a study of the marine faunas-On the faunistic affinities between North and South America-The flora of Central AmericaMonkeys and raccoons-On birds, tortoises and snakes-The 
fresh-water crabs and their dispersal-The European element in the fauna of Central America-On discontinuous distribution of animals as a proof of their antiquity . . . 233-260

\section{CHAPTER XI}

\section{THE WEST INDIAN ISLANDS AND THEIR INHABITANTS}

The geology of the Antilles-Palaeography as illustrated by the distribution of snails-Antiquity and dispersal of snails, their relationship and European affinities-On the theory of the ancient Atlantis-The problem of the supposed permanence of ocean basins-The marine mammals of the Antilles and their origin-Evidences in favour of a mid-Atlantic land bridge-

א The terrestrial mammals of the West Indian islands-Evidences of former changes of level in the Antillean area-The blind animals of Cuba-On the ancient Antillean continent .

\section{CHAPTER XII}

\section{THE FAUNA AND FLORA OF THE GALAPAGOS ISLANDS}

Darwin's visit to the islands and his views on the origin of their animals and plants-On accidental dispersal-The birds, tortoises and snails of the Galapagos islands-Origin of the flora-Baur's criticisms of Darwin's views--Euphorbia and its past history-Conclusions as to the origin of the Galapagos fauna-The geological history of the Pacific Ocean-On the supposed former Pacific continent-Mr. Guppy's researchesCoral reefs and their history-A circum-Pacific land beltEvidences of ancient lands westward of Central America-On faunistic affinities between the Atlantic and Pacific oceansThe Humboldt current . . . . . . . 295-335

\section{CHAPTER XIII}

THE ANIMALS OF THE NORTH-WESTERN STATES OF SOUTH AMERICA

The geological history of South America-The faunal elements of the continent-Palaeontology-Course of development of the continent during the Tertiary Era-Peripatus and its distribution in South America-On the origin of Clausilia and its relations-The South American bear-On the tapirs and their origin-The dwarf deer of South America-On the supposed existence of former land connections-Derivation and history of the fossil elephants-The river Amazon . . . 336-362 


\section{CHAPTER XIV}

THE FAUNA OF EASTERN SOUTH AMERICA

PAGK

South American monkeys, their distribution and geological history - Sloths-The birds of South America-On fossil mammals and Old World affinities - The theory of an ancient land connection

$X$ between South America and Africa-Evidence derived from the distribution of reptiles, amphibians, fishes, mollusks and fresh-water crabs-Dr. von Ihering's researches-Fernando de Noronha and St. Helena--The fauna of St. Helena and its antiquity-Tristan da Cunha . . . . . . 363-394

\section{CHAPTER XV}

\section{ARGENTINA AND CHILE}

The fauna of Argentina-Prof. Ameghino's discoveries of fossils and their importance-Fossil edentates and rodents-Faunistic affinities - The llama and its origin-Fossil elephants-Ancient land connections between South and North America-Fossil plants-Floral affinities-The circum-Pacific land beltAntarctic problems-On the Antarctic continent-Affinities of the faunas of Patagonia and New Zealand-On a Pacific continent-The marine fauna of Patagonia-The Falkland islands-Antarctic expeditions-The pendulation theory 395-435 



\section{LIST OF ILLUSTRATIONS}

FIG.

1. Map of North America (reproduced from Meiklejohn's oroscopic maps by permission of Messrs. Meiklejohn \& Son) .

2. Map of the North Atlantic, showing the supposed conditions of land and water during later Pliocene times (reproduced by permission of the Council of the Royal Irish Academy) .

3. Map of North America, showing the distribution of the Moose Deer (reproduced by permission of Mr. Thompson Seton) .

4. Map showing the outlines of the White Mountain Plateau and Mount Washington, with an inset Map of North America indicating the geographical position of the White Mountains

5. Map of North America showing the original distribution of the Bison, the range of the same species after the completion of the Union Pacific Railroad and its present range (reproduced by permission of Dr. Hornaday) . . . . .

6. Map of North America, showing the original distribution of the Wapiti deer, and its range in 1900 (reproduced by permission of Mr. Thompson Seton) . . . . . . .

7. Map of the northern parts of the northern hemisphere, showing the supposed land connections and the extent of the sea in the early part of the Glacial Epoch . . . .

8. Map of the World, indicating the distribution of the newt Spelerpes . . . . . . . . . .

9. Map of North America, showing the distribution of the Starnosed Mole (reproduced by permission of Dr. True) • . 142

10. Map of North America, showing the distribution of the Reindeer (reproduced with some modifications by permission of Mr. Thompson Seton) . . . . . . . .

11. Map of North and South America, showing the distribution of the snail Helicina

12. Map of the World, showing the distribution of the family of fishes Cichlidae (reproduced by permission of Mr. Tate Regan) 
13. Map of the West Indian Area, showing the position of the principal islands

14. Map of North and South America, indicating roughly the supposed conditions of land and water about the commencement of the Tertiary Era

15. Map of the World, showing the conditions of land and water in upper Cretaceous times according to Dr. Ortmann (reproduced with the author's permission)

16. Map of North and South America, indicating roughly the supposed conditions of land and water about the middle of the Tertiary Era

17. Map of the World, showing the conditions of land and water during the Eocene Period, according to Dr. von Ihering (reproduced with the author's permission) . . . .

18. Map of South America (reproduced from Meiklejohn's oroscopic maps, by permission of Messrs. Meiklejohn \& Son)

19. Map indicating the distribution of the snail Clausilia in the Mediterranean region, in Africa and America, with an inset figure of Clausilia (Nenia) . . . . . . .

20. Map of the World, showing the conditions of land and water in lower Tertiary times, according to Dr. Ortmann (reproduced with the author's permission) . . . . .

21. Map of the World, showing the conditions of land and water in late Cretaceous and basal Eocene times, according to Professor Osborn (reproduced with the author's permission) 



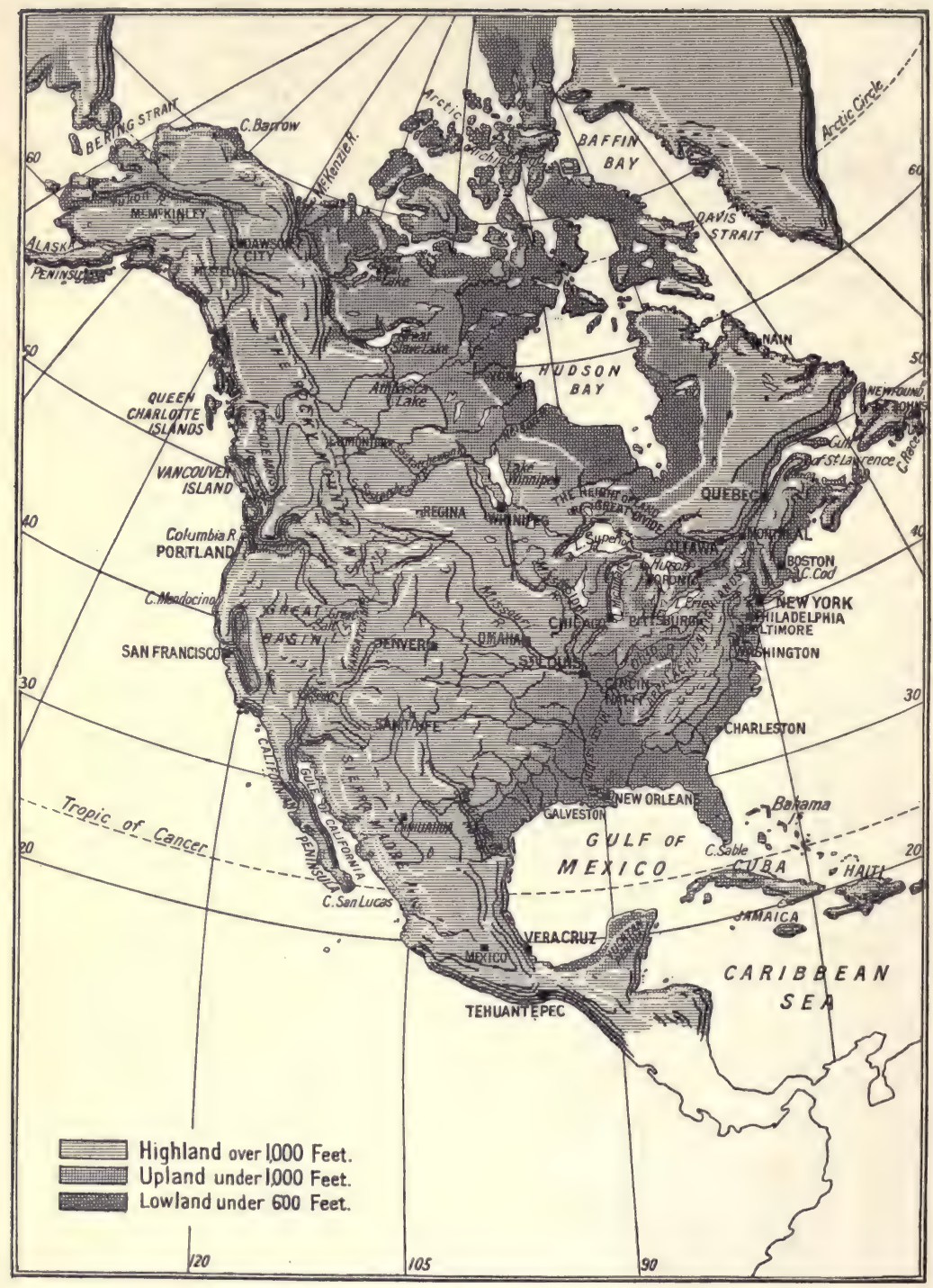

Fig. 1.-Map of North America. (Reproduced from Meiklejohn's Oroscopic Map, by permission of Messrs. Meiklejohn \& Son.) 


\section{Distribution and Origin of Life in America}

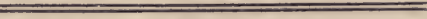

\section{CHAPTER I}

\section{THE FAUNA OF GREENLAND}

Greenland geographically belongs to arctic America rather than to Europe, and, as it no doubt formed part of the land bridge that once connected America and Europe, its past $X$ history contains chapters of the greatest interest. Scanty as the fauna and flora of Greenland are, they afford us many a clue as to former changes of land and water which that country has undergone. Their study enables us also to trace the origin of the animals and plants of the neighbouring portion of continental America, which is one of the objects of the present work.

Greenland is now too well known to need a long description. Yet few readers realise the vast size of this stern and uninviting country, which covers an area considerably larger than the whole of France and Germany together. Threequarters, at least, of this area being completely buried under an enormous glacier ice-sheet, or inland ice, only a comparatively narrow belt of partly barren rocky ground is left along the shore on which animal and plant life is possible. The broadest exposed strip of land on the west coast of Greenland is about a hundred miles wide. Here and there two kinds of willows and the dwarf birch together form scrubby low-growing woods, the stems rarely rising more than a few feet from the ground. Thickets of alder, white birch and dwarf juniper likewise occur, while in sheltered nooks the 
Lapland rhododendron, many kinds of saxifrages, cinquefoil, crowfoot, a willow-herb, a lousewort, the narrow-leaved arnica and other flowering plants for a time infuse variety into the brownish-grey landscape, giving it quite a gay appearance with the many brightly-coloured blossoms. During a couple of weeks in the short summer the natives may even have the advantage of gathering crow-berries (Empetrum nigrum), which grow in great abundance almost everywhere, just as they do in boreal America and Europe. 'The bilberry and cowberry are also noticeable, but they are less common and do not seem to be used by the natives, nor is the cloudberry, whose fruit rarely ripens. All these are well-known American and European plants. The most valuable vegetable, which is largely used for food, is a tall angelica. It sometimes attains a height of six feet in favourable localities.

During early Tertiary times many species of conifers and several of our common deciduous oaks, poplars, walnuts, maples, lindens, magnolias and beeches flourished in Greenland. Many of the same trees also lived in Iceland, Spitsbergen, Grinnell Land, boreal North America and the New Siberian islands. It is evident that the climate all round the Arctic Ocean must have been mild. Many causes have been assigned for the change from the former temperate climatic conditions to the arctic ones now prevailing in the same region. A less restricted circulation of warm ocean water into the circumpolar area might, as has been suggested, help to bring about such a state. Yet it would not alone be sufficient. Sun and light for a longer period than now obtains would seem to have been necessary to ripen the wood of the trees and bring the fruit to maturity. At any rate, all this luxuriant flora must have disappeared from these northern regions long before the Ice Age. It is quite possible, and I even think it probable, that many of our common arctic and alpine plants originated in these remote Tertiary times. I cannot adduce any direct geological evidence for such a belief, since few of these plants possess properties which would enable the remains of their leaves to be preserved in a fossil condition. The assumption is founded chiefly on their wide geographical distribution.

As I am dealing mainly with faunistic problems, the 
animals of Greenland have to be considered more in detail. It is especially the beasts or mammals that are of importance because their distribution and geological history are better known than those of the smaller animals. They also enable us to readily appreciate the more recent changes in the fauna, and the causes which have led to them.

The most noteworthy and best known of the Greenland mammals is the reindeer. The term reindeer (Rangifer tarandus) is employed for the sake of convenience in its wide sense. In America it has been the custom for many years past to distinguish under the names of "barren-ground caribou," and "woodland caribou" two strikingly different forms which occur on the continent, the term "caribou" being probably derived from the Indian word "maccaribo." Not only have these two kinds of 'reindeer dissimilar habits, they also differ from one another in size, and in the structure of their skulls and antlers. More recently, smaller groups of reindeer have been discovered, showing distinctive characters in their antlers alone. Several of the nine forms thus recognised as American are founded upon comparatively slight differences. An illustrated account of these various American reindeer has been given by Mr. Madison Grant.*

$\mathrm{Mr}$. Lydekker $\dagger$ holds that they and the Old World forms are all referable to one single species, of which he distinguishes six varieties. Whether these differences are to be regarded as specific or varietal is a matter of opinion, but, as the antlers of reindeer are so very variable, it has been suggested by Professor Camerano that the structure of the skull might be utilised to greater advantage in discriminating between the various varieties or species. In his researches on the Spitsbergen form, he argues that there are three species, viz., the reindeer of Spitsbergen (R. spitsbergensis), the one inhabiting Greenland, Norway, Lapland and part of Siberia (R. tarandus), and lastly the American reindeer (R. caribou). Among the last two species he distinguishes again between the reindeer possessing cylindrical (cylindricornis) and those having compressed (compressicornis) antlers.

It is worthy of note that the reindeer of Scandinavia and

* Grant, Madison, "The Caribou."

† Lydekker, R., “The Deer of all Lands," p. 33. 
Greenland constitute a single variety, according to Professor Camerano,* while Mr. Lydekker separates the Scandinavian from the Greenland race. Following Professor Camerano's example, Dr. Lönnberg † prefers the nasal bones of the skull, to the antlers for specific diagnosis. He unites the Greenland, Spitsbergen and Scandinavian forms with the American barren-ground reindeer in one group, characterised by their flat nasals. The Finland and Siberian reindeer he holds to be quite distinct races, particularly the former, which, with its elevated nasal bones and somewhat flattened antlers, approaches the American woodland caribou. Even Robert Brown $\ddagger$ long ago commented on the likeness of the Greenland and European reindeer, remarking that some reindeer horns from Greenland could not be distinguished from European ones. Since Professors Camerano and Lönnberg, moreover, take both skull characters and antlers into consideration, we may assume that this view of the affinity of the Greenland to the north-west European race is likely to be the correct one.

An anonymous writer in "Natural Science," (p. 358, 1899) gave it as his opinion that there are no grounds for deciding whether the Old or the New World was the original home of the reindeer. No doubt he meant to convey that we know nothing of the ancestry of the reindeer. I ventured, $\S$ on the contrary, to put forward the theory that the reindeer had originated in the Polar area, beyond the confines of the European Continent, while Professor Schlosser || argued that it was evidently of American origin. Neither of these views is supported by positive geological evidence; nevertheless I cannot agree with the above critic that we possess no grounds for deciding the place of origin of the reindeer, as the results of Professor Camerano's and Professor Lönnberg's cranial researches seem to indicate the existence of a closer relationship between the west European and the Greenland and

* Camerano, L., "Renne delle Isole Spitzberge," p. 167.

† Lönnberg, Einar, “Taxonomic Notes about Reindeer," p. 10.

† Brown, Robert, "Mammals of Greenland," p. 352.

$\S$ Scharff, R. F., “ History of European Fauna,” p. 155.

|| Schlosser, M.," Beziehungen d. ausgestorben. Säugethier-faunen," p. 617. 
arctic American varieties than between the west European and the Siberian reindeer. The assumption that the species originated in Greenland or arctic America and thence spread along old land connections east and west to Europe and Asia, is, therefore, not quite so unjustified as Dr. Stejneger * seems to think.

But we must not forget the possibility of the reindeer having originated in the Old World. Dr. Brown $†$ argues that the barren-ground variety spread to America from western Europe by way of a Spitsbergen-Greenland land connection, while the other traversed Siberia, and crossed to the New World by Bering Strait. In the more southern parts of its range in America, new varieties may have arisen, perhaps owing to changes in the natural surroundings. Long cylindrical antlers were no doubt a disadvantage to reindeer in wooded districts, hence the beam became reduced in length and increased in width in what is known in America as the "woodland caribou." Some of these varieties, or species as many American naturalists choose to call them, intergrade to such an extent as to be difficult to discriminate from one another. Thus Rangifer stonei is a form of barren-ground reindeer living in Alaska, while Rangifer osborni is a woodland form. Dr. Allen, who first described them, considers them as well-marked species, while Mr. Osgood, $\%$ during his travels in Alaska, finds that the differences between the two are all relative, that they are excessively variable and rather intangible. The mountain caribou (Rangifer montanus), originally described by $\mathrm{Mr}$. Thompson Seton, is considered by Dr. Allen $\S$ to be allied to the woodland form, but distinguished from it in colour, size and shape of antlers. Mr. Seton, $\|$ who has published a most instructive map of the geographical distribution of the caribou in North America, which has furnished me with the materials for the map given in this work (Fig. 10), thinks that in future the

* Stejneger, L., "Scharff's History of the European Fauna," p. 112.

$\dagger$ Brown, A. E., "North American Big Game," p. 87.

‡ Osgood, W. H., "North American Fauna," 33, p. 17.

$\S$ Allen, J. A., “Mountain Caribou,” pp. 8 \& 9.

II Seton, E. Thompson, "Northern Animals, I.," p. 192. 
ten species now recognised in America will be reduced to four well-marked species.

How long the caribou or reindeer has been in existence we do not know. Its remains have been discovered both in Europe and America in deposits believed to have been laid down during the Pleistocene Period, and as these occur far to the south of its present range, it has invariably been assumed that the species was compelled, owing to unfavourable climatic changes to abandon its more northerly habitat. When the climate became once more suitable to its requirements, the reindeer is supposed to have returned to its, original home. This idea suggests that the reindeer originated in pre-Glacial times, and this view is, in my opinion, supported by the evidence of its occurrence, conjointly with the hyaena, in Irish cave deposits.*

The whole subject of the influence of the Glacial Epoch on animals and plants will be dealt with later on, and need not be considered here. The fact of the occurrence of undoubted reindeer remains far to the south of its present range certainly requires an explanation, and this is more easily given in conjunction with other facts to be stated in this chapter. While the reindeer still lives in Europe no further south than the fifty-second degree of latitude, in America it is found no less than seven degrees further south. In former times it inhabited Oregon and Kentucky. In the east it came down to the neighbourhood of the present site of New York City, whereas in Europe it advanced as far as Mentone on the shores of the Mediterranean, and penetrated. to the north of Spain, i.e., to the latitudes of the thirty-eighth degree in America and of the forty-third degree in Europe. $\dagger$

The musk ox (Ovibos moschatus) is another even more arctic mammal than the reindeer. So called from the musky odour of its flesh, this species was believed to be more closely. allied to the sheep than to the ox, which it resembles more in size. In its geographical distribution it differs strikingly from that of the reindeer in so far as it is now quite confined to Greenland and arctic North America. It no longer inhabits

* Scharff, R. F., “ European Animals," p. 112.

† Brauer, A., "Die arktische Subregion." 
the Old World. Yet in Europe it penetrated as far as England and France in Pleistocene times, having apparently reached these countries from an eastward direction. While the reindeer occurs even in southern Greenland, the musk ox frequents only the north and east of that country.

According to Dr. Conwentz, it has only wandered eastward from the north coast of Greenland in recent times. At any rate, Professor Nathorst alleges that Scoresby, in the year 1822, did not observe it in the neighbourhood of the Sound which bears his name, though it is now found there. Nevertheless, the discovery of some very ancient skulls between the seventieth and seventy-fifth degrees of latitude on the same coast make it probable that the musk ox lived in that region in more remote times, afterwards becoming extinct only to advance once more to its former habitat in' recent times.*

The musk ox to most observers has appeared to be subject to little variation. Mr. Lydekker, however, described a form from eastern Greenland (Ovibos moschatus wardi) with a whitish face-patch and lighter general colouration, which Dr. Allen $\dagger$ has since raised to specific rank, showing that it also differed from the type in the structure of the horns and hoofs. The latter likewise pointed out that it was not confined to Greenland, but inhabited also Ellesmere and Grinnell Land.

Another form of musk ox, an almost black one, from the far north of Canada, was first noticed and described by $\mathrm{Mr}$. Elliot. A renewed examination of musk ox skins and skulls was recently undertaken by Dr. Kowarzik $\ddagger$ with rather remarkable results. He recognises two strikingly distinct groups of musk oxen, a western and an eastern group, characterised by very important osteological and external features, which had apparently escaped the attention of previous observers. In a private letter he admitted to me that the musk ox must have originated in North America, Boötherium being probably its direct ancestor. Yet he is evidently inclined to believe that, after spreading by way of

* Conwentz, "Verbreitung d. Moschusochsen," pp. 429-431.

† Allen, J. A., " Musk-Oxen of Arctic America," p. 76.

$\ddagger$ Kowarzik, R., “Der Moschusochs," p. 120. 
Asia to Europe, it became extinct in America as well as in Greenland.

Part of one section of the old musk ox stock returned to North America by way of Asia, while another travelled by means of a north Atlantic land connection to southern Greenland, gradually finding its way along the eastern and western coasts to northern Greenland. Meanwhile the musk ox had entered Alaska again from Asia and crossed the Mackenzie River into aretic Canada, where some of the peculiar forms originated.

Dr. Kowarzik promises us further contributions to this interesting problem from a palaeontological point of view. These will be of particular value in elucidating the question of the relationship between the European and the Greenland forms of the musk ox. I agree in so far with Dr. Kowarzik, as I feel convinced that the musk ox originated in North America in pre-Glacial times, but I differ in most of his other views. If land connections existed between North America and Asia, and between North America and Europe, they must have persisted through Pliocene to early Pleistocene times. I am of opinion, therefore, that the musk ox spread eastward to Europe and westward to Asia as long as land bridges enabled it to do so. It is quite possible that the Asiatic section subsequently travelled westward to Europe, but neither of them suciceeded in returning to their native land. The musk oxen we find in Greenland and arctic America probably survived the Ice Age where they now live. This opinion has the support of Dr. F. Wright* and Professor Upham as the result of their special study of the geological history of Greenland.

Not long ago the musk ox was still found in Alaska. Now it has been quite exterminated west of the Mackenzie River. As Dr. Allen remarks, the genus Ovibos is a declining type, which has attained its last stronghold in the aretic barren grounds. Wherever it is within the grasp of man it will soon be a creature of the past.

We possess no undoubted evidence of the existing species of musk ox having ever penetrated as far south as the United States, nevertheless it is quite possible that the fragmentary

* Wright, F. F., and Warren Upham, "Greenland Icefields," p. 332. 
remains which have been discovered in caves and other superficial (Pleistocene) deposits in Pennsylvania, Kentucky, Missouri, Iowa and Ohio may have belonged to varieties of Ovibos moschatus rather than to extinct species of musk oxen.

There are two other arctic mammals which are of special interest to us, since both of them inhabit Greenland. They are the arctic hare (Lepus variabilis $=\mathrm{L}$. timidus) and the arctic lemming (Dicrostonyx torquatus = Cuniculus torquatus).

Like the reindeer, the arctic hare is subject to great variation over the vast area which it inhabits, and some of these varieties or races are now recngnised by many zoologists as species. Mr. R. Brown* long ago felt the difficulty, nay, almost impossibility, in discriminating between the Greenland hare and the aretic or varying hare of Europe. The same embarrassment has confronted many subsequent authors. In America the Greenland hare is now generally considered as specifically distinct from the arctic American hare, Mr. Rhoads $\uparrow$ having pointed out some important features in its incisor teeth, while Mr. Nelson $\ddagger$ finds that its excessively heavy wool-like coat of fur, the long claws and tapering upper mandible sufficiently distinguish it from its relatives on the American Continent to give it the rank of separate species. However, as Mr. Rhoads aptly remarks (p. 356) the peculiar dentition, long fur, and long claws are due partly to the scantiness and character of plant life, and partly to the depth and long continuance of the snow in Greenland. These features seem to have gradually impressed themselves on the Greenland hare in modifying it in the direction indicated. In Major Barrett-Hamilton's § opinion the chief differences between the European arctic hares and the Greenland form, from an external point of view, are only of a sub-specific value, while Dr. Winge $\|$ does not specifically distinguish the American or European arctic hares from the Greenland one.

The same problem of affinity has recently been investigated from a new standpoint by Mr. Hinton. His researches have

* Brown, R., "Mammals of Greenland," p. 351.

† Rhoads, S. N., "Polar Hares of North America," p. 368.

$\ddagger$ Nelson, E. W., "Rabbits of North America," p. 68.

§ Barrett-Hamilton, G. E. H., “The Variable Hare,” p. 92.

|| Winge, H., “Grönlands Pattedyr," p. 376. 
led him to a comparison of the fossil hare remains from the ossiferous fissures of Ightham in England with the recent polar or arctic hares as a whole. He has been exceptionally fortunate in disposing of large osteological collections, and his conclusions are of particular interest and of much value in elucidating some important zoogeographical problems. Dwelling upon the close affinity existing between the English fossil and the Irish living arctio hare, he regards the latter as the direct descendant of the former. I should not have mentioned these particulars except that they give rise to farreaching deductions. From the fact of the fossil English and recent Irish forms being the least specialized members of the whole group of arctic hares, Mr. Hinton concludes that it is highly improbable that the group can have had a boreal origin.*

That the Irish arctic hare has always lived in Ireland under temperate conditions is an opinion which I expressed long ago in my works on the European fauna, and in this view Mr. Hinton concurs. But I also believe, as I shall endeavour to demonstrate later on, that even southern Greenland and all the lands surrounding the north Atlantic had a milder climate during the Pleistocene Period. It is principally the climate of arctic America and Greenland, I think, that became much more unfavourable within recent geological times, while that of the British Isles has undergone comparatively little alteration. Meanwhile specialization among the animals constituting the Greenland fauna probably proceeded at a more rapid rate than in Ireland, where the hare had no need to become adapted to different conditions of food and temperature. In spite of Mr. Hinton's argument, I still believe in the arctic origin of the group in Pliocene times, mainly because I do not admit that we have any evidence for the assumption that Ireland was connected with Great Britain during or after the Pleistocene Period. Mr. Hinton thus differs from me in regarding Central Asia as the centre of origin of the arctic hares in Pleistocene times.

I mentioned that the banded lemming (Dicrostonyx torquatus) was found in Greenland. Of late years it has been

* Hinton, M. A. C., "The fossil hare of Ightham," pp. 263-264. 
customary to distinguish the New World form (D. hudsonius) from the Old World banded lemming (D. torquatus), but they are very closely allied. Several varieties of the former inhabit the mainland and islands of arctic America, including the north and east coasts of Greenland. The whole genus Dicrostonyx (Myodes), is confined to the Arctic Regions. As in the case of the reindeer and other arctic species, we possess fossil testimony of a former southern extension of the range of the banded lemming in Europe.* It occurred in Central Europe, and also in England and Ireland, yet, as far as we know, it never penetrated into the United States in Pleistocene times. That the banded lemming is not a recent immigrant to Greenland, but has persisted there from pre-Glacial times seems to be indicated by the fact that Colonel Feilden $\uparrow$ discovered its remains, with those of the reindeer and musk-ox, in post-Tertiary (Pleistocene) deposits from sea-level to an altitude of 1,000 feet in northern Greenland.

There are a couple of other mammals in Greenland, viz: the arctic wolf and the arctic fox, which need not be specially considered here. Nevertheless, a significant factor in connection with one of these carnivores has been pointed out by Major Barrett-Hamilton and Mr. Bonhote. $\neq$ It is that the arctic fox (Vulpes lagopus) of Spitsbergen, Novaya Zemlya and Iceland agrees with that from eastern Greenland, forming a variety distinct from those of the European and American mainlands.

All the mammals alluded to as inhabiting freenland, live also in Europe in identical or closely allied forms, or did so in former times. Hence it is permissible to argue that a landconnection once bridged over the intervening ocean. The affinity between Greenland and aretic America in some respects is even closer than that between Greenland and Europe. Only the narrow Davis Strait and the still narrower Kennedy Channel separate the two countries. Another

* Scharff, R. F., G. Coffey, and others, "Caves of Kesh," p. 196.

† Feilden, H. W., and C. E. de Rance, "Geology of Arctic Coasts," p. 566.

$\ddagger$ Barrett-Hamilton, G. E. H., and I. L. Bonhote, "Sub-species of Arctic Fox," p. 288. 
sound of inconsiderable width, Bering Strait, divides arctic America from the Asiatic Continent. We can easily imagine what a comparatively small change in the configuration of land and water would thus bring Greenland into direct touch with Asia, by way of arctic America (compare Fig. 1).

It has actually been suggested by several writers that the faunal relationship which exists between Greenland and Europe is due to former land bridges across Bering Strait and Davis Strait, facilitating the passages of animals from Europe by way of Asia. That such land connections really existed in recent geological times, I do not doubt, and they will be further described in this and one of my next chapters. Still, their existence does not preclude the possibility of Greenland having likewise been connected by land directly with Europe. A close relationship exists between some of the western European and Greenland mammals. In some instances that affinity is no longer apparent in the recent mammalian fauna, but can be demonstrated to have once been a prominent feature. The extinct Irish reindeer for example, clearly indicates, in the character of its skull and antlers, that it was closely related to the present Greenland and arctic American races of reindeer, thus suggesting the former existence of some more direct means of transit from Greenland to Ireland, or vice versa, than by the circuitous route across Europe, Asia and arctic America. Many authorities, indeed, have on other grounds insisted upon the former presence of a land bridge uniting Scotland, the Faröes, Iceland and Greenland, with America.

The story of the extermination of the indigenous reindeer in Iceland in the twelfth century is too vague to be of much use in connection with these researches. It appears certain, at any rate, that no reindeer had inhabited Iceland for some hundreds of years before the end of the eighteenth century, when the ancestors of the present stock were brought over from Finmark. The assumption of the existence of such a land connection as that referred to, in Pliocene, and perhaps early Pleistocene times, or, in other words, just before and during the beginning of the Glacial Epoch, is generally based upon other ground than the distribution of mammals. I have recently collected the various sources of evidence in favour 
of the theory from the oceanographical, geological and biological standpoints.*

A second land bridge apparently united northern Greenland and Lapland at about the same time. This I described on a previous occasion. It will not be necessary for me to repeat all the arguments I advanced for and against the hypothesis, and I must content myself with a short statement of the main facts. The theory of the Greenland-Iceland-Scotland land bridge (Fig. 2) had been put forward by quite a number of authorities on independent grounds. Yet while some maintain that it merely existed in early Tertiary times, others contend that it could only have been made use of by the members of our present fauna and flora after the Glacial Epoch, because the. latter had not yet come into existence before that time.

One of the most important facts in favour of the existence of this land bridge is presented, in my opinion, by the geographical distribution of the land snail known as Helix hortensis. I have quoted many other instances in my paper on this subject, but this no doubt affords the most striking biological support for the belief in a land connection between Scotland, Iceland, Greenland and Labrador.

$\mathrm{X}$ Helix hortensis is a typically west European species, being quite unknown in the eastern parts of Europe or in Asia. Beyond the mainland of Europe we find it in Great Britain, in Ireland, the Shetland Islands, the Faröes, Iceland, in southern Greenland, Labrador, the islands off the north-east coast of North America, and part of the opposite mainland.

Biologists are often too ready in invoking human agency when endeavouring to explain the occurrence of certain common European species in unexpected localities abroad. When this snail was first discovered in North America, its presence there was universally attributed to the action of man, and was often cited as a good instance of the facility with which terrestrial mollusks are introduced into foreign countries and become established there. Until the year 1864 no other theory was even thought of. During that year, however,

* Scharff, R. F., "On a former Land Bridge between Europe and North America." 
Professor E. Morse first discovered the shell of this snail among the contents of ancient "kitchen-middens," those peculiar refuse heaps of primitive man, on some of the islands off the east coast of Maine. He pondered over this singular mystery and finally came to the conclusion that the snail must have slowly wandered, during a long series of centuries, from the Old World to the New, by means of an ancient North Atlantic land bridge. Mr. Johnson,* to whose instructive paper I am indebted for this information, states that Dr. Binney and Professor Cockerell concurred in Professor Morse's opinion. He also informs us that the Rev. Winkley and he were of opinion that the arrival of the snail Helix hortensis in America must have taken place before the advent of the Glacial Epoch.

This theory, as can be imagined, was by no means generally accepted in America. All doubts, however, as to the claim of Helix hortensis being an indigenous American species are now set at rest, through the discovery by Dr. Dall $\dagger$ of the shell of this snail in undoubtedly Pleistocene deposits in the State of Maine. Some naturalists might still be inclined to urge that greater facilities for occasional transport across the Atlantic may have existed in those remote times than at present, and that the argument in support of a land bridge is not convincing. No evidence, however, in favour of an ocean current from Europe to North America in Pleistocene times has as yet been brought forward, while the conviction in the former presence of a land connection between north-eastern America and north-western Europe is based upon other biological observations. From a geological point of view we can scarcely hope to be able ta determine the period or periods during which this land bridge existed. The bathymetrical features of the north Atlantic, according to Professor Hull, $\ddagger$ Dr. Spencer $\S$ ånd Dr. Nansen, \| point to a preGlacial elevation of the land in northern latitudes. Dr.

* Johnson, C. W., "Distribution of Helix hortensis," p. 73.

† Dall, W. H., "Land and Freshwater Mollusks of Alaska," p. 20.

† Hull, E., "Submerged Terraces and River Valleys."

§ Spencer, J. W., "Submarine Valleys," p. 224.

\| Nansen, F., "North Polar Expedition," p. 192. 
Wright * and Mr. Upham, two well-known authorities on glacial phenomena expressed the view that the northern lands must have been gradually elevated in Pliocene times, becoming continuous before the Ice Age. Further particulars on this subject are contained in Dr. Spencer's article $\dagger$ on high continental elevation.

Sir Henry Howorth opposes this view, urging that Greenland, Scandinavia, and North America were all at a much lower level in so-called Glacial times than they are now. If this be so, then the epeirogenic theory has no base to stand upon. I do not think that Sir Henry Howorth's $\ddagger$ statement is applicable to southern Greenland or eastern North America. At any rate, it is not contended by anyone that the high level condition of these countries persisted during the whole of the Ice Age.

The theory that the Ice Age or Glaicial Epoch was brought about mainly by the closing of the Arctic Ocean to the influence of the Gulf Stream is a very tempting one. The temperature of the Atlantic Ocean would under such conditions have been higher than it is now, because its heat would not have been modified by cold arctic currents, as it is at present. Southern Greenland, Iceland, and the lands on both sides of the Atlantic should also have had a more favourable climate than obtains under existing circumstances, since the warm ocean would have had considerable influence upon their climate for a certain distance inland. There is evidence, on the European side of the Atlantic, that, at a not very distant geological period, and presumably at a time when the coasts of France, south-west of England and south of Ireland were still united, the southern fauna and flora crept steadily northward along the ancient shore-line. That this did not take place in very recent times is evidenced by the fact that the southern marine shore forms of mollusks, crustaceans and other invertebrates have a somewhat discontinuous range on the west coast of the British Islands, and do not occur in the English Channel or in the southern part of the North Sea.

* Wright, G. F., and Warren Upham, “Greenland Icefields" p. 331.

† Spencer, J. W., "High Continental Elevation."

$\ddagger$ Howorth, H. H., “Ice or Water,” Vol. I., p. 136. 
Hence they evidently wandered northward under different geographical conditions than exist at present, and only maintain a slender hold in isolated localities, where they form relict colonies. I assume that this northward advance of the marine fauna took place in late Pliocene times when the northern Atlantic was closed, and the temperature of the ocean raised. As Dr. Dall wrote to me " the Pliocene all over the northern hemisphere was a period of warmer sea water than the Miocene or Pleistocene." My attention was also recently drawn by Professor Morse* to the fact that even littoral European species have extended their range across the ocean to North America. As long ago as 1855 he received specimens of the common European "Periwinkle" (Littorina litorea) from Chaleur Bay in the Gulf of St. Lawrence. Later on this mollusk was reported also to occur on the coast of Nova Scotia and Labrador. It is steadily advancing now in a southward direction, while it is becoming scarce in the north.

Dr. Ashworth $\dagger$ tells me that the lugworm (Arenicola marina) which is common on the west coast of Europe is also met with on the coasts of the Shetland islands, the Faröes, Iceland, Greenland, Labrador and Nova Scotia. It is absent from the coasts of the Pacific Ocean. Hence he concludes that a continuous shore-line formerly existed between the two areas on each side of the Atlantic Ocean in which this worm is now found. Dr. Ashworth believes that the extensive stretch of ocean at present existing between Europe and America forms just as much a barrier to the dispersal of the littoral lugworm as it does to that of the terrestrial Helix hortensis just alluded to.

Commenting on this occurrence of European littoral marine mollusks on the north-east coast of North America, Mr. B. B. Woodward writes to me that no other theory than that of the previous existence and subsequent rupture of a land bridge in the direction indicated can satisfactorily account for the present disjointed distribution of the two divisions of the boreal fauna.

It was assumed by Professor Nathorst $\ddagger$ that a portion of * Morse, E. S., “Dispersion of certain Mollusks," p. 8.

+ Ashworth, J. H., Catalogue of Chaetopoda part I.

‡ Nathorst, A. G., " Pflanzengeographie der Vorzeit," p. 267. 


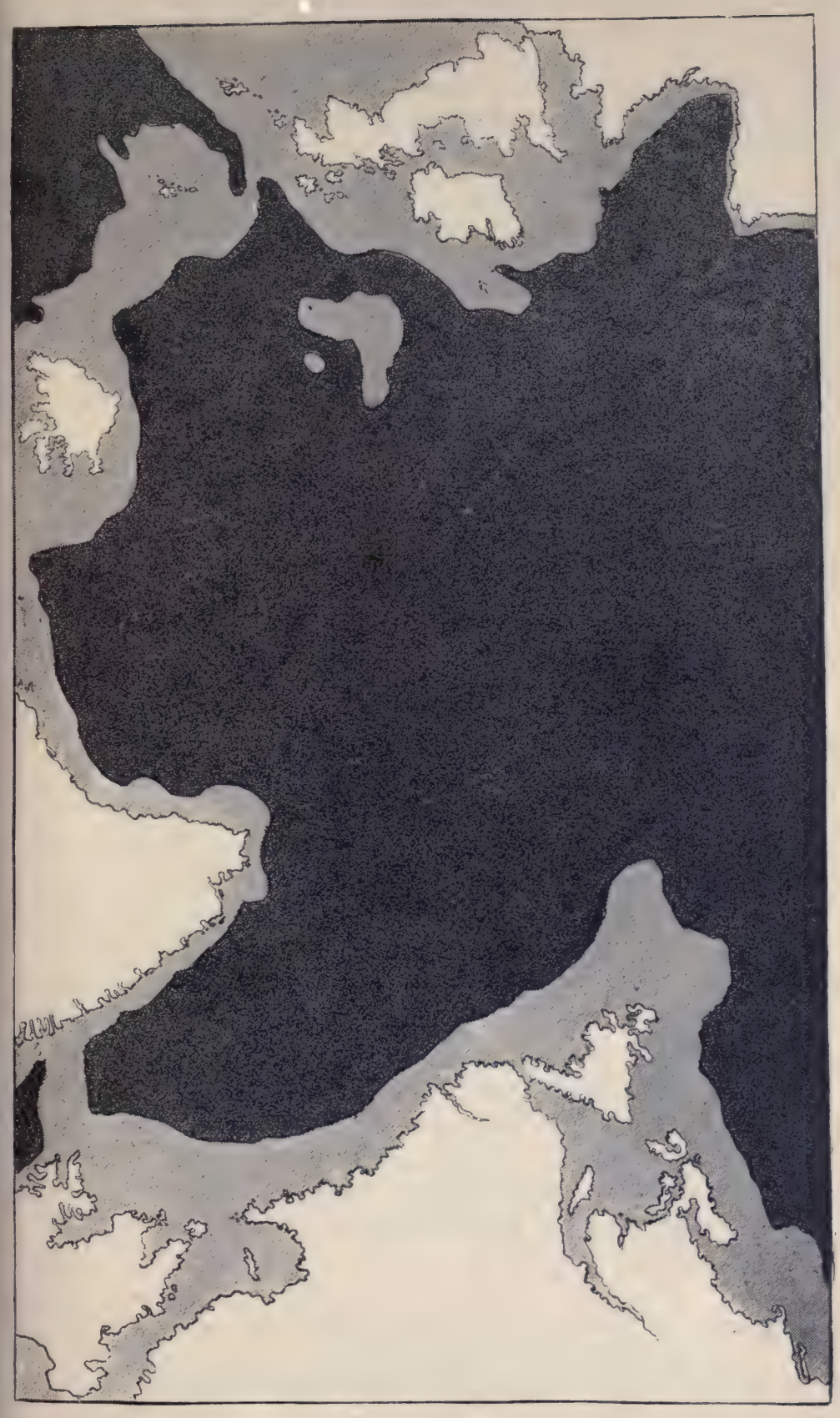

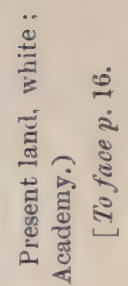

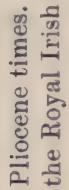

के

ฐ

응

일

. $\frac{\mathrm{C}}{2}$

ज्ञ

흔

돌.

के

$z_{0}$

$\Xi$ 을

$\Xi \Xi$

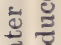

$\geqslant$

ฮี

를

ชै

ฮี ฮี

窝

ฮี 을

च है

\%

를 귱

ज

ड़

60

䒕

का

ลิ है

길

!

อั 

the arctic flora had originated in Greenland in pre-Glacial times and had been scattered east and west across the existing land bridges on the advent of the Glacial Epoch, during which the maintenance of life was no longer passible in that country.

Sir Joseph Hooker* long ago expressed the opinion that, although many Greenland plants were possibly destroyed during the Ice Age, the existing remnant of a much richer flora had survived in the southern parts of the country, whence it subsequently spread northward again.

One of the biological arguments I adduced in favour of a former north Atlantic land bridge was derived from the wellknown fact that deposits of dead marine shallow-water species had been dredged in deep water in various localities such as Rockall Bank and off the coast of Iceland. This peculiar circumstance has been applied by several authorities in support of the theory of a gradual sinking of the land, the shallow-water species having thus been moved to a position in which they are no longer able to live. It is this part of the biological argument on the land bridge theory which has received most of the adverse criticism. Dr. Johansen, $\dagger$ for instance, pointed out that the evidence derived from the marine shallow-water shells is untrustworthy, because their presence in great depths in the northern Atlantic is not due to a sinking of the land, but mainly to various casual or accidental activities of transport. The theory of the north Atlantio land bridge, in so far as it is founded upon the occurrence of shallow-water marine shells at great depths, does not, therefore, meet with his approval.

Similarly, Dr. Appell $\phi \mathrm{f} \ddagger$ insists that the most recent discoveries on the "Faröe Bank" are of considerable zoogeographical significance, since they are opposed in some measure to the theory of the sinking of the land. He informs us that among the thick layer of dead shallow shells found on the Faröe Bank living specimens of several of the species were met with.

* Hooker, J. D., “Distribution of Arctic Plants,” pp. 252-2ã5.

$\dagger$ Johansen, A. C., "On the Sinking of Sea-beds," p. 403.

$\ddagger$ Appellpf. A., "Norwegian Fisheries," Vol. II., pp. 83-89.

L.A. 
No doubt this discovery provides an argument for the opponents of the land bridge theory, yet we know how adaptive certain species are to a change of conditions, and how long they can maintain themselves under adverse circumstances. I am not, therefore, disposed to attach too much importance to Dr. Appell $\phi f^{\prime}$ 's discovery. In any case, the land bridge theory is not dependent on the evidence alluded to.

Dr. Spethmann,* on the other hand, reiterates what we already know, that from a purely geological standpoint there are no positive proofs in favour of a former land bridge between Europe and Greenland.

These seem to be the principal arguments that have been advanced in opposition to the land bridge theory, and they are, in my opinion, not very formidable ones.

The question of the supposed survival of plants through the Ice Age in Greenland is closely connected with that of the land bridge alluded to. Whether any plants survived, and what proportion of those previously existing, largely depends on the nature of the Ice Age or Glacial Epoch and on the former extension of the glaciers in Greenland. Professor James Geikie $\dagger$ maintains that it is a fair assumption that the ice of Greenland in Glacial times completely buried the land and, perhaps, protruded beyond it. It has recently been very clearly demonstrated, however, by the leader of the German Greenland Expedition, Dr. E. von Drygalski, $\neq$ that the strip of land now free from ice on the west coast of Greenland has never been entirely invaded by glaciers. No doubt it can be proved, he remarks, that the ice in past times had a greater extension. All the same, glaciers never reached the cliffs and rock pinnacles which abound on all parts of the coast land of Greenland.

No special reason can be adduced, therefore, why the present flora of Greenland should not have survived the Ice Age in that country, particularly as we have some grounds for the belief that the land in parts of the Aretic Regions then stood higher than it does now, and that consequently more land was

* Spethmann, H., "Aufbau d. Insel Island," p. 8.

† Geikie, J., "The Great Ice Age," p. 736.

† Drygalski, E. von, “Grönland Expedition," Vol. I., p. 385. 
available for plant life. Indeed, Professor Vanhöffen* who describes the plants and animals observed during the expedition, adopts this attitude. He not only believes in the survival of the flora of Greenland through the Ice Age, but he also argues that the great mass of the fauna is indigenous to the coůntry.

Though he does not deny the possibility of organisms being accidentally carried by birds, and other occasional means of transport, he protests against the assumption that the fauna of Greenland, as a whole, owes its origin to such a mode of conveyance. Dr. Brehm $\uparrow$ quite concurs in this view. $\mathrm{He}$ is convinced that the fauna of Greenland is autochthonous.

It is very generally believed that the climate of Greenland was much colder during the Glacial Epoch than it is now, although we possess no direct evidence that it was so. A mild climate in South Greenland during the existence of the land bridge is implied by the fact that a number of European species found in north-western North America, and which no doubt travelled by way of Greenland, have since become extinct in the latter country.

Greenland must, therefore, have passed through a phase during which existence became impossible for these species. Yet, for all we know, it may be only quite recently that the climate of Greenland has grown so inhospitable. It has been suggested by Professor Whitney, and more recently by Sir Henry Howorth, that the Arctic Regions enjoyed temperate conditions during the Glacial Epoch and are only now passing through the more severe post-Glacial stage. In view of the accumulation of evidence pointing to a southward advance of the Arctic fauna and flora in Pleistocene times, such a suggestion may seem contrary to biological evidence. I shall endeavour to show, however, in the next few chapters that we possess a good deal of valuable testimony, principally of a biological nature, in support of Professor Whitney's and Sir Henry Howorth's contention.

With regard to the species which I believe to have made use

* Vanhöffen, E., “Grönland Expedition," Vol. II., p. 174.

† Brehm, V., “Entomostraken d. Danmark Expedition,” p. 316. 
of the ancient north Atlantic land connection, and are supposed to have subsequently become extinct on the intermediate stations between the two continents, particular attention may be drawn to the range of the " running beetles" of the genus Carabus. They are of great value in aiding us to solve problems of this nature, because, being usually found under stones and clods of earth, they are not liable to occasional transport by floods. Being wingless they cannot be carried to distant lands by winds; and lacking any kind of means by which they might become attached to a mammal or bird they would not be conveyed in such an accidental manner from one locality to another. The great importance of the species of Carabus has been recognised, and their distribution brought to bear upon zoogeographical problems by Mr. Born.* He cites two of the species, viz., Carabus catenulatus and Carabus nemoralis, as evidences of a former land bridge between northern Europe and North America, although they no longer occur in Iceland or in Greenland. Both these running beetles are typically European species, being quite absent from Asia. The conspicuously ornamental Carabus memoralis is confined in North America, to Nova Scotia and New Brunswick. Hence it somewhat agrees in its American range with that of Helix hortensis. The other species of Carabus has a wider distribution in boreal North America.

Such instances lead us to believe, therefore, that the faunas of Greenland and Iceland were richer in pre-Glacial times than at present. They are certainly suggestive also of a survival of species having taken place through the Ice Age within the glaciated area of North America. We possess no evidence that these beetles and the snail Helix hortensis, and many other animals belonging to the same group of European invaders, were pushed south during Pleistocene times into the United States, and that they then regained their former northern habitat, after having become extinct again in their more southern stations.

The extinction of a large part of the former beetle fauna of Greenland may be inferred from the fact that Greenland only possesses forty-one species of beetles, while there are

* Born, P., “Zoogeographisch-carabologische Studien,” p. 8. 
ninety-one in Iceland.* Of the more hardy spiders the percentage of survival is very different, for there are fifty-three species in Greenland and only twenty-four in Iceland. $\dagger$

The theory of the survival of species in Greenland may be tested by some other examples. Besides Helix hortensis about a dozen other kinds of land and freshwater mollusks inhabit the country. $\neq$ Eight of these either have their centre of distribution in Greenland or are quite peculiar to the country. These are Planorbis nathorsti, P. arcticus, Limnaea vahli, L. holbolli, Succinea groenlandica, Vitrina angelicae, Conulus fabricii and Pupa hoppii. The two species of Planorbis are also known from Labrador; Succinea groenlandica occurs in Iceland; P. arcticus has been met with in Seandinavia, Finland and Siberia. The first of the Limnaeas ranges from Greenland to Alaska, the other is peculiar to Greenland. The latter, however, is replaced in boreal North America by the closely-allied Limnaea retusa. Vitrina angelicae is not found in America, but occurs in Iceland and Norway. Conulus fabricii is probably only a variety of the common Conulus fulvus of northern Europe, Asia and America, while Pupa hoppii is confined to Greenland. With the single exception of Planorbis arcticus all these species live at present well within the glaciated area, that is to say, within that portion of the northern regions supposed to have been either wholly or partially buried by ice during the Glacial Epoch. As none but Planorbis arcticus have ever been found fossil outside that area, we may assume with some justification that most of them originated in Greenland, and that all, at any rate, survived the Ice Age in that country. Planorbis arcticus, as Mr. Kennard $\S$ informs me, has been taken in Pleistocene deposits in Denmark and in the south of England. (Compare also Kennard and Woodward's paper.)

It is more difficult to demonstrate that butterflies and moths

* Poppius, B., "Coleopteren des Arktischen Gebietes," p. 428.

† Strand, E., "Arktische Araneae," p. 436.

† Mörch, O. A. L., "Land and Freshwater Mollusca of Greenland."

$\S$ Kennard, A. S., and B. B. Woodward, "Extinct post-pliocene Mollusca of Southern England," p. 5. 
have survived the Glacial Epoch in Greenland, yet several authors who have written on the lepidopterous fauna of that country maintain that the theory of a former land bridge with Europe and North America is quite consistent with the facts of distribution. Mr. Petersen, ${ }^{*}$ for example, concludes from his studies that land connections in high northern latitudes enabled certain arctic butterflies and moths to spread from a polar centre to Europe and North America. After alluding to a large number of moths common to Canada and Europe, Mr. Girard $†$ emphasises the significance of this fact as indicating the former existence of a land bridge between North America, Greenland and Europe.

Although no butterflies occur in Iceland, Coleas nastes, Argynnis chariclea and A. polaris are known even from the barest and most exposed districts of Greenland, where nothing but Dryas octopetala and some slender grasses grow. These species have a wide range in boreal America, Europe and Asia, but of the nine butterflies known from the arctic American archipelago five are European, while only two are met with in Asia, according to Dr. Pagenstecher. Many striking examples, showing the relationship between Greenland and the neighbouring continents occur among the moths. especially among the Noctuidae. Anarta melanopa inhabits only Colorado, the White Mountains, Labrador, Scandinavia, Scotland and the Alps. Anarta leucocycla and A. lapponica are found in Labrador, Greenland and Scandinavia. Mr. Grote $\neq$ alludes to no less than twenty-eight other Noctuids that are common to Europe and North America, even excluding those met with in Labrador or circumpolar species. All these facts tell in favour of the view I have endeavoured to elucidate.

No matter what group of terrestrial invertebrates we choose, similar close relationships may be discovered between American and European species, which cannot be explained by the assumption of a former land connection across Bering

* Petersen, W., " Lepidopteren-fauna d. arkt. Gebietes, p. 44.

† Girard, Maurice, "L'Entomologie de l'Amérique du Nord," p. 287.

† Grote, A., "Noctuidae of North America," p. 313. 
Strait alone. Mr. Emerton* makes mention of several instances among spiders.

Such cases can be traced among earth-worms, beetles, woodlice, ants and other groups. In some cases the identity or similarity of species occurring on the two continents may be due to the fact that the species originated in Greenland or some polar centre, no longer in existence, and subsequently. travelled in different directions towards their present habitat. This conception, however, has very little in common with that of a polar origin of life which was first mooted by Dr. Allen. $\dagger$ He argued that the northern circumpolar lands máy be looked upon as the base or centre from which have spread all the more recently developed forms of mammalian life.

A few years later Dr. Haacke $\ddagger$ directed attention to the peculiar circumstance that the most primitive orders of mammals and birds all have their living representatives in outlying areas of the southern hemisphere, such as Australia, New Zealand, Madagascar, South Africa and South America, notwithstanding that these animals are known to have formerly inhabited the northern hemisphere. This, he thinks, implies that a southward retreat has taken place of the more ancient forms before the advancing host of higher orders of life. It would seem, therefore, as if streams of more and more highly specialized orders of mammals and birds had been slowly evolved in the north and had constantly pressed the older ones southward. This suggested to Dr. Haacke the idea of a polar continent from which the various orders had gradually been distributed across the continents. Dr. Wilser $\S$ even assumes a polar origin for man.

A similar theory was pronounced by Canon Tristram $\|$ in explanation of the present distribution of the higher groups of birds and their migrations. The migratory instinct, he contended, was due to their having originated in a polar centre

* Emerton, J. H., "Spiders common to New England and Europe," p. 129.

† Allen, J. A., “Geographical Distribution of Mammals," p. 375.

† Haacke, W., "Nordpol als Schöpfungszentrum."

§ Wilser, L., “Der Nordische Schöpfungsherd,” p. 134.

|l Tristram, H. B., "Polar Origin of Life." 
and having subsequently been dispersed southward by different routes. He believed that the tendency of birds to migrate northwards was due to a natural instinat to return to the home of their ancestors.

What I chiefly endeavoured to prove in this chapter was the existence in pre-Glacial and early Glacial times of a land bridge joining Scotland, Iceland, Greenland and Labrador. The evidence in favour of such a land connection must be largely, if not entirely, biological; but the testimony, as far as it goes, leads me to believe that the theory is well founded. I shall allude to a similar land connection in another chapter which probably joined North America and Asia. If the climatic changes ushered in by the Glacial Epoch were produced by the closing of these two highways to the Aratic Ocean, it is evident that the preceding warm period must have been due to a greater flow of warm currents to the Arctic Regions.

A few years ago.I drew attention to the fact that the animals and plants found on the Faröes and Iceland in particular imply the existence of a former land connection between Scotland and the latter country. The occurrence in Iceland of the European field-mouse (Mus sylvaticus), of the snail Arianta arbustorum, which also inhabits the Faröes, of the beetle Nebria gyllenhali, which likewise inhabits Greenland, and many other forms not likely to have been conveyed by accidental means, all favour the view that the fauna of Iceland owes its existence mainly to the land bridge referred to. But, as I pointed out, Iceland also possesses a distinctly American element in the snail Succinea groenlandica and others, while some of the American plants have even invaded the continent of Europe by the Greenland-Iceland land bridge. One of the objections raised against this view is that the low temperature in the north would have prevented any faunistic interchange across the land bridge. The temperature, on the contrary, in Iceland, southern Greenland, Labrador and Scotland would have been considerably higher under such geographical conditions than it is now. If so, why should not the whole fauna of northern North America have streamed across this bridge to Europe and that of northern Europe to North America? If we examine the fauna of Canada we find that it 
is largely composed of Siberian immigrants. It is possible that these only began to enter North America from the extreme west at the time when Labrador was already joined to Greenland. Moreover, we may assume that as soon as the North Atlantic land connection excluded the Gulf Stream from the Arctic Ocean, glaciers began to gather on all the mountain ranges surrounding the northern parts of the ocean, thus preventing many forms of animal life from taking advantage of the facilities afforded by the land bridge of passing from the one continent to the other. The greater warmth on the northern coasts led to greater evaporation of sea water and more ample condensation of moisture on the elevated lands surrounding the ocean. All this will be more fully discussed in the succeeding chapters.

Apart from the authorities already cited who expressed themselves in favour of a north Atlantic land connection, between northern Europe and North America, Professor Lobley,* Dr. Brown, $†$ Mr. Grant $\ddagger$ and Mr. Krishtafovitch $\S$ have all urged the same view on different grounds.

* Lobley, J. L., “American Fauna and its Origin,” p. 26.

† Brown, A. E., “American Big Game,” p. 87.

$\ddagger$ Grant, M., "Mammals of North America," p. 12.

$\S$ Krishtafovitch, N. J., “La dernière période glaciaire," p. 296. 


\section{CHAPTER II}

\section{NORTH EASTERN NORTH AMERICA}

Crossing Davis Strait from southern Greenland to Labrador, we land in a country whose barren headlands look just as stern and uninviting as those on the opposite side of the Strait. But whereas the west coast of Greenland presents a shore-line varying between rugged precipices and undulating plains, the whole sea-front of Labrador, for over a thousand miles, rises abruptly from sea-level to a height of about 1,000 feet or more. Labrador presents an irregular plateau with a general elevation of from 1,500 to 2,000 feet above sea-level (see Fig. 1). It forms part of the oldest known land on the continent of North America, and, so far as we know, it has never been entirely covered by the sea since very remote geological times. The rocks are largely metamorphic with ancient igneous intrusions greatly resembling those of Greenland, which, like Labrador, is a fragment of that ancient continent to which Professor Suess applied the name "Laurentia." *

A cold current of water loaded with icebergs from the Arctic Ocean sweeps down the east coast of Labrador. Off the coast of Newfoundland it meets a branch of the Gulf Stream, thus producing the dense fogs so characteristic of the Grand Banks. This aretic current is mainly responsible for the inhospitable nature of the Labrador coast.

The vegetation is mostly stunted in character. The dwarf birch (Betula nana), the mountain-ash, alder and some willows here and there form small woods, while many of the familiar Greenland flowers reappear. Yet the flora is distinctly richer than that of Greenland. Even close to the coast, in sheltered ravines, occasional specimens of the white spruce, which is more hardy than the black spruce, are noticeable.

* Suess, E., "Antlitz der Erde," Vol. III.2, p. 284. 
To some of those who landed on the coast and explored the nooks and valleys, the country seemed full of beauty, of attractiveness, and even of a rich and appealing fertility. At certain times it presents an amazing wealth of strikingly coloured flowers. So thickly sown are they that at certain seasons they remind one of a cultivated garden.*

Once we leave the coast region and enter the interior of Labrador, the climate becomes less aretic in character and timber increases in quantity. In fact there are two distinct climates in Labrador, the arctic on the coast, the north temperate in the interior.

According to Dr. Packard, $\uparrow$ the Greenland and arctic forms of animal and plant life occurring on the coast are the remnants of the glacial or arctic fauna and flora which, being formerly spread over the entire territory of British America and the north-eastern United States, still retain their hold on the treeless and exposed islands and headlands of Labrador. In many respects the Labrador fauna and flora resemble those of the far distant White Mountains in New Hampshire, as we shall learn later on (p. 35).

When we survey the fauna of the coast of Labrador more closely we find that, besides the Greenland or aretic element, another much richer one has apparently invaded the territory. previously occupied by the former. This new fauna becomes more and more abundant as we proceed westward and southward. Thus the existence of the barren-ground caribou of Labrador which resembles the reindeer of Greenland, is threatened by enemies such as the glutton or wolverine (Gulo luscus), and these do not penetrate farther north. Occasionally the Canadian porcupine (Erethizon dorsatus) has been noticed in the coastal territory. Besides the lemming (Dicrostonyx hudsonius), which is probably identical with the Greenland form, quite an assembly of distinct ground rodents make their appearance, among them Synaptomys innuitus, Microtus enixus, Microtus pennsylvanicus, Evotomys ungava, Evotomys proteus, Zapus hudsonius, and Peromyscus maniculatus, also the arctic fox, red fox, several

* Grenfell, W. T., “ Labrador,” pp. 393-395.

+ Packard, A. S., “The Labrador Coast,” p. 194. 
small carnivores and a variety of the black bear (Ursus americanus).*

The small mouse-like creatures belonging to the genus Synaptomys are aptly called "lemming-voles" because, externally like lemmings, their teeth approach those of voles. When Dr. Merriam undertook his revision of the species of Synaptomys, $\uparrow$ seven kinds were known to him. A few more have since been discovered. The genus is entirely confined to the North American continent, and all the species except two have a limited range in the boreal region. One of the latiter (Synaptomys cooperi) is found from Massachusetts westward to Minnesota and southward to North Carolina, the other is peculiar to Mount Washington. Almost all the other species are confined to Canada and Alaska. It does not seem, therefore, as if Synaptomys innuitus, which inhabits the coast of Labrador, were a recent immigrant from the south. On the contrary, the genus Synaptomys, being almost confined to the north, is probably of boreal American origin, one adaptable species having advanced far southward along the east coast of America.

The next two species alluded to, Microtus enixus and $M$. pennsylvanicus, are true voles, though the last-named animal is generally known in the States by the name of "meadowmouse." Both of them belong to a sub-genus which is very widely spread in Europe, Asia and boreal North America.‡ Some migrations across ancient land connections must have taken place, no matter whether we assume that the sub-genus is of Old World or New World origin. It only remains for us to determine whether Microtus crossed the North Atlantic land bridge or the one supposed to have been situated at Bering Strait, assuming that there was such a one. Professor Tullberg thought the members of the genus Microtus had travelled to America in Pliocene times by means of the first land bridge. $\S$ This view does not appear to me probable, because the family is entirely absent from Ireland,

* Bangs, O., "Mammals of Labrador."

† Merriam, C. H., "Revision of Synaptomys."

† Bailey, V., "Revision of Microtus."

§ Tullberg, Tycho, "System der Nagetiere," p. 499. 
Iceland and Greenland. There is no fossil evidence that voles ever lived in any of these countries, where we might expect them to have survived had any extensive migration taken place from Great Britain to North America. Neither in Europe nor in North America are there any fossil remains of the subgenus Microtus older than Pleistocene, if we accept Mr. Barnum Brown's estimate of the age of the Potter Creek deposits.* Nevertheless, it is possible that these voles originated in North America long prior to the Pleistocene Period. If so I believe they made use of the Bering Strait land connection rather than the North Atlantic one, in passing from the New World to the Old.

Evotomys, another genus found in the coastal district of Labrador, has a range somewhat similar to that of Microtus. It is closely allied to it and scarcely deserves the name of "red-backed mouse" as the Americans call it, because it is distinctly a vole, without any mouse-like characters about it. The relationship between the American and Old World forms, as in the case of Microtus, must be due to the existence of a former land bridge across Bering Strait.

The jumping-mice (Zapus), to which Zapus hudsonius belongs, are, in many respects, an interesting group of rodents. Somewhat kangaroo-like in their movements, they are almost entirely confined to boreal North America. The Labrador jumping-mouse is a variety of Zapus hudsonius, which ranges from Alaska to Labrador and New York. A single species of jumping-mouse (Zapus setchuanus) occurs in China. $\dagger$ The theory that a former land bridge across Bering Strait enabled its ancestors to traverse the northern Pacific seems quite evident in this case. Yet we must not forget that the American jumping-mice also have somewhat more distant relations in the Old World, the jerboas, from which the remote ancestors of Zapus may possibly have descended.

We need not at present deal with the other rodents or the carnivores found in the coast district of Labrador, as most of these will be referred to again in subsequent chapters. The animals that have just been alluded to show us that the

* Brown, Barnum, "Conard fissure," p. 208.

† Preble, E. A., "Revision of the Jumping Mice." 
Labrador fauna is largely composed of indigenous American species, which have not penetrated to Greenland. This seems to suggest that the points of resemblance in the fauna of Labrador and Greenland may have been more marked in remoter times, before the influence of the continental fauna had impressed itself upon the outlying peninsula of Labrador. Considering the extreme probability of Labrador having been connected by land with Europe by way of Greenland and Iceland in Pliocene times, we might expect some European mammalian types to have occurred in north-eastern North America. The little evidence we possess tends to show that the mammalian life of the extreme north of western Europe was always poor. We cannot assume that insurmountable barriers prevented European mammals from invading America, because certain species such as the reindeer and lemming seem to have passed from America to Europe across a North Atlantic land bridge. It might be argued that European animals did cross over, but were unable to maintain themselves in America, a fate which has largely befallen the American immigrants in Europe. For such a supposition, however, we still lack evidence. If no examples of European animals or plants were known from the American side of the water, we might assume the land bridge to have been a discontinuous one, as Mr. Hedley suggested to me, connecting Greenland alternately with Labrador and Scotland. But one of our strongest supports for the North Atlantic land bridge is, as I said, the presence of the European Helix hortensis in North America. It still occurs in Labrador. From Labrador it travelled southward along the coast. Is it possible that the whole strip of coast was at that time cut off by some barrier from the interior of North America?

Supposing the western parts of the Labrador plateau had become covered by glaciers as soon as the North Atlantic land bridge was formed, it might have produced an effectual barrier against western invaders and yet have allowed eastern forms to reach Labrador.

Later on I intend to return to this problem again. Meanwhile, let us journey westward across the high plateau of Labrador towards Hudson Bay and Central Canada. As we 
enter the vast forest region, plant life as well as animal life become more and more abundant and differentiated. Instead of the barren-ground caribou, we now meet with the woodland form accompanied by another large ungulate, the moose, while the flying squirrel, chipmunk, the ground squirrel, woodchuck, white-footed mouse, musk-rat, beaver, skunk, weasel, shrews, moles and many other beasts tenant the forests, meadows, and banks of rivers.*

A few amphibians, even, have succeeded in surviving the rigours of the arctic winter of those regions, and have successfully established the most northern outposts in eastern North America. The leopard frog (Rana pipiens), one of the commonest as well as one of the most brilliantly coloured of American frogs, is one of these. The pickerel (Rana palustris), also the northern wood frog (Rana cantabrigiensis) and the northern frog (Rana septentrionalis) have all been observed in the neighbourhood of Hudson Bay. The most interesting species is the swamp-tree frog (Chorophilus nigritus), whose northern variety has advanced into this inhospitable region, though almost all of the other members of the tree frog family (Hylidae) are typically southern forms. $\dagger$ Whether newts occur in the Hudson Bay region is not definitely known, but the salamander (Plethodon cinereus), at any rate seems to have been met with. All these species are peculiar to America.

No reptiles have been noticed. The distribution of the terrestrial mollusks, the snails and slugs, implies that an advance in a northward direction, similar to that recorded in the case of mammals and amphibians, has taken place among some groups of invertebrates. The typically American snails, Polygyra monodon and Strobilops labyrinthica, have been collected near Hudson Bay.

When we analyse the constitution of all these western and southern groups, and trace the relationship of the members more carefully, we notice that many of them are not of American ancestry. They all have lived, no doubt, long enough in America to have become thoroughly established,

* Preble, E. A., "Hudson Bay Region."

† Dickerson, Mary C., "The Frog Book," p. 158. 
being part of the indigenous fauna, yet we recognise that their ancestors must have entered the continent from Asia in comparatively recent geological times.

Let us take for example the moose deer (Alces americanus). Its range extends from Bering Strait, in a broad tract of forest land eastward, along the northern shores of the Great Lakes as far as Nova Scotia on the Gulf of St. Lawrence. Only along the Rocky Mountains, as Mr. Thompson Seton has so clearly indicated in his map of the range (Fig. 3), does the moose occur further south.*

There are a few historical records, and also some fossil ones, which indicate that the moose once penetrated further into the United States in various directions, but it evidently never diverged very much from its present range. $\dagger$ The bones of a couple of closely allied animals have been met with in the Pleistocene deposits of Washington territory, and the skeleton of a peculiar moose, somewhat resembling the Alaskan variety, has been discovered in the Pleistocene of New Jersey, and placed by Professor Scott into a distinct genus (Cervalces). Whether this animal was ancestral to the living moose, as has been suggested, or whether it represents an aberrant type which has come in from Siberia with the moose, as Mr. Grant seems to think likely, are problems which may be left to future researches. $\neq$ Certain it is that when we cross Bering Strait into Northern Asia, we meet with a moose (Alces bedfordiae) which in its simple antlers somewhat resembles the young American moose. Further west as far as Scandinavia, we find another species (A. machlis) differing but slightly from Alces americanus. It seems almost as if the moose had originated in eastern Asia from some more generalised type like Alces bedfordiae, and had gradually produced the forms with more palmated antlers in America and Europe by a process of convergent evolution. In any case, we are led to assume that Bering Strait was dry land when the ancestors of the existing moose entered the New World. Even if we suppose the moose to have originated in America, a land bridge connecting the latter with Asia was a

* Seton, Thompson, "Life Histories of Northern Animals, I.," p. 151.

† Grant, Madison, "Moose."

$\ddagger$ Grant, Madison, "Origin and Relation of Mammals," p. 23. 


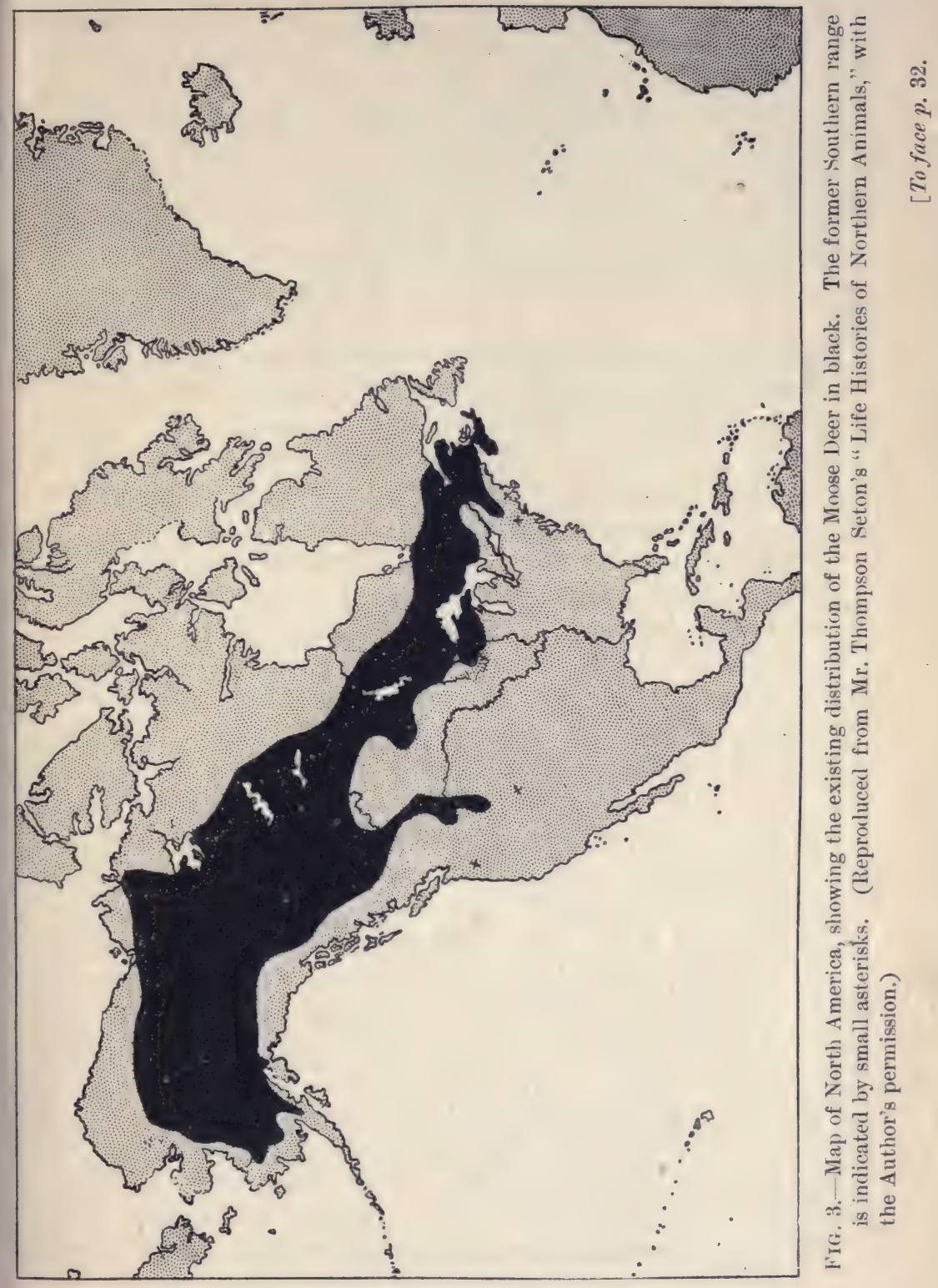



necessity. This problem of the Bering Strait land bridge, however, will be more fully discussed later on (pp. 83-86).

The moose, or elk as it is called in Europe, has been stated to occur in the Caucasus, but its range only extends to the forests north of this mountain range. Like the reindeer, it. occurred much further south formerly, even as far as northern Italy, and yet no theories as to a former arctic climate are founded on this fact. In Caesar's time the elk was still abundant in the Black Forest in southern Germany, while it is now confined to certain parts of Russia and Scandinavia.

Many other American species resemble the moose in their range, except that they manifest more clearly their Asiatic origin. The further west we travel the more often do we meet with such types of animals.

We have now become acquainted with species that seem to be of arctic American or Greenland origin. A few apparently travelled across from Europe. Others were partly of southern extraction having advanced northward from the United States, and partly derived from a western invasion of the continent. What we want to find out next is the geological age of some of these invasions into boreal America. The writings on this subject of the prominent biological authors are largely biassed by the prevalent geological opinions with regard to the nature of the Ice Age.

It is currently believed that a climatic change towards the end of the Pliocene Period caused ice-masses to form in various Canadian centres, so as to produce continental glaciers of the type of the ice-sheet now covering Greenland. These glaciers are supposed to have spread from at least three centres in Canada, termed the Labradorean, Keewatin, and Cordilleran. During this time, viz., in our most recent geological age, the "Pleistocene Period," fully one half of North America is thus assumed to have been gradually buried beneath these vast sheets of ice. Ice is believed to have extended practically all over the continent from Newfoundland in the east to Vancouver in the west, and from the Arctic Ocean to the present site of the City of St. Louis.* Relying

* Russell, I. C., " North America," p. 315.

L.A. 
on the accuracy of these data, on which the majority of geologists are agreed, biologists have endeavoured to work out the past history of the American fauna in strict accordance with the facts these phenomena are thought to reveal. "Throughout the growth of the great ice-mass, and its extension from the north southward," says Dr. Merriam, "it is clear that the animals and plants that could not keep pace with its advance must have perished, while the steady pushing towards the tropics of those that were able to escape to the rapidly narrowing land in that direction must have resulted in an overcrowding of the space available for their needs and a corresponding increase in the severity of the struggle for existence."* Immediately upon the close of the Glacial Epoch life began to reclaim the regions from which he thinks it had so long been shut out.

Dr. Allen's views are very similar. "There is evidence," he remarks, "that towards the close of the Tertiary, a marked change in the earth's climate took place, culminating in the Glacial Period, during which the whole northern half of the northern hemisphere became covered with a heavy ice-cap, lasting for possibly thousands of centuries, and extending its chilling influence nearly to the northern tropic. The rise of the Glacial Period was of course gradual, and the southward progress of the great ice-cap drove before it all forms of life capable of any considerable powers of locomotion, while those unable thus to escape must have perished from cold. Finally the ice receded to its present limits and the whole north, under radically altered climatic conditions, became again available for occupation by the more or less modified descendants of the pre-Glacial exiles." $†$

The bog plant societies so graphically described by $\mathrm{Mr}$. Transeau probably existed, he thinks, along the whole ice front. The bog and tundra types were eventually the first to push into the barren ground left by the retreating ice. $\neq$

Professor Adams takes a more independent attitude. $\mathrm{He}$ assumes that repeated glaciation had almost sterilised the

* Merriam, C. H., "Life in North America," p. 45.

† Allen, J. A., "Distribution of North American Birds," p. 100.

† Transeau, E. N., "Distribution of Bog Plant Societies," p. 414. 
northern part of the continent, still he concedes that even during the Glacial Epoch, life of the tundra type may have flourished in Alaska.*

Hence it is not unreasonable to argue from his point of view that life could also have existed in Greenland at that time, and this opinion I endeavoured to vindicate in the last chapter. Even Professor Adams does not venture to cast a doubt upon the correctness of the current geological theories, and speaks of three distinct belts of life in the vicinity of the ice margin (p. 56). The latter being fringed to the south by tundral biota (fauna and flora), next to which came the northern trans-continental coniferous forest belt and its associated fauna, and finally the deciduous forests. All these are assumed to have moved forward to the north on the disappearance of the ice.

That the so-called "tundral" or what we might call arctic fauna and flora actually did advance far south of their present habitats can be demonstrated much more clearly than by the occurrence of a few stray fossil reindeer's antlers south of the area covered by glacial drift.

Whether the past southward migrations of the reindeer were influenced by climatic changes or by other considerations, we cannot definitely assert. Since we are told that there was a refrigeration of the climate during the Glacial Epoch, we are apt to assume that this lowering of the temperature drove the reindeer and other arctic species to more southern localities. The former occurrence of an animal of such a roving disposition as the reindeer in more southern districts may have been due to a natural expansion of its range, and this need not imply a change of temperature.

The fauna and flora of the White Mountains has been cited as a living testimony of a former arctic climate in latitudes where temperate conditions now prevail.

Surrounded by an entirely alien assemblage of animals and plants we find in the White Mountains of New Hampshire, not far from the city of Boston, an extraordinary gathering of species, many of which are only known elsewhere in Labrador and Greenland. A thousand miles away from their

* Adams, Chas. C., "Dispersal of North American Biota," 
natural home, they form in the White Mountains a peculiar island colony on a bare plateau which lies about 5,000 feet above sea-level, and out of which project a series of conical peaks. These constitute what is known as the Presidential Range, the highest being Mount Washington (6,293 feet) (Fig. 4). The plateau on which this remarkable relict fauna and flora lives may be reached by the railroad that now takes the traveller to the top of Mount Washington or by following a very rough trail leading to it from the Pass called " Crawford's Notch" through the dense forest. It was the latter route I chose to gain the wind-swept ridge. As we approach the ridge, the fine spruce, balsam and paper birches are gradually replaced by diversified conifers, which become increasingly stunted by exposure in the more elevated parts of the range. At last, on emerging from the remnants of the forest, we have gained not only a wide expanse of open country, but we can imagine ourselves transplanted all of a sudden to the Arctic Regions. Here and there may be gathered specimens of Rhododendron lapponicum and Salix phylicifolia, growing among Arenaria groenlandica, Phleum alpinum, Diapensia lapponica, Campanula rotundifolia, Gentiana nivalis and hosts of others, few of which can be studied elsewhere nearer than Labrador.

Moreover, as Dr. Scudder remarked, no State in the Union presents so striking an assemblage of animal life as New Hampshire, where the White Mountains form so conspicuous a feature. Swiftly running over the bare rocks of the high plateau we notice the black spider, Pardosa groenlandica, which, though occurring also in the Rocky Mountains, is otherwise confined to the White Mountains, Labrador and Greenland.* The grasshopper, Pezzotettix glacialis, is, I believe, peculiar to Mount Washington, while another species, Pezzotettix borealis, is a near relative of the North European Pezzotettix frigida. Fluttering among the arctic vegetation, we notice the butterfly Oeneis semidea, which has never been taken nearer than Labrador, while the moths Dasychira rossii, Arctia quenselii and Anarta melanopa, are all well-known

* Chamberlin, R. V., "Revision of North American Lycosidae," p. 200. 


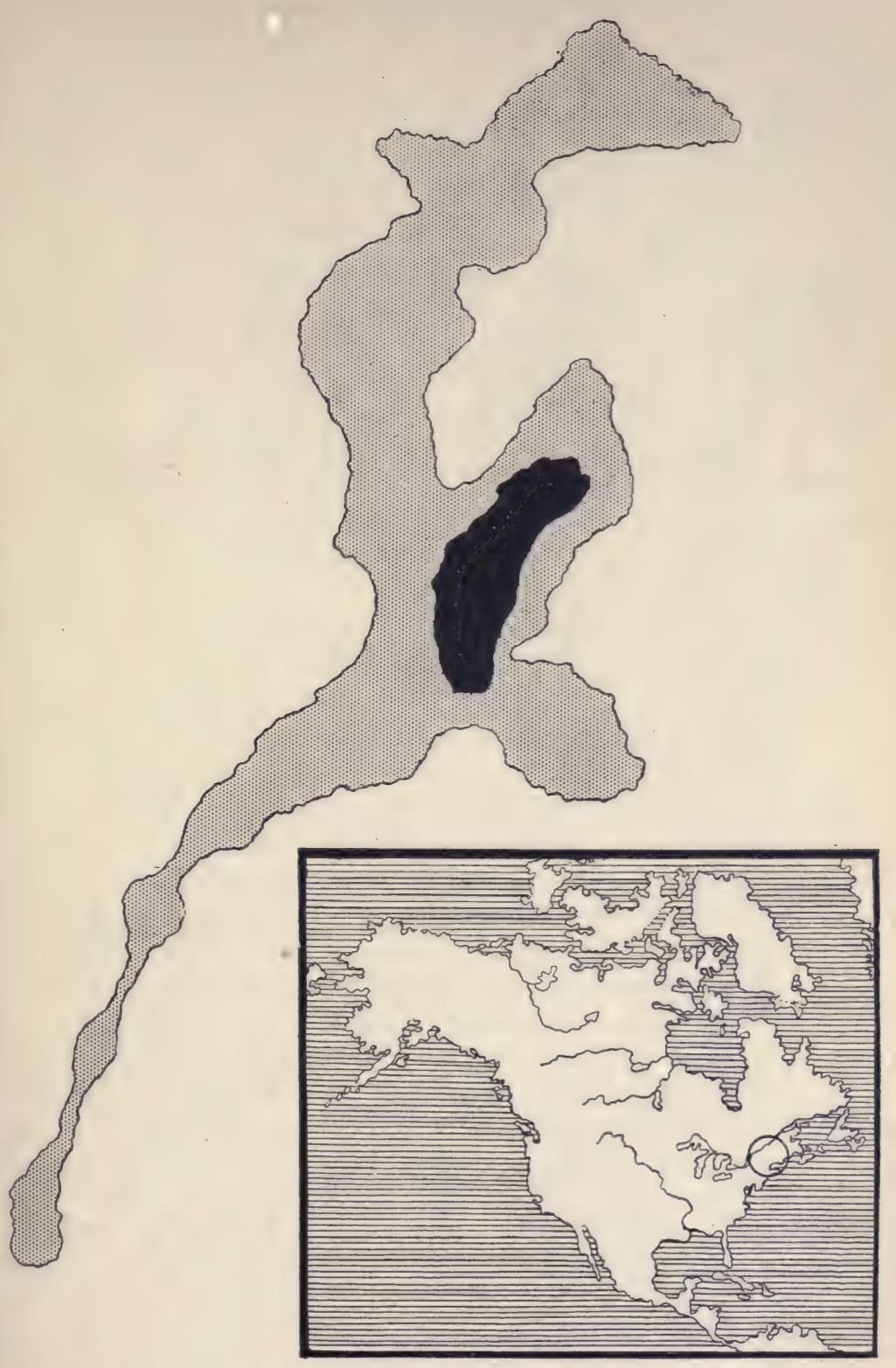

FIG. 4.-Map showing the outlines of the White Mountain Plateau (shaded) and Mount Washington Range (black), with an inset Map of North America, indicating the position of the White Mountains (in the centre of small circle).

[To face $p .36$. 

arctic species occurring on the White Mountain plateau.* Among the beetles, too, and other groups of invertebrates, there are many arctic forms, showing clearly the intimate relationship that exists between the faunas of the White Mountains and Labrador. $\dagger$

Even among mammals we have some most interesting boreal representatives, the White Mountain lemming-vole (Synaptomys sphagnicola) being peculiar to this region. $\neq$ In alluding to the mammalian fauna of Labrador I specially dealt with this genus, and expressed the belief in its aretic origin and subsequent southward dispersal (p. 28).

If merely a few arctic plants and insects inhabited this remarkable plateau, the argument might be permissible that they had been carried southward by wind currents from their northern home at great intervals of time and had successfully established themselves in this manner on the White Mountains, because the latter proved to be uninhabitable by the fauna and flora of the surrounding country. No one, however, who has seriously studied this congregation of animals and plants as a whole, can for a moment entertain such an idea. We must therefore take for granted that a fauna and flora similar to that now existing in Greenland, Labrador and on the White Mountains once extended over a large portion of Canada and at any rate the north-eastern United States. The problem to be solved is, what were the circumstances which led those animals and plants to extend their range so much southwards? The prevalent theories regarding these movements have already been referred to. They are simple enough. Similar ones have been current in Europe for many years past. I shall quote Professor Adams§ again, as his views seem to me to express those generally entertained on this subject. After an allusion to the final northward retreat of the ice which he supposed to have crept down from the north "grinding to pieces everything beneath its awful

* Scudder, S. H., "Distribution of Insects in Now Hampshire," pp. $331-341$.

† Gardiner, F., "Coleoptera of the White Mountains."

† Miller, G., "Mammals of New Hampshire Mountains."

$\S$ Adams, ('harles C., "Post-glacial Origin of the life of NorthEastern United States," p. 309. 
weight," it once more permitted life from the south to move into the newly opened territory. The first wave of life, he thinks, which became dispersed over the glaciated region, as I have already mentioned above, was the barren-ground fauna and flora, the types of the far north. "Hardly a trace," he continues, "now remains in the eastern United States of this pioneer class, and this class is now restricted to very limited areas or mountain top 'islands,' as in the White Mountains. The present distribution of these arctic-alpine 'islands' brings up a number of very interesting points. How is it that these alpine plants and animals are now found so far south and only upon high mountain peaks? This question could not be rationally explained until the influence of the Ice Age upon life became recognised, and would, indeed, be a difficult one to answer if we did not take into consideration past conditions of climate and topography. We must recall that the arctic conditions which now occur outside of the arctic regions only on high mountain tops at that time extended to the very base of the mountains, and as the ice retreated to the north this cold zone gradually moved up the sides of the mountains carrying with it a characteristic flora and fauna. Thus with the retreat of the ice the first wave of life had two evident possibilities before it: first, to follow the ice north, or to follow the cold zone up the mountains. By this means small colonies of arctic plants and animals became. separated from the main body of forms, and thus became alpine. To be sure, this segregation could only occur where the mountain peaks are isolated. If the mountains had been of sufficient height and had extended far to the north, a highway would have been retained to the original stock, and thus the distribution would not have become discontinuous. From the above interpretation it seems fair to conclude that the arctic forms which now occur at alpine heights are relicts of the former widespread glacial fauna and flora, whose distribution has become discontinuous by a change of climate."

Very similar ideas were held by Mr. Grote.* He thought the White Mountain butterfly (Oeneis semidea) was pushed southwards by the advance of the great northern ice-sheet.

* Grote, A. R., "Effect of Glacial Epoch," p. 441. 
On the decline of the ice-sheet the butterflies turned northward, again returning to their native home. Some of the specimens strayed by the way and were destined to plan. colonies apart from their companions as, for example, on the White Mountains.

Botanists entertain analogous views. Dr. Harshberger* argues that the tundra vegetation and other aretic species of plants occupied during the Glacial Epoch the southern margin of the great ice-sheet, and that when most of them migrated north, on the disappearance of the ice, some remained behind to form the vegetation of sphagnum bogs and alpine summits of the higher mountains.

If these theories are correct, the Asiatic invasion and the much more insignificant one from Europe, of which Helix hortensis is one of the most striking representatives (p. 13), should both be more recent than the flora and fauna of the White Mountains, for the former have not penetrated beyond the lower slopes of these mountains.

Helix hortensis does not occcur nearer the White Mountains than Portland in Maine, which is fully seventy miles to the east. I have traced Oniscus asellus, a wood-louse probably belonging to the same group, as far as the base of the White Mountains. The earth-worm, Lumbricus castaneus, which seems to have spread from continental Europe to the Faröes and Iceland, reappearing on the other side of the Atlantic in Canada and New England, may be a member of the same dispersal. At any rate, I feel sure there are a great many more of such species that have not spread to the higher parts of the White Mountains, and therefore proclaim themselves as more recent immigrants than those which are now in possession of the high plateau referred to. The latter are likewise clearly older than the Asiatic immigrants, which will be more fully described later on.

But since Helix hortensis occurs in the lower Pleistocene clays of Maine, it, as well as the whole group of European immigrants, are pre-Glacial in age, and in this opinion I concur with several of the authorities who have discussed this problem (p. 14). The members of this group arrived

* Harshberger, John W., "North American Plant Dispersal," p. 2. 
in America before the time when the glacial drift was deposited, or, in other words, when the northern ice-sheets were supposed to have advanced to their southern limits. The glacial drift, I may mention again, is the mantle of clay, sand and boulders believed to have been left by the ice as it retreated northward. Whether this drift or boulder clay really is the product of immense glaciers, or whether it was deposited in the sea by floating icebergs, it is evident that wherever the country is covered by it the pre-existing fauna and flora must have been destroyed. The evidence seems to me all in favour of destruction rather than emigration.

The idea of a gradual southward withdrawal of the fauna and flora, that they fled like a conquered army before an advancing foe, sounds very plausible, but is there any foundation for such a belief ?

No evidence can be adduced from fossil specimens that any members of what I have called the European invasion ever penetrated southward of the limits of the drift in North America. They do not seem to have been pushed south in front of the advancing masses of northern ice. Theoretically, they ought to have survived the Ice Age somewhere in south-eastern North America. If they did, they must subsequently have reoccupied the very parts, viz., Labrador, Newfoundland and the coast of New England, where they originally set foot on American soil after completing their travels across the North Atlantic land bridge. But is it possible that they quitted the south-eastern States without leaving a trace of their former presence there? As Dr. Harshberger* points out, not a single species of thirty-four plants characteristic of the area just south of the glacial drift deposits, is a native of Europe. On the other hand, of the plants growing on the drift itself, about one-third are common to northern Europe and America. All the available evidence, therefore, points to a survival of the European element within the glaciated area.

Could any islands have existed in the midst of this glaciated area, where this assemblage of European plants and animals

* Harshberger, J. W., "Comparative Age of Floristic Elements," p. 606 . 
might have survived the Ice Age, without being affected by the Ice-sheets?

Labrador was one of the areas which was believed to have had an independent centre of glaciation, yet Professor Daly,* after making a special study of the geology of Labrador, remarked "nothing is more striking in the glacial geology of the southern part of the coastal belt than the almost complete absence of drift deposits." In the Torngat Mountains of Labrador no signs of glaciation were noticeable above 2,000 feet. That there were considerable tracts of Labrador which were free from ice must be evident, and I presume the European plant and animal migrants survived the Glacial Epoch there and also further south. The island of Newfoundland seems to have had quite a separate area of glaciation, and the same was probably true of Nova Scotia, according to Professors Chamberlin and Salisbury. $\dagger$

The two countries of Labrador and Newfoundland have many species of animals and plants in common, and in both no doubt a large part of the pre-existing fauna and flora survived the Glacial Epoch. I have urged in the last chapter (p. 14) that the land probably stood at a much higher level towards the beginning of the Pleistocene Period than at present, the whole of the Bank of Newfoundland, and southward as far as Cape Cod, being raised high above sea-level. While I claim that the remainder of boreal North America has subsequently become largely submerged, these eastern tracts are likely to have remained above water, thus forming an asylum for the survival of the aretic and Old World fauna and flora. This opinion is confirmed by Professor Upham's $\ddagger$ remark that the elevation of the fossiliferous marine beds lying on the glacial drift increases as we proceed north-westward from Boston, that is to say, inland, while along the lower St. Lawrence it decreases again, so that in Nova Scotia actually on the sea-coast marine deposits are wanting.

The current geological theories of the Ice Age or Glacial

* Daly, R. A., "Geology of Labrador," pp. 245-251.

† Chamberlin, T. C., and R. D. Salisbury, "Geology," Vol. III., p. 336.

† Upham, Warren, “Marine Shells near Boston,” p. 140. 
Epoch do not seem to me to harmonise at all with the geographical distribution of animals and plants. If we assume that an arctic climate prevailed at that time all over Canada and the northern United States, we are faced by numerous difficulties. The biological evidence favours the view that the climate in boreal North America, though much more humid than at present, so that it led to extensive glaciation on all higher mountain ranges, was not arctic but temperate, and that in many parts within the so-called glaciated area there existed islands where life was abundant and survived to the present day.

Let us return to the animals and plants inhabiting the White Mountains. Their relationship is almost altogether with Lapland and Greenland, and yet that affinity has clearly been brought about at a much earlier date than that of the arrival of the European element in North America.

During the Pliocene Period movements seem to have taken place resulting in an increased height of land. This need not necessarily have affected the whole of North America. It was probably more or less confined to the north-eastern and northwestern parts. While the closing of the North Atlantic left the coastal districts open to the beneficial influence of the Gulf Stream, the temperate fauna and flora must have gradually disappeared from the more inland boreal parts of the continent, thus leaving room for the expansion of the arctic animals and plants in various directions. It was during the Pliocene Period, I think, or earlier, and, at any rate, long before the commencement of the Glacial Epoch, that the animals and plants from Labrador thus found their way southward to the White Mountains. However, 1 shall bring forward further evidence later on which will throw additional light on the problems I have discussed.

The theory that the animals and plants were driven south of the ice foot or southern margin of the supposed great ice-sheet ought to be supported by biological evidence.

Theoretically it is assumed that the barren-ground or arctic fauna and flora lived close to this margin, as already stated, and the temperate forms further south. The only fossil evidences we possess of arctic animals having actually lived south of the ice-sheet, or, as we might say, south of the limits of 
the drift, are rather problematical. Most, if not all, the occurrences of reindeer and musk ox bones lie within the drift area. As already mentioned, animal remains have been met with in caves and other deposits, close to the limits of the drift, and supposed to belong to the Pleistocene Period, which seem to indicate a climate somewhat milder than the present one.

The most noted Pleistocene fossiliferous strata within the drift area lie in Canada, and these contain largely the remains of plants. Since the first place as tests of climate has generally been assigned to plants, ${ }^{*}$ their testimony will be of particular value in our present enquiries. These deposits have been principally studied by Professors Coleman $\dagger$ and Penhallow. Some are in the neighbourhood of Toronto near the shores of Lake Ontario, others further west near the Moose and Albany Rivers, both of which empty their waters into Hudson Bay.

In dealing with the beds in the neighbourhood of Toronto, Professor Coleman reports that those of Scarboro' Heights contain mosses, diatoms, a few fresh-water shells and a considerable number of elytra of beetles. According to Dr. Scudder the latter, numbering twenty-nine species, are all extinct, and related to species occurring in Lake Superior and Hudson Bay regions, the fauna having a boreal aspect. The fossils from the Don River deposits were found to be surprisingly different. They seemed to point to a climate as warm as that of Toronto, if not much warmer, while the forest trees suggest a temperature far from glacial. Not a trace of an arctio fauna or flora could be discovered. It was concluded, therefore, by Professor Coleman that both these series of beds were inter-glacial, that is to say, laid down during the mild phases which are supposed to have separated the intensely arctic ones from one another.

The plant remains from the other deposits were like those of Scarboro' Heights and Montreal. They were essentially of the same character representing a vegetation similar to that of our own time, or perhaps even a little more severe.

* Seward, A. C., “Fossil Plants as Tests of Climate," p. 10.

+ Coleman, A. P., "Glacial and Inter-glacial Deposits," pp. 625-640.

$\ddagger$ Penhallow, D. P., "Pleistocene Flora of Canada," p. 77. 
Four years later a valuable report on the Pleistocene fauna and flora of Canada was read at the British Association Meeting at Bradford by a committee which had been appointed to investigate the subject. Of this committee, Professor Coleman and Professor Penhallow were members, as well as Sir William Dawson.* The number of beetles brought to light from the Scarboro' Heights had now increased to seventy-two species, of which seventy were pronounced by Dr. Scudder to be extinct. The new species confirmed Dr. Scudder in the opinion, previously expressed, that on the whole the fauna has a boreal aspect, though by no means so decidedly boreal as one would anticipate.

No less than eighty-three species of plants were studied from eighteen different localities, one of the plants, viz., Acer pleistocenicum, being extinct. The abundant occurrence of some species, such as the Osage orange (Maclura aurantiaca), the paw-paw (Asimina triloba) and others, point to the prevalence of a much warmer climate than now prevails. On the other hand, the equally abundant occurrence of boreal types at Scarboro' Heights suggests the existence of a cooler climate at the time these deposits were laid down.

Once more, in 1907, Professor Penhallow $\dagger$ dwelt upon the results of his researches on the plant remains of the Don River beds, urging that the same flora must have characterised the entire region between Virginia and Ontario in Pleistocene times, whilst a much warmer climate than at present prevailed.

If similar evidence were brought to light from any other deposit than the Pleistocene, there can be no doubt as to the conclusions that would be drawn from it. The climate in boreal North America during the Pleistocene Period, as revealed by the plant and animal remains, must have been on the whole a temperate one. Yet geologists maintain, in the face of this testimony, that all these plant and animal remains only represent the so-called interglacial phase of the Glacial Epoch, during which the climate was supposed to have been temperate or mild. The other phase of the Ice Age, they

* Dawson, J. W., D. P. Penhallow and others, "Canadian Pleistocene Fauna and Flora," p. 334-338.

† Penhallow, D. P., “Pleistocene Flora of Canada,” pp. 443-450. 
argue, has left no traces of animal or plant life in all the numerous deposits which have been examined.

The whole conception of these interglacial phases of the Glacial Epoch has given rise to a good deal of animated discussion. Professors Chamberlin and Salisbury have adopted Professor James Geikie's view that there were six great advances and retreats of the ice-sheets, separated by five interglacial intervals, during which a mild climate prevailed. But the evidences for these alternate advances and retreats of the glaciers are by no means admitted as valid by all geologists. Some maintain that there were only three such great advances and retreats. Others admit only two of them. Some authorities disbelieve altogether in mild interglacial phases, and admit only one advance followed by a gradual retreat of the ice. Even after studying the Toronto clays, which Mr. Lamplugh * acknowledges impressed him strongly as affording the kind of evidence which he has sought in vain in Britain, he is still of opinion, as expressed in his address to the Geological Section of the British Association, that there is no proof of mild interglacial epochs, nor even of one such epoch.

My own conclusions as to the nature of the Glacial Epoch, and the causes that produced the glacial clays, being almost entirely based on the evidence derived from the past and present fauna and flora, I have no hesitation in agreeing with Mr. Lamplugh's views. There is no biological evidence in North America in favour of one or more interglacial phases. Everything moreover points to the fact that during the socalled Glacial Epoch there was no diminution of temperature, or if so only a very partial one, although the higher mountain ranges were covered by glaciers. In many parts of North America there was probably a higher temperature during the Ice Age than obtains at present. The first to advocate the idea of a higher mean temperature being compatible with a greater extension of glaciers was, I think, Professor Lecoq. $\dagger$

Much more recently a similar theory was very ably main-

* Lamplugh, G. W., "On British Drifts and the Inter-Glacial Problem," p. 26.

† Lecoq, H., "Des Glaciers et des Climats." 
tained by Professor Whitney.* and was supported by weighty arguments, while Sir Henry Howorth $†$ has contributed additional testimony in favour of a mild climate having prevailed during the so-called Glacial Epoch or Ice Age.

That extensive glaciers existed during that Epoch in western Europe and north-eastern North America is primarily due to the closing of the North Atlantic. This produced a rise of temperature in the Atlantic Ocean and intense precipitation over western Europe, particularly Scandinavia, and also over north-eastern America, especially Labrador. As Professor Whitney observes, the regions mentioned are the only two in the world in which the topographical and climatic conditions seem to have been considerably different during the Glacial Epoch from what they are at present. The prevailing opinion, however, among geologists is, that not only was there a centre of glaciation in Labrador, but also in the Keewatin district to the west of Hudson Bay. The latter being a perfectly flat region, without even a suggestion of a mountainous nucleus, constitutes, indeed, as Professors Chamberlin and Salisbury $\ddagger$ acknowledge, one of the most marvellous features in ice dispersion. All our notions as to the behaviour of glaciers are derived from careful observations on existing ones. But nowhere on earth can a glacier be seen which, having originated on level land and developed quite independently of any adjacent higher region, proceeds to invade the neighbouring areas. Hence a biologist may be excused for expressing some hesitation in accepting so extraordinary an hypothesis in spite of the fact that we are assured that the days of reasonable doubt as to the former existence of these almost inconceivably large ice-fields are past.

To attempt even to discuss all the various lines of evidence which have led to the almost general acceptance of the land-ice theory, as understood at the present day, would be impossible in a work of this nature. I only wish to bring forward some of the chief reasons which have prevailed upon me to reject this theory. I gan scarcely venture to hope that

* Whitney, J. D., “ Climatic Changes,” p. 321.

† Howorth, H. H., "Ice or Water," Vol. II., p. 492.

† Chamberlin, T, C, and R. D. Salisbury, "Geology," III., p. 332. 
my criticisms will be readily accepted, yet they may possibly help in clearing up some points which hitherto could not be satisfactorily elucidated by other methods. The vast drift deposits which shroud the country like a great mantle of clay, sand and stones, frequently contain the remains of the exclusively marine group of foraminifera. Mr. Joseph Wright, a well-known European authority, has shown that the species of foraminifera have a very wide distribution in European boulder-clays. And it appears, on the authority of Sir Henry Howorth,* that Mr. Wright has likewise identified foraminifera from American glacial clays. Samples were submitted to him by the late Dr. G. Dawson from Saskatchewan River, 1,850 feet above sea-level, from Selkirk in Manitoba, and from Ottawa. The sample from Saskatchewan contained specimens of foraminifera referable to recent species, one of which (Nonionina depressula) is also common in European boulder-clays.

It is quite possible that foraminifera may be found in many other localities in the same clays; indeed, Sir Henry Howorth mentions that Sir William Dawson had found them generally diffused in the Pleistocene clays of Canada. This fact, therefore, tends to support Colonel Feilden's $\uparrow$ contention that all the glacial deposits, which he had examined in Arctic and Polar lands, with the exception of terminal moraines now forming above sea-level, are glacio-marine beds.

Supposing the waters of the Arctic Ocean had risen, perhaps in consequence of the closing of the Atlantic Ocean, and had poured into Hudson Bay, overflowing its banks, and had then crossed the low-lying watershed separating this northern region from the depressions of the Great Lakes, the latter would soon have been filled with brackish water, killing or driving away many of those forms of life that were unable to adapt themselves to this change of conditions. I presume, of course, that troughs, not necessarily like the lakes now existing, already occupied the same region in preGlacial times. Such an hypothesis of this area having been invaded by the sea in Pleistocene times is supported by some

* Howorth, H. H., "Ice or Water," Vol. II., p. 216.

† Feilden, H. W., " Glacial Geology of Arctic Europe," p. 57. 
biological evidence, though it is usually argued that the ocean crept inland through the St. Lawrence or Hudson River Valley.

Fifty years have elapsed since Professor Lovén * first drew attention to the presence of several crustaceans, allied to marine forms, in Swedish lakes, and endeavoured to prove that the latter must have been covered by the sea in recent geological times. One of these crustaceans is the fresh-water shrimp Mysis relicta, closely related to the common Arctic marine form Mysis oculata. Since the latter does not occur in the Baltic, the theory that Mysis relicta is a recent immigrant from that sea is untenable. It seems much more probable. that it gradually developed from its marine relative Mysis oculata, when the Arctic Ocean covered the lowlands of northern Russia, Sweden and northern Germany. This view is confirmed by the fact that Mysis relicta has now been discovered, along with other marine organisms, in several lakes, all of which are situated within the area covered by the north European drift. I have also alluded to its occurrence in Lough Neagh in Ireland. $\dagger$

Now it is of great interest that this small fresh-watier shrimp Mysis relicta, which is so closely related to a marine species, should also occur abundantly in Lakes Superior and Michigan. First discovered in the stomach of a Coregonus taken in Lake Michigan by Dr. Hoy, it was subsequently met with by Dr. Stimpson, $\ddagger$ living in about fifty fathoms of water in the same lake. It has since been noticed in Lake Superior by Messrs. Smith and Verrill, but in no other of the Canadian lakes. This is in so far significant, as neither of these two lakes are supposed to have been invaded by the sea in Glacial and post-Glacial times. All that geologists acknowledge is that the sea crept up the Hudson River and the St. Lawrence, as far as the western end of Lake Ontario. The latter and Lake Champlain had then a marine fauna, and it is there that we should expect Mysis relicta to occur.

But besides this fresh-water shrimp, another small

* Lovén, S., " Über einige Crustaceen."

† Scharff, R. F., " European Animals,” p. 155.

† Stimpson, A., “Fauna of Lake Michigan,” p. 403. 
crustacean, called Pontoporeia hoyi, allied to a marine form, inhabits the Lakes Michigan and Superior, while in the former still another marine form (Pontoporeia filicornis) and a remarkable fish called Triglopsis thompsoni have been met with.

Professor Peschel first applied the term "relict lakes" * to lakes like those referred to, because they contain the relicts of a former sea, and the word has since been largely adopted in the sense in which it was first proposed. Nevertheless, some authorities, notably Professor Credner, $\uparrow$ who treated the subject most exhaustively, maintain that these so-called relict animals have either immigrated to the freshwater lakes directly from the sea, or have been transported from their marine habitat by accidental means. He notes with surprise the absence from all the so-called relict lakes of marine mollusks or species allied to such, contending that some of them ought to be found in these lakes, if the latten had ever been covered by the sea. Professor Credner's arguments against the relict nature of such lakes as Superior and Michigan, seem at first sight very convincing. But zoologists are now well acquainted with the fact that all marine mollusks have free-swimming larvae. These being altogether a prey to currents would infallibly be swept into the sea if placed into running fresh water. Thus the parent marine mollusks would be unable to propagate their kind in fresh water even if they could adapt themselves to it. This circumstance seems to account in a satisfactory manner for the absence of marine mollusks from relict lakes. Quite apart from this objection to the relict theory, Professor Credner's contention of an active migration of marine organisms to fresh water is particularly inapplicable in the case we have been considering, because none of the "relict species" alluded to occur in the lower lake of Ontario, which, moreover. is separated from the upper lakes by the impassable Niagara waterfall. It is of interest also to note that the only other locality in which the fish Triglopsis thompsoni has been taken, besides that of the Great Lakes, is in tidal pools on the west coast of Hudson Bay.

* Peschel, O., "Vergleichende Erdkunde," p. 167.

† Oredner, R., " Reliktenseen," I., p. 105.

L.A. 
Other species of fishes related to marine forms live in the Great Lakes. But we need not suppose that typical freshwater fishes are absent. The family of Cyprinids, those essentially fresh-water fishes to which the carp belongs, is well represented there. Hence if we suppose that they were destroyed during the invasion of that region by the sea, the lakes must, at a subsequent period, have been freely connected with rivers which were stocked with fresh-water fish. And it appears that this actually has been the case.

Whether the St. Lawrence was choked by obstructing ice masses, or whether it was filled with detrital matter carried down from the neighbouring eastern heights, does not affect our present inquiries. It seems that after the ice, or, if we prefer it, after the retreating sea, had left the district, there were only three lakes instead of the five as at present. These three lakes, which have been called "Duluth," "Chicago" and "Maumee," were independent of one another. Lake Duluth emptied its waters into the Mississippi, Lake Chicago excavated an outlet which has since become the Chicago drainage canal, while Lake Maumee communicated with the Wabash River. All, of course, eventually helped to swell the waters of the Mississippi. Lake Maumee gradually developed into the huge Lake Warren. Later on the other lakes joined, and poured their waters into Ontario, which then communicated with the Hudson by means of the Mohawk River. It was only then that the sea finally broke down the barrier which had prevented an overflow into the St. Lawrence, and advanced as far as the western end of Lake Ontario, one marine channel communicating with the Atlantic by way of the Hudson Valley.

We can easily imagine how the fresh-water fishes of the north, which were either killed or driven south, such as the redfin (Notropis cornutus) and Notropis atherinoides (it does not seem to possess a common name) managed to return to their northern stations after the Glacial Epoch. Yet I feel sure that a survival even of some fresh-water fishes took place within the drift area in some of the eastern mountain ranges. Near Freeport in Maine, quite an isolated colony of the beautiful red-bellied dace (Chrosomus erythrogaster) occurs. This is probably a pre-Glacial relict. Nor is it likely that 
the silver chub (Semotilus corporalis), which only frequents clear streams, could have spread in post-Glacial times from the south-eastern counties to the St. Lawrence basin. Two more examples might be mentioned that are practically. confined to the drift area and they are among the most interesting geographical puzzles of North America.

The first of these is the mud minnow (Umbra limi), a small minnow-like fish frequenting muddy and reedy ponds near the Great Lakes as far east as Quebec. A closely allied species lives in streams and ponds in the eastern States from Connecticut to South Carolina. The only other relative of these two little fish, in fact the only other member of the family of mud-minnows (Umbridae), is Umbra krameri found in Hungary. Dr. Gill* gives a most interesting account of their habits.

Blanding's pond tortoise (Emys blandingi) is the second example I have in my mind. It is a small species, the black carapace or shell being dotted all over with numerous yellow spots. It is entirely confined to the drift region from Wisconsin in the west to New Hampshire in the east. It agrees with Umbra in so far as its only relation inhabits Europe. The European species (Emys orbicularis) is common in central and southern Europe. A map of its range is given in my work on the European animals. $\dagger$

A more striking instance of a case of survival within the glaciated, or drift area, is afforded by the fresh-water pearlmussel (Margaritana margaritifera). Being an immensely ancient species which no doubt originated in North America, it has taken advantage of old land connections to invade Europe and eastern Asia. In North America it occurs within the ancient eastern land-mass in several localities, notably in Labrador, on Newfoundland and Anticosti Islands, in the Quebec province and in New England. $\neq$ From its western station in the lower Saskatchewan it is separated by a tract of over one thousand two hundred miles in which it is unknown. This discontinuous distribution implies

* Gill, Theodore, "The Umbras."

† Scharff, R. F., " European Animals," p. 179.

$\ddagger$ Walker, Bryant, "Distribution of Margaritana margaritifera," p. 127. 
the destruction of the species in the drainage area of the Upper St. Lawrence. What other cause but the Glacial Epoch can be assigned for this partial destruction? And in explanation of this and other similar cases it seems reasonable to conclude that certain areas within the drift region were entirely free from the devastating agency, be it land-ice or the sea, which destroyed so much of the preexisting fauna and flora. We might argue, of course, that the pearl-mussel had advanced northward in two independent streams in post-Glacial times, one along the Mississippi valley and the other along the Atlantic coast, and that they had thus reached the northern habitats alluded to. But quite apart from the difficulties connected with pushing its way along the coast from river to river, there seem to me to be no grounds for such a supposition. The fact that Margaritana margaritifera is the only fresh-water mussel (Naiad) belonging to the Atlantic river system which is now found living within the Mississippi drainage area, shows how inconceivably slowly these mollusks spread. The fresh-water mussel fauna, so characteristic of the Mississippi drainage area, is believed to have descended in a scarcely broken line from that of the Cretaceous Period, and many recent forms are only distinguishable with difficulty from those that lived in those remote times.

However, the question of survival or non-survival in the drift area is not confined to the instance alluded to. Lampsilis (Unio) borealis, Lampsilis superiorensis, Anodonta marginata, Anodonta kennicotti, and Anodonta pepiniana are all restricted in their range to the drift area, and are not known to have ever lived outside it.*

There is no doubt ample zoological evidence for the assumption that many species of vertebrates and invertebrates survived the Glacial Epoch within the area commonly supposed to have been covered by vast ice-masses. But there is another important point which the geographical distribution of the fresh-water pearly mussels may elucidate. Several times I have referred to the theory that in pre-Glacial times the land between northern Labrador and eastern Massa-

* Simpson, C. T., "Synopsis of pearly freshwater mussels." 
chusetts was raised to a much higher level than it is now, and that it has gradually sunk to its present position. If this had been the case, the rivers on the western side of this highland would have drained westward and would have formed part of the Mississippi drainage, while the eastern streams would have emptied their waters straight into the Atlantic. The latter ought therefore to show distinct signs in the composition of their fauna of having been isolated from the Mississippi drainage system. Dr. Simpson describes the fresh-water pearl-mussels of the Mississippi drainage system as large, ponderous and ornamented with beautiful and odd patterns of colour and sculpture. The waters that drain into the Atlantic on the other hand are inhabited by a totally different set of mussels. They are moderate in size, frail and not remarkble for either colour or sculpture. Only very few of the eastern species extend westward to the head waters of the St. Lawrence.*

In the interesting report on the Pleistocene fauna and flora already cited, there is a list of twelve species of fresh-water mussels that have been observed in the Don valley deposits. None of them belong to extinct species, though it is a significant fact that nearly one half of them no longer inhabit the St. Lawrence drainage, being now confined to the Mississippi and its tributaries. $\uparrow$

This certainly implies that the Mississippi was more intimately connected with the upper St. Lawrence system in early Glacial and probably in pre-Glacial times than it is now, for it is not unjustifiable to assume that these southern forms found their way northward before the commencement of the Glacial Epoch. It is possible that those southern species, found in the Don deposits, which still have a wide range in Canada, may have survived the Glacial Epoch in that country. Dr. Simpson $¥$ pointed out that almost all the Mississippi valley species of mussels now living in St. Lawrence drainage area have become more stunted and more simple in outline, while their characteristic sculpture and colours are

* Simpson, C. T., “On some Fossil Unios.” pp. 591- 592.

$\dagger$ Dawson, J. W., D. P. Penhallow, \&c., "Canadian Pleistocene Flora and Fauna," p. 331.

† Simpson, C. T., “On Mississippi Valley Unionidae,” p. 384. 
nearly obliterated. This change in form is so striking, says Dr. Simpson, that many of these northern races of Mississippi mussels have been described as distinct species. Dr. Simpson is of opinion that this remarkable change in form among the Mississippi species inhabiting the St. Lawrence drainage system has been produced since the Ice Age began to draw to a close, because, he argues, it is almost certain that all fluviatile and lacustrine life under the ice sheet was destroyed.

The prevalent geological opinions as to the nature of the Ice Age thus dominate all biological thought in reference to problems of distribution. If we emancipate ourselves from these pre-conceived notions in our speculations on the origin of the existing fresh-water mussel fauna, we must arrive at different conclusions.

Two almost diametrically opposed theories have been propounded to explain the origin of the geographical features of the river system of north-eastern North America in preGlacial times. According to Professor Grabau,* Mr. Warren Upham and Professor I. C. Russell are of opinion that the greater part of the Laurentian basin formerly discharged its waters southward to the Mississippi. With this view Professor Grabau agrees. Much of the Archaean region in north-eastern North America must have stood greatly higher than at present, the slope of the land being toward the south-west. Two great rivers then existed, according to Professor Grabau, in place of the present Great Lakes, the Saginaw and the Dundas Rivers, both of them draining into the ancient Mississippi. Dr. Spencer is in agreement with Dr. Grabau in so far as he contends that the land stood at least two thousand feet higher than at present. He differs from the other writers in his belief that the lake region and the more north-easterly highlands were equally affected by the uplift, so that the rivers which replaced the lakes in pre-Glacial times drained into the St. Lawrence just as the waters from the lakes do now. $\dagger$

The first of these two theories seems to me to explain the origin of the eastern fauna in a satisfactory manner. The

* Grabau, A. W., "Geolugy of Niagara Falls," pp. 42-54.

† Spencer, J. W., "Falls of Niagara," pp. 400-405. 
other does not. We may suppose that the species inhabiting the Mississippi during the period preceding the Ice Age were not precluded from advancing up stream towards the highlands of Labrador. But only the hardiest forms, those that could adapt themselves to waters probably brackish and laden with mud, might have succeeded in surviving, though not without becoming stunted in form and undergoing various other changes. Such forms as the pearl-mussel (Margaritana margaritifera), accustomed to pure mountain streams, only survived in isolated localities in the eastern and western parts of its range, becoming extinct in the central parts, where the conditions must have been less favourable for its survival.

Let us now examine the land fauna of another part of this north-eastern Archaean land surface which is supposed by Professors Upham and Grabau to have stood at a relatively much higher level to the lake region than it does at present. Labrador has been amply dealt with, but Newfoundland, which must have been completely isolated from the mainland for some time past, being a large island situated at the mouth of the mighty St. Lawrence River, ought to contain some interesting pre-Glacial relicts. We have no reason to assume that Newfoundland has been connected with the mainland since the passing away of the Ice Age, nor is there any evidence to show that mammals or other terrestrial vertebrates have reached the island by swimming across the Strait of Belleisle or down the St. Lawrence. Geologists tell us that Newfoundland was not overridden by the huge Labradorean glacier, but that it had a system. of local glaciers quite independent of those of the mainland. Even if all the higher parts of the island had been buried in snow and ice, tracts of land near the coast must have remained free from ice, as in Greenland, and so have given shelter to the survivors from pre-Glacial times. This view is certainly strengthened by the fact that all the mammals hitherto observed on the island belong to well-marked varieties or species peculiar to it. The Newfoundland caribou, the only deer inhabiting the island, has antlers differing conspicuously from those of other races of reindeer, and many authorities now recognise it as a distinct species under the 
name of Rangifer terraenovae. All reindeer are expert swimmers, yet the Newfoundland reindeer or caribou has never been known to cross over to the mainland. The following other species of mammals are all peculiar to Newfoundland. The Newfoundland musk rat (Fiber obscurus), the Newfoundland vole (Microtus terraenovae), the Newfoundland arctic hare (Lepus bangsi), the Newfoundland lynx (Lynx subsolanus), the Newfoundland fox (Vulpes deletrix), the Newfoundland otter (Lutra degener), the Newfoundland marten (Mustela atrata). A bear and a wolf are also said to oocur.

The fauna of Newfoundland, moreover, is characterised by the remarkable absence of all such mammals which we might reasonably expect to have come from Asia in comparatively recent geological times, such as the moose, wapiti deer, brown bear and many smaller species. The island does not seem to have been affected by the great stream of new-comers which poured into the country and reached other parts of eastern America, such as Nova Scotia.

In speaking of the present land bird fauna of Nova Scotia, Dr. Trotter argues that it was derived from two faunal stocks, a more primitive boreal one which occupied the region from remote times, and a later transition fauna which invaded the peninsula since the re-elevation of the previously sunken isthmus. He speaks of this as a "venturesome statement," yet he suggests that many boreal types belonging to the genera Pinicola, Carpodacus, Loxia, Spinus, Sitta, Regulus, Certhia and Parus may have occupied Nova Scotia even during the Glacial Epoch, since glaciers do not preclude forest growth, while food must have been abundant during the short breeding season.*

It has been my intention in this chapter to briefly direct attention to the extreme north-east as one of the salient bio-geographical features of the American continent. More than fifty years ago Professor L. Agassiz spoke of "the zoological island of New England," which he described as encircled by a uniform combination of fresh-water animals,

* Trotter, Spencer, "Land Bird Fauna of North-Eastern America," p. 226. 


\section{ANIMALS OF NEWFOUNDLAND}

being itself isolated in character and approaching more to that of the Old World.* He was then unaware that this zoological island, which his keen insight and judgment had recognised, extended really far to the north of New England, that it formed part, in fact, of the north-western prolongation of the European continent in late Pliocene times, preserving until the present day many characters in common with the Old World.

* Agassiz, L., "Fishes of the Tennessee," pp. 363-364. 


\section{CHAPTER III}

\section{THE CANADIAN NORTH WEST}

Leaving Newfoundland, the St. Lawrence and the region of the Great Lakes on our north-westward travels, we now enter the drainage area of the mighty Mackenzie River which conducts its muddy waters to the Arctic Ocean. We know from Mr. A. H. Harrison's * recent exploit that it is possible to journey down the one thousand eight hundred miles from the Athabaska landing and reach the Arctic Ocean entirely by boat. But we obtain a better idea of the fauna and flora of this vast Athabaska-Mackenzie region by crossing the country on foot, or by a perusal of the excellent report lately published by the biological survey of the United States Department of Agriculture. The task of furnishing this report was entrusted to Mr. Edward A. Preble, $†$ a naturalist who already had the advantage of accomplishing the difficult survey of the Hudson Bay region, and who had shown himself possessed of the necessary qualifications for such an undertaking.

The Mackenzie basin comprises a vast region of nearly 700,000 square miles, or about six times the size of the British Islands. As is usually the case in regions covered by glacial drift, the country is studded with innumerable fresh-water lakes extending in a more or less connected system from Lake Superior to the Arctic Ocean. With the exception of a large area in the north, which is mainly outside the actual drainage basin of the Mackenzie, much of this region is entirely covered with forests. The principal trees are white and black spruce, the canoe birch, tamarack, aspen and balsam

* Harrison, A. H., "In Search of a Polar Continent."

+ Preble, E. A., "Athabaska-Mackenzie Region." Compare also Macfarlane, R., "Mammals of North-West Territory." 
poplars, Banksian pine and balsam fir. With these are associated, generally in the form of undergrowth, a variety of shrubs, some of which have a continuous distribution through the forest zone, whereas others are more or less restricted in range. But the whole region between Hudson Bay and the mouth of the Mackenzie River is by no means all forested. North of a line drawn from the mouth of the Churchill River to the mouth of the Mackenzie, the country belongs to what are known as the "barren-grounds," which have already been alluded to in previous chapters. "They are largely covered with short grass, moss and small flowering plants interspersed with patches of sedgy or peaty soil on which grow Labrador tea, crowberries, dwarf birches, and willows. Both flora and fauna, in fact, remind us vividly of certain parts of Greenland and Labrador.

The only large mammals, as in Greenland, are the barrenground caribou and the musk ox. The former is simply spoken of as the "deer" by the northern hunters. Zoologically it belongs to the barren-ground form (Rangifer arcticus) which, as I remarked, seems to be closely allied to the Greenland reindeer. It is not so with the musk ox, as Dr. Kowarzik has recently shown. After a very careful and extended examination of a number of skins and skulls of musk oxen from this region, he was able to show that they differed from those living elsewhere by the possession of a deep lachrymal pit and two mammary glands. The Greenland musk ox, which belongs to the eastern group, has no lachrymal pit and four mammary glands. There are other minor differences clearly proving that Dr. Kowarzik's * Ovibos moschatus mackenzianus is much more than a mere race. It is, in fact, a species perfectly distinct from the one inhabiting Greenland. In spite of these differences, the casual observer is easily misled by the apparent external resemblances among all the musk oxen.

The general similarity in the fauna of the Mackenzie region and that of Greenland is by no means superficial, and holds good to some extent even among the smaller kinds of beasts. The aretic hare seems much like the Green-

* Kowarzik, R., “Der Moschusochs und seine Rassen,” p. 120. 
land hare, and the lemmings resemble the creatures we have already met in the same country. Yet there are two perfectly distinct kinds of lemming in these barren-grounds. In winter they are easily discriminated since one of them does not change its rusty brown fur, while the other (Dicrostonyx hudsonius) becomes white all over. The former we have not met with before. It neither occurs in Greenland nor in Labrador, and appears to be a more recent immigrant to North America. This supposition is strengthened by the fact of the occurrence of this lemming (Lemmus trimucronatus) from Alaska as far east as Melville Peninsula. In Alaska even another species of the same genus (Lemmus minusculus) occurs, and on the Pribilof Islands still another, the black-footed lemming (Lemmus nigripes) Beyond Bering Strait in eastern Asia other kinds make their appearance, whilst in Europe the common lemming (Lemmus lemmus) was well known long before the days of Linnaeus. Its remains having been discovered in many European caves along with those of other arctic animals, it is not unreasonable to assume that the genus Lemmus is of Old World origin and one of the many Asiatic immigrants that have invaded the North American continent in the past, though only a few of the latter have chosen the inhospitable barren grounds for their home.

Another new form which we have not met with before is the ground squirrel known as the Hudson Bay spermophile (Citellus parryi). It is abundant all over the barren-ground region alluded to, the earth being occasionally riddled with their burrows. These "spermophiles " or "gophers" as they are sometimes called, occupy a somewhat intermediate posi. tion between squirrels and marmots. Numerous species are known from North America, altogether about forty. In Asia and Europe there are fewer kinds of spermophiles, yet they. do occur, and this circumstance, while tending to prove once more that Bering Strait was dry land, renders the search for the original home of the genus more difficult. The fact that in Europe Citellus(Spermophilus) only inhabits the east, having invaded the continent in Pleistocene times, and then retreated again towards the country whence it came, points to Asia as the home of the spermophiles. On the other hand, 
the remains of Citellus douglasi have been recorded from Potter Creek cave in California, and those of Citellus tridecemlineatus from the Conard fissure in Arkansas. Both of these deposits are regarded as Pleistocene in age.* If these caves were in Europe they certainly would be held to be preGlacial, for about fifty per cent. of the species contained in them are extinct, while Mastodon, Megalonyx and other ancient forms accompany the spermophiles in the Californian cave. The two spermophiles alluded to are still living in North America and have a wide range. If the genus had invaded Alaska from Asia in Pleistocene times, it is scarcely credible that there would have been time for the development of the two species and their enclosure in these distant caves within the Pleistocene Period, especially when we consider that the whole of Canada is believed to have been buried under a thick mantle of ice. It is possible, of course, that there were two distinct invasions into North America of the genus Citellus, one having entered from the west, as I shall explain later. on, in Miocene times, the later one from the north-west towards the end of the Pliocene Period.

Among the carnivores of the barren grounds, the barrenground bear (Ursus richardsoni), the wolverine (Gulo luscus), and the barren-ground wolf (Canis occidentalis albus) are the most noticeable.

I have scarcely as yet attempted to bring the study of the geographical distribution of birds within the scheme of this present work, partly because our knowledge of their past history is so defective in comparison with that of many other groups, and partly because mountain ranges or narrow channels of the sea do not as a rule afford effective barriers to their dispersal. Occasionally, however, birds are extremely circumscribed in their range, and there can be no doubt that a study of their geographical distribution is well worthy of careful attention. If I had not a superabundance of better material for my purpose, I should gladly dwell a little longer on the problems suggested by their range. Many of them, however, are quite useless for our purpose, loons and auks, for instance, two groups of arctio birds attached to the sea coast. Many

* Brown, Barnum, "Conard Fissure," pp. 166-167. 
others are circumpolar but too migratory. Only the genus Lagopus is of special interest, because it occurs in all the regions and countries so far discussed. It includes the American and Old World ptarmigans and the European grouse, all of which are more or less permanently resident in the countries they inhabit.

The willow ptarmigan (Lagopus albus) breeds in the barren-grounds and further south. It has a very wide range, inhabiting northern Asia, northern Russia, and northern and central Scandinavia. It is not found in Greenland or Newfoundland, being replaced there by the rock ptarmigan (Lagopus rupestris). The latter also lives in Iceland, western Asia, arctic America and Japan. The third American species is the white-tailed ptarmigan (Lagopus leucurus) which frequents the Rocky Mountain summits from Alaska to New Mexico. It is sometimes called the "white or snowquail." Besides the willow ptarmigan, we have in Europe the common ptarmigan(Lagopus mutus), the red grouse(Lagopus scoticus), peculiar to the British Islands, and Lagopus hyperboreus of Spitsbergen and Franz Josef Land. Long ago I ventured to express the opinion that the genus Lagopus was of North American origin having thence spread to Europe and Asia.*

Dr. Stejnegert has since pointed out that, by an unfortunate oversight, I had included Greenland in the range of the willow ptarmigan instead of the rock ptarmigan. He also argued that the willow ptarmigan of Scandinavia is more likely to have originated from the British red grouse than, as I thought, vice versa. Though I still believe that the genus had a North American ancestry, I quite concur with Dr. Stejneger in the view that the points he raised cannot be reconciled with the conclusions I formerly arrived at. The subject is certainly worthy of further careful study. At any rate, this instance shows clearly the much greater difficulties we have to contend with in tracing the geological history of birds than that of mammals.

As we proceed southward from the barren-grounds we first

* Scharff, R. F., “ History of European Fauna,” p. 336.

† Stejneger, L., "Scharff's European Fauna," p. 105. 
enter a belt of more or less stunted timber before reaching the real forest. Yet even here quite a number of new forms of animal life are met with that are quite absent in the more northerly districts. They are mostly species occurring also in the forest zone of western Labrador. In referring to them in the last chapter, I alluded more fully to the geological history of the moose (pp. 32-33), but I dwelt also on the fact that the flying squirrel, musk rat, chipmunk, woodchuck and others made their appearance as soon as we entered the forest from the east. And it is precisely these forms of animal life that make such a change in the appearance of the fauna as we leave the Mackenzie region barren-grounds on our way to the great Canadian forest region.

The flying squirrel (Sciuropterus sabrinus) of northern Canada and arctic America is also found further south. Other species of the same genus inhabit the United States. The skin at the sides of its body extends between the limbs in suchi a manner as to act like a kind of parachute, but nothing in the nature of actual flight takes place. The flying squirrel is rarely seen, being an entirely nocturnal creature. The distribution of these flying squirrels is decidedly interesting. They are found from Florida to Alaska, and are only known as fossils from the Potter Creek Cave in California. They have almost certainly been in the country since Pliocene times. Hence Sciuropterus yukonensis, which is peculiar to Alaska, has, in all probability, survived the Glacial Epoch in that country. On the western side of Bering Strait, in Kamchatka, another species is found whose range extends westward as far as Scandinavia. Southward, as we cross China into Burma and India, we still encounter species of flying squirrels, and even on the islands of Java, Sumatra and Borneo. And all these belong to the same genus Sciuropterus. Such an extensive distribution implies that the genus must be an ancient one, and, indeed, we are acquainted with several species of Sciuropterus from the Miocene and Pliocene deposits of France. This in itself is no proof that the flying squirrels originated in Europe. They may have spread there from Asia in later Tertiary times and have subsequently died out in Europe, only to be re-established more recently from a later Asiatic invasion. In any 
case, the presence of flying squirrels in America seems to be due to a migration from Asia, and that this took place at a time when a land bridge existed between the two continents is evident.

The musk rat (Fiber zibethicus) * derives its popular fame chiefly from the fact that thousands of its skins are annually, exported from North America by the fur traders. Having. adopted the more attractive name of "musquash" for these skins, the dealers have no difficulty in disposing of them. Like beavers, these creatures inhabit subterranean burrows on the banks of lakes and streams, and are expert swimmers, yet they, are really more allied to the voles. Varieties of the common musk rat are met with from the Mackenzie River to Labrador and southward as far as New Mexico. In the Yukon district and westward Fiber spathulatus replaces the common musk rat; and far to the east in Newfoundland the district dusky musk rat (Fiber obscurus) occurs. Only two other living kinds of musk rat are known to science. One of them inhabits the State of Oregon, the other the dismal swamp in Virginia. This genus, therefore, is one of the most typically North American we have noticed so far, and no doubt it has originated in North America. This view is entirely confirmed by fossil evidence, for no musk rat remains are known outside North America. The common musk rat has been observed in the Pleistocene deposits of South Carolina, New Jersey, and Pennsylvania, while the jaw of an extinct species (Fiber annectens) has been found by $\mathrm{Mr}$. Barnum Brown $\dagger$ in the Conard fissure of Arkansas. The remarkable circumstance about this jaw is that the teeth it contains strongly resemble those of Neofiber, a sub-genus of Microtus. Hence this cave species forms a connecting link between the genera Fiber and Microtus, and this fact supports the opinion I ventured to put forward (p. 29) as to the American origin of the latter.

Before describing some of the other small beasts, I must refer now to an animal which is not only the largest living terrestrial American mammal, but likewise one that we, from

"Hollister, N., "Synopsis of Muskrats."

† Brown, Barnum, "Conard Fissure," p. 197. 


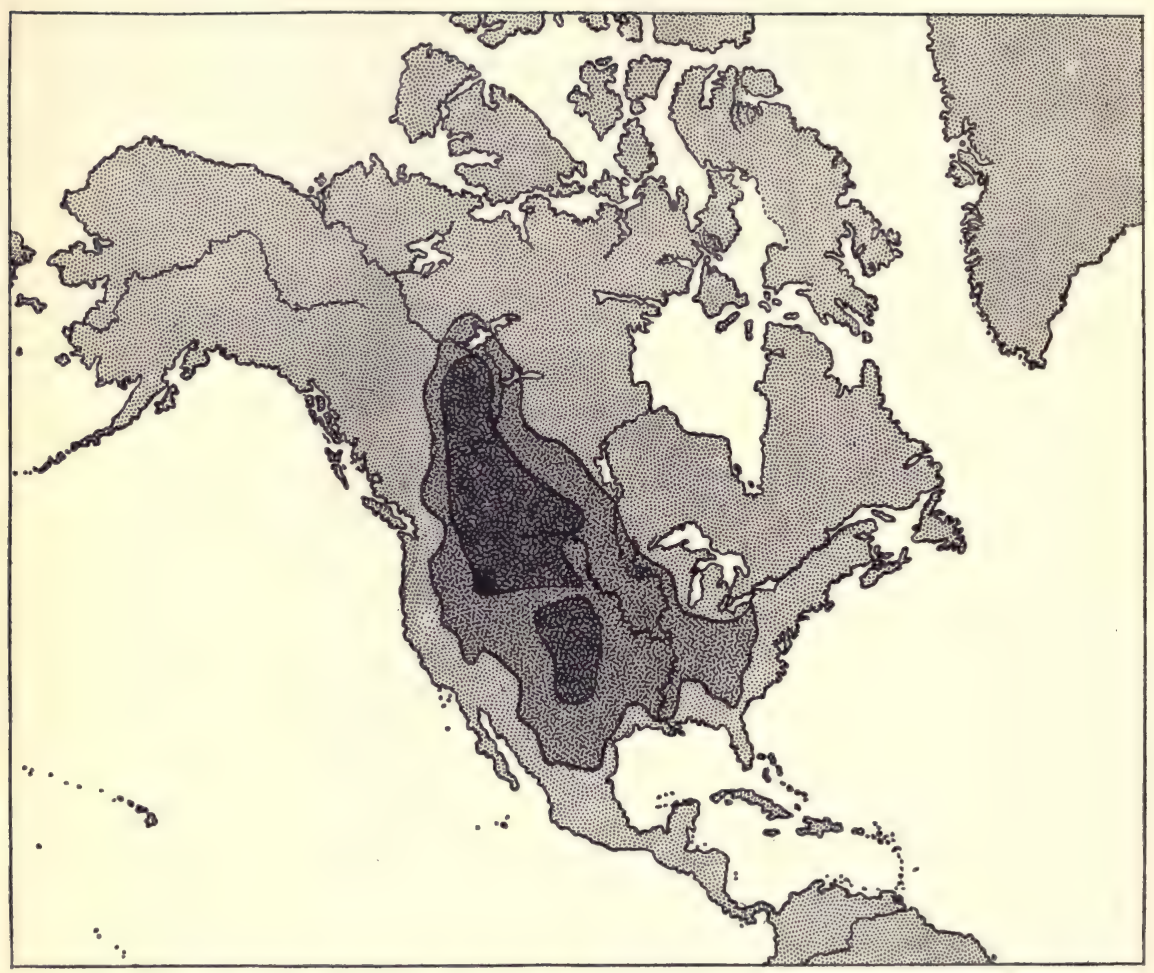

FrG. 5.-Map of North America, showing the original distribution of the Bison (lightly shaded), the range of the same animal after the completion of the Union Pacific Railroad (darkly shaded), and the present range in Yellowstone Park (black). (Reproduced with Dr. Hornaday's permission.) 
a European point of view, are accustomed to associate above all with North America, namely, the bison, or so-called buffalo.

The bison (Bison bison) is now almost extinct in its wild state, yet here in the Mackenzie region, a little to the south of the Great Slave Lake, are still found some wild herds of this magnificent creature, the last remnants of the millions that once roamed over the continent.

Dr. Howard* contributed many years ago an interesting article to "Science" on the manner in which insects and other creatures are disseminated over the States through the agency of man. An equally instructive paper might be written on the manner in which man has been the means of destroying a portion of our fauna. For no one can doubt that human agency alone is responsible for the rapid destruction of the bison and other animals.

When the Spaniards landed in America in the year 1521, the bison was still plentiful in Northern Mexico. In the commencement of the following century the English found it in abundance in the neighbourhood of the present site of the city of Washington. No doubt the range of this huge ungulate extended over about one-third of the entire continent of North America. The extreme south-eastern limit was on the coast of Georgia. The western boundary was in New Mexico. From these two southern localities to the shores of the Great Slave Lake in Canada, vast herds of bison were known to exist even in the early parts of the last century. According to Dr. Hornaday's $\dagger$ graphic description, they lived and moved, as no other quadrupeds ever had, in great multitudes, like grand armies in review, covering scores of square miles at once. They were so numerous that boats were sometimes stopped by them in the rivers, and they threatened to overwhelm travellers on the plains. In later years they occasionally, derailed locomotives and cars. One herd, seen by Colonel Dodge in 1871, only forty years ago, and described by him, extended for a distance of twenty-five miles and must have included a million individuals. The Indians believed that these buffaloes issued from the earth continuously, the

* Howard, L. O., “The Spread of Species by the Agency of Man."

+ Hornaday, W. T., "Extermination of American Bison."

L.A. 
supply being consequently inexhaustible. As long as these wild tribes only possessed the bow and arrow, bisons were comparatively safe from their depredations, in spite of the great drives that they were accustomed to organise. On the introduction of firearms, the Indians assisted civilised man to the best of their ability in his utterly wanton destruction of these helpless creatures. The building of railroads across the continent naturally hastened the process of extermination, the completion of the Union Pacific line dividing for ever the bisons of the United States into two great herds. These subsequently became known as the northern and southern herds. The great slaughter of the bison really only began in 1871. Four years later the southern herd had ceased to exist. The year 1881 witnessed a similar destruction of the northern herd, and at present this most picturesque and impressive member of the American fauna is practically extinct in its wild state, but for the small herds alluded to in northern Canada (see Fig. 5). There are other small herds preserved in the Yellowstone Park and in some reservations in western Canada. In them the bison can no longer be said to live altogether in the wild state.

I mentioned that the bison was looked upon as one of the most typically American species. Nevertheless, we have in eastern Europe a bison which is closely allied to the American species, and from the circumstance that it formerly roamed over a large part of that continent, it might be argued that its cousin from the New World is but a new-comer and in no way typical of America. A certain amount of support for that argument might be derived from the well-known fact of a Pliocene bison (Bison sivalensis) being known from India and Java and another from China. But in America there are likewise bison remains (Bison alleni) which were considered by Professor Marsh to belong to the Pliocene series, while Professor Cope described one even from Nicaragua and Southern Mexico (Bison scaphoceras). More recently, however, Dr. Lucas * has clearly demonstrated that Cope's bison is a sheep, and that Marsh's specimens are probably referable to the lower Pleistocene, so that it does seem likely after

* Lucas, F. A., “Fossil Bisons of North America," pp. 756-766. 
•.

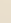
更 列
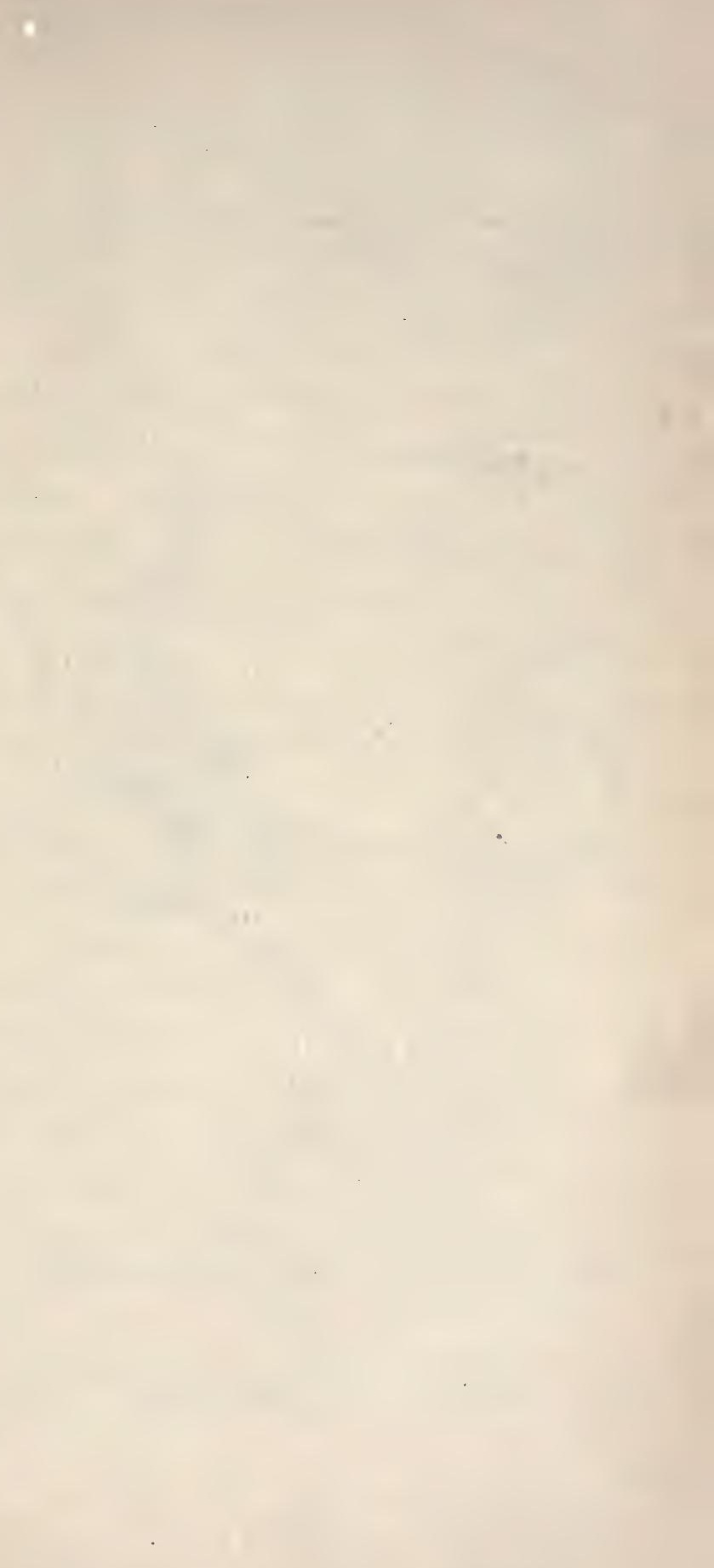


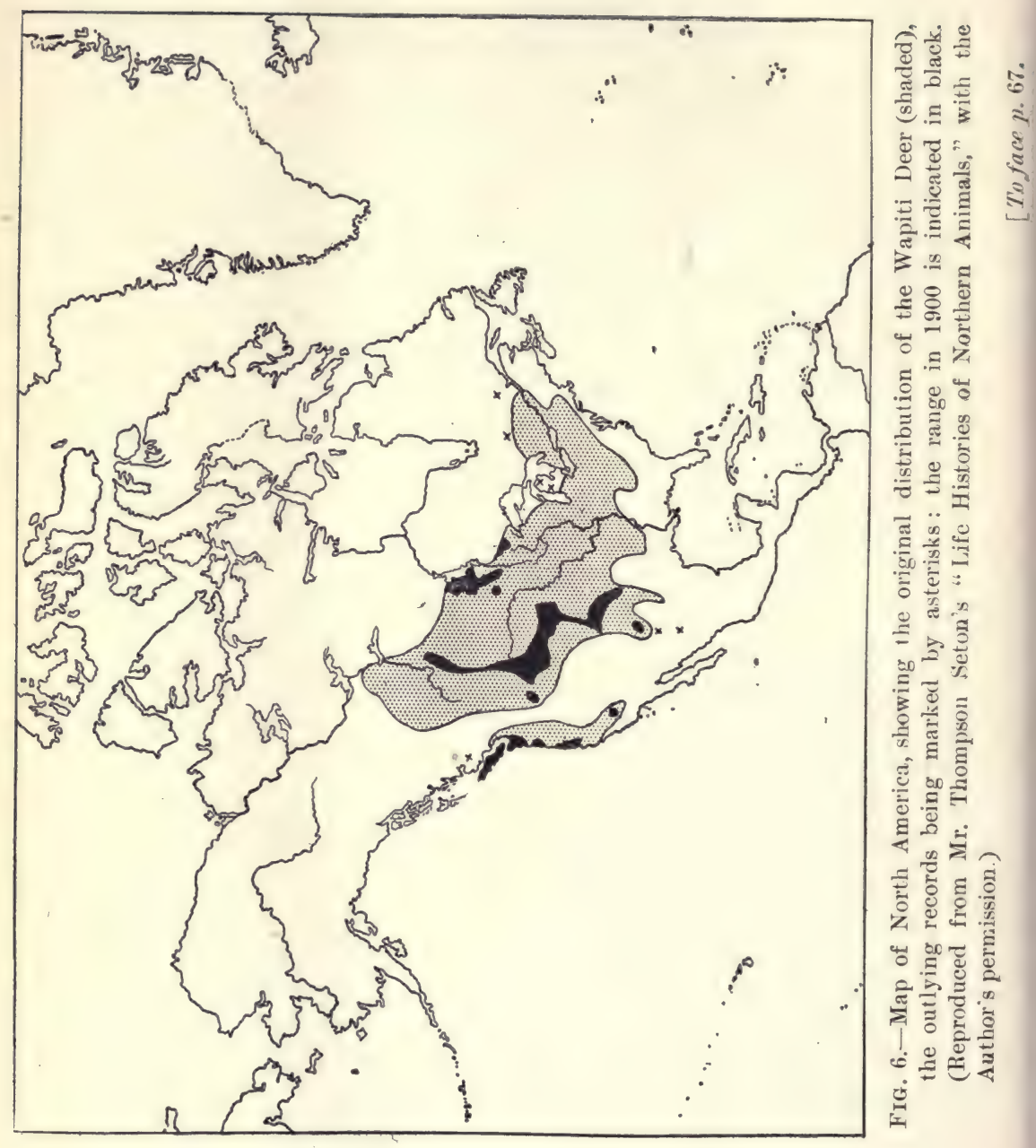


all that the ancestors of the American bison came originally from Asia. The exact geological period of this supposed Asiatic invasion will be discussed in the next chapter, when we come to deal with Alaska. Some other extinct bisons are known from America besides those alluded to. Bison crassicornis, according to Dr. Lucas, is confined to Alaska. Mr. Lydekker, ${ }^{*}$ on the other hand, considers it identical with Bison priscus, an extinct bison which ranged throughout arctic Siberia and a large part of Europe.

South of the belt of stunted timber lie the vast forests of the Athabaska and Peace River valleys, and a great zone of warmer country abounding in animal life, as we proceed in the same direction. A noble representative of the deer tribe which we meet here reminds us of the European red deer. In the States it is commonly known as the elk (Cervus canadensis), though it has no connection with the moose, which in Europe is known by that name. In Canada it is more generally called "wapiti deer." While the range of the moose seems to be on the increase in the Mackenzie Region, it is curious that the wapiti has become almost extinct in the northern parts of its former geographical range, and now only occurs there in small numbers.

Mr. Thompson Seton $†$ tells us that originally, that is to say about the beginning of the sixteenth century, the wapiti was found from the Mackenzie Region as far east as Boston, and as far south as Arizona and Alabama (see Fig. 6). Its destruction proceeded unchecked until the year 1895, when a change in public opinion took place. Henceforth the wapiti was protected; and it is now actually on the increase in Manitoba and along the Rocky Mountains from Alberta to. the borders of New Mexico and also along the Pacific States.

The wapiti has only been observed in a fossil state in Pleistocene deposits. We know from these records that its range extended in Pleistocene times southward as far as Florida and from North Carolina to New Jersey and Kentucky.

The resemblance between the American wapiti and, at any

* Lydekker, R., "Catalogue of Fossil Mummalia," II., p. 24.

† Seton, Ernest Thompson, "Life Histories of Northern Animals," I , p. 43. 
rate, the eastern European races of the red deer is so close that Dr. Caton * was sometimes at a loss to discriminate between them. The late Professor Nehringt also drew attention to the resemblance of certain fossil deer antlers from central and eastern Europe to those of Cervus canadensis. As we proceed westward in Europe the distinctive characters of the red deer become more prominent, and less so as we travel towards America through Asia. Dr. Tcherski, I think, was the first to direct attention to the fact that the wapiti was a variety of the Siberian maral. And a similar opinion has more recently been expressed by Mr. Lydekker.

It is many years since I argued that the Elaphus group of the genus Cervus, to which the Canadian wapiti and the European red deer belong, originated in Central. Asia, and I have not had any cause to modify my views in this respect. $\|$

Cervus canadensis differs from all other American deer and agrees with the great majority of the Old World forms in so far as the proximal portions of the lateral metacarpal bones persist. This is, as Sir Victor Brooke first pointed out, an important structural character. In the possession of these small leg-bones the Canadian wapiti stands entirely apart from its more distant relations of the American Continent, while clearly betraying its close relationship to the Siberian maral and the Old World deer generally. Its presence in America, therefore, forms one of the most powerful arguments in favour of the view that North America and Asia have been united by land within fairly recent geological times. We shall meet with so many similar examples during the course of this work, that one might almost be inclined to say that the matter requires no further proof, that it is an established fact. Notwithstanding, one of the most distinguished authorities in America is not disposed to accept the view that there was such a recent land connection. Nor is it expedient for us to adopt the attitude of the modern glacialist who, in referring to the theory of the presence of

* Caton, J. D., “Antelope and Deer of America," p. 214.

† Nehring, A., "Tundren und Steppen," p. 203.

† Tcherski, J. D., “Das Janaland, \&c.,” p. 496.

§ Lydekker, R., "Geographical History of Mammals," p. 315.

"| Scharff, R. F., "Mammifères de la région holarctique," p. 448. 
gigantic glaciers during the Ice Age, exclaims "this is no vain hypothesis or speculation founded on uncertain data, no mere conjecture which the light of future discoveries may explode. The evidence is so clear and so overwhelmingly convincing that we cannot resist the inevitable conclusion."*

The Canadian wapiti deer is a typical example of a recent Asiatic immigrant. In some previous cases it was doubtful whether the species referred to was of truly American or Asiatic origin. Again in others we were able to trace a distinctly American ancestry, but not beyond the more recent deposits.

I want now to mention an interesting creature whose lineage we can follow through several geological ages, and whose most remote ancestors had, as we might say, not a drop of foreign blood in their veins. The species I allude to is the Canadian tree porcupine (Erethizon dorsatus). It is in many respects a most striking and remarkable animal.

In Europe, in fact everywhere in the Old World, porcupines are ground animals, and they usually dig their burrows in the earth. The American porcupines differ from them in many important anatomical characters. They, moreover, all live on trees, and generally have prehensile tails. We have here two entirely distinct groups, as among the deer, though externally all porcupines have a strong family likeness. As far as trees grow right up to the barren-grounds the Canadian porcupine was once abundant, but yielding wholesome food and being easily killed it has been exterminated in many districts. Whenever it is undisturbed it is plentiful, feeding on leaves and bark, and it seems entirely unaffected by climatic extremes. The Canadian tree porcupine lives in Canada from the Rocky Mountains in the west to southern Labrador in the east, and enters the United States in Maine and New Hampshire. Formerly it occurred all along the Alleghenies, through Pennsylvania into Virginia and Kentucky to Arkansas. In these southern parts of its range it no doubt fell an easy prey to the Indian hunters who were always fond of its flesh. The destruction of forests on the arrival of the white man hastened its northward retreat.

* Geikie, James, “The Great Ice Age,” pp. 67-68. 
There is no sign here of a post-Glacial centre of dispersal south of the drift area. The centre of dispersal, on the contrary, lies in Canada and it is from there that it has spread southward. Yet the species had already come into existence when the sabre-tooth tiger and peculiar kinds of peccaries haunted the forests of Arkansas, for its remains have been found together with these extinct creatures in the Conard fissure.* It likewise lived in Pennsylvania at a time when the great Mylodon, Megalonyx and Mastodon still flourished there.

Beyond the Mackenzie Region, in the far distant Alaska, there lives another porcupine very closely related to the Canadian species. This yellow-haired porcupine (Erethizon epixanthum), as it is called, ranges from Alaska through the Rocky Mountains and westward to the Pacific as far south as northern Mexico, thus exhibiting the same indifference to climatic conditions as its near relative. Both of these North American porcupines have short tails. In Mexico, Central and South America we meet with numerous species, all allied to Erethizon, but with prehensile tails, which considerably assist them in climbing trees.

Now if the genus to which these tree porcupines belong had originated in Alaska or Canada, we should certainly expect it to have traversed Bering Strait into Asia while the wapiti deer and many other Old World forms poured into America. That it has not done so does not tend to disprove the assumption of the former existence of a Bering Strait land bridge. It only implies that the genus Erethizon is of southern origin, and has merely spread northward within recent geological times. The south-western region, that vast country of mountains and plains which contains the most important centre of dispersal in North America, has no doubt given rise to the genus Erethizon. Of its past history we know nothing as far as North America is concerned. South of Mexico, as already stated, all tree porcupines possess prehensile tails, and are distinguished by other minor differences from Erethizon. For these reasons they have been placed into the distinct genus Coendu. These southern forms

* Brown, Barnum, “Conard Fissure,” p. 166. 
of tree porcupines have apparently advanced northward along the isthmus of Central America and have reached Mexico within quite recent times. There are no grounds, however, for the supposition that Erethizon is a modified Coendu. When North and South America became joined by the existing isthmus of Central America in Pliocene times, Erethizon no doubt was already an inhabitant of the northern continent. Since the two genera belong to the same family Coendidae, which differs fundamentally from the old World family Hystricidae, we must assume that long anterior to the Pliocene Period North and South America, or such portions of those continents which then existed, had already been united and then become disconnected again. These theories are not founded on zoogeographical data alone. Professor Osborn* urges on palaeontological grounds that North and South America were joined in Cretaceous and perhaps in early Tertiary times, and then separated again until the Pliocene.

All this will be discussed in detail when we come to deal with Central America. I only mention the matter now because in the Santa Cruz beds of Patagonia the skeleton of a peculiar tree porcupine has been discovered and placed by Dr. Ameghino into the new genus "Steiromys." More recently, Professor W. B. Scott† re-examined these Steiromys remains, and noted the remarkable fact that they are more like the recent Erethizon of North America than any of the modern South American tree porcupines. $\mathrm{He}$ even argues that Steiromys is the direct ancestor of Erethizon.

As this implies a former land connection between Patagonia and North America, independently of the remainder of South America, it largely aided me in the theoretical construction of an ancient land bridge between south-western North America and Chile. $\neq$ It is on this land bridge, I think, that the ancestor of the North American Erethizon wandered northward from Patagonia in early Tertiary times. All this will be more fully explained later on.

* Osborn, H. F., "Progress in Mammalian Palaeontology," p. 99.

† Scott, W. B., "Report of Princeton Expedition," V., pp. 413-417.

† Scharff, R. F., "Early:Tertiary Land-Connection," p. 521. 
It may be of interest now to inquire as to how far a group of less mobile creatures than the mammals, the snails, for instance, can be classified into species whose ancestors were Asiatic, and such as were originally native to the soil. Of course we need only consider snails resident in the Athabaska-Mackenzie Region. A direct European influence among the fresh-water molluscan fauna is apparent, since certain species such as Limnaea stagnalis, L. truncatula, L. palustris, and Aplexa hypnorum inhabit the Mackenzie Region as well as Europe. How they have spread to America is not readily ascertainable. The points of resemblance between the two regions are clearly of long standing, but none of these species need necessarily have come from Europe direct, as they all inhabit Siberia as well as Canada.

Among the land snails we also meet with forms familiar to the European conchologist, such as Pupa muscorum, Cochlicopa lubrica, Hyalinia radiatula, H. nitidula, Euconulus fulvus, Zonitoides nitidus, and others. All these are no doubt very ancient species, too ancient in fact to help us materially in our present inquiries. It is possible, moreover, that they have special facilities for accidental dispersal, that is to say for dispersal other than the ordinary mode of progression on land, although my studies have not led me to believe in the efficacy of such a mode of conveyance in permanently stocking a country.

The strictly American Pupa armifera and P. holzingeri, Vertigo ventricosa, V. ovata, Vitrina limpida, Patula solitaria, and $P$. striatella are all easily transported by flooded streams, and thus scattered far and wide. In spite of the fact that the land and fresh-water mollusks of the Mackenzie Region indicate that a distinct Old World influence is recognisable, nothing points definitely to a recent land connection with either Europe or Asia. They do not confirm the view that any survival of the molluscan fauna through the Glacial Epoch has taken place in that region. On the contrary, the absence of species peculiar to the region implies, as among the mammals, that that part of America has only recently been stocked with animals from another portion of the continent. Whether we assume that gigantic glaciers covered the country, or whether we argue that the ocean invaded it, the. 
ultimate effect would be somewhat similar. In reality it would not be quite the same, because in the latter case it is conceivable that the whole Rocky Mountain chain, which lay to the west of the flooded territory, could have supported a fairly rich fauna and flora. If a huge glacier really existed in the Keewatin district, it is inconceivable to suppose that any but the most scanty fauna and flora could have found a stray asylum on the few isolated "Nunatakkr" projecting beyond the Rocky Mountain ice-fields.

The mollusks do not favour either theory. The mammals, on the other hand, show clearly a geologically recent invasion of Old World forms from the west, which is more compatible with what I may call the marine theory.

Mr. Walker * contends that the Glacial Epoch was a great factor influencing the distribution of the North American molluscan fauna. I can only perceive signs of local destruction. The distribution of the land and fresh-water mollusks in North America took place evidently long before this Glacial Epoch, and was not seriously influenced by the latter.

Both theories will be more fully dealt with in the next chapters in which the animals, principally of Alaska, will be described. These animals afford us more material for our inquiries, being of great importance to the just appreciation and understanding of the varied origin and development of the American fauna.

* Walker, Bryant, " Origin and Distribution of Mollusca," p. 53. 


\section{CHAPTER IV}

THE FAUNA OF ALASKA

Since Alaska came into the possession of the United States its progress has been a rapid one. The sudden development of the resources of this vast country attracted public attention and led to urgent demands for further exploration of its natural wealth. This work has been actively prosecuted within the last few years, so that we now possess some knowledge of the geography, geology and mineral resources of the country. Situated in the north-westerly extremity of North America, its area equals in size about one fifth of the United States (see Fig. 1). It is nearly three times as large as the German Empire.

A broad mountain belt spreads along the Pacific coast of Alaska, its western prolongation being still recognisable in the chain of the Aleutian Islands. The north-eastern extension of the Rocky Mountains curves rapidly westward on reaching the Arctic Ocean and there forms a range almost parallel with the north coast of Alaska. Between these two mountain systems lies partly a plateau and partly a great plain drained by the Yukon River, the latter sending its waters into the Bering Sea. About one quarter of Alaska lies within the Arctic Circle. Hence, from the standpoint of geographic position, it must be regarded as an Arctic province. The southern sea-board, on the other hand, which is exposed to the warm winds and waters of the Pacific Ocean, gives a comparatively mild climate to the entire southern portion of the territory. Thus Dr. Brooks * draws attention to the fact, which few of us probably realize, that the range of climate in Alaska is greater than that between Maine and Florida.

The capital of the country, Sitka, has a slightly lower mean

* Brooks, A. H., "Geography and Geology of Alaska," p. 11. 
temperature than Scotland, but it has a much greater rainfall. This enormous precipitation on the Pacific coast has a striking effect on the vegetation. The whole of south-eastern Alaska is densely timbered with forests of spruce and hemlock, also red and yellow cedar and other trees, their luxurious growth contrasting strongly with the open forests of the interior and the more northern treeless barren-grounds. Yet the lowlands of the interior are usually well wooded with spruce, cottonwood, birch, willow and alder. At a height of from about 2,000 to 3,000 feet above sea-level, forest growth ceases altogether. Here the climate becomes continental in character, with great extremes of heat and cold. In the northern parts of the country the surface everywhere is covered with dense growth of moss and grass, with an abundance of wild flowers, whereas the ground beneath is perpetually frozen.

Alaska possesses many other features of unrivalled interest. The magnificent peaks clustering about Mount Fairweather as a centre, and containing Mount St. Elias, Mount Logan and Mount McKinley, the latter with a height of 20,400 feet being the loftiest mountain in North America, have excited the just admiration of those who have been fortunate enough to visit this region. Splendid glaciers here and there descend from the great mountain valleys down to sea-level, while further west we notice in Mount Wrangell a fine example of an active volcano. The vast glaciers have given rise to the popular idea that Alaska is a country of unlimited snow and ice. As a matter of fact they are almost entirely confined to the Pacific mountain system.

Near the sea border the climate is, as I mentioned, much milder than in the interior of the country, yet an abundant precipitation from the warm moisture-laden winds here produces the extensive snow-fields from which the glaciers are fed. On the land side of the Pacific Mountain range glaciers are very poorly developed. Further inland they are entirely absent.

Since a vast area of land in Alaska remains uncovered by ice, in spite of a low mean temperature, we must recognise the justice of Professor Whitney's assertion, that a still greater increase of cold would not cover those regions with ice, nor 
bring about the conditions of a Glacial Epoch. On the contrary, it is evident that the opposite result would take place. The conditions of a Glacial Epoch, says Professor Whitney, are not to be sought for in a general diminution of temperature. "It is true," he argues, "that the regions in which the glaciers take their rise cannot be so warm that precipita tion takes the form of rain; but the required low temperature must be confined to a limited area, and be brought about by local causes, and not be something in which all the other portions of the earth are sharers. There must be copious precipitation, which, although locally in the form of snow, can in reality only be the result of a high mean temperature in other regions. In short, warmth, as a phenomenon of general occurrence, is more indispensably necessary than cold, because the latter may always be produced, where locally wanted, by increase of elevation or by the shifting of the ocean currents."*

We now know that the glaciation of Alaska during the Ice Age must be regarded as an extension of the present system of glaciers. They were no doubt considerably larger, while glaciers also existed in the Endicott range in northwestern Alaska. Nevertheless, no signs of former glaciation have as yet been discovered in the interior of the country. The latter is now generally believed to have been entirely unglaciated. If we adopted Professor Whitney's views, and endeavoured to picture to ourselves the conditions of Alaska in the Glacial Epoch, we must imagine the Pacific to have been warmer than it is now and the climate of Alaska much milder and more humid. A more luxuriant flora would, under such circumstances, have been able to flourish in the interior of the country, and consequently a richer and more varied fauna.

And how much is this conception of the Glacial Epoch at variance with the theories generally propounded! I may be excused, for example, for again citing Professors Chamberlin and Salisbury's $\dagger$ words, that one of the most marvellous features of the ice-dispersion during the Glacial Epoch was

* Whitney, J. D., “Climatic Changes,” p. 388.

† Chamberlin, T. C., and R. D. Salisbury, "Geology," Vol. III. pp. $332-333$. 
the pushing out of the Keewatin ice-sheet from a low flat centre, without even a suggestion of a mountainous nucleus, to one thousand miles westward, while the Rocky Mountain glaciers were thrust eastward, but little beyond the foothills.

The ice from this great centre of dispersion is supposed to have reached the mouth of the Mackenzie River close to the borders of Alaska. Nevertheless, the same authors acknowledge that the plains of Alaska were apparently free from glaciation, even during the time when, two thousand miles further south, the waters of the Ohio and the Missouri were actually believed to have been turned from their courses by the encroaching ice-sheets. How can we reconcile the co-existence of these two extraordinary and altogether anomalous climatic conditions in adjoining parts of the same continent? Surely there must be some mistake. At present there is far less precipitation of moisture in the Keewatin region of Canada than in any of the western mountain ranges. The existing conditions of land and water must consequently have been entirely altered during the Glacial Epoch. Indeed, even our conceptions of the nature of climates would have to undergo some change before we can realize how this stupendous ice-sheet in the Keewatin region came to be built up, while Alaska was only able to form a few local glaciers. In a previous chapter (p. 46) I ventured to make some critical remarks on the supposed gigantic ice-sheets of the Glacial Epoch, and I hope to show now that the biological evidences are altogether opposed to the views that the Ice Age was an epoch of exceptional cold. My criticisms on the current beliefs in the landice theory are by no means new. We need only peruse the fascinating volumes entitled "Ice or Water" published" by Sir Henry Howorth, in which the claims of water as a powerful agent in the formation of so-called glacial deposits are ably discussed. My object, however, in writing this work was not to investigate the origin of the Ice Age. This short digression into the domain of glacial geology merely serves to acquaint the general reader with some of the special difficulties we have to contend with in explaining certain phenomena connected with the Alaskan fauna.

Since the beginning of the last century it was known that 
fossil ivory might be gathered on the shores of Alaska. Several Russian authorities reported on its occurrence there, animadverting to the fact that the remains of elephants had also been discovered on some of the Pribilof Islands. Within recent years several expeditions have been sent to Alaska from the United States with a view to discovering more about these and other remains of extinct animals. The first of these was dispatched by the Smithsonian Institution of Washington in 1904. Mr. Maddren, who had already visited the country. several times and had travelled extensively in the interior, was charged with the expedition, and he issued an interesting report on his return.

He contends that the lowest beds in Alaska in which mammoth remains occur are the "lacustrine silts," which form an extensively developed feature in the country. Scattered through these Pleistocene deposits we find remains of skeletons, isolated cheek-teeth, tusks and bones, the animals to which they belonged having probably died near the shores of the lakes in the bottom of which they became embedded. These fluvial and lacustrine beds of Alaska, with their occasional gravels, rest unconformably on the eroded surfaces of the older formations. At the time the silts and clays were forming Alaska was for the most part, according to $\mathrm{Mr}$. Maddren,* a low-lying country, characterised by enlarged rivers with slow drainage, and many lakes.

The general conclusions arrived at by Mr. Maddren are, " that while remnants of the large Pleistocene mammal herds may have survived down to the recent period, and in some cases their direct descendants, such as the musk ox, have done so, most of them became extinct in Alaska with the close of the Pleistocene. The most rational way of explaining this extinction of animal life, says Mr. Maddren, is by a gradual alteration of the climate from more temperate conditions, permitting of a forest vegetation much further north than now, to the more severe climate of to-day. Recent changes, while checking the vegetation and thus reducing the food supply, have acted injuriously on animal life, only leaving those forms that were capable of adapting themselves to the new

* Maddren, A. G., “Smithsonian Exploration in Alaska,” pp. 25--28. 
conditions. Mr. Maddren urges that there are no facts to support the contention that the climates of the Arctic and sub-Arctic regions ever had been colder than they are at present. He thinks that there are no phenomena presented by the past history of these regions that require a more severe climate than that now existing to account for them. There are no ice deposits in Alaska, he says, except those of large glaciers, that may be considered of Pleistocene age. There are no ice-beds, he continues, interstratified with the Pleistocene deposits of Alaska. Finally he argues that the various forms of land ice, together with the deposits of peat, now existing throughout the Arctic and sub-Aretic regions of Alaska, belong to the Recent Period, and that these deposits may be most conveniently and logically classified by their position with reference to the Pleistocene and Recent formations, and that the ice deposits cannot be differentiated satisfactorily into deposits of snow or water origin by their physical structure and character alone.*

A second Smithsonian expedition to Alaska was dispatched a few years later under Mr. Gilmore. He noticed that the scattered remains of Pleistocene animals occurred throughout the unglaciated region of Alaska and the adjacent Canadian territory in three distinct deposits, viz., in what is locally known as " black muck," which is accumulated in the valleys of the smaller streams, then in the silt and clays already: referred to, and finally in the more recent fluvial and alluvial beds. The best-preserved remains were obtained in the muck deposits, and in these occurred certainly several examples of primary entombment. A magnificent skull with tusks of the mammoth was discovered in the muck forty-two feet below the surface, near Dawson, in the Yukon territory in northwestern Canada. Mr. Gilmore $\dagger$ is convinced that the determinable species of mammals found are sufficient to show at once that they represent, a typical Pleistocene fauna, some of them, such as the moose, caribou, musk ox, sheep, bear, and beaver, having persisted down to the present day.

* Maddren, A. G., "Smithsonian Exploration in Alaska," pp. 65-66.

† Gilmore, C. W., "Smithsonian Exploration in Alaska," pp. 26-38. 
The complete list of mammals is as follows:-

\begin{tabular}{|c|c|c|}
\hline $\begin{array}{l}\text { Mammoth } \\
\text { genius). }\end{array}$ & primi- & $\begin{array}{l}\text { Extinct musk ox (Symbos- } \\
\text { tyrelli). }\end{array}$ \\
\hline $\begin{array}{l}\text { Mastodon (Mastodon } \\
\text { canus). }\end{array}$ & ameri- & $\begin{array}{c}\text { Bison (Bison crassicornis). } \\
, \quad \text { (Bison occidentalis). }\end{array}$ \\
\hline Horse (Equus sp.). & & ", (Bison alleni). \\
\hline Moose (Alces sp.). & & Sheep (Ovis sp.). \\
\hline Reindeer (Rangifer & & Bear (Ursus sp.). \\
\hline Musk ox (Ovibos sp.) & & Beaver (Castor sp.) \\
\hline
\end{tabular}

The results of these two expeditions excited so much interest in the United States that another was sent out to Alaska by. the American Museum of Natural History under $\mathrm{Mr}$. Quackenbush.* He was fortunate enough in discovering part of a mammoth skeleton which still retained the flesh, skin and hair similar to those found in northern Siberia. This discovery is of particular interest, as it elucidates an extremely important feature connected with the preservation of the soft parts of mammoths in Siberia. It has been stated that the preservation of the bodies of mammoths is due to their being embedded in underground ice. Mr. Gilmore informs us that fossils in Alaska have never been found in pure ice masses. On the contrary, he makes it quite clear that the flesh, skin and hair of the mammoth were preserved to the present time because they had been pressed down into the soft mud by the weight of the rest of the body. All that remained exposed of the body rotted away. The author agrees with the previous writers in considering the mammoth and the mammalian remains as Pleistocene. He argues that the climate of this period must have been somewhat milder than that of the present time, because large trees had been met with associated with these mammalian remains in regions which are now treeless. He also adds Bootherium bombifrons, the wapiti deer and the wolf to the Pleistocene species already known from the Yukon territory of Canada.

From these three most valuable reports we can gather certain remarkable facts which are apparently antagonistic to

* Quackenbush, L. S., "Alaskan Mammoth Expeditions," pp. 125127. 
the theory of the existence of enormous ice-sheets in districts adjoining Alaska during Pleistocene times. All the writers agree that the numerous mammals, whose remains were discovered in Alaska lived there in the Ice Age during climatic conditions which were vastly more favourable than those now prevailing. Evidences of a milder climate are furnished by the abundance of mammoth remains in Alaska. Horses, reindeer and herds of bisons likewise roamed all over the country. Hence rich meadows and forests must have been plentiful to support them all with food. Nothing whatsoever has been brought to light which would sustain the theory expressed by some writers that this fauna inhabited Alaska during a mild post-Glacial or inter-Glacial stage. No trace of the existence in Alaska of a cold period preceding the supposed interGlacial or post-Glacial stage has been found. We must conclude, therefore, that Alaska and the neighbouring countries during the whole of the Pleistocene Period had a temperate climate.

These heterodox views on the climate during the socalled Ice. Age are not new. They were enunciated by Sir Henry Howorth and supported by able arguments more than twenty years ago. Very little was then known of Alaska, but the remains of innumerable large mammals had been unearthed in northern Siberia and even on the New Siberian Islands situated in the Arctic Ocean. These disclosures naturally caused a good deal of speculation. They led to the conclusion that the cold of the Ice Age or Glacial Epoch was succeeded by a warm or temperate climate during which these animals were tempted to wander into the Aretic Regions. After carefully examining the problem, however, Sir Henry Howorth * expressed the conviction that this mild or temperate epoch did not follow the Ice Age, but prevailed during the whole of it. The creatures alluded to must, therefore, have lived in those northern regions during the Pleistocene Period, which was temperate in character. Since the close of that period Siberia has gradually become more and more inhospitable.

A few years later the extremely valuable scientific results of

* Howorth, H. H., “ Mammoth and the Flood,” p. 265.

L.A. 
Dr. Tcherski's * expedition to the New Siberian Islands were published by the Academy of Sciences in St. Petersburg; and it is of interest to note that he arrived at conclusions similar to those of Sir Henry Howorth. He contended that the causes which produced glaciation in Europe acted in quite a different manner on the conditions of life in northern Siberia, where the climate remained as a direct continuation of that prevailing in Tertiary times, so that this country had a higher temperature during the Pleistocene Period than obtains at present.

$\mathrm{He}$ looks upon Siberia as a country in which the processes of general refrigeration of the northern hemisphere and the deterioration of the conditions of existence for plant and animal life during the post-Tertiary Period took a regular and steady course.

Baron von Toll concurs with Tcherski and other writers in their opinion that the large mammals whose carcases and skeletons are now unearthed in the extreme north of Siberia really lived there, but he urges that they did not arrive there until after the Glacial Epoch. Underground ice, as in some parts of Alaska, is extensively met with in northern Siberia and in the New Siberian Islands. Its occurrence, according to Baron von Toll, is due partly to a recent origin in crevices and lateral infiltration, partly to a former glaciation of Siberia, the ice having been preserved as " relict ice " from the Glacial Epoch. Being a follower of those who connect that period with a universal lowering of temperature, his contention is that northern Siberia enjoyed a milder climate in post-Glacial times, and that the mammoth, horse, rhinoceros and other mammals were thereby induced to visit the shores of the Aretic Ocean and the New Siberian Islands, which, according to Baron von Toll, $\uparrow$ were then connected with Siberia and arctic America.

The mammoth and many other animals, as I have indicated, invaded America from Asia. Consequently, if we can determine whether a land connection existed between the two continents, how long it lasted, and what species made use of it in their travels, some valuable data may be obtained as a

* Tcherski, J. D., “Das Janaland,” p. 469.

† Toll, Eduard von, “Die fossilen Eislager,” pp. 80-85. 
basis for discussion of some of the problems referred to. Other attractive inquiries, such as the influence of the Glacial Epoch on animal migrations, might be elucidated. With the climatic problem alone are connected so many important geological speculations that the subject is well worthy of a most careful scrutiny.

At a meeting of the Biological Society of Washington about ten years ago the theme chosen for discussion was the supposed former land bridge between Asia and North America. Dr. F. A. Lucas spoke in favour of a geologically recent brief land connection, and supported his theory by the geographical distribution of the wild sheep and the brown bears of North America, both of which have their near relations in Asia. He also pointed to the remains of mammoth and bison in Alaska as evidence of the same view. An older land connection, he thought, was indicated by the occurrence of a fossil Nemorrhaedus in Colorado and of Elephas columbi. Dr. Theodore Gill concurred with the last speaker, and suggested that the presence in America of such species of fishes as the pike and Scaphirhynchus tended in favour of the older land connection. Mr. F. V. Coville dwelt upon the importance of plants in sustaining the view of a transient and geologically recent land bridge. Additional testimony in favour of an old land connection of long duration was brought forward by Dr. Stejneger. He particularly emphasised the occurrence in Asia and America of the alligator and the salamander Cryptobranchus. Dr. W. H. Dall alone dissented from the opinions expressed, urging that such mammals as the mammoth might have crossed over Bering Strait by an icebridge which he thought might have joined North America and Asia during the Glacial Epoch.*

Dr. Dall $\dagger$ gave no reasons for his aversion to the belief in a geologically recent land connection between North America and Asia; although, in acknowledging that northeastern Asia and Alaska have certain species of land and fresh-water mollusks in common, he recognised the intimate relationship existing between the two areas.

* Lucas, F. A., Th. Gill, and others, "Former Land Connections."

† Dall, W. H., "Mollusk Fauna of Alaska and Eastern Siberia," pp. $365-366$. 
The problem at issue is obviously not to be solved by the application of purely geological reasoning. Dr. Brooks, in his splendid contribution to the geology of Alaska, carefully avoids any discussion of a former land connection with Asia. In his brief statement that a land bridge between Asia and North America could only have been utilised for Glacial or post-Glacial migrations of Asiatic types, Professor Suess* does not make us acquainted with the reasons for his supposition that the land connection did not also exist in Pliocene times. He alludes to the striking circumstance that the hypothetical land bridge was used apparently by Asiatic types only, and leaves us wondering why American types should not have taken a similar advantage of pouring inta Asia. That, however, is part of the problem which we must reserve for a later stage of the discussion.

Dr. Matthew $\dagger$ does not share Professor Suess' opinion, for he indicates a wide land connection, and Professor Osborn follows him in that respect, between North America and north-eastern Asia in the Bering Sea region in Oligocene, Miocene, Pliocene and Pleistocene times.

As a rule the opinions of geologists on this problem are based on biological evidence alone. It is the latter, therefore, that we have to rely upon. Curiously enough, Mr. Knopf $\neq$ maintains that all the stratigraphical testimony from which conclusions of some positiveness can be drawn, record only epochs of more widely-spread submergence and increased separation of the continents, although he recognises the strength of the palaeontological demands in favour of more or less continuous inter-continental communications. I shall endeavour, now, to critically examine the problem from that point of view. I have already had several opportunities of expressing my own views on this subject (pp. 32 and 68), and these are entirely in favour of a geologically recent Bering Strait land bridge (see Fig. 7). But we require to know more than this. We want evidence which will lead to the determination of the geological age of the bridge and the approximate date of its beginning and end.

* Suess, R., “Antlitz der Erde,” Vol. III., p. 764.

† Matthew, W. D., "Hypothetical Outlines of Continents."

$\ddagger$ Knopf, A., "Probable Tertiary Land Connection," p. 419. 
Dr. Allen* considers the inter-relationship of the boreal mammals inhabiting North America and northern Asia so intimate that it could only have been brought about by the existence of a geologically recent land bridge connecting the two areas. He thinks that most of the more northern forms of mammal life on the two continents are probably the slightly modified descendants of types which formerly had a continuous circumarctic distribution, and which have become slowly differentiated, mainly, no doubt, since the disruption of the former land connection at Bering Strait.

Every naturalist who casually surveys the boreal fauna of North America and northern Asia must be struck by the apparently large predominance of Asiatic invaders in North America, such as the moose, bison, wapiti deer, American wild sheep, glutton, brown bears, the now extinct mammoth and many others, over the American element in Asia. In fact, we scarcely recognise any signs of an exodus having taken place in the opposite direction. Typically American mammals, such as the common American musk-rat, the porcupine, the black bear, and others, for example, have representatives in Alaska, nevertheless they are quite unknown on the western shores of the Bering Sea. At the same time Dr. Allen draws our attention to the occurrence along the Siberian and Kamchatkan coasts of certain mammalian types that are of distinctly American origin. These are a species of weasel (Putorius pygmaeus) closely related to the arctic American weasel (Putorius rixosus), and only remotely akin to any Eurasiatic species; a spermophile (Citellus buxtoni), closely allied to the boreal American Citellus paryi ; the Kamchatkan bighorn (Ovis nivicola), which is more nearly related to American forms of sheep than to Asiatic ones, and several others.

Whether the presence of these closely connected forms on both sides of Bering Strait proves the case of an American invasion of Asia appears to me still somewhat doubtful, especially as the sheep (Ovis) is, as far as we know, of Old World origin. A sheep is known from the Pliocene Forest Bed of England, while it only appeared in America in

* Allen, J. A., “Mammals from North-Eastern Siberia," p. 183. 
Pleistocene times. Moreover, the Kamchatkan sheep (Ovis nivicola) is generally looked upon as a very near relation to another Siberian wild sheep also inhabiting part of Kamchatka, and which has been found fossil by Teherski in the New Siberian Islands, viz., Ovis borealis. To judge by the recent as well as by the fossil sheep in America, the genus Ovis, to which all sheep belong, must, I think, have penetrated to North America, together with the mammoth and other mammals, in comparatively recent geological times. I shall return to the distribution of the American sheep later on.

I should have thought the genus to which the musk ox (Ovibos) belongs was a better example of an American intruder into Asia. Although no longer inhabiting the Old World, its incursions into Asia and Europe must have taken place about the same time as the mammoth's advent in America. A still more striking instance of an American invader into Asia is the camel, although Professor Osborn's * statement, " in the Pleistocene the camels wandered into Asia from America, while the bears passed them en route to America," can scarcely be considered as strictly correct, since two kinds of camels are known from the Pliocene Siwalik deposits of India. The brilliant researches of American palaeontologists have long ago acquainted us with the fact that the camel family (Camelidae) inhabited America since the dawn of the Tertiary Era, while the Indian occurrences alluded to are the earliest indications of camels having reached the Old World. It is in Pliocene times, therefore, or earlier even, that a land connection between America and Asia must have existed, for no one would venture to propound the theory that camels could have crossed from one continent to another on an ice bridge.

Sir Henry Howorth $\uparrow$ collected in 1892 some valuable testimony showing that the mammoth had lived in western Europe in pre-Glacial times. In the following year Dr. Tcherski $\ddagger$ reminded us that a complete skeleton of the mammoth was

* Osborn, H. F., “Faunal Relations of Europe and America,” p. 58.

† Howorth, H. H., "The Mammoth and the Drift."

† Teherski, J. D., “Das Janaland,” p. 474. 
discovered in an undoubtedly pre-Glacial deposit at Troizkoje, near Moscow.

In Alaska the mammoth is the only elephant that has been found fossil. In the United States its remains are associated with those of two other elephants, viz., Elephas columbi and Elephas imperator, which, according to Professor Osborn,* are analogous to the European Elephas antiquus, and E. meridionalis. The ranges of these species overlap, yet their distribution seems to imply that the mammoth was the lastcomer, or that it became modified in structure further south, giving rise to the two other species of elephants. The deposits in which the mammoth occurs in the United States are generally looked upon as Pleistocene. But in the Potter Creek Cave in California it is associated with Mastodon, Megalonyx and other types belonging to extinct genera. $\dagger$ This cave contains nearly fifty per cent. of extinct species, and if situated in Europe would probably be classed among Pliocene deposits.

Similar cases illustrating the invasion of Asiatic types by way of Alaska, and their apparent modification in character as they travelled southward, occur in almost all groups of animals. Sometimes, however, we meet with instances that are very difficult to explain by the assumption of their ancestors having utilised the land bridge alluded to. The magpie (Pica rustica), for example, is a handsome and strikingly coloured bird inhabiting the whole of Europe, North Africa, central and eastern Asia and western North America. Various races and varieties are recognisable among the Asiatic magpies, while the north African form is likewise distinct. Curiously. enough, the American variety resembles the European form more closely than it does any of the Asiatic ones, and it accurs from Alaska to Mexico, and eastward as far as the Missouri River, whereas no magpies at all have been noticed in the extreme north-east corner of Asia. The distribution is therefore somewhat discontinuous, the most easterly district in Asia where it is known being southern Kamchatka. In the extreme south-west of its American range in southern

* Osborn, H. F., "Mammalian Palaeontology," p. 111.

† Brown, Barnum, "Conard Fissure," pp. 167-168. 
California quite a peculiar yellow-billed magpie has arisen, which is sometimes distinguished by the name of Pica nutalli.

It is not at all evident that the ancestors of these American magpies entered America by way of Alaska, and yet if magpies had originated in America there would probably be many species there; at any rate, they would inhabit the whole of the continent, and perhaps central America as well. Being confined to the west, and differing but slightly from Old-World forms, their origin points to Asia. At the same time the fact that the American magpie is more like the European form than the Asiatic one is a feature which cannot be lost sight of. Dr. Diederich discusses the problem whether the American magpies arrived in America before or after the Glacial Epoch. In spite of the fact that magpies in America are entirely migratory and have lived on the continent sufficiently long to develop the peculiar Californian race just referred to, Dr. Diederich * inclines to the belief that they entered the New World in post-Glacial times. Without any fossil or other evidence to guide us, it is difficult to express an opinion on this subject. But it seems to me that the magpie should be placed into one group with a good manyi other forms of animal life which reached North America long before that event, as I shall more fully describe in one of the subsequent chapters.

Dr. Gill, as I mentioned above (p. 83), expressed the opinion that the occurrence of Scaphirhynchus in Asia pointed in favour of an older land connection between that continent and North America. The fish known in America as the shovel-nosed sturgeon (Scaphirhynchus platyrhynchus) is abundant in the river system of the Mississippi to which it is confined. It is now known that its nearest relatives are two species inhabiting central Asia which are no longer classed with Scaphirhynchus, but are placed into the distinct genus Kessleria. All these ganoid fishes belong to a very ancient group, most of which are extinct. The skeleton of the ganoids is generally cartilaginous, and they retain many other archaic characters in their anatomical structure. Another example is the paddle-fish (Polyodon spathula). It

* Diederich, F., "Verbreitung der Elstern," p. 51. 
likewise lives in the Mississippi and its tributaries, while its next of kin, Psephurus gladius, occurs in the Yangtse Kiang and Hoang Ho rivers in China. These also are ganoid fishes and, like the true sturgeon and bony pike, are the only few remaining members of a very ancient and formerly abundant group of fresh-water fishes. The fact of their survival in these two continental centres might tempt us to adduce these instances in support of the theory stated above, that Asia and North America were recently connected with one another by land, whereas the migration of these fishes is an old story dating back to some remote geological period when their ancestors no doubt spread from one continent to the other by means of a land connection which probably lay further south. Their geographical distribution has obviously nothing to do with the subject under discussion, which concerns a geologically recent event. The cat-fishes or horned-pouts (Ameiurus) are possibly of a more recent origin. They swarm in every quiet stream and pond, especially in the eastern States of America. A single species (Ameiurus cantonensis) is found outside the American continent, viz., in China. Finally I may mention that the "suckers" (Catostomus), which are very numerous in the American streams, are confined to North America, with the exception of one species (Catostomus rostratus), which inhabits eastern Siberia. The last case certainly indicates a former land connection between North America and Asia, and consequently a dispersal from the former to the latter, at a geologically recent date. Still in the present state of our knowledge we are unable to determine whether the passing across to Asia of these fishes coin cided with that of the great mammals whose dispersals I have endeavoured to elucidate.

It is impossible to discuss the relationship of all the Asiatic to the Alaskan groups of animals, but no matter what class or . order we examine with a view to testing this kinship, we find among almost all of them some indications of it. Dr. Horváth, * for instance, recently dwelt on the large number of species of Hemiptera (a group including bugs and allied insects) common to Europe and North America. He quoted no

* Horváth, G., "Faunes hémiptérologiques," p. 7. 
less than a hundred and twenty-two species found in temperate and northern Europe, and also in North America, reasoning that since the greater number of them also live in northern Asia they must have spread from one continent to another across Bering Strait. He does not definitely state that he considers the Strait to have been a land surface at the time these species are supposed to have passed across it. Still he emphasises the intimate relationship of the Alaskan and the opposite Siberian shore fauna, by citing the names of four species of Hemiptera which are confined to these two countries.

A rather striking example clearly illustrating the gradual advance of a genus across Asia, and its final immigration into North America, is shown by Parnassius, a genus of butterflies to which the European "Apollo" belongs. The Apollo group of butterflies originated, according to $\mathrm{Mr}$. Austaut, towards the latter part of the Tertiary Era in Asia, at the time when some of the great mountain chains of that continent were being formed. I alluded to the European species of Apollo in my work on European Animals, gave a map of their distribution and enlarged upon their origin. I am in full agreement with Mr. Austaut's views as to the Asiatic centre of dispersal. The only point in which I differ is with regard to the period of its origin, which $I$ believe to have been considerably earlier than Mr. Austaut* thinks likely.

In Europe we possess only three species of Parnassius, whereas there are thirty-five in Asia, Turkestan being the richest country in Apollos. Some species are peculiar to the Altai Mountains in Siberia, and аธ we go eastward new forms replace those with which we had become familiar. In Amurland there are others, and yet when we cross Bering Strait to Alaska we still meet with an Apollo (P. nomion) which also occurs in the Altai Mountains, while the Californian Apollo (P. clodius) is very closely related to Parnassius clarius of these same mountains. The Asiatic character has thus been retained by two of the American species. Two others, Parnassius thor of Alaska and Parnassius sminthus, are quite distinct from any others, indicating that the passage from

* Austaut, J. L., “ Les Parnassiens,” pp. 62-63. 
Asia to America of the genus is not a recent event. It must have taken place at a time sufficiently remote from the present to permit the gradual evolution of the two new species from the ancestral forms. This may possibly have coincided with the eastward advance of the mammals referred to. A land connection in the neighbourhood of Bering Strait would certainly have facilitated the dispersal of these butterflies and other insects just as much as that of mammals.

In a discussion on the relationship of the Asiatic and North American forms of another genus of butterfly (Vanessa), Dr. Standfuss * also supported the theory of the former land connection between Asia and North America in pre-Glacial times. The Glacial Epoch, he contends, subsequently segregated the butterfly fauna into insular districts in which many species survived, and whence they afterwards spread to other parts.

Before we consider the land bridge problem from the point of view of the marine fauna, some remarks on the general character of the present mammalian fauna of Alaska will be of interest. Both Labrador and Newfoundland, the two districts in the east which seem to have been little affected by the Glacial drift, and on which the still existing mammalian fauna probably survived from pre-Glacial times, were found to contain a certain number of peculiar species. We should, therefore, expect such a vast region as Alaska, which was also scarcely affected by Glacial drift deposits, to contain even a larger number of indigenous species of mammals that survived the Ice Age in the country. We do not positively know that any mammals survived the Ice Age in Alaska, but since we are unacquainted with any reasons why they should not have done so, that assumption is warrantable. The number of mammals peculiar to the country is surprisingly large, and this alone implies that these animals inhabited the country for a sufficiently long time to develop characters distinguishing them specifically from those of the neighbouring parts in North America. The objection has been raised that American naturalists hold somewhat narrower views as to specific distinctions than are current among

* Standfuss, M., "Palaearktische Gross-Schmetterlinge," pp. 296-298. 
European zoologists, and that many of their so-called species are nothing more than varieties or races. In many cases this criticism is not justified, but even if we regarded the fortyfive species of mammals peculiar to Alaska merely as varieties, the fauna still retains a remarkably distinctive character which can only have arisen through long-continued isolation. I herewith give a list of the species of mammals confined to Alaska. In doing so it must be understood that I am not committing myself to any opinion as to their specific distinctness.

Alces gigas.

Rangifer montanus.

Oreamnos kennedyi.

Sciuropterus yukonensis.

Citellus osgoodi.

$$
\begin{array}{ll} 
& \text { nebulicola. } \\
" & \text { beringensis. } \\
" & \text { barrowensis. } \\
" & \text { stonii. }
\end{array}
$$

Microtus operarius.

$$
\begin{array}{ll}
" & \text { unalascensis. } \\
" & \text { kadiacensis. } \\
" & \text { yakutatensis. } \\
" & \text { sitkensis. } \\
" & \text { innuitus. } \\
\Rightarrow & \text { abbreviatus. }
\end{array}
$$

Ochotona collaris.

Tamias caniceps.

Peromyscus sitkensis.

Teonoma saxamans.

Evotomys dawsoni.

$$
\text { , orca. }
$$

Evotomys wrangeli.

Lemmus minusculus.

$$
\text { , nigripes. }
$$

Fiber spatulatus.

Lepus othus.

" poadromus.

Synaptomys wrangeli.

$$
\text { , dalli. }
$$

Vulpes kenaiensis.

', pribilofensis.

" beringensis.

Ursus middendorffi.

, kidderi.

, dalli.

, eulophus.

„, kenaiensis.

" emmonsi.

Mustela kenaiensis.

, areticus.

Sorex tundrensis.

, glacialis.

" pribilofensis.

The late Professor Asa Gray was the first to draw attention to the relationship of the flora of America and that of Asia. He was struck particularly with the remarkable resemblance of some of the plants found in the eastern United States to those inhabiting Japan. This particular feature, however, will be discussed in one of the subsequent chapters. It was not till much more recently that botanists became acquainted with the intimate floristic relationship between Alaska and 


\section{THE LONDON SCHOOL OF ECONOMICS}

\section{AND POLITICAL SCIENCE.}

(University of London.)

\section{NEW PUBLICATIONS.}

Studies in Economics and Political Science.

$$
\text { No. 22.-MUNICIPAL ORIGINS. }
$$

An Account of English Private Bill Legislation relating to Local Government, I740-I835; with a chapter on Private Bill Procedure.

By F. H. Spencer, Ll.B. With a Preface by Sir Enivard Clarke, K.C. igil; vii. and $333 \mathrm{pp.}$ Demy 8vo, cloth, Ios. 6d. net.

Constable and Company, Ltd.

No. 24.-GRANTS IN AID.

A Criticism and a Proposal.

By Sidney Webb, LL.B. I9i ; vii. and i 35 pp. Demy 8 vo, cloth, 5s. net.

Longmans, Green and Company.

No. 25.-THE PANAMA CANAL.

A Study in International Law and Diplomacy.

By Harmodio Arias, B.A., LL.B. igil ; xiv. and I 88 pp. Two Maps and Bibliography. Demy 8vo, cloth, Ios. 6d. net.

$$
\text { P. S. King and Son. }
$$

Copies of the above may be had on application to the LiBRARIAN, LONDON SCHOOL OF ECONOMICS, CLARE MARKET, LONDON, W.C. 

north-eastern Asia. Professor Engler* cites a large number of arctic-alpine plants, most of which are met with in these two regions, and extend southward in America along the Rocky Mountain chain. He argues that some of the species were probably capable of spreading from the one continent to the other under the existing conditions of land and water. Of others he does not consider that they could have drifted across the ocean by occasional means of transport, and he urges that only a former land connection in the north could satisfactorily explain their presence in Asia and North America.

Finally a few observations on the land bridge problem from the marine faunal aspect may elucidate some doubtful points. Dr. Dall $\dagger$ divides the existing marine fauna of the northeastern Pacific into three zones, viz., the Oregonian, Aleutian and Arctic. The Oregonian extends from Monterey to the Shumagin Islands. The Aleutian passes westward from the Shumagin Islands, includes the Aleutian chain, and reaches northward to the floating ice in Bering Sea, bounded by a depth of five hundred fathoms. The arctic zone stretches indefinitely southward beyond the five-hundred-fathom line, and is bounded in the north by floating ice, or water of thirty. two degrees. Some arctic species have crept southward to the northern islands of Japan and Cape Newenham, while a series of isolated arctic colonies occur from Cook's Inlet southward and eastward.

Dr. Dall's views are mostly derived from a study of the marine mollusea, and it is interesting to note that in the main points they are confirmed by Miss Rathbun $\ddagger$ after an examination of the northern Pacific crustacea. She states that arctic species often continue southward through Bering Strait, along the west coast of Bering Sea, to Okhotsk Sea and the Kurile Islands. Some of them extend eastward to Puget Sound and even further south. Miss Rathbun noticed that in exceptional cases, for instance Philyra pisum and Cancer

* Engler, A., “Entwicklungsgeschichte der nördl. Florengebiete," pp. $22-43$.

† Dall, W. H., “Marine Faunal Region of North Pacific," p. 206.

† Rathbun, Mary J., "Decapod Crustaceans of North-West Coast," p. 6. 
amphiaetus, Japanese species are found to occur in approximately the same latitude on the American coast, without obvious connection by way of Alaska.

The Black Stream of Japan, the "Kuroshiwo," comparable to the Gulf Stream of the Atlantic Ocean, keeps outside the island chain of the east coast of Asia, skirts the Aleutian Islands, and then makes itself felt on the south coast of Alaska. The fish fauna of the northern Sea of Japan has nineteen per cent. of species in common with the south coast of Alaska. With the Bering Sea the latter has about twice as many fishes in common. All of these are forms frequenting cold seas.*

Dr. Dall $\dagger$ recently expressed the opinion, based on a study of Tertiary marine deposits, that the conditions indicated by the faunas of the post-Eocene Tertiary on the Pacific coast from Oregon northward are a cool temperate climate in the early and middle Miocene, a warming up towards the end of the Miocene, culminating in a decidedly more warmwater fauna in the Pliocene, and a return to cold, if not practically arctic, temperature in the Pleistocene. Further south, on the Californian coast, the Tertiary marine faunas, especially those of San Pedro, have been very carefully studied by Professor R. Arnold. The Pliocene fauna, he remarks, though not quite similar to the fauna at present living off San Pedro, still contains many species which now only occur north of that locality. Many of these northern species are limited in range to the boreal waters north of Puget Sound. Hence he concludes that these Pliocene deposits were laid down in water much colder than that now found off San Pedro. In the lower beds of the Pleistocene, he continues, the cold climatic conditions prevalent during the later Pliocene were giving place to a warmer climate, which had its effect on the boreal species of San Pedro. Southern species gradually increase in number while northern ones become scarcer. Finally the upper Pleistocene beds contain $14 \cdot 2$ per cent. of species that are only now found living south of San Pedro,

* Schmidt, P., "Verbreitung der Fische im Stillen Ocean," p. 564.

† Dall, W. H., "Climatic Conditions at Nome," p. 457. 
while 6.1 per cent. at present occur exclusively north of this locality. Professor Arnold* is thus led to the conclusion that semi-tropical conditions prevailed during the deposition of the Pleistocene formation. He also emphasises the fact that the later Tertiary and Pleistocene faunas of Japan and the west coast of the United States resembled one another much more than the faunas of the two sides of the Pacific do at the present time.

Nothing could be more contradictory than the two statements of Dr. Dall and Professor Arnold as to the elimatic conditions prevailing in two portions of the Pacific coast of North America in Pliocene and Pleistocene times. It seems almost as if the deposits from which Dr. Dall derived his conclusions were not contemporaneous with those that led Professor Arnold to pronounce the views just stated. It is scarcely possible to conceive that, while a warm-water fauna existed on the Oregon and Alaskan coasts in Pliocene times, California should have had a cold climate. Arctic conditions are then supposed to have supervened on the north Pacific coast. On the Californian coast, on the other hand, the cold Pliocene climate is stated to have been succeeded by a semitropical one during the Pleistocene Period.

It is now generally recognised, I think, that Central America, in its present configuration, originated by a final union of pre-existing independent land-masses in Pliocene times. That an inter-oceanic current, now no longer existing, might have produced altogether peculiar climatic conditions on the Californian coast in Miocene times but not later seems admissible. If we suppose that the Japanese "Kuroshiwo" current formerly sent part of its warm waters through a wider opening at Bering Strait into the Arctic Ocean, would it have had the effect of inducing the Mexican fauna to advance northward and the arctic fauna to pour southward towards the coast of Oregon? I doubt, even under such geographical conditions, whether the Pleistocene faunas of California and Oregon could have differed to such an extent as described by Dr. Dall and

* Arnold, Ralph, "Marine Pliocene and Pleistocene of San Pedro," pp. $6 \tilde{-}-67$. 
Professor Arnold. At any rate, it is reasonable to infer that a rise to a higher temperature of the northern Pacific Ocean, coupled with an increased conveyance of Asiatic species to the American coasts and a northward advance of southern forms must have coincided with the closing of Bering Strait. And it was not until Pliocene times, according to Professor J.P. Smith, * that the marine faunas of Japan and the western coast of America began to be remarkably similar, many species being identical. From this fact we must conclude that intermigration between'the two continents had set along a northern shore line. During the preceding Miocene Period the marine fauna of California consisted of endemic species mixed with southern and circumboreal ones, but without any Asiatio admixture. Consequently there was probably a wide communication between the Pacific and the Arctic Ocean, favouring the entrance into the latter of a warm current which profoundly affected the Arctic Regions. The curious relationship to Pacific mollusks which is noticeable among some forms of the English Crag deposits may possibly date from this theoretical Miocene current, which may have carried marine species right across the Polar Seas to Europe.

At the beginning of the Pleistocene Period, the same conditions existed, according to Professor Smith, as in the Upper Pliocene. As the waters of the Californian coast gradually became warmer, he remarks, Mexican species began to creep northward. But this, he says, does not mean that connection with Japan was cut off. The continuation of the conditions that permitted Japanese species to migrate to California, merely allowed marine animals to make their way up the American coast also. Here I must beg to differ from Professor Smith. If a change in the fauna of the upper Pleistocene of California took place as asserted, that change was in all probability due to a gradual sinking of the land in the north, for a moderate subsidence in northern Alaska at any rate has been recorded by Dr. Dall $\uparrow$ during later Pleistocene times. A gradual modification was thus brought about in the disposition of land and water, the continents of Asia and North America slowly assuming their present shapes.

* Smith, J. P., “Periodic Migrations,” pp. 225-226.

† Dall, W. H., “ Neocene of North America," p. 278, 
I have endeavoured to show in this chapter how the more striking instances of relationship among the animals of Asia and North America can be explained, how they arose and under what climatic conditions. That Alaska was once joined by land to the opposite shore of Asia has been almost universally acknowledged by biologists and geologists. But for our purpose we required something more definite than a statement such as that of Professor Heilprin,* " it appears likely that the bears, swine, oxen, sheep, antelopes and elephants originated in the Old World, whence they were transplanted, by way of some land connection existing in the north into the New World." Even Dr. Arldt's † remark, "the bridge between Asia and North America remained until the Glacial Period," is too vague. I think I have brought together suffcient data to show that a land connection existed in the region of Bering Strait during Pliocene times until the commencement, or perhaps until the end, of the early part of the Pleistocene Period. As far as I know, the only fact that can be brought forward against such an assumption is the discovery by Dr. Dall $\ddagger$ of marine gravels at Nome, in Alaska, containing shells which he believed to be of Pliocene Age. Considering, on the other hand, that the gravels in question only contained one distinct species, it is quite possible that they may not be so old as Dr. Dall thinks. And even if their Pliocene age should be established by further researches, it only proves that the land connection was not so wide as we are apt to, believe. These gravels do not disprove the existence of the land bridge, for Nome is situated to the south of Bering Strait on the shores of the Bering Sea.

I have adduced testimony showing that Alaska, not only in Pliocene times, but also during part of the Pleistocene Period, had a comparatively mild climate. Many of the larger mammals seem to have become exterminated within more recent times owing to a change of climate. There is no indication of any wholesale destruction of the fauna during the Glacial Epoch followed by a recent introduction from the

* Heilprin, A., "Geographical Distribution of Animals," p. 179.

† Arldt, Th., " Entwicklung der Kontinente," p. 293.

† Dall, W. H., “ Climatic Conditions at Nome," p 457. 
south. If such an event had happened we should not have had such a large percentage of peculiar forms of animal life in Alaska, and more southern forms ought to have found their way there, such as the American deer and many others.

It would seem, therefore, as if both the Atlantic and the Pacific Ocean became closed in the north simultaneously and remained so for a considerable time (Fig. 7). The southern shores of both the great land bridges were then under the direct influence of warm ocean currents resulting in favourable conditions for the growth of vegetation and the food supply for large mammals. The northern shores of the land bridges, on the other hand, were in immediate contact with a closed Arctic Ocean, whose waters would naturally have remained frozen for the greater part of the year. During winter the snowfall all round the northern Atlantic and northern Pacific Oceans was probably considerable. The land being, moreover, at a higher level, this would have resulted in the production of local glaciers. Marine transgressions from the Arctic Ocean then seem to have taken place across northern Russia, as I described in my, work on the History of the European Fauna,* and across the lowlands of arctic Canada as indicated on pp. 46-49. My views on the Glacial Epoch and its nature are thus at variance with those held by most geologists of the present time. They agree with those put forward by Sir William Dawson, $\dagger$ and are more in accordance with the current opinions at the time when the Glacial Epoch was spoken of as the "Diluvial Age."

It is very generally believed, as I mentioned before, that the climate in northern Europe and northern North America was very cold, and that all that vast region which is covered by the deposit known as " Glacial drift" had been invaded during the Glacial Epoch by thick masses of land ice, so as to destroy. practically all life or drive it far southward of the southern limits of the drift. I stated in another chapter (p. 77) that I did not intend to make a special point in discussing the origin of the Glacial Epoch. I only incidentally bring forward a

* Scharff, R. F., “History of European Fauna,” p. 172-184.

† Dawson, W., "Ice Age in Canada." 


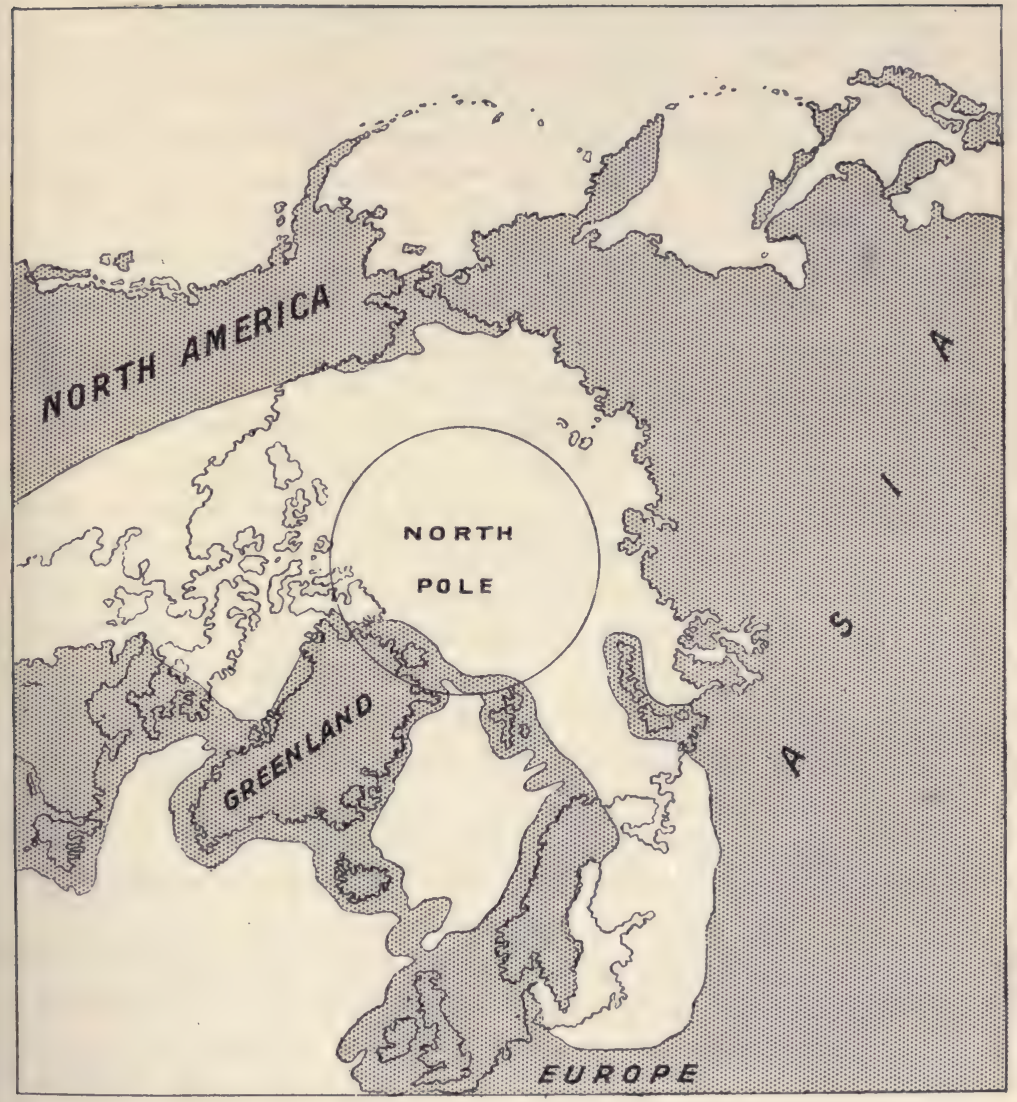

F'IG. 7.-Map of Northern portion of Northern Hemisphere, with supposed land connections in early part of Glacial Epoch (shaded) and extent of sea (white). 

theory of its origin and nature which appear to me to agree better with the geological history of the boreal fauna and flora, as far as we are able to ascertain them, than the hypotheses which have been so widely accepted by scientific men.

Professor Shaler* reminds us that the extension of relatively warm climates which has occurred at certain stages of the Earth's history is perhaps explicable in an equally: simple manner as that of the Glacial Epoch. He expresses the belief that if Bering Strait were as readily open to the warm stream of the Pacific or "Kuroshiwo" as the Atlantio is open to the Gulf Stream, the temperature of the region about the North Pole would be lifted by at least thirty degrees above its present mean annual. Indeed, if the Glacial Epoch had been due to a simultaneous closing of the Arctic Ocean to the genial influences of both Atlantic and Pacific, a mild climate all over the Arctic Regions must have coincided with a more copious flow of the "Kuroshiwo" into the Arctic Ocean. And here apparently lies the great stumbling block to my theory. on the origin of the Glacial Epoch. If the warmer temperature in the Arctic Regions in Miocene and Oligocene times had been due to a wider Bering Strait, and, consequently, to the fact that a greater volume of the "Kuroshiwo". then poured into the Arctic Ocean, how are we to account for the faunistic affinities existing between Asia and North America during this part of the Tertiary Era? There are numbers of animals in North America which have an Asiatic ancestry, but could not have entered the Continent with the great invasion that I described as crossing the Bering Strait land bridge. These and many other facts point to the existence of a land bridge between Asia and North America in early Tertiary. times. All the same, several important features imply that before the Pliocene Period the "Kuroshiwo" really sent its warm waters altogether to the Arctic Ocean.

As I mentioned above, no Japanese affinities are recognisable in the American Miocene marine fauna. On the pother hand, there is some evidence that the Miocene floras of Sakhalin and Japan were intimately related to the Miocene flora of North America. These apparently contradictory

* Shaler, N. S., "Nature and Man in America," p. 143. 
evidences can only be due to the fact that a portion of the Pacific coast of North America was connected by land in Miocene times with Sakhalin and Japan, whereas the "Kuroshiwo "flowed northward between these islands and the mainland of Asia. In the subsequent chapters the evidence which has led me to these conclusions will be more fully dealt with. 


\section{CHAPTER V}

\section{THE ROCKY MOUNTAINS}

From Alaska we retrace our steps to Canada, by that magnificient mountain range popularly known as the "Rockies." I have already mentioned that the Rocky Mountains practically end near the shores of the Arctic Ocean. They begin in northern Mexico. Although we can approximately fix the beginning and end of this vast range of mountains and even its eastern border, the western boundaries are more vague and indefinite. In British Columbia, which is so famed for its grand and impressive scenery, its rugged mountains and great forests, the northern spurs of the Cascade Mountains appear to merge into the Rockies, so that it becomes a matter of some difficulty to discriminate clearly between the two. Further south the Rocky Mountains cross the high plateau of Wyoming, sometimes spoken of as the "Laramie region." We also meet here the complex mountain groups to which the name of "Stony Mountains" has been applied. South of the plateau the mountains again grow more irregular and lofty than to the north of it. Another great plateau covers part of southern Utah, western Colorado, New Mexico and northern Arizona. With a height of over 6,000 feet above sea-level, this region has suffered great erosion, and is deeply trenched by fantastic gorges which intersect it in every direction. The most famous of them, the Colorado Canon, is a clean-cut chasm, which, in the course of ages, has been slowly carved by the river to the stupendous depth of 6,000 feet in the horizontal strata.

It is not only the lover of scenery, but particularly the naturalist and palaeontologist who appreciate the unrivalled attractions of the Rocky Mountains. These mountains, more over, have been the direct means of exposing what are probably 
the most valuable and extensive deposits of fossils in existence.*

As we enter the United States, proceeding along the Rocky Mountains, we soon find ourselves in the midst of the Miocene and the lower Oligocene beds (White River) of Montana. Further south, in Wyoming, we come to the Wind River beds, while on our left to the east lie the Wasatch deposits, both of which belong to the lower Eocene. Westward we cross into the middle Eocene Bridger and Washakie beds of Wyoming, and also the upper Eocene Uinta of Utah. Much further south we finally meet with the famous Puerco, Torrejon and Wasatch formations of the San Juan basin in New Mexico, which are held to be of basal and lower Eocene age. Owing to the labours chiefly of Leidy, Marsh, Cope, Scott, Osborn, Wortman, Matthew, Hatcher, and others, a most remarkable assemblage of fossils has been obtained among these immensely rich deposits. Our knowledge of the former inhabitants of North America has thus greatly increased within recent years, and has aided us in tracing the gradual changes of land and water that the continent has undergone in past times. Great efforts are now being made to work out the correlation of the North American mammal-bearing horizons. I propose to return to this subject later on, and need not dwell on it any longer at present.

Although glaciers have now almost entirely disappeared from the Rocky Mountains, abundant proofs have been left of their past presence in the shape of moraines, and polished as well as striated surfaces. These signs of former glaciation are very different from the thick mantle of drift that we noticed in Canada, and which is likewise attributed to the action of glaciers. Only the highest summits and the most elevated valleys of the Rocky Mountains were ever accupied by ice, and there does not appear to be any sign of a deposit in the whole range resembling the northern drift. $\dagger$

These glaciers, no doubt, owed their existence to a greatly increased precipitation of moisture in the Rocky Mountains during the Ice Age, for we possess quite an unmistakable

* Russell, I. C., "North America," pp. 122-136.

+ Whitney, J. D., “Climatic Changes," pp. 64-72. 
record of a past humid period in the basin of the Great Salt Lake in Utah. All round the present lake we find a most interesting series of terraces at varying heights, which clearly. represent ancient shore-lines. It has thus been established that in Pleistocene times, during its greatest development, the lake had the enormous area of more than 19,000 square miles, that is, nearly the size of Lake Michigan, with a depth of about 1,000 feet. This ancient "Lake Bonneville," as it has been called, has since been greatly reduced in size by the slowly increasing aridity of the country. Its diminutive descendant, the Great Salt Lake, is rapidly drying up, its average depth being only twenty feet. Other large fresh-water lakes existed in the Great Basin during the Glacial Epoch.

Sometimes it is customary to include the western Sierra Nevada and Cascade Mountains under the term "Rocky Mountains." Asa Gray and Sir Joseph Hooker have even added to this area that of the Great Basin in their account of the Rocky Mountain flora. More recently the distinctiveness of these two mountain systems is being more generally. recognised. The forests of the Rocky Mountains are distinguished from those of the eastern States by the prevalence of the pyramidal evergreen conifers, whereas in the east the trees are round-headed and mostly deciduous. The endemio flora, consisting of thirty-three per cent. of all the plants found in the Rocky Mountains, forms a prominent element.*

We have noticed that some of the alpine plants inhabiting the White Mountains are unknown in western America, for instance, Diapensia lapponica and Loiseleuria procumbens. On the other hand, a large number of the alpine Rocky Mountain species do not occur in the east, whereas a few, such as Rhododendron lapponicum, Arctostaphylos alpina, Rubus chamaemorus and Veronica alpina, are common to both, pointing to the great antiquity of this element in the flora. $\dagger$ Many of the plants occur also in Asia; others are closely related to arctic-alpine species. Most of the endemic element of the Rocky Mountain flora has clearly been derived from that

* Gray, A., and J. D. Hooker, "Vegetation des Rocky Mountain Gebietes," p. 267.

† Rydberg, P. A., "Composition of Rocky Mountain Flora," p. 870. 
of the lower slopes of the mountains, and to it belong the typically American alpine species. They reach their greatest development in the southern portion of the Rockies.

One of the most remarkable features, which I shall have occasion to draw attention to again in another chapter, is the occurrence in the Rocky Mountains of some species of plants, which reappear in the southern Andes, without being represented either in the Mexican highlands or in the tropical Andes. Among these, Professor Engler* mentions the dwarf gentian (Gentiana prostrata), the mealy primrose (Primula farinosa), the hoary draba (Draba incana) and the alpine foxtail (Alopecurus alpinus). All these are common well-known European species. A few more have since been added by Professor Bray $\dagger$ This small group of species is of peculiar interest, not only because somewhat analogous instances of distribution occur among insects, but also because this feature is by no means limited to mountain forms. In another chapter I shall allude to : a number of species inhabiting the arid regions of southwestern North America that likewise are quite unknown in the moist tropical and sub-tropical belts of country to the south, yet reappear in the extreme south of South America. Whether all these species possess particular facilities for dispersal over wide areas or whether former conditions of land and water were more suitable than they are at present for dispersal will be discussed later on (p. 414).

The fauna of the Rocky Mountains resembles the flora in its composition, except that among the higher animals, at any, rate, the species are almost all endemic. Two kinds of animals in particular are associated with the Rocky Mountains in sportsmen's minds, namely, the mountain sheep, or big-horn, and the Rocky Mountain goat. The former used to be known as Ovis canadensis. But from the systematic mill of the zoologist, as Dr. A. E. Brown $¥$ puts it, have been produced seven new species and sub-species, all very closely related to one another. As already stated, the Kamchatkan

* Engler, A., "Entwicklungsgeschichte," II., p. 256.

† Bray, W. L., "Relations of North American Flora," p. 713.

$\ddagger$ Brown, A. E., "Zoology of North American Big Game," p. 69. 
sheep (Ovis nivicola) is more nearly akin to the American sheep than it is to other Asiatic ones, and the occurrence on both sides of Bering Strait of such near relations forms one of the strongest buttresses for the belief in a geologically recent land connection between Asia and North America in the neighbourhood of Bering Sea. The various forms of American sheep are entirely confined to the western mountain region, where they are found from the Alaska mountains to the mountains on the long peninsula of Lower California, and eastward as far as Yellowstone Park. The home of the big-horn is the loftiest rim-rock of the high mountain plateaux, or the most rugged and forbidding badlands of the middle altitudes. In summer, says Dr. Hornaday,* its favourite pastures are the treeless slopes above the timber-line, and in winter it paws through the snows of the mountain meadows to reach the tallest spears of grass. When the raging storms and deep snows of winter drive the elk and deer down into the villages for food and shelter, the mountain sheep makes no perceptible change in its habitat. Its agility is nothing short of marvellous, and, from its wariness and difficulty of approach, it is a favourite object of pursuit of the experienced hunter.

If, as it seems likely, the American mountain sheep has entered North America from north-eastern Asia within recent geological times, the fact of its having spread to Lower California and developed several distinct forms is an argument in favour of a pre-Glacial immigration. That sheep had already penetrated to North America in Pliocene times is also proved by the discovery of the horn cores of a sheep (Ovis scaphoceras) in northern Nicaragua. $\dagger$

The comparatively dull-witted Rocky Mountain goat (Oreamnos montanus) shares with the big-horn the almost inaccessible peaks and ridges of the Rocky Mountains, but, being clumsy and slow, it rarely ventures far from its usual haunts. Unlike the sheep, the Rocky Mountain goat has a very local and discontinuous range. $\neq$ It seems almost as if its original home had been in the coast ranges of Oregon and Washington,

* Hornaday, W. T., "Notes on the Mountain Sheep," p. 77.

† Lucas, F. A., "Fossil Bison of North America," p. 756.

† Grant, Madison, "The Rocky Mountain Goat," p. 9. 
and that it had then spread northward to British Columbia and southern Alaska, and eastward to the Rocky Mountains. Its whole distribution is thus confined to the north-western United States and western Canada. The term "goat" is really a misnomer. It is not a true goat, nor yet a true antelope. We might with more justification call it a "goat-antelope."

In some respects it resembles the European chamois (Rupicapra), in others the serow and goral (Nemorrhaedus) and the takin (Budorcas). The last three are confined to Asia, and all of them, though generically distinat from the Rocky Mountain goat, belong to the same group of goat-antelopes.

A species of Nemorrhaedus occurs in the mountains of Japan and northern China, and we might, with Dr. Brown, be tempted to assume that Oreamnos has arisen in America from some Pleistocene immigrant of the genus Nemorrhaedus. $^{*}$ But surely the genus Oreamnos, to which the Rocky Mountain goat belongs, must be a very ancient one. The peculiar discontinuous range of the whole group implies antiquity. The remains of the mountain goat have been discovered in Potter Creek Cave of California, while Mr. Cragin is said to have described a fossil species of Nemorrhaedus from the Pleistocene of Colorado. I have not been able to trace the description or further particulars. At any rate, the more remote origin of Oreamnos is shrouded in obscurity. We certainly have no definite evidence that its ancestors came from Asia in Pleistocene times. They probably reached the continent much earlier.

The Rocky Mountain goat occasionally falls a victim to the cougar or puma, better known in the west as the "mountain lion," which, like its prey, is a typically American animal. From a distributional point of view it is one of the most remarkable mammals, as it exceeds all others in the great extent of its range. Its utter indifference to climatic conditions is shown by its occurrence from southern Patagonia right through the tropics to western Canada. It flourishes from the plains of Florida to the regions of the permanent snows in the Rockies and Andes. It is true that those who take note of small differences no longer believe in one species

* Brown, A. E., "North American Big Game," p. 75. 
possessing this vast range. Like almost all other mammals, the cougar (Felis concolor), which in all its essential habits and traits remains the same, whether living in mountain, open plain or forest, under arctic cold or tropical heat, has yet been split up into several distinct species.

The nearest Old World relations of the cougar are the lion and tiger, both of which differ from it very strikingly in size, habit and colour. It is perfectly obvious, therefore, that it is not a geologically recent immigrant from Asia. T'wo very closely allied species of large cats, moreover, have been discovered in Pleistocene deposits in Argentina; while the cougar itself has left its remains, along with those of extinct members of the cat tribe, in the Conard Fissure. Another large cat (Felis hillianus) has been found fossil by Professor Cope in the Blanco formation of Texas, this being now looked upon as middle Pliocene. Hence it is probable that the ancestors of the cougar already flourished in North America as well as in the southern continent in Pliocene times. The facts of its recent distribution seem to point to its having entered North America from the south, and it may possibly have done so in Pliocene times when the northern continent became definitely connected with South America. Further details as to its early history are still lacking.

As we descend the mountains through the forest belt and finally reach the foot-hills, we meet with two large ungulates whose acquaintance we have not hitherto had an opportunity of making. Both of these are confined to the western States, and are well known to the hunters of the Rocky Mountain region. The black-tail, or mule deer (Odocoileus hemionus), as it is often called on account of its big prominent ears, seems at first sight not to be very different from the American elk or wapiti, except in size. But the latter belongs to quite a different genus. If we examine the antlers of the two more carefully, we notice that the brow tines are lacking in the mule deer. There are also distinctions in the skull, while the lower parts of the metacarpal bones of the front limbs are retained in the mule deer. The wapiti deer is descended from an Old World stock which, as I explained (p.68), crossed over from Asia by a land bridge in Pliocene or early Pleistocene times. I In it only the upper metacarpals remain, 
and it differs in other fundamental characters from the mule deer, which has apparently no near relations in the Old World, and which we may justly call the true American deer.

Fossil remains of the mule-deer have been found in the Conard Fissure.* The fossil bones of other deer from the Pleistocene of Illinois, Iowa, Wisconsin and Indiana, have been referred to extinct species of the genus Odocoileus to which the mule-deer belongs. No Pliocene or older traces of this genus have as yet been discovered in North America, if we adopt the generally accepted view of the Conard Fissure being of Pleistocene age. Altogether there are three fairly distinct species of the type of the mule-deer in North America, namely the one I have just described, the white-tailed deer (Odocoileus virginianus) and the black-tailed Columbian deer (O. columbianus).

It is of considerable interest to know that this genus lives not only in Central America, but right to the southern extremity of South America in Chile. This fact alone is remarkable, for nowhere else in the world are deer found south of the Equator. They are entirely absent from Africa and Australia. However, it is by no means the only noteworthy circumstance about this American group of deer. Those who are acquainted with the habits and life history of the deer tribe know that the young of deer with large branching antlers: at first possess no antlers. Afterwards small, simple and unbranched processes appear on their heads. From year to year they are shed and new ones take their place, and these are always a little more complex than the previous ones. The gradual development of the race seems to follow that of the individual. It is only in the more recent geological periods that deer with branching antlers make their appearance. As we go back to earlier deposits the deer skulls only bear simple antlers with one or two branches. In still older strata we meet with deer that were devoid of antlers, while they generally possessed long canine teeth which no doubt were useful as organs of defence. It has been rightly argued that the complex antlers have only been developed in comparatively recent geological times, and that deer with simple antlers

* Brown, Barnum, "Conard Fissure," p. 205. 
which we find living here and there in isolated districts, are more ancient in point of origin.

In South America we have still living at the present moment deer of the type of the mule-deer, only smaller, with simple forked antlers. Other still smaller deer possess merely minute spike-antlers. Extinct deer, moreover, with all the different kinds of antlers, have been observed in South American Pleistocene and Pliocene deposits. One species (Odocoileus avius), which, according to Professor Ameghino, belongs to the group with complex antlers, has even been noticed in the upper Miocene of Argentina.

Both fossil and recent evidence thus clearly points to South America as the source of these true American deer. If we supposed that the ancestors of the North American species of Odocoileus had penetrated northward in Pliocene times, when Central America assumed its present shape, we should have a reasonable explanation for the fact that the genus has never spread to the peninsula of Alaska, nor into northeastern Canada and Newfoundland.

What prevents the general adoption of the theory of the South American origin of this group of deer? Clearly the fact that while the deer family (Cervidae) is represented from the Oligocene to the most recent deposits in Europe, it only makes its appearance in South America in the upper Miocene. The original home of the family is therefore believed to be in the northern hemisphere, and this assumption is strengthened by the circumstance that nowhere except in South America have deer penetrated to the southern hemisphere. Since it is inadmissible to argue that mammals so near akin as the Old World and New. World deer should have appeared quite independently of one another in two distinct centres, these affinities can only be explained by migration from the one centre to the other. According to most palaeontologists who expressed an opinion on this problem, the South American deer could only, for the reasons stated, have entered South America from North America. Whether they were developed in the Old World or the New, it is evident, remarks Mr. Lydekker,* that the American deer originated in the

* Lydekker, R., “Deer of all Lands,” p. 245. 
northern hemisphere, and that they are comparatively modern immigrants into South America, where they now attain their maximum development.

Mr. Lydekker gets over the difficulty of the simple-antlered South American deer, or brockets as they are called, by the admission that because they are unknown in North America, they are not ancestral forms. He thinks they should be regarded as degraded or arrested types of the group (p. 296).

Professor Marsh* was inclined to look upon the North American Leptomeryx as the probable progenitor of the Cervidae. His suggestion led to further researches on the part of Dr. Matthew $†$ who supplied a connecting link in the chain of ancestry of Odocoileus in the Miocene Blastomeryx. That Dr. Matthew's view, however, is not generally accepted may be gathered from Professor Osborn's $\ddagger$ recent remark in reference to the Pleistocene Period in North America, that among the newly entering northern forms are Odocoileus, Ursus and Erethizon. Professor Osborn's § opinion is that the origin of the Cervidae will probably prove to be Asiatic. I quite concur in the view that they are of Old World origin, and yet I hold that the ancestors of the North American Odocoileus have invaded the northern continent from South America. The remote ancestors of Odocoileus must, therefore, have penetrated from the Old World to South America without attaining North America. How they have done so is the problem I shall endeavour to solve.

Later on, when we come to deal with the zoogeographical relationship of South America and Africa, I shall show that we possess valuable evidence for the belief' in a former land connection across the southern Atlantic between these continents. This, however, will not help us in explaining the deer problem, because no deer have ever been found fossil in Africa south of the Sahara, and those species which have succeeded in establishing themselves in northern Africa have clearly done so in recent geological times. Deer are absent from all the

* Marsh, O. C., "Introduction of Vertebrate Life in America," p. 36.

† Matthew, W. D., “Osteology of Blastomeryx,” p. 535.

† Osborn, H. F., “Cenozoic Mammal Horizons,” p. 88.

\$ Osborn, H. F., “Ten Years Progress in Palaeontology," p. 107. 
remainder of the continent. On the other hand, there is living in Europe and Asia at the present time a genus of deer (Capreolus) which has several important characters in common with Odocoileus and its more primitive South American relations. The genus Capreolus, which includes the roedeer, is distinguished from all the other Old World deer in its tele-metacarpal front limbs, that is to say in the possession of the lower remnants of the lateral metacarpal bones. It resembles, as we already know, in this character the true American deer. Moreover, as Mr. Rörig * has pointed out, this is not the only feature of resemblance between Capreolus and Odocoileus. The antlers of the former likewise agree with those of the New World deer, rather than with those of the Old World. Capreolus has the backwardly directed tine of Odocoileus, and lacks the brow tine of Cerrus. Even in the period of renewal of the antlers, the roedeer agrees with the American deer, this change taking place in the winter months, while it occurs in all the other Old World deer in the spring and summer. Only three kinds of roedeer exist at present. In Miocene and Pliocene times, however, France and Germany were tenanted by quite a large assemblage of tele-metacarpal deer, all of which lacked the brow tine like Capreolus. The earlier history of these deer is largely obscured by the circumstance that only fragmentary parts of the skeleton are known. Thus the Miocene species of Dicrocerus, which is supposed to be related to the living Cervulus, possessed antlers that can be almost matched by some of the recent South American mountain forms of Odocoileus, whereas other South American forms (Blastocerus) remind one of the modern roebuck. $\dagger$

I venture to think that all the deer of South America have originated from one or more ancestors which invaded that continent direct from western Europe in early Tertiary times. Although it is true that we possess little palaeontological evidence in support of such a theory, a land connection must then have joined Europe with South America. The probable period of this migration from Europe to South America,

* Rörig, Ad., "Wachstum des Geweihes," p. 424.

† Rörig, Ad., " Phylogenie des Cervidengeweihes," p. 542. 
as well as the nature of the land bridge which enabled the deer to reach western America rather than the east, will be discussed in one of the subsequent chapters. Some of the more primitive forms still survive in South America, where they have now been pressed into the mountain regions. The newer and more vigorous types must have passed into North America as soon as that continent became definitely connected with South America in later Tertiary times.

In speaking of the western North American fauna, Professor Osborn * tells us that in middle Miocene the peculiarly American Hypertragulidae disappeared, while the European Cervidae and the distinctly American Merycodontinae took their place. Professor Osborn alludes no doubt to Palaeomeryx and Blastomeryx which seem to have originated in southern Europe, and spread subsequently eastward to India and onward to America. Both apparently became extinct in North America before the advent of Odocoileus from the south.

The other large hoofed animal I alluded to as frequenting the lower slopes of the Rocky Mountains is one of the most peculiar creatures in existence. It is so different from other animals that it occupies the exclusive position of being the solitary member of a distinct family. Known among zoologists as the "prong-horn" (Antilocapra americana), and among hunters as the "antelope," this splendid animal possesses the graceful movements of the latter, while its horns have a superficial resemblance to the antlers of a deer. There is not the least real likeness, however, between the antlers of the prong-horn and those of a deer, for they are not solid, but hollow like the horns of a goat. The horn-sheaths, like the antlers of a deer, are shed and reproduced at regular intervals. The prong-horn ranges from eastern Mexico to Saskatchewan in Canada and from the Missouri River in the east to the Cascade Mountains of Oregon in the west. Hence it is now a peculiarly western species, while it had crossed the Mississippi during the Pleistocene Period, and roamed about Illinois and Wisconsin. The closely-allied extinct genus Merycodus (Cosoryx) made its first appearance in the

* Osborn, H. F., “Cenozoic Mammal Horizons,” p. 77. 
"Deep River" deposits of Montana in middle or lower Miocene, and persisted until the Pliocene. During the latter period several new genera, viz.: Capromeryx, Platatherium and Leptotherium, branched off from the ancestral stock, and made their way into newly-opened areas. The last two have occurred in recent beds in Brazil, the other in Nebraska. Thus the family Antilocapridae to which the recent pronghorn and all these fossils belong, originated in America and never left it.

Among the birds of the Rocky Mountains the dippers are very characteristic. They are quite unrepresented on any of the eastern mountain systems, being also absent from Greenland and Labrador. In the Old World they are more or less confined to the mountains, but not nearly to the same extent as in America. In my "European Animals"* I have already cited Dr. Stejneger's interesting article on the geographical distribution of the dippers (Cinclus), and I may again briefly summarise the results of his studies. He places the origin of the genus on the great plateau adjoining northern India. At the dawn of the Tertiary Fra the species radiated from this centre east and west. America being then connected by land with northern Asia, the ancestors of the present dippers had special facilities for crossing to the New World from Asia. They are supposed to have spread since along the Rocky Mountains and Andes to the very furthest end of South America. Dr. Stejneger's theoryt certainly explains the existing range of Cinclus in a satisfactory manner, but there seems to me still another view of looking at the problem. If, as I believe, the Atlantic Ocean was bridged over by land in the direction of southern Europe in early, Tertiary times, it is possible that the dippers may have been introduced into the New World in that manner. At any rate, the problem is worth considering from that point of view, when the dippers come to be worked out in a thoroughly systematic way. Among the older forms of both animals and plants there are in western America a surprisingly large number of groups which are closely related to European ones.

* Scharff, R. F., “European Animals,” p. 200.

† Stejneger, L., "Geographical Distribution of Cinclus," p. 425.

L.A. 
In a later chapter I shall mention many of these. I would only here draw attention to a striking botanical example which seems to me due to direct migration from Europe to western North America and not by way of Bering Strait.

Anemones are so much cultivated now in gardens that almost everyone is familiar with them. Their geological history no doubt has been a very remarkable one. Not a single fossil anemone is known to science, because the plant contains no part that might readily be preserved, and yet it can be asserted that the genus must have originated in very remote times. The occurrence of many species in isolated mountain regions, the extremely discontinuous and wide range of others, and especially the high percentage of endemism, clearly imply that we have to deal with an ancient genus. Dr. Ulbrich, * to whom we are indebted for a splendid monograph of the genus Anemone, is of opinion that some of its sections were already developed in early Tertiary times. His view is, of course, entirely derived from what we might call circumstantial evidence, just as Dr. Stejneger's was in regard to the age of the genus Cinclus. One of these species of anemone (A. baldensis), a well-known alpine plant, is, according to Dr. Ulbrich, probably of Miocene age. It grows also in the Carpathians, the Apennines, the Pyrenees and northern Spanish Mountains, but nowhere in Asia. Nevertheless, the same species occurs in the highest elevations of the Sierra Nevada in California, in the Cascade and Rocky Mountains. A very closely-allied form of anemone (A. tetonensis) lives at a height of over 10,000 feet in Idaho, and another (A. jamesoni) at about the same elevation in the Andes of Ecuador. All these nearly related forms, therefore, are confined to Europe and western America.

Among all the older American forms both of animals and plants, other possible routes of migration besides the Bering Strait one have to be taken into consideration. Returning to the birds again, it seems to me that the genus Regulus to which the European golden-crested wren belongs, must have entered North America in Pliocene times along with the great mammals alluded to in the last chapter. In

* Ulbrich, E., “Geograph. Verbreitung d. Gattung Anemone," p. 325. 
North America we have Regulus cuvieri, only one specimen of which is known, Regulus satrapa and Regulus calendula. None of these have succeeded in penetrating southward beyond Guatemala in Central America, the genus having a wide range on the continent. Hence it is reasonable to suppose that the ancestors of Regulus invaded North America from Asia by way of the Bering Strait land connection.

Among the invertebrates of the Rocky Mountains the beetles and butterflies are probably the best-known groups. They may be considered by some as of little importance in the solution of such problems as we have been dealing with, because these insects are generally believed to be very liable to accidental dispersal. One of the most powerful distributing agents of insects subject to accidental dispersal is no doubt the wind. Nevertheless many naturalists, who have made a serious study of the geographical distribution of animals and plants, have come to the conclusion that neither wind nor other agencies of accidental dispersal are of such paramount importance as we are often led to believe. The species of a genus, even of butterflies or beetles, as a rule, are clustered round a centre from which we can easily imagine them to have been slowly dispersed in the course of time. Usually we can trace an intimate relationship between the species whose areas of distribution adjoin one another. The conditions of dispersal, in fact, even among winged insects, must be quite similar to those with which we are acquainted among the higher mammals. The latter spread gradually on land from their centre of origin. Sometimes we meet with allied groups of species among beetles and butterflies whose ranges are separated by extremely wide areas in which no near relations occur. We might be tempted to attribute such instances to accidental dispersal by wind. We might suppose that an exceptionally powerful storm had carried these frail insects a few thousand miles away to a spot, where on alighting they found the conditions for their future development favourable. When similar cases of distribution occur among mammals they are explained in a different manner. We then argue that the related, but now widely separated or "discontinuous," groups must long ago have had a perfectly continuous range 
and that for some reason or other they have subsequently been destroyed over wide areas, leaving at present only isolated colonies. In some instances this theory of the origin of discontinuous colonies of animals has been amply confirmed by fossil evidence. Camels, for example, or we might say the family Camelidae to which they belong, are only represented in South America and Asia; but since numerous fossil members of the family occur in North America, we possess decisive evidence that long ago the range of the camel family was continuous. Discontinuity of range among mammals is always looked upon by zoologists as an unmistakable sign of antiquity. It is only when a similar range occurs among the more easily dispersed invertebrates and plants that naturalists are in the habit of calling to aid exceptional forces of nature in explaining their origin. The undoubted facility with which human importations are scattered far and wide and become successfully established in districts remote from their original home seems to encourage and invite speculations as to the origin of discontinuously distributed invertebrates of all kinds. Actual records of seeds, insects, snails, etc., sowed broadcast by accidental agencies far from their native land, appear to confirm the theories derived from successful human transplantations. So much are these in vogue that the ordinary and normal mode of dispersal is almost forgotten. Winds no doubt exert an influence in driving species in the direction in which they blow. But many animals, beasts as well as beetles or butterflies, possess the faculty in a high degree of detecting the presence of their own kind by the sense of smell. Winds would, and do, as we know, convey scents from one animal to another, thus tending to bring the sexes together. This has been very clearly established by Mr. Webster.* The insect, being apprised by scent of the presence of its own kind, would endeavour to travel in the direction contrary to that of the prevailing wind in order to reach it. It may possibly be true that some insects are apt to spread in the direction of the prevailing wind, as Mr. Webster asserts. But, judging from the few examples

* Webster, F. M., "Diffusion of Insects," p. 797. 
he quotes, I do not think there is sufficient evidence for the belief that insects as a whole are influenced in their dispersal by that agency. His statement that the influence of high winds on insects is illustrated by the great number of butterflies that are sometimes encountered by ships at sea at long distances from land, is somewhat misleading. As a matter of fact, remarkably few species of butterflies have been observed far out at sea, and these always belong to species that are in the habit of migrating. It is a well-known. phenomenon that certain species of butterflies and moths, such as the painted lady (Vanessa cardui), the milk-weed butterfly (Anosia archippus) and the moth Urania leilus, congregate into flocks or swarms and migrate in a body at certain times of the year. And it is such swarms that are occasionally scattered by storms and carried out to sea. These are, however, altogether exceptional instances, and we are not justified in drawing conclusions from them and applying them to insects as a whole, very few of which possess any migrating instincts. On the contrary, the facts of the geographical distribution of insects are, as a rule, quite in conformity of those of mammals. Even the distribution of the strongly-winged Sphingidae in North America shows a distinct division into an Atlantic and Pacific subregion.

I have already alluded, on p. 90 , to the range of the genus of butterflies Parnassius in North America, pointing out that it had apparently entered the continent in Alaska and had then spread along the Rocky Mountain chain. Altogether, the butterflies and moths of the Rocky Mountains show a close resemblance to those of the Old World; among them we meet with the familiar genera Colias, Argynnis, Erebia and Oeneis.* The main advance has apparently taken place in a southward direction from the north along the crest of the mountains.

Much remains to be done before we can obtain even a general idea of the beetle fauna of the Rocky Mountains, but it is certain that many Old World genera and even species have travelled southward along this chain for a considerable

* Pagenstecher, A., "Lepidopteren d. Hochgebirges," p. 145. 
distance. On the other hand, typically American genera, like the oil beetles (Eleodes), have gained access to heights up to 8,000 feet in the southern spurs of the Rocky Mountains.

Of fossil insects, in spite of Mr. S. H. Scudder's * classic researches and Dr. Handlirsch's splendid treatise, we know comparatively little. But our knowledge has been particularly enriched by the discovery, in the midst of the Rocky Mountains of a deposit of shales containing a wealth of the most beautifully preserved specimens of insects and plants. During one of the volcanic eruptions, which were so frequent in Tertiary times throughout the greater part of the Rocky Mountains region, great masses of leaves and innumerable insects were entombed among the fine volcanic ash, and were thus readily preserved. Over six hundred species of insects are now known from these Florissant shales of Colorado, which, according to Professor Cockerell $†$ are not of Oligocene age, as Mr. Scudder thought, but of Miocene age. The absence of mammalian remains, however, increases the difficulty of estimating the exact age of these deposits. It is possible, moreover, that some of the shales may be much older than others.

I cannot leave the Rocky Mountains without expressing a few words of appreciation as to the wisdom and forethought of the Americans in preserving large tracts of country in the wild state. These large land reserves, as Mr. Roosevelt $\ddagger$ so forcibly reminds us, are mainly to keep the forests from destruction, but likewise to preserve, for future generations, the wild animals that live in them.

The first and most famous game preserve in the world was established in 1872 and set apart as a public park or pleasure ground for the benefit and enjoyment of the people. Congress provided against the wanton destruction of fish and game, or their capture or destruction for merchandise or profit. As a result of this wise enactment we find to-day thousands of deer of various kinds in this magnificent world-famed enclosure known as the "Yellowstone Park," the name being derived from Yellowstone, the largest tributary of the Missouri

* Scudder, S. H., "Tertiary Insects of North America."

† Cockerell, T. D. A., “Fauna and Flora of Florissant," p. 160.

‡ Roosevelt, Th., “Wilderness Reserves,” pp. 23-24. 
River. I need not enlarge upon the fascinating spectacles of the hot springs or the geysers, waterfalls and other natural wonders which attract sightseers to this district.

Since the opening of the Yellowstone Park, largely owing to the efforts of the Boone and Crockett Club and its founder: $\mathrm{Mr}$. Theodore Roosevelt, many other game and forest preserves have been established in the United States. The American Bison Society and the New York Zoological Society also worked incessantly towards the same end, so that at present over seven million acres in the United States are devoted to the preservation of the native fauna and flora. The two largest enclosures are the Yellowstone Park in Wyoming, and the Grand Cañon Game Preserve in Arizona. This growth of sentiment in favour of protecting animals and plants from destruction has also spread beyond the borders of the States into Canada, and induced the authorities there to imitate these beneficent measures. In their enthusiasm to vie with their neighbours, Canadians have even provided game preserves which exceed in size the largest of those referred to, for the new Jasper Park in Alberta has an area of nearly three and a half million acres, while Rocky Mountain Park in Alberta has two million seven hundred thousand acres. Two others have over a million acres.

Hidden game preserves of the past life of North America, as I mentioned before, lie among the vast accumulations of Tertiary rocks in the same mountains that shelter the modern representatives of the American fauna. In the beginning of the chapter I just alluded to the names of some of the more important deposits and the geological formations they belong to. Enough is now known of the remains of the animals contained in these deposits to enable palaeontologists to compare their relationship with that of fossil assemblies of animals in other continents. Professor H. F. Osborn has recently published an excellent summary of our knowledge of these western beds and their mammalian fauna, and I cannot do better than quote some of his conclusions.

The Eocene Tertiaries of the mountain region, lying in the Rockies and west of them, were partly formed by. the postCretaceous or post-Laramie uplift, accompanied by great voleanic activity, lava flows and eruptions of volcanic dust, and 
by the formation of a series of lake, river and flood-plain basins, filled with volcanic and erosion sediments. During the first faunal phase of the Eocene Period a land conneation with South America seems to be indicated by the occurrence of similar mammals in the upper Cretaceous or basal Eocene of Patagonia. Additional evidence of South American connection is afforded by the subsequent occurrence of animals related to the Edentata-Dasypoda in the American middle Eocene. A momentous change occurs, according to Professor Osborn, during the second faunal phase of the Eocene. Similar faunas appear almost simultaneously in south-western North America and in western Europe. In Professor Osborn's * judgment this remarkable circumstance is due to the gradual southward extension of the fauna from a hypothetical northerly American-Asiatic land mass.

Not a single specimen of an Eocene mammal has been discovered in northern Asia or the northern parts of North America. Professor Osborn and many other authorities assume the Eocene existence of a great American-Asiatic land mass, because large tracts of land in the north certainly. are very ancient, and must have been raised above the sea in Eocene times. That is about all the evidence we possess for the belief that the great similarity of the western European and western North American fauna during the Eocene Period was due to some land connection via northern Asia and northern North America.

I should prefer to throw my hypothetical land bridge straight across the Atlantic from western Europe to North America. In another chapter I shall endeavour to show that we possess important zoogeographical evidence for the belief in such a transatlantic bridge in Eocene times. Professor Schlosser $\uparrow$ contends that geological researches are alone capable of yielding information about former land connections. He does not believe that much weight can be attached to ancient reconstructions of continents based on zoogeographical or distributional data. I hold, on the contrary, that since certain old groups of animals, even genera and species,

* Osborn, H. F., “ Cenozoic Mammal Horizons," pp. 19-35.

† Schlosser, M., “"Uber Tullberg's System der Nagetiere," p. 748. 
have originated in the far distant past and are now scattered here and there in isolated colonies, their present range indicates former conditions of land and water. By comparing the discontinuous distribution of such old groups in the different continents, we come to certain conclusions as to the conditions of the continents during the time when their range was continuous. We have already become acquainted with several genera and species showing discontinuous distribution. I argued, in the first and fourth chapters, mainly from distributional evidence, that North America was connected with north-western Europe and with north-eastern Asia in Pliocene times. We know of relict genera and species which represent the life and the geographical conditions of still more remote stages of the Tertiary Era, namely, the Miocene, Oligocene and Eocene, and even periods of the secondary or Mesozoic Era. We thus possess in our recent fauna an invaluable adjunct to palaeontological research. That this statement is not a mere asssumption will be amply demonstrated in the next few chapters.

Returning to Professor Osborn's researches, he directs attention to the striking diminution of European types in the last stages of the Eocene deposits. This, he argues, might have been due to the existence of prolonged geographic or climatic barriers between the two continents. In Oligocene times the faunal community with western Europe once more becomes closer. It is important to note, Professor Osborn remarks, that many American lower Oligocene types are represented by more primitive forms of European upper Eocene and partly of north African types. This stage is followed by a long period of independent evolution and partial extinction of the same fauna to the close of the lower Miocene age. About the middle of the Miocene Period another profound change in the mammals of North America occurs. This is mainly due to the sudden appearance of a large number of new forms of African and Eurasiatic origin, such as the elephants, which are believed to have come from Africa, and the rhinoceroses and the true ruminant animals, which are supposed to have had their home in Asia or Europe. These North American middle Miocene deposits contain animals which first appear in the lower Miocene of Europe. Hence there is distinct evi- 
dence for the assumption that the general movement of the fauna has been from the Old World to the New. Finally, in the Pliocene beds of North America, we perceive clearly that an invasion of South American animals has taken place.*

* Osborn, H. F., “Cenozoic Mammal Horizons,” pp. 42--82. 


\section{CHAPTER VI}

\section{ANIMALS OF THE EASTERN STATES}

When a naturalist from western Europe crosses the Atlantic, and after landing at one of the great ports on the east coast of the United States, takes a stroll in the country on a fine summer's day, a great many novel features strike his eye. Let us suppose, for instance, that he is specially interested in reptiles and amphibians. Although the neighbourhood of New York and Boston abounds with ideal dry sandy banks which would be alive with lizards if situated in France or Germany, these reptiles seem to be completely absent. This is actually the case. No lizards have been observed in the neighbourhood of these cities. If he went further inland to ascertain whether America is really devoid of lizards, our visitor might succeed, after crossing the Hudson River, in capturing some. Two kinds of lizard have been recorded from the western parts of the State of New York, viz., the blue-tailed lizard (Eumeces quinquelineatus) and the common swift (Sceloporus undulatus).* The first of these is a strikingly handsome species with five vividly yellow lines along the back and a tail of brilliant blue. It is altogether different from the ordinary European lizards, for the scales are shiny like those of the slow-worm. The blue-tailed lizard forms part, in fact, of the large family of skinks (Scincidae) most of which inhabit the tropical portions of the Old World. The genus Eumeces (Plestiodon) to which the American bluetailed lizard belongs, is largely confined to the south-eastern and southern States of North America. A few species are found in the south-west and in Mexico, while the genus is entirely absent from South America and Europe. Eight species are known from Asia. Now the most remarkable point

* Eckel, E. C., and F. C. Paulmier, “New York Reptiles,” p. 390. 
about this blue-tailed skink is that a species, until recently considered absolutely identical with it, is found in Japan, being unknown on the mainland of Asia. Some differences have now been detected between these two skinks, but they are no doubt very closely related to one another. We are confronted, therefore, with the extraordinary problem how to account for the occurrence of two species, so nearly akin, in localities so distant from one another. It must be clear to anyone who is familiar with distributional problems that accidental dispersal within recent times either by man or by any other agency is out of the question. This is a case of geographical distribution which must be explained by the ordinary modes of migration. If it was quite a unique instance of such a remarkably discontinuous range, it might be a matter of some difficulty to discover a plausible explanation to account for it. But it is by no means the only example of such a range. Quite a number of instances are known. A still more striking one is that of the so-called ground lizard (Lygosoma laterale).*

The ground lizard, with its minute limbs, thick tail and sluggish movements, reminds one more of a salamander than a lizard. It lives, moreover, under the bark of trees or among rotten wood, and is thus altogether different in habits from the ordinary lizard. Now this peculiar ground lizard occurs in identically the same form in North America, in China and Japan. $\dagger$ The most searching comparison by the best experts has hitherto failed to elicit the slightest difference between the Asiatic and this North American ground lizard.

It is interesting to note that the ground lizard and the blue-tailed lizard, both of which exhibit such a remarkably East Asiatic relationship, are members of the family Scincidae. But, whereas we possess in America over thirty species of the genus Eumeces, to which the blue-tailed lizard belongs, there are only two American species of Lygosoma. We now have to ascertain whether these two genera Eumeces and Lygosoma, are of American origin, or

* Cope, E. D., "Crocodilians, lizards and snakes of North America," p. 622.

† Stejneger, L., “Herpetology of Japan,” p. 219. 
whether they have come to America from some other part of the world. Lygosoma laterale is known from eastern Mexico in the south-west, and from all the southern and eastern States as far north as New Jersey. Altogether fifty species of the division of Lygosoma, to which the American species belong, have been described.* Five of them live in New Zealand, twenty in Australia and the adjacent islands, seven in the Pacific Islands, four in the Philippines and Borneo, seven in India, two in the Nicobar Islands, one in Mauritius, two in West Africa, one in Central America, while a single species, as far as we have learnt, is found in China, Japan and North America. The wide range of the species in North America shows that it has not been introduced. It is no doubt indigenous. Yet, to judge from the range of the genus Lygosoma, America is certainly not its home. We may also safely conclude, from its most discontinuous range, that it is of very great antiquity, although quite unknown as a fossil. New Zealand, according to Dr. Wallace, $\uparrow$ received its flora and fauna during the latter part of the Secondary Era, and has not since been connected with any mainland. Since this view has been widely accepted, it would tend to show that the genus Lygosoma was already in existence in Mesozoic times, and that it possibly gained its present distribution towards the end of the Secondary or early in the Tertiary Era.

The second genus Eumeces may help us in our enquïry as to the mode of entry into North America. There are about twenty species of Eumeces in North America, ranging from Mexico in the south to Minnesota in the north, and New Jersey in the east. Considerably over one-half of these inhabit the south-western States and Mexico. Certainly the centre of distribution in America lies in the south-west. The various species seem to have radiated from this centre in all directions except the south. The genus must have existed in this southwestern centre for a very long time past, because one species peculiar to an island in the Bay of Campêche, another to the Island of Bermuda, and still another to southern Florida, are

* Boulenger, G. A., "Catalogue of Lizards," Vol. III., pp. 253-289.

† Wallace, A. R., "Island Life," p. 506. 
known to science. Eumeces must have lived in North America possibly since early Tertiary times. The genus has also been observed in India. One of the species ranges from Baluchistan, right through Persia, Syria and Egypt to Tunis, having there probably given rise to the allied form confined to Algeria and Morocco.

If Eumeces had already existed in south-western North America in early Eocene times, we should expect it to have travelled to South America during the supposed Eocene land connection with that continent. That it has not done so may be due to the fact that its original home is in south-eastern Asia. This assumption is strengthened by the circumstances that its nearest relations are the genera Tribolonotus of New Guinea, and Brachymeles of the Philippine Islands.

Since Lygosoma, like Eumeces, also occurs in the southwestern States, it may likewise have made its entry into North America in that region, though its original home seems to have been somewhere in the western Pacific. Being probably an older genus than Eumeces, both may, nevertheless, have taken the same route in reaching North America. Where that route lay and what were the geographical features of North America at the time will be discussed later on when more material has been gathered from other sources.

I alluded above to another lizard which has penetrated as far north as New Jersey, namely, the swift (Sceloporus undulatus), so called from the great activity and speed of its movements.* Its scales are strikingly different from those of the skinks. They are large and coarsely keeled, terminating in sharp, bristly points. The swifts belong to the typically American family Iguanidae. All the Iguanidae, and there are many of them, are confined to North and South America, with the exception of one genus which inhabits the Fiji Islands and two others living in Madagascar. It is quite possible, however, as Dr. Gadow† suggests, that the Madagascar genera represent cases of convergent evolution from some common ancestor.

Although a species of Iguana has been described from the

* Ditmars, R. L., “The Reptile Book,” p. 123.

† Gadow, H., "Amphibia and Reptiles," p. 501. 
Eocene deposits of France and England, we have no reason to doubt that the family has originated in America. The Cretaceous genera Iguanavus and Chamops from Wyoming, have always been considered as belonging to the Iguanidae. Since the family scarcely enters eastern America even at the present day, the western States must always have been its headquarters. How the dispersal from the American continent to the Fiji Islands was effected is another problem which I defer to a later discussion.

As for the genus Sceloporus, to which the swift (S. undulatus) belongs, almost all the species inhabit Mexico, that country forming the centre of distribution. From there the genus ranges as far south as Nicaragua. One species occurs in the western States, while the single northern species, Sceloporus undulatus, ranges from Guatemala to the eastern States. Both the nearest relations of this genus, Phrynosoma and Uta, have their headquarters in the south-western States and Mexico. We possess, consequently, satisfactory evidence, both from its recent as well as its fossil distribution, that the family Iguanidae is of North American origin, and that the latter can be traced to the end of the Mesozoic Era.

In spite of the occurrence of these three species of lizards in some of the north-eastern States, these reptiles certainly are scarce in the east. It is not so with the snakes. No less than twenty-three different kinds have been observed in the vicinity of New York,* whereas in the whole of France there are only about half that number. The eastern States of America are, in fact, remarkably rich in snakes. Snakes have even penetrated to the eastern islands, for several species, including the dreaded rattlesnake, occur in Long Island.

The commonest of these eastern and probably of all the American snakes, is the garter-snake (Thamnophis or Eutenia sirtalis). It is abundant from southern Canada to Florida, and I have met with it even on the edge of the White Mountains plateau at a height of 5,000 feet. Very closely allied to, and scarcely distinct from the genus Tropidonotus, the garter-snakes (Thamnophis) form a most troublesome group

* Eckel, E. C., and F. C. Paulmier, "New York Reptiles," p. 356388. 
from a systematic point of view. Several of the species are exceedingly variable, and all are difficult to discriminate from one another.

The genetic relationships of the various species and the causes which have given rise to the differentiation of the garter-snakes are most attractive subjects for study. Dr. A. E. Brown * has discussed the connection between moisture and variability, especially in the direction of colour intensity in this group of snakes. More recently an ingenious and novel method of carefully estimating the value of the characters commonly held to be specific in snakes has been adopted by Dr. Ruthven. He shows that the reductions in the number of rows of dorsal scales as the girth of the body decreases in the individual snake, are brought about by the dropping of certain definite rows. This leads him to the conclusion that specific variation in the scale rows follows the same sequence and is also correlated with the circumference of the body. Similarly, presence, absence or fusion of the labial scuta are dependent on the length of the head. Dr. Ruthven's † assumption is that the garter-snakes started in America with the maximum number of dorsal rows of scales known in the genus, and that the forms resulting from geographical extension are mostly due to dwarfing in consequence of unfavourable environment. He then traces four lines of descent, which all emanate from northern Mexico as the centre of origin of the genus. The area inhabited by the nineteen species of garter-snakes includes all North America and southward as far as the southern boundary of Guatemala. The genus is evidently a geologically recent immigrant to Central America.

It is of the greatest interest to the student of zoogeography. that Thamnophis differs from its nearest American relative, Tropidonotus, by the absence of scale pits, and by the presence of an undivided anal plate, for it seems almost certain that Thamnophis has originated in North America from some ancestral form of Tropidonotus (Natrix), the latter being clearly a much older genus. Tropidonotus has a vast range

* Brown, A. E. Variations of Eutaenia."

† Ruthven A. G. "Variations of the Garter Snakes." 
from north Australia through the Malay Archipelago and northward to Japan. Westward it extends to India, Africa and Europe. In America the genus occurs principally in the eastern States, but there is also a species in Cuba and several in Central America. None have penetrated to South America. From Dr. Boulenger's * catalogue and Dr. Stejneger's description of Japanese forms, $\uparrow$ it seems evident that the east Asiatic forms are not very closely related to the American ones. On the other hand, Tropidonotus validus, from Lawer California, Arizona and Mexico, is nearly akin to the west European Tropidonotus. viperinus, whose high antiquity is indicated by its occurrence in Sardinia and Algeria. I may have another opportunity later on of dealing with this interesting genus, but it must be conceded that although we possess no fossil evidence, the origin of Tropidonotus must date back at least to the commencement of the Tertiary Era. In another chapter I shall show how extraordinarily intimate is the relationship of the south-west American and the West European faunas. Evidence will then be given in support of the theory that southern Europe and the south-western parts of North America have been connected with one another by land, and that we probably owe the resemblance in the animals and plants of these two regions to that fact. The species of Tropidonotus, in America at any rate, are semi-aquatic. They are so much attached to water that they are popularly known as "water-snakes," whereas the garter-snakes are much less bound to the neighbourhood of water. The latter are not uncommonly found on higher ground and in drier situations, a change in the climatic conditions of the south-west may thus originally have given rise to the Thamnophis branch from the original Tropidonotus stock. The headquarters of Tropidonotus now lie in the eastern States, where the conditions for its existence are more favourable than in the south-west. All the same, it seems probable that the original centre of dispersal was in the south-west, for when Tropidonotus arrived

* Boulenger, G. A., "Catalogue of the Snakes in the British Museum,', Vols 1.

† Stejneger, L., “Herpetology of Japan,” pp. 264-294.

I.A. 
in North America the climate of that region must have been very different from what it is at present.

I may just mention two other examples of innocuous snakes which frequent the north-eastern States, viz., the smooth green snake (Liopeltis vernalis), and the rough green snake (Cyclophis aestivus). The former is abundant in New York State and northward as far as south-eastern Canada. Southward it ranges to the Gulf of Mexico and westward to Now Mexico, becoming rarer as we approach the drier and warmer districts. The other does not extend nearly so far north. On the other hand, the rough green snake is found westward as far as northern Mexico and California. Both of them share the peculiarity of being the only members known in America of the genera to which they belong. That is not the only feature of interest about their distribution. I have just urged that the ancestors of the American species of Tropidonotus must have come from Europe. We cannot claim the same origin for the American species of Liopeltis and Cyclophis, for neither of these genera inhabits Europe. Both of them are absent also from Africa. Their headquarters are in southern and eastern Asia, but they do not extend as far north as Japan. Formerly these snakes were classed among that insoluble zoogeographical enigma, namely, the group of animals and plants peculiar to eastern Asia and eastern America. Now we have advanced in so far as we have been able to trace some of the eastern forms to an originally western American range. It has been made easier, therefore, for those naturalists who are in the habit of explaining anomalies of dis:tribution by the convenient flotsam-jetsam theory, to bring their views to bear upon problems such as those suggested by the two green snakes. That these snakes could have been floated across the Pacific Ocean on a raft by any possible chance, is to me inconceivable. That they should have utilised the Bering Strait land connection, and subsequently have become extinct all along north-eastern Asia and north-western North America does not appeal to me either as likely. We must only leave the consideration of the problem for the present, as was done in the case of the lizard genera Eumeces and Lygosoma, which also apparently had an east Asiatic origin. 
From the popular point of view, as Dr. Ditmars * remarks, the venomous rattlesnakes are the most interesting of the American serpents. The Old World naturalist involuntarily associates America with rattlesnakes ; and the ominous warning sound produced by the unique appendage at their tail alone exercises a strange fascination on everyone who has become acquainted with them. Not only is the common rattlesnake (Crotalus horridus) abundant in some of the hilly portions of New York and Massachusetts, it actually appears to be increasing in numbers in these populous States, owing to the decrease of its natural enemies. From a zoogeographical point of view rattlesnakes are of considerable importance, because, being strictly limited to the ground, they are less liable to accidental dispersal than the members of many other genera which are expert swimmers or fond of climbing trees. The rattlesnakes are generally divided into two genera, viz., the pigmy rattlesnakes (Sistrurus) and the rattlesnakes proper (Crotalus). Both genera range almost all over the United States, a couple of species even cross the borders of Canada. Southward, Sistrurus is also met with in Mexico. The true rattlesnakes (Crotalus), on the other hand, have a much wider distribution in America, one species (C. terrificus) having been found in Mexico as well as in Yucatan, Bolivia, Venezuela, northern Argentina, and southern Brazil.

Remains of rattlesnakes have been noticed in a couple of the North American caves, otherwise they are unknown in earlier deposits. Their range is confined to America, and we have no reason to suppose that they have originated in any other continent. Their home is, no doubt, as Dr. Brown $\dagger$ suggests, in the south-western States in what he calls the Chihuahuan district. We have no means of estimating the age of the two genera of rattlesnakes. Yet Crotalus seems to be the more ancient, and, like its near relation Lachesis of southern Asia, Central and South America, has probably a remote ancestry. It may possibly have inhabited North America since early Tertiary times.

I have drawn particular attention to the fact that the

* Ditmars, R. L., "The Reptile Book," p. 426.

† Brown, A. E., "Texas Reptiles and their Faunal Relations," p. 558. 
great scarcity of lizards and the abundance of snakes are characteristic features of the north-eastern States of North America. But I have not yet alluded to the most remarkable feature of the reptilian fauna of that region, as it is not a character readily noticeable to the untrained naturalist. It is the great wealth of land and fresh-water tortoises. In England it is customary to distinguish the marine, paddlelimbed kinds of Chelonians as "turtles," all others as " land and water tortoises." In America the term "turtle" is usually employed quite indiscriminately to true tortoises and turtles. In adopting the common American names applied to these tortoises, I am only endeavouring to make my remarks quite clear to American readers.

I have had occasion already to refer to one species of fresh-water tortoise (p. 51), sometimes called "semi-box" turtle (Emys blandingi), and to discuss the peculiar range of the genus, which is confined to parts of Canada and the northern States in America, and to central and southern Europe in the Old World. We possess no fossil remains of any members of the genus except from recent geological deposits. Although we must assume that a migration has taken place either from North America to Europe, or vice versa, in more remote times, palaeontology gives us no clue as to the origin of Emys. We can only surmise that the genus and species of Emys are ancient from the fact that the genus Clemmys occurs in the Eocene of North America, while Chrysemys has been discovered in the Eocene of Europe. Both of these are still living genera of turtles and closely allied to Emys. They are classed among what are called "terrapins" in North America.

The terrapins are characterised by their broad, flattened shell. The hind feet are extensively webbed, and they are good swimmers. Perhaps the best known of the terrapins is the "diamond-back" (Malacoclemmys centrata)* which frequents the salt marshes of the Atlantic coast. It is in great favour in the States as an article of diet. The less. familiar spotted turtle (Clemmys guttata) is of greater zoo-

* Ditmars, R. L., "The Reptile Book." Siebenrock, F., "Synopsis der Schildkröten." 
geographical interest. Four species occur in North America, three of them being limited in distribution to the eastern States. Only one, viz.: Clemmys marmorata, is quite confined to the rivers and ponds west of the Cascade and Sierra Nevada Mountains in Oregon and California. In Central and South America the genus is unknown, but in eastern Asia we find four species. One of them inhabits Japan, another the island of Hainan, and a couple of them China. Far away in western Asia we meet with another species in Persia and Mesopotamia, spreading across Asia Minor to Greece and Turkey, while finally Clemmys leprosa lives in Spain, Portugal and north and western Africa as far as Senegambia. The genus is thus quite confined to the northern. hemisphere. We might suppose that the ancestor of the American Clemmys insculpta had spread northward from eastern Asia in Pliocene times and, after crossing the Bering Strait land bridge, had invaded Alaska and Canada, ultimately reaching the eastern States of America in that manner, and subsequently becoming extinct in the vast tract of country which now separates the Chinese from the eastern American species. The south-western Clemmys marmorata would thus have been the latest development of the genus in America. Such a supposition seems unlikely, owing to the unsuitability of the western States for such. turtles. The few that now inhabit the west are rather to be regarded as ancient survivals of a long-distant age when the climatic conditions were much more favourable for them than at present. The earliest member of the genus indeed (C. morrisiae), is found in a western Eocene deposit (Bridger beds), and Dr. Hay* expresses the opinion that North America is probably the original home of Clemmys. If so, the genus could not possibly have spread to Asia, and thence to western Europe in Pliocene times. The existing centres of distribution must have become established during much more remote geological periods. Anyhow, although the majority of the American species of Clemmys are now con . fined to the east, we have ample palaeontological evidence of its having formerly lived in the west.

* Hay, O. P., "Fossil Turtles of North America," p. 290. 
Besides these so-called fresh-water turtles, we have in America even terrestrial ones. The box-turtles (Terrapene = Cistudo), for instance, are strictly confined to the land, where they live largely on vegetable matter and berries. The six species are distributed from Mexico in the south-west to the New England States in the north-east. In the more northern habitats they burrow to some depth in soft ground and pass the winter there. All the box turtles inhabit North America, the genus Terrapene to which they belong being, in Dr. Hay's opinion, of North American origin. The oldest fossil species (T. putnami) comes from a deposit in Florida stated to be of Pliocene age. Dr. Hay * is inclined to the belief that the genus arose in North America, having probably been derived from Emys. If this should be the case, the origin of Emys itself must have taken place at a much earlier date than the Pliocene. Indeed it is possible that Emys is one of the most ancient of Chelonian genera, for Dr. Boulenger $\uparrow$ argued that it is in many respects the least specialized of the Emydidae and that it should be placed at the base of the family. It is of interest to note that although box turtles lived in North America at least since Pliocene times, they have not been able to spread beyond the confines of the continent. This gives us some idea of the slow rate of dispersal of these creatures.

Of the family of snapping turtles (Chelydridae) a few fossil remains are known from the Jurassic and Cretaceous, though not of existing genera. To judge from their distribution the latter must nevertheless be very ancient. These large fresh-water Chelonians with their proportionately huge and sinisters heads, are, according to Dr. Ditmars, bold and aggressive fighters, their massive, keen-edged jaws causing them to be the terror of most of the aquatic and semi-aquatic creatures. There are three species in North America. One of these ranges from Mexico, east of the Rocky Mountains, to Canada, but far to the south of Mexico the same species (Chelydra serpentina) reappears in Ecuador. Such a very peculiar discontinuous range is not unknown among fresh-

* Har, O. P., "Fossil Turtles of North America," p. 360.

† Boulenger G. A., "Catalogue of Chelonia," p. 49. 
water animals, as we shall learn later on. A second species (Chelydra rossignonii) is confined to Mexico and Guatemala. The so-called alligator snapping-turtle (Macroclemmys temminckii), which belongs to another genus, frequents the rivers emptying into the Gulf of Mexico, being common in the Mississippi as far north as Missouri. Now the most striking zoogeographical feature of the family Chelydridae is, that right across the Pacific Ocean we meet with another snapping turtle (Devisia mythodes) in the Fly River of New Guinea, the same river that contains the unique members of the family Carettochelyidae. In many other respects New Guinea has acquired the reputation of being the home of remarkable and peculiar types of animals, and no doubt the island once formed part of an ancient land, most of which has long since been submerged.

Quite as instructive and important from a distributional point of view as the reptiles are the amphibians. We can roughly divide the latter into tailed amphibians, such as the newt and salamander, and tailless ones, of which the frog and toad are examples. All these are amply represented in the north-eastern States of North America, and we notice among them that same curious relationship between eastern America and eastern Asia which has given rise to sa much comment among naturalists.

Two kinds of giant salamanders are known to exist in the world. One of these, the so-called "hellbender" (Crypto. branchus allegheniensis), lives in the eastern States of North America, the other, (Cryptobranchus or Megalobatrachus japonicus), in the mountain streams of Japan. The hellbender is a voracious lead-coloured slimy creature, living in the Allegheny and other eastern rivers, where it feeds on worms and fish. It grows to a length of two feet, while its Asiatic relative attains to double that size. Of the geological history of the giant salamanders we know nothing as far as America and Asia are concerned, but in the Miocene of Switzerland a large amphibian was discovered, which appears to be closely allied, though now referred to the distinct genus Proteocordylus. To suppose that these relicts of bygone ages are no older than Miocene would scarcely be justified. In the absence of palaeontological evidence, we must 
depend upon the testimony based on the remarkably discontinuous ranges of the two recent species. Any theory as to the home of the giant salamanders should be founded on that of other animals possessing a similar range.

The hellbender is not the only large amphibian frequenting the rivers of the eastern States. A somewhat eel-like creature, with feeble diminutive limbs and three pairs of bushy external gills, inhabits many of the larger streams and lakes in the north-eastern States. * It grows to about the same length as the giant salamander, but belongs to quite a different family. It is commonly known as the "Mud puppy" (Necturus maculatus), and does not occur west of the Rocky Mountains. Now in this case the nearest relation of the east American form does not live in Eastern Asia, but, like that of the mud minnow (see p. 51), in Eastern Europe. This European member of the family Proteidae has manifestly undergone a certain amount of degeneration. It possesses only three fingers and two toes, is completely blind, and is restricted to the subterranean waters of Dalmatia and the neighbouring provinces of southern Austria. The "Olm" (Proteus anguineus), as it is called, is scarcely a foot long, and quite white except for the gill bunches which are brilliantly red in colour. It was believed that the Texas subterranean newt (Typhlomolge rathbuni) was related to the mud puppy. Miss Emerson, $\dagger$ however, has shown that it is a salamandrid. No fossil remains of any of these amphibians are known, and any theories as to the origin of the discontinuous distribution of the members of this ancient family, must be based on zoogeographical data. .

The family of true salamanders and newts (Salamandridae) likewise comprises certain members which seem to be of very ancient origin, such as the blunt-nosed salamanders (Amblystoma). Being only semi-aquatic animals, they possess greater facilities for dispersal than the purely freshwater forms. Most of them are large species, the tiger salamander (Amblystoma tigrinum) growing to nearly a foot in length, and they only repair to the water in the spring to

* Cope, E. D., "Batrachia of North America," p. 26.

+ Emerson, E. T., "Anatomy of Typhlomolge," p. 72. 
deposit their eggs. The tiger salamander is variable in colour. Generally of a dark brown, it is marked with irregular yellow blotches, and is commonly met with under stones and in decayed hollow trees. At the time when the Spanish conquerors landed in Mexico, the natives were in the habit of eating roasted or boiled fresh-water creatures, which they called "axolotls." It is now known that these axolotls are nothing but the larval forms of the tiger salamander, which is found from Mexico to the city of New York. Under certain conditions, the larva, instead of losing its gills and turning into the terrestrial salamander, retains them, and continues its existence in the medium in which it was born, growing into a creature somewhat resembling the hellbender, and breeding without leaving the water.

The genus Amblystoma is almost confined to Mexico, the United States and Canada. Only one species (A. persimile), which most resembles Amblystoma jeffersonianum of the eastern States and Canada, inhabits the far distant mountains of Siam and Upper Burmah. This represents, therefore, another example of that curious relationship between eastern North America and Asia. In this case, however, it is with southern instead of eastern Asia, while the genus in North America occurs in the south-west as well as in the eastern States.

Several smaller kinds of newts have been observed in the eastern States. Among them there are several belonging to the genus Spelerpes, which are worthy of special comment. They all display remarkably brilliant colours, and these make them more attractive than salamanders usually are. Quite apart from this feature, their method of feeding is interesting to watch. Like chameleons, they possess an enormously long tongue, ending in a soft sticky knob, which is shot out of the mouth with extreme rapidity at any insect coming within range and likely to be a dainty morsel. About twenty species of Spelerpes are known to science, the headquarters of the genus being in Mexico. Dr. Gadow* discovered several of them at considerable heights. Spelerpes orizabensis and S. leprosus ascend to 12,000 feet, and S. chiropterus to 10,000 feet, above sea-level.

" Gadow, H., “Mexican Amphibians and Reptiles," p. 203. 
Their earliest centre of distribution lay in what has been called Sonoraland, or south-western North America, and from here the species have spread in Miocene times, according to Dr. Gadow, to the eastern States, to the island of Haiti and even to Peru. The latter occurrence is of particular importance, as we shall see later on, when we come to the consideration of the points of resemblance between the Mexican and the South American faunas. Still more remarkable is the fact that a single species of Spelerpes ( $\mathrm{S}$. fuscus) is known from some of the remaining fragments of the ancient Tyrrhenian continent in southern Europe (see Fig. 8). Even Dr. Gadow, * who shows little inclination for reconstructing ancient land bridges, does not suggest that this salamander could have crossed the Atlantic Ocean without their assistance. He thinks a land connection joining northeastern North America with north-western Europe, by way of Greenland, might have enabled the south European Spelerpes to cross from the New World to the Old. I concur with Dr. Gadow in the belief of the former existence of a land bridge in the extreme North Atlantic, but I am of the opinion that it had not yet made its appearance at the time when Spelerpes undertook its journey to Europe.

This short review of some of the characteristic northeastern reptiles and amphibians has clearly revealed a relationship of some of the older forms with those of southern and eastern Asia and also of southern Europe. In several instances it was demonstrated that the eastern States were not the original home of the genera, but that the North American centre of distribution lay in the south-west. Hence it seems possible that the south-west was in remote times, say about the commencement of the Tertiary Era, the great centre from which reptiles and amphibians wandered eastward. Owing to subsequent changes in the climatic conditions of the south-west, some genera, and even families, probably became extinct there, thus obscuring the original relationship of that part of North America with Asia and Europe. Without fossil evidence to guide us, it would seem as if these

* Gadow, H., “Mexican Amphibians and Reptiles,”'p. 244. 


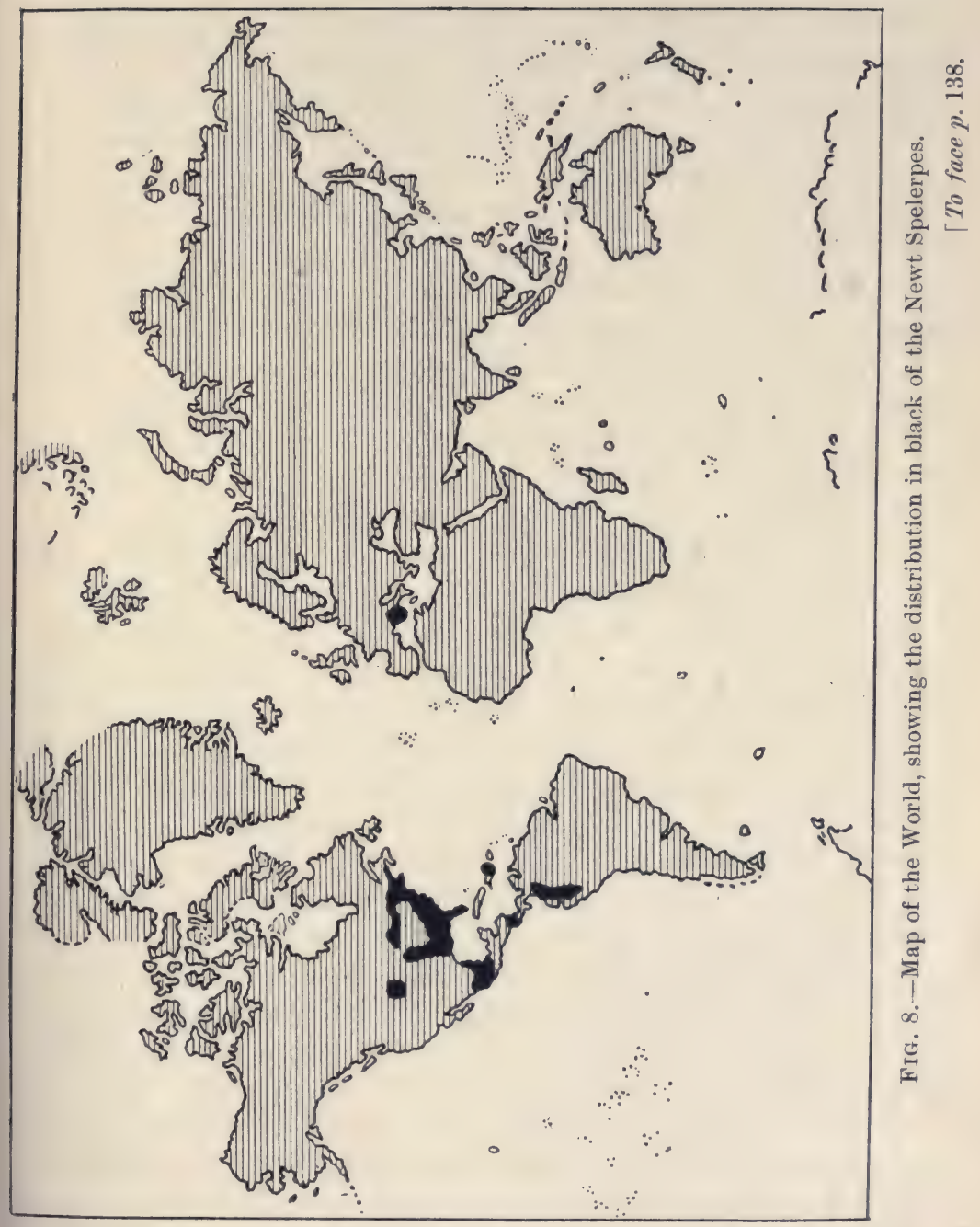



speculations were based on somewhat unreliable foundation. We may therefore call to our aid another branch of the geographical distribution of living organisms, namely that of plants, so as to test the validity of these theories.

Professor Asa Gray * was the first to direct attention, in 1859 , to the striking similarity of the flora of eastern Asia to that of the eastern States of North America. In a popular account of the distribution of the North American flora, Sir Joseph Hooker again alluded to this feature more recently, stating that there is actually specific identity in about two hundred and thirty cases, and very close representation in upward of three hundred and fifty. What is most curious, he says, is that there are not a few very singular genera of which only two species are known, one in east Asia, the other in east America. In some of these instances the Asiatic species is a widespread plant in east Asia, whilst the American is an extremely scarce and local plant. This and other conditions render it conceivable, according to Sir Joseph Hooker, $\uparrow$ that the Asiatic element in east America is dying out.

Still more recently Professor Engler discussed the same subject very fully. He believes that the number of species common to the eastern States and eastern Asia is far less than Sir Joseph Hooker thought. Some of these occur also in the north, others in western North America. Yet there are certain plants which exhibit extraordinarily discontinuous distribution, quite comparable to what we have noticed among reptiles. Monotropa uniflora and Phryma leptostachya, for instance, occur only in the eastern States, in Japan and the Himalayan Mountains. Professor Engler looks upon these as relicts of a flora which was uniformly distributed in Tertiary times between the Himalayan Mountains and North America. Of the genera Liquidambar, Ostrya, Platanus, and Castanea, we know that they lived further north in Tertiary times than they do now. We have also learned from the Pliocene and Miocene beds of the Rocky Mountains, as Professor Engler points out, that the flora west of these mountains was formerly not so distinct from that of the

* Gray, A., "Relations of Japanese Flora."

+ Hooker, J. D., "North American Flora," p. 573. 
eastern States as it is at present. A more pronounced climatic differentiation between the two parts of North America supervened, he thinks, in later Tertiary times, and while many of the species became extinct in the western States owing to the gradually increasing dryness of the climate, new forms better adapted to the altered conditions arose. Hence certain types of plants are represented in the western States by many, and in the eastern by few species.

It is evident that Professor Engler* favours the view that the western States were once much more nearly related in their flora to eastern and southern Asia than the eastern States, and that the present similarity between the latter regions has arisen as a secondary character. Professor Engler, moreover, believes-and in this respect my views differ from his-that Japan, western and eastern America were connected with one another in the north during the Tertiary Era and probably even in Cretaceous times, forming three great peninsulas of land joined at their northern bases. At any rate, the distribution of plants in America seems to offer a certain amount of support to the view suggested, that the relationship of the east American and east Asiatic faunas is due to the recent geological changes in south-western North America having obliterated the more striking features of resemblance between the latter and eastern Asia.

In connection with the character of the north eastern flora just referred to, I might offer a few remarks on the subject of the supposed former eastward extension of the land. This subject was discussed towards the end of the second chapter. I then maintained that, although the north-eastern States had been under water in Pleistocene times, unsubmerged land existed to the eastward quite $\operatorname{clos} \theta$ to, and including portions of the present shore-line.

Probably one of the best recognised and most characteristic elements of the eastern North American floras, as Mr. Hollick remarks, is the one generally known as the "Pine-barren flora," which is such a prominent feature throughout the eastern and southern parts of New Jersey and southward.

* Engler, A., "Entwicklungsgeschichte d. Florengebiete," I., pp. 2237. 
Now this flora has a curiously discontinuous range further north-eastward. It disappears from the mainland almost entirely, but reappears on Staten Island and Long Island. Still further east comes a stretch of eighty miles of sea, beyond which the pine-barren flora once more is in evidence on Martha's Vineyard and Nantucket Islands. On a limited stretch of the opposite mainland, near New Bedford, the same flora again makes its appearance. Further north, isolated members of the flora such as Magnalia glauca, from near Cape Ann, are known from certain coastal tracts.

It might be argued that this discontinuous distribution is due to marine currents or winds, but both the prevailing winds and the currents set in from the opposite direction. It would not explain the fact, moreover, that the pine-barren flora is almost limited to the islands. Hence it seems more likely that Long Island was connected by land with Cape Cod, forming a continuous strip of land, which was separated from the mainland by a broad river or a lake, as Mr. Hollick* suggests. Mr. Hollick's theory not only explains the method of dispersal of the southern pine-barren flora, it gives us a clue to the problem why the northern Helix hortensis, which has evidently survived as a relict form, should be almost confined to the islands off the coasts of Maine and Massachusetts. However, while I believe that much of that land which lay off the Atlantic coast remained unaffected by the Glacial deposits, and that the southern flora survived the Glacial Epoch on these islands, Mr. Hollick considers the eastward extension of Long Island, and with it the pinebarren flora, of post-Glacial age.

I have mainly dealt with reptiles and amphibians in this chapter, because they form a very characteristic feature of the north-eastern States. Besides no opportunity occurred of mentioning them in the earlier part of this volume. The mammals, on the other hand, scarcely need further comment here. Only comparatively few species are peculiar to this province. Nevertheless, there is an order which has not hitherto been alluded to, and which contains some remarkable forms confined to the eastern States. The

* Hollick, A., " Plant Distribution," pp. 191-201. 
order is that of the Insectivora or insect-eaters. They are distinguished externally by their small size and soft dense fur, while many of them are adapted for an underground life and possess specially modified front limbs for the purpase of digging.

Five different genera of moles (Talpidae) are known from North America, and three of these are restricted in distribution to the eastern States. One of them, containing but a single species, the star-nosed mole (Condylura cristata), has its headquarters in the north-eastern States, extending northward as far as Hudson Bay, and southward to North Carolina (Fig. 9). The name was given to it from the fact that a ring of riband-like appendages surrounds the end of the muzzle, in the middle of which are situated the nostrils. Like its European relative(Talpa europaea), it constructs extensive galleries underground, throwing up a ridge of loose earth along the line of the tunnels. No fossil remains of the starnosed mole having ever been discovered, palaeontology furnishes no evidence as to its past history, and we must assume that it has originated in north-eastern North America.

What is often known as the common mole (Scalops aquaticus) in the States, is no near relation of the European species of that description. It is more appropriately called naked-tailed mole. The Latin name aquaticus was given to it because its webbed hind-feet led to the inference that it must be a water animal, whereas it actually lives underground in dry sandy soil. Two species of Scalops are known, one of them oecurs from Massachusetts to Florida, the other further west, in the Indian Territory.

Still another eastern species is the so-called hairy-tailed mole (Parascalops breweri), whose habits are very similar to those of the other moles, though it is readily distinguished from them by its thickly-haired black tail. Its range extends along the Atlantic coast, from New Brunswick in the north to North Carolina in the south, and inland to the shores of the Great Lakes. It is even said to occur on Martha's Vineyard Island off the coast of Massachusetts, which locality is of interest in connection with the view expressed above as to this island having formed part of an ancient land surface now partially submerged. 


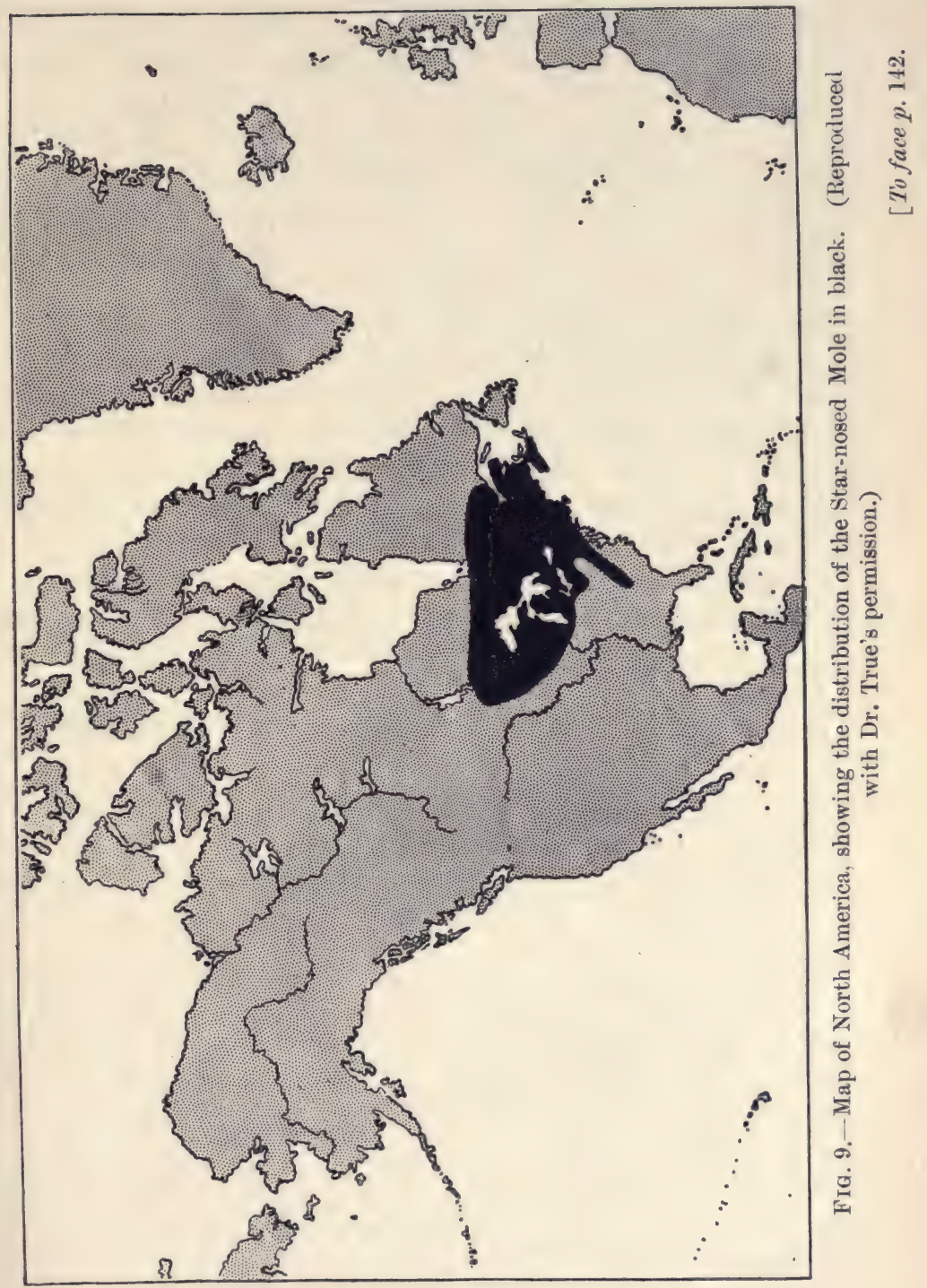



As for the geological history of these forms, a number of insectivores with talpoid dentition have been met with in the middle Eocene (Bridger) of North America, and referred to the mole family (Talpidae), but, according to Dr. Matthew, most of them are incompletely known and of doubtful affinities.* The first undoubted member of the family (Proscalops) makes its appearance in the Oligacene beds of Colorado, being apparently related to the modern Scalops. Owing to their subterranean habits, the moles are rarely found fossil, except in fissures such as those of La Grive St. Alban in southern France. Palaeontology does not aid us materially in solving the problem as to the place of origin of the Talpidae, or the geological period during which the moles have wandered from one continent to the other. We are also entirely in the dark as to the route they have taken on entering the New World from the Old or vice versa. They may possibly have spread eastward from the western States, but a careful comparative study of the living American moles seems more likely to elucidate this problem than palaeontological research.

* Matthew, W. D., "Carnivora and Insectivora of the Bridger," p. 536. 


\section{CHAPTER VII}

\section{THE CONTINENTAL BASIN}

Bounded in the east by what might collectively be termed the Atlantic Mountains and in the west by the Pacific Mountain system lies the immense continental basin. It is open to the sea both in the north and south, extending in one continuous series of plains and plateaux from the Gulf of Mexico to the Arctic Ocean. The northern portion of this great interior basin has already been briefly described in the second and third chapters. The rivers of this part of the continent drain eastward to the Atlantic Ocean and northward to Hudson Bay and the Arctic Ocean. The drainage of the southern portion is supplied almost entirely by the Mississippi, and is thus discharged into the Gulf of Mexico. It is this southern section of North America and its fauna with which I propose to deal very briefly in this chapter.

The low-lying and gently seaward-sloping belt of land bordering the Gulf of Mexico is known as the "gulf plains." It is here in this rich soil that sugar-cane, cotton and rice are cultivated. The west-central part of the continental basin is occupied by the "prairie plains." By the term "prairie" we recognise a level region, either a plain or a plateau, without forests, but clothed in a carpet of luxuriant grasses and flowering annuals. On their eastern and northern border these prairie plains merge into the adjacent forested plains, while in the west they gradually pass into the more elevated and drier high plains, where bunch grass, with bare intervals between the scattered tufts, takes the place of the continuous sod of the true prairies.

There is a widespread popular belief in Europe that the whole of the vast American continental basin is one extensive prairie or pasture land. This is quite a mistake. As we approach the Mississippi River from the west we gradually. 
pass from the treeless prairie to the forest region, which is continued eastward as far as the Atlantic Ocean. In the prairie region a struggle has been in progress for thousands of years between the conditions favouring tree growth and those adverse to them. The increase in the mean annual precipitation from west to east is the determinant factor in forest production. The main cause, therefore, of the absence of trees in the prairies lies, according to Professor Russell,* in the climatic conditions, and principally in the lack of sufficient rain during the long, hot summers.

A thorough survey of the fauna of the prairie region has still to be made. Dr. Merriam $\dagger$ devotes only a short paragraph to it. Most other writers have confined themselves ta a description of one or two typical prairie forms. The sole attempt to give us a more lucid impression of the general features of the vertebrate life of the region was made by Dr. Ruthven. He noticed that the peculiar conditions of the prairie region had an effect on the fauna in modifying the species as they entered this region from the adjoining ones. Yet he thinks that there is a great difference in the extent to which the species of eastern North America push westward, or the plains-forms eastward, into the prairie region, before becoming modified or checked. Dr. Ruthven's studies lead him to the conclusion that the prairie region is an extensive area of transition between the plains and eastern forest regions, but he expresses the opinion that the conditions of environment are either not intensive or not extensive enough to mould the animals into a peculiar fauna.

What was once the most characteristic animal of the prairie region is now practically extinct in the United States in its feral condition. I need no longer dwell on the history of the extinction of the bison, the animal I am alluding to, for it has been sufficiently described in the third chapter (pp. 65-67). When discussing the question of the bison's origin, I suggested that its ancestors might have invaded North

* Russell, I. C., "North America," pp. 89-96.

† Merriam, C. H., "Life in North America," p. 20.

† Ruthven, A. G., "Faunal Affinities of Prairie Region," pp. 390393. 
America from Asia in pre-Glacial times. Long before the advent of the Eunopean conquerors in the New World, herds of another large ungulate, the horse, roamed about these same prairies and no doubt shared the abundant fodder with the bison. When the Spaniards landed in America in 1521 it was already extinct, and the natives had not any knowledge even of the former existence of the horse in their continent. Yet even in Pleistocene times several different kinds of wild horses still lived in North America and were probably contemporaneous with early man. One of these (Equus giganteus) seems to have exceeded in size any known race of horse either living or extinct.* What caused the sudden extinction of the wild horse all over America we do not know. Professor Osbornt suggests that a disease of the nature of the African " rinderpest" might have done it. The "tse-tse fly" renders thousands of square miles of Africa uninhabitable for horses, and the invasion of a similar pest into America might possibly have swept away the whole of the equine stock in a short time. But the interest aroused among zoologists by the discovery of fossil horses in America was not only connected with their unexplained disappearance in modern times, it yielded what was thought to be absolutely demonstrative evidence of the theory of evolution. Fossil forms no doubt had already been discovered in Europe which seemed to indicate that the remote ancestors of the existing horse had five digits on every foot while intermediate stages with three fully developed toes were known. In America, horses, or at any rate animals possessing all the essential characters of a horse, have been brought to light from very early Tertiary deposits, possessing four toes and a rudimentary fifth on the hind foot and short-crowned teeth. These are succeeded in Oligocene and Miocene strata by others with three toes and shortcrowned teeth. In still more recent deposits, horses occur with three toes and long-crowned teeth which are finally followed by horses of the modern type with one toe and longcrowned teeth.

* Gidley, J. W., "Revision of North American Species of Equus," p. 137.

† Osborn, H. F., "Causes of Extinction of Mammalia," p. 835. 
In a revision of the American Eocene horses, Mr. Granger* distinguishes twenty-six species, all the three genera to which they belong being distinct from the early horses found in Europe. The American Eohippus appears to be closely related to the Old World Hyracotherium, while Epihippus approaches Lophiotherium. We thus have a somewhat parallel series in the two continents.

In the Oligocene deposits the horses are still small, some of them less than eighteen inches high at the withers. Twenty-eight species, belonging to the two genera Mesohippus and Miohippus, have been described by Professor Osborn. $\dagger$ Sixty more species are mentioned by Mr. Gidleył as having been procured in the Miocene and Pliocene beds, and over half a dozen more from Pleistocene strata. Thus we know from America already about one hundred and twenty different kinds of fossil horses. They gradually increase in size as we proceed from the older to the newer deposits. The species with many toes are replaced by others with fewer toes, until we come to the highest form of specialization in the modern horse. All that remains of the outer toes is a splint-bone left on each side of the single toe, while the teeth which originally possessed short crowns have now long ones. There is apparently a gradual evolution from smaller and simpler forms to larger and more complex ones, as we glance from the older horse remains to the recent ones. And jet not a single gradual transition from one genus to the other seems to be known. No wonder that one of our foremost palaeontologists exclaims : "The supposed pedigree of the horse is a deceitful delusion, which simply gives us the general process by which the tridactyle foot of an ungulate can be transformed in various groups into a monodactyle foot in view of an adaptation for speed, but this in no way enlightens us on the palaeontological origin of the horse." §

Considering the extraordinary abundance of horse remains in North America, and even in the south of South America,

* Granger, W., "American Eocene Horses," p. 233.

† Osborn, H. F., "New Oligocene Horses."

$\ddagger$ Gidley, J. W., "Miocene and Pliocene Horses of North America."

§ Depéret, C. H., "L'évolution des Mammiferes Tertiaires," CXL., p. 1517 . 
it would seem as if the family Equidae had originated in America and had sent certain offshoots to the Old World during such times when America was connected by land with either Asia or Europe. Professor Depéret* certainly takes the view that both Anchitherium and Hipparion reached Europe by means of a land connection with America, and that the two continents were several times joined to one another by land during the Tertiary Era. This opinion is amply supported by the most weighty zoogeographical evidence, as will be shown in one of the succeeding chapters (pp. 226-231). There is, indeed, a very general agreement among palaeontologists on this point. The only difference of opinion concerns the exact location of the site of these ancient land bridges.

One of the most characteristic animals of the great plains is the so-called "prairie dog" (Cynomys ludovicianus). The name has been applied to it on account of the peculiar barking sound it emits when alarmed. Otherwise it has nothing to do with the dog family, being more nearly related to the ground squirrels and marmots. It loves the sunshine and a dry atmosphere, and becomes less and less numerous as we approach the humid prairies from the west. The prairie dog is a social creature living in colonies, and these, according to Dr. Merriam, $\dagger$ are sometimes from twenty to thirty miles in length. The damage done to crops by these animals is enormous, while their increase is greatly favoured by the spread of agriculture. The cultivation of the soil enables them to support larger families, whereas the cultivator further protects them by destroying their natural enemies.

The prairie dog inhabits a vast area between Montana in the north and southern Texas in the south. Altogether seven species of Cynomys are known, some of which range into Arizona and Mexico, whereas none occur in the eastern or extreme western States of America. No fossil remains of Cynomys from Tertiary deposits have been identified, except from the Miocene Republican River deposits of Kansas and Nebraska, and even they only doubtfully belong to the genus.

* Depéret, Ch., "Transformations of the Animal World," p. 313.

† Merriam, C. H., "Prairie Dog,” pp. 258-263. 
Cynomys, however, is certainly of American origin, though some of its near relations, as I have shown, have probably an Asiatic ancestry.

The coyotes or prairie wolves have been described as the most inveterate enemies of the prairie dog. They are small, graceful creatures hunting in packs like other wolves, but living in burrows on the plains. Not long ago only a single kind of coyote (Canis latrans) was recognised. More than a dozen species are distinguished now ; some of them on rather slender grounds. ${ }^{*}$ All these occur west of the Mississippi. The presence of wolves in the Arctic regions of America has been alluded to (p. 11 and p. 61), but I have not hitherto made any remarks on their past history and origin.

The dog tribe (Canidae), to which all wolves belong, is more widely spread in the world, that is to say, it has a larger geographical distribution than any other family of carnivores, one species being even found wild in Australia. Judging merely from the extent of its range, the family Canidae should be a very ancient one, and this assumption is fully borne out by the knowledge we have obtained from fossil remains of the dog tribe.

According to one of the most recent views, it would seem as if the Cretaceous ancestors of the Carnivora, the greati order to which the dog tribe belongs, were a group of small arboreal mammals resembling the opossum in size and habits, while more nearly allied to the primitive Insectivora. The most strictly terrestrial types, such as the Canidae and Hyaenidae, have departed widely from the primitive skeletal structure. In the Eocene we already find several families of the Carnivora fully developed, one of which, the Miacidae, is regarded by Dr. Matthew $\dagger$ as the precursor of the dog family.

The latter originated in Oligocene times, but it was not until the Miocene. Period that the genus Canis marked its first appearance in America and Europe simultaneously. Since it is highly improbable that the same genus should have arisen

* Merriam, C. H., "Revision of the Coyotes."

† Matthew, W. D., "Carnivora and Insectivora of the Bridger," pp. 328 -350 , 
independently in two different continents, the genus Canis must have originated either in America or Europe. Dr. Matthew* directs attention to the fact that the modern representatives of the Canidae living in the Oriental region and in South America are more akin to the Oligocene and lower Miocene species than are the true wolves, jackals and foxes. Assuming the original centre of evolution to have been somewhere in Europe or North America, we might argue that the older types of dog-like creatures spread into distant parts and were preserved there, while they were superseded in their ancestral home by more modern types.

But we are apt to forget that the two species of Canidae which live furthest from our hypothetical centre of origin are most nearly related to what we generally look upon as the most modern of the dog tribe. I am alluding to the wild dog of Australia (Canis dingo) and to the Falkland island wolf (Canis antarcticus). It is a most remarkable fact that the latter is not nearly related to a single South American species of the dog tribe, whereas it really belongs to the aoyotes which, as we have noticed above, are confined to western North America. Similarly the Australian dog, which is now generally considered a truly wild species and not a recent human introduction, is akin to one of the European Pleistocene dogs. There is a wild dog in the mountains of Java (Canis tenggerana) which also appears to be nearly related to the dingo of Australia. These two anomalous cases do not seem to fit in with any of the existing theories. Dr. Wallace $\uparrow$ maintained that it must have been as far back as the Secondary Era of geological history that Australia was in actual connection with the northern continents, and received from the latter the ancestors of the present fauna. There was no subsequent land connection, according to Dr. Wallace, so that from that remote time until now the Australian lands have thenceforth evolved the various Marsupial and Monotreme types which we now find there.

It is evident that Dr. Wallace did not believe in the indigenousness of the Australian dog when he made these remarks.

* Matthew, W. D., "Lower Miocene Fauna from Dakota," p. 180.

+ Wallace, A. R., "Geographical Distribution," I., p. 465. 
Yet even those who do are at a loss to account for its presence in Australia. Professor Weber * favours a very early human introduction, even in Pliocene times. I myself have been unable to form a definite judgment on this subject.

The origin of the Falkland island wolf is in so far a very much more difficult problem to solve, as none of the species of the dog tribe living on the opposite mainland of South America are at all nearly related to it. Dr. Wallace 7 and also Mr. Lydekker $\ddagger$ express the opinion that the Falkland islands were evidently connected with the mainland at no distant date. Dr. Wallace believed that this wolf was closely allied to a Patagonian species.

Later on (p. 430) I shall have some further remarks to make on this subject. I only mentioned these two instances of distribution to show the difficulties which we frequently have to contend with.

The raccoon (Procyon lotor) is by no means a typical inhabitant of the prairie, still as it occurs here and there and is very characteristic of North America it may as well be mentioned here. By nature a forest animal, the raccoon, with its omnivorous propensities and great adaptability, easily accustoms itself to the most diverse surroundings, and as a rule thrives and breeds well in confinement. It inhabits the whole of the United States and southern Canada and belongs to a family (Procyonidae) which is quite confined to North and South America, and always has been. We need not hesitate in this case in attributing its origin to America. The raccoon family has the same ancestors (the Early Tertiary Miacidae) as the dog family, according to Dr. Matthew, $\S$ one of the members of the former, Cercoleptes (Potos), being actually the nearest in its skeletal construction to the Eocene Miacidae. It has been stated by Dr. Matthew that the lower Miocene Phlaocyon from Colorado is approximately, though not exactly, ancestral to the raccoon; but in view of the fact that both Dr. Ameghino and Dr. von Ihering || emphatically

* Weber, M., "Der Indo-australische Archipel," p. 40.

+ Wallace, A. R., "Geographical Distribution," II., p. 49.

† Lydekker, R., " History of Mammals," p. 140.

$\S$ Matthew, W. D., "Carnivora and Insectivora of the Bridger," p. 331.

|| Thering, H. von, "Südamerik. Raubtiere," pp. 159-160. 
support its being one of the dog tribe (Canidae), we should hesitate before accepting the earlier opinion.

The genus Procyon, to which the North American raccoon belongs, only makes its appearance in the Pleistocene Period. Nevertheless, it is quite possible that cave deposits, such as that described from McCloud River in California containing the new species Procyon sinus, may eventually be placed in the Pliocene series.* At any rate, the genus Procyon must have existed before Pliocene times, and it seems to me probable that it originated either in South America or in some western lands which have long since subsided. Dr. von Ihering $\dagger$ believes that the Procyonidae have undoubtedly come from eastern Asia. Why he should think so I cannot imagine, for neither recent nor fossil species are known from that continent.

It is now generally admitted, as I mentioned already (p. 95), that Central America assumed its present shape and contours at some time during the Pliocene Period (compare p. 243). As soon as this land bridge became habitable for terrestrial animals, northern species are supposed to have poured across it into South America. We possess strong evidence certainly that a steady stream of southern animals invaded the northern continent in Pliocene and even in Pleistocene times and that northern ones succeeded in reaching the south.

The group of the so-called toothless mammals (Edentata), comprising the ant-eaters, sloths and armadillos, are almost entirely confined to South America; and that continent no doubt is their original home. A few penetrated in some mysterious manner to North America in Eocene times, as I shall explain more fully in another chapter. Shortly afterwards they seem to have become extinct again in North America, for no traces of edentates have yet been discovered in the succeeding Oligocene deposits. It is only in the Miocene beds of North America that we again meet with examples of this curious group. They were representatives of the huge Megalonyx which is closely allied to a southern

* Gidley, J. W., "Fossil Raccoon from Californian Cave."

† Thering, H. von, “Südamerik. Raubtiere,” p. 160. 
genus. Megalonyx and Mylodon, 'which follows in Pliocene times, were giant ground sloths almost the size of elephants, while Glyptotherium, another Pliocene species, had a great shield-like bony armour covering the whole body. The plio cene species were accompanied by a great peccary (Platygonus), a llama of a very large size (Pliauchenia) and a number of other interesting creatures, all of which have now completely vanished from the northern continent.

In the succeeding deposits from the great plains and mountain regions, which have been classified by Professor Osborn * as belonging to the lower Pleistocene series, we notice the remains of two large elephants (Elephas columbi and E. imperator), a true camel(Camelus)and two other members of the same family, the great peccary Platygonus and the two large ground sloths, Mylodon and Paramylodon. The rivers were tenanted by beavers, otters, musk rats and a curious semi-aquatic creature about the size of a bear, called Castoroides. Related to some of the groups of South American rodents, the latter suddenly makes its appearance in the Pleistocene beds of eastern North America.

Now we come to the cave deposits, which I have alluded to already on several occasions, and which Professor Osborn includes in the middle Pleistocene or Glacial series. The Port Kennedy cave in Pennsylvania contains no less than four species of the great edentate Megalonyx, also a Mylodon, two kinds of sabre-tooth tigers, a Mastodon, four species of peccaries and a tapir. In the Potter Creek cave of California were discovered, among others, four species of Megalonyx, a camel and a Mastodon. Finally, the Conard fissure of northern Arkansas revealed two species of sabre-tooth tigers, three kinds of peccaries and numerous small animals. Apart from a few deer bones and the remains of the curious Symbos; an animal allied to the musk ox, it contained no traces of large ungulates. Their presence in the district adjoining the fissure is, nevertheless, indicated by the sabre-tooth tigers.

What I wish to make clear is that huge creatures requiring an abundance of vegetable food poured into North America, not only in Pliocene but also in Pleistocene times. Many

* Osborn, H. F., “Cenozoic Mammal Horizons," p. 85. 
other mammals apparently had their original home in this continent. Peccaries and tapirs, which, as we know, require a hot and moist climate, lived as far north as Pennsylvania even during the time when vast glaciers were supposed to have covered the whole of Canada and a substantial slice of the United States. We are told that the fauna of this period clearly reveals the state of the climate. If the remains of the animals above referred to indicate anything, they show us undoubtedly that the climate was mild, with an abundance of vegetation and animal life. In common with most other geologists, Dr. Hay believes that the climate of the Glacial Epoch must have been cold in North America, because he assumes the certain existence of vast ice-masses at that time even in New York, in Indiana and in Missouri. If we deal with this climatic problem from an independent standpoint and endeavour to reconstruct the conditions prevailing during the Glacial Epoch from purely faunistic evidence, our conclusions cannot point to the prevalence of an exceptionally cold climate. Proof of the existence of a cold climate in the United States during the Pleistocene Period seems to be furnished, says Dr. Hay, ${ }^{*}$ by the occurrence of the three genera of mammals, Rangifer, Boötherium and Symbos.

The name Boötherium is now applied to an extinct large sheep-like creature, viz., B. bombifrons, whose remains have been discovered in Pleistocene deposits of Kentucky. According to Dr. Kowarzik (see p. 7), Boötherium was probably the direct ancestor of the northern genus Ovibos, which has never been found in any Pleistocene beds in the United States. Boötherium can scarcely be claimed as an exponent of a cold climate, because it has never lived north of the United States. The latest discoveries seem to indicate that a number of sheep-like animals originated in the United States towards the latter part of the Pliocene Period, and left their remains in various parts of the country. Thus the extinct Euoeratherium, first identified by Dr. Sinclair and Mr. Furlong from a cave in California, and Preptoceras from another Californian cave, are both allied to Boötherium and Ovibos. Hence Ovibos is the sole member of this group which has survived, having

* Hay, O. P., "On the Changes of Climate," p. 372. 



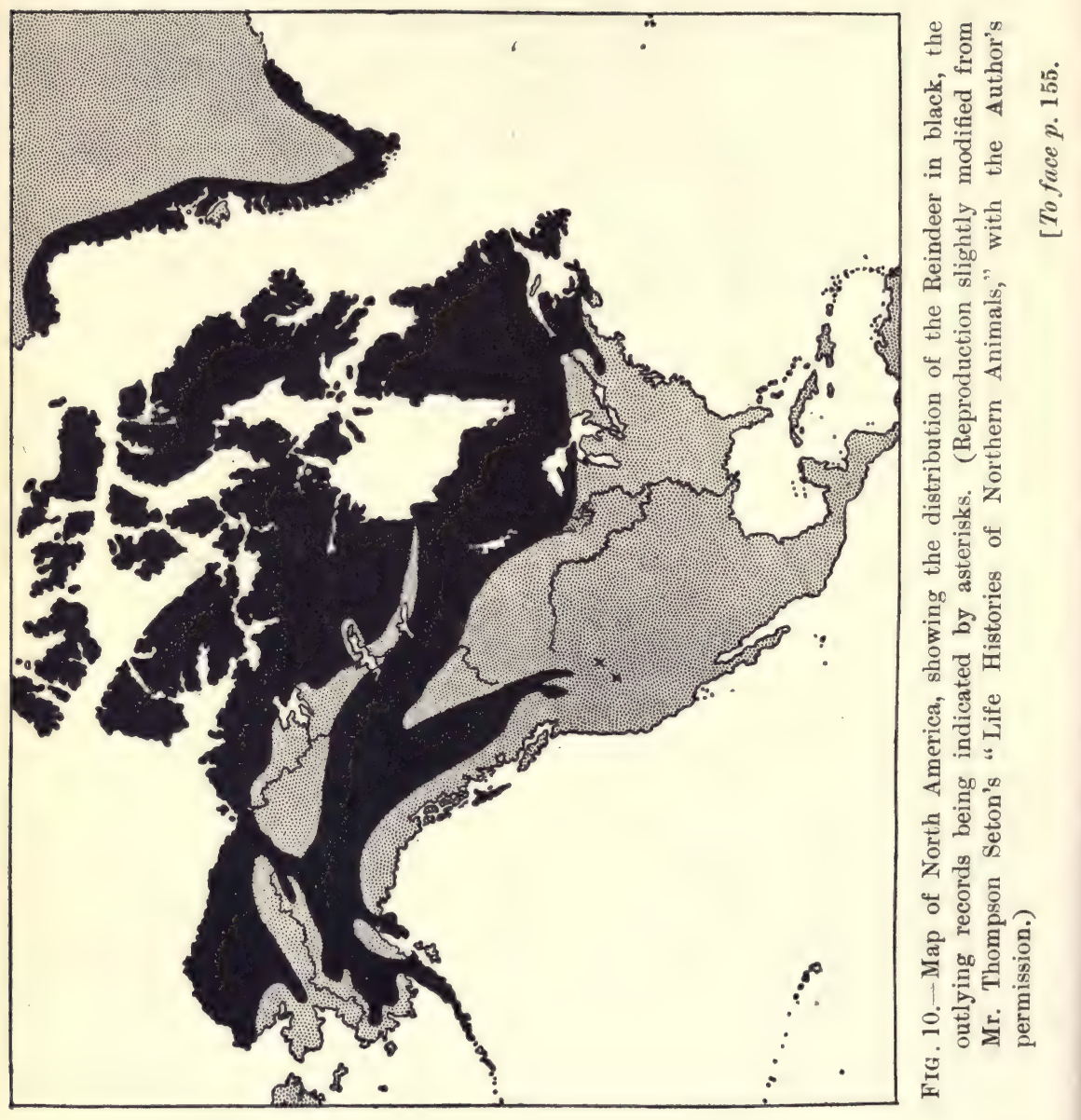


succeeded in adapting itself to an arctic habitat. The available evidence is all in favour of a gradual advance having taken place of those large sheep-like forms from a more southern to a northern habitat during late Tertiary times. Mr. Osgood* has now discovered another extinct relation of the musk ox in the Yukon Territory of north-western Canada. He first described it as Scaphoceros tyrelli (including Ovibos cavifrons of Leidy in the same new genus), and suggested that Scaphoceros may be ancestral to Ovibos. According to Mr. Barnum Brown, the name Symbos has now been substituted for Scaphoceros. Hence Symbos is known from Indian Territory, Iowa, Missouri, Ohio, Pennsylvania, Kansas, Arkansas, from Yukon Territory and from Alaska. Yet even its former presence in Alaska cannot stamp Symbos as a coldloving animal, for close to its remains were dug up those of a Mastodon, and who would be prepared to argue that the Mastodon is an indicator of a cold climate?

Lastly, Dr. Hay claims that the reindeer (Rangifer) having occurred so far south of its present habitat (Fig. 10) in Pleistocene times is a proof of the existence of a cold climate at that time in the United States. I have discussed this problem once before (pp. 3-6), but I may add a few remarks. If the drift area of North America had been covered largely by the sea, as I believe it was, during part of the Glacial Epoch, the country which was still habitable for the reindeer must have been greatly reduced. Hence a southward emigration was the only possible chance of survival for some herds of reindeer. Driven out of their home by the stress of circumstances, they would have passed into a district, even if the latter had been unsuitable to their requirements. At any rate, we know that reindeer can live perfectly well in a temperate climate and that they still inhabited Scotland in the twelfth century long after the Glacial Epoch had passed away. I cannot therefore consider its former presence in the United States a proof of a cold climate. That it could anly have penetrated south in small numbers is indicated by its total absence from all the North American caves hitherto examined except one, and from almost all the other Pleisto-

* Osgood, W. H., “Scaphoceros tyrelli,” p. 178. 
cene deposits. On the other hand, we have noted that peccaries lived in the United States during the Pleistocene and the preceding geological periods. They were not exterminated by the severity of the climate. Representatives of the peccary family not only survived the Glacial Epoch, they even showed their indifference to it by invading the area which had only just been forsaken by the supposed Wisconsin glacier, for their remains, as Dr. Hay tells us, were found in deposits overlying the Wisconsin drift at three different localities. In the single cave in which the reindeer occurred its remains were mingled with those of a species of peccary (Tayassus tetragonus) very closely allied to that still living in the Southern States and in South America. Nor was the Glacial Epoch any more trying to the great ground sloth, Megalonyx, for it also survived it and invaded the area covered by the drift. The remains of a species of that giant edentate were found some years ago, according to Dr. Hay, in an old filled-up pond, just within the alleged outermost moraine of the Wisconsin glacier near Millersburg in Ohio. My own views as to the nature of the climate prevailing during the Pleistocene Period, and particularly during that phase of it known as the "Glacial Epoch" or Ice Age, are derived from a careful scrutiny of the living and extinct fauna and flora. This study of the animals and plants does not reveal to me' that the Pleistocene Period was a period of extreme cold. On the contrary, as I remarked before, the climate seems to have been milder in a large portion of the northern hemisphere than it is at present. An apparent increase of temperature after the passing away of the "Ice Age" is supposed to be indicated by the appearance of forms of animal and plant life requiring a higher temperature than is compatible with the arctic condition believed to have prevailed during the height of the Glacial Epoch. It is really due, I think, to that perfectly natural re-occupation of tracts of country on which both plants and animals had been destroyed. The destructive agent, in my opinion, was not ice but water.

Glaciers no doubt existed on all the higher mountains near the Atlantic and Pacific coasts. They owed their presence, however, not to cold, but principally, as I mentioned before, to the higher temperature of the eastern and western oceans. 
Towards the latter part of the Glacial Epoch, when the existing geographical conditions of the northern lands were gradually brought about, the temperature of the Atlantic and Pacific Oceans decreased, causing a diminution of precipitation on the continents. With slight climatic oscillations the conditions almost all over the northern hemisphere gradually seem to have grown less favourable for the survival of Tertiary animals and plants than they were during the Ice Age. Warmth and moisture-loving species are almost everywhere being replaced by others that can support greater extremes of temperature, and the former only exist here and there in diminishing colonies as relicts of the past.

In the United States we have evidence of such a course of events, not only among the higher groups such as the mammals; some of the more slowly-moving invertebrates are even more trusty indicators of the past geological history of the country.

Three species of an operculate snail belonging to the family Helicinidae inhabit the United States. One of them(Helicina chrysocheila) occurs in Texas near the mouth of the Rio Grande. Another (H. orbiculata) has a wide range from Florida and Texas as far north as Arkansas and Tennessee. A third (H. occulta) lives in isolated colonies among loose leaf-mould in well-wooded districts from Carolina to Wisconsin and Minnesota. Though inhabiting States where severe winter frosts are common, it is amply protected against them by its mode of life. Mr. Cooke* maintains that all operculate land mollusks are exceedingly sensitive to cold, and that the whole group is undoubtedly a product of tropical or semi-tropical regions. This view is borne out by the range of Helicina. Far to the west of North America, beyond the Pacific Ocean, a few stragglers occur in Burma and on the Nicobar islands. As we advance eastward they increase in number in certain parts of southern Asia. Almost throughout Polynesia we meet with some species, and also on the West Indian islands (Fig. 11). That the genus is a very ancient one must be evident from its geographical distribution. It had already reached America in early Tertiary times, for Dr. Dall

* Cooke, A. H., "Molluses," p. 24. 
describes a species from the Oligocene Silex beds of Tampa in Florida apparently related to a Helicina still inhabiting the Bahama islands. Considering that the genus Helicina is almost confined to tropical and semi-tropical countries, we may assume that it spread northward at a time when very mild climatic conditions prevailed in the northern United States, and that a few more hardy species have survived in isolated colonies wherever they could obtain sufficient protection against frost. This view is confirmed by the fact that Helicina occulta, now an extremely rare shell, is abundant in the Pleistocene loess beds of Indiana, Iowa and Nebraska. Mr. Shimek* likewise expressed the opinion that the still existing northern colonies of Helicina occulta appear to be the remnants of a once common race which is evidently dying out.

A family which resembles the Helicinidae, in so far as it is largely confined to tropical and sub-tropical regions, is that of the Phasmidae. $†$ They comprise orthopterous insects of the shape of a small twig, and hence are known as "walking sticks," also " prairie alligators " or " stick-bugs " in America. All the species found in the United States are wingless. They are thus not liable to accidental transport except perhaps by water. All are vegetable feeders, and over a dozen kinds inhabit the southern States. Among these walking-stick insects there is one which has a remarkably northern range, viz., Diapheromera femorata. I met with it on Goat Island, above the Niagara Falls. It has also been observed near T'oronto, and several other places in southern Canada. We possess no fossil evidence of the geological history of the genus Diapheromera; nevertheless, the fact that the family, Phasmidae was already represented in Jurassic times, according to Dr. Handlirsch, $\ddagger$ justifies the assumption that Diapheromera originated and began to spread northward in preGlacial times, and that it may be regarded as a southern relict in its present northern habitat.

Two well-known instances of survivals of southern species

* Shimek, B., "Helicina occulta."

$\dagger$ Caudell, A. N., "The Phasmidae of the United States," p. 874.

† Handlirsch, A., “Die Fossilen Insekten,” p. 1191. 


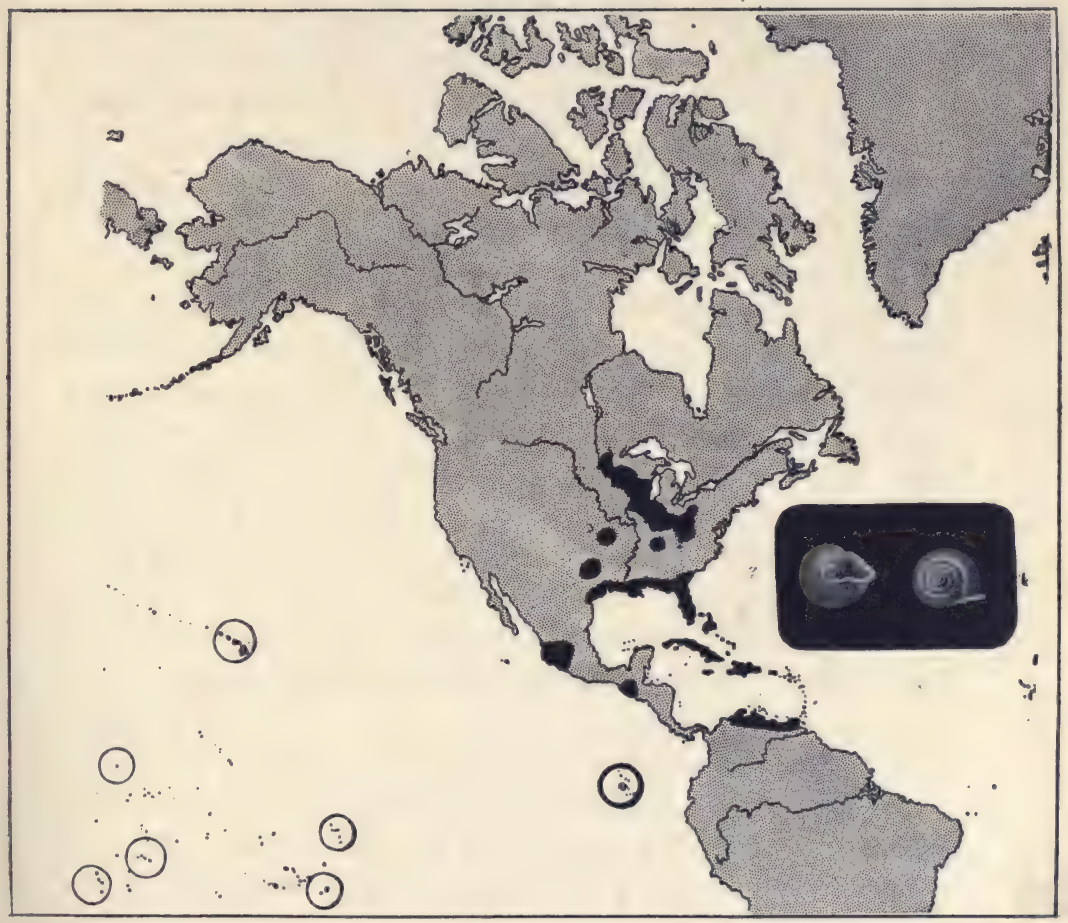

F'IG. 11.-Map of North and South America, showing the distribution (in black and within the area surrounded by small circles) of the snail Helicina. 

of birds in northern habitats occur to me. Strictly speaking, they should not be quoted, because they are now extinct in their northern habitats. But as their extermination happened within historic times, and has been caused by human interference, I may venture to include them in this group of southern invaders. They are the turkey and the Florida parrot.

The wild turkey (Meleagris gallopavo) belongs to a distinctly southern group of birds. In the time of the early settlers it was common as far north as Massachusetts, and extended westward to Colorado and southward to Mexico and Florida. Being a much-prized luxury of the pioneer hunter, it was soon exterminated in the more populous districts. It still occurs in some of the southern States, while an allied species is known from Central America. The genus Meleagris was already an inhabitant of North America in Oligocene times, for Professor Marsh described a species from the White River deposits in Colorado. No doubt it has lived in North America ever since those early Tertiary times. All we know from fossil evidence is that the remains of two other species were identified from Pleistocene deposits in New Jersey, while the bones of the wild turkey itself have been noticed in a cave in Pennsylvania. Like the edentates and peccaries this southern genus of birds flourished in the northern States throughout the Glacial Epoch and survived there until historic times.

The Florida parrot (Conuropsis carolinensis) is the only example of the large parrot tribe indigenous to the United States. It is now restricted to the comparatively small area of the Gulf States and the lower Mississippi Valley. Yet the early settlers noticed this bird even near the shores of the Great Lakes, and occasionally it was observed near the cities that were springing up in the eastern States. No doubt it survived in these northern districts from remote times, although we possess no fossil evidence of this fact. It cannot be contended that the parrot left its former habitat through persecution; nevertheless, man in his agricultural pursuits, must have interfered with it, possibly by reducing the birds' food supply.

I wish now to make a few remarks on the inhabitants of the mighty river and its tributaries flowing through the 
continental basin, as they are of such importance in tracing the geological history of the fauna. The Mississippi lies wholly within the boundaries of the United States, and drains more than two-fifths of their area. Originating in Lake Itasca in Minnesota, the Mississippi receives during its long course four great tributaries, the Missouri, Ohio, Arkansas and Red River, and a large number of smaller ones. The two principal groups of animals inhabiting this great river system are the fishes and fresh-water mussels. Some of the fishes are able to live in brackish water, others spend part of their lives in the sea, so that they are not of such extreme importance from a zoogeographical point of view as the freshwater mussels.

Fresh-water mussels, or Naiades as they have been called, all die quickly if immersed in salt water or if removed to the land. Their distribution being world-wide, they have been looked upon by some naturalists as among the best indicators of former changes of land and water over the globe. Others have urged that the wide range of these mussels may be due to accidental conveyance by birds or fishes. It was thought that the eggs or the newly-hatched fry of the mussels had been thus transported. Many species immediately after their fry has been hatched from the eggs, develop hooklets on the temporary shell, by which the young mussels can attach themselves to foreign objects. It has been argued that such larval mollusks might become attached to the feet of aquatic birds and be carried by them in their flight from the fresh waters of one region to those of other regions and there be set free. Theoretically, such an accidental transport would seem quite a possible one from time to time, certainly much more likely than a similar conveyance of the fry by fishes from one river system to another. In a country like North America, where millions of migratory birds pass annually north and south, and to some extent east and west, the effects of a conveyance such as suggested should be clearly discernible in the composition of the North American fresh-water mussel fauna. Yet although there are over four hundred different kinds of fresh-water mussels in the Mississippi drainage area, some of them having existed there almost unchanged since Cretaceous times, the fauna to the east and west of that area is 
entirely different.* The geographical distribution of freshwater mussels in North America thus constitutes a practical demonstration of the correctness of the view so ably maintained by Dr. von Ihering, $\dagger$ and supported by Dr. White, that these mollusks are not appreciably affected by chance or accidental dispersal.

The family Unionidae, to which all the North American fresh-water mussels belong, first appeared during the Triassic Age. Their principal diffusion over the globe may possibly have been effected in Secondary or Mesozoic times. During the closing period of the Mesozoic Era, the Cretaceous, the family attained an extraordinary development, particularly in the Laramie strata. The remarkable feature is that many of the species in these beds are so nearly like the living species that according to Professor Whitfield $¥$ they are to all intents and purposes the same. There were at that time (the Cretaceous Period) two great land masses in place of the North American continent viz., one in the east, the other in the west. The fresh-water mussel fauna occupied then as far as we know, mainly the eastern flank of the western land-mass. The latter was probably connected, as I shall endeavour to show later on, with some old land-masses on the west coast of South America. South America may thus have acquired its Unionidae in Mesozoic times.

The two great families of fresh-water mussels, Unionidae and Mutelidae, have been recognised for some time past, also the restriction in distribution of the latter family to Africa and South America. It was not until the year 1891 that Dr. von Ihering $\S$ made the striking discovery that all the Unionidae begin their existence on hatching from the egg, as so-called "glochidium" larvae, while the Mutelidae have an entirely different "lasidium" larva. The Unionidae, of which about one thousand species are now known, have since been subjected to a thorough critical revision by Dr. Simp-

* White, Charles A., "Ancestral Origin of North American Unionidae," pp. 77-79.

† Ihering, H. von, " Najaden von S. Paulo," pp. 133-140.

† Whitfield, R. P., "Fossil Unionidae from Laramie Clays,” p. 624.

§ Thering, H. von, "Anodonta and Glabaris."

L.A. 
son,* as a result of which we now recognise sixty-one genera.

To return to the strictly North American fresh-water mussels, it has been found that a common assemblage inhabits the entire Mississippi drainage basin, and that a considerable number of the species have a distribution covering the greater part of this area, as well as the whole of Texas and even parts of eastern Mexico. The streams which fall into the Atlantic are peopled by an entirely different set of forms, the Appalachian chain seeming, according to Dr. Simpson, to act as a sharp barrier between the two regions. In the greater part of Mexico and Central America a totally different fresh-water mussel fauna is found. Two Unios, one Margaritana and some half-a-dozen Anodons, are all that have hitherto been credited to the immense region on the Pacific slope of North America. One of the Unios, says Dr. Simpson, $\dagger$ has been recorded in error, the other is a form of the most abundant and most widely distributed Unio, viz., U. luteolus. The causes which led to this striking difference between the fresh-water mussel fauna of the Central basin and that of the Pacific slope will be discussed in another chapter. I may only mention that a somewhat similar-disparity between the two faunas has been observed among the fresh-water fishes. Before dealing with these there is one other matter of importance that I should like to refer to in connection with the geographical distribution of fresh-water mussels.

The far-reaching results of the study of the geographical distribution of such a group as the fresh-water mussels is exemplified in a striking manner by the following physiographic problem. In discussing the origin and recent history of the physical features of the southern Appalachians Messrs. Hayes and Campbell advocated the theory that the upper Tennessee river, now a tributary of the Ohio, formerly flowed into the Gulf of Mexico by way of the existing Coosa and Alabama Rivers. The conclusions were based entirely

* Simpson, C. T., "Synopsis of the Naiades."

† Simpson, C. T., "Relationship and Distribution of Unionidae," pp. $354-358$. 
upon physiographic evidence-such as the character of the Tennessee-Coosa divide, the nearness of the gorge below Chattanooga, and the general arrangement of the drainage lines.* Now it is a remarkable fact that Dr. Simpson has quite independently come to a similar conclusion from a study of the fresh-water mussels. The upper Tennessee and also the Alabama River abound in species of the genus Pleurobema, which is quite absent in the lower Mississippi. The species, moreover, found in these two rivers are very closely allied, so that this and other characters led Dr. Simpsont to the conviction that at some time in the middle or later Tertiary, the Tennessee River must have flowed southward into some of the streams of the Alabama drainage, discharging its waters in this manner direct into the Gulf of Mexico.

In the fourth chapter (p. 88) I cited some ganoid fishes of the Mississippi in illustration of the zoological relationship existing between eastern North America and eastern Asia. Two other well-known and very remarkable ganoid fishes live in the Mississippi basin, viz. the bow-fin (Amia calva) and the bony-pike (Lepidosteus osseus). The former is the sole surviving member of the family Amiidae. Long ago, in early Tertiary times, the genus Amia inhabited middle and western Europe, while it is amply represented in the Eocene (Bridger) deposits of Wyoming. Bony-pikes lived in Europe from Eocene to Miocene times. In America they likewise appeared in the Eocene period, and persisted until the presentiday. It is evident that both the bow-fin and bonypike are extremely ancient types, which have managed to survive a great many geological changes of the American continent. Their ancestors must have travelled to Europe in the dawn of the Tertiary Era, assiuming of course that North America was the birthplace of these genera. Did they travel from river to river and from lake to lake across North America and Asia to Europe, or did they utilise the fresh-water streams of a shorter direct land bridge to Europe? These are problems to be solved. The zoological

* Hayes, C. W., and M. R. Campbell, "Relation of Biology to Physiography," p. 131.

† Simpson, C. T., "Evidence of Unionidae," pp. 134-135. 
f affinity between Europe and North America is so strong, and already so many instances of this relationship have been referred to, that nothing short of a wide and convenient land bridge with lakes, rivers and mountains will suffice to explain the meaning of the palaeontological facts. All we know is, that in early Tertiary times these fishes multiplied and migrated from their original centre of dispersal. The genus of the bow-fin is all but extinct. Only a single species remains. The bony-pikes exhibit a little more vitality, no less than three species being still living. The common form (Lepidosteus osseus) ranges from the Great Lakes to Vermont in the east, and from there south-westward as far as Mexico. A much larger bony-pike lives in the southern States, in north-eastern Mexico and in the island of Cuba, while a smaller species (L. tropicus) has been observed in Tabasco, Guatemala, Nicaragua and Panama.* If Lepidosteus were a fish directly limited to fresh water, we might argue that at some remote time in the past, a land mass extended from Mexico to Cuba and southward to Panama, but being ocoasionally met with in brackish water it is possible that bonypikes can traverse short distances by sea. We cannot for this reason base any conclusions regarding minor changes of land and water on the present distribution of these fishes. Nevertheless it is a significant fact that the western States are devoid of bony-pikes and perches as they almost are of freshwater Unios.

Besides the Mississippi fauna, the curious dwellers of subterranean waters in the Mississippi drainage area throw a certain amount of light on the past conditions of the country. A brief account of them at any rate will be of interest before concluding this chapter.

I believe Mr. Putnam † was the first to exhibit a collection of blind fishes and crustaceans from the Mammoth Cave to a scientific meeting. In doing so he expressed the opinion that most of the animals inhabiting the cave are of comparatively late introduction, since they are closely allied to forms

* Regan, C. Tate, "Biologia Centrali-Americana," p. 181.

† Putnam, F. W., "Mammoth Cave and its Inhabitants," pp. 194195. 
living in the vicinity of the cave. Nevertheless he claimed for the blind fishes and some of the invertebrates a different origin, because the former had no immediate relations among fresh-water forms, while the lernean fish parasite was a more decidedly marine than fresh-water form. He took these facts to indicate that part of the great cave system was supplied by marine life.

Professor Packard * makes no allusion to Mr. Putnam's view in his account of the origin of the subterranean fauna of North America. Mr. Putnam's theory indeed appears to be scarcely tenable. His remark that the blind fishes of the Mammoth and other caves have no immediate relations among fresh-water forms has to be modified in accordance with our existing knowledge of fishes. The blind fishes, all of which belong to the family Amblyopsidae, are no doubt a very ancient group, and, as Drs. Jordan and Evermann $\dagger$ suggest they are probably descendants of the eyed genus Chologaster, or at least forms very closely allied to it. Now one species of Chologaster inhabits swampy marshes in the southern States, and two others live in the subterranean streams of Tennessee, Kentucky and Illinois. The most typical blind fishes, Typhlichthys subterraneus and Amblyopsis spelaeus, are met with in the underground streams of Indiana and Kentucky.

Professor Garman $\ddagger$ expressed the opinion that the blind species observed in the caves.were already blind prior to the formation of the caves, and that they only collected there from various directions owing to the favourable conditions for their requirements. Whether this theory is based on sound . evidence need not be discussed, but his statement that Typhlichthys subterraneus has a very wide range has been questioned by Professor Eigenmann, § who showed that the apparently identical species from Missouri is really quite distinct from that of the Mammoth Cave. Professor Eigenmann points out that we have to deal with a remarkable and

* Packard, A. S., "Origin of subterranean fauna."

† Jordan, D. S., and B. W. Evermann, "Fishes of North America," Vol. I., p. 702.

† Garman, H., “ Origin of Cave Fauna," pp. 240-241.

§ Eigenmann, C. H., “A Case of Convergence," p. 281. 
instructive case of convergence. The two very distinct forms have converged because of the similarity of their environment, and especially owing to the absence of those elements in their environment that lead to external protective adaptations.

The family Amblyopsidae is confined to North America, and its nearest relations are no doubt the Poeciliidae, a group of fresh-water fishes with a wide distribution in America, southern Europe, Asia and Africa. There are therefore no grounds for the supposition that the blind fishes of the subterranean waters of North America are descended from marine ancestors. 


\section{CHAPTER VIII}

\section{THE SOUTH-EASTERN STATES}

THe inhabitants of the south-eastern States, which I shall endeavour to describe in this chapter, form, in many respects, a great contrast to those of the continental basin. The greater humidity of the Atlantic States produces that characteristic wealth and profusion in floral life which constitutes so attractive a feature as we approach the ocean from the west. And no one can fail being struck by the change in vegetation even in travelling southward through the Atlantic States from the north. The oaks, chestnuts and hickories become more varied, evergreens of all kinds increase in number, new and magnificent magnolias make their appearance, while vines and creepers mingle their foliage with that of shrubs and trees. The splendid white pine of the north is replaced in the south by the long-leaved yellow pine, whose hard, strong and durable wood serves such a wide range of uses. We also notice an entirely new conifer, the cypress, which, like the tamarack, sheds its leaves in the autumn. Further south in Florida, still greater changes await us, and in the extreme tip of that peninsula we are surrounded by tropical vegetation. Low fan palms and the palmetto grow even further north, but here we meet for the first time with the royal palm, which for height and grace of shape is unequalled, and many other characteristic denizens of the tropics. Indeed, as Mr. Brendel * points out, the flora of southern Florida should not be looked upon as part of the North American flora but as a link between it and that of the West Indies. Over two hundred and thirty species of plants do not extend north of Tampa, whereas southern Florida has one hundred and eighty seven in common with the West Indian Islands.

This affinity between the floras of southern Florida and

* Brendel, F., "Notes on the Flora of Florida," p. 449. 
the Antilles is generally believed to be due to accidental dispersal. The seeds of these plants are supposed to have been conveyed to southern Florida from the West Indian Islands by winds, ocean currents or migratory birds. Professor Engler,* for instance, argues that a direct land connection between the West Indies and North America by way of Florida could never have eixsted, because the latter had been submerged beneath the sea until the end of Tertiary times, and that seeds are easily conveyed to Florida by the branch of the Gulf Stream sweeping along the northern shore of Cuba in a north-eastward direction, carrying quantities of vegetable matter and often even tree trunks. Winds could only transport such seeds that are specially adapted for long flights. As regards migratory birds, which are popularly believed to carry seeds to great distances in their crops and among their feathers, it may be pointed out that the main highway for birds travelling between the eastern States and South America is by way of north-western Florida and Cuba, and not by southern Florida.t If birds had any special influence in the transport of seeds, not the southern portion of Florida but the northern one should show affinities in the flora with the West Indies. If the resemblance in the vegetation of southern Florida and the Antilles were mainly due to the Gulf Stream, we should expect to find the most pronounced similarity between the two floras among the strand plants of Florida. This is not the case. The great majority of the flowering plants now known to be common to the West Indies and North America occur in what is called the "hummocks" of the southern extremity of Florida. These hummocks consist of isolated groups of hardwood trees, shrubs and vines, and are scattered like islands in the everglades and pine forests, instead of being surrounded by the ocean. Moreover, the flora of southern Florida is by no means exclusively West Indian in character. About forty species of plants are peculiar to southern Florida, and over twenty are found elsewhere only in Mexico. $\neq$

* Engler, A., "Entwicklungsgeschichte d. Florengebiete," II., p. 215.

† Cooke, W. W., "New Facts about Migration of Birds," p. 376.

‡ Harshberger, J. W., "Floristic Elements of Eastern North America," p. 612 . 
A West Indian fauna, too, is associated with the flora in this portion of the United States, as will be shown later on. The problem presented by the origin of this tropical element in the North American flora at any rate is not quite so simple as it appears at first sight. Dr. Harshberger is of the opinion that the hummock lands on which the tropical flora principally. grows represent part of an ancient system of islands which existed at a time when the Gulf Stream passed right across the then submerged portion of northern Florida. We might, therefore, make further enquiries as to whether this theory is supported by geological or other evidence, before taking for granted that the tropical element in the fauna and flora of Florida is of purely accidental origin.

Professor Shaler* informs us that along the coast of Florida, both on the eastern or Atlantic and the western or Gulf side, there arise from beneath the sea a number of submarine springs. They thus discharge great tides of fresh water, originally gathered on the land, through openings on the floor of the ocean. He argues that these springs probably shed their waters along the margin of the sea above high water level, and remarks, "I cannot conceive any such underground waterways to have been produced under the existing conditions of land and water." He assumes consequently, that Florida, or a certain part of it at any rate, must have stood at a higher level in relation to the sea than it does now within comparatively recent geological times.

Through the discovery of a submerged system of drainagevalleys off the coasts of Florida and the Antilles, Dr. Spencer is led to believe in an elevation of this area during the earlier part of the Pleistocene Period to the extent of 8,000 to 12,000 feet or more. During a subsidence which followed, according to the same author, the greater part of the existing peninsula of Florida was submerged. Dr. Spencer $\dagger$ does not specify what parts of it remained above water, but presumably the whole of the southern Florida which is low-lying was included in the submerged portion. If

\footnotetext{
"Shaler, N. S., "Nature and Man in America," pp. 104-106.

† Spencer, J. W., "Reconstruction of Antillean Continent," pp. 128 129.
} 
the tropical flora had gained admission to southern Florida during its supposed land connection with the West Indies in lower Pleistocene times, it would have been all destroyed again subsequently. If Dr. Spencer's theory were substantiated, the tropical flora of Florida should owe its origin to accidental transport.

When Dr. E. A. Smith * visited Florida in 1880 he made some geological notes on the peninsula which do not bear out Dr. Spencer's views. He maintains that Florida was elevated nearly to its present height above sea-level after the deposition of the Vicksburg limestone, that is to say, after the Eocene Period, and that this elevation persisted until the Pleistocene, when the country was partly submerged.

No one, however, has done more practical geological work on the peninsula than Dr. Dall, $\dagger$ who, in his monumental treatises on the Tertiary fauna of Florida, presented us with a masterly survey of the past life of that portion of the United. States. His opinion on the geological history of Florida deserves, therefore, most serious consideration, and it may be stated at once that he is strongly opposed to. Dr. Spencer's views, declaring them to be " incompatible with every geologic and palaeontologic fact of South Florida which has come to my knowledge."

As the result of his researches Dr. Dall expresses the opinion that the peninsula of Florida, together with the larger Antillean Islands and the Middle American highlands, were uplifted, and the two Americas thus united in Oligocene times, that is to say, during the early part of the Tertiary Era.

Professor Gregory $\ddagger$ had a similar idea, except that he did not specify any geological period.

When Florida again became disconnected from this Antillean continent is not clearly stated, but Dr. Dall thought that it formed a peninsula of the southern continent as it does now of the northern. Florida, according to the same author, became definitely united to North America towards

* Smith, E. A., "Geology of Florida," p. 306.

† Dall, W. H., "Tertiary Fauna of Florida," IV., p. 1546.

f Gregory, J. W., "Geology of West Iudies," p. $30 \overline{.}$. 
the end of the Miocene Period, while a slight depression occurred in Pliocene times, and little change since. Whether the tropical flora of southern Florida, or part of it at any rate, is the relict of an Oligocene invasion from the south is left undetermined by Dr. Dall's researches. Yet, from the fact that a species of the terrestrial mollusk Glandina occurs in the Pliocene Caloosahatchie beds of south-western Florida, we might be led to infer that other southern forms might have survived on the peninsula till Pliocene and possibly recent times.

Dr. Hill concurs in so far with Dr. Dall's conclusions as he establishes in Jamaica signs of a tremendous orogenic movement in late Oligocene or Miocene times, resulting in an uplift whereby many of the West Indian Islands and possibly an insular southern portion of Florida became united with one another. In Miocene or early Pliocene the islands, according to Dr. Hill,* were severed from one another by submergence, assuming gradually their present outlines which they have since retained.

That some kind of union of the island of Florida with the West Indies took place in Miocene times is likewise indicated. by Dr. Matthew † in his attempt to delineate the hypothetical outlines of the continents in Tertiary times, for he distinctly unites southern Florida and Cuba by land.

According to Dr. Vaughan, $\$$ the Florida plateau already existed in pre-Oligocene times, but it was only towards the end of the Oligocene Period that a portion of the plateau rose above the sea and apparently remained so ever since. Although this constituted only a small island ("Orange island " as he calls it), the deposits of the whole plateau are full of sand and arenaceous material implying proximity of land.

From the opinions cited on the geological history of Florida it is evident that there is nothing distinctly antagonistic to the view that part of the tropical flora of southern Florida is a relict from Tertiary times, many of the species being

* Hill, Robert T., "Geology of Jamaica," p. 224.

† Matthew, W. D., "Continents in Tertiary Times," p. 366.

‡ Vaughan, T. W., "Geologic History of Floridian Plateau." 
probably the descendants of those which passed northward from the Antilles at a time when a land connection (possibly in Oligocene times) joined the latter with the old island of Florida. The fauna of Florida lends some support to this view. At any rate, it gives us more solid foundations for estimating the nature of the physical changes which the peninsula has undergone within more recent geological times.

In the last chapter I alluded to a species of parrot (Conuropsis carolinensis) which in historic times still extended its range as far north as the Great Lakes, and which seems at present to be retreating towards its original centre of dispersal in the south-east. Now this Carolina parrot, as it is generally called, has no near relations. Its closest ally, Conurus, is a genus of parrot ranging from Paraguay and eastern Bolivia in the south to Mexico and the West Indian Islands in the north. The fact of its occurrence in the West Indies alone implies that it is an ancient genus, for these islands have undoubtedly been separated from the continent for a long time. Moreover, Cuba, Haiti, Mona Island off Porto Rico, Jamaica and St. Thomas all possess distinct species of Conurus. It seems not unlikely that Conuropsis is an eastern offshoot of the older Conurus, just as Rhynchopsittacus has originated from it in the west. The occurrence of this parrot on the mainland does not necessitate the former existence of a land bridge to the West Indies, but, if other facts point to it, the presence of the Carolina parrot in the south-eastern States and its subsequent invasion of the northern States is more readily explained by it.

I also made allusion before to the newt Spelerpes, a genus confined to America and southern Europe. One of its peculiar characters is that its tongue can be jerked out to a considerable distance. Only one other newt peculiar to Florida and Carolina, viz., Manculus, agrees with Spelerpes in the nature of its tongue, and, like it, must be an ancient genus. Another very peculiar amphibian is Amphiuma means, an eel-like creature with tiny limbs, inhabiting the ditches of rice-fields and swamps of the south-eastern States. No fossil remains of this interesting species are known, but there can be no doubt that it is a very old form. Pseudobranchus lateralis, 
another most primitive amphibian, is likewise confined to the south-eastern States, while Siren lacertina has its headquarters in the same region. A very striking amphibian is the Florida tree frog (Hyla gratiosa), the largest tree frog of North America, which is common in Florida, extending from there across the borders of Georgia and Mississippi.

The most remarkable member of the fauna of Florida, from a zoogeographical point of view, is one of the worm-lizards (Amphisbaenidae). The Florida worm-lizard (Rhinema floridana) is a limbless, blind, worm-like creature which spends its entire existence under ground. It is no doubt of immense antiquity, and the only member of the family known from North America.

Whether the curious glass-snake (Ophisaurus ventralis) has originated in the south-west or south-east is a difficult problem which future researches may help to solve. Professor Cope * speaks of an eastern and western type, and it may possibly have spread northward from two independent centres. I need scarcely mention that the glass-snake, like the European slow-worm, is a limbless lizard. Anyone may convince himself of this fact by examining the eyes, which possess well-developed eyelids, while the presence of ear openings also distinguishes these creatures from true snakes. The particular point of interest in the presence of the glass-snake in America lies in the circumstance that a closely allied species (O. apus) inhabits Marocco, the Balkan Peninsula and Asia Minor, while a second glass-snake is known from the eastern Himalayas and Burma. This extremely discontinuous range denotes great antiquity. The glass-snakes, moreover, live principally underground, and, like the wormlizard, are not liable to accidental conveyance by any of the occasional means of dispersal that we hear so much of. Their occurrence on both sides of the Atlantic gives great weight to the evidence, cited in previous chapters, of the former existence of a land bridge right across the middle of the Atlantic. I need not discuss the subject any further now, because it will be amply dealt with in some of the succeeding chapters, when new arrays of facts in support of my contention will be sub-

* Cope, E. D., “Crocodilians, Lizards and Snakes," p. 496. 
mitted. We may as well collect the facts tending to support this theory as we proceed, since a great accumulation of material in one place might appear wearisome.

The distribution in America of one of the genera of earthworms (Diplocardia), on which glass-snakes largely live, somewhat resembles that of the glass-snakes in America. There is a species in Florida and three in Carolina. Further north the genus appears in Illinois and Nebraska and we also have a couple of species in Mexico and Lower California.

It was Professor Adams, ${ }^{*}$ I think, who first directed attention to the presence of two very distinct and powerful centres of dispersal, one in the south-east and one in the south-west. Although I am by no means so impressed, as Professor Adams and Dr. Brown are, by the significance of the southeastern centre of dispersal as compared with the southwestern one, which is incomparably more important, I quite concur in their opinion that the former faunistic centre is perfectly recognisable. These writers moreover discuss the problem which I have dwelt upon so many times above, viz., that of the climate during the Ice Age.

Having adopted the current views of the existence of giant glaciers in the northern United States accompanied by an arctic climate Professor Adams + and Dr. Brown $\neq$ were obliged to search for suitable "biotic preserves" where the pre-Glacial fauna could have safely weathered the Ice Age. These they discovered in the two centres of dispersal alluded to, in the south-east and south-west, and from them they suppose the waves of migrants to have streamed forth northward after the Glacial Epoch was over. The presence of a few stray remains of northern animals south of their present habitat lent a certain amount of credence to the theory in $a_{0}$ southward extension of the arctic climate. But we must remember that these northern creatures, when actually pressed out of their boreal home by a restriction of their habitats, found themselves in the northern United

* Adams, C. C., "South-Eastern States as a Centre of Distribution," p. 121.

+ Adams, C. C., " Post-Glacial Dispersal of North American Biota."

† Brown, A. E., "Post-Glacial Nearctic Centres of Dispersal." 
States among an almost semi-tropical fauna of colossal sloths, peccaries and other southern forms that have long since vanished, and which lived through it all in close proximity to the supposed ice-sheets and arctic climates. The great majority of the Pleistocene deposits in the north indicate that the country had a milder climate during the Ice Age than at present, and this is particularly shown by those containing plant remains. As plants are supposed to be more trustworthy guides than animals, as indicators of former climatio conditions, I will give one more example of a Pleistocene deposit from the southern States which has come to my knowledge.

A Pleistocene deposit in north Carolina examined by Professor Berry* yielded no boreal or even cool temperate plants. Hence it may safely be concluded, he thinks, that the temperature of the Pleistocene Period in the same latitude was not lower than it is now. If anything, he says, it was slightly higher. Additional facts pointing to the same general conclusion are the former more northward extension of the cypress (Taxodium distichum) and of Planera aquatica. That these plants did not flourish during mild inter-Glacial phases of the Glacial Epoch, remarks Professor Berry, is indicated by their being associated in Maryland with ice-borne boulders of considerable size.

To return once more to southern Florida, we find that what we observed among plants, namely, the tropical element, is likewise recognisable in the fauna. According to Dr. Merriam $\dagger$ the semi-tropical insect fauna of southern Florida comprises in all not less than a thousand species of Antillean insects, half of which are beetles.

Among the mollusks there are a number of Antillean genera represented in southern Florida, such as Chondropoma, Liguus, Cepolis, Varicella, and others spoken of by Dr. Pilsbry as Mexican genera, such as Eglandina, Praticolella and Drymaeus (dormani type). Dr. Pilsbry regards only the last group as genuine natives of the soil. He believes that their ancestors entered Florida at the close of the Miocene

* Berry, E. W., "Pleistocene Flora of Carolina," p. 347-348.

$\dagger$ Merriam, C. H., "Distribution of Life in North America," p. 53. 
Period by a land passage, but does not state clearly whether they came by a more direct route than exists at present. All the other snails are considered by Dr. Pilsbry * to be waifs and strays derived from Cuba and the Bahama islands, by the agency of hurricanes, drifting trees and the like.

I do not know why Dr. Pilsbry should make this reservation in favour of Drymaeus, as one of the species found in southern Florida (D. dominicus) is also known from Haiti and Cuba, besides the Mexican habitat. On the other hand, we must not forget that Dr. Dall $\uparrow$ discovered a number of species of the land-snails Bulimulus and Cepolis in the

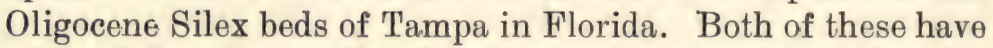
come from the south, for Bulimulus, though extinct in Florida, still lives on the island of Fernando de Noronha in a species almost indistinguishable from one of the Floridian ones. Cepolis still inhabits Florida, but is not found elsewhere in the United States. It has its headquarters in the West Indies, and was a European resident, according to Sandberger, in early Tertiary times. Of the land snail genus Oxystyla, allied to Drymaeus, the species 0 . undata has a wide range in the West Indies, and is also known from southern Florida. Yet the Floridian specimens both belong to varieties peculiar to the peninsula.t Similarly, the Cuban varieties of Liguus fasciatus are not the same as occur in Florida.

The tropical forms of mollusks alluded to by Dr. Pilsbry as inhabiting southern Florida are by no means the only ones that have been collected there. The southern genera Choanopoma, Truncatella, Microceramus, Cerion and Veronicella (Vaginulus) have also entered this region. One of the Urocoptidae lived in Florida already in Oligocene times, and it is quite possible that Microceramus pontificus and M. floridanus, which are peculiar to southern Florida, have existed there ever since. Among many groups of invertebrata long specific persistence is much more common than is generally. realised. The fact that some of the Floridian species are

* Pilsbry, H. A., " Origin of Molluscs of South Florida," p. 193.

† Dall, W. H., "Tertiary Fauna of Florida," Part IV., p. 156 õ.

† Pilsbry, H. A., "Manual of Conchology (Pulmonata)," Vol. XII., pp. 109-110. 
identical with West Indian ones does not necessarily imply a recent introduction. Some mollusks, at any rate, seem to have preserved their specific characters unchanged through several geological periods. On the other hand, although there cannot be the slightest doubt that a certain number of species introduced by human agency thrive in other localities besides their native homes, I am not convinced that mollusks spread across any wide expanse of sea by other accidental transport. With Mr. Bryant Walker* I prefer to attribute the tropical land mollusks of Florida largely to a former land connection between the then island of Florida and a larger southern landmass. I cannot, however, agree with Mr. Walker's view that this event took place in comparatively recent times. Dr. Simpson urges that the Floridian area must have been joined to the greater Antilles by way of the Bahamas in Eocene times. Nevertheless, he does not derive the tropical species of Florida from the southern invasion which must have taken place at that time. He favours a recent colonisation by accidental transport. The rich fauna of the Bahama islands seems to him entirely derived from the greater Antilles in that manner. $\dagger$

There are certain geological grounds for the supposition that an ancient Archaean land-mass trending north-eastward from the northern end of the Andes once existed, and that traces of it are still recognisable in Guatemala, Cuba and Haiti. $\$$ Much of this early land may still have stood above sea-level in early, and perhaps middle, Tertiary times, forming a centre from which the North American continent derived part of its present fauna.

Dr. Ortmann $\S$ demonstrated in a very convincing manner that the fresh-water crayfish belonging to the genus Cambarus originated in Mexico, spreading from this centre of dispersal into the United States at the beginning of the Tertiary Era. The centres for the more advanced forms of the sub-genus Cambarus, and for the sub-genera Faxonius and Bartonius,

* Walker, Bryant, "Origin of American Mollusca," p. 56.

† Simpson, C. J., "Land and Freshwater Mollusks of West Indian Region," pp. 447-448.

† Frazer, T., "History of Caribbean Islands," p. 398.

$\S$ Ortmann, A. E., "Affinities of Cambarus," pp. 124-125."

L.A. 
are situated in the southern States of North America. It is suggested by Dr. Ortmann that the south-eastern centre of the early forms of Cambarus originated from the more ancient south-western one by a process of migration across the present continent. May not these early forms have travelled eastward from Mexico towards Cuba and Florida when the latter were connected directly by land with Central America? A species of Cambarus still lives in the rivers of Cuba.

Instead of mollusks or crayfish we may take almost any group of North American invertebrates and readily discover among them certain ancient forms, which are either confined to small areas in the south-eastern States or have evidently spread northward from a south-eastern centre.

Scorpions, for instance, are universally acknowledged to be a very ancient group. The genus Centrurus has its headquarters in the West Indies and Central America. Now four species of Centrurus are known from Florida, viz., C. gracilis, C. carolinianus, C. margaritatus and C. hentzi, the latter being peculiar to Florida. The allied genus Tityus, which is rather more southern in distribution than Centrurus, has one endemic species in Florida, viz., T. floridanus.* Altogether the southern part of Florida shows marked affinities with the West Indies. There are also some species in Florida such as Cupiennius sallei, Keys, not yet recorded from the Antilles, which are known from Central America. Quite a similar southern relationship has been noticed among many of the Floridian Orthoptera $†$ and the Coleoptera.t One of the most noteworthy genera of beetles recorded from Florida is Rhopalomesites. It has spread northward as far as Delaware, and reappears across the Atlantic in western and southern Europe.

As regards the dragon-flies and their allies (Neuroptera), a few species are common to the West Indies and the northern continent. Some of these may have flown, or have been conveyed by a storm, from one region to the other. Such a method of colonisation, however, cannot have been used by Enallagma,

* Banks, Nathan, "Arachnida of Florida," p. 142.

+ Rehn, J. A., and M. Hebard, "Orthoptera of Florida."

† Schwarz, E. A., "Coleoptera of Florida." 
according to Prof. Kolbe,* on account of its feeble development and weak flight. Taking into consideration the general distribution of this genus, he favours the view of a former ancient land connection between the Antilles and North America.

In its butterflies and moths Florida is united to Central America and the Antilles, and it is from the latter that such genera as Heliconius, Dione and Agraulis gained a foothold in the northern continent. $\dagger$

An exceedingly ancient group are the woodlice (Isopoda) or "sowbugs" as they are sometimes called in America. In eastern Europe at Odessa, and again in north-western Africa, an interesting very peculiar species occurs which is known as Tylos latreilli. The same species has been met with in southern Florida and in the Bermuda islands. A case of that kind is generally set down at once as an instance of human importation. The possibility of the survival of such a species through several geological ages is not even discussed. But in southern Florida a second species of Tylos has been discovered which accurs elsewhere only in Bermuda. This species, known as Tylos niveus, is white in colour and possesses structural differences distinguishing it from the other. Of the genus Cubaris, which is widely distributed through the Antilles and westward to Mexico and California, a single species (Cubaris pisum) occurs in Florida, and is peculiar to it. $\ddagger$

All these, it may be objected to, are inconspicuous creatures that might have been overlooked elsewhere. Too much importance, it might be urged, should not be placed on their occurrence in Florida. We may return, therefore, to more conspicuous objects.

Everyone in America knows, or has heard of, the alligator (Alligator mississippiensis), though it is only found in the southern states of North America. Its distribution in fact is rather limited. From Florida it extends northward to Carolina and westward as far as the Rio

* Kolbe, H. J., "Neuroptera der Antillen," pp. 157-158.

† Pagenstecher, A., "Verbreitung der Schmetterlinge," p. 3509.

t Richardson, H., " Isopods of North America." 
Grande. Only one other species of alligator is known, viz., Alligator sinensis from the Yangtse River in China.* This enormously discontinuous range is significant, and implies great antiquity. Fortunately we possess most valuable palaeontological evidence as to the alligator's antecedents. Even the most pronounced advocate of accidental dispersal would not venture to apply the usual methods of wind, waves or hurricanes to explain the origin of this example of distribution. The generally accepted theory, I believe, is that some ancestor of the American alligator has travelled northward, and succeeded in crossing the former land bridge across Bering Strait to north-eastern Asia, thence wandering southward to China. We possess no fossil evidence for such a belief. All we know is that the nather generalised alligator Diplocynodon lived already at the very commencement of the Tertiary Ena both in North America and in Europe, and that it persisted in Europe until Miocene times. Hence it seems likely that the modern genus Alligator originated in early Tertiary times either in Europe or North America, and spread thence to Asia. That America was probably the centre of dispersal is indicated by certain characters the Chinese alligator has in common with the South American caimans.

An equally remarkable fact of distribution is that the true crocodile has succeeded in obtaining a footing on the North American continent in one single small area, namely, in that in which I have already signalled so many tropical species, in southern Florida. We are apt to associate crocodiles with Africa. Yet they have a much wider distribution. The genus Crocodilus occurs in Africa, Syria, India and eastward as far as northern Australia. Westward it reappears in South America, the West Indies and Central America. The species alluded to (Crocodilus americanus) is the only member of the family inhabiting the West Indian islands, and it also occurs in Central America, Columbia, Ecuador and Venezuela. Remains of crocodiles found in the Eocene of Wyoming and the eastern States have been referred by Leidy, Cope and others to the genus Crocodilus. The presence of crocodiles in America dates back, then, to the very beginning of the Tertiary Era, and it seems surprising that they have not

* Barbour, Th., "Chinese Alligator." 
spread more widely in America. Although the American crocodile is fond of salt marshes, and some of the eastern crocodiles actually frequent the sea coast, I cannot for a moment believe in the possibility of a crocodile crossing an ocean such as the Atlantic. Only a land connection between America and the Old World in early Tertiary times can explain its present geographical distribution.

Of West Indian mammals none have so far been observed in Florida, unless we include the raccoons among them. It is a most remarkable fact that a raccoon (Procyon maynardi) inhabits New Providence, one of the Bahama islands. At the first impulse we might think of a chance introduction by floating trees from the mainland of Florida. But Florida lies one hundred and seventy miles west of New Providence, and is separated from it by a swift current flowing northward. Raccoons occur nowhere else in the West Indian islands, and the New Providence species differs from that of the mainland. In the last chapter (p. 151) I contended that the whole family Procyonidae was certainly of American origin, and I thought the genus Procyon might have arisen in Pliocene times. Possibly it is much older, though we possess no palaeontological evidence in support of such a supposition. If the Bahama islands had still been joined to Florida when the latter had already become a peninsula of North America, we should expect a good many of the smaller mammals to have crossed over to the Bahamas, which they have not done. So far, the occurrence of this species of raccoon in the Bahamas is a complete puzzle to me.

Before concluding this brief survey of the south-eastern fauna I should like to dispel the impression I may have given that the tropical element forms any great share in the vertebrate fauna of Florida. On the contrary, the majority of the genera and species undoubtedly poured into the peninsula from the north and north-west, and they appear to be gradually displacing the southern element. At any rate, I look upon the latter as a relict of the Tertiary Era.

There are many species of mammals peculiar to Florida, but not so many as we might expect from the favourable climatic conditions of the country. On the whole, the mammalian fauna of the peninsula bears the impress of a 
newly emerged land which has been populated from the north within recent geological times. The most noteworthy species that might be mentioned is the Florida water vole (Microtus alleni). It is not alone the only North American water vole, but also the sole member of the sub-genus Neofiber, and thus forms a connecting link between the genera Microtus and Fiber, that is to say, between the meadow voles and the musk rats.*

I have endeavoured to describe in almost every chapter the range of some typically 'North American mammal. Some have not yet been alluded to, among them the opossum. Two species are now often distinguished in North America, $†$ one of which is supposed to extend its range into South America. As a matter of fact the northern and southern forms are extremely difficult to discriminate from one another, and many authorities are of opinion that they merely represent varieties of one species (Didelphys marsupialis) which thus has an enormously extensive distribution in North and South America.

The existing marsupials, or pouched animals as we may call them, are generally regarded as modern survivors of one of the ancient groups of mammals, which apparently spread almost all over the globe before the superior beasts of more recent times had made their appearance. It is believed that at the time of their prime, Australia became separated from the mainland of Asia, so that this southern continent now forms the headquarters of the group, while in other parts of the world they succumbed in the struggle with superior and better fitted animals. Yet in America, where competition with the more highly developed and more aggressive beasts ought to be very keen, opossums, which belong to the marsupials, are by no means on the verge of extinction. On the contrary, they hold their own perfectly against the more modern competitors. The genus Didelphys is much more abundantly represented in South America than on the northern continent, and other genera of marsupials occur there besides opossums. To judge from these modern repre-

" Bangs, Outram, "Mammals of Florida and Coast Region."

+ Allen, J. A., "North American Opossums." 
sentatives of the marsupials, it would not be unreasonable to argue that the opossums had invaded North America from the southern continent. Mr. Lydekker's * conclusion is that opossums are only recent immigrants from the south, although he does not believe that South America was their original home. $\mathrm{He}$ (p. 55) selects south-eastern Asia as the birthplace of the opossum family (Didelphyidae), urging that the latter scattered from this centre towards Europe and North America. He also contends that the allied family Dasyuridae priginated in southern Asia, spreading thence to Australia, and by an antarctic land connection from there to South America. I shall return to this subject in some of the subsequent chapters (p. 283 and p. 366).

There is still another problem of exceptional interest which I wish to enlarge upon, namely, that of the origin of the Bermudan fauna. The island of Bermuda has certain faunistic affinities with Florida, and we may therefore consider the origin of its fauna as an appendix to this chapter. It consists in reality of a series of about one hundred islands and islets, their total area being less than twenty square miles. The island of Bermuda, as we may call it for the sake of brevity, lies approximately seven hundred miles eastward of North Carolina, being apparently surrounded on all sides by a depth of from 1,500 to 2,000 fathoms. Dr. Wallace, $\dagger$ who gives us a brief description of the fauna and flora of the island, concludes that Bermuda furnishes us with one of the most instructive facts as to the power of many groups of organisms to pass over seven hundred miles of open sea. There is no doubt whatever, he remarks, that all the indigenous species have thus reached the island.

I may as well say that my own views differ entirely from those of Dr. Wallace as regards the origin of Bermuda and of its indigenous fauna and flora. I believe the island to have formed part of a wide belt of land, which extended northward from the West Indies, joining the mainland of North America somewhere near Massachusetts, at a time when most of the

* Lydekker, R., "Gengraphical History of Mammals," p. 108.

† Wallace, A. R., "Island Life," p. 273. 
existing coast line of the Atlantic States south of Massachusetts was submerged (Fig. 14). I look upon the indigenous animals and plants of Bermuda as relicts of an ancient fauna and flora. I hold, moreover, that Bermuda furnishes us with one of the most instructive facts of the exceedingly slow change that many species of animals and plants undergo through successive geological ages, and that it does not support the theory advocated by Dr. Wallace that many organisms possess the power of crossing seven hundred miles of open sea.

The geology of Bermuda, so far as the visible structure is concerned, is identical with that of the Bahamas, except that the coral reefs are of greater importance in the latter. The rocks in both are limestone, and red clays resulting from its decomposition. Nearly all the rocks of Bermuda above sea-level, and to a considerable depth below it, are made up of wind-drifted shell sand with very little material derived from corals and other organisms. These materials, according to Professor Verrill, when consolidated, form a true aeolian limestone. The island is surrounded by coral reefs in such a manner as to give it the appearance of an atoll of the Pacific Ocean. It was actually regarded as such by Professor Rice.* The greater Bermuda or "Pliocene Bermuda" as it has been called, which was once dry land, had an area of about two hundred and thirty square miles. That this greater Bermuda represents an older land surface was revealed during the excavations made in 1870 for harbour works. These extended to over fifty feet below sea-water level. At a depth of fortysix feet, as Mr. Jones $\dagger$ tells us, a stratum of peat and red earth two feet thick was found, containing the vertical stumps of cedar trees. This again rested on hard aeolian limestone, containing fossil land shells of the genus Poecilozonites. There is clear evidence, therefore, of a subsidence of the land to the extent of at least fifty feet. A re-elevation to that extent would nearly restore the island of greater Bermuda. Beyond this, in a south-westward direction, several shallows have been detected, all being surrounded by great

* Rice, W. N., "Geology of Bermuda," p. 9.

† Jones, J. M., "Recent Observations in Bermudas," p. 262. 
depths, yet indicating that they represent a range of drowned mountains.

According to Professor Verrill it is now generally admitted that Bermuda is the flattened and greatly eroded summit of a vast submarine volcano, and he thinks it most reasonable to suppose that its last activity corresponded in time with the last great volcanic eruptions of the nearest American mainland. This, as he remarks, would imply that the Bermuda volcano was formed or completed during the Triassic Period or at its close. Immense outbursts of volcanic material took place all along the eastern coast of America at that time, giving rise to enormous trap-dykes. In Nova Scotia these dykes have a nearly north and south direction, and they may have had some direct relation with the volcano of Bermuda. It is estimated that the latter had a height of about 15,000 feet.*

The whole surface structure of Bermuda reminds us vividly of the Bahamas. The latter owe their configuration to the same process of waste which has been going on during their subsidence. The coral reefs surrounding the Bahamas form but an insignificant part of the topography of the islands. The same aeolian rocks as in Bermuda cover all the visible parts of the Bahamas, and we find an intercalation of similar red earth. Altogether there is, as Professor Agassiz points out, clear evidence of the comparatively recent subsidence of at least three hundred feet of the Bahama Bank.t

A slightly greater elevation would have had the effect of shutting out the Gulf Stream from the northern Atlantic, for it now pursues its swift northern course through the shallow channel lying between the Bahama Bank and Florida. Now it is interesting to note that the ancestral Gulf Stream did not flow where it does now, but across northern Florida, thus separating the northern from the southern portion of the peninsula. Not only were northern Florida and Georgia submerged. Tertiary marine deposits are known even as far north as New Jersey. The sea covered a vast area of the present southern Atlantic States. That a strong current flowed through the channel of north Florida is evidenced by the fact

* Verrill, A. E., "Bermuda Islands-Geology," XII., pp. 47-82.

† Agassiz, A., "Reconnaissance of Bahamas," p. 7. 
that during early Tertiary times Antillean species were carried even as far as New Jersey. At no succeeding Epoch, says Dr. Dall, do we find such tropical and semi-tropical mollusks extending northward to such a distance from their present range. All these Tertiary deposits cease north of the Hudson estuary, and I have shown in a previous chapter ( $p .41$ ) that in later Tertiary times, at any rate, the coasts of New York, Massachusetts and Maine extended far out into the present Atlantic. The hypothesis of the latter land extension having once joined Bermuda and the Bahamas, etc., seems to me supported by a variety of circumstances which I shall allude to later on. This would have excluded the Atlantic Ocean either partially or wholly from the Gulf of Mexico and the southern Atlantic States. Some time during the Miocene Period, or earlier, a sudden influx of northern species into the area hitherto occupied by southern forms occurred. Dr. Dall and $\mathrm{Mr}$. Harris * endeavoured to account for this phenomenon by the supposition that the course of the Gulf Stream was gradually turned more off shore than it was before or is at present.

If we assume, however, that a belt of land such as above described had hitherto existed, the gradual breaking down of its northern portion might have admitted the Atlantic waters into the sea which covered the southern States and have brought with it the new fauna, which had meanwhile developed in the northern Atlantic Ocean (see Figs. 14 and 16). For a time these northern, cooler inshore waters were even able to penetrate into the Gulf of Mexico. Even if we grant the correctness of Messrs. Dall and Harris's supposition of the altered course of the Gulf Stream, the cause of this deflection is more likely to have been produced by a change in the configuration of the northern land-masses than by that of Florida.

Let us now study the flora and fauna of Bermuda, and endeavour to ascertain whether it supports in any way the theory I have advocated. $\dagger$ It is quite evident that the existing flora of Bermuda is only a remnant of the original one, before the early settlers, accompanied by hogs and rats, played havoc

* Dall, W. H., and G. D. Harris, “Correlation Papers," pp. 185-187.

† Heilprin, A., "The Bermuda Islands." 
with it. The old records speak of thousands of palmetto trees that were cut down, and of cedars used for the construction of ships and buildings. The palmetto (Sabal blackburniana) is a species of palm much like that of southern Florida, but differing sufficiently to form a distinct species. All the islands were once thickly covered with the cedar (Juniperus bermudiana), and it also accurs in a semi-fossil condition in the red earth. Among the one hundred and fifty six kinds of land plants now considered native to Bermuda, about fifty species are very restricted in their distribution, most of them being of West Indian origin. Altogether one hundred and eighteen species are native of the West Indies. Of these ninety are also found in Florida, the remainder being only met with in the West Indies. About the same number of plants as are common to Bermuda and the West Indies only, are also peculiar to Bermuda and continental North America. A few, such as the blue-eyed grass (Sisyrinchium bermudianum), have their nearest relatives in the north-eastern States. Most of the botanists who have investigated the Bermuda flora, especially Mr. Hemsley, Mr. Moseley and more recently Professor S. Brown, Dr. Harshberger and Professor Verrill * are agreed that all the native plants of the island have been introduced by natural agencies prior to the advent of man. Professor Verrill is of opinion, and I feel sure his view is almost generally accepted, that migratory birds have probably always been the chief agencies for these introductions of plants, especially those from north-eastern North America. Currents, floating timber and hurricanes are also supposed to have had their share in transporting plants from various parts of America to Bermuda. I am among the few who do not recognise the potency of these agencies of transport. That seeds are occasionally cast by currents upon the shores of lonely islands like Bermuda has been amply proved, but there is no evidence available to show that migratory birds distribute seeds on such islands, or that hurricanes carry seeds across seven hundred miles of sea and safely deposit them on an island. These theories are very widely accepted, but I think on insufficient grounds.

* Verrill, A. E., “ Bermuda Islands,” XI., pp. 587-588. 
Dr. Wallace * makes the statement that the few species of birds which are resident in Bermuda and breed on the island are so constantly crossed by individual migrants of the same species from the mainland that none of the former have acquired any special peculiarity constituting even a distinct variety. It is perfectly true that the resident land birds are very few in number, but the opinions of most recent authorities differ very considerably from those enunciated by Dr. Wallace.

Only ten species of land birds are resident on the island, and three of these have been introduced by man. The indigenous fauna includes, therefore, seven kinds of birds, namely, the ground dove, the Florida gallinule, the crow, the white-eyed Vireo, the blue bird, the cat bird and the cardinal.

Of these the Bermuda ground dove (Columbigallina bermudiana) is described as a species very distinat from the American C. passerina. The Florida gallinule (Gallinula galeata) does not seem to differ from the continental form. The crow of Bermuda is probably separable from the American crow, but has not been sufficiently studied. The white-eyed Vireo (Vireo bermudianus) is described by Messrs. Bangs and Bradlee as very different in all its ways from its shy, retiring, continental relative, V. noveboracensis. $\dagger$ The blue bird is not usually recognised as distinct from the continental form, but Dr. Sharpe of the British Museum held that its characters were certainly striking enough to deserve specific recognition, and he described it as Sialis bermudianus. Now I may mention that the blue bird belongs to one of those genera which seem to have retained their generic characters for very long ages past, probably throughout several geological periods. We know nothing of its past history from palaeontological evidence, but its present geographical distribution, and that of its nearest relative, are so peculiar as to suggest their being of great antiquity. Sialis, with its three closely-allied American species, has its nearest relative (Grandala) in the Himalayan Mountains. I only mention this fact so as to show that the apparent specific identity of the Bermudan and the continental

* Wallace, A. R., "Island Life," p. 269.

† Bangs, O., and T. S. Bradlee, "Birds of Bermuda," pp. 249-257. 
blue bird need not necessarily be adduced as an argument for the recent geological origin of the former. The Bermuda catbird (Galeoscoptes bermudianus), though closely resembling the continental species, is considered distinct by Messrs. Bangs and Bradlee and by Dr. Sharpe. Finally, the Bermuda cardinal (Cardinalis bermudianus) can at once be identified from its continental relative by its characteristic bill.

Dr. Wallace alludes to the Bermudan lizard as being the only vertebrate animal which exhibits any peculiarity. But much more can be said about it. It is a member of the family of skinks (Scincidae), which is of cosmopolitan range and undoubtedly of great age. The Bermudan skink (Eumeces longirostris) is said to be nearly related to the American blue. tailed lizard (Eumeces quinquelineatus), still we must remember that the latter has long been considered identical with the Japanese skink (Eumeces latiscutatus) from which it can be separated only by very careful study.* It may safely be argued, therefore, that the Bermudan skink has originated in early Tertiary times (compare pp. 123-126).

Dr. Rehn $\uparrow$ records twenty-eight species of Orthoptera, two of them, viz., Paroxya bermudensis and Gryllus bermudensis, being peculiar to the island. If we exclude the cosmopolitan and circumtropical forms which the author regards as probably introduced by commerce, the remainder are more closely related to continental than to Antillean species.

Only a single ant is peculiar to Bermuda, viz., Prenolepis kincaidi, because some of the more active recently introduced warlike species have no doubt exterminated the greater part of the older resident ant fauna. $\ddagger$

Mr. Pocock \& recognised two species of myriopods from Bermuda as doubtfully distinct, though he described them as new species. These are Lithobius provocator and Lithobius bermudensis. Altogether he believes that only six species of centipedes and millipedes are native to Bermuda, and that three of them belong unquestionably to the Mediterranean

* Garman, Sam, "Reptiles of Bermuda," p. 287.

† Rehn, J. A. G., "Orthoptera of Bermuda," p. 3.

† Wheeler, W. M., “Ants of Bermuda," p. 347.

$\S$ Pocock, R. I., "Myriopoda of the Challenger Expedition," pp. 123124. 
fauna. This is a point of considerable interest and importance, and requires to be more closely studied in a reconsideration of the true relationship of the members of other groups of invertebrates.

This relationship is clearly recognisable among the terrestrial Isopods or wood-lice, which have been described by Miss Richardson. Tylos latreilli, as already quoted, is a typical Mediterranean species, which has been discovered in southern Florida, where also another species, Tylos niveus, occurs. Both of these are now recorded from Bermuda. The European genus Porcellio is represented by two species, one of them (Porcellio parvicornis) new to science. Metoponorthus sexfasciatus, a typically Mediterranean species, also found in the Canaries and Azores, occurs in Bermuda, but nowhere else in America. Another species peculiar to Bermuda (Philoscia bermudensis) is closely related to the west European Philoscia couchi. The American affinities are likewise surprisingly interesting. Uropodias seems to be related to the West Indian genera Haplarmadillo and Sphaeroniscus, and this strikingly distinct genus is quite confined to Bermuda with the one species, Uropodias bermudensis. The truly archaic Actoniscus ellipticus, which is only known from Bermuda and from the coast of the mainland near New Haven and Long Island Sound, is one of the only two members of the family Trichoniscidae. Its distribution is suggestive of a former land connection towards north-eastern North America. The other Actoniscus is confined to California. Finally, Leptotrichus granulatus, also peculiar to Bermuda, may be mentioned as the only occurrence of a very ancient Old World genus in America.*

The only native spider which, according to Dr. Verrill, $\dagger$ was mentioned by the early writers, was the great silk spider (Nephila clavipes). The enormous webs which this spider constructs between trees at a distance of fifty feet from one to another excited their admiration, and suggested to them that the threads might be used in the manufacture of silk tissues. This has actually been done in Brazil, I believe,

* Richardson, Harriet, "Isopods of Bermuda."

† Verrill, A. E., “Bermuda Islands,": XI., p. 829. 
where this spider occurs. The silk spider is known from Brazil, from Central America as far north as Texas, and from Southern Florida. Professor Dahl* argues that the group to which this species belongs already had a wide range in Cretaceous times. Its nearest relation, Nephila clavata, is peculiar to China and Japan. It is quite possible, therefore, that the American form may have existed since early Tertiary times. But, as Dr. Marx $\uparrow$ observes, the spiders introduced by human agency have not only acclimatised themselves; they have also, in a more or less marked degree, driven away and exterminated the indigenous spider fauna. Yet among the remnants of that ancient fauna we recognise four species that are peculiar to Bermuda. Most of the remainder are identical with American forms.

One of the most noteworthy animals that might be adduced in favour of the theory that Bermuda represents the remnant of a large land surface once connected with the mainland is the land nemertean Geonemertes agricola. This very peculiar worm is found in abundance at several distinct localities in Bermuda. It might be said that this worm is not of much zoogeographical value, since it is able to resist immersion in sea-water for some time. On the other hand, it must. be remembered that land nemerteans have an extremely discontinuous range on ancient land surfaces. Hence their distribution is suggestive of great antiquity. Nine species of the genus Geonemertes are now known from Australia, New Zealand, New Guinea, Pelew Islands, Rodriguez Island, the Seychelles and Bermuda. To suggest that Geonemertes agricola owes its presence in Bermuda to an accidental introduction would be quite inadmissible, because it has never been found elsewhere. $\neq$

Of greater importance than any of the foregoing invertebrates are the land and fresh-water snails inhabiting Bermuda. Dr. Pilsbry distinguishes autochthonous species, drift waifs from the West Indies, and snails imported by the agency of man. The last group we need not consider here,

* Dahl, F., "Verbreitung d. Spinnen," p. 278.

† Marx, G., "Spiders of Bermuda," p. 100.

$\ddagger \mathrm{Coe}, \mathrm{W} . \mathrm{R}$., "Geonemertes agricola," p. 534. 
although some members of it are probably indigenous. The remainder include several snails, only once recorded, and not again found on the island in recent times. The so-called waifs from the West Indies are of greater significance. Dr. Pilsbry identifies Succinea bermudensis with S. barbadensis, yet acknowledges that the shells of this genus are peculiarly uncharacteristic, and that species of different regions frequently resemble each other. All conchologists, however, are agreed that the semi-amphibious amber-snail (Succinea), with its almost world-wide distribution, must be a very ancient one. The mere fact of several Bermudan species being identical with West Indian ones is no proof that they were conveyed to Bermuda by accidental means of transport. I have argued this point again and again, but it is a widespread assumption which can only be effectually disproved by palaeontological evidence. No such evidence is available in the majority of cases. Yet of some of these supposed accidentally and recently introduced species of Bermuda I might mention Rumina decollata. It is certainly native in the Mediterranean region, where it exists as a relict of the past, and $I$ have given a map of its range in my work on European animals.* The family Stenogyridae, to which it belongs, is an entirely tropical one. Rumina decollata has adapted itself to the European climate, though its shape has remained unchanged since Oligocene times. It has been known to exist outside Europe in Cuba, South Carolina and Bermuda. Are we justified in the assumption that this exceedingly old member of a tropical family of snails has been accidentally introduced into these localities? I think not, and yet this surmise is received by almost everybody as an established fact.

The really interesting members of the Bermudan fauna of mollusks are those styled "autochthonous" by Dr. Pilsbry, viz., Helicina convexa, Thysanophora hypolepta, all the species of Poecilozonites, and the slug Veronicella schivelyae.

I have already dwelt upon the distribution of the genus Helicina (p. 158), and on its occurrence in the Oligocene Silex beds of Tampa in Florida, and have indicated that it

* Scharff, R. F., “European Animals," p. 222. 
represents a relict of early Tertiary times. The ancestors of Helicina convexa, which is peculiar to Bermuda, reached the island presumably in the Oligocene Period, when we know that the genus inhabited the island of Florida.

Thysanophora is a member of the large family of Helicidae. It is most characteristic of the West Indian region and Central America, and Dr. Pilsbry* declares that it represents the oldest stock of the West Indian Helix fauna. The ancestors of Thysanophora hypolepta may well have wandered to the Bermudan area from the West Indian region in early Tertiary, times. This suggestion is strengthened by the fact that along with Succinea and Poecilozonites it is found fossil in the "red earth." The genus Poecilozonites, with its four Bermudan species, is peculiar to Bermuda. Recently Professor Boettger $\dagger$ again drew attention to the intimate relationship existing between this genus and the German lower Miocene Helix imbricata, in spite of Dr. Pilsbry's plea that the German savant was only chasing an "ignis fatuus." Dr. Pilsbry $\ddagger$ prefers to derive Poecilozonites from an old American stock, arguing that it is related to Gastrodonta. To trace the exact affinity of a recent to a fossil form is always a matter of considerable difficulty, but since several other European palaeontologists have dwelt upon the remarkable and undoubted relationship existing between the present West Indian fauna and the fauna of the European early Tertiary. deposits, and as I shall be able to bring forward additional evidence in favour of their views, I am certainly on Professor Boettger's side in this controversy. That Poecilozonites is not a recent arrival from elsewhere, quite apart from the fact that it is unknown outside the Bermudan area, is likewise indicated by its fossil occurrence in the red earth, which' is held to be of Miocene or Pliocene age. Dr. Gulick $\S$ records eleven species and sub-species of Poecilozonites from the red earth, as well as Succinea bermudensis and a number of genera that have since become extinct.

* Pilsbry, H. A., "Manual of Conchology," Vol. IX., p. 56.

+ Boettger, O., "Helix-Arten aus d. Tertiär Europas," p. 103.

‡ Pilsbry, H. A., "Mollusks of Bermuda," pp. 491-509.

$\S$ Gulick, A., "Fossil Land Shells of Bermuda."

L.A. 
Mr. Vanatta * recently made the interesting discovery that several typical fresh-water species inhabit Bermuda. Among them there is a Physa, two Planorbis, one Ancylus, a Paludestrina and a Pisidium. All are new to science.

The genus Veronicella (Vaginula), of which a species (V. schivelyae) inhabits Bermuda, includes slug-like creatures which should certainly not be suitable for accidental dispersal by the usually quoted agencies. It is of interest, therefore, to note that Messrs. Robbins and Cockerell $\dagger$ record a variety of the Bermudan Veronicella from the Bahama islands, and direct attention to its close relationship with the Mexican Veronicella moreleti.

From the foregoing brief survey of the Bermudan fauna it is manifest that although that most destructive of all creatures "man," has played havoe with the native animals and plants, largely exterminating them, a recognisable residue has survived from remote times. As far as the ancestry of this relict fauna can be traced, it seems to be derived from the southeastern and north-eastern States of America, from the West Indies and even from southern Europe. Many species, particularly such as are unfit to take advantage of accidental modes of transport, namely, the Bermudan skink, the terrestrial nemertean worm, and various kinds of terrestrial isopods and snails, are peculiar to Bermuda. Is there any reason for the supposition that these animals, all of which bear the impress of vast antiquity on them, were conveyed to Bermuda in the past by accidental means? We have no evidence whatever that terrestrial invertebrates are transported alive across seven hundred miles of sea and subsequently propagate their kind except through the agency of man. Why should we assume, therefore, that Bermuda has received its entire fauna and flora by accidental means such as winds, hurricanes or ocean currents ? It is evident that the great depths of the ocean surrounding the little group of islands is the chief, if not the sole, stumbling block to the acceptance. of the survival theory. Yet in view of the fact vouched for by

* Vanatta, E. G., “ Bermuda Shells,” pp. 668-672.

† Robbins, W. W., and T. D. A. Cockerell, “Veronicella," p. 383384 . 
Professor Suess, that a subsidence of land amounting to 10,000 feet has taken place between the island of Rhodes and the mainland of Syria in post-Pliocene times, whereas marine deposits of late Pliocene age occur in the southern Andes at a height of 5,000 feet, is it really such an unlikely theory that the supposed ancient belt of land connecting Bermuda with a southern land-mass has subsided to a similar extent within comparatively recent geological times? I need not dwell any longer on this problem. When I come to deal with the Antilles and the origin of their fauna further allusions to it will be made. 


\section{CHAPTER IX}

SOUTH-WESTERN NORTH AMFRICA

THE region to be dealt with in this chapter is of enormous extent. To speak of it vaguely as south-western North America is apt to give the impression as if only Texas and the adjoining western States were being considered. What is described here under that designation contains almost the whole of the western States with Mexico in addition. There is material enough for several chapters. Nevertheless, the profound zoogeographical importance of this portion of North America will be more readily realized, I think, if the leading facts are compressed into one brief essay. The Rocky Mountain fauna, moreover, which enters largely into the south-western region, has already formed the substance of a special chapter.

The term "Sonoran Region" was first applied by Professor Cope to part of this important south-western life area, because he recognised the striking difference it presented as compared with other parts of the United States. In one of the previous chapters I alluded to the scarcity of lizards in the eastern States in comparison with western Europe. I might have said "western States of North America" instead of western Europe, for lizards especially, and reptile life in general, abound in the region we are now considering.

The term "Sonoran,"* derived from Sonora, a province of northern Mexico, is now often applied to the fauna of the whole of North America except the boreal portion; and Professor Carpenter $\uparrow$ supports the contention that the continent can be readily divided into two faunistic sections, one of which is distinctly autochthonous, the other derived from northern Europe and Asia. I have already put forward my reasons for

* Merriam, C. H., "Distribution of Life in North America," p. 26.

† Carpenter, G. H., "Nearctic or Sonoran?" pp. 53--5i. 
abandoning faunistic regions in a work of this kind, and I feel there is little advantage in discussing the merits of one regional system above another. I only wish to direct attention to the fact that the distinctness and importance of this south'western part of North America had long ago been recognised by zoologists. Professor Carpenter urges that two distinct faunas exist in America. I can trace even more than two, for a South American element is very prominently diffused throughout a large portion of the States. I cannot concur at all in Dr. Merriam's view* that "except for the presence, chiefly in the southern United States, of a comparatively few forms derived from the tropical region, the fauna and flora of North America are as distinctive and independent of the existence of this area as if separated from it by the broad ocean." To place ourselves within fixed and strictly limited boundaries at all seems to me a mistake. I do not limit myself in any way to political frontiers, and if I had set myself a boundary, I should have been inclined to place it across the isthmus of Tehuantepec. At this point North America was evidently separated for some time from Central America by a marine channel, though this division was not so effectual in keeping two great faunas distinct as one might expect. All this, however, will be discussed at greater length when we come to deal with the fauna of Central America.

Although vast tracts of south-western North America are nothing more than deserts, there is, on the whole, an extraordinary abundance and variety of animal life. I have repeatedly pointed out in previous chapters that the roots of certain groups of eastern animals must be looked for in the south-west or west. In drawing attention to the strange affinities of some apparently very ancient east-American forms, such as the smooth and the rough green snakes, and east-Asiatic snakes, I urged that they must originally have spread eastward from south-western North America (p. 125). Among the tortoises, too, certain eastern groups can be traced to a remote western origin, although no longer, resident there. Thus there has arisen a comparatively modern repetition of that dissimilarity between the eastern and

* Merriam, C. H., "Distribution of Life in North America," p. 37. 
western faunas which was the characteristic feature of the two ancient land-masses during Mesozoic times when the latter were separated from one another by a wide ocean. Dr. Pilsbry * once advocated the view, from a conchological standpoint, that the Sierra Nevada divided North America into two primary faunal provinces, a division which he thought commenced in Jurassic times with the upheaval of this mountain range, the latter having proved insurmountable to most land snails. The true autochthonous American fauna east of the Sierra Nevada range seemed to him to have developed, with very little or no trace of Old World influence, from an early period, probably the Cretaceous.

This difference between the east and west is in many. respects less pronounced when we include Mexico in our western district. Few species of the characteristically eastern snail Polygyra are found in California. Further south, however, in Mexico, their numbers again increase. The family of perches(Percidae) are quite absent from the western States. In Mexico they again appear. Among the garpikes (Lepidosteus) and the Unionidae we notice a similar distribution, but it is not discontinuous. Their range passes gradually from the Gulf States into Mexico. Among other groups or genera a greater discontinuity of distribution is noticeable between the Mexican and the east American centres of dispersal. The tribes that are affected by desert conditions, and many of them are, would find the arid regions lying directly to the north of Mexico effectual barriers to dispersal in that direction. But we have good reasons for the belief that these desert conditions are comparatively modern developments, and have little to do with the origin of the distribution. referred to. The geological history of the south-western States may throw further light on this problem.

From Cambrian to Jurassic times the greater part of California was raised above sea-level. Towards the end of the Mesozoic Era there existed in western North America a broad strip of land running north and south being bounded on each side by the sea. $\dagger$ Mexico must have extended further

* Pilsbry, H. A., "Check-list of Land Shells," pp. 194-195.

$\dagger$ Schuchert, Charles, "Paleogeography of North America." 
west at that time, since no late Mesozoic deposits are known from the western parts of that country. If we supposed that western Mexico had then been connected with some other land surface, a faunistic interchange could have taken place between the latter and western North America.

In early Tertiary times the central sea, which formed the eastern boundary of the western belt of land referred to, had almost disappeared from the interior of America, but large tracts of western California were still under water (see Fig. 14). Professor Smith * argues that a temporary connection must have existed during the Eocene Period between the Atlantic and the Pacific Ocean, because the characteristic Atlantic shell Venericardia planicosta had been met with in the Eocene deposits of California and Oregon. In Oligocene and Miocene times the whole of the eastern borders of Mexico were submerged, while the sea was at first retreating from western California and then again invading it. During the latter part of the Miocene Period the sea even encroached on western Mexico. $t$ All the same, certain parts of the coast ranges in western California never seem to have been entirely submerged during Tertiary times and probably formed part of the Pacific land belt which has now almost entirely vanished. I think the alternative union and disruption of these western Californian land-masses with the mainland of North America must have played an important role in the origin and development of the American fauna. It seems as if Mexico had at first formed the stepping-stone to North America for new immigrants, and later on western California. I have endeavoured to represent this idea on two maps (Figs. 14 and 16), but how the changes were actually brought about has not been made quite clear to us through geological research.

It has been suggested by Messrs. Ordonez and Aquilera that the Cape portion of lower California really forms the western

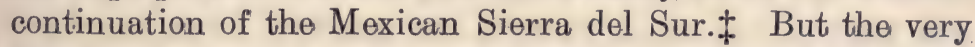
important question now arises from a zoogeographical point

* Smith, Perrin, "Geological History of California," pp. 347-348.

† Arnold, Ralph, "Tertiary Pectens of California."

† Suess, E., "Antlitz d. Erde," II², p. 487. 
of view, how far westward and southward of the Gulf of California did this land extend? No Cretaceous or Tertiary deposits have yet been discovered on the greater portion of the Pacific coast of Central America. Geological evidence is, therefore, rather in favour of the supposition that this western land formerly extended further south.

As regards the present arid semi-desert conditions of Arizona and New Mexico, they supported in early Tertiary times, as I have already mentioned, a wealth of animal. life. In the neighbouring state of Colorado the wonderfully preserved impressions of insects in the volcanic tuffs of Florissant, which have been described by Dr. Scudder and more recently by Professor Cockerell, * leave no doubt as to the former climatic conditions of that part of America and its suitability for plant and animal life. The vast outpouring of lava and general volcanic disturbance in the Rocky Mountain region continued through Miocene and partly through Pliocene times. All the same, the immigration of tropical types of mammals from South America into the Western States at that time would seem to imply the existence in the latter of a luxuriant flora. Even in Pleistocene times an abundance of large mammals, such as elephants and mastodons, existed in southern California, and probably in the neighbouring States, to judge from the number of sabretooth tiger remains recently discovered in the asphaltum beds of Rancho la Brea near Los Angeles. The gradual desiccation noticeable in some of the south-western States is obviously a recent development, though the abundance and diversity of cactuses and of reptiles adapted to a desert. life imply that local arid areas must have existed for long ages past.

If the geological history of the extreme south-west of North America has been correctly interpretated in this very brief summary, we should certainly find relicts of ancient animal and vegetable types in some of the western areas that have remained unsubmerged during Tertiary times. For although most animals would tend to spread from these old centres as new land became available for their dispersal, some of the

* Cockerell, T. D. A., "Fossil Fauna and Flora of Florissant." 
less active and less vigorous types must have remained in their ancient western habitats.

Among the order Insectivora which is now on its way towards extinction, several peculiar mammals, such as Atophyrax, Notiosorex and Scapanus are entirely western in range. The most noteworthy is what has been called the mole-shrew (Neürotrichus), on account of its shrew-like look combined with its digging habits. The single species Neürotrichus gibbsi is a western rather than a south-western animal, being confined to northern California and Washington State. It has no near relations in America. Its nearest akin inhabit eastern Asia and Europe, but it has not yet been satisfactorily established to which of its two Old World branches it has most affinity. The whole group to which all these insectivores belong is known from the European Eocene onward. Nowhere else have fossils been found. Palaeontological evidence would, therefore, point to Europe as the centre of evolution. Possibly the ancestors of Neürotrichus may have originated somewhere in the Mediterranean region, have crossed the Atlantic by a mid-Atlantic land bridge to California, as I shall explain later on, and have then passed to Japan, where a closely related genus occurs.

The mole-mice (Onychomys), which are typical rodents, constitute a section which has evidently originated in the south-west, and has since spread northward and eastward so as almost to reach the Mississippi, though none of them have crossed this river. The wood-rats, belonging to the genera Nelsonia, Xenomys, Neotomodon, Teanopus and Hodomys are all confined to small areas in the south-west. The fourtoed and the five-toed kangaroo-rats (Dipodomys and Perodipus) are almost all peculiar to the south-western States.

Among the carnivores with a similar range may be mentioned the raccoon foxes (Bassariscus) and the western skunks (Conepatus).

The most striking examples tenanting the ancient southwestern land areas must be looked for, as I remarked, among the more sessile and slow-moving creatures. The reptiles and amphibians yield good instances. Among the former the most noteworthy is the so-called "Gila monster," a repulsive, stout, thick-tailed lizard. It has gained the unenviable notoriety 
of being the only poisonous lizard in existence. The genus Heloderma, to which it belongs, ranges from Mexico, through Arizona, to western Texas. No near relations of the Gila monster are known, but it possesses some distant affinity to a lizard living in Borneo.

Better known probably are the horned toads (Phrynosoma). Owing to their greater activity they have been able to spread much further north and east of their original centre of dispersal. The horned-toads are lizards belonging to the large and important family Iguanidae which has a peculiar distribution suggestive of great antiquity, as I have already indicated (p. 126). I mentioned that the family lived in America as far back as Cretaceous times, and that beyond that continent it was only known from the Fiji Islands and Madagascar. Leaving the latter out of consideration for reasons stated (p. 126), we have only to discuss the origin of the Fiji members of the family. The geological history of the Polynesian fauna will be fully dealt with in a subsequent chapter. I may mention, however, that I believe in the former existence of an ancient circum-Pacific belt of land which was joined to south-western North America (Fig. 14), and that the Iguanidae passed across this land during their wanderings from America to Fiji or vice versa.

Let us turn from the active Iguanidae, and take, as an example, a slowly-moving creature such as the Californian limbless lizard Anniella. It inhabits barren sand-dunes, lying buried in the sand and exposing only the anterior part of the head.* Not only is it a reptile which spreads very slowly, but it is eminently an animal requiring a continuous land surface for its dispersal. As might be expected, the genus Anniella is quite peculiar to the south-western States. No other member of the family Anniellidae is known, though it is closely related to the Anguidae, which are almost confined in their distribution to America and Europe.

We also possess a single species of that remarkable family, of burrowing lizards, the Amphisbaenidae, in lower California and Mexico, viz., Euchirotes biporus. It is a significant fact that two peculiar genera of that ancient family occur in the

* Coe, W. R., and B. W. Kunkel, "Californian Limbless Lizard," pp. $350-351$. 
two southern corners of North America, one (Rhineura) in Florida, the other (Euchirotes) in Lower California and Mexico. The only North American members of the blind snakes (Glauconiidae) are limited in their range to the southwestern States. One of them (Glauconia dulcis) lives in Mexico, New Mexico and Texas, the other (Glauconia humilis) ranges from California as far as Arizona. These degenerate worm-like creatures are entirely subterranean, and feed on earthworms and larvae of insects. Hence their distribution is of great zoogeographical value. Besides the districts referred to the family is found in the Lesser Antilles, Central and South America, south-western Asia and Africa. That these snakes should have passed all through the continent of North America and through northern Asia in spreading from South America to Africa or vice versa without leaving a trace of their former wanderings seems to me very unlikely. Yet geographical distribution of that kind is frequently explained by the supposition of a former Bering Strait land bridge offering the only means of land communication between the Old World and the New. There being no fossil evidence to guide us, we must judge such cases altogether from the present distribution, and it appears to me that an ancient land bridge across the mid-Atlantic explains the latter more satisfactorily than the other hypothesis.

The theory of the former existence of such a land bridge is not built upon a single instance of distribution. I have mentioned many others in previous chapters, and I shall allude to several in subsequent ones. One other striking example may appropriately be mentioned here, viz., the distribution of the boas (Boidae). These are mostly large and active snakes. Nevertheless, they are related to the small and slowly-moving blind snakes, because, like them, they possess rudiments of a hip-bone and hind limbs. Boas inhabit all tropical and sub-tropical countries. Only in two districts do they pass into temperate climates, viz., in the southwestern States of North America and in south-eastern Europe. In these countries are found the two closely-allied genera Lichanura and Eryx. One of the North American boas (Lichanura trivirgata) is confined to the extreme south of Lower California, another to southern California and 
Arizona, while a third, the rubber boa or silver snake actually passes into Washington State and central Nevada.

The recent increase of dryness in the south-west has no doubt affected the original fauna considerably. Semi-aquatic forms and aquatic ones have either been destroyed or forced to take refuge in the neighbouring States where climatic conditions were more favourable. To this cause may be attributed the present scarcity of amphibians in most of the southwestern districts, where many of them, we may presume, originally had their headquarters. The only American member of certain toads, which on account of the peculiar shape of their tongues have been called Discoglossidae, occurs in Washington State in western North America. This family has always been looked upon with particular interest, because to it belongs the solitary amphibian known from New Zealand. This toad (Liopelma) must have reached New Zealand, according to Dr. Stejneger, ${ }^{*}$ before Cretaceous times by means of a very ancient land connection with the north. The same author expresses the opinion that the Himalayan Mountains, or rather the region to the south-west of them, was the original home of these discoglossoid toads, and that they spread from there to New Zealand and North America. On the latter continent we still find, as I remarked, a single genus of the Discoglossidae (Ascaphus). The present centre of dispersal of these discoglossoid toads is southern Europe, since three genera are found there, viz., Discoglossus, Alytes and Bombinator. The first two are strictly European, whereas a single species of Bombinator also inhabits northern China and Korea. Considering the fact that these toads do not occur in southwestern Asia, and that both Discoglossus and Bombinator have been found in European Miocene beds, the Mediterranean Region seems more likely to have been the original centre of dispersal than south-western Asia. At any rate, that event leads us, no doubt, to the dim and distant past of the early part of the Mesozoic Era.

The allied family Pelobatidae is likewise of great faunistic interest, as the two genera Scaphiopus of North America and Pelobates of Europe are only distinguished by slight differ-

* Stejneger, L., "Distribution of Discoglossoid Toads," pp. 91-93. 
ences. The spade-foot toads (Scaphiopus), as they have been called, have their headquarters in Mexico and the southwestern States, whence they have spread northward along the Pacific coast and eastward to the Atlantic States.* One species, the hermit spade-foot (S. holbrooki) is worthy of special note, owing to its occurrence on Martha's Vineyard Island, in view of the remark I previously made (p. 183) that this and other north-eastern islands are the remnants of an ancient land mass formerly connected by land with the mid-Atlantic land bridge.

The faunistic relationship between Europe and southwestern North America deserves an ample discussion, being one of the most important and noteworthy features of the American fauna. Besides the points already referred to there are a few others which throw light on the nature and origin of this relationship.

I do not intend to dwell on the merits of the various classifications which have been adopted for the land mollusks. Even if we base our system upon purely anatomical grounds, different points of view may sometimes give rise to considerable differences in classification. Thus Dr. von Ihering $\dagger$ contends that the family Helicidae, as far as North America is concerned, is entirely confined to the western States. Dr. Pilsbry, $\$$ on the other hand, in including Polygyra among the Helicidae, naturally records for that family a very different range.

Both authors agree in attaching great importance to the molluscan fauna of the western and south-western States, and both are inclined to attribute its origin to immigration from Asia. That Dr. Pilsbry supposes the mollusks to have wandered across an old Bering Strait land bridge, while Dr. von Ihering $\S$ argues in favour of a much more southern Oligocene land connection between eastern Asia and California, is not perhaps of such fundamental importance. The general agreement is all the more remarkable, as both authors have formed radically different views on the interpre-

* Gadow, H., “Mexican Amphibians and Reptiles,” p. 205.

† Thering, H. von, "Verbreitung der Heliciden."

$\ddagger$ Pilsbry, H. A., " Manual of Conchology," Vol. IX., p. xxxii.

$\S$ Ihering, H. von, "Verbreitung der Heliciden," p. 442. 
tation of some anatomical facts. Dr. von Ihering supports the opinions, upheld by almost all the prominent European conchologists, that the west American shells, which so greatly resemble the European Ariantas and Campylaeas, are really genetically connected with the latter. He even contends that no anatomical distinction worth mentioning exists between some of the American Epiphragmophoras and the European Arianta. Dr. Pilsbry, on the other hand, does not recognise any very intimate anatomical relationship between the European and west American Helicidae, except in so far as he considers both to be branches of an ancient south Asiatic stock. As I shall explain later on, I concur with Dr. von Ihering, Dr. Sandberger, Professor Oppenheim, Professor Boettger and Dr. Kobelt in the opinion that many of the Antillean and west American forms are intimately related to extinct and recent European Helicidae. The great resemblance of the shells of Arianta and some of the Epiphragmophoras alone seem to imply a near relationship between them.

The genera Ashmunella, Sonorella and Oreohelix are quite peculiar to south-western America, a large number of species having been described by Dr. Pilsbry and Mr. Ferris * in a series of articles contributed within the last few years to the Proceedings of the Academy of Natural Sciences of Philadelphia. The same region contains many other distinct genera of land mollusks. The Urocoptidae, a family of snails somewhat resembling the European Clausilia in shape, and having their headquarters in the Antilles, are represented by two genera, viz., Holospira and Berendtia, peculiar to southwestern North America.

Of some interest is the occurrence in southern Mexico, in lower California, and on the intervening islands, of many species of the large and ponderous genus Bulimulus. The difficulty of satisfactory identification unfortunately is such that there is little agreement among the various authorities as to the limits or range of species, nor is the nomenclature of these shells in a more satisfactory position. All the same as I shall mention later on, we can gather some useful hints from their distribution.

* Pilsbry, H. A., and J. H. Ferris, "Mollusca of the South-Western States." 
The point, however, I wish to direct special attention to is the fauna as a whole inhabiting the southern part of the long peninsula of Lower California. This peninsula, for which many people retain the Spanish name "Baja California," is a narrow strip of broken mountainous land, nearly eight hundred miles long, and averaging about fifty miles in width. On the western side of this region there are a series of isolated peaks or ridges rising to a height of about 2,000 feet. An older range of mountains, composed of granite and gneiss, lies along the eastern flank of the peninsula. Most of this vast country is bare and desert-like, with a scanty flora, water being difficult to obtain.* As soon as we enter what is called the "Cape Region" all this is changed. Running water can be procured throughout the whole year, in the larger cañons at any rate, and this gives rise to an extremely rich and exuberant vegetation. While almost the whole of the fauna and flora of the peninsula are merely a continuation of those of California and Arizona, having evidently passed into it from the north and east, the southernmost tip, or Cape Region, has an entirely different set of animals and plants. I have already alluded to the occurrence here of Euchirotes biporus, a very peculiar burrowing lizard belonging to the ancient family of Amphisbaenidae, and of the boa Lichanura trivirgata. Another reptile, which is quite peculiar to the same district, is Ctenosaura hemilopha. This great lizard, of nearly two feet in length, possessing a high crest along its back, a green head and pale yellow body spotted with olive, brown and black, is a most remarkable and striking object. The only near relations of the burrowing lizard, and of the great active Ctenosaura, live in south-western Mexico. But the Mexican forms do not belong to the same species. We cannot, therefore, assume that these lizards have been accidentally carried across the Gulf of California, which has a width of about one hundred miles near the tip of the peninsula. The genus Ctenosaura, it may be mentioned, is related to Cyclura of the West Indies, and Brachylophus of the Fiji and Friendly Islands, these genera all belonging to the great family Iguanidae, which has inhabited America since Cretaceous times (p. 202). $\dagger$

* Merrill, G. P., "Lower California."

† Denburgh, J. van, “Herpetology of Lower California,” p. 78. 
The flora of the Cape Region is sub-tropical, a considerable proportion of the plants being West Indian. There are also a few genera which do not occur elsewhere on the American continent or the neighbouring islands. A small tree abundant in the Cape district belongs to the genus Albizzia, which is otherwise confined to Australia and the warmer parts of Asia and Africa.* Although the lower Californian species is quite distinct, its occurrence there might be attributed by some naturalists to accidental distribution by marine currents during some former period. No other occasional means of transport could be thought of. But Albizzia is by no means an isolated instance of floristic relationship between the countries bordering the west and east sides of the Pacific Ocean. Difficult problems of distribution of that nature are apt to be looked upon as instances of accidental dispersal. Yet these puzzling cases of distribution often supply us with valuable clues with reference to possible changes of land and water that may have taken place. That the Cape Region of Lower California is really a fragment of an ancient land-mass is suggested by the occurrence there of the burrowing lizard Euchirotes, of two species of the fresh-water oligochaet worm Kerria, and by a good many other faunistic features. Kerria is only met with in that region, in the West Indies and in southern South America.

Among the mast interesting members of the Cape fauna are the land shells of the genus Bulimulus above referred to. Dr. Cooper, $\dagger$ in his series of valuable papers, only mentions a fow species found in that region, but he alludes to the noteworthy fact that two of the Bulimuli only live on the peninsula of Lower California, and in a similar situation on the coast of southern South America, though quite absent from the intervening moist tropical region. Dr. Dall, $;$ and more recently Dr. Pilsbry, have shown, however, that the Cape species are not identical with the South American ones, though extremely like them in general appearance, and that they, together with those of southern Mexico and the intervening islands, form a group by themselves. About twenty species

* Brandegee, T. S., “Flora of Baja California,” p. 222.

† Cooper, J. G., "Molluses of Lower California," p. 99.

† Dall, W. H., " Bulimulus in Lower California." 
of this genus of large snails are peculiar to the Cape Region, several others being identical with Mexican ones. Some of them have spread along the peninsula northward, yet it seems certain that the Lower Californian centre of dispersal lies in the Cape district, for no species occurs in California proper. If we examine the range of the genus Bulimulus as a whole, we find that its headquarters are in the West Indies. From there it has travelled to eastern South America possibly across a very ancient land surface. Another branch has gone westward and populated the distant Galapagos islands. A third stream apparently invaded the coast lands of South America from the west, for we find numerous groups of Bulimuli in certain western areas in Bolivia, Peru and Chile. Still another section has struck directly westward across southern Mexico to the southern parts of Lower California. A couple of species have passed into Texas and further east from this Mexican centre.

Considering that the closely related genus Placostylus inhabits New Zealand, as well as a series of archipelagoes between it and the Solomon Islands, it must be admitted that in Bulimulus we have to deal with an almost archaic genus, and that the land-masses and islands on which it is now found are probably fragments of ancient continuous lands. Accidental dispersal of shells has formed the subject of $\mathrm{Mr}$. Hedley's * special study. Yet he shows that the species, particularly of the southern Placostylus, being heavy massive shells, are singularly unfitted for crossing distant seas by occasional means of dispersal. Hence he arrives at the conclusion that the Solomon and Fiji islands, the New Hebrides, Loyalty Islands, New Caledonia, Norfolk Island, Lord Howe Island and New Zealand form a zoological province, and are to be considered as the fragments of a shattered continent.

A similar argument might be applied to Bulimulus, which is so closely related to Placostylus. It seems permissible to argue that the West Indies in early Mesozoio times were a large united land-mass, that the latter was continued southeastward so as to join the archaic lands of eastern Brazil, that it swept westward across what is now Central America out 339.

* Hedley, C., "Placostylus," A Study in Ancient Geography, pp. 337- 
into the Pacific Ocean, and that wherever in Bolivia, Peru and Chile we find groups of Bulimuli, the land on which they live represents some portion or fragment of that ancient land which once occupied part of the eastern Pacific Ocean. If we had no other data in support of such theories, they would be based on very slender evidence. But all this will be more amply discussed when we come to deal with the general fauna of the Galapagos Islands and western South America.

The only other point bearing on the westward extension of the ancient "Antillea," as the supposed West Indian continent has been called, is the singular occurrence here and there of traces indicating land westward of California. Along the coast of southern California lies a little cluster of eight islands which have lately attracted the attention of naturalists. Now, as Mr. Greene informs us, on Santa Catalina Island may be found Crossosoma, a plant so peculiar as almost to represent a distinct natural order, and more closely related to the Asiatic and Australian Dilleniaceae than to any plant on the American Continent, except a single congener recently discovered in south-eastern California. Speaking of Santa Cruz, another of this group of small islands, he comments on its unique feature in possessing no less than forty-eight species of plants not found on the opposite mainland and expresses the opinion that the whole set of islands must have a very peculiar geological origin and history. Species belonging to distinctly Californian genera, like Dendromecon, Eschscholtzia, Thysanocarpus and Zauschneria, abound in such numbers as to suggest the question whether it was not from these islands that the mainland plants of the same genera were derived. The remarkable fact that Lyonothamnus, Hazardia and the Lavateras, all of which have Asiatic or Australian affinities, occur on these islands in several distinct species, being quite unknown on the American continent, makes Mr. Greene* wonder whether this group of islands has not formerly been connected by land with some other continent than America.

Surprising and apparently inexplicable as this feature may: seem, California and south-western North America generally

* Greene, E. L., "Botany of Santa Cruz Island,” pp. 377-388. 
reveal a still more extraordinary phenomenon in distribution. We may imagine, and many people actually do, that the power of wind and waves to carry objects from one part of the world to another is almost unlimited. One of the most striking and remarkable characters of California, however, is its very close faunistic affinity with western Europe. Even the most enthusiastic supporter of the flotsam-jetsam theory will feel that some other cause than this must have been responsible in producing this effect. A former land connection between the two regions, without others being affected, seems out of the question. Yet almost all those who have endeavoured to explain the origin of this western fauna have preferred to choose the old Bering Strait land connection as offering a safe passage to European animals, rather than disturbing the general arrangement of the existing oceans and continents. If the faunistic resemblance of California to western Europe had really been caused by a migration of animals from one area to the other across the whole Asiatic continent, eastern Asia ought surely to show affinity with California to a much more pronounced degree than western Europe does. As a matter of fact, certain groups in California are distinctly eastern Asiatic in affinity, as I have just mentioned, while others are just as clearly, south and west European in character. I have given a few instances already of these faunistic relationships, and further evidence will now be adduced in support of this statement.

I think it was the snail Arianta arbustorum, so prominently alluded to in my work on European animals, which first drew the attention of American zoologists to this relationship, for, as already remarked, a snail extremely similar in appearance lives in California. Even Dr. Pilsbry* admits that the resemblance in shell characters of the Californian and European species is astonishing, although he adds that it is due to a purely secondary modification that these shells have been moulded to a deceptive likeness, the genitalia having been left unchanged to tell more faithfully, the story of their lineage. Having made an anatomical study of this Californian Arianta-like group, Dr. Pilsbry arrives at the conclusion that

* Pilsbry, H. A., “Manual of Conchology,” IX., p. 196. 
the latter belongs to the same great family Helicidae as the European Arianta, but that otherwise it is quite unrelated to it. He places the Californian forms, therefore, into the genu,s Epiphragmophora, contending that its nearest relations are the Helices of Japan. In another place (p. 46) he adds the remark that it is unnecessary to throw land bridges across the depths of the Atlantic and Pacific Oceans to account for the distribution of Helices. Such hypotheses, he thinks, are contrary to many facts indicating that such groups of snails as are common to America and Europe have radiated from an Oriental centre westward to Europe and eastward, by way of a former Bering Strait land bridge, to America. Yet Dr. Pilsbry's conclusions, as I have already mentioned, are contested by Dr. von Ihering likewise on anatomical grounds. Although Dr. Pilsbry maintains that his opponent bases his deductions on figures and not dissections (p. 195), Dr. von Ihering, in a recently published paper, again insists that, after having made a careful anatomical investigation of Arianta, (or Helicigona as he calls it,) and the American Epiphragmophora, he could perceive no difference worth mentioning between the two. Hence Dr. von Thering's* opinion is that the American Helices, which are now generally known under the name of Epiphragmophora, and which are entirely confined to the Pacific coast of America, possess their nearest relations not in Asia but in western Europe.

Let us take another group, that of the well-known European family of slugs, the Arionidae. In 1896 Messrs. Pilsbry and Vanatta $\uparrow$ showed by anatomical investigations that the American slugs Ariolimax and Aphallarion belong to this family. Later on the same writers added the genera Anadenulus, Hemphillia, Hesperarion and Prophysaon to this list. The whole of this great assembly of Arionidae is quite confined to the Pacific region between British Columbia and southern California. No other slug of this family has as yet been discovered anywhere in the New World, except one or two European species in the northeastern States, which may either have been introduced

* Thering, H. von, “System der Heliciden,” p. 422.

† Pilsbry, H. A., and E. G. Vanatta, "Revision of North American Slugs." 
or have crossed over by a former North Atlantia land bridge. In western Europe and north Africa we have the four genera Arion, Geomalacus, Ariunculus and Letourneuxia. Only the first of these has a wide range, one species extending through Russia to northern Siberia. In Asia only a single genus (Anadenus) of the family is known, inhabiting the Himalayan Mountains and China. The Arionidae thus have a most discontinuous range, and their origin and dispersal form an interesting problem. Since Geomalacus and Letourneuxia are confined to the western borders of Europe and North Africa, and Arion obviously has its headquarters in the same region, Professor Simroth* argued that the European Arionidae had either originated on a sunken land which lay out in the Atlantic, or wandered across an ancient Atlantis from western America. Dr. Pilsbry $\dagger$ also is in favour of an American genesis for the Arionidae, but he believes that the ancestors of the Old World genera just alluded to must have crossed over to Asia by means of a former Alaskan land bridge, and then have wandered along, dropping Anadenus on the way, until they finally reached western Europe. Of the two theories Professor Simroth's appears to me the more plausible one. And his hypothesis is strengthened by the occurrence in south-western North America of a species of slug either identical or very closely related to a European one, viz., Amalia hewstoni. The European Amalia (Milax) gagates must be regarded as an exceedingly ancient species, certainly dating back to beyond Tertiary times. Geological evidence for such a belief there is none, nor could we expect to find the remains of slugs in ancient deposits. In a matter of that kind we have to rely purely on distributional evidence. That Amalia gagates could be transported to any island from the mainland by the ordinary means of dispersal is out of the question. It can only have reached its present habitat on many very remote islands by human introduction or by former land connections with the mainland. It is by no means a slug that congregates near human habitations, nor is it commonly found among vegetables like some of the Limaces and Arions. Yet it occurs in

* Simroth, H., “Nacktschnecken Russlands," p. 60.

† Pilsbry, H. A., "Phylogeny of Arionidae,” p. 103. 
variously modified forms on the islands of Madeira, Sicily, Sardinia and Teneriffe, on the Azores, the Cape Verde islands, St. Helena, Tristan d'Acunha and Bermuda. It has never been reported from any of the West Indian islands, Central America or the southern States of North America. In western North America it has a wide range, being known as Amalia hewstoni, from British Columbia to Mexico. On the east coast it occurs only along the coast of Massachusetts and New York, exactly where so many other members of an ancient fauna reside. In Asia, except Asia Minor, no Amalia has hitherto been discovered. In Africa it is only met with along the north coast and in Cape Colony (A. ponsonbyi). From south Australia a similar form has been described as Amalia pectinata, while others occur in Now Zealand and the Sandwich islands. Most zoologists will insist that such an enormously wide and discontinuous range of a species, though exhibiting distinctive characters in its various habitats, can only be due to artificial introduction by man. My own opinion is that it has reached all the localities referred to by the natural means of progression on land during a long series of geological periods, and Professor Simroth,* the best living authority on slugs, shares the same view. As far as its occurrence in western North America is concerned, Professor Simroth's Atlantis, a land bridge connecting Portugal with the West Indies and the lands beyond it across the Atlantic, would suit our purpose. The slug's absence from the Antilles might be due to the fact that it became extinct there during the extensive submergence which the West Indian area has undergone in Tertiary times.

The eminent authority on butterflies and moths, Dr. Pagenstecher, $\dagger$ tells us that California possesses an independent character among the North American fauna, in being more nearly related to Europe than to the eastern States. With the exception of Ctenucha and Agarista all the genera are European, while Pyrameis atalanta, P. cardui, Vanessa antiopa, Arctia caja, Phragmatobia fuliginosa, Scoliopteryx libatrix, Brachionycha nubeculosa, Amphipyra pyramidea and Agrotis exclamationis are common to California and Europe.

* Simroth, H., "Pendulations Theorie," p. 92.

† Pagenstecher, A., "Verbreitung d. Schmetterlinge," p. 359. 
Among the most abundant beetles in California there is a group of flightless forms which when touched will emit a pungent, oily secretion. Owing to their curious habit of elevating their bodies when alarmed they have received in the west the popular name of "circus bugs." Now this section Eleodinae of the large family Tenebrionidae are, in North America, quite peculiar to the south-west. A few species have spread northward into Washington State and eastward as far. as the Mississippi. The great mass of these thick-bodied oily creatures lives in Mexico and California, where, according to Mr. Blaisdell,* they have probably originated. The only near relation of this south-western group in the New World is the genus Nycterinus, which is peculiar to Chile. But throughout the Mediterranean Region we meet with a very large number of similar beetles, commonly called "oil beetles," and although many of them are also found in Persia, Turkestan, Central Asia and even China, south-eastern Europe must be looked upon as the headquarters of the genus Blaps, to which they belong.

The same family Tenebrionidae also offers instances of intimate relationship between the Antilles or Central America and southern Europe. I need only recall the American Gnathocerus maxillosus which likewise inhabits Madeira, the Canary and Mediterranean islands, as well as Sitophagus hololeptoides of Central and South America, the Antilles and Madeira.

Dr. Kolbe $\dagger$ mentions similar examples of distribution among the coprophagous lamellicorn beetles. Thus Oniticellus and Glaresis are quite peculiar to the south-west in North America, whereas in Europe they are confined to the Mediterranean Region. Only the former has spread further southward into Africa and eastward into Asia.

Of all the insects, faunistically the most interesting are the ants. In my work on European animals I alluded to Stenamma westwoodi as one of the members of the Lusitanian fauna, which penetrated as far north as south-western Ireland. The same species is met with in America in a few varieties. One lives in California, the other in British

* Blaisdell, F. E., "Eleodinae of the United States," pp. 28-29.

† Kolbe, H. J., "Verbreitung d. Coprophagen Lamellicornier," p. 499. 
Columbia, the third in the north-east.* Honey-ants, at least certain members of their colonies, possess the faculty of storing quantities of honey within their bodies, which swell up to a great size, and on that account are somewhat remarkable objects. In North America two species of honey-ants occur, namely, Myrmeocystus melliger and M. mexicanus, both being confined to Mexico, Arizona and the neighbouring regions. The other species of the genus Myrmeocystus inhabit the Mediterranean Region and further east as far as central Asia.† In southern Europe a soft, velvety ant is found belonging to the genus Liometopum. The same species was likewise supposed to inhabit California, but Professor Wheeler $\ddagger$ found that although the two forms are very closely related, the American differs slightly in shape and even in its habits from the European species. Whereas the former constructs its nests underground, the latter utilises for that purpose the abandoned burrows of beetles under the bark of trees. Hence he calls the American ant, Liometopum apiculatum. It is limited in its range to California and Mexico. Only two other species of Liometopum are known. One, (L. microcephalum), as I mentioned, lives in southern Europe, the other (L. lindgreeni) in Assam. It is not often that we actually become acquainted with the extinct ancestors of such interesting invertebrates as these. But fossil forms of Liometopum have been discovered, according to Dr. Handlirsch $\S$ in the Lower Miocene of Croatia and the Oligocene of Colorado. Even in Tertiary times the genus seems to have occupied much the same localities as it does to-day; it only spread formerly further north no doubt owing to the more favourable climatic conditions then prevailing.

Many other similar instances might be quoted. I will only allude to one more. The two well-known European ants Formica cinerea and Formica rufibarbis had been reported from the south-western States of North America, but Professor Emery doubted the correctness of the identification until Professor Wheeler sent him American specimens. Both

* Emery, C., "Nordamerikanische Ameisenfauna," p. 299.

† Wheeler, W. M., "Honey Ants," p. 347.

† Wheeler, W. M., "North American Liometopum," p. 321.

$\S$ Handlirsch, A., "Die Fossilen Insekten," p. 870. 
species must have been established in America for long periods past, as their range extends inland in a north-eastward direction beyond the Rocky Mountains.

Instances of specific identity in the two widely separated regions of California and southern Europe are to be found in several groups. Professor Kraepelin * reports, for example, that the scolopendrid Theatops erythrocephalus is such a case. From California it has spread as far as Oregon. In southern Europe it is known from Portugal, Italy, Dalmatia and Hungary. The genus Theatops is confined to North America, including the Sandwich islands, and southern Europe.

A member of the order Palpigradi, a minute creature somewhat resembling a scorpion in shape, has been observed in Texas and named Koenenia wheeleri after Professor Wheeler. Two other members of the genus are known from South America, one from Chile, the other from Paraguay. But the nearest relations of the North American form are evidently Koenenia mirabilis of Sicily and Tunis, and K. draco of the Balearic islands. The only two other species live in Siam. $\dagger$ We thus have in this ancient group again the same intimate affinity between southern Europe and south-western North America as in some ants, beetles and butterflies, showing clearly that the same potent cause, which is certainly not accidental distribution, has contributed to bring it about. In order, however, to make quite sure that these are genuine instances of migration on a land surface, and not due to occasional or accidental transport, let us now examine carefully the range of a large fresh-water form and endeavour to trace its origin.

Fresh-water crayfishes, as Dr. Ortmann remarks in his excellent account of them, do not possess any exceptional means of dispersal. They are restricted to fresh water and cannot exist out of it, neither in salt water nor on land. Moreover, they do not possess, during any stage of their life history, means or devices which might favour their passive transport from one fresh-water system to another. The whole character of their range is opposed to the assumption that

* Kraepelin, K., " Revision der Scolopendriden," pp. 64-66.

† Hansen, H. J., “On Koenenia.” 
their dispersal has been caused by any exceptional or abnormal means of transport. Few zoologists will consequently disagree with Dr. Ortmann's * assertion that fresh-water crayfishes are among the most important animals in so far as the study of their distribution elucidates past changes of land and water over the globe. The crayfishes have been brought into great prominence by Professor Huxley's well-known treatise on the subject. More recently it is principally in America that their structure and distribution have been studied with great assiduity. Dr. Faxon $\dagger$ was the first to recognise that besides the American genera Potamobius (Astacus) and Cambarus, there is a third genus of freshwater crayfishes which inhabits north-eastern Asia. The latter, it is true, is only 'considered a sub-genus of Potamobius by Dr. Faxon and also by Dr. Ortmann, but, as $\mathrm{Mr}$. Stebbing $\$$ has pointed out, its intermediate position between Potamobius and Cambarus entitles it to rank as the distinct genus Cambaroides.

The geographical distribution of these crayfishes (Potamobiidae) is very suggestive and interesting. Europe is the headquarters of the old and well-known genus Astacus, which name, in the unfortunate search for priority, has had to give way to Potamobius. The genus ranges practically throughout Europe, from north to south and from east to west, and only very little beyond' it. Beyond the Caucasus it crosses into Transcaucasia, Turkestan and western Siberia. It is quite unknown in the remainder of Asia. In the rivers of eastern Asia, in Korea, Japan and eastern Siberia we meet only with members of the small group Cambaroides referred to. The somewhat close resemblance of this Asiatic genus to the American Cambarus does not point to blood relationship, according to Dr. Ortmann, merely to convergence. In America we find not only Cambarus, but also Potamobius, the European crayfish, the latter genus being in America entirely. confined to the western States. Professor Huxley and Dr. Faxon both urged that the American species of Potamobius resembled the European crayfishes much more than the Asiatic

* Ortmann, A. E., "Distribution of Freshwater Decapods," pp. 315-316.

+ Faxon, W., "Revision of Astacidae."

† Stebbing, T. R. R., "Crustacea," p. 208. 
ones, yet, like Dr. Ortmann, they maintained that Europe was supplied with its crayfish fauna from the East. In his lucid essay on this subject, Dr. Ortmann argues that a primitive group of Potamobiidae, ancestral to all the living ones, must formerly have existed in eastern Asia, which region should be regarded as the centre of dispersal of the family. This ancient group, he thinks, sent one branch westward to Europe and another east'ward across the old Bering Strait land bridge to western North America. Thus, three centres of dispersal gradually originated in which the old stock developed on independent lines. The middle one changed to Cambaroides, while the two branches retained the ancient characters. From the American branch eventually originated Cambarus, which spread eastward into the eastern States of North America (see pp. 289-91).

I accepted Dr. Ortmann's explanation in my work on European animals as an hypothesis, which satisfactorily accounted for the present distribution of the Potamobiidae. Doubts, however, have since arisen in my mind as to whether there is not a better theory. The more I studied the problem the less I felt disposed to agree with Dr. Ortmann's explanation. Why should the old stock, for instance, have become modified into Cambaroides in its original centre of dispersal, while still flourishing in two centres enormously distant from one another? And these two new centres were reached after many struggles and vicissitudes, after long and weary travels, probably through hundreds of miles of unsuitable ground. One would imagine the two distant branches to have become more and more unlike one another. Five species of the old stock Potamobius still inhabit the streams of western America, from California in the south to Alaska in the north. If Dr. Ortmann's theory were the correct one, the centre of dispersal of the more modern genus Cambarus, which has developed from some member of the old stock, ought to be in north-western America. Everything, nevertheless, points to the conclusion that the new genus Cambarus originated in Mexico, and Dr. Ortmann (p. 291) is of that opinion, having recently supported it by means of many additional facts of distribution.*

* Ortmann, A. E., "Affinities of Cambarus." 
It is to south-western North America, therefore, that we must look for the original home of the ancestral group of Potamobius. They still inhabit that area, and may have spread from there northward to Alaska, and even further to north-eastern Asia, eventually giving rise to Cambaroides. Taking these and many other remarkable facts of distribution into consideration, it appears to me quite possible that the presence of the crayfish Potamobius in Europe and North America, and its occurrence in the western parts only of the latter continent, may be due to an ancient land connection which, as already suggested, joined western Europe and Mexico by way of the West Indies. Whether the family originated in North America or in Europe will have to form the subject for future researches. That this migration took place in very remote times, is implied by the fact that Cambarus primaevus (which Dr. Faxon believes to be a Potamobius), occurs in the Eocene beds of western Wyoming. If such a land bridge as that alluded to actually existed in early Tertiary or late Mesozoic times, it may be asked why do we not meet with any members of the genus Potamobius in the streams of the West Indian islandis? To this we may answer that geologists are practically agreed that in post-Eocene, or even during Eocene times, the whole area of the Antilles was greatly submerged, so that we may suppose that the ancient fauna that wandered across that area from either Europe or North America was largely exterminated. That the islands were subsequently again connected with the mainland we may assume from the presence of Cambarus cubensis, a crayfish peculiar to the island of Cuba.

My views as to the nature and extent of that mid-Atlantic land bridge will be more fully explained in the chapter dealing with the West Indies. The presence or absence of such a land connection, however, is of such vital importance to the elucidation of the phenomena of distribution, that I may be excused for quoting still further examples of animals whose range throws light on the solution of this problem.

In the beginning of this chapter (p. 205) I mentioned the fact that the spade-foot toads (Scaphiopus) have their headquarters in Mexico and the south-western States of North America, and that their nearest relations are the members 
of the genus Pelobates which inhabit Europe. Only a single species (P. syriacus) has been discovered in Asia Minor. The others extend from western Europe to the Caspian. Another genus (Pelodytes) of the family Pelobatidae has one species in Portugal and a second in the Caucasus. All the other genera of the family are found in the East, and are more remotely akin to Scaphiopus than Pelobates is. Hence we may conclude that the distribution of these two genera is distinctly favourable to the suggested trans-Atlantic land bridge.

Another interesting amphibian that I have alluded to (p. 137) is the newt Spelerpes, which, with the exception of a single European species, is peculiar to America (see Fig. 8). The centre of dispersal certainly lies in Mexico, from which country various sections have spread northward into the States, southward as far as Peru, and eastward to the island of Haiti. That this discontinuous distribution could not have been brought about under existing geographical conditions is evident, nevertheless, since no fossil Spelerpes are known, we can only judge of the age of the genus from its distribution. Dr. Gadow * suggests the Oligocene Period, and thinks that a north-Atlantic land connection, such as the one I have described in the first chapter of this work, from Labrador to Scotland via Greenland, might have brought about the existing range of Spelerpes. Since the single European species inhabits only Sardinia and the mountains bordering the Gulf of Genoa, while most suitable ground for its existence is found further north, I cannot admit that Spelerpes fuscus reached Europe in that manner. The land bridge by which it crossed the Atlantic must have lain much further south.

I have already alluded to the fact (p. 173), that there is apparently a south-western and a south-eastern form of the American glass snake (Ophisaurus ventralis), and that both of them extend northward for considerable distances. The only other members of the genus are the European glass snake (Ophisaurus apus), which inhabits the Mediterranean region and is very like the American, and the Asiatic species, which is found from the eastern Himalayas to Burma.

* Gadow, H., "Mexican Amphibians and Reptiles," p. 244. 
Dr. Ruthven's valuable researches into the origin and distribution of the garter-snakes (Thamnophis = Eutenia) have been discussed in an earlier chapter (p. 128). I need only restate that he traces the home of the genus to northern Mexico. And Thamnophis is clearly an offshoot from the older water-snakes (Tropidonotus), which have almost a world-wide range. As in the case of Potamobius and Cambarus, both genera seem to have spread northward from their south-western centre, the south-western Tropidonotus validus having its nearest relation in the Sardinian Tropidonotus viperinus. Dr. Brown * recognised perfectly that the affinity between such forms as the European and American species of Tropidonotus necessitated the existence of a former land bridge between the two continents. $\mathrm{He}$ also urged that the existence of this bridge must have coincided with a warm climate in the north, for he naturally. assumed that only in the extreme north could there have been such a land connection. Its geological age he fixes at about the early Miocene, though he believes many of the present genera to have been in existence even in Eocene times. My objection to Dr. Brown's theory is that we have no evidence in Europe of a southward advance of Tropidonotus from a former northern centre of distribution, nor are the northern species in both continents more closely related to one another than the southern species. The former existence of a more southern trans-Atlantic land bridge in early Tertiary times, on the other hand, is supported by such a number of palaeontological facts, as we shall learn later on, that the evidence is overwhelmingly in its favour.

It is quite possible that the western tortoise Clemmys marmorata, or its ancestors, for the genus, as I mentioned (p. 133), has inhabited south-western North America since Eocene times, has spread across the same mid-Atlantic land bridge to western Europe, a near relation (Clemmys leprosa) being peculiar to Portugal, Spain and north-western Africa.

That all these animals living in south-western North America and western Europe which show close relationship, are relicts of very remote geological times is rendered prob-

* Brown, A. E., “Post-Glacial Nearctic Centres," p. 466. 
able, partly from palaeontological evidence, and partly from other methods of reasoning. That most of them trace their origin in America or Europe to the former existence of a direct land bridge across the mid-Atlantic seems also obvious. Yet many geologists are very strongly opposed to a theoretical bridging of the Atlantic. Nothing short of a wellmarked mammalian affinity between the two areas alluded to will satisfy them. We can produce little of such evidence, because most groups of mammals have changed very rapidly during the course of the Tertiary Era. A few, however, such as the rodents, appear to have the faculty of preserving their ancestral characters for longer periods, and some, apparently, have undergone little change since remote times.

There are two instances, one among the voles, the other among the hare family, that seem to point to the existence of the land connection just discussed, and these cases may possibly throw more light on the age of the land bridge than the invertebrates or reptiles can do. Professor Tullberg * contends that the meadow voles (Arvicola $=$ Microtus) only entered Europe in Pliocene times from Asia, where they had already existed for some time previously. He also expressed the opinion that these voles subsequently crossed over to America from Europe by a north-Atlantic land connection, which I presume must be the Scotland-Greenland-Labrador bridge. We know very little of fossil meadow voles. If Professor Schlosser is correct in his assertion that only geological researches can give us any clues as to former changes of land and water, and that zoogeography cannot do so, the meadow voles ean teach us very little.

Yet if we examine the present range of one of the subgenera of meadow voles, such as Pitymys, we find it very remarkable and instructive. One species lives on the Mont d'Or in France, at a height of over 4,000 feet, another on one of the southern Alpine spurs, at a height of 6,000 feet. De Sélys long ago described a species (Pitymys incertus) from the St. Gothard mountain, a locality which is over 7,000 feet high; another related form inhabits the Pic du. Midi in the Pyrenees, and still another a mountain in Sicily. Quite

* Tullberg, T., "System der Nagetiere," p. 499. 
a number of species are now known from southern Spain and Portugal, owing to the researches of Mr. Thomas, Mr. Miller and Dr. Forsyth Major. To judge from its recent distribution, these voles of the sub-genus or genus Pitymys ought to be of very great antiquity, yet not a single fossil specimen has ever been found. The most remarkable fact in the distribution of Pitymys is that it is entirely confined to Europe in the Old World, whereas across the Atlantic, in Mexico, we again meet with a member of this group known as the Jalapa meadow vole (Pitymys quasitor). It lives there at an altitude of about 5,000 feet. Only two other species are known from North America, one (P. nemoralis) from the Boston Mountains in the Indian Territory, the other from certain areas in the eastern States. The latter (P. pinetorum) occurs from southern Florida to Carolina, a variety of it on the Allegheny Mountains, and another from Long Island to the borders of Illinois. The range of the three American species is disconnected, and confined to Mexico and the United States. What is the relationship of these species to one another, and which is the oldest, will have to be determined by future researches, also whether the extinct species discovered in Pennsylvania by Professor Cope really belongs to Pitymys or Microtus proper. At any rate, there is nothing in the range of Pitymys that might lead us to suspect that it entered North America from the north-west, no member of the group having as yet been found in any part of Canada or Alaska. In Europe Pitymys is unknown in the north-west, whereas a number of species inhabit the south-west. Henoe the American group of Pitymys may possibly have been derived from one or more species which crossed the Atlantic on the land connection above referred to.

The hare family (Leporidae), as a whole, has a very wide distribution in Europe, Asia, Africa and America, but some of the sub-genera, which are gradually being raised to the higher dignity of genera, are confined within certain circumscribed limits. In his study on the recent and fossil Lagomorpha, Dr. Forsyth Major * comes to the conclusion that this family might conveniently be divided, according to the osteo-

* Major, Forsyth, "Fossil and recent Lagomorpha," pp. õ14-515. 
logical characters of its members, into two groups, viz., the Caprolagus and Lepus groups. The first of these, which is of particular interest, contains the four genera Caprolagus, Nesolagus, Oryctolagus and Sylvilagus. Caprolagus lives in Asia, and is likewise represented in European Pliocene beds. The second is peculiar to the island of Sumatra. The third, which includes the European rabbit, has an extremely discontinuous range, being confined, according to Dr. Major, to the Mediterranean Region, Western Europe and South Africa. Sylvilagus is peculiar to America. From its very scattered range the Caprolagus group of hares and rabbits would seem to be of ancient lineage. In a more recent study of the hares and their allies, Dr. Lyon recognised nine genera of this group. He separates the South African form of rabbit from the European, raises several of Dr. Forsyth Major's sub-genera to the rank of genera, and adds the new genus Pentalagus from the Liu Kiu islands near Japan. Whereas Dr. Forsyth Major recognised four sub-genera of the American Sylvilagus, Dr. Lyon places only two sub-genera under this genus. Although Dr. Lyon gives a fuller and more complete account of all parts of the skeleton in the different species of Leporidae than Dr. Forsyth Major. He was moreover able to detect certain prominent structural characters, which apparently escaped Dr. Major's notice. While the latter believed in the close relationship of the European and the Cape rabbits, Dr. Lyon* demonstrates that the nearest relation of the former is the American Sylvilagus. The skulls of the two genera, taken as a whole, are not markedly different, and the teeth are essentially alike.

The European rabbit also possesses marked affinities with Limnolagus, another American genus of rabbits, but not with any of the Old World genera of the family. The genus Oryctolagus, with its single species the European rabbit (O. cuniculus) is confined to the countries round the Mediterranean. Only in France, that is to say, in western Europe, is there a tendency to a northward extension of this range, and in that it resembles a great many other typically Medi. terranean animals. Its relation, Sylvilagus, ranges from the

* Lyon, M. W., "The Hares and their Allies," p. 406.

L.A. 
northern border of the United States, all over the States and Central America. In South America its exact distribution is still unknown, but it possibly reaches Patagonia. The cotton-tails and brush rabbits (Limnolagus) occur only in the southern States. We thus note the remarkable fact that rabbits of close relationship are separated in one direction by a comparatively short intervening space of sea water, in the other by a very much longer area of almost uninterrupted land, which is tenanted almost exclusively by the more distantly related hares. The other American rabbits, the pigmy rabbit (Brachylagus), and the Popocatepetl rabbit (Romerolagus), are confined to Mexico and western North America. The south-western region must, therefore, be looked upon as the centre of dispersal of the rabbits.*

The fossil history of the American Leporidae is meagre in the extreme. Only a few Oligocene species of the extinct Palaeolagus are known, and these, according to Dr. Major, seem to be ancestral to the modern genus Lepus. No forerunner of the existing Sylvilagus and Oryctolagus has yet been found. It possibly lived in south-western North America in early Tertiary times. Palaeolagus already possesses incisors of the modern type, and Dr. Matthew thinks that we may look among Eocene rodents, or even in the fauna of Cretaceous deposits, for guidance as to the manner of evolution of the teeth of the Lagomorpha. $\dagger$

This leads us back once more to the general consideration of the American Tertiary deposits and the affinities of their fauna. These deposits, above all, ought to yield indications as to whether there was a direct land connection between south-western North America and western Europe across the mid-Atlantic, such as the one I advocated.

We are confronted in America by two grand problems, says Professor Osborn, $\%$ one being the chronological correlation of the purely fresh-water horizons with one another, the other the chronological correlation of American horizons with Eurasiatic vertebrate horizons. When these are worked out, continues the same writer, we shall be able to establish a

* Nelson, E. W., "Rabbits of North America."

† Matthew, W. D., "A Horned Rodent from Colorado," p. 307.

† Osborn, H. F., "Cenozoic Mammal Horizons," pp. 29-30. 
complete and very accurate geological time scale for the entire Tertiary Era, and to speak with precision regarding the time of successive migrations. Much still remains to be done to establish the approximate ages of the various Tertiary deposits in Europe and America before we can definitely say whether a certain group of mammals made its first appearance in Europe or in America. l'ossibly we may not reach such a state of knowledge for a long time to come.

In New Mexico what are known as the "Puerco" and the "Torrejon" formations have yielded remains of archaic mammals, some of which are related to mammals occurring in late Mesozoic or early Tertiary deposits of Patagonia, others indicating affinity with those of a similar age in France. Now, as Professor Depéret tells us, it is inadmissible to argue that mammals so nearly akin to each other could have arisen independently in three distinct centres, in Patagonia, in south-western North America and in France. We can only explain these palaeontological affinities by migrations from one area to the other. Professor Deperet * believes that the cradle of these early placental mammals was in North America, and that they crossed over to Europe by utilising the "territories of the North Atlantic which had risen from the sea." This is a somewhat vague statement, yet it indicates clearly that the great French palaeontologist had in his mind the existence, in these remote geological times, of some kind of north Atlantic land bridge. He does not explain how the North American mammals reached Patagonia, but Professor Osborn $\dagger$ speaks distinctly of a contemporary, that is to say, early Eocene or previous (Cretaceous) land connection between North America and South America, and he actually places it in the same position as it occupies at present (see Fig. 21). I propose to discuss it later on. At present we may confine ourselves strictly to the European affinities of North America.

A momentous change occurs, according to Professor Osborn, in the succeeding Wasatch formation of New Mexico and Wyoming. The parallelism of similar stages in the archaic mammals of western Europe and south-western

* Depéret, C., "Transformations of the Animal World," pp. 308-309.

† Osborn, H. F., "Cenozois Mammal Horizons," p. 33. 
North America remains as before. The new feature is the sudden appearance of true carnivores, ungulates, primates and rodents. I have already referred to Eohippus (p. 147) as an early representative of the hardse family. Another modern family which traces its origin back to these remote times is that of the tapirs, for the Eocene Systemodon has all the characters peculiar to the recent Tapiridae. Whether the early primates were lemurs or true monkeys is as yet undecided. The rodents all belong to the extinct Ischyromyidae, which Dr. Matthew * believes to have been arboreal creatures, somewhat resembling squirrels in shape, although more nearly related to the peculiar and typically west American sewellel (Aplodontia).

This sudden and simultaneous appearance of modern families of mammals, along with several extinct ones, in western Europe and south-western North America is very striking, and has to be accounted for. To begin with, we have to determine the origin, or original centre of dispersal of this fauna. Professor Osborn feels certain that this fauna originated neither in Africa nor in South America. There remain, he thinks, four possible sources. They may have come from the Great Plains Region of North America, from the more northerly American Mountain Region, from the northerly Eurasiatic Region, or from the American-Asiatic land-mass. $\mathrm{He}$ is in favour of the last theory, namely, that of the intermediate or North American-Asiatic source of this fauna. Still he believes that the actual origin of this modernised fauna will not be determined until Eocene fossil mammal beds in the northern portions of America and Asia shall have been discovered. Such beds have not yet been met with, nor is there any reason to suppose that they will be. Have we any geological evidence for the supposition that there actually existed any such large and intimately connected northern land-mass at this stage of the geological history of the earth as Professor Osborn $\dagger$ implies? No doubt it is generally assumed that Alaska and north-eastern Asia were joined by land in Eocene times, and Professor Schuchert, $\neq$

" Matthew, W. D., "Osteology of Paramys," pp. 64-69.

† Osborn, H. F., "Cenozoic Mammal Horizons," pp. 35-36.

† Schuchert, C., "Paleogeography of North America," Plan 96. 
in his palaeontological maps, unites America in this manner with Asia, and by way of Greenland with Europe. But Professor Suess contends that, although these affinities in the Eocene faunas of America and Europe imply united continents in the north, this land connection was probably not in the vicinity of Bering Sea. On the contrary, he rather favours a more direct land bridge between North America and Europe.*

During the latter stages of the Eocene Period, while the Wind River, Bridger and Uinta beds were being laid down, the descendants of the archaic and of the modernised mammals gradually evolved, and we may suppose that the archaic mammals finally succumbed in the struggle for existence. At any rate, they slowly disappeared, and during the process of their elimination, the fauna of America assumed a more independent aspect, the affinities with Europe becoming less pronounced. This need not necessarily imply a cessation of the intimate geographical relationship between the two continents. The growth of an impenetrable forest, like that in the interior of Brazil, the development of local desert conditions, or the existence of temporary volcanic disturbances on the supposed trans-Atlantic land connection, would have been sufficient to faunistically isolate the two continents from one another. In the succeeding period, the Oligocene, the faunal resemblance of western North America and western Europe once more became conspicuous. The land area available for the development of mammalian life certainly increased in America during early Tertiary times, while a corresponding decrease may have taken place on the transAtlantic land connection, thus bringing a renewed influx of strange forms to the New World. Professor Osborn $\dagger$ tells us that in the White River, John Day and other American Oligocene formations, sixteen new families of mammals made their appearance, most of them still existing, and that a very similar modernisation occurred in western Europe. Six new families appear, apparently simultaneously, in both areas. It is worthy of note that the opossu'm family (Didelphyidae) and the rhinoceroses (Rhinocerotidae) now make their first entry

* Suess, E., "Antlitz der Erde," Vol. III.2, pp. 764-765.

† Osborn, H. F., "Cenozoic Mammal Horizons," pp. 58--59. 
into North America, while the monkeys (Primates) disappear for ever from the continent.

In his restoration of Oligocene conditions in North America, Professor Schuchert still depicts North America as being joined in the far north by wide land bridges with Asia and Europe, while practically submerging the whole of the West Indies. As we shall learn later on, an intimate relationship exists between the shallow water marine forms of early Tertiary European and Antillean deposits, and this has given rise to the suggestion that a land bridge must then have united Europe and the Antilles. If my view should be substantiated, that the resemblance in the Oligocene faunas of Europe and south-western North America is due to the existence in Oligocene times of a mid-Atlantic land bridge, the West Indian area, of course, could not have been submerged at that time.

After a short phase of independent evolution, during which the Oligocene deposits of western North America insensibly pass into Miocene ones, the succeeding Middle Miocene beds are characterised by the appearance of a large number of new forms, among which the elephants (Proboscidea) deserve special mention. Some of these new immigrants are, apparently, of African, others of Eurasiatic origin. The Miocene beds of Europe and of America are remarkable for the similarity of their fauna. The conclusion deduced from this fact by Professor Osborn * is that the North American middle Miocene formations contain animals which first appear in the lower Miocene of Europe, just as the American lower Miocene contains animals that first appear in the upper Oligocene of Europe.

Now it is quite possible that while the faunistic interchange between western Europe and western North America took place by means of one land connection during early Tertiary times, this land bridge was replaced later on by an entirely different one. Professor Depéret $\dagger$ had some such idea in his mind in expressing the view that the Miocene and Pliocene migrations from Europe to America probably arrived by way of Asia and the Bering Strait, while the earlier

* Osborn, H. F., "Cenozoic Mammal Horizons," p. 76.

† Depéret, C., "Transformations of the Animal World," p. 314. 
ones came direct from Europe. Professor Suess,* on the other hand, favours a north Atlantic land connection in high latitudes between Greenland, Iceland and Scotland, and he thinks its origin dates back to the beginning of the Miocene period. Considering that there is such unanimity in favour of some kind of land bridge between the Old World and the New at this time, it is strange that Professor Schuchert should entirely isolate North America in his palaeogeographical maps from the Old World, not only in Miocene, but even in Pliocene times.

Although the Pliocene fuuna, according to Professor Osborn (p. 81), is as yet only imperfectly and sparsely known, being characterised by hosts of southern invaders which now flood the continent, a direct land bridge between North America and the Eurasiatic continent must likewise have existed, unless we assume that the mighty elephant Tetrabelodon (Dibelodon) which is represented by several species in the New World, reached North America by way of South America. Whether the still existing more hardy stock of Asiatic immigrants came to North America towards the end of Pliocene, as I argued in a previous chapter (p. 97), or during Pleistocene times, is a question which had not hitherto, I think, been seriously debated. That their presence in North America is due to a wide land bridge across Bering Strait (see Fig. 7) seems to me evident.

In this very brief survey of the past faunas of North America I have endeavoured to show that an important centre of evolution and dispersal existed in western North America in the past, just as it exists to a lesser degree at the present day. The strong faunistic affinity between western North America and western Europe, which we can still trace at this moment among many of the invertebrates and lower vertebrates of the two areas, seems to be the outcome of an ancient direct geographical communion between these land-masses. Certain features in mammalian palaeontology appear to strengthen my views, which are primarily based on a study of the modern fauna. In the succeeding chapters I shall bring forward further evidence showing that North America

* Suess, E., "Antlitz der Erde," Vol. III.2, p. 765.

† Schuchert, C., "Paleogeography," Pl. 98-100. 
and Europe were joined in the south, while northern Asia was in all likelihood disconnected from the former. The principal point which I think has been clearly demonstrated is that the south-western centre of dispersal has exerted a powerful influence on the development of the living fauna of North. America. There still remains one other feature that I wish to allude to before concluding this chapter.

I have mentioned above that, while eastern Mexico was either wholly or partially submerged by the sea during later Mesozoic and early Tertiary times, most of western Mexico and a portion of the Californian coast remained dry land, as far as we know, all through geological history. It ought on that account to be a preservation ground for all kinds of relicts of bygone ages. And so it is. I have cited a number of them already, although the country can scarcely be considered as being exhaustively explored. The fresh-water fishes more than any other group show what zoological riches may still be discovered there. The Lerma river system, for example, in south-western Mexico has a fish fauna, according to Dr. Meek, * which is quite as distinct and characteristic as if it were on an island in the sea. Of the forty-nine species of fishes now known to occur in this area, not a single one is found elsewhere. These forty-nine species belong to seventeen genera, ten of them being quite peculiar to this region. This result is all the more surprising, as it has often been argued, by advocates of accidental introduction, that the eggs of fishes are apt to adhere to the legs or feathers of water birds, being thus easily transported to other river systems or isolated lakes. The extremely distinct and isolated character of the Lerma river area implies that dispersal of fishes is not affected by such agencies of accidental transport. Fishes only migrate from one river to another when a change of drainage occurs in the head waters, or when the stream itself shifts its course.

* Meek, S. E., "Fishes of Mexico," pp. 775-784." 


\section{CHAPTER X}

\section{THE FAUNA OF CENTRAL AMERICA}

THE problems presented by a study of the fauna of Central America are of the utmost significance in our investigations into the origin of the American fauna as a whole. Even the casual observer cannot fail to perceive that certain animals from each of the two great continents lying to the north and south of Central America, tend to spread along the narrow isthmus, and thus intermingle with one another. When we look at Dr. Wallace's map of what he calls the "Neotropical Region," and notice how the South American fauna has apparently invaded the whole of Central America, and even crept northward along the lowlands of Mexico, so that the triangular table-land of that country, with its northern inhabitants, looks as if it had been forced like a wedge between the two wings of the southern army of invaders, the whole history of events seems to be clearly unfolded before our eyes. Apparently, quite a simple zoogeographical problem, and one that is easily soluble by a study of the distribution of existing animals. Thus it seemed to Dr. Wallace. Of the geology of Central America nothing was known when he wrote his famous work on the distribution of animals. Nevertheless, he argues (pp. 10-13), from the sudden appearance in postTertiary times of numerous South American forms of edentates in temperate North America, and from such facts as the occurrence of some identical species of sea fish on the two sides of the Central American isthmus, that the union of North and South America must be a comparatively recent event, and that these continents must have been separated during Miocene and Pliocene times by a wide arm of the sea. When the evidence of both land and sea animals support each other as they do here, adds Dr. Wallace, ${ }^{*}$ the conclusions

* Wallace, A. R., "Distribution of Animals," Vol. II., pp. 57-59. 
arrived at are almost as sure as if we had geological proof of these successive subsidences. The author of the "Geographical Distribution of Animals" thus not only claims that zoogeography is of great value as an interpreter of geological phenomena, but he feels confident of having indicated the correct solution to the problem of the faunistic relationship between the two continents. There are one or two points, however, in the fauna of South and Central America, which seem to throw doubt on Dr. Wallace's interpretation of the facts of distribution. He states (p. 58) that when the final union of the two continents took place, the tropical climate of the lower portion of Guatemala and Mexico would have invited rapid immigration from the south, while some northern forms would have extended their range into and beyond the newly elevated territory. That the fauna of South America has advanced across the isthmus, and has even invaded the State of Texas, appears probable from a study of the existing fauna. We need not even cite the presence of the South American fossils in North America in favour of this view. All sections, indeed, of the fauna seem to have taken part in this northward advance, even the fishes.

Take for example the members of the family Cichlidae. Over one hundred and fifty species of this strictly freshwater group are known from America, the great majority being confined to South America. Mr. Regan * is of opinion that the Central American and Mexican species are more specialized than the South American ones, and that the former have certainly been derived from the latter. No member of this family of fishes is known from the Mexican plateau, and only three or four species extend northward on either side of it, North America being almost devoid of Cichlidae (see Fig. 12). All the available evidence thus points to South America as the place of origin of the family, as far as the New World is concerned; and thence it has spread northward, like hosts of other groups of animals. This advance must, of course, have taken place as soon as a connected land passage with suitable lakes and rivers enabled them to proceed northward. Dr. Wallace thinks that the sudden appearance of the large South American edentates

* Regan, C. Tate, "Fishes of Central America," pp. xiii-xvi. 


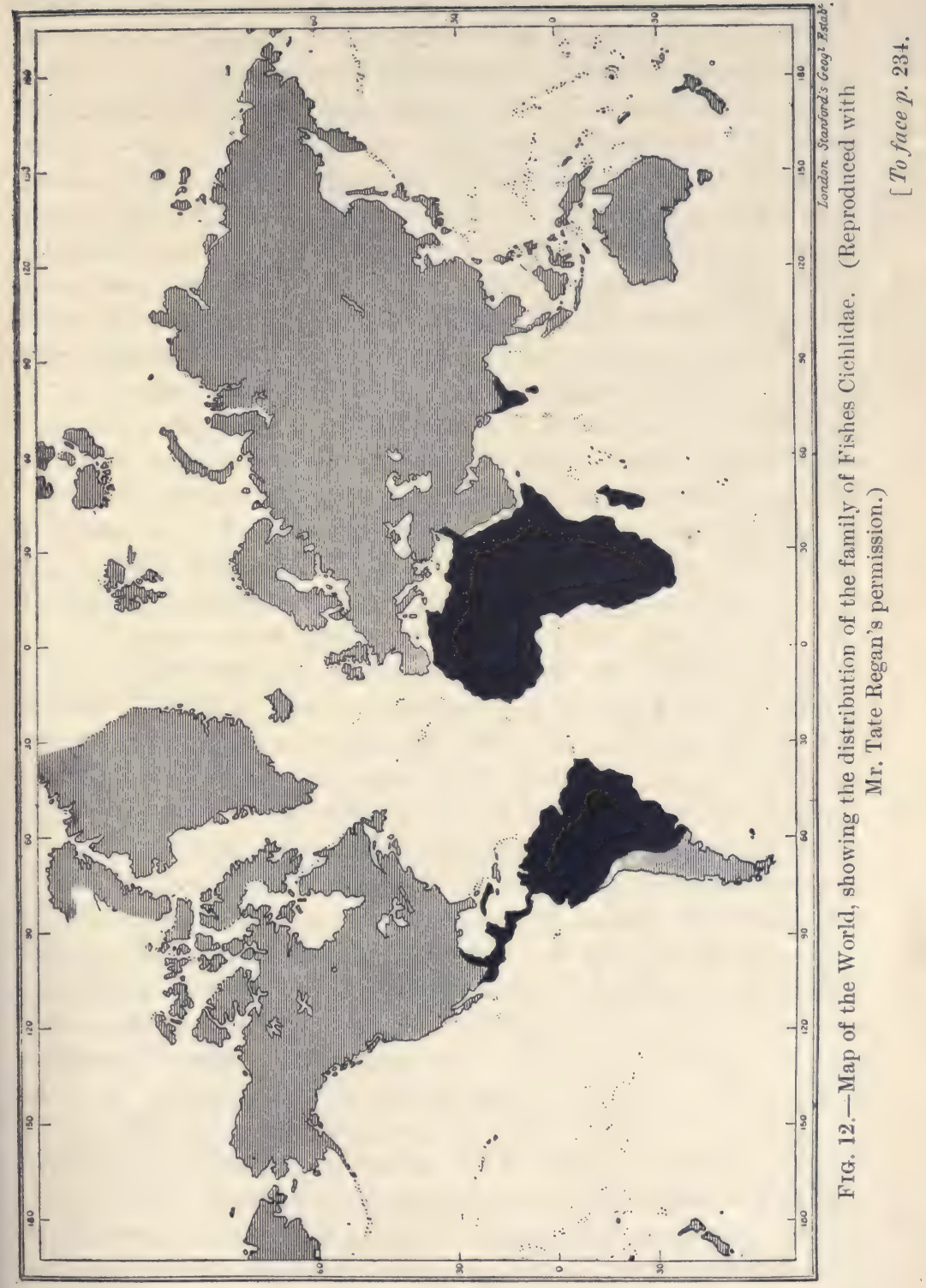



in North America occurred in post-Tertiary times, for he believes Central America to have been still submerged during the Pliocene Period. The term "post-Tertiary," I may mention, is synonymous with Quaternary or post-Pliocene. Any geological deposits more recent than Pliocene come within the meaning of that term. But the skeletons of the great South American Mylodon and Megalonyx certainly occur in Texas in true Pliocene beds. I do not think there is any geologist in America now who would uphold the Pleistocene, or even less the post-Glacial age of these deposits. My contention, therefore, is that the northward advance from South America is a pre-Glacial or pre-Pleistocene event.

Now one of the most remarkable and astonishing features of that faunistically so peculiar continent of South America is that, whereas its tropical fauna has very little affinity with the fauna of North America, the more remotely placed Chilean and Patagonian faunas present in some groups of animals a striking resemblance to it. This character will be more fully dealt with in another chapter (pp. 410-419). It may be mentioned, however, that numerous groups, and even species, of northern plants are met with in Chile, which are wholly, or almost entirely, absent in the intervening region, occupying an area of thousands of miles. Northern genera of butterflies and beetles, such as Argynnis, Colias and Carabus, all of which are almost unknown in the countries immediately south of Mexico, reappear in numbers in the extreme southern tip of South America. Dr. Wallace thought that this southward migration of northern forms of animal life must have been effected mainly during successive Glacial epochs, when the mountain-range of the isthmus of Panama, if moderately increased in height, might have become adapted for the passage of northern forms, while storms might often have carried insects from peak to peak, over intervening forest lowlands, or narrow straits of sea. Dr. Wallace's idea that the mountains all along Central America were formerly higher than they are now and sustained northern forms of animal life is not supported by any evidence. Considering that he imagined the long isthmus to have been slowly rising from the sea since pre-Glacial times, Dr. Wallace's suggestion that the mountains were so much higher during the Glacial Epoch 
than they are now, hardly seems well founded. Another still stronger objection to Dr. Wallace's * theory is that the northern forms alluded to as occurring in Chile and Patagonia belong almost all to different species, sometimes even to different genera, from their northern relations. If storms had anything to do with this distribution they could only have acted during very long intervals of time so as to produce such specific and generic differences. Moreover, how could winds or storms affect the distribution of Carabus, which is a flightless ground insect living under stones? How could these agencies have transported fresh-water species across the immense tropical area, for several Chilean fresh-water forms exhibit a similar northern affinity? These are some of the problems that present themselves to us. There are numbers of others. Why should the family of tortoises, Dermatemydidae, which is known to have inhabited the North American continent since Cretaceous times, have become extinct there and be now confined to Central America ?

The scarcity of land and fresh-water fossils in Central America obliges us to resort to zoogeography and to the meagre geological information we possess in elucidating these and other problems. Before dealing with the general faunistic features of Central America, a few remarks on some of the more important geological characters will be of interest.

The long neck of Central America from the isthmus of Tehuantepec to Panama, which joins North and South America to one another, has a length of about one thousand five hundred miles. We are sometimes apt to forget that it does not lie in ai north and south direction, but almost east and west. Nearer South America the neck of land starts in a due westerly direction and only gradually turns somewhat towards the north and finally north-westward. Very little of this immense stretch of land has as yet been geologically surveyed. Nevertheless, some valuable hinits as to its geological history have been gathered. In his essay on the geology of the isthmus of Panama, Professor Hill † tells us that, possibly before the vast accumulations of more modern igneous and sedimentary rocks of Tertiary and post-Tertiary age were

* Wallace, A. R., " Distribution of Animals," Vol. II., p. 45.

† Hill, R. T., "Geological History of Panama," pp. 241-257. 
laid down, a foundation of granitic rocks, occurring in an east and west arrangement, existed on the site of Central America. Apparently parallel granitoid ridges extended from the longitude of Trinidad directly across the path of the main continental trends through forty degrees, as far north as Acapulco in Mexico. These fragmentary data, he says, are sufficient to indicate that in pre-Tertiary times there may have been a basement barrier of granitic rocks forming an east and west arrangement which outlined the Central American region, and constituted an ancient buttress against or upon which the higher mountain folding has originated. Professor Suess,* too, speaks of the mountain chains of Yucatan and Guatemala as the western continuations of the Antillean system, contending that North and South America are to be looked upon as two radically distinct continents, separated from one another by a third element, that of Central America and the Antilles. All this agrees to some extent, as we shall see later on, with the conclusions we can draw from a study of zoogeography. Central America and the Antilles, which are collectively spoken of sometimes as the remnants of an ancient "Antillean Continent," possess a distinct and peculiar fauna quite apart from the South American one which has invaded this area.

Towards the end of the Mesozoic Era parts of this Antillean continent must have begun to subside. About that time signs of the coming volcanic activity appeared all along the Central American region. During the successive igneous eruptions in early Tertiary times, which have been continued with varied intensity to the present day, the Atlantic Ocean seems to have invaded the existing area of Central America and submerged portions of it. At any rate, Professor Hill $\dagger$ states that biological and geological evidence led him to the conclusion that a shallow marine transgression must have existed somewhere in Central America during Eocene times, although there is nothing to show with certainty that the isthmus of Panama was the exact site of this inter-oceanic connection. All the same, Professor Schuchert $\ddagger$ seems to be

* Suess, E., “ Antlitz der Erde,” Vol. I., p. 700.

† Hill, R. T., "Geological History of Panama," p. 265.

† Schuchert, C., "Paleogeography of North America," pp. 96-97. 
satisfied that the isthmus of Panama was submerged during the Eocene Period, and that the submerged area of Central America greatly increased in Oligocence times. Professor Hill, who has dealt with various lines of enquiry in regard to the geological history of Central America, contends that they all give evidence for the belief that no connection has existed between the Pacific and Atlantic Oceans since the close of the Oligocene (p. 270). A very careful re-examination of the fossils of Gatun, near the Panama Canal, by Professor Toula, however, throws considerable doubt on the supposed Eocene age of the deposits containing these fossils. He gives reason for his belief that they are of upper Miocene, possibly even of lower Pliocene age, and estimates the depth of water of the marine channel uniting the two oceans at about a hundred and fifty feet.*

In conjunction with Dr. Böse, the same author also investigated the Tertiary deposits of the isthmus of Tehuantepeo in southern Mexico with very noteworthy results. The fossil mollusks contained in them indicate that the sea covered the land to a depth of from fifty to two hundred fathoms, that is to say from three hundred to one thousand two hundred feet. As the isthmus does not rise much beyond eight hundred feet, the existing land, even as far north as this region, was submenged by a shallow sea. Dr. Böse is inclined to attribute to this fauna an early Miocene age, while Professor Toula believes it to be younger, in fact distinctly " jungtertiär." $\dagger$

Now it has been argued, and the argument appears most reasonable, that we are able to check these results indicating a submergence of parts of Central America by means of two other tests, viz., the distribution of living animals and the palaeontology of North America. The first deals mainly with the amount of affinity existing between the marine animals of the Atlantic and Pacific sides of Central America. From the nearness or remoteness in relationship of the species on the two opposite coasts it was thought we might determine at what particular geological period, if at any, the Atlantic and the Pacific Oceans were joined to one another across Central

* Toula, F., “Jungtertiäre Fauna von Gatun,” pp. 744-745.

†Böse, E., and F. Toula, "Eauna von Tehuantepec," pp. 221 and 273. 
America. The second test is that of the fossil mammals of North America. It was pointed out that, as no trace of typically South American species occur in North American Oligocene or Miocene deposits, the two continents must have been separated by a sea during the period in which these beds were laid down. Let us examine these evidences more closely.

A good many writers have discussed the problem of the former junction of the Pacific and Atlantic Oceans across Central America, from a purely biological point of view. Professor Gregory, ${ }^{*}$ who last summarised the subject, came to the conclusion that the waterway across Central America was finally closed in the Lower Miocene, or possibly even in the Upper Oligocene. Among others he alluded to the researches of the two Agassiz, father and son, stating that, from a study of the sea-urchins, they proposed to date the junction of the two oceans much further back. These zoologists referred the separation of the two oceans and the formation of the Gulf Stream, to the period at the close of the Cretaceous, that is to say, to the end of the Secondary Era. Professor Verrill $\dagger$ finds that no species of corals are identioal on the two sides of Central America, while even the genera and families show remarkable contrasts. The numerous genera and families of reef-building corals, so abundant on the Atlantic side, are wholly wanting on the Pacific, with the exception of Porites, which is represented by three or four small species.

Mr. Belt $\ddagger$ maintained that the marine mollusks on the two coasts separated by the narrow isthmus of Darien were almost entirely distinct. So remarkably distinct are the two faunas, he says, that most zoologists consider that there has been no communication in the tropics between the Pacific and Atlantic Oceans since the close of the Miocene Period. An apparently rather remote junction of the two oceans is suggested by all these authors, but none of them express any very strong convictions on the subject. Dr. Ortmann, on the other hand, states that the affinities of the Decapod fauna of the Atlantic and Pacific are unmistakable, and that we have ample and convincing evidence of a former connection between these oceans.

* Gregory, J. W., "Palaeontology of the West Indies," pp. 304-305.

† Verrill, A. E., "Comparison of Coral Faunae," p. 500.

$\ddagger$ Belt, Th., "Naturalist in Nicaragua," p. 264. 
Seven species of crabs and their allies are identical to the two oceans, while many others are closely related. The fauna as a whole implies that the union of the seas cannot have been of a very recent date. Accordingly Dr. Ortmann * is of opinion that there was no communication since Miocene times.

In 1880 Dr. Günther $\dagger$ declared that the genera of fishes, with scarcely any exception, are identical on the two sides of Central America. Of the species found on the Pacific side, nearly one half, he states, have proved to be the same as those of the Atlantic, and he upholds the view of the existence of straits and channels between the two seas until a geologically recent period. Since Dr. Günther expressed these views, the fish fauna of this region has received renewed attention and study, over a thousand species now being known from the coasts of the two seas. Of this large number only seventyone species, or six per cent., are common to the two oceans, according to the latest researches of Professor Jordan. This great discrepancy between Dr. Günther's and Professor Jordan's results arises, of course, to a large extent from the different views these observers hold as to specific limits. To account for the remarkable identity of genera and the divergence of species, Professor Jordan $\ddagger$ suggests that the isthmus of Panama was depressed in or before Miocene times, that the channel was shallow, and that the currents set chiefly westward, thus favouring the transfer of Atlantic rather than Pacific types. In the case of the Medusae, the affinity between the littoral faunas of the two sides of Central America is much closer according to Dr. Bigelow $\S$ than in the higher groups.

It has been suggested by Messrs. Gill and Bransford || that the occurrence of marine fishes in the great lake of Nicaragua is to be looked upon as an indication that the sea once flooded the area now occupied by these lakes. That these fishes are true "relicts" of the past, representing the survivors of a marine fauna, has recently been reaffirmed by Dr. Meek.

* Ortmann, A. E., “Distribution of Decapods,” p. 398.

† Günther, A., "Study of Fishes," p. 280.

† Jordan, D. S., "Study of Fishes," Vol. I., pp. 272-280.

§ Bigelow, H. B., "Medusae," p. 228.

\| Gill, Th., and J. F. Bransford, "Fishes of Lake Nicaragua," p. 179.

T Meek, S. E., "Fishes of Nicaragua," p. 99. 
The species in question are, in the first instance, two sharks, viz., Carcharhinus nicaraguensis and Pristis antiquorum, as well as Pomadasis grandis and others whose ancestors are marine forms. The antiquity of the region is indicated by the occurrence both in Lake Nicaragua and Lake Managua of the Central American gar-pike (Lepidosteus tropicus).

The studies of geographical distribution, particularly those of marine species, have thus led to the conclusion that the Central American land bridge has been in existence certainly since pre-Glacial times. No zoologist has suggested even the possibility of a submergence of Central America having taken place as late as the Pleistocene Period. No biological support can be given, therefore, to the theory which has been advanced by some writers, that the Glacial Period was due to a diversion of the Gulf Stream across the isthmus of Panama. On the other hand, Central America was certainly submerged by a shallow sea in two or more places in early Pliocene or Miocene times. Another very important character, which is revealed both from a study of the recent and fossil marine fauna, is the Atlantic facies of the animals. The movement of the species seems to have taken place from the West Indian area towards the Pacific Ocean, thus implying the existence of a strong current in that direction. Speaking of the Tertiary deposits of Tehuantepec, Dr. Böse* remarks that the main mass of the species contained therein are related to Atlantic forms. Only very few show affinities with Pacific types. Similar views were expressed by Professor Jordan and Dr. Ortmann in regard to the recent marine fauna.

A further complication, as Professor Gregory $\dagger$ pointed out, remains to be considered. It is not at all certain, he thinks, that when the Isthmus of Panama was submerged there was free communication between the Atlantic and the Pacific Oceans. The Caribbean Sea, he argues, may then have been a gulf of the Pacific, separated from the Atlantic by the land area of the hypothetical "Antillia." As I shall show in the next chapter, which deals with the origin of the West Indian fauna, the Caribbean Sea could not have been'separated from the Atlantic Ocean at so late a geological period as that

* Böse, E., and F. Toula, “Fauna von Tehuantepec," p. 220.

+ Gregory, J. W., Palaeontology of the West Indies," p. 305.

L.A. 
during which the sea spread across Central America. The general opinion seems to be that the submergence-of Central America was due to extensive subsidence in the Caribbean area and likewise in the Gulf of Mexico. The Mediterranean character of the West Indian marine fauna, moreover, implies the probability of a free migration from the one area to the other along some ancient shore-line. 'A land bridge joining North and South America along the chain of the Lesser Antilles, alluded to by Profiessor Gregory, may possibly have existed; but it must, I think, already have been destroyed at the time of the submergence of the Isthmus of Panama. And yet I concur with Professor Gregory in thinking that when the latter was submerged there need not necessarily. have been free communication between the Atlantic and the Pacific Oceans. We must remember that all efforts have hitherto failed to discover any traces of Tertiary sediments on the sea-board between southern Mexico and Panama. This seems to imply that land lay to the west of Central America, and that the Pacific Ocean was formerly situated further westward than at present. What would appear as connections between the two oceans may have been merely shallow bays in the land referred to. Certain peninsulas would then have projected eastward from this old Pacific land towards those parts of Central America that were then in existence (see Fig. 16). Without giving further evidence, these theories may appear somewhat visionary, but as the subject will be more fully discussed later on (p. 408), I need not enlarge upon it at present.

A comparison of the marine faunas of the two shores of Central America does not yield such satisfactory results in establishing the geological age of the submergence, because we have as yet little idea of the length of time during 'which' animals may retain their specific characters. The evidence derived from the first appearance in North America of distinctly South American mammals would seem to give us a better clue as to the date of the formation of the present Central American land bridge.

This appeal to the past dispersals of mammals in reconstructing former conditions of land and water has been utilised in several of the previous chapters, and in this case many bio- 
logists have attested their strong belief in the validity of the argument. A very early Tertiary or late Mesozoic influx of mammals from South America into North America has already been alluded to. After this event long periods of time elapsed, during which the two continents were seemingly separated from ane another. Then southern mammals once more appeared in the north. This later invasion is proved from the contents of the deposits in Texas. Here we meet with gravigrade edentates, and these deposits have now been definitely placed by Professor Osborn* to the middle Pliocene. Hence Central America in its present form and shape would be of Pliocene origin. Although Mr. Lydekker $\dagger$ places this event at the end of the Miocene Period, Professor Depéret $\ddagger$ and Dr. Smith Woodward § concur in the opinion expressed by Professor Osborn which is in conformity with that elicited by Professor Toula. The latter bases his evidence on the fossils contained in the Panama and Tehuantepec deposits.

Since the testimony derived from the recent marine fauna also agrees fairly well with the above conclusions, it seems reasonable to conclude that Central America in its present outlines, forming a highway for intercommunication between North and South America, came into existence about the beginning of the Pliocene Period. Thus one of the problems alluded to at the beginning of the chapter is apparently solved.

Yet still another difficulty has suddenly arisen owing to the recent most surprising discovery of true edentate remains of Megalonyx type in the Mascall beds of Oregon, which are of Middle or Lower Miocene age.\| If the Gatun deposits near Panama are really, as Professor Toula affirms, of Upper Miocene age, how can we reconcile the submergence of Panama, and probably also of the isthmus of Tehuantepec, with this latest discovery in Oregon? The whole problem is evidently much more complex than it at first ap-

* Osborn, H. F., “Cenozoic Mammal Horizons,” p. 82.

† Lydekker, R., "History of Mammals," p. 119.

† Depéret, C., "Transformations of Animal World," p. 292.

\$ Woodward, A. Smith, "Palaeontology," p. 42y.

|| Osborn, H. F., "Age of Mammals," p. 289. 
peared. In the Oligocene deposits of the northern continent, as above mentioned, there are no distinctly South American species. Yet, curiously enough, when we come to still earlier strata, we again meet with remains of animals that exhibit characteristically South American features. In the Puerco formation, in north-western New Mexico, a number of peculiar mammalian bones have been discovered, which were referred by Professor Cope to the extinct order Tillodontia, whereas Dr. Wortman endeavoured to show that Cope's genera Psittacotherium, Onychodectes and Conoryctes were ancestral to the Gravigrada or ground sloths of South America. Dr. Wortman * proposed that they be placed in a new suborder of the edentates, which he named Ganodonta. But he did not look upon these animals as immigrants from South America. He thought this order of primitive mammals must have actually arisen in North America, and have thence emigrated to South America before the close of the Eocene Period. Although these Ganodonta are no longer considered as ancestral to the ground sloths, the same Puerco formation has yielded other mammals which show distinctly 'South American or rather Patagonian affinities. Dr. Wortman's theory as to the North American origin of the Ganodonta has not found favour. Dr. Osborn, in fact, urges that a direct land connection with South America is indicated at this stage of geological history in order to account for the South American features in the North American fauna. This view has been amply confirmed by the remarkable discovery in Wyoming, in a deposit of Middle Eocene age (Bridger), of the remains of a true armadillo closely related to the modern armadillos, but exhibiting a few more primitive characters. $\dagger$

Since Dr. Ameghino's researches in Patagonia have brought to light such a wealth of edentates from the earliest Tertiary, and probably even from Mesozoic deposits, scarcely anyone can doubt that South America is the original home of that group of mammals, and that they have passed from there during the Eocene Period and earlier into North America, and not vice versa, as Dr. Wortman suggested. But very few would assert that the physical geography of the

*Wortman, J. I., "Psittacotherium," pp. 259-262.

† Osborn, H. F., “An Armadillo from the Eocene," p. 163. 
New World was the same then as it is now, and that Central and South America had already been evolved in anything like the present outlines. As I shall endeavour to demonstrate later on, South America did not then exist as a distinct great continent. A large land-mass evidently lay in the neighbourhood of the existing State of Brazil and another further south. And as far as we know, the southern land-mass was the original home of the edentates. Between it and Central America on the site of the present South American continent there were one or more broad marine channels, or oceans, as we might call them. And yet the edentates succereded in attaining North America. I do not now wish to discuss my reasons for the supposition that western Mexico was then united by a direct land bridge with Chile. I only mention it in order to indicate that the appearance of edentates in the Eocene of North America does not afford a proof of the existence of Central America at that time, nor during the Miocene Period.

Professor Osborn, as I mentioned before, indicates the nature of the land connection between North and South America in the dawn of the Tertiary Era on a map which he kindly allowed me to copy (Fig. 21). However, he expresses the belief that already in early Eocene times, that is to say almost before the appearance of the above-mentioned armadillo in North America, the land bridge had ceased to exist. We are too apt, I think, to look upon South America as exclusively the home of edentates, forgetting that many other mammals may have originated there too. We may not all agree with Dr. Ameghino* in attaching the importance he does to that continent as a source of the Tertiary mammalia, but I believe we possess other evidences of a faunistic interchange between Chile and Patagonia on the one hand, and western North America on the other, during the ages that passed between the Lower Eocene and the Miocene.

In southern Africa we meet with a group of small blind subterranean creatures, the golden moles (Chrysochloridae) which are among the most primitive mammals in existence. They are quite confined at present to South Africa. But

" Ameghino, Fl. "South America, the Source of Mammalia." 
within recent years the remains of a small insectivore have heen met with in the early Tertiary Santa Cruz deposits of Patagonia. This mammal, according to Professor Scott,* is genetically related to the African golden moles. The South American Necrolestes, as it has been called, is certainly more primitive in structure than its African relations. Moreover, in western North America fossil mammals have been discovered both in Oligocene and Miocene strata which have been referred to the same family Chrysochloridae. It is true that Dr. Matthew $\dagger$ is now inclined to place the Oligocene Apternodus among the nearly related family Centetidae, but the two other genera Xenotherium and Arctoryctes are still looked upon as true chrysochlorids. A possible land connection between Africa and South America will be discussed later on. Whether Patagonia was the original home of the chrysochlorids or South Africa we cannot tell, but the family may possibly have spread from South America to North America by utilising the hypothetical land bridge that I think lay to the west of the present continent.

A few words of appreciation of the splendid work that has been done in making us acquainted with the rich fauna and flora of Central America are due to Mr. Godman. For years he and Mr. Salvin laboured with great industry and at considerable expense in bringing together an immense collection of vertebrates and invertebrates, subsequently publishing the series of beautifully illustrated volumes of the "Biologia Centrali-Americana" in which the results of their studies were made known to the scientific world. In the volume describing the botany of Mexico and Central America there is an excellent summary dealing with the constituents of the flora and their relationships. No such summary has been attempted in the other volumes, so that Mr. Hemsley's account of the plants of Mexico and Central America is of particular value to those who are engaged in a study of the zoogeography of that region.

The first item of interest is one which we have noticed occasionally among apparently very ancient groups of North American animals. Genera like the amphibians Spelerpes and Amblystoma, which have their headquarters in Mexico,

* Scott, W. B., "Report of Princeton Fxpedition," Vol. V.

† Matthew, W. D., "The Skull of Apternodus," p. 35. 
are either absent or very rare in the western United States of North America, while abundant in the eastern States. Some of these bear an impress of their antiquity in their wide and discontinuous range. Now Mr. Hemsley enumerates the following genera of trees as occurring in southern Mexico and in the Atlantic States of North America, though they are absent from the Pacific forests of the western United States: Magnolia, Asimina, Tilia, Robinia, Liquidambar, Ilex, Diospyros, Bumelia, Ulmus, Celtis, Morus, Ostrya, Carpinus and Carya. Even species of plants from southern Mexico and the Atlantic States of North America are sometimes identical, such as Liquidambar styraciflua, Ostrya virginica and Carpinus americana. And yet only four out of the fourteen genera referred to extend even to northern Mexico. Of some of these we possess fossil evidence that they lived in Europe already in early Tertiary times, and we may safely assume that the whole group is of great antiquity. The flora of Guatemala is essentially of the same composition, according to $\mathrm{Mr}$. Hemsley, as that of southern Mexico, though apparently less rich in specific diversity. Some of the trees just alluded to, such as limes (Tilia) and elms (Ulmus), are unknown in Guatemala; others, for instance sweet gums. (Liquidambar), mulberries (Morus), lever-wood (Ostrya) and hornbeams (Carpinus), occur in that country. The southern floral province of Mr. Hemsley comprises Nicaragua, Costa Rica and Panama; and, as might be expected, these countries exhibit a much closer relationship with the South American tropical flora than Guatemala or Mexico do. The endemic generic element of the whole of Mexico and Central America is rather inconspicuous, but the southern floral province is by far the poorest of the three into which the region has been divided. One of the most curious features in the constitution of the flora of Mexico is one which I have already briefly. referred to, namely, the presence there and in the extreme south of South America of certain northern genera of plants which are absent or only represented in a few scattered districts in the intermediate region. Mr. Hemsley assumes that such plants have spread southward in remote times. There are likewise genera of distinctly southern origin with a similarly discontinuous range in a northward direction. I need 
only mention Fuchsia, which is abundant in Chile and Patagonia, reappears more sparingly in Colombia, and is almost unknown further north until we come to Guatemala and Mexico. The extreme antiquity of this genus is indicated by its occurrence on the island of Haiti (F. triphylla), while it is altogether absent from the rest of the West Indian Islands.

In his analysis of the flora of the whole region, $\mathrm{Mr}$. Hemsley* informs us that the northern province, that is to say the plateau of Mexico, is the focus of a xerophilous flora extending into the dry regions of south Mexico and into the territories north of Mexico. The central province, comprising southern Mexico and Guatemala, possesses a mingling of northern and southern types exhibiting an extraordinarily rich production of local species. The southern province is merely an outlier of the American tropical flora. The tropical element of the whole flora is more closely allied to that of eastern South America than to that of the West Indies.

The relationship of the Mexican and Central American floras to those of other parts of the world is also of importance. Thus Mexico and Central America have a large number of genera in common with eastern Asia, with Africa, Madagascar and Europe. They likewise exhibit affinities with the Galapagos islands, with New Zealand, Australia and Polynesia.

Now, if we compare the results of the study of botany with those derived from an examination of the mammalian fauna, we are struck at once by the fact that the plants among which the mammals live must le of much greater antiquity than the latter. As Mr. Alston $†$ tells us, the mammals of Mexico and Central America are composed, partly of southern species not found southward of Mexico, of a few that extend as far south as Panama, and chiefly of South American ones which have spread across Central America. There are also a number of autochthonous species in this region. Yet very few of the genera are found in other parts of the world than America.

Among our new acquaintances we meet for the first time with the kinkajous, one species of which (Potos flavus) has succeeded in reaching the State of Vera Cruz in Mexico.

* Hemsley, W. B., "Botany of Central America," pp. 306-315.

$\dagger$ Alston, E. R., "Mammals of Central America." 
From my previous remarks (p. 152) it would appear as if the raccoon family (Procyonidae) had originated in some western land in America, and yet the genus Cercoleptes (Potos), which belongs to this family, is certainly an invader from the south. Indeed, when we examine the range of the members of this typically American family of Procyonidae, we notice the peculiar feature that almost all the species are confined to the Pacific coast. The raccoon (Procyon lotor) no doubt has extended its range to the eastern States, while the allied species Procyon maynardi, as we have learnt, is even confined to the Bahama islands, and one, the coati (Nasua rufa), has a wide distribution in South America from Bolivia eastward. Almost all the other members of the family, however, inhabit curiously disconnected areas in the vicinity of the Pacific Ocean. Bassaricyon lives in Ecuador, Panama and Costa Rica. One species of Bassariscus is peculiar to the island of Espiritu-Santo near lower California, another ranges from Mexico to the western States, a third occurs in western Mexico, Guatemala, Costa Rica and on Mount Chiriqui, in western Panama, at a height of 6,000 feet. Of the coatis (Nasua), one species passes from Mexico northward to California and southward to Costa Rica, another is confined to the island of Cozumel, a third lives in the Ecuador mountains at a height of 7,000 feet, whereas Nasua olivacea is met with in Santa Fé de Bogota and in the Merida of Venezuela at heights up to 12,000 feet. Altogether it looks as if the members of the family Procyonidae had spread from various western foci. Some of them may have retained their original distribution, while the more adaptable genera sent outposts eastward into the great continents. The early stages of this evolution must have taken place before either Central America or South America had become consolidated into anything like their present shapes. Later on I shall have occasion to discuss other similar cases of discontinuous distribution occurring among the lower vertebrates. All of these appear to be due to the same peculiar features in the physical geography of Tertiary America.

In eastern Mexico we make our first acquaintance with monkeys. In early Eocene times, as already mentioned, monkeys, belonging to extinct groups, probably entered the 
United States from the south. They seem to have had a short existence in North America, for no trace of them has been noticed in later deposits. Ever since renewed facilities for a northward advance occurred an entirely new invasion has taken place, and one of the "howlers" can now be heard at night even in the forests of Vera Cruz in eastern Mexico. A spider monkey (Ateles vellerosus) may be seen in the same district gracefully swinging from branch to branch. These monkeys differ in distribution from the raccoon family in so far as they have their centre of distribution in Brazil and northern South America, from which they no doubt invaded Central America in more recent geological times. There are other families of mammals which we meet here for the first time. We need not dwell on them any longer, as we shall have occasion to become acquainted with them in subsequent chapters.

The wealth of new bird life in Central America is very striking, and is vividly described in Mr. Belt's * delightful book of travels in Nicaragua. Among the more noteworthy families are the toucans (Rhamphastidae), with their enormous gaily-coloured bills, the humming-birds (Trochilidae), a great variety of parrots, the peculiar curassows and many others. Some of these of course, like the humming-birds, enter the United States largely during their northward migrations, and to some extent are resident in the southern States. I should also mention the most beautiful of all birds, the quesal (Trogon resplendens), or royal bird of the Aztecs as it has been called, with its delicately tinted plumage of metallic green and blue, and its long waving plumes. The Trogonidae now have their headquarters in Central and South America, but Trogon gallicus occurs in France in Miocene deposits; and this seems to suggest in what manner the early members of the family crossed over to Africa and the Oriental Region, where some genera are still found living; the discontinuous range corroborating the palaeontological evidence of the great antiquity of the group. As Messrs. Salvin and Godman $†$ remind us, the avifauna of Central America is essentially

* Belt, J., "Naturalist in Nicaragua."

+ Salvin, O., and F. D. Godman, "Birds of Mexico and Central America," . 
neotropical, with certain peculiar endemic forms, the greater number among the latter being confined to Mexico and Guatemala.

I alluded above to the fact that the family of tortoises, Dermatemydidae, is entirely confined to Central America. The only species of the family (Dermatemys mawi) inhabits precisely that part of Central America which we have reason to believe to be one of its oldest parts, viz., Guatemala and the neighbouring Honduras and Yucatan. Several members of the family formerly lived in North America. They first appeared in Cretaceous times, and still inhabited the southwestern States during the Eocene Period. It is possible they may then have spread to Guatemala, becoming subsequently extinct in their centre of dispersal.* Another family which I mentioned before (p. 134), the "snapping turtles " (Chelidridae), occur in eastern North America from Mexico to Canada. Southward of their range they are found only in Guatemala and Ecuador. We have noted examples of a similar discontinuous range before. Others will be cited in the next chapter.

More important from a faunistic point of view are such creatures, as for instance the snake-like limbless amphibians, belonging to the family Coeciliidae. They live in moist ground, and lead altogether a burrowing life. Their distribution ought to give us, therefore, some valuable hints as to former changes of land and water. Dr. Sarasin † looks upon this family as a pre-Cretaceous relict, on account of its peculiar discontinuous range, namely India, the Seychelles, east Africa, west Africa, South and Central America. Whether we agree with him or with Dr. Alcock, $\ddagger$ who believes that the family wandered along a continuous land surface from India across Africa to northern South America in early Tertiary times, there can be no doubt at all as to these subterranean amphibians being exceedingly ancient. The American home of this circumtropical family, as Dr. Gadow § points out, is South America. No members are known from the West Indies or the Galapagos

* Hay, O. P., "On Fossil Turtles,” p. 32.

† Sarasin, F., "Geschichte d. Tierwelt von Ceylon," pp. 74-76.

$\ddagger$ Alcock, A., "Description of Apodous Amphibian," p. 270.

$\S$ Gadow, H., “Distribution of Mexican Amphibians," pp. 199-200. 
islands. Dr. Gadow next proceeds to argue that because one of these coecilians inhabits eastern Mexico, its ancestors must have travelled slowly across the whole neck of Central America since the close of the Miocene Epoch, when he assumes the isthmus to have been first opened up for southern immigrants. This argument is in so far faulty, as the coecilians need not necessarily have passed through Central America. The intimate relationship that exists among many ancient species of Central America to those of northern South America suggests the existence of some far older link between these countries. In very remote times species were, I believe, able to reach certain areas such as Guatemala and western Mexico long before the present Central America had come into existence, that is to say long before Pliocene times. Dr. Gadow himself urged that the Isthmus of Panama is but the last vestige of a former much broader land connection between North and South America (p. 243). In my opinion this should read " the Isthmus of Panama contains some vestiges of a former much broader land connection."

To the uninitiated the Typhlopidae would seem nearly related to the coecilians. Both are snake-like burrowing creatures, and yet the former are true snakes and, therefore, reptiles, while the others are merely limbless amphibians. On close examination the true burrowing-snakes (Typhlopidae) are found to be covered with minute cycloid scales, and to exhibit other reptilian characters. Their distribution is extremely discontinuous and extensive, and they are largely confined to solitary islands. That they possess no special facilities for accidental dispersal across the ocean is evident, and yet it is held by some zoologists that their presence on islands, such as Christmas island for instance, can only be due to such a cause. At any rate, the family exhibits all the signs of antiquity, and, in the absence of any positive evidence of accidentally distributed species, I am firmly convinced that they spread by the usual method of slow migration on land. Dr. Sarasin* places the dispersal of the family into preCretaceous times, in spite of the fact that we possess no palaeontological evidence of their antiquity. All the same he

* Sarasin, F., "Tierwelt von Ceylon," p. 75. 
is perfectly justified in doing so, because it can be shown from various other tests that the great continents must have been united by certain land connections, and that the present distribution of the Typhlopidae can be readily explained if we assume that their dispersal took place at the same time. The presence of Typhlops tenuis in Guatemala and Mexico, on that account, points to an ancient union between these countries and to a survival in them of a relict fauna during a long course of geological ages, in which the two countries may have been separated.

I suggested above (p. 131) that the rattlesnakes, belonging to the genus Crotalus, were of early Tertiary origin. The centre of dispersal lies in the south-western States of North America, all the species except one being confined to that continent. The black-tailed rattlesnake (Crotalus terrificus) is the only one which, according to Mr. Boulenger,* ranges frnm south-western North America to South America. Whether the South American species is identical with the North American one is a matter in which authorities disagree. All concur, however, in the view that the genus Crotalus reappears in South America in one or more forms, differing but slightly from those inhabiting Mexico. And these South American forms are not, as we might expect, confined to the west coast, but have even penetrated to eastern Brazil, if Mr. Boulenger's records are reliable. At the same time it seems as if their range in South America was very discontinuous.

The fresh-water fish fauna of Central America is described by Professor Eigenmann $\dagger$ as poor, the genera south of the Isthmus of Tehuantepec being practically all South American. The North American fauna is entirely distinet from that of tropical America, the former not having contributed a single element to the fresh-water fish fauna of South America. It is interesting to compare this view with those founded on other fresh-water groups such as the mollusks and crustaceans.

* Boulenger, G. A., "Catalogue of Snakes," Vol. III., p. 573.

$\dagger$ Eigenmann, C. H., "Freshwater Fishes of South America," pp. 521 -522 . 
I suggested above (p. 161) that the fresh-water mussels (Unionidae) probably effected their principal dispersal during the Mesozoic Era, and that this circumstance might account for the fact that we possess distinct proofs of a migration of species from North to South America. The great genus Unio has recently been subdivided by Dr. Simpson into numerous genera. One group of Unio (Plagiola), ranging from Mexico to the Mississippi drainage basin, reappears southward in Nicaragua, another (Lampsilis) is known from Guatemala to Yucatan. Other groups of Unio are confined to South America. Unio-Tetraplodon occurs in Ecuador, having spread from there into the Amazon valley. Unio-Castalina lives in southern Brazil, Unio-Castaliella in Surinam and so forth. Finally Unio-Diplodon principally inhabits Chile, Argentina and Patagonia, while it reappears right across the Pacific. in New Zealand and Australia.

The range of these groups of Unio is apparently very complex in South America. Nevertheless, I quite concur with Dr. Simpson * in the belief that they all are the descendants of certain members of the family Unionidae, which wandered slowly from one river system into another, during the Triassic or some later Mesozoic Period, from North America to South America. To judge from the general distribution of the Unionidae in South America, they entered that continent from the west and only reached the eastern States subsequently. The group Unio-Hyria, as Dr. von Ihering $\dagger$ tells us, is nothing but a modified Unio, which has comparatively recently penetrated from Guiana into Brazil. The most surprising fact which is so strongly brought out in that author's remarkable researches is, that, while these Unionidae live in company with other families of fresh-water mussels in eastern South America, in Central America, Ecuador, Peru and Chile, that is to say westward of the Andes, Unios alone occur. This confirms the opinion I expressed several times in previous chapters, that the faunistic interchange between North and South America took place between the western portions of the two continents.

* Simpson, C. J., "Synopsis of the Najades," p. 507.

† Thering, H. von, "Archhelenis und Archinotis," p. 122. 
The fresh-water crabs (Potamonidae) must have invaded Central America from the south. The family is confined to southern Asia, southern Europe, Africa, South and Central America. Except for a few species in Mexico, fresh-water crabs are entirely absent from North America, nor do we possess any evidence of their ever having lived there.* A comparison with the range of Unio is, therefore, of particular interest. The two South American groups of fresh-water crabs apparently spread westward from eastern South America, that is to say in a direction opposed to that taken by the Unios. We need only consider the northern group which, to judge from its range, is much the oldest. Dr. Ortmann $\uparrow$ distinguishes the three genera Kingsleya, Epilobocera and Pseudothelphusa. Kingsleya only occurs in Guiana, while Epilobocera is peculiar to the Greater Antilles. The third genus, Pseudothelphusa, ranges from the Amazon through Guiana, Venezuela and Colombia northward as far as Mexico, and south-westward to Ecuador, Peru and Bolivia. There are quite a number of endemic species of fresh-water crabs in Central America. Yet are we to conclude from this fact that a slow migration took place across the long isthmus since Pliocene times? On the contrary, if, as Dr. Ortmann suggests, the genus Epilobocera arose in the West Indies from some ancestral Central American Pseudothelphusa, that event must have happened in much more remote times. It is customary to assume that the great mass of the South American fauna, including mammals, birds, reptiles, fishes and invertebrates all surged across the newly opened highway towards Mexico in the Pliocene Period. If Epilobocera succeeded subsequently in crossing from Central America on a land bridge to Cuba, Haiti and Portorico, how can we account for the fact that the existing faunas of Central America and the Greater Antilles do not show more affinity. to one another than they actually do? As compared with Central America the mammalian fauna of the West Indies is strikingly distinct and poor in species. We have also to take into consideration that certain species of Pseudothelphusa

* Rathbun, Mary J., "Freshwater Crabs of America." 309.

† Ortmann, A. E., "Distribution of Freshwater Decapods," pp. 306- 
possess a remarkably discontinuous range. Pseudothelphusa colombiana inhabits the United States of Colombia. In the extreme western end of Panama, in the Chiriqui region, it occurs at a height of 4,000 feet, and a thousand miles north of this locality it is met with in Mexico. All along the great isthmus, on the other hand, there are isolated localities in which distinct species are found. Both the ranges of Unio and Pseudothelphusa in Central America seem to me more in agreement with the theory of the existence to the west of Central America of an ancient continuous land surface uniting Colombia and certain parts only of Central America, while the rest of the latter was still largely submerged.

One of the chief zoogeographical features in the range of the land and fresh-water mollusks of Central America consists in the intermingling of South and North American forms within the limits of this area, rather than in the endemic species, and in the relationship of the molluscan fauna to that of the West Indies.* The affinity of the Antilles with South America, however, is much more pronounced than with North America, if we exclude Mexico. The distinctly endemic elements of Central America and the West Indian islands appear to have invaded both North and South America to some extent. The family Helicinidae for instance, as I mentioned (p. 157), is probably of semi-tropical origin, its range indicating that it has reached America from the west, establishing itself primarily in Central America and the West Indies at a very remote time of geological history. The operculate land mollusks, to which the Helicinidae belong, are of great faunistic interest. Let us take for example the large family Cyclophoridae, which has its headquarters in southern Asia and southern Europe. In America the family is almost limited to Central and South America and the West Indian islands. Only in Mexico does it touch North American territory. As the geographical distribution of the family is now fairly well known, a great deal of interesting information can be derived from its study. The genus Cyrtotoma is peculiar to southern Mexico. Its nearest relations are Buckleyia of Colombia and Ecuador, and Crocidopoma of Haiti, Cuba and Jamaica. The

* Martens, L. von, "Mollusks of Central America," p. xiv. 
larger genus Amphicyclotus has its centre of dispersal in Colombia and Ecuador. From there it pressed eastward through Venezuela into Guiana and across Trinidad to the island of Martinique, which must have been connected for some time with the southern mainland. In Central America the genus has a discontinuous range. A few species occur in Costa Rica, Guatemala and southern Mexico. Not a single species is known from the Greater Antilles.

There is one very important feature in the fauna of Central America which I have scarcely dwelt on as yet, and that is its affinity with Europe. It is not at all striking. Yet it does exist. The large group Diplommatininae belonging to the family Cyclophoridae is almost entirely confined to southern Asia, the Pacific islands and Australia.* Only the single genus Adelopoma occurs in America. Its wide and extremely discontinuous range in the New World marks it as a very. ancient immigrant, for it is likewise known from Argentina, Peru, Guatemala and Trinidad. Now the Guatemalan species (Adelopoma stolli) has its nearest relation in the Miocene beds of Oppeln in Silesia, for Professor Andrea $\dagger$ informs us that the fossil Adelopoma martensi occurring in these deposits is scarcely distinguishable from a species inhabiting Central America. Our first impulse on hearing of this extraordinary discovery is to attribute it to convergence or even misidentification. But the identification has been confirmed by Professor Boettger, one of the most eminent of European specialists, while Adelopoma stolli is not by any means the only Central American land mollusk that possesses European affinities. Many other instances will be alluded to in the next chapter (p. 265). Those who wish to interpret all cases of intimate relationship between American and European forms, as arising from a remote migration across a hypothetical Bering Strait land bridge, will find it difficult to reconcile this particular occurrence with the fact that no Adelopomae inhabit any part of Asia or North America.

Professor Stoll, $\ddagger$ who made a special study of the mites of

* Kobelt, W., "Cyclophoridae."

† Andreae, A., " Binneneonchylienfauna von Oppeln," II., p. 23.

† Stoll, O., "Zoogeographie d. Wirbellosen," pp. 19-20.

L.A. 
Guatemala during a residence there of several years, states that the mite-fauna of Central America is composed of the same genera as that of middle Europe. In some cases even the species are identical. It is true that most of these genera also inhabit Asia, though Linopodes, Haplophora, Nicoletiella and Uropoda have not yet been recorded from that continent. As some of these are known from the Oligocene Baltic amber deposits, it is probable that the genera date back to at least early Tertiary times.

Of the nearly related spiders and harvestmen, Mr. PickardCambridge * remarks, that while the majority of the Central American species are peculiar to the Nearctic and Neotropical regions, the genera are in many cases identical with those of the Mediterranean region, India, Australia or Africa. There are not now in existence any land connections, he concludes, which an arachnidal fauna could take advantage of in order to pass from Africa, Australia or Europe to North or South America, and we can only suggest that at some period or other these now widely separated regions must have been linked together by land which has long since disappeared.

The various groups of Central American insects are as yet far from well known, and their relationships with the insects of other regions have been but imperfectly determined, notwithstanding the fact that Messrs. Salvin and Godman have published a series of fine volumes about them. The consensus of opinion of the writers, who have contributed to the "Biologia Centrali-Americana," is that Central America is essentially a part of South America. The purely North American forms are few in number, their southern limit being as a rule in Mexico. This verdict agrees also with that of Dr. Calvert, $\uparrow$ who in his recent researches on the dragonflies (Odonata) of Mexico and Central America, comes to the conclusion that in the endemic as well as in the non-endemic species, the South American element is much the strongest.

Before concluding this chapter, I might again emphasize the fact that the occurrences of northern genera and species in Central America are almost all discontinuous. I need only

* Pickard-Cambridge, O., "Araneida of Central America."

† Calvert, P. P., "Odonate Fauna of Central America," p. 467. 
mention among northern plants, the oak (Quercus) and the plane (Platanus), among animals, the newt Spelerpes, the snapping turtles (Chelidridae) and the fresh-water mussels (Unionidae). Many other northern animals and plants have a similar disjointed range in the midst of an entirely alien southern fauna. These, and the northern groups that are altogether absent from Central America, but reappear much further south, are, I think, part of a very ancient invasion of South America. If it is true that the South American animals and plants which have taken almost complete possession of Central America, poured into the latter from the south in early Pliocene times, surely the northern groups must be immeasurably older! In their discontinuous range and frequent isolation on mountain tops they show every sign of antiquity, and it seems likely that they are being crowded out rapidly by their stronger southern rivals, which are better fitted to support the present climatic conditions of this region. Dr. Wallace * suggested, as I mentioned above, that the northern faunistic affinity of South America which is so characteristic, especially of Chile, but which we find to some extent all along the Pacific coast, is mainly due to the Glacial Epoch. He fancied that a migration, aided by gales and hurricanes during successive Glacial Epochs, when the mountain range of the Isthmus of Panama, if moderately increased in height, might have become adapted for the passage of northern forms, would explain all these extraordinary features of distribution. Dr. Wallace thought the resemblance only consisted in a few plants and insects. He had very little idea of the real extent and character of the northern element that has actually penetrated into Central and South America. It is unlikely that he would have supported these views had he known of the range of the newts, turtles, freshwater mussels and other groups. Moreover, we also have evidence of ancient migrations of mammals and other animals, as well as plants, in an inverse direction from the south to the north. It is perfectly certain, therefore, that long anterior to the southern invasion into the existing area of Central America, two streams of animals and plants passed between the great

* Wallace, A. R., "Distribution of Animals," II., p. 45. 
continents, leaving certain traces of their transit in the more ancient portions of the country. And yet I believe, and shall produce ample evidence in support of my contention, that only certain fragments of Central America formed part of that land which long ago served as the highway between North and South America. This fact is not so readily revealed from a study of the Central American animals and plants. All we can gather from our present researches is that there are certain ancient elements in the fauna and flora of Central America exhibiting affinities with North America, Asia, Europe, Africa, the West Indies and South America, and that these older elements are being dispossessed or driven into the more inaccessible parts by the members of the new and most recent invasion from the south which traversed the newly formed Central American isthmus. It is believed that this must have commenced in Pliocene times. Of the two marine barriers which previously prevented this southern advance, one was in the neighbourhood of the Panama Canal, the other at the Isthmus of Tehuantepec, but to judge from the animals and plants of Central America, the former had already disappeared when the more northerly one was still in existence. 


\section{CHAPTER XI}

\section{THE WEST INDIAN ISLANDS}

NoRth and South America are to be regarded, according to Professor Suess, * as two essentially distinct land-masses, between which is interposed, as a third element, the area of Central America and the Antilles. This geological distinctness of Central America and the Antilles from the two neighbouring continents is scarcely recognisable in the fauna of the great isthmus. But the West Indies are comparable to a wedge driven in between two faunistically, more or less, independent and distinct land masses. Almost everyone who has dealt with the fauna or flora of the West Indian islands has expressed his surprise at this fact. In position, says Dr. Wallace, $\uparrow$ the Antilles form an unbroken chain uniting North and South America, in a line parallel to the great Central American isthmus. Yet instead of exhibiting an intermixture of the productions of Florida and Venezuela, they differ widely from both these countries, possessing in some groups a degree of speciality only to be found elsewhere in islands far removed from any continent.

One other important feature which strikes the visitor to the islands is their extreme poverty in the higher groups of animal life. It is not that the Antilles are climatically unfavourable to animal life. On the contrary, they are exceptionally favoured by nature to support a luxuriant and varied fauna and flora. Their temperature is high and uniform, there is an abundance of moisture, the soils are very fertile, while high mountains as well as gentle plains abound, at least in the larger islands. Cuba, the largest of them, exceeding Ireland in size, and being far more favourably situated, has

* Suess, E., "Antlitz der Erde," I., p. 700.

† Wallace, A. R., "Distribution of Animals," II., p. 61. 
not half-a-dozen species of land mammals, while Ireland possesses nearly three times that number. There are only two ways in which we can account for this great deficiency in the higher animal life on the Antilles. We may suppose that either the islands have not been connected with the mainland since early Tertiary times, or if they have, that their fauna was largely destroyed since their isolation. In the latter case the apparent poverty of the fauna might be due to great destruction of animal life during a submergence of the land, and the consequent reduction of the habitable area. On the other hand, we should expect the relict fauna of the islands to exhibit marked affinities with that of the two great continents lying to the north and south respeotively. However, as I have mentioned, the fauna on the whole is essentially dissimilar from that of North and South America. The problem of the origin of the West Indian fauna, therefore, like that of Central America, is much more complex than it would at first sight appear. I alluded to the apparent poverty of the fauna because, although it does appear very poor in the higher groups some of the lower forms of animals are represented by a large number of species. The land-snails, in fact, are extremely varied in character, and the abundance of species is one of the most remarkable features of the West Indian fauna. A study of their distribution and their relationship will probably give us a better insight into the origin of the fauna as a whole than the higher vertebrates, which are so poorly represented on the islands.

Before describing the molluscan fauna of the Antilles, a few preliminary remarks on the islands may not be out of place. The islands as a whole form a natural breakwater or barrier between the Atlantic Ocean on the one hand, and the Gulf of Mexico and the Caribbean Sea on the other, which lie on the opposite side of it (Fig. 13). A mere glance at the map is sufficient to show that we have to deal with two distinct sets of islands. A series of large ones belong together, viz., Cuba, Haiti or San Domingo, Jamaica and Portorico, with mountain crests running in an east-westward direction, while a chain of the much smaller, Anguilla, Guadeloupe, Dominica, Martinique, St. Vincent, Barbados and others, placed in north and southward position, constitute quite an independent 


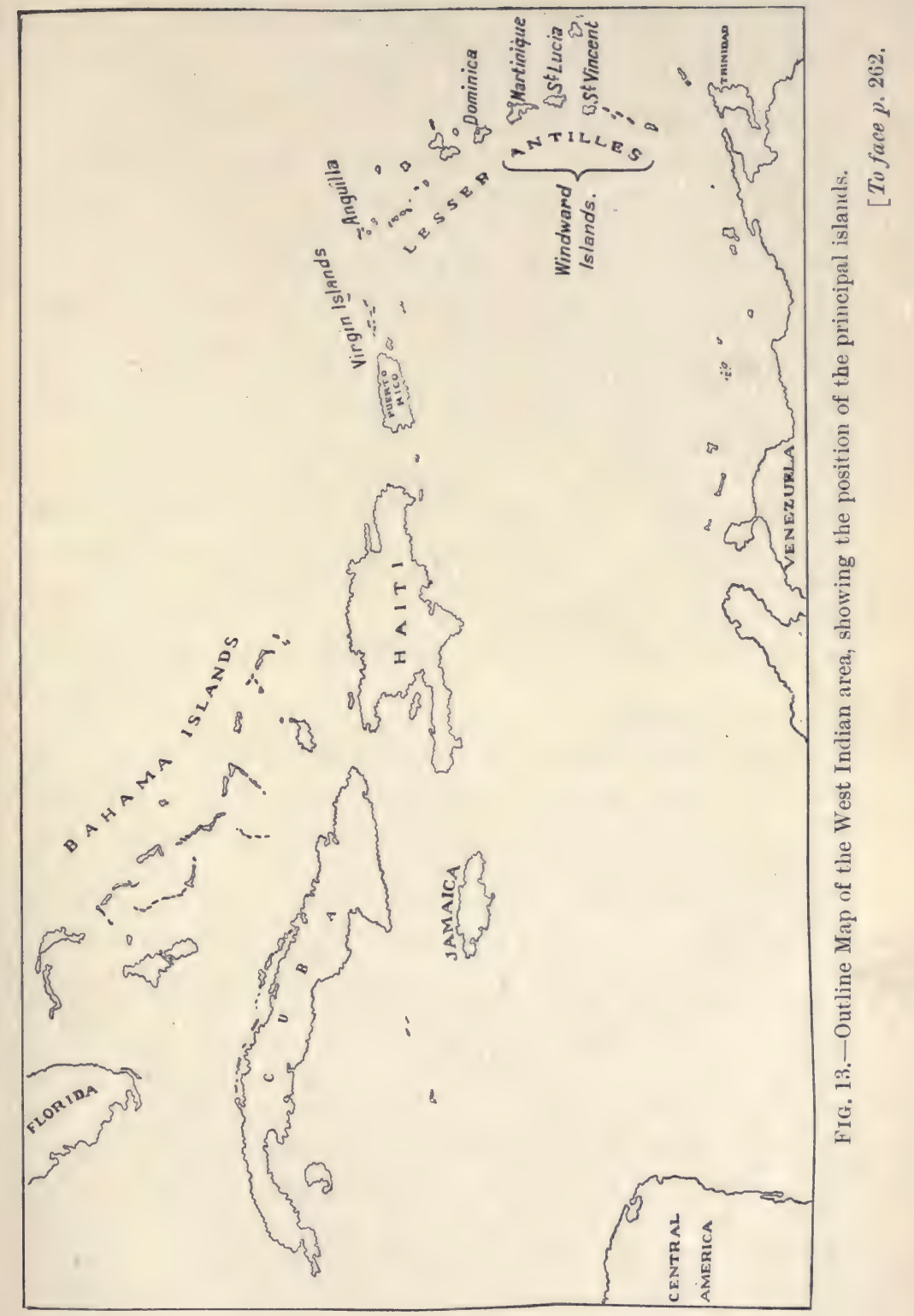



group. The former are always spoken of as the "Greater Antilles," and the latter as the "Lesser Antilles." With Professor Suess * we may look upon the mountain ranges of Yucatan and Guatemala, which trend in a west-easterly direction, as the western continuations of the mountain system of the Greater Antilles. The latter, as well as a few of the northern Lesser Antilles, are composed of sedimentary rocks of Mesozoic and Cainozoic, possibly even of Palaeozoic age, while many of the remaining smaller islands, which cluster together in a concave arc, seem to be of comparatively recent volcanic origin. The Bahamas, and some of the more southerly flat islands, including part of Barbados, are apparently of young Tertiary age. The whole of the main series of the Antilles, from Cuba through Jamaica, Haiti and Portorico to Barbados, is composed of similar rocks. Granite, older eruptive rocks, serpentine, glauconitic sandstone and cretaceous limestone, form the visible remnants of a once connected mountain range. Westward the latter divides into several branches. One of them passes from southern Haiti through Jamaica to Honduras, another by way of Cuba to Guatemala.

There is some evidence, according to Professor Hill, that the east coast of North America lay far eastward of its present site in pre-Cretaceous times, whereas some faunistic facts point to a continuation of this condition until the Tertiary Era. The Pacific marine fauna transgressed eastward during the Jurassic Period, probably across the Mexican plateau, fossils of Pacific type having been found in western Cuba. This implies that the barrier separating the Atlantic from the Pacific in those remote times must have been situated to the east of Cuba. Professor Hill $\dagger$ argues that the chain of low-lying islands between Florida and north-eastern South America represent the remnants of this ancient Jura-Cretaceous isthmus between the two great continents. Whether such a land bridge existed is difficult to determine from faunistic evidence, but the Atlantic waters seem to have entered the Caribbean Sea in Lower Cretaceous times. During part of the Eocene and Oligocene Periods, extensive

* Suess, E., “Antlitz der Erde,” I., pp. 700-707.

† Hill, R. T., “Geology of Jamaica,” pp. 200-216. 
subsidences drowned the Antilles to such an extent, according to Professor Hill, that only the higher summits of Cuba, Haiti and Jamaica remained above sea-level as small islands. The West Indian islands were subsequently raised into a large continuous and connected land. In late Miocene and Pliocene times the gradual and final dismemberment of the Antillean lands took place. Still more recently a further elevation occurred, not sufficient, however, to establish a united Antillean continent. Whether Professor Schuchert* supports Professor Hill's hypothesis of a wide land connection between Florida and Venezuela in late Jurassic times is not clearly indicated in his maps. But during the Cretaceous Period all the West Indian islands except the Bahamas are represented as being entirely submerged. In Eocene times the greater part of Cuba was above sea-level. In the succeeding Oligocene Period all the islands, except the Bahamas, once more disappeared. Thenceforth all the Greater Antilles retained their present outlines. Only during the Pliocene Period was there a land connection between Cuba and Yucatan. All these writers thus concur in the view that some time during the earlier part of the Tertiary Era there was a very profound and widespread subsidence of almost the whole of the Antillean area. Yet, according to Professor Schuchert, the Bahamas, or some land area in the position of the Bahamas, if I correctly interpret his maps, remained above sea-level practically from the earliest Palæozoic ages to the present day. The idea that there was once a land connection between North and South America along the chain of the Lesser Antilles, Cuba, the Bahamas and Florida is also advocated by Professor Gregory, $\uparrow$ though he admits that the area of the Windward islands was submerged at the period when the oceanic deposits of Barbados were laid down. There is no adequate evidence, he thinks, to show that there was more land at any subsequent time in this region than there is at present.

Now as for the light thrown on these various problems by a study of the geographical distribution of the West Indian 100.

* Schuchert, Charles, "Paleogeography of North America," Maps 89-

† Gregory, J. W., "Geology of the West Indies," p. 305. 
land mollusks, it may be urged, in the first instance, that the value of the evidence is greatly impaired by the possibility of occasional or accidental dispersal. That a certain percentage of the fauna of an island is due to importation by human agency is, I think, well established. That a small proportion of the West Indian fauna may possibly have been carried from island to island and from the mainland by other accidental means is likewise possible. But I quite concur with Dr. Simpson in his belief that we are not justified in explaining the whole distribution of the terrestrial mollusks in the West Indian islands by such an hypathesis. The very nature of the West Indian fauna, and its distinctness from that of the neighbouring continents, precludes the assumption of any extensive accidental dispersal. Hence we may take for granted the correctness of the theory that the main mass of these mollusks have migrated from island to island when the latter formed a united land surface. This belief is vouched for, moreover, by the fact that the study of practically all other groups of West Indian animals brings us to precisely the same conclusion. In their general agreement with the results arrived at from a geological study, all these groups tend to show that the study of geographical distribution is a science of profound importance as an indicator of former changes of land and water.

The facts adduced by Dr. Simpson, that the operculate species form so large a proportion of the Antillean landsnail fauna, that a majority of the genera is found on two or more of the islands and the mainland, while nearly every species is absolutely restricted to a single island, is a strong testimony in favour of a former general land connection in this area. Dr. Simpson* very carefully compared the molluscan fauna of the various islands with one another and with that of the mainland, and bases his conception of the geological history of the Antilles mainly on the results so derived. He believes a considerable portion of the species inhabiting the Greater Antilles to be ancient, and to have developed on the islands where they are now found. Probably some time

\section{8.}

* Simpson, C. T., "Distribution of Mollusks in West Indies," pp. 447- 
during the Eocene Period the Greater Antilles were at a higher level, so that the islands were united with one another and with Central America. This resulted in an exchange of species between the two regions. A land connection is also indicated between Cuba, the Bahamas and Florida. At this time, he thinks, the more northern isles of the Lesser Antilles were not yet elevated above the sea, or, if so, they have since probably been submerged. After this period of elevation there followed one of general subsidence. During it Jamaica was the first island to be separated, then followed Cuba, and afterwards Haiti and Portorico. The connection between the Antilles and the mainland was broken, while the subsidence continued until only the summits of the mountains of the four Greater Antillean Islands remained above water. Eventually there was another period of elevation which lasted, no doubt, until the present time. The Bahamas gradually. emerged and were populated by forms drifted from Cuba and Haiti. In this last conclusion Dr. Simpson unfortunately fails to appreciate the full value of his own studies. If all the snails, amphibians and reptiles known to inhabit the Bahamas-and many of them are peculiar to these islandshad reached them by accidental dispersal, this mode of conveyance must be of enormous importance. In such a case I think we should scarcely be justified in basing our theories of the geological history of the Antilles on the geographical distribution of animals.

Now among the families of snails alluded to in Dr. Simpson's paper as being abundant in the West Indies, there are some that have received special attention by American malacologists. One of these, the Urocoptidae, or Cylindrellidae as they were formerly called, comprises small snails with an elegant fusiform shell composed of many narrow. whorls. They are found in the Antilles, in southern Florida, along the northern coasts of South America, in Central America and in Mexico, as well as the adjacent parts of the United States. The centre of distribution thus lies in the West Indies.

Since it has been proved by fossil evidence in Jamaica that numerous sub-generic groups of land snails, in essentially. their modern forms, were established before the close of the 
Oligocene Period, generic differentiation probably dates from a much earlier time. Indeed, Dr. Pilsbry * is of opinion that the first radiation of the Antillean group of the Urocoptidae may have occurred on a Mesozoic Antillean land area. The succeeding Eocene depression, he thinks, isolated various branches of the existing stocks, western Cuba being probably the first fragment to be dismembered. It was probably not until near the close of the Tertiary that continuity of land was restored with east Cuba. Haiti and Jamaica would seem to have remained united after both western and eastern Cuba had seceded. Finally, these islands were widely separated by the subsidence culminating at the end of the Eocene, or in the beginning of the Oligocene Period. This depression was again followed by an elevation in later Oligocene times, and it is likely that there was a transitory connection between Jamaica and Haiti. Between the latter and Cuba the land connection probably lasted longer, thus producing the homogeneous distribution of several groups. It is likely, says Dr. Pilsbry, that during this mid-Oligocene elevation, the Haitian land included Portorico, the Virgin islands and the islands of the Anguilla bank, that is to say, some of the northern group of the Lesser Antilles. Dr. Pilsbry argues that the presence of large fossil mammals of South American type (Amblyrhiza and Loxomylus) in Pliocene deposits of Anguilla demonstrates that the whole Caribbean chain of islands was elevated into a ridge connected with South America during the Pliocene Period. He likewise expresses the opinion that the genus Brachypodella, one of the Urocoptidae, extended its range westward to Yucatan. Nevertheless, he contends that there is but scanty evidence of any direct land connection between the Greater Antilles and the mainland of Central America during the whole of Tertiary time.

Thus, while differing from Dr. Simpson on several minor points, Dr. Pilsbry's careful researches confirm his view, and that of many geologists, that originally there was a large area of land of which the Antilles are the last remnants, and that some time during the Tertiary Era almost the whole of

* Pilsbry, H., "Manual of Conchology," XVI., pp. xx.-xxiv. 
this old land was submerged having since gradually regained its present position.

The great age of the West Indian fauna and the inter-relationship between the islands and the mainland is well exemplified by the ancient family of operculate snails-the Cyclophoridae.* The genus Neocyclotus inhabits principally. northern South America and the Antilles. From this apparently very old centre of dispersal some members of the genus have pushed southward as far as Peru in the west and Rio de Janeiro in the east. A few have entered Central America. One distinct group (Plectocyclotus) has no less than thirty-two species in Jamaica and only one in Portorico. Another genus (Crocidopoma) is entirely confined to Jamaica, Haiti and eastern Cuba. This indicates strikingly the relationship of the three Great Antilles and their distinctness 'from western Cuba, which was already pointed out by Dr. Pilsbry, while geologists maintain that western Cuba was submerged quite independently from the remainder of the islands. It also illustrates the extreme slowness with which the dispersal of these mollusks takes place.

Still more instructive is the whole group to which Crocidopoma belongs. With Cyrtotoma, Amphicyclotus and Buckleya, it forms, as already mentioned (p. 256), a group of closely related genera of operculate snails. I alluded also to the fact that three of them had a discontinuous range in Central America, and that Amphicyclotus had apparently travelled eastward from Ecuador, invading Venezuela and Guiana, and had thence passed inta the islands of Martinique, Guadeloupe and Dominica, when the latter were connected with one another, and with the mainland. It might be urged that accidental dispersal is responsible for their presence on these islands. But we have no reason for such a supposition, because the species occurring on the islands are quite distinct from one another and from those of Venezuela. Some evidence is afforded by these snails for the belief that the Lesser Antilles are remnants of older land which extended northward from Venezuela, although all the visible parts of the islands are covered by modern volcanic deposits.

* Kobelt, W., "Cyclophoridae.” 
We are too apt to argue that the fauna of an island covered by recent volcanic deposits must necessarily have been derived by occasional means of dispersal. I need only cite the case of the Galapagos islands, which are entirely volcanic, and have seemingly risen from the floor of the ocean. Nevertheless, it can be demonstrated from a faunistic point of view, as I shall show later on, that they have once formed part of an ancient continuous land surface.

Still another group of operculate land snails contains the two genera Megalomastoma and Tomocyclus. The centre of dispersal is Cuba, chiefly the western part of the island. From there Megalomastoma reached Haiti, Portorico and the Virgin islands, which lie close to the latter. Tomocyclus inhabits only southern Mexico and Guatemala. Thus it seems probable that Cuba, Guatemala, and southern Mexico were connected with one another by land in very remote times.

Let us take as another example, that of the ancient and large family Bulimulidae. In another chapter I have dwelt.t on the great age of this family of snails (p. 209) and its general range. It contains mostly large, ponderous snails with somewhat conical shells. Anatomically they are related to the Helicidae. Although represented by a great many species, only a few genera enter the West Indies. One of these (Plekocheilus) inhabits almost exclusively Guiana, Venezuela, Colombia, Ecuador, Peru and Bolivia, that is to say the northern and western States of South America, where the different species are often found at great heights in the mountains. Only two species enter the West Indies, viz., P. aurissileni, which is peculiar to St. Vincent, and P. aulacostylus, which is only met with in the island of St. Lucia. These islands are two of the most southern group of the Lesser Antilles. The ancestors of the two species of Plekocheilus have probably entered these islands when the latter. were connected with one another and with the mainland of Venezuela, and, as the species are very distinct from one another, this could not have happened within very recent geological times.

The species of the genus Bulimulus, as I have already had occasion to state, are exceedingly difficult to discriminate 
from one another. Dr. Pilsbry divided them roughly into three groups, only one of which inhabits the Antilles. To trace the relationship of the various species to one another seems to be a task even beyond the powers of this distinguished American conchologist. The minor sections being arranged geographically in Dr. Pilsbry's work, it does not enable us to draw any conclusions as to their former dispersals. One interesting fact, however, has been brought to light, which proves not only the antiquity of this family but the extraordinary persistency of specific characters among some of its members. The Oligocene Bulimulus americanus of Florida is practically identical with $\mathrm{B}$. ridleyi, still living on the island of Fernando de Noronha.

The genus Drymaeus (Otostomus), which is as difficult to classify as Bulimulus, has mainly a continental range. Only a few species live in the West Indies. Among these we likewise notice a remarkable persistency of specific characters. Drymaeus dormani, for instance, occurs in southern Florida, while the closely allied D. dominicus is resident in Haiti, Cuba, Florida, Yucatan, Nicaragua and Mexico. At the first thought we might feel inclined to attribute such a strikingly discontinuous range to accidental distribution ; but a careful study of the whole family has impressed me with the conviction that we have to deal with a set of very ancient and very persistent types of mollusks.

Even less satisfactory to identify than Bulimulus and Drymaeus are the Orthalicinae, another large group of Bulimulidae. Dr. Strebel * has recently undertaken their revision, utilising several characters which had hitherto not been employed in the discrimination of the species. It is an attempt, at least, to trace the complex relationship of the innumerable closely allied forms, although the author does not seem to realize the great antiquity of the group. His arguments in favour of wholesale accidental dispersal, even from western Mexico to the Antilles, are quite at variance with the lesson the study of the West Indian fauna has taught us. The species of Simpulopsis are mostly South American, but a small aberrant group with smooth apical whorls is confined to Portorico,

* Strebel, H., " Revision der Orthalicinen." 
Haiti and Mexico. The genus Gaeotis is quite confined to Portorico, while Amphibulima is limited to the Lesser Antilles.*

All these studies yield the same fundamental results, namely, the presence within the Antillean area of an extremely ancient stock distantly related to that of Central America and northern South America. After this fauna had developed to some extent, a widespread destruction apparently took place, due probably to submergence, followed by a reimmigration from the south and west. A more precise knowledge, however, of the minor physical changes which the West Indian islands have undergone can be acquired when we compare the results derived from the sedentary or slowly moving mollusks with those drawn from the more active members of the fauna. But there is one more element of importance in the Antillean molluscan fauna which has not yet been considered. It is especially in view of the remarks I made in the ninth chapter, on the striking relationship of the south-western American fauna to that of Europe, that I wish to direct particular attention to the European affinities of the Antillean fauna.

I think it was Dr. Kobelt $\dagger$ who first animadverted on the resemblance between the European molluscan fauna and that of the Antilles and Central America. At first sight, as he remarks, the two faunas seem to be as distinct as any disciple of the principle of multiple centres of creation could wish. After a careful study, however, we certainly perceive distinct traces of relationship. The carnivorous snail Glandina, which is represented in the Mediterranean region of Europe by a single species, has its headquarters in the Antilles and in the surrounding States. It cannot be looked upon as a recent introduction to Europe, because its discontinuous range bebetween the Caucasus and Algeria is altogether opposed to any such supposition. Several species of Glandina, moreover, occur in French and English Eocene, Oligocene and Miocene deposits, some of them being almost identical with still

* Pilsbry, H. A., "Manual of Conchology," Vols. X.-XII.

† Kobelt, W., "Verhältniss d. Europäischen Landmolluskenfauna, \&c.," p. $145-148$. 
existing American forms. The operculate genera Tudorella and Leonia of the Mediterranean region are certainly related to West Indian forms, though not so closely as was formerly: believed. These and other considerations induced Dr. Kobelt to postulate a land connection between Europe and North America, which was only severed in Miocene times. The German Miocene genus Subulina, the large Glandinae and the early Tertiary European Oleacinae, are considered by Professor Boettger * as the nearest relations or direct ancestors of Central America or West Indian genera and species. The same authority also alludes to the American facies of the Tertiary flora of Europe, and concludes that a land bridge right across the Atlantic Ocean existed up to early Miocene times. Finally Professor Andreaet supports the same theory, on account of the occurrence of the West Indian Boltenia, Strobilus and Pleurodonte in the Miocene deposits of Silesia in Germany. And he was the first to definitely fix the position of the land connection as one uniting western Europe with the Antillean area.

Still other features of relationship between these regions remain to be considered. Long ago Mr. Woodward $\ddagger$ pointed out that the presence of the European genus Clausilia in the West Indies and in northern South America (see Fig. 19) implied the existence of a former more direct land way across the Atlantic than would be afforded by the land connection which was supposed to have once united the boreal regions of Europe and North America. Since that time others have repeated his assertion. Clausilia is now known to have lived in Europe since Cretaceous times, and has probably originated there. It is partial to high altitudes, large numbers of species being found in the Alps, the Dalmatian mountains and the Caucasus. Only a single European species resembles the American group (Nenia), namely Clausilia pauli of the western Pyrenees, and it is so closely related to the members of that group that both Mr. Bourguignat and Mr. Locard, two French conchologists of the "nouvelle école," failed to find any satisfactory difference between them. It is quite

* Boettger, O., "Verwandschaftsbeziehungen d. Helix Arten," p. 116.

† Andreae, A., "Binnenconchylienfauna d. Miocäns," II., p. 31.

† Woodward, S. P., "Manual of the Mollusca," p. 112. 
true that another group of Clausilia, knawn as Garnieria, from tropical and eastern Asia also approaches the American group closely. Yet the fact that no Clausilia, either fossil or recent, has ever been discovered in northern Asia or North America, although many species, as I remarked, thrive in high altitudes and cold climates, speaks strongly against the supposition of the ancestors of the West Indian and South American stock having wandered through Asia and North America to these regions. The geographical distribution of Clausilia thus offers one of the most cogent arguments in favour of a direct land bridge between the Mediterranean and the Antillean regions. Opponents of this view may urge that Clausilia is merely represented by a single species in the West Indies, while none are known from Central America. We may explain this curious circumstance by the fact that the West Indies were submerged probably before the newly immigrated Clausilias had time to gain possession of the higher eminences, so that most of them would have been destroyed. In Central America fewer traces of European affinity have been detected than in western North America or western South America, because in the latter regions the faunas remained more or less isolated for long periods, while the great rush of South American invaders, combined with climatic changes, swept all before them in Central America. Why Clausilia has succeeded in reaching western South America without attaining western North America will be discussed in the next chapter but one.

Dr. Simroth suggests that the ancestors of the American Bulimulidae, at least the group of Orthalicinae, may be of European origin, while I venture to think that the curious Rumina decollata, which is supposed to be a human importation in Cuba, may be indigenous there, since it is now known to have lived unchanged in the Mediterranean region since Oligocene times. In view of my remarks in previous chapters on the relationship of the North American snake Tropidonotus, of the crayfish Potamobius, of the slugs belonging to the family Arionidae, of the glass snake, of all that remarkably European assemblage of animals in the south western States, of the snail Adelopoma in Guatemala and numerous other instances, such as the range of the flamingoes, it need 
not be surprising that I am a strong adherent of the theory just stated, that a land bridge existed right across the Atlantic between the Mediterranean and the Antillean regions, and that the European element of the fauna made use of it in passing to America (Fig. 14). This land connection, of course, was quite independent of the one I described (p. 13) as having once joined Labrador and Scotland by way of Greenland. The latter may possibly have come into existence when the other had already crumbled away. At any rate, the two are quite distinct as to age and position.

Before I had an opportunity of making this more thorough study of the North American fauna, I was under the impression that the "Southern Atlantis," as we may call this land connection, joined Africa with South America, and that there was no other land bridge across the mid-Atlantic.* I am still an advocate, as I shall explain more fully later on, of what Dr. von Thering calls "Archhelenis," the hypothetical continent of the southern part of the Atlantic Ocean. But I maintain that a more northerly land bridge likewise existed, and that the two were completely separated by a wide ocean.

The disciples of Dr. Wallace will exclaim, "What about the permanence of ocean basins, a theory which receives such weighty support from some of the most eminent geologists of the day?" This question of the permanence of ocean basins, and we may say of continental areas too, really lies at the root of most of our inquiries into the past changes of the earth and its animal inhabitants. The internal characters of the rocks we see around us, remarks Sir Archibald Geikie, $\dagger$ point unmistakably to deposition in comparatively shallow water. "Their abundant intercalations of fine and coarse material, their constant variety of mineral composition, their sun-cracks, ripple-marks, rain-pittings and worm-tracks, their numerous unconformabilities and traces of terrestrial surfaces, together with the prevalent facies of their organic contents, combine to demonstrate that the main mass of the sedimentary rocks of the earth's crust was accumulated close to land, and that no trace of really abysmal deposits is to be found among them." From these considerations, says Sir

* Scharff, R. F., “Atlantis Problem,” p. 279.

† Geikie, A., "Text Book of Geology," p. 911. 
Archibald Geikie, we are led to the conclusion that the present continental areas must have been terrestrial regions of the earth's surface from a remote geological period. Subject to repeated oscillations, continues Sir Archibald Geikie, so that one tract after another has disappeared and reappeared from beneath the sea, the continents, though constantly varying in shape and size, have yet maintained their individuality. So far, I think, most geologists will agree with Sir Archibald Geikie. It is his inference, that the existing ocean basins have probably always been the great depressions of the earth's surface, which has not met with such general approval. Dr. Wallace supports Sir Archibald Geikie's view on the grounds, not only of the enormous depths and great extent of the oceans, and of the circumstance that the deposits now forming in them are distinct from anything found upon the land surface, but also owing to the supposed extraordinary fact that the countless islands scattered over their whole area (with one or two exceptions) never contain any Palaeozoic or Secondary rocks, that is, have not preserved any fragments of ancient continents, nor of the deposits which must have resulted from their denudation during the whole period of their existence! The exceptions alluded to by Dr. Wallace* are New Zealand and the Seychelles islands, both situated near to continents and, according to the same writer, not really oceanic. "The vast areas of the Atlantic, Pacific, Indian and Southern Oceans are thus left almost without a solitary relict of the great islands or continents which some naturalists believe to have sunk beneath the waves of these oceans." Thus writes Dr. Wallace. Another argument in favour of the permanence of ocean basins has recently been brought forward by Professor Joly. $\dagger$ It is based on the facts of solvent denudation. He regards the sodium in the ocean as the key to the history of solvent denudation, arguing that it was derived from the igneous rocks of the earth by the processes of weathering and solution progressing throughout geological time. He shows that the quantity of oceanic sodium agrees with the sediments

* Wallace, A. R., "Island Life," p. 105.

+ Joly, J., "Radioactivity and Geology," pp. 127-131. 
as we find them upon the existing continents, and concludes that there cannot be yet other continents with their own burdens of sediment hidden beneath the ocean. That former continents of any antiquity or magnitude are not hidden beneath the waves, says Professor Joly, seems certain, unless the estimates of sediments are quite erroneous. Whether the estimates are correct is a question which must be left to authorities in physical chemistry; but it has been argued by Professor Carthaus* that the waters of the ocean, as well as those of continents, were originally rich in sodium chloride, and that fresh-water organisms only came into existence comparatively recently, that is to say in late Mesozoic times. When we consider the enormous area of North America that was under water in Cretaceous times for instance, less than an equivalent strip of land in the shape of a trans-Atlantic land bridge would be all that is required for our purpose. We need not call it a continent.

As for the arguments in favour of the permanence of continents and ocean basins raised by Sir Archibald Geikie and Dr. Wallace, they are based on the following facts and assumptions, viz., great ocean depths, absence of abysmal rocks on present land surfaces, and absence of older Mesozoic or Palaeozoic rocks (with one or two exceptions) on oceanic islands. It has been shown, however, by Professor Suess that great depressions on the surface of the earth's crust are not necessarily old or permanent. Quite near the south-west coast of Asia Minor, and close to the mighty Ak Dagh (10,000 feet high), a depth of over 10,000 feet has been recorded. This depth is all the more remarkable when we consider that freshwater Pliocene beds of the mainland are continued across to the neighbouring island of Rhodes, thus showing that the latter was, until such a recent geological period as the Pliocene, still joined to the continent. Altogether Professor Suess $†$ inclines to the view that geological evidence does not prove, nor even point to a permanence of the great depths, at least in the oceans of the Atlantic type. The next point which has been raised in favour of the view of the permanence

* Carthaus, E., " Klimatische Verhältnisse der Geologischen Vorzeit."

† Suess, E., "Are Great Ocean Depths Permanent?" pp. 182-186. 
of oceans and continents is the supposed absence of abysmal deposits on any existing land surface. The discovery, however, of true deep-sea ooze in Barbados and Cuba shows that. this argument is no longer valid.* There only remains one other argument in favour of this theory, and that is the structure of the oceanic islands. With two exceptions, remarks Dr. Wallace, they do not contain any Mesozoic or Palaeozoic rocks, being mostly volcanic. Hence he concludes that these islands must be of modern origin. How illusive this conception is may be gathered from Dr. Blanford's $\uparrow$ remarks on this subject: "If Africa, south of the Atlas, sub. sided 2,000 fathoms, what would remain above water? So far as our present knowledge goes, the remaining islands would consist of four volcanic peaks, the Camaroons, Mount Kenia, Kilimanjaro, and Stanley's last discovery, Ruwenzori, together with an island, or more than one, containing part of the Abyssinian tableland, which, like the others, would be composed of volcanic rocks, but, unlike them, would consist of horizontal or nearly horizontal lava flows, probably of of Mesozoic age. In southern Africa, too, the peaks of the Stormberg and Drakensberg, though not rising, or scarcely rising above 10,000 feet, are the highest in the country and consist of volcanic rocks. The same is the case with the highest peaks in Madagascar, in Mexico, in the Caucasus, in the Elbruz chain south of the Caspian, and in many other parts of the world; though the case of Africa is perhaps the most remarkable."

The question whether all the numerous oceanic islands that are scattered about the Pacific and Atlantic Oceans are really modern volcanic products or of recent organic origin, has also received some attention recently. According to Dr. Arldt, $\neq$ Archaean rocks have been noticed on the Solomon islands, gneiss and allied rocks occur on the New Hebrides and New Caledonia, while even from the Marquesas have been recorded ancient rocks.

So far I have discussed only a very small portion of the purely zoological aspect of the trans-Atlantic land connection

* Gregory, J. W., "Geology of the West Indies," p. 307.

† Blanford, W. T., "Anniversary Address," pp. $34-35$.

† Arldt, Th., "Entwicklung der Kontinente," pp. 457-458. 
problem. This problem has been approached from many other points of view. On the evidence of the fossil marine mollusks of the West Indian and the Mediterranean regions, Mr. Guppy* concluded that a migration must have taken place right across the Atlantic along an ancient shore-line. More recently, Professor Gregoryt dwelt upon the intimate affinities that exist between the fossil sea-urchins of the West Indian and Mediterranean areas, and urged that it could only be explained by the assumption of a belt of shallow water across the Central Atlantic in, at latest, Miocene times. A few years later he adduced evidence from the fossil corals of Barbados, that the West Indian fauna is only a fragment of that of the Mediterranean Miocene, having received nothing from the Pacific. That this fauna did not follow along the shores of the North Atlantic basin is shown by its absence from the northern Miocene of Europe and America.f Mr. Guppy§ has lately renewed the discussion of this subject and once more affirmed his adherence to the theory he expressed long ago, which has meanwhile recoived so much additional support. Even the recent marine fauna of the Antilles is intimately related to that of the Mediterranean. Some of the faunistic marine affinities between the two regions referred to might just as well have been produced by a dispersal along a land bridge between Africa and South America. Such, for instance, is the occurrence in early Tertiary deposits of the aquatic snake Pterosphenus in Egypt and Alabama. Dr. Andrews, $\|$ indeed, thought it yielded an argument in favour of the more southern land connection.

Let us now examine what light the recent marine mammals inhabiting the Caribbean Sea and the Gulf of Mexico throw on the problem. On the south-east coast of Florida we meet with one of the most curious of American mammals. With its seal-like head and flattened tail it is at once recognised as something quite distinct from other marine creatures. The

* Guppy, R. J. L., “West Indian Geology,” p. 501.

† Gregory, J. W., "American and European Echinoid faunas," pp. 101-108.

士 Gregory, J. W., "Geology of the West Indies," p. 307.

$\S$ Guppy, R. J. I., "Geological Connexions of the Caribbean Region."

\| Andrews, C. W., "Tertiary Vertebrates of the Fayum," p. xxv. 
manatee (Trichechus manatus), as it is called, does not inhabit the open ocean. It frequents shallow bays and lagoons, where it browses peaceably on seaweeds, just as cattle graze on land. This northern manatee lives also near the coasts of Cuba, Haiti, Jamaica and other islands, as well as along the shores of Central America and northern and eastern South America. Curiously enough, a second species (Trichechus inunguis) seems to be confined to the upper reaches of the Orinoco and the river Amazon. Still more remarkable is the fact that a third species (Trichechus senegalensis) is confined to the coasts and rivers of West Africa, for since the open ocean is to the manatees just as much a barrier to migration as it is to terrestrial mammals, the distribution of these manatees implies the existence of a former shore-line across the Atlantic. It is quite true that in early Tertiary times manatees have lived much further north than they do now, but the European ones, at any rate, belonged to different genera from those now living. We possess no evidence, therefore, for the supposition that the ancestors of the American species passed along the eastern shores of North America and crossed to northern Europe along the ancient Greenland-Iceland land bridge, thus eventually reaching Africa. Another theory, even less probable I think, is that suggested by Professor Osborn.* He thought a migration might have taken place from Africa by way of the Pacific coasts of Asia and North America, the ancestors of the West Indian manatees entering the Atlantic through a strait, which is supposed to have connected that ocean with the Pacific, in mid-Tertiary times. He considers this circuitous route a more probable one than the trans-Atlantic one. Yet he does not clearly explain how the close relationship between the West African and eastern South American forms was brought about.

This, however, by no mean completes all the evidence derived from the manatees in favour of the theory of a transAtlantic land bridge. Dr. Dilg $\dagger$ has pointed out that the molar teeth of the adult living manatees resemble those of

* Osborn, H. F., "Age of Mammals," pp. 493-494.

+ Dilg, Carl, "Morphologie des Schädels bei Manatus," p. 139. 
the Eocene Prorastomus, which must be looked upon as the ancestor of Trichechus. I mentioned before that Prorastomus has been discovered in the Eocene of Jamaica. The teeth of another form (Prorastomus veronensis) are known: from Italy. Thus the affinity still existing between the South American and West African forms was apparently foreshadowed already during the Eocene Period by the relationship of the two species of Prorastomus, the ancestors of the. modern manantees. Dr. Smith Woodward, however, informs me that the relationship of these species is too uncertain to be used as evidence in favour of an Eocene land bridge.

All the seals inhabiting the North Atlantic, both on the European and North American side, belong to the genera Halichoerus or Phoca. As soon as we enter the Antillean region these genera disappear, their place being taken by the genus Monachus. On the opposite shores of Europe it is just the same. As far south as Portugal we still find the common seals, but as we enter the Mediterranean we again meet with the same genus Monachus. The Antillean form (Monachus tropicalis), like the Mediterranean Monachus albiventer, seems to be on the verge of extinction. The former was once common off Florida and near most of the islands. Now it is only noticeable in the neighbourhood of Cuba and some of the islands near Yucatan. We can hardly believe, remarked Messrs. Sclater,* that these creatures could easily traverse the whole Atlantic. The hypothesis of a former barrier of land between Africa and America, which we know to be supported by other facts of distribution, would alone explain the difficulty, according to these authors. They only had the supposed land connection between Africa and South America in mind, but what strengthens the evidence in support of another more northerly mid-Atlantic land bridge between the Antilles and the Mediterranean region is the fact that the only localities outside the Mediterranean where Monachus albiventer occurs are on the coasts of Madeira and the Canary islands.

Among the terrestrial species of vertebrates and invertebrates of the Antilles, as I observed, the affinity with Europe is less marked perhaps than it is in the south-western States

* Sclater, W. L., and P. L. Sclater, "Geographyiof Mammals," p. 217. 


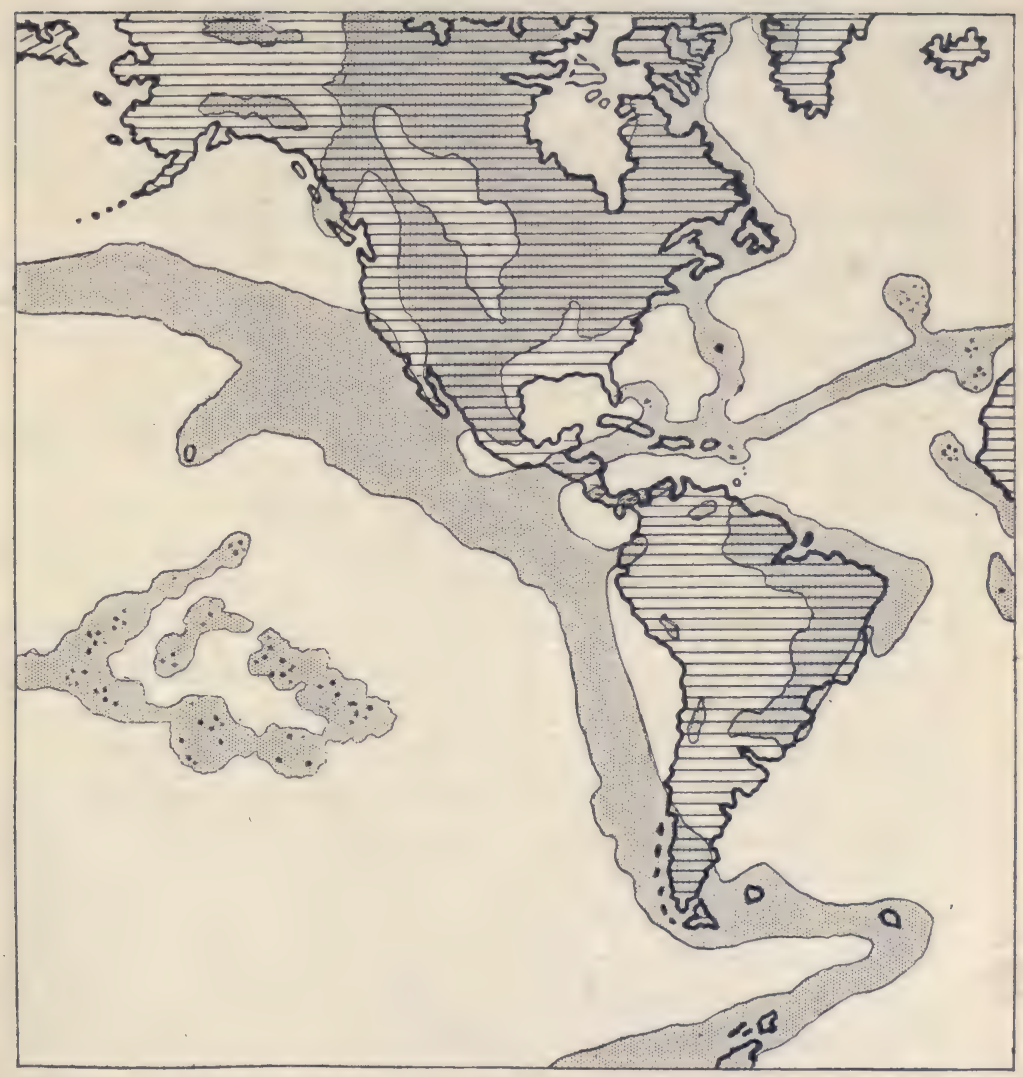

FIG. 14.-Map of North and South America, indicating roughly the supposed conditions of land and water about the commencement of the Tertiary Era. The ancient land is slightly tinted. 

of North America. I explained this by the supposition that the widespread submergence of the Antilles destroyed most of the immigrants from Europe. It ought not to have affected the emigrants to Europe from the Antilles to the same extent, I mean those forms which spread from the Antillean centre, because they would have had more time to adapt themselves to the more elevated regions in the West Indies, and would thus have had more chance of surviving the submergence which did not entirely cover the islands.

One of the most noteworthy examples of that kind, though not a very conspicuous one, is the newt Spelerpes. I alluded to its range in North America on several occasions (pp.137138 and p. 221), pointing out that its headquarters were in Mexico, while a single species had succeeded in reaching the Mediterranean region. We may assume, therefore, that certain members of the old American Spelerpes stock emigrated, in early Tertiary or even in Mesozoic times, by, means of the trans-Atlantic land bridge, that extended from the Antilles to a land area which covered part of the western Mediterranean (Fig. 14). That Spelerpes long ago existed all over the Antilles is indicated by the fact that a single species (Spelerpes infuscatus) still inhabits the island of Haiti.

Another instance I alluded to (p. 173) in support of the mid-Atlantic land bridge theory, is the glass-snake family (Anguidae). The genus Ophisaurus, which is found in the Mediterranean region, does not occur on the Antilles, but several species are known from the mainland of North America. The genus Anguis is quite confined to Europe, western Asia and north Africa. On the other hand, numerous relations live in the West Indies. Sauresia and Panolopus are confined to Haiti, whereas Celestus (Diploglossus) inhabits Portorico, Haiti, Jamaica, Cuba, Central America, Mexico and northern South America. The headquarters of the Anguidae certainly are in the West Indies and Central America, and it is from there that they must have spread to Europe and beyond, as far as the Himalayas, when a land bridge across the Atlantic permitted them to do so.

Let us now return to the investigation of the geological history of the Antillean area. Among the vertebrates, the mammals perhaps are of the greatest importance, in so far 
as they are not supposed to be subject to accidental dispersal. The West Indian mammals * consist of a mixture of exceedingly ancient and of apparently much more modern types, and yet all are distinct enough from mainland forms to exclude the idea of recent land connections of the Greater Antilles either with Central America or the two neighbouring continents.

The most ancient mammal found in the West Indian islands is the curious insectivore Solenodon. It is the sole genus of the family Solenodontidae, whose nearest living relations are the Centetidae of Madagascar and West Africa. The two Antillean forms (S. paradoxus and S. cubanus) $†$ are in general quite similar. Yet they differ somewhat in size, colour and dentition, as well as in the shape of the skull, and for that reason are perfectly distinct species. The first is confined to Haiti, the other to Cuba. Professor Lech $₫$ expresses the view that Madagascar lost its continental land connection already during the Eocene Period. Hence the Centetidae may be of early Tertiary or even Mesozoic age. Professor Leche believes in a former land connection between Madagascar and Africa, and in another between Africa and Brazil. Both of these must have existed about the same time, and they were used presumably by the ancestors of the Centetidae and Solenodontidae in passing from Madagascar to South America, and thence to the West Indies, or vice versa.

The only large West Indian mammals, Capromys and Plagiodontia, belong to the rodents. The hutias, as they are called, remind us somewhat of the great rat-like South American coypu, but the tail is longer and they possess arboreal habits and certain structural characters differing from the latter. The two genera of hutia are quite confined to the West Indies. Three species of Capromys are known from Cuba, one from the Bahamas and one from Jamaica. Still another Capromys inhabits the small Swan island, in the Gulf of Honduras, mid-way between Jamaica and Central America. Nevertheless, the genus is quite unknown from the mainland. The other genus (Plagiodontia) only occurs on

* Allen, Glover M., "Mammals of West Indies." (This work was received too late for discussion.)

† Allen, J. A., "Notes on Solenodon paradoxus," pp. 507-515.

$\ddagger$ Leche, W., "Centetidae, Solenodontidae, \&c.," pp. 132-139. 
Haiti. Of the past history of these hutias we only know that one extinct species (Capromys columbianus) has been discovered in the Pleistocene deposits of Cuba. The only near relation living is Procapromys geayi, from the neighbourhood of Caracas in the mountains of Venezuela. This implies southern affinities of the genera Capromys and Plagiodontia. Proceeding further south in search of their passible ancestors we meet with another nearly related genus (Matyoscor) in the Pleistocene of Bolivia. Still further south we find on some of the islands of the Chilean coast, as well as in Chile, Peru and Argentina, the coypu (Myocastor coypus), already alluded to as resembling the hutias. Finally, in the Pliocene, Miocene and Eocene beds of Patagonia, various ancestral types of these modern forms have been discovered by Professor Ameghino. Thus the available evidence points to a remote Patagonian origin of the hutias. The question then arises, have the ancestors of these West Indian mammals proceeded northward through eastern or western South America? The testimony we possess is distinctly in favour of the latter theory, though it is mainly of a negative character. In the west we have the living coypu and the extinct Matyoscor, while the former has only invaded Brazil in recent geological times. The Venezuelan Procapromys might lead us to believe that the ancestors of the hutias had gained admittance to the Antillean region by an old land connection across the lesser Antilles. But since no trace of the former presence there of any coypu-like mammal has been discovered, and as a species of hutia exists on Swan island, the hypothesis that the ancestors of these mammals reached the West Indies directly from some western lands seems to me the most probable.

Except the Bahama raccoon (p. 181) and a species of opossum (Didelphys marsupialis), which inhabits the islands of Trinidad, Dominica, Grenada and St. Vincent, all other Antillean mammals are small and inconspicuous. The raccoon may possibly be very ancient, but we know too little about its geological history to enable us to speculate on its origin in the Bahama islands. The presence of the opossum on some of the Lesser Antilles seems to indicate that they had been connected with one another and with Vene- 
zuela within comparatively recent geological times, a conclusion which perfectly agrees with the results obtained from other faunistic evidence.

The groups of smaller mammals which have representatives in the West Indies are the rice-rats (Oryzomys) and the musk-bearing rats (Moschophoromys=Megalomys). Like the hutias and solenodons, the latter are confined to this region, but they are only known from the Lesser Antilles, Moschophoromys desmaresti being peculiar to Martinique, whereas M. luciae is only found on St. Lucia. The occurrence of this peculiar genus of small mammals on the Lesser Antilles implies that their connection with the mainland must be of longer standing than is generally supposed. The opossum (Didelphys marsupialis), is one of the few species of terrestrial mammals having a wide range in both North and South America, and must, therefore, be considered as a persistent specific type of great antiquity. It may possibly have retained its specific characters, while the ancestors of the musk-bearing raits rapidly became modified on the islands. That the latter are not recent introductions is likewise indicated by the fact that an extinct species of Moschophoromys is known from Barbados.

The rice-rats (Oryzomys) inhabit both the islands and the mainland. Their very wide and discontinuous range in North and South America at once suggests an ancient origin. One species (O. antillarum) was so abundant in Jamaica, and did such damage to the crops, that the mongoose, a small carnivore, was imported from India for its destruction. For a time the experiment appeared to be quite successful. After some ten years, however, when the rice-rats became scarce, the mongoose began to pay attention to snakes, lizards, tortoises and birds. As it developed a taste for them they in their turn became scarce, until it was found that the mongoose was worse than any other animal pest, for, owing to the great destruction of the useful mombers of the fauna, insects and ticks had increased to an alarming extent. The disturbance of the due balance of nature by man is always risky, and thus sometimes leads to incalculable damage.

A second species of rice-rat (O. victus) is peculiar to the 
Lesser Antilles. A few others live in Trinidad. It is improbable that Jamaica was at any time connected by land with the Lesser Antilles, independently of the larger islands. It is possible, therefore, that the genus, being mainly South and Central American, entered the Antilles in twa independent streams, one from the south, the other from the west. This may have taken place when the other large islands had already become isolated from Jamaica.

We have still to consider the remains of some extinct mammals which have been traced in the Antilles. To judge from recent cave researches in Cuba, we are only now beginning to acquire a knowledge of the past history of this fauna, though certain indications enable us to speculate as to its general nature and origin. Dr. Spencer* alludes to the discovery in a Cuban cave of large edentate remains belonging to Myomorphus cubensis. This creature, which Dr. Matthew informs me is now known as Megalocnus, was about the size of a small bear, being a peculiar aberrant specialization apparently derived from some Miocene (Santa Cruz) ground sloth. Professor Ameghino $†$ describes a new species of man (Homo cubensis) from a cave in Cuba; and from a preliminary report read at the International Congress of Geology at Stockholm by Professor de la Torre, we are led to infer that other edentates, and also several kinds of rodents, lived on this island within comparatively recent geological times. Dr. Matthew writes to me that the mammalian remains from Cuba sent to the American Museum of New York are awaiting determination. Dr. Spencer $\$$ also makes reference to several large species of rodents of the genus Amblyrhiza which were found in the phosphate beds of the small island of Anguilla. The Amblyrhiza remains are now thought to belong to a single species (A. inundata), closely related to Castoroides, a giant beaver, which made its first appearance in North America during the Pleistocene Period. The former presence in Anguilla and Cuba of large mammals naturally suggests that these islands had some continental connection. Dr. Spencer, indeed, quotes these fossils in support of the

* Spencer, J. W., "Antillean Continent," pp. 128-138.

† Ameghino, Fl., "Nueva especie del género Homo," p. 5.

† Spencer, J. W., “Fossil Mammals in Cuba,” pp. $512-513$. 
theory, largely based on the supposed drowned valleys of the Antillean area, that the two American continents were united with one another by means of a West Indian land bridge during the Pleistocene Period. He thought this land must have had the enormous altitude of from 8,000 to 12,000 feet. Against this view it may be urged from a general faunistic study that such a land bridge is out of the question, because the Antillean fauna would be quite different from what it actually is. A very small part of southern Florida may have been still joined, by way of the Bahamas, to Cuba and Anguilla in Pliocene times. But southern Florida must then have been separated from North America by a marine channel. Nor could there have been any junction of the greater Antillean land with South America, by means of the Lesser Antilles, at any time during the Tertiary Era. In all probability the West Indies, while still partly united with one another, had some kind of land connection with Central America, while the latter was cut off by the sea from both North and South America. Hence the mammalian supply came mostly from the west. Still, it may be asked, how did this fauna reach Central America? Almost all the Antillean mammals, both recent and extinct, can be traced to a southern ancestry, except Castoroides, of which we only know that it appeared in the north along with a host of southern invaders. I believe the cause of the mystery connected with the occasional entrance during various periods in Tertiary times of South American forms into North America is now buried beneath the waves far out in the Pacific Ocean (see Fig. 14). I have frequently suggested the theory that a large land surface, mainly tenanted by a South American stock, lay westward of Central America. A good deal of the next chapter will be devoted to its consideration. Meanwhile, I can only state my conviction that the animals alluded to, and many others, had their origin on that western Pacific land whence they streamed into the neighbouring continents whenever physical conditions offered an opportunity for doing so.

The main conclusion which this brief study of the mammalian fauna of the Antilles has revealed is that the larger islands were formerly united with one another, and with the 
Bahamas, by land. How far eastward this land extended cannot be determined from the mammals, but it certainly must have reached beyond the Virgin islands to Anguilla, one of the most northerly islands of the Lesser Antilles. Many islands of the Lesser Antilles may have been completely submerged at that time. Later on Cuba, the Bahamas and Jamaica were connected with the mainland, after the other islands had already been separated from the Antillean landmass, and lastly, Cuba and Jamaica were independently joined to Central America before the existing physical features were brought about.

Many more details are required before we can construct an approximate history of the geological events which led to the present conditions of the fauna and flora of the Antilles. In his chapter on the evolution of middle America Dr. Gadow* deals with the problem from the aspect of the reptilian and amphibian fauna. He does not attempt to reconstruct the geological history from a study of this fauna alone. His maps are derived and abstracted from the opinions expressed by various geological authorities. They are in so far of importance, as he thinks, that the general conclusions based on a geological study appear to fit those founded on faunistic considerations. Several striking points may be gathered at a glance from his maps. At no time since the Cretaceous Period were the Antilles directly connected with the main continent of North America. Only in Miocene times was "Antillea" (the term used for the united Antilles) joined to southern Florida, the latter being then disconnected from North America. Antillea had only one continental connection, namely, during the Miocene Period by means of Central America. It follows, therefore, that Antillea never was directly joined either to North or South America, at least not since Cretaceous times. If Dr. Gadow's maps are correct, the whole of the Antillean fauna and flora, in so far as they are derived from migration on land, should be of Miocene age or older. Dr. Gadow's conclusions would have been of greater value had he trusted more to the evidence based on geographical distribution and less on that of geology. As pointed out by

* Gadow, H., "Mexican Amphibians and Reptiles," pp. 234-237. 
Dr. Stejneger,* a few Antillean genera, such as Ameiva, Amphisbaena, Typhlops and Alsophis, possess a isouthern relationship. The species of burrowing snake, Typhlops lumbricalis, is even confined to the West Indies and British Guiana without entering Central America. Dr. Stejneger does not actually speak of a former land connection of Antillea with South America, but I explained above that some geologists advocate an ancient union of the two continents by way of the Lesser Antilles. If such a connection existed, I think it must have been in the pre-Cretaceous times. Most zoologists would deride the idea of any terrestrial species having been transmitted to us unchanged from pre-Cretaceous times to the present day. We have no geological evidence of such a fact, but Dr. Sarasin expresses the opinion that the genus Typhlops, at any rate, is older than the Cretaceous Period. We gather from Dr. Stejneger's researches that the great majority of the Portorican species are western in their affinities, and that Portorico and the more easterly Virgin islands certainly must have been connected with one another in comparatively recient geological times.

As regards Jamaica, Mr. Barbour gives us some interesting details as to its reptiles and amphibians. He emphasises the fact, which I have already alluded to in speaking of the mammals (p. 285), that the distinctive characters of this island are not shared by the rest of the Antilles. Jamaica is related faunistically to Central America and Haiti, while the relationship with Cuba is much more remote. Mr. Barbour thinks that the early separation of Jamaica from the mainland and from Haiti would account for the absence of types having such a distribution as Bufo and Amphisbaena, which may have reached Haiti from Central America by way of Cuba. If fortuitous dispersal has played practically no part in providing the Antilles with a fauna, as Mr. Barbourt is inclined to think, the Bahamas certainly must have belonged to Antillea and cannot have been submerged since. Sixteen

* species of reptiles and amphibians are described by $\mathrm{Mr}$. Barbour $\neq$ as occurring in the Bahaman archipelago. Several

* Stejneger, L., "Herpetology of Porto Rico," pp. $561-563$.

† Barbour, Thomas, "Herpetology of Jamaica." pp. 277-285.

† Barbour, Thomas, "Batrachia and Reptilia of Bahamas." 
of these are peculiar to the group. And yet in spite of this feature, in spite of the fact that two kinds of mammals live on the islands, and that numerous mollusks and other invertebrates are quite confined to the Bahamas, we often read the statement that the fauna of these islands is entirely a product of accidental transport by winds, waves or human agency.

How little influenced the Antilles are by accidental introductions is well shown by a study of such groups as the dragon-flies and their allies (Neuroptera and Pseudoneuroptera), and the butterflies and moths (Lepidoptera). If winds played any active part in their dispersal, we should find many species from, North America in the Greater Antilles, whereas the affinities agree almost precisely with those of the other animals already considered. Several genera of dragon-flies, "known 'both from North and South America, such as Chauliodes, Corydalis, Mantispa and others, are wanting in the West Indian islands, thus showing that the migration between the two continents did not take place across the Antillean area. The great majority of the genera are South or Central American. Only two genera of dragon-flies are confined to the Antilles. On the other hand, many continental ones are absent. The Lesser Antilles contain some South American species which are wanting in the Greater Antilles.* Similarly the Lepidoptera exhibit affinities with northern South America, Central America and Florida. Several characteristically southern families, nevertheless, are wanting in the Antilles. The four large islands are characterised by the absence of many neotropical genera, and the presence of a genus and many species that are peculiar to them. Jamaica. shows some special features of interest. $\dagger$

The birds exhibit similar peculiarities in their geographical distribution. One whole family, the todies (Toditae), are confined to the larger islands of Cuba, Jamaica, Haiti and Portorico. They bear a certain resemblance to the kingfishers, but differ in colour, whereas in habits and shape of bill they resemble the flycatchers. In reality they are related to the Central American motmots. We also have the same striking

* Kolbe, H. J., "Neuroptera und Pseudoneuroptera d. Antillen," pp. $154-161$.

† Pagenstecher, A., "Verbreitung der Schmetterlinge," pp. 391-394.

I.A. 
number of absentees and peculiar species among the birds, as in other groups. Dr. Chapman* is evidently puzzled how to account for the avifauna. Nevertheless, he makes the remarkably suggestive statement that if it could be shown that Central America was cut off from both continents at the time when it was joined to the West Indies, the origin of the island fauna could be explained in a satisfactory manner. That is precisely, I think, what did happen, as I have indicated above.

Cuba presents some special aspects of interest. We have in the first instance quite a remarkable assemblage of fossil mammals. Western Cuba, with its extensive limestone districts, abounds in caves, many of which contain stagnant water or running streams. One of the most remarkable features of these subterranean waters is that they are tenanted by two kinds of fishes belonging curiously enough to a family of deep-sea forms (Brotulidae). These species, Stygicola dentatus and Lucifuga subterraneus, moreover, are blind, as might be expected from their habitat. Another typically marine genus, Atherina, possesses a single fresh-water species (A. evermanni) which is only known from western Cuba. Whether the presence of these marine species in fresh water implies that western Cuba had been submerged below sealevel is a debatable question that need not be further pursued. Other Cuban fresh-water fishes are forms often found in brackish water, or marine forms migrating into fresh water. Besides these there are two species of Heros, a Symbranchus, a Lepidosteus and one Agonostomus, all of which belong to purely fresh-water groups that could only have reached Cuba by means of a continuous system of lakes and rivers between the mainland and the island. Heros tetracanthus and Heros nigricans are members of the family Cichlidae, which has a wide range in South and Central America, only a single species entering the United States. Agonostomus monticola has a wider distribution in the West Indies, and is also met with in Mexico. Lepidosteus tristoechus lives in Mexico and the southern States, while Symbranchus marmoratus is widely distributed in the fresh waters of tropical America. If, as

* Chapman, F. M., "West Indian Bird Life," p. 330. 
geologists claim, western Cuba has been deeply submerged, it seems equally certain that it must have been subsequently joined to Central America. As Professor Eigenmann* remarks, this Cuban fauna has greater affinity with that of Mexico than with that of Florida, showing that the fishes probably reached Cuba by way of Yucatan.

Western Cuba possesses, among other curiosities, blind crustaceans (Palaemonetes). They are what we might call monster prawns, and have probably had marine ancestors. An allied species is known from the subterranean waters of Texas. Faunistically they are not of great importance. Not so, however, the fresh-water crayfishes, which are justly regarded by Dr. Ortmann † as among the most valuable means for demonstrating former changes of land and water. All the species of Cambarus but one inhabit either Mexico or the United States. Only a single crayfish occurs in the isolated position of Cuba. This species (C. cubensis) is closely related to Cambarus mexicanus, whereas the United States species are more distant relatives. Dr. Ortmann assumes on that account a former land connection between Mexico and Cuba.

The fresh-water crabs, as I already indicated, advanced northward from the south, eventually invading the Central American territory and the West Indies. Thus three species of Pseudothelphusa have been discovered in Cuba. One of these (P. americana) ranges from Mexico through Cuba to Haiti. Another (P. terrestris) is confined to Mexico and Cuba, while a third (P. affinis) is restricted to Cuba. Moreover the genus Epilobocera is peculiar to the Greater Antilles, viz., Cuba, Haiti and Portorico, and some smaller neighbouring islands. A species of Pseudothelphusa closely allied to a Venezuelan form is likewise known from some of the Lesser Antilles.

From these facts Dr. Ortmann (pp. 344-347) concludes that the first immigration of fresh-water decapods represented by Epilobocera, into the Greater Antilles, belongs to the end of the Cretaceous or the beginning of the Tertiary era. Cambarus cubensis, he suggests, possibly belongs to it also.

* Eigenmann, C. H., "Freshwater Fishes of Cuba," pp. 220-221.

† Ortmann, A. E., "Distribution of Freshwater Decapods," p. 31 . 
Although it is a primitive form, he prefers to put its immigration in the Tertiary rather than in the Cretaceous. The history and development of the Central American and West Indian region he imagines to have been as follows: "Central America, the West Indies and the northern margin of South America, formed in the Mesozoic Period (certainly during the Jurassic and Cretaceous) a continental mass (Antillean Continent), which was bounded by sea to the north and south (Fig. 15). This continent broke up at the end of the Cretaceous, the chief factor in its destruction being the formation of the Caribbean Sea. The northern remnant of this continent, consisting of the Greater Antilles and parts of the present Central America, probably remained a unit up to the Eocene." At the end of the Eocene, he continues, and during the Oligocene and Miocene Periods, the connection between the Greater Antilles and the mainland was severed, being subsequently re-established toward the end of the Tertiary Era (Fig. 20) and again destroyed in recent times.

$\mathrm{My}$ own views are in some respects similar to those of Dr. Ortmann, yet they differ in a few important points. If we begin, say with later Cretaceous times, when a wide marine channel still separated eastern from western North America, northern South America was submerged, and could not have formed part of the supposed Antillean Continent. Towards the end of the Cretaceous Period, all the Antilles, except the Bahamas, were entirely covered by the sea, according to Professor Schuchert's paleogeographic maps (Map 95). Yet although the peninsula of Yucatan was then submerged, no deposits of this age are known from Guatemala or Honduras, nor have any Mesozoic or Tertiary beds been discovered in these countries. The North American relationship of the relict fauna inhabiting these countries indicates that they were connected by land with western Mexico. I shall also show later on that this region was united by land with western South America before the Isthmus of Panama came into existence. Possibly the Greater Antilles were not so completely covered by the sea as is assumed. They may have been represented by small islands, and these would have possessed fragments of an ancient fauna and flora. Cuba, at any rate, 


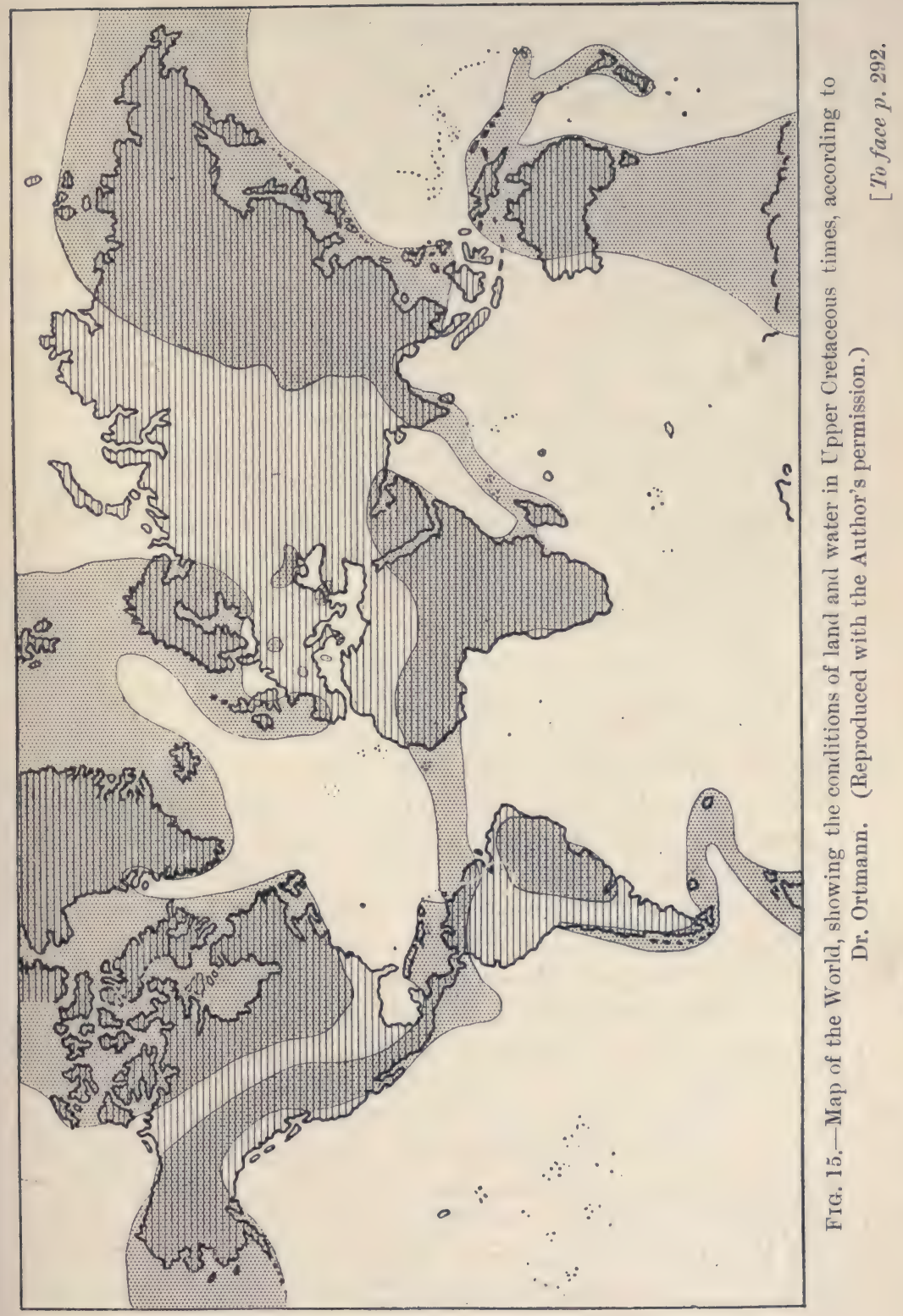



emerged at the beginning of the Tertiary Era, and must then have been joined by land with Mexico. Some time during the Oligocene Period Professor Schuchert again records a complete submergence of all the West Indian islands except the Bahamas. But such ancient types as Typhlops, Solenodon and many others, could not have been destroyed. We might suppose that they took refuge on the Bahamas, and thus repopulated the other islands subsequently. Such a theory, however, is exceedingly unlikely. A much more probable explanation is that the Antilles were reduced to small islands, and retained their old animals and plants. In early Miocene times all the Greater Antilles were certainly raised above the sea, and must have been then connected with one another. Jamaica was joined to Guatemala, and Cuba to Mexico, but Jamaica must have separated early from Haiti. While the islands were joined to one another, an intermingling of the more active ancient types occurred, the less progressive ones being forced to the higher altitudes by the new arrivals from Mexico and Central America. During the whole of Miocene times Yucatan was apparently below sea-level. When it rose in the Pliocene Period, it may have had a short land connection with the Antilles by way of western Cuba. An opportunity was then afforded the mammals of South American type like Amblyrhiza, Megalocnus, and others to spread to the islands. The smaller West Indian mammals came earlier. Central America, during the existence of this Yucatan land bridge, may still have been separated from North and South America. At this time the Lesser Antilles probably had an independent land connection with Venezuela; but that there was an Antillean Continent connected with the mainland in Pleistocene times, as suggested by Dr. Spencer, when Central America had already been invaded by the North and South American immigrants, is entirely opposed to the results derived from a study of the fauna and flora.

As for the trans-Atlantic land bridge, we cannot assume that it oscillated up and down like the Antillean area, where peculiar local conditions produced exceptional changes of land and water. Some time during the Eocene Period it must have enabled European types to travel right across the Antilles and whatever portions of Central America then 
existed, to western North America. I have endeavoured to roughly represent on a map my conception of the geographical conditions then prevailing in North and South America (Fig. 14). Then followed a complete cessation of the migratory stream to North America. This must have corresponded with the depression of the Antilles.' During the Oligocene Period Professor Osborn recorded a re-establishment of the faunal resemblance of western North America with western Europe. Here our correlation of Antillean geology with that of the continental mammalian deposits fails us completely. The supposed Oligocene beds of the Antilles may really belong to the Eocene Period. Another phase of independent evolution then succeeded this faunal interchange with western Europe. This has been represented on another map (Fig. 16), although I am fully aware of the extreme difficulties and pitfalls connected with such an attempt. Later on, in Miocene times, a fresh invasion occurs from the Old World. This, I think, certainly did not come from the same quarter as the others. We may conclude, therefore, that the land bridge between the Antilles and Europe ceased to exist some time during the Oligocene Period. It is quite possible that long after that time large islands may have marked the former site of the land bridge, while temporary land connections between the Azores and Europe, and between the Canary islands and Africa, may have involved certain fragments of the older trans-Atlantic land connection. 


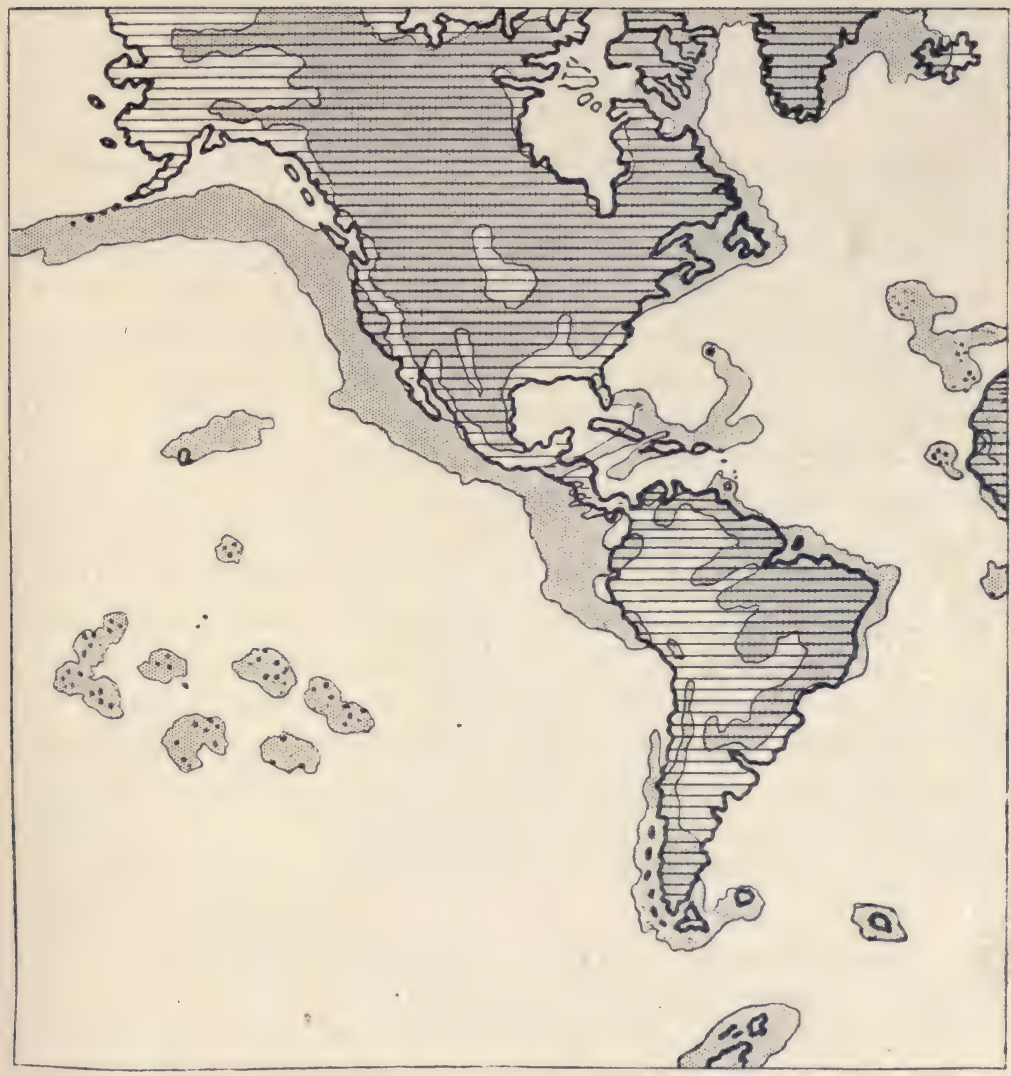

FIG. 16.-Map of North and South America, indicating roughly the supposed conditions of land and water about the middle of the Tertiary Era. The ancient land is slightly tinted. 



\section{CHAPTER XII}

\section{THE GALAPAGOS ISLANDS}

Right on the Equator, off the west coast of South America, in the Pacific Ocean, lies a small group or archipelago of islands known as the "Galapagos islands." There are five large islands and twelve small ones, the most extensive (Albemarle) being about eighty miles long and of very irregular shape, while the four next in importance (Chatham, Indefatigable, James and Narborough) are each about twenty or thirty miles in length, and of a rounded or elongate form. They are best seen on the map representing the range of Helicina (Fig. 11) being situated within the circle nearest South America. The climate of the islands is cooler than that of any other equatorial land at sea-level, because the temperature of the surrounding water is singularly low. This is caused by the Humboldt current, which strikes the islands during its north-westerly course on its way from the cold southern regions. The lower slopes of the islands suffer from want of rain. At a height of a thousand feet and upwards sufficient moisture is condensed to provide for a fairly luxuriant vegetation.

The Galapagos islands differ in two important respects from many of the West Indian islands. They are entirely formed of volcanic rocks, according to $\mathrm{Mr}$. Darwin, who gave us the first reliable description of them, and they are situated at the great distance of seven hundred and fifty miles from the mainland of South America. The nearest land, apart from the small Cocos islands, is Ecuador, to which state the Galapagos archipelago now belongs. In the case of the Antilles almost all authorities are agreed that the nucleus of the fauna represents survivals from the time when the islands were joined to the mainland, and that accidental distribution has not greatly modified the original faunu. In the Antilles we meet 
with a number of ancient types of animals and plants. In the Galapagos islands similar relicts of bygone ages are found, yet their presence on the islands is not generally considered to be due to a former land connection with the mainland. But the question whether the animals and plants inhabiting this archipelago are the descendants of purely accidental visitors or not, is of more than usual importance in this case. Both Mr. Darwin and Dr. Wallace expressed the opinion that the Galapagos islands are of the oceanic type, and that they originated from sub-oceanic volcanoes, having never formed part of a continent or any large land-mass. Many of the more recent observers have followed the lead of our two great naturalists. I need only mention Professor Agassiz, Dr. Wolf, Mr. Salvin, Dr. Dall and Dr. Stearns. On the other hand, Professor Baur was the first to seriously contest the view of these authorities. His researches led to a reconsideration of the problem presented by the fauna and flora of the Galapagos islands and a rejection by many naturalists of the theory so ably maintained by Darwin and his followers.

Islands, as I have already indicated, possess many advantages over continental areas for the study of the laws and phenomena of distribution. The islands we are now dealing with, moreover, are of the most profound importance in connection with the geological history of the two great American continents. We might almost say that the problem of the Galapagos fauna presents the key to the solution of the most complex and intricate questions concerning the American fauna with which we are confronted. It is for this reason that the whole of this chapter will be devoted to an exhaustive survey of the Galapagos islands and their inhabitants.

When Darwin landed on the archipelago in 1835, he noted in the first instance the fact that all the islands were formed of volcanic rock and that they contained numerous craters. The craters he found to consist either of lava and scoriae, or of finely-striated sandstone-like tuff. All the latter, which he examined, had the southern sides either much lower than the other sides, or quite broken down and removed. He concluded from this fact that all these craters were formed beneath the sea, and that their broken state was due to the action of the waves produced by the southern trade winds. On the other 
hand, Darwin's* remark that he noticed a few fragments of granite curiously glazed and altered by heat among the ejectamenta, would seem to imply that the bases of the craters are composed of older forms of eruptive rocks. This supposition is strengthened by an observation made by Professor Suess, $\uparrow$ that on the whole of the Pacific coast of America only a single mountain range comes to an abrupt termination on the Pacific coast, namely, the Central American continuation of the Antillean Cordillera, and that precisely at the point where we might imagine the arcuate prolongation of this chain to meet the principal South American mountains lie the volcanic Galapagos islands. At any rate, as Dr. Blanford $\ddagger$ has pointed out, the rocks of an island may be entirely volcanic, although. the island may nevertheless be a remnant of a continental mass. Except that some of the craters have their southern faces broken down, which may be due to some other cause than that suggested by Darwin, the Galapagos islands could just as well represent the mountain tops of sunken land as the summits of originally submarine volcanoes. Neither of these two theories is supported by strong geological evidence. No one was more impressed by this fact than Darwin himself, and he bases his theory of the origin of the Galapagos fauna and flora almost entirely on the nature, composition and distribution of the animals and plants he found on the islands. His conclusions were that all the animals and plants must be derived from accidental transport by sea-currents or by birds, except for a few recent immigrants which were introduced by man.

The natural history of the islands, as Darwin truly remarks, is eminently curious and well deserves attention. Of terrestrial mammals, he says, there is only one which must be considered as indigenous, namely a mouse (Mus galapagoensis). A rat also is sufficiently distinct from the common kind to have been named and described, "but," continues Mr. Darwin, "as it belongs to the Old World division of the family, and as this island had been frequented by ships for the last hundred and fifty years, I can hardly doubt that this rat is merely a

* Darwin, C., "Journal of Researches," pp. 270-271.

† Suess, E., "Das Antlitz der Erde," ПI., p. 263.

† Blanford, W. T., "Anniversary Address," p. 34. 
variety, produced by the new and peculiar climate, food and soil to which it has been subjected." Hence Darwin * considered the rat as imported by man, and he adds that the transportation of the mouse in a vessel from the mainland is not improbable.

Dr. Wallace concurs with Mr. Darwin in the belief that the Galapagos islands agree with all other oceanic islands in so far as they are devoid of indigenous mammals. He acknowledges that the mouse, which had since been found to belong to the American genus Hesperomys, differs somewhat from other known species. Yet he remarks that we can scarcely consider the species to be indigenous, firstly because these creatures have been little studied in South America, and that there may still be many undescribed mice there, and in the second place because even had it been introduced by some European or native vessel, there would have been ample time in two or three hundred years for the very different conditions to have established a marked diversity in the characters of the species. Dr. Wallace + reiterates in conclusion Darwin's statement that the islands are really destitute of truly indigenous mammals.

Now since these great naturalists wrote about the Gala. pagos archipelago, and stated their opinions on the mammalian fauna of the islands, the latter have been visited by many competent observers, who brought their collections home for careful study. Thus the mammals collected by Dr. Baur on the islands were described by Dr. Allen, who recognised among them a typical brown rat (Mus decumanus). He also thought that a skeleton which was picked up on South Albemarle belonged to the black rat(Mus rattus). There was likewise a bat which he identified as closely allied to a Chilean form, but sufficiently distinct to deserve the separate name of Atalapha brachyotis. Dr. Allen, $\ddagger$ moreover, points out that the Galapagos mouse does not belong to the Old World genus "Mus" nor to "Hesperomys," but agrees with Oryzomys, the well-known American rice-rats. Besides

* Darwin, C., “ Juurnal of Researches," p. 275.

† Wallace, A. R., "Island Life," p. 278.

$\ddagger$ Allen, J. A., "Mammals from the Galapagos Islands." 
Oryzomys galapagoensis he found a second distinct form which he named Oryzomys bauri.

A more important natural history survey of the islands was made by the Hopkins Stanford Expedition in 1898. In addition to the mammals already known from the archipelago, it was discovered that Narborough, Indefatigable and Seymour islands are inhabited by rice-rats, which show such structural distinctness in the interorbital portion of the skull that Mr. Heller * proposed their being placed into the new genus "Nesoryzomys." Four mouse-like mammals are thus known to be peculiar to the Galapagos islands, viz., Oryzoinys galapagoensis, O. bauri, Nesoryzomys indefessus and N. narboroughi. The only other terrestrial mammal not found elsewhere is Atalapha or, as it is now called, Lasiurus brachyotis.

It is interesting to note that the genera to which these species belong are characteristically American. Both Oryzomys and Lasiurus have a wide range in North and South America as well as in the Antilles. We have learned that Oryzomys antillarum is confined to Jamaica. Another species lives on St. Vincent, and several more on Trinidad, while a species (O. nelsoni) is peculiar to the Tres Marias islands off the west coast of Mexico. A genus ranging from New Jersey in the north to Tierra del Fuego in South America, with a large number of species, must be a very ancient one; and yet not a single species occurs outside the New World.

I have never hitherto alluded to bats because they are so generally regarded as of little value in faunistic problems. Specialists of this group, such as Dr. Knud Andersen, $\dagger$ inform us, however, that this assumption is by no means correct, and that in most cases bats are as good and reliable zoogeographical guides as other small but non-flying mammals. The fact that although Lasiurus is found from Canada to Patagonia it has nevertheless preserved its original habitat in the New World, and has not even crossed Bering Strait into Asia, would seem to support Dr. Andersen's contention, while its antiquity is vouched for by the occurrence of distinct species of Lasiurus on several remote American islands.

* Heller, Edmund, "Mammals of Galapagos Archipelago."

† Andersen, K., "Geogr. Distribution of Rhinolophus," p. 652. 
Lasiurus has likewise succeeded in reaching one other group of islands besides the Galapagos archipelago, namely the Sandwich islands. The latter are inhabited by Lasiurus semotus, which is peculiar to them, and cannot therefore be considered as a recent human importation.

Our present knowledge of the mammalian fauna of the Galapagos islands has added one factor of extreme importance to those hitherto known, namely the certainty that there are indigenous mammals on the archipelago. For this reason the Galapagos islands should be excluded from the oceanic islands, and be placed among the islands which once formed part of a larger land-mass or continent. It is not certain, however, that Darwin and Wallace would have taken that view, even had they been convinced that the mammals alluded to were truly indigenous in the islands. Some naturalists hold that even mammals can be successfully transported across the ocean on tree trunks and floating islands. Dr. Stearns, ${ }^{*}$ in alluding particularly to the Galapagos fauna, remarks that a single tree of large size might carry with it not only molluscan and insect life, but also living individuals of many vertebrate forms that found refuge or safety upon it. Thus, he continues, if the environmental conditions were at all favourable, colonies of many animal forms could be transplanted to distant regions. The possibility of such an accidental transportal must have been carefully considered and rejected by Darwin and Wallace. The Humboldt current I alluded to as striking the Galapagos islands does not come from the coast of Ecuador nor from Central America. It originates in the far south, and, passing northward, skirts the coast of Chile and southern Peru, and then leaves the land in a north-westward direction. The tree trunks spoken of by Dr. Stearns as carriers of all kinds of animal life would have had to travel several thousand miles, no doubt experiencing stormy weather on the way, before they could have safely deposited their loads of vertebrates on the shores of the Galapagos islands. If these floating trees are responsible for the present mammalian fauna of these islands, how is it that they have brought nothing new to them since their occupation by man ?

* Stearns, R. E. C., "Mollusk-fauna of the Galapagos Islands," p. 366. 
Man has brought the brown and the black rats apparently. Why should the agencies of accidental transport have been so much more potent in the distant past than they are now ? We might add also, is it possible that these same agencies should be able to select the most ancient forms of life as more suitable for transport than more modern productions? Of course, these ideas of mammals being carried across a vast expanse of ocean and safely landed on a distant shore are mere conjectures unsupported by any evidence.

"Of land-birds," says Mr. Darwin, "I obtained twenty-six kinds, all peculiar to the archipelago and found nowhere else, with the exception of one lark-like finch (Dolichonyx oryzivorus) from North America." Of waders and water-birds he succeeded in capturing eleven kinds, only three of them being new species. In 1875 the number of land-birds known to $\mathrm{Mr}$. Salvin had increased from twenty-five to thirty-six species. Most of the genera to which they belong are of very wide distribution; seven, however, are confined to continental America, leaving five peculiar to the islands. Mr. Salvin * expresses no doubts as to the correctness of Darwin's interpretation of the origin of the Galapagos islands. Hence he concludes that the birds now found on the islands, being related to American birds, must have emigrated from America and have become modified by the different climatic conditions with which they were surrounded. A later review of the Galapagos birds was undertaken by Mr. Ridgway $\dagger$ in 1897, when the number of land-birds recorded from the islands was nearly doubled. He notes the exact distribution of the various species and varieties in detail, and shows how circumscribed their range is. Of the five genera peculiar to the islands only two, viz., Nesomimus and Nesopelia are of evidently American relationship. The remaining three, he thinks, have so obvious a leaning towards certain Hawaiian dicaeidine forms, that the possibility of a former land connection with the Sandwich islands, either continuous, or by means of intermediate islands as "stepping stones," becomes a factor in the problem of their origin. "It may be," he adds, "that the resemblance of Cocornis, Cactornis and Camarhynchus

* Salvin, O., "Avifauna of Galapagos Archipelago."

† Ridgway, R., “Birds of Galapagos Archipelago,” p. 467. 
to the above-mentioned Hawaiian forms, is merely a superficial one, and not indicative of real relationship. Drs. Rothschild and Hartert, indeed, believe that this is the case, but as a certain affinity between these widely separated islands undoubtedly exists in some other groups, Mr. Ridgway's view may possibly turn out to be the correct one. Moreover, as Mr. Ridgway points out, two of the Hawaiian Procellariidae, viz., Aestrelata phaeopygia and Oceanodroma cryptoleucura occur in the Galapagos islands.

Drs. Rothschild and Hartert* derive the whole avifauna from America. All the same, their studies do not lead them to adopt Darwin's theory. They remain uncertain whether the fauna points to a former land connection with the mainland or whether it owes its existence to accidental dispersal. That there should be this doubt in their minds is rather surprising, considering their own statement that the geological evidence is entirely opposed to the theory of a former land bridge between the islands and America.

The most recent study on the birds of the Galapagos archipelago is that of Messrs. Snodgrass and Heller.† Taking the general results of all these papers, there can be no doubt that the avifauna is mostly related to South and Central America and the West Indies, thus agreeing in that respect with the mammalian fauna.

The reptiles of the Galapagos islands certainly offer the greatest difficulty to the acceptance of Darwin's theory that the islands have risen from the floor of the ocean and have never been connected with one another or with the continent. Darwin observed only one small lizard belonging to a South American genus, two different kinds of the great lizard Amblyrhynchus - a genus confined to the islands-one kind of snake and a land tortoise. He noticed that the one kind of Amblyrhynchus lived altogether on land, the other being semi-aquatic. The latter he described as a hideous looking black creature up to four feet in length, with a laterally. flattened tail and webbed feet. Sluggish in their movements on shore these huge lizards are expert swimmers, darting

* Rothschild, W., and E. Hartert, "Ornithology of the Galapagos Islands," pp. 137-139.

† Snodgrass, R. E., and E. Heller, "Birds of the Galapagos Islands." 
among the rock-pools and feeding there on seaweed. The terrestrial species has no webs on the toes, and is of about the same size as its aquatic relative, reddish brown above and yellow underneath. It inhabits burrows, which occur in such numbers that the soil is constantly giving way as one walks over them, much to the annoyance of the tired traveller, as Mr. Darwin * remarks. Some of the tortoises, according to Darwin, grow to an immense size, yielding as much as two hundred pounds of meat. Like the two lizards they are entirely vegetable feeders.

When Dr. Günther $†$ described the reptilian fauna of the islands he distinguished five species of lizards instead of the three mentioned by Darwin. The gigantic tortoises, moreover, he thought, were referable to five distinct forms, every one of them inhabiting a different island. He did not speculate on their origin or past history, but mentioned that, although large land-tortoises are now restricted to the two widely separated regions of the Galapagos islands on the one hand, and the Mascarenes and Seychelles on the other, they formerly had an extensive range. In the Miocene Period they lived in India, southern Europe and in North and South America. We may consequently look upon the few survivors as relicts of Tertiary times. $\neq$

More recent researches on the reptiles show that there are far more distinct forms than was anticipated even by $\mathrm{Dr}$. Günther. Mr. Garman $\S$ alludes to twenty-two species, among them several geckos. He does not enter into a discussion as to their origin; he merely states that two theories have been advanced to explain the affinities of the fauna.

The Hopkins-Stanford Expedition of 1898 made such extensive collections on the islands that many additional forms were discovered among the material sent to the Museum of the Stanford University. Mr. Heller, who describes the reptiles, mentions twenty-five species and several varieties. Nine of these are giant tortoises, fifteen are lizards, and there is one snake. Among the lizards there are six geckos (Geckonidae)

* Darwin, C., "Journal of Researches," pp. 278-284.

† Günther, A., "Zoological Collections from Galapagos," p. 66.

‡ Günther, A., "Gigantic Land-tortoises," p. 253.

§ Garman, S., "Reptiles of Galapagos Islands." 
belonging to the two genera Gonatodes and Phyllodactylus. The single species of Gonatodes is most closely allied to a species found in the West Indies, while the genus also occurs along the coast of Ecuador and Peru. Of the five species of Phyllodactylus, four are peculiar to the Galapagos archipelago and more or less nearly related to P. tuberculosus, the non-peculiar species being distributed along the west coast of Mexico, Central and South America as far as Ecuador. All the species of Tropidurus, a genus belonging to the family Iguanidae, are peculiar and closely related forms, most of them being confined to different islands. The genus is principally found in Peru and Ecuador. The two very large lizards which Darwin observed really belong to distinat genera. Two species of Conolophus are now recognised, while the aquatio form still retains the original name of Amblyrhynchus cristatus. Both genera of Iguanidae are quite peculiar to the archipelago and distantly related to a South American genus. Finally, the snake Dromicus biserialis, which is met with on seven of the islands, is nearly akin to D. chamissonis of Chile and Peru.

The reptiles thus exhibit affinity with those inhabiting western South America, Central America and the West Indies. If they had reached the Galapagos islands by means of marine currents, as has been alleged, one may be tempted to ask the same question as I put before-Why should practically all the species belong to ancient types? Giant tortoises seem to have become extinct on the continents in Miocene times, while the lizards of the archipelago belong to the two families Geckonidae and Iguanidae. Although no fossil representatives of the Geckonidae are known, the resemblance of their vertebrae to those of the Palaeozoic Microsauri has been commented upon as indicating their ancient lineage. The genus Phyllodactylus occurs in tropical America, in Africa, Madagascar, Australia and on Norfolk and Lord Howe's islands in the Pacific. A single species inhabits the western Mediterranean region. The distribution of the genus, therefore, is suggestive of a very remote origin. Of the Iguanidae, as I have already pointed out, (p. 127), we know that they lived in America in Cretaceous, and in Europe in Eocene times, while at present they are confined to North and South America with the outlying 
Tres Marias, Galapagos and Chiloë islands. Beyond this centre of distribution there are only two remote stations, one in Madagascar, the other on the Fiji islands. We could not have a better example of discontinuous distribution, which, as Dr. Wallace has always urged, is a proof of antiquity. Lastly, the Galapagos snake belongs to the ancient family Colubridae, which also includes Tropidonotus, a genus specially alluded to (pp. 128 and 222).

In spite of these facts, Mr. Heller* expresses the opinion that the archipelago is mostly of Tertiary age, and that the fauna has been chiefly derived from material carried by ocean currents.

Still another expedition has lately been sent to the archipelago by the California Academy of Sciences. Dr. Van Denburgh $\dagger$ who was asked to report on the reptiles feels quite convinced that the islands must all at some former period have formed parts of a single land-mass. In a letter which he addressed to me, he implies that several species of snakes inhabit the islands. He states that "the closest relatives of the serpents of the Galapagos archipelago are native to the Bahamas, Greater and Lesser Antilles, Costa Rica and the whole of South America. This being true, the snakes of these localities must have had a common origin. Either the West Indian and Galapagos snakes have been derived from South America, or else all must be descendants of species occupying a great central land-mass which has sunk below the level of the sea, leaving mere remnants in Central America, northern South America, the Antilles and the Galapagos. Either view implies a former land connection and a continental origin of the Galapagos ophidian fauna. I cannot bring myself to share the opinion of those who believe that the fauna of the Galapagos has reached these islands by the more or less accidental agency of the winds and ocean currents."

When Dr. Stearns $\ddagger$ reported upon the land and fresh-water snails inhabiting the Galapagos archipelago, he alluded to one

* Heller, E., "Hopkins-Stanford Expedition : Reptiles," pp. 46-48.

† Denburgh, John Van, "Preliminary Descriptions of Land-tortoises," p. 1.

† Stearns, R. E. C., "Mollusk-fauna of the Galapagos," pp. 359-370. L.A. 
species of Hyalinia, a large number of Bulimuli, two Pupae, one Leptinaria, a Succinea and a Helicina as having been collected on the islands by previous visitors. He then dilates upon the various accidental means of transport, and concludes that the agency of winds and ocean currents is amply sufficient to explain the origin of the molluscan fauna. He acknowledges that the archipelago is situated within an almost windless area, where storms are of rare occurrence, yet maintains that during the course of ages the climatic features may have been different from those obtaining at present. $\mathrm{He}$ also emphasises the fact of the tenacity of life of mollusks and the length of time they are able to subsist without food, claiming that a theory which will fairly explain a good portion of the phenomena of distribution by such agencies and operating directly under our eyes, is preferable to those, however plausible and attractive, involving conjectural and remoter conditions.

In his endeavour to support the theory of accidental distribution as applied to the origin of the Galapagos fauna, Dr. Stearns seems to forget that no observation has ever been made clearly indicating the conveyance of mollusks or their eggs in drift-timber. Mollusks have never been found in the crevices or under the bark either of trees encountered on the sea or of those stranded on foreign coasts. Very shortly after the trees are stranded, they are no doubt invaded by all sorts of creatures seeking moisture and shelter; but the theory of accidental distribution, so ably advocated by many eminent naturalists still involves a good deal of the conjecture which Dr. Stearns is so anxious to avoid. Although Dr. Dall * fully acknowledges that we possess no actual proof in support of the drift-theory, he also concurs with Dr. Stearns in the opinion that there can be little doubt of the land snails having been introduced to the Galapagos islands in that manner. In his review of the molluscan fauna of the islands, he mentions thirty-three species of Bulimuli, two species of Vitrea and one of Conulus, two Pupae, four Succineae, one Tornatellina (Leptinaria), one Helicina and finally one Endodonta. Of these forty-five species, only a 
couple are probably common to the islands and the mainland. All the others are restricted and quite peculiar to the Galapagos archipelago.*

The genus Bulimulus, to which most of the Galapagos snails belong, comprises mostly species with ovate large heavy shells, which would seem to be peculiarly unfit for accidental transport by marine currents, though many live almost habitually on shrubs. As defined by Dr. Pilsbry, the genus is restricted, as I have already indicated, to the western borders of South and Central America and beyond the latter as far north as Mexico and Lower California. Eastward it passes along the northern States of South America to Brazil, it extends to the Antilles, and from Mexico to the southern United States. Thus it is limited to North, South and Central America, the West Indies and Galapagos islands. The Melanesian genera Liparus and Placostylus are closely related. The range of the large family Bulimulidae is very similar, one group being confined to America, the other to the opposite side of the Pacific, from Tasmania in the south through Australia to China northward, and eastward to the Society islands. One is almost tempted to invoke a Pacific continent in explanation of this curious discontinuous distribution. It seems as if the family had originated in some central Pacific area and had taken refuge on the nearest lands east and west on the disappearance of its ancient habitat. But we need not consider this problem at present.

There are three groups of apparently very closely related Bulimuli in Chile and Peru, in the Galapagos islands and in Lower California. The shell in these groups certainly is very similar, being narrow and elongated, and possessing the same texture. All the same, Dr. Pilsbry $\dagger$ is of opinion that this similarity in appearance is not to be looked upon as indicating close relationship, but as a case of convergence produced by similar environments. He recognises three sections of Bulimulus according to the sculpture of the apical whorls of the shell. The first of these lives in Argentina, Chile, Peru and Bolivia, the second in tropical America, the Galapagos islands

* Dall, W. H., "Insular Land-shell Faunas : Additions."

† Pilsbry, H. A., "Manual of Conchology," (Pulmonata), X., p. 127. 
and West Indies, the third in Mexico and the United States.

The two species of Vitrea (Hyalinia) seem to be related to the Vitrea radiatula group, which, like Conulus, has a very wide range in the Old World and the New. One of the Galapagos species of Pupa is apparently found in Ecuador also, the other is peculiar to the islands. The genus has a worldwide range. All the species of Succinea, a genus which has an enormous range, are confined to the islands. Tornatellina chathamensis is closely rèlated to the Hawaiian Achatellina and belongs to a typically Polynesian genus. Helicina, as already pointed out (pp. 157-158), has evidently invaded America from the Pacific. Considering that it is an operculate shell, and therefore supposed to be specially fitted for transport across the sea by marine currents, it is surprising that only a single species of Helicina should have taken advantage of these facilities (compare Fig. 11). Lastly, one species of Endodonta (E. helleri) has been observed on the archipelago. Of the Galapagos mollusks this is one of the most interesting, because the extremely primitive genus Endodonta is almost confined to the Pacific region, including New Zealand, Tasmania, Australia, New Guinea and the Philippine islands. Only St. Helena, where it is also found, lies entirely outside the area. It is significant that not a single species is known from the American or Asiatic mainlands or the West Indies.

I cannot help thinking that the attempt to derive the Galapagos molluscan fauna from America is a mistake. The family Bulimulidae is Pacific in origin, rather than American. Succinea and Pupa have a wide range in the Pacific islands, Tornatellina and Endodonta are altogether Pacific, being unknown in America, Helicina is mainly Pacific, and it has entered America from the west. Only Vitrea and Conulus may be looked upon as typically American and Old World genera of great antiquity. With their exception all the other genera except two are more likely to have passed into America from the direction of the Galapagos islands than vice versa. The two others stopped short at the Galapagos archipelago and went no further east.

Too little is as yet known of the insects of the islands and 
their distribution to be of much service in this study, but Dr. Günther records a woodlouse (Cubaris galapagoensis), which is apparently related to a West Indian form. The genus Cubaris, which is otherwise confined to the West Indies, Florida, Central America, California and South America, is the American representative of Armadillo. The latter has its headquarters in southern Europe. Cubaris, no doubt, owes its presence in America to the fact that some ancestor common to it and the European Armadillo crossed over by the transAtlantic land bridge described in the last chapter.

On the whole, remarks Dr. Wallace, * the flora agrees with the fauna as indicating a moderately remote origin, great isolation, and changes of conditions affording facilities for the introduction of organisms from various parts of the American coast, and even from the West Indian islands and the Gulf of Mexico. As in the case of the birds, he continues, the several islands differ considerably in their native plants, many species being limited to one or two islands only, while others extend to several.

A point of great importance in connection with the theory of dispersal of seeds by marine currents is the condition of the coasts of the Galapagos islands. The dried up desert aspect of the islands on landing has been commented upon by Darwin. Dr. Wolf $\dagger$ gives us his impression of the same islands during the rainy season. The lower zone up to six hundred feet is only very sparsely covered by vegetation. The whole landscape has a greyish-brown appearance. A Lantana, a couple of Crotons and a few Euphorbiaceae and Compositae are the principal members of this wretched flora. The only plants that thrive in this district are two giant Cactuses, reaching to a height of about twenty feet. They seem to select the driest and roughest spots, where nothing else will grow. Herbaceous plants are restricted in this lower zone to a few parched grasses and a few shrivelled diminutive plants. There are very large districts, moreover, where nothing whatsoever will grow, the ground being paved, as it were, with enormous blocks of lava. At a height of about

* Wallace, A. R., “Island Life," p. 289.

† Wolf, Th., "Die Galapagos Inseln," pp. 257-260. 
seven hundred feet the scenery changes completely. A fresh and moisture-laden wind greets us from the south-east, the ground is covered with short dense grasses, evergreen, shady little woods are dotted about here and there, and the flora as a whole is quite different from that below. Those acquainted with the flora of Ecuador will feel as if transplanted to the woods of the Páramo region, which flourish at a height of about 9,000 feet. The most striking character of the flora is its strong endemism, every one of the larger islands having its peculiar species, which do not range to the others even when the islands are in close proximity to one another.

From Dr. Wolf's graphic description we can gather valuable information. In its strongly endemic character the flora of the archipelago agrees perfectly with the fauna. As among the animals so it has been noticed among the plants that the various islands all possess their own species, though the latter are related to one another. But, in answer to our inquiries into the causes of this singular distribution, we are told by Dr. Wolf that he concurs with Darwin in the belief that the islands received their plants, as well as their animals, by accidental means of transport. He does not specify these means of transport. Darwin* makes it perfectly clear to us that winds could not have played any part in it. "As the archipelago is free to a remarkable degree," he says, "from gales of wind, neither the birds, insects, nor lighter seeds, would be blown from island to island." If the seeds were carried by marine currents from the mainland to the archipelago, how were they afterwards conveyed from the inhospitable shores of the islands across the almost absolute desert of the lowlands to the higher level? We are unacquainted with any forces except wind, which would carry the seeds to a height of seven hundred feet, but Darwin expressly tells us the islands are remarkably free from wind. Moreover, we should expect the plants found at that height in the Galapagos islands to agree to some extent with the flora of the lowlands of the continent. Few, if any, seeds carried down by rivers would come from the highlands of the Andes. Yet the Gala-

* Darwin, C., "Journal of Researches," p. 290. 
pagos flora possesses affinities with the highlands rather than the lowlands.

In this brief account of the main features of the fauna and flora of the Galapagos archipelago I have endeavoured to state mainly the opinions of those who agree with the theory of elevation as propounded by Darwin. Some authorities formulated no decisive views on the subject. It is currently believed that the first criticism of this theory was brought forward by Professor Baur * in 1890 , in a paper on the variation of the genus Tropidurus in the Galapagos islands. Although it was the first serious criticism, Mr. Andrew Murray $†$ remarked much earlier that Darwin's observations on the Galapagos fauna had led him to an entirely different conclusion. "The American type of the whole group," he says, "speaks primarily of connection with the continent. The family facies of the group inter se, speaks of a period when the whole islands were separated from America, but united to each other. The endemic peculiarity of the species of each individual island tells of subsequent separation and change wrought in each, probably at the same time, by the alteration of climate from continental or terrestrial, to isolated and oceanic."

It was not until 1891, when a more popular account of Professor Baur's views appeared in the "American Naturalist," that his opinions led to considerable discussion both in America and in Europe. It had seemed as if Darwin's theory, supported as it was by Wallace, Hooker, Agassiz and many other naturalists of less note, was unassailable. Nevertheless, Professor Baur's careful reasoning induced many subsequent writers to adspt his views in preference to older ones. He urged with Dr. Wallace that all islands may be divided into Continental and Oceanic ones. The first have developed from continents or larger bodies of land through isolation or subsidence. The second have not been so formed, but have arisen from submarine portions of the earth by elevation. He thought that the fauna and flora of the first group of islands would be more or less harmonic, that is to say, the islands would be like satellites of the continent from which they took their origin. The fauna and flora of the second

* Baur, G., "Variieren der Eidechsen-Gattung Tropidurus."

† Murray, A., "Distribution of Mammals," p. 17. 
group, however, ought to be disharmonic, for it will be composed of quite a different mixture of animals and plants, since they have been introduced accidentally from other land areas. Accidental immigrants will also reach the continental islands eventually in a similar manner. Thus continental islands may be composed of two faunal and floral elements, an original and a secondary one. Oceanic islands, on the other hand, can only contain a secondary faunal and floral element, and will, therefore, not exhibit harmonic distribution. Since the distribution of the animals and plants on the Galapagos islands is harmonic, just as it is on the West Indian islands, both of them, according to Professor Baur, represent the remains of land-masses that have been split off from the adjoining continent, and they have not risen from the floor of the ocean. Though agreeing in his final conclusions with Professor Baur, I am unable to follow him in regard to his definitions of "harmonic" and "disharmonic." Some of the Pacific islands are looked upon by Professor Baur himself as remnants of a Pacific continent, others, I believe, are not. Where is the exact distinction between them in the nature of their fauna?

A few years later Professor Baur* once more returned to the subject in order to answer the objections brought against his theory by numerous critics. He also intended to make some remarks on the geological history of the Pacific Ocean, and from his preliminary observations it is evident he believed in its comparatively recent age; but before he could complete his interesting series of articles his sudden death unfortunately deprived us of further communications. From his writings, however, we know that Professor Baur believed that the Galapagos archipelago represented the remnants of a large peninsula which joined the West Indies by way of Cocos island and Central America. As some of his oritics maintain that in his views Professor Baur stands almost alone, and is opposed by most of those who have discussed the fascinating problem of the origin of the Galapagos archipelago, a few remarks may be permissible in support of this theory.

Alluding to the gigantic land-tortoises which have survived

* Baur, G., "New Observations on the Galapagos Islands." 
on the Galapagos and various other islands, Dr. Gadow * asks the pertinent question-Where did all these creatures come from, and how did they get to these oceanic islands? Accidental transport is out of the question, as land-tortoises are drowned within a few hours after immersion in water. Since none of their kind inhabit the great continents now, although they lived there formerly, we are constrained to assume that the existing species are the survivors of tortoises which proceeded to the islands when they were connected by land with the adjoining continents. In another place Dr. Gadow quotes the Galapagos tortoises as supporting the hypothesis of an Oligocene extension of land, considerably to the west and south of the present Central America.' In his maps illustrating the palaeogeography of Middle America, he actually joins the Galapagos islands with the Antilles, as Professor Baur had done, by way of Cocos island. $\dagger$

Professor Boettger $\ddagger$ approves of the results obtained by Professor Baur's methods of investigation, arguing that the facts of distribution are much more easily explained by the assumption of a former land connection between the Galapagos archipelago and Central America than by the theories hitherto accepted.

While in general agreement with the same views, Dr. Sarasin § suggests that the ancient land bridge lay in a northeastward direction, that is to say, from the Galapagos islands towards Mexico rather than to Ecuador.

The fossil marine mollusks and their distribution are employed by Dr. von Ihering $\|$ in support of the same theory. He draws attention to the remarkable fact that the species of the Tertiary Chilean deposits only appear on the Californian coast in Pleistocene times, and that similarly the Californian Tertiary forms only reached the coasts of Chile about the same time. On these grounds alone Dr. von Ihering bases his theory of a Tertiary peninsula extending westward into the Pacific Ocean and embracing the Galapagos islands,

* Gadow, H., "Amphibia and Reptiles," p. 373.

† Gadow, H., "Mexican Amphibians and Reptiles," p. 211.

† Boettger, O., "Baur's Differentiation of Species," p. 462.

§ Sarasin, F., "Die Fauna der Galapagos Inseln," p. 293.

|| Thering, H. von, "Fauna der Neotropischen Region," p. 296. 
which thus acted as a barrier in separating the North American from the South American fauna (see Fig. 17).

That the distribution of reptiles and mollusks on the Galapagos islands points to a former land connection with the American mainland is especially urged by Dr. Arldt,* but, like Dr. Ortmann, he thinks the islands must have been isolated since the end of the Mesozoic era. The land connection referred to is shown in Dr. Ortmann's $†$ map illustrating the distribution of land and water during the Upper Cretaceous Period (Fig. 15).

As regards the flora, Messrs. Robinson and Greenman contend that no species to be found on the different islands illustrates the noteworthy racial divergence in related forms better than Euphorbia viminea. This species differs markedly in foliage from any other known member of the large genus Euphorbia and is characteristic of the Galapagos archipelago. Being essentially a desert plant, it can subsist even upon those islands of the archipelago which are of low altitude and do not attain the upper regions of moist atmosphere. The most cursory inspection of the forms from the different islands discloses marked variation in the contour, size, thickness, rigidity and colour of the leaves, as well as in the length of the internodes, colour of the stems and so forth, whereas more careful examination shows that these are not mere individual differences, due to chance, state of development, or individual environment, but that each form appears in general to be restricted to a single island.

The question consequently presents itself, according to Messrs. Robinson and Greenman, " "If this archipelago is composed of islands of elevation, built up from the sea-floor independently by volcanic action, how has such a distribution been effected?" If the vegetation has been derived from the mainland by chance transportation of seeds, it is quite impossible to believe that each island has received a slightly different form of the same species, and we are forced to the much more natural assumption that racial and varietal divergence has

* Arldt, T., "Entwicklung der Kontinente," p. 116.

† Ortmann, A. E., "Distribution of Decapods," p. 381.

t Robinson, B. L., and J. M. Greenman, "Galapagos Flora," pp. 135137. 


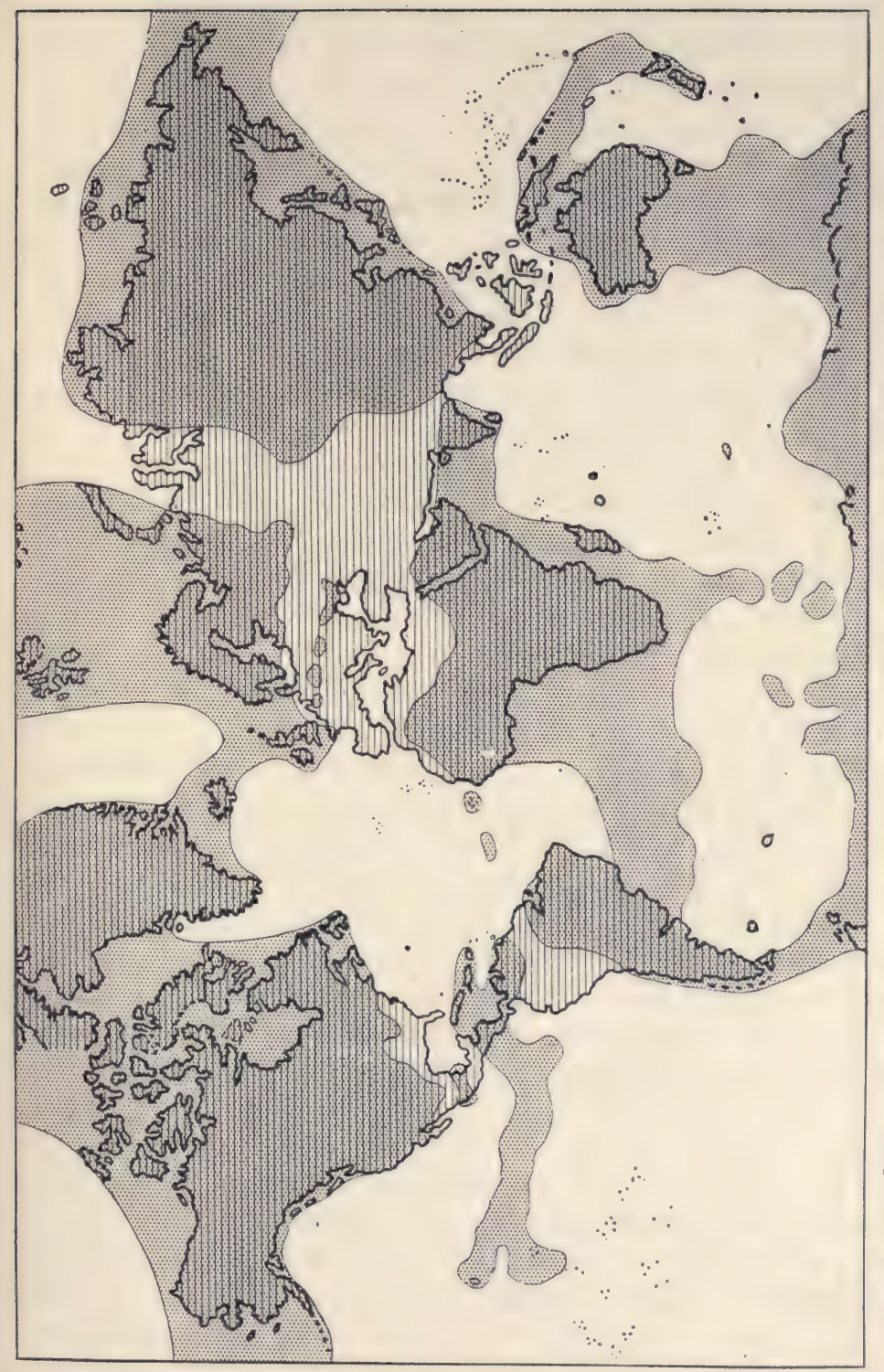

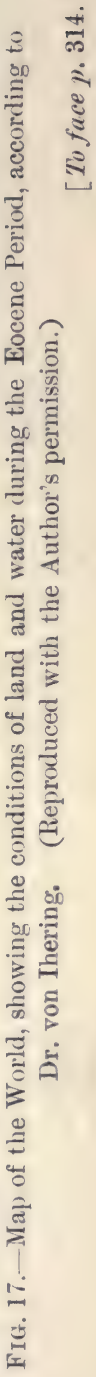



come about after the introduction of the species on the islands. Continuing the supposition that these are islands of elevation, the seeds of Euphorbia viminea must have reached them in one or two ways. Either every one of the nine islands where we know the species now to occur must have received its seed directly from the mainland, or, what is much more natural, seed must have reached one or more of the islands and from these have spread to the rest. That the same species should have reached all these islands presupposes a considerable facility of transportation. But as soon as this is granted, it is impossible to understand the highly individual development of the forms on the different islands. For relative or complete isolation seems necessary to account for the racially divergent floras of the islands, and especially for the occurrence of only one form on each island. On Dr. Baur's assumption of a former union between the islands, and subsequent separation by subsidence, the authors maintain that not only is an explanation of the facts possible, but the existing flora of the archipelago is just that which would most naturally result from such an origin. A former union of the islands would account at once for the occurrence of identical ancestral species upon the different members of the group. The subsequent separation would give the needed isolation for varietal and racial divergence, while the latter could not have come about if a continual interchange of seed were taking place from island to island.

Messrs. Robinson and Greenman's careful reasoning is just as well applicable to the birds of the genera Geospiza, Certhidea and Nesomimus, to the reptilian genera Tropidurus and Testudo, and to the snail Bulimulus as it is to Euphorhia viminea, and from a study of any of them we should come to precisely the same conclusion as these authors. $\mathrm{Mr}$. Hemsley * thinks the biological data which we possess from the Galapagos islands are strongly in favour of Professor Baur's views, and he supposes the area on which the islands stand to have been continued eastward to the mainland of Veraguas.

Professor Stewart does not produce any new data for or

* Hemsley, W. Botting, "Insular Floras," VI. (A), p. 299. 
against the theory of a former land connection between the islands and the mainland. He scarcely discusses the problem from a botanical point of view, but assumes that the Galapagos islands are of oceanic origin.*

Personally, I am in agreement with Mr. Andrew Murray's and Professor Baur's theory that the archipelago originated through subsidence of a land-mass which was connected with the mainland. From the latter the islands received the principal members of the fauna and flora, and these progressed from the one to the other on a solid land surface. Subsequently, possibly owing to volcanic disturbance, the land subsided, leaving only the mountain tops with their animals and plants as fragmentary relicts of a rich and varied fauna and flora. So far I am in agreement with Professor Baur's theory, but I believe that the geological history of the Galapagos archipelago forms only part of a much larger and far more complex problem. In the first place, it is evident that the whole fauna and flora of the Galapagos islands cannot have originated in Central America or the West Indies. A large proportion of the animals and plants seem to have their nearest relations in Ecuador and Colombia. Others point to a still more southern or northern origin. If we derive the fauna and flora principally from a former land connection with the mainland of America, that connection must have had several branches. The affinities of the archipelago appear to be chiefly with Central America and Ecuador and much less with Chile. On the other hand, a certain relationship, for instance among the Bulimuli, exists with the southern extremity of Lower California. All these different areas of North, Central and South America may have been joined with the Galapagos land-mass by peninsulae, though one or more of them may have become disconnected long before the others. Dr. Arldt $\dagger$ indicates something of that kind in his map illustrating the conditions of land and water in Cretaceous times. At least, he connects western Mexico and Ecuador by a broad land bridge westward of Central America and across the area of the Galapagos archipelago. I ventured

* Stewart, A., "Botanical Survey of Galapagos Islands," p. 239.

† Arldt, J., "Entwicklung der Kontinente,"-Karte 19. 
to propound the theory that North and South America might have been joined by means of a land bridge between Mexico and Chile across the Galapagos islands at a time when the greater part of South America was still submerged.* But that land connection is evidently one which must have ceased to exist in its entirety, at least in early Tertiary times (see Fig. 16).

I have likewise alluded above to a supposed affinity of some of the Galapagos birds to species found in the Sandwich islands, pointing out that in other groups this relationship undoubtedly exists, although only to a slight extent. I have mentioned examples among the mollusks. Among plants the composite Lipochaeta is a good example. The genus is confined to the Sandwich islands, except one species which inhabits the Galapagos archipelago. Instances of affinity of the Sandwich islands with Mexico and Central America also occur, though as a rule the relationship is a remote one. Still, it has been tentatively suggested by several writers that some time or other in the past Mexico or California were joined by a land bridge to these islands. It might be considered somewhat beyond the scope of this work to discuss a faunistic relationship of this nature, but it really forms part of the great problem as to the origin of the older Asiatic stock on the American continent.

What I described above (p. 97) as the latest or most recent immigration of Asiatic types into North America took place, I think, in Pliocene and perhaps early Pleistocene times. A large proportion of the more northerly animals and plants now living in. North America readily reveal their Asiatic origin as slightly modified descendants of a stock once common to both Asia and North America. These we must regard as the offspring of the latest Asiatic invasion. The American species which thus indicate their Asiatic lineage were described as Asiatic invaders principally in the early chapters. In the fourth chapter the time and the place of their invasion across Bering Strait were more fully discussed. Throughout the subsequent chapters I drew attention to the existence of severally geologically more ancient invasions from Asia, ex-

* Scharff, R. F., "Early Tertiary Land-connection," p. 525. 
pressing my belief, contrary to the opinion of almost all those who had occupied themselves with this problem, that these earlier Asiatic immigrants took an entirely different route from the later ones. The opinion I had formed was founded on a variety of circumstances.

If the theory I had formulated is correct, namely that the effects presented by the Glacial Epoch were due to the simultaneous closing of the Arctic Ocean from the Atlantic and Pacific by the formation of two land bridges, one of which connected North America with Europe in the east, while the other joined North America and Asia in the west (see Fig. 7), the warmer climate in pre-Glacial times must have been due to the fact that the Arctic Ocean then received a greater amount of heated water than it does now. That the two land bridges must have existed at nearly the same time seems to be amply demonstrated from biological evidence. During the Miocene Period the climate in the extreme north of Europe and North America must have been much milder than in Pliocene times. The evidence from northern Europe is against the supposition that the Gulf Stream entered the Arctic Ocean more freely during the Miocene Period than it does at present. The Japanese "Kuroshiwo," or possibly some even more powerful marine current, must have passed, therefore, entirely into the basin of the Arctic Ocean across Bering Strait. I remarked before (p. 96) that the appearance of certain Pacific species of mollusks in the English Crag deposits may perhaps be due to this cause. It was not until Pliocene times, according to Professor J. P. Smith, * that the marine faunas of Japan and the western coast of North America began to be remarkably similar, thus implying that a migration at that time took place along a continuous shore-line. The Californian Miocene marine deposits seem mostly to contain endemic species with a slight admixture of southern and circumboreal ones. All this evidence favours the view of an open Bering Strait in Miocene times, and a closed one during the Pliocene Period. Dr. Dall $\uparrow$ states that the Kenai leaf beds in Alaska (now generally considered of Eocene or Oligocene age) are

* Smith, J. P., " Periodic Migrations," pp. 225-226.

† Dall, W. H., “Correlation Papers-Neocene," p. 251. 
succeeded by Miocene beds with a marine fauna. Similarly he describes a series of Miocene marine mollusks from sandstones obtained at the head of the Gulf of Penjinsk on the opposite shore of Asia. As in Alaska, these Miocene sandstones are apparently resting on leaf-bearing lignites, thus strengthening the assumption of a wide and freely open passage in the north, between the Pacific and Arctic Oceans.* Professor Schuchert† separates North America from Asia by a marine channel throughout Miocene and Pliocene times in his maps illustrating North American paleogeography. All the evidence, says Mr. Knopf, $\ddagger$ from which conclusions of some positiveness can be drawn, record only epochs during the Tertiary Era of more widely spread submergence and increased separation of the continents. And yet his extensive studies of the mammalian fauna led Professor Osborn § to the conclusion that the emergence of continents progressed during the Miocene Period and that North America was broadly united with eastern Asia. How can we reconcile these diametrically opposite views? I have shown that in Oligocene times, or during part of that Period, a trans-Atlantic land connection probably enabled the Old World types to travel to North America. A Bering Strait land bridge is not essential, therefore, in explaining existing Oligocene or Eocene affinities between the Old World and the New. But I have given a large number of instances among North American plants as well as animals, indicating a direct migration either from Asia to North America or vice versa, in early and late Tertiary, at any rate in pre-Pliocene times. I need only allude again to the close relationship of the hellbender of the eastern States to the Japanese giant salamander, of the blue-tailed skink of the eastern States and Japan, and of the absolute identity of the American and Japanese ground lizards (Lygosoma laterale). The only living relation of the American alligator inhabits the Yangtse river in China ; the nearest akin to the American green snakes (Liopeltis and Cyclophis) reside in south-eastern Asia. The family of snapping turtles (Chely-

* Dall, W. H., "Miocene Fauna in Arctic Siberia," p. 473.

† Schuchert, C., "Paleogeography of North America," Maps 98-100.

$\ddagger$ Knopf, A., "Tertiary Land-connection," p. 419.

$\S$ Osborn, H. F., "The Age of Mammals," p. 244-245. 
dridae) are confined to America and New Guinea, the Aglypha, a division of the Colubrine snakes, inhabit south-eastern Asia and Papuasia, except one genus which is restricted to Central America. The pythons are mainly Australian and southern Asiatic, but a single species (Loxocemus bicolor) lives in southern Mexico. The American land-snail Bulimulus, as we have seen, has its nearest relation (Placostylus) in Australia and the islands of the western Pacific. The geographical distribution of the land isopods belonging to the group of Spherilloninae, from New Zealand, Australia, Polynesia, south-eastern Asia and Japan to south-western North America, seemed to Mr. Budde-Lund* so very peculiar that he invoked a Pacific continent to explain it. As a matter of fact we have very numerous similar instances indicating a striking faunistic affinity between North America and eastern Asia. But these examples belong to an entirely different category from the animals and plants referred to as forming the later Asiatic immigration. Certain closely allied or even identical forms such as the alligator, the blue-tailed skink and the ground-lizard in America and eastern Asia apparently point to a geologically recent faunistic interchange between these countries. But alligators are known even from the earliest Tertiary deposits, while the range of the ground-lizard (Lygosoma) from New Zealand, Australia and southern Asia as far north as Japan, indicates that the genus is probably of Mesozoic origin, and that we have to deal with a remarkably persistent ancient type.

When we take a general survey of the range in North America of these older Asiatic animals (and the plants perfectly agree with them), we find that their number decreases as we go north-westward, but increases towards the southwest and Central America. The whole stream of these ancient Asiatic immigrants seems to have issued forth from the southwest, precisely from the same part of North America that also yielded the European colonists. It is in south-western North America, I think, that we have to search for indications of the older land connection with Asia, and not in the Bering Strait. Another point that strikes us during our general

* Budde-Lund, G., "Revision of Crustacea Isopoda Terr.," II., p. 40 
survey is that the American and Asiatic forms related to one another are in Asia mainly confined to the south-eastern border generally, or to Japan. Australia, New Zealand and New Guinea also possess a large number of species and genera very closely allied to west American ones. These seem rarely to extend further north in Asia than Japan. Are we to throw a bridge across the Pacific ocean from Japan in order to find a possible explanation of this former invasion of south Asiatic and Australian types into western America, or does any other theory meet all the facts of the case?

Since Dr. Augustus Grould * first mooted the hypothesis of a former Pacifia continent about sixty years ago, the idea has been widely discussed by biologists and geologists. Mr. Murray's $\dagger$ attention seems to have been first drawn to the subject by the occurrence of the beetle Meristhus scrobinula in Mexico and China, and by the presence of the mole Urotrichus in California and Japan. The Japanese and Californian moles are no longer placed into the same genus, but no one doubts that the American Neürotrichus and Japanese Urotrichus are very nearly related to one another and that they must have had a common ancestor.

The supporters of the theory of the permanence of our great ocean basins explain such cases by means of a former Bering Strait land bridge, but, as already stated, the solution of this problem must be sought elsewhere. That several of the premises on which the theory of the permanence of ocean basins is founded are incorrect has been demonstrated (pp. 274277). Darwin's theoretical considerations on the formation of coral reefs and atolls, which demanded a long continued subsidence of the mid-Pacific region, have been amply verified. To put his subsidence theory to a practical test Darwin suggested that a boring should be made into one of the cores of an atoll. Through the perseverance and energy of Professor Sollas $\ddagger$ and Professor Edgworth David a boring on Funafuti atoll was carried to a depth of one thousand one hundred and fourteen feet, where cores were obtained showing that the whole mass of rock was composed of pure coral. Since

* Gould, A., "Remarks on Mollusks," p. 78.

† Murray, A., "Geographical Relations of Coleopterous Faunas," p. 37.

‡ Sollas, W. J., "The Atoll of Funafuti."

L.A. 
the organisms that form coral reefs are unable to live at a greater depth than one hundred and fifty feet, it is manifest that the floor of the ocean must have subsided very slowly and continuously, thus enabling the reef-building corals to raise their structures to the requisite depth of water. The verdict of Funafuti is thus clearly and unmistakably in favour of Darwin's theory of subsidence. The fact that a slight local elevation seems to be taking place in some parts in no way detracts from the truth which has been so firmly established.

It would lead me too far from my main object to allude to the numerous papers that have been written on the Pacific Continent controversy. After Gould and Murray it was Captain Hutton, * I think, who again revived the theory, which he later on discussed in his presidential address to the Philosophical Institute of Canterbury in New Zealand. His idea was that New Zealand, eastern Australia and India formed one biological region in early Mesozoic times. In Lower Cretaceous times a large Pacific Continent extended from New Guinea to Chile, and from the latter a long lobe of land stretched southward to New Zealand. This Pacific Continent, in his opinion, supported plants, insects, snails, frogs, some lizards, perhaps snakes and a few birds, but no mammals. Later on, during the Cretaceous Period, New Zealand became separated, while the Pacific Continent broke up.

More recently Dr. von Iheringt alluded to a Pacific Continent which he believes to have gradually subsided during the Mesozoic Era, but without going into further details as to its nature and size. I may mention that the supposed antarctic land connection between Patagonia and New Zealand is a subject which I am not dealing with at present. Dr. Pilsbry assailed the problem entirely from the point of view of the molluscan distribution. He points out that many genera of land-snails reach back to the Oligocene Period unchanged save in specific characters, and that the modern family groups of these snails undoubtedly diverge far back in Mesozoic time. Now it is a most significant fact that the Pacific islands are almost entirely tenanted by the most primi-

* Hutton, F. W., "Origin of Fauna and Flora of New Zealand."

$\dagger$ Ihering, H. von, "Relations between New Zealand and South America," p. 444. 
tive and oldest groups of land-snails. And, as Dr. Pilsbry facetiously puts it, "it is very easy to show that snails may. have been carried from place to place by a hurricane, a floating tree or 'floating island,' or that their eggs may find room in the pellet of earth clinging to a bird's feather, but it is incumbent upon the theorist who peoples the mid-Pacific islands by such means to show why such dominant groups as the Helicidae, Bulimulidae, Rhytididae, Streptaxidae -in fact the whole Holopoda and Agnathomorpha, with the higher members of the aulacopod families, as well as the higher operculates-should have utterly failed to take advantage of these means of transport." Instead of being a faunal dependency of the Australian or Oriental regions, Polynesia has every appearance, says Dr. Pilsbry, of being a region which started with a fauna long antedating the present Australian and Oriental faunas, developing along its own lines, retaining old types because they did not come into competition with the higher groups of animal life. Dr. Pilsbry's conclusion is that a Pacific Continent existed, which was finally separated from other lands as early as the middle of the Mesozoic Era, and that the northern portion became disconnected when the remainder was still joined to the mainland.*

A careful review of the distribution of the ants and lizards in particular led Professor Baur $\dagger$ to formulate the theory of a former Indo-Pacific Continent extending from Malaysia to the west coast of America. He looked upon the Pacific islands as the last remnants of this continent, which still existed, he thinks, until the commencement of the Miocene Period.

Mr. Hedley, $\ddagger$ who took part in the famous Funafuti Expedition, and has had the advantage of studying the problems of dispersal on the spot, altogether disbelieves in a Pacific Continent in the sense of Baur, Pilsbry and Hutton, but he suggests that New Zealand was formerly connected with Australia by way of New Caledonia, the New Hebrides, Solomon islands and New Guinea. Even the Fiji islands come within this scheme. Some years earlier he had already demonstrated

* Pilsbry, H. A., "Genesis of Mid-Pacific Faunas," pp. 569-578.

† Baur, G., "New Observations on the Galapagos Islands," p. 869.

$\ddagger$ Hedley, C., "Zoogeographic Scheme," pp. 400-405. 
the essential unity of the area inhabited by the snail Placostylus, * thus regarding New Zealand and the archipelagoes of Solomon, Fiji, New Hebrides, Loyalty, New Caledonia and Lord Howe as portions of a shattered continent which he called the "Melanesian plateau." The short review on the subject by Dr. Holdhaust in favour of a Pacific Continent in Tertiary times adds little to the arguments already advanced by Professor Baur.

A most determined and thoroughgoing onslaught on the theory of a supposed former Pacific Continent was recently. made by Mr. Guppy. It seems scarcely fair to compare the results of his studies with those just alluded to, because he derives his arguments almost altogether from the flora of the Pacific islands, while the others were founded on faunistic data. Still, Mr. Guppy's works $\ddagger$ contain a great deal of personal observation, and his careful labours in this particular field of enquiry will be sure to attract the serious attention of the student of geographical distribution. His discussion of the subject is disappointing in some respects. "If the distribution of a particular group of plants or animals does not accord with the present arrangement of the land," he remarks, "it is by far the safest plan, even after exhausting all likely modes of explanation, not to invoke the intervention of geographical changes." A little further he explains "I scarcely think that our knowledge of any one group of organisms is ever sufficiently precise to justify a recourse to hypothetical alterations in the present relations of land and sea." In reading such passages one wonders whether Mr. Guppy can have become acquainted with the science of geology, or with the principles that underlie the geographical distribution, for example, of mammals. His opinions differ radically even from those of Dr. Wallace, who cannot be said to have been unduly. rash in any of his conclusions as to former changes of land and water. One would also expect from Mr. Guppy an abundance of important facts concerning the dispersal of seeds by the various means of accidental transport. But he tells us

* Hedley, C., " Range of Placostylus," p. 339.

† Holdhaus, K., "Argumente f. d. Existens eines pazif. Kontinents."

$\ddagger$ Guppy, H. B., " A Naturalist in the Pacifie," I., p. 380. 
that the story of plant distribution in the Pacific is bound up with the successive stages of decreasing activity in the dispersing agencies. He thinks that the area of active dispersion, as illustrated by the non-endemic genera of plants, at first comprised the whole of the tropioal Pacific.* Afterwards it was limited to the southern Pacific, and finally to the western Pacific only. The birds that carried seeds all over this ocean became more and more restricted in their range, probably, as Mr. Guppy suggests, on account of increasing diversity of climatic conditions. The plants of necessity responded to the ever narrowing conditions of bird-life in this ocean, the differentiation of the plant and bird taking place together.

Mr. Guppy dislikes the idea of hypothetical alterations in the present relations of land and water, and yet what an amount of hypothesis he has to resort to in his endeavour to explain the theory which he is so anxious to support! There is not a scrap of evidence for the belief that dispersing agencies have practically ceased at the present time, nor that the migrations of birds have diminished. On the contrary, ornithologists have done their utmost to trace the origin of all bird migrations to the gradually increasing diversity of climatic conditions during the Tertiary Era, which they suppose to have culminated in the Glacial Epoch. Although we have little evidence for such a belief, it seems a reasonable supposition. But what can be said in favour of Mr. Guppy's theory, that, owing to the increasing diversity of climatic conditions, the seed-carrying birds have become more restricted, that is to say, less migratory?

A careful perusal of Mr. Guppy's work must make it evident to anyone, that, although plants have far greater facilities for accidental transport, and have in many cases actually been thus conveyed from one land surface to another, they agree on the whole perfectly with animals, in so far as the Pacific islands are largely tenanted by very ancient types. If we adopt the theory of accidental dispersal for the origin of the Pacific island flora, we must apparently assume that the means of occasional conveyance were far more efficient in former times

* Guppy, H. B., “A Naturalist in the Pacific," II., pp. 519-520. 
than they are at present. Even Mr. Guppy, however, sometimes relents and partly withdraws from his precepts when confronted by really difficult cases of distribution. Thus he acknowledges that the conifer Dammara vitiensis, which grows on the Fiji islands, is unfitted for accidental dispersal by any of the known modes of conveyance. The genus Dammara is confined to New Zealand, eastern Australia, New Caledonia, the New Hebrides and Fiji islands. From this region it extends westward to Java and Borneo, the centre of distribution being in the western Pacific. The absence of the genus from the neighbouring Samoan and Tongan groups is, as Mr. Guppy * remarks, very significant, and it is evident that the ordinary agencies of dispersal by birds, winds or currents have here failed to extend Dammara over a few hundred miles of sea. For once Mr. Guppy concedes, therefore, that the present relations of land and sea do change sometimes, and that, " nolens volens," we must admit that Dammara may well be cited in support of any continental hypothesis affecting the western Pacific. Later on, in fact, he expresses the opinion that the Fiji islands mark the site of a Mesozoic continental area in this region.

There is thus a certain amount of distributional evidence in favour of the theory of the existence of a large land surface in the western Pacific. Whether the remainder of that ocean was ever completely occupied by land is a more difficult question to answer. But even on the distant Marquesas islands granites and gneisses occur, as I mentioned before. In the tuffs of the Kermadec islands numerous boulders of hornblende granite have been found. New Caledonia consists of an ancient series of mica schists and slates with a general north-easterly strike. There are also shales containing fossils identical with those of the New Zealand Trias, followed by beds of coal of Jurassic age. Gneisses, crystalline limestones and serpentines, like those of $\mathrm{New}$ Caledonia, are reported from the New Hebrides. Crystalline schists, granular limestone, granite, diorite and gabbro have been discovered on the Fiji islands. The occurrence on the Tonga group of fragments of garnet, tourmaline and uralitic gabbro suggests the close

: * Guppy, H. B., "A Naturalist in the Pacific," II., pp. 297-306. 
proximity of an area of metamorphic rocks, while a series of plutonic rocks have recently been described from Tahiti.

Thus, according to $\mathrm{Mr}$. Speight,* there appears to be geological evidence of the former extension of continental conditions over a large area of the mid-Pacific region. As he remarks, it is highly probable that many volcanic islands classified as oceanic will ultimately have to be looked upon as built up on the remnants of a continental area. We may imagine that a large land area or continent covered the greater part of the present Pacific Ocean in Palaeozoic and early Mesozoic times, and that there was a subsidence during later Mesozoic and Tertiary times with more recent local elevations.

Professor Haug, $\dagger$ discusses the Pacifio problem from another point of view. His studies of the geosynclinals, which he calls the essentially mobile regions of the earth's crust, led him to the conclusion that the circumpacific geosynclinal implied the former existence of a continent in place of the present Pacific Ocean.

The well-known parallelism of the different groups of Pacifia islands has likewise been utilised in support of the same theory. It may be explained by the supposition that these islands are either the remnants or the initial stages of a series of mountain chains. $\ddagger$ The Funafuti boring results seem to point to the first of these as the more likely assumption.

That Darwin's theory of subsidence still meets with a good deal of determined opposition by the believers of the permanence of ocean basins may be gauged from Sir John Murray's writings on the structure and origin of coral reefs. I think it is unnecessary for me to discuss the bearings of his arguments on the American problems raised in this chapter, because, in the first place, it seems probable that both Murray's hypothesis of elevation and Darwin's of subsidence may, be applicable to certain cases, and, secondly, because a Pacific continent in the sense of Hutton, Pilsbry and Baur cannot evidently be cited in support of most of the older Tertiary affinities between Asia and North America that I have alluded

* Speight, R., "Petrological Notes on Rocks from Kermadec Islands," pp. $244-250$.

† Haug, E., "Géosynclinaux et aires continentales," p. 646.

f Arldt, T., " Parallelismus d. Küsten v. Südamerika." 
to. If a Pacific continent existed, and I quite concur with those who are of that opinion, it must have largely subsided before the Tertiary Era. It seems to me as if the central part of it had broken down gradually, the margins slowly following suit, both on the eastern and western Pacific, only leaving here and there a few remnants which either remain as isolated pillars far out in the ocean or have become joined to more recent land-masses. I imagine that the latest prePliocene land connection between North America and Asia was not the Pacific Continent, but merely its margin, which persisted probably until Oligocene or Miocene times. In a geological sense, remarks Dr. von Drasche, ${ }^{*}$ it is more correct to draw the western boundary of the Pacific Ocean through Kamchatka, Japan, the Philippines, New Guinea and New Caledonia, because they all possess old crystalline or ancient sedimentary rocks. But the oceans, as Professor Walther $\dagger$ has pointed out, are areas of depression surrounded by folds or flexures which give rise to extravasation of eruptive material. The chain of the volcanic Aleutian islands lie in such a fold. Near the east coast of Japan the depth greatly increases. On the eastern side of the Pacific, in western North America, the igneous rocks skirt the coast for some distance, whereas in the south-west the volcanic centres lay far inland, justifying the assumption that the Tertiary coast-line extended some distance inland, which is fully established by geological observation. Although the Pacific is known to have invaded Californian territory, there is no evidence that the coast hills and outlying islands were covered by the sea ; and these probably remained as part of the marginal land which skirted the west coast of North America. It is from this old land, I think, which contained Asiatic immigrants, that North America received its ancient Tertiary fauna from Asia. I suggest, therefore, that in early Tertiary times a belt of land, possibly. representing the margin of the more ancient Pacific Continent, extended from the south-west coast of North America in a great curve to Japan and further south (see Fig. 14). The extraordinary similarity of the east Asiatic, Mesozoic and

* Drasche, R. von, “Palaeozoische Schichten auf Kamtschatka," p. 268.

† Walther, J., "Über den Bau der Flexuren, \&c." 
early Tertiary marine faunas to those of California would. thus receive a satisfactory explanation without invoking a land connection across Bering Strait. As soon as the marine channel which separated the coast hills in California from the rest of the country disappeared, a number of Asiatic immigrants entered North America. But the flora, especially of the small islands lying off the coast of California, still bears the impress, as Mr. Greene* has pointed out, of belonging phytogeographically to another continent than America.

I also mentioned that the European invasion of North America, which travelled by the trans-Atlantic land bridge, had ultimately entered the Continent from the south-west. The two elements, the Asiatic and the European, must have joined there eventually. To judge from purely faunistic testimony, that was evidently the course of events (compare p. 211). Somewhere about the Miocene Period extensive subsidence of the land west of California must have compelled the fauna and flora to seek refuge on the continent with which the Pacific belt of land seems to have become united. Palaeontological evidence gives us reason for such a supposition. Take for example the great land-tortoises. Their sudden appearance in south-western Miocene deposits suggests that they. came from the west with other new-comers. This hypothesis likewise throws light on their survival near at hand in the Galapagos islands, which no doubt once formed part of the Pacific belt of land alluded to. There are such a variety of problems connected with this theory that I shall defer the further discussion of it till the next chapter. In conclusion, a few additional remarks on the nature of the supposed extension of land west of Central America will facilitate the comprehension of the scheme of land connections that have only been roughly outlined so far.

When I described the remarkable fauna and flora of the Cape region of Lower California (p. 207) and their marked affinities to those of the opposite coast of Mexico, I made no reference to the fact that this interesting assemblage of animals and plants is living in a hilly district being separated from the nearest mountains to the north of it by a wide extent

* Greene, E. L., " Botany of Santa Cruz Island,” pp. 377-388. 
of a low-lying plain. This district, moreover, is entirely granitic and composed of a number of high ridges running parallel in an east-westerly direction, the remainder of the great peninsula being largely formed of calcareous rocks with mountain ranges running in a north and south direction. Between the two lies a great plain several hundred miles long with a height of scarcely one hundred and fifty feet above sealevel. The two mountain ranges manifestly belong to entirely different systems, and the junction between the two must have been a comparatively recent geological event. Mr. Eisen* was so much impressed by the supposed severity of the climate during the Glacial Epoch that he believed the whole Cape region was at that time wrapped in snow and ice and devoid of animal life. But he also contends that it must have been an island and that during its rise animals and plants gradually reached it from the mainland by accidental transport. That the Cape Region has only recently become part of Lower California is highly probable. To judge from the fauna and flora, it must have been connected by land with some part of Central America or southern Mexiso, though it possesses affinities, too, with Asia and the Pacific islands (compare, p. 208). Rather more than half-way across the sea between the Cape Region and the south coast of Mexico lies the small group of the Tres Marias islands, and it might be argued that they had once formed the connecting link between the mainland and that faunistically so remarkable Cape Region of Lower California. The animals and plants of these islands, however, although clearly showing that the islands have been joined to one another and to southern Mexico, exhibit no near relationship to those of the Cape Region. $t$ Hence it is probable that the faunistic and floristic affinity between the Cape Region and southern Mexico is due to the fact that both regions have acquired their animals and plants, in more remote times, from the same source in Central America. I suggested in a former chapter (p. 237) that the mountains of Guatemala had once extended further westward. Guatemala certainly seems to have been a land surface

* Eisen, G., "Explorations in the Cape Region," p. 735.

† Nelson, E. W., L. Stejneger, and others, "Natural History of the Tres Marias Islands." 
since very remote geological times, while its ancient mountain system, trending in a west-eastward direction, abruptly terminates on the Pacific coast. I ventured to explain the many instances of curiously discontinuous distribution in Central America by the supposition that an ancient land occupied the adjoining portion of the Pacific, and that the present Central America is partly formed of the remnants of that land having eventually become moulded together by geologically recent volcanic deposits. If we assume that the Cape Region of Lower California belonged to that Pacific land which really formed the southern continuation of the north Pacific belt of land alluded to, a reasonable explanation is advanced for the faunistic affinity of the Cape Region to Central America, the West Indies and Asia, and its dissimilarity with the rest of Lower California. The hypothesis of a former westward continuation of portions of Central America is not founded purely on zoogeographical considerations. In his reference to the older Tertiary sediments of Central America Professor Hill* states that it is impossible to avoid the conclusion that they were derived from a near-by land which existed at the time of their deposition. The only hypathesis, he says, that can fit the condition of their present lay and arrangement is that this land existed towards the Pacific coast or in the area now covered by the Pacific waters of the Isthmian Region. The "old land" or early representative of the isthmus of Panama, remarks Mr. Hershey, t lay mainly south of the present isthmus. That it was a land-mass of considerable extent, he continues, is indicated by the heavy beds of conglomerate formed from it, and he argues that the peninsula of Azuero which projects out into the Pacific is a remnant of this land, while on its northern border were laid down the more recent formations which make up the main body of the isthmus. Geologically there is, therefore, some evidence, too, for the assumption of a former extensive land surface on the Pacific side of Central America. It must be remembered that while Central America as a whole has a south-east and north-west

* Hill, R. T., "Geological History of Panama," p. 263.

† Hershey, O. H., "Geology of Isthmus of Panama," p. 249. 
trend the isthmus of Panama runs in an east-westward direction.

That this Pacific land persisted to some extent until comparatively recent geological times, seems to be indicated by several notable features. When Mr. Agassiz surveyed the ocean floor from the steamer "Albatross," he found the Pacific side of Panama faunistically poor compared with the Atlantic side, but he attributed that condition to the absence of a great oceanic current on the south side of the isthmus. The absence of deep-sea corals on the Pacific side was most striking. Yet, he remarks that there is on the west coast of Central America, even in deep water, a considerable fauna, which finds its parallel in the West Indies and recalls later Cretaceous times when the Caribbean Sea was practically a bay of the Pacific. This assumption that the Caribbean Sea was once a bay of the Pacific has been put forward by other writers. The faunistic resemblance, or parallelism, as we might call it, between the seas on each side of Central America may be due to a former westward extension of the Atlantic Ocean just as much as to an eastward extension of the Pacific. However, one of the most remarkable features brought to light by the "Albatross" expedition was the condition of the ocean floor. There was not a station between Acapulco, on the coast of Mexico, and the Galapagos islands, according to Mr. Agassiz, of which the bottom could be characterised as strictly oceanic. At the most distant points from the shore the bottom specimens invariably showed some trace of admixture of terrigenous material. All the way, even to a depth of 2,000 fathoms, the trawl became filled with a sticky mud containing logs of wood, branches, twigs and decayed vegetable matter. Being a firm believer in the permanence of ocean basins, Mr. Agassiz * naturally attributed this extraordinary condition of the sea floor to the existence of currents, which, striking Central America from north and south, are reflected in a westward direction. He likewise argues from this discovery that it offers a very practical object lesson regarding the manner in which the Galapagos islands received their fauna and flora. The peculiar condition of the ocean

* Agassiz, A., "Reports on 'Albatross' Expedition," pp. 11-77. 
floor may, I think, be explained in an entirely different way. We might possibly expect a condition such as Mr. Agassiz describes off the mouths of the Amazon or Orinoco rivers, but there are no vast rivers anywhere on the Pacific coast to furnish all this vegetable detritus he speaks of. A similar condition, moreover, occurs only to a very limited extent on the Atlantic side of the isthmus. That the ocean floor is covered with tree trunks, twigs and other vegetable detritus may be due to the existence within recent geological times of a welltimbered land between Central America and the Galapagos islands which has since vanished beneath the ocean.

And yet that all was not land on the Pacific side of Central America is proved by many distinct lines of evidence.

Mr. Guppy * tells us that Laguncularia racemosa, Rhizophora manglé, Anona paludosa and Conocarpus erectus, all of which are plants of the mangrove formation, occur not only on the Pacific and Atlantic coasts of America, but also on the west coast of Africa. We cannot suppose that such characteristic sea-shore species can be conveyed across a land area by any known means of accidental dispersal. Moreover, since that vegetation does not occur south of the Bay of Guayaquil, it could not have reached the coast of Ecuador from eastern South America by travelling round Cape Horn. Thus the most likely explanation of the occurrence of the flora on both sides of Central America is to assume the existence of a former continuous shore line between Ecuador and Venezuela.

In the list of stalk-eyed crustacea found on the coast of Peru, Miss Rathbun † reports that a few species of crabs, like Acanthonyx petiverii, Microphrys platysoma, Panopeus bermudensis and Geograpsus lividus, are common to both sides of Central America, while a most striking feature is the faunistic uniformity of the marine area between the Cape Region of Lower California and the coast of Chile. Dr. Dallf divided this whole fauna into two provinces, viz., the Panamic, extending from Lower California to Guayaquil, and the Peruvian, from the latter to the island of Chiloe in Chile,

* Guppy, H. B., "A Naturalist in the Pacific," p. 498.

+ Rathbun, M. J., "Stalk-eyed Crustacea of Peru."

$\ddagger$ Dall, W. H., "Report on the Shells of Peru," p. 185. 
but the two have many forms of mollusks in common, and should be regarded perhaps as sub-divisions of one faunistic marine area. According to Dr. von Ihering,* Chile received, in early Tertiary times, certain tropical genera of mollusks which never succeeded in attaining the North American coasts, yet are represented also in Patagonia, while others, such as Conus, Purpura, Oliva, Concholepas, Cassis, Cypraea and Rissoa are absent from the latter country. They are supposed to have travelled along the north coast of South America to Ecuador, Peru and Chile by means of a Central American marine channel. Certain species even of that ancient marine migration have persisted to the present day, not only on the coast of Chile, but on the west coast of Africa and in the Mediterranean. Even in Miocene times the influence of the Caribbean and European marine faunas was felt on the coast of Peru, according to Dr. Ortmann. $t$ Certain northern species of the genera Saxidomus and Chlorostoma, says Dr. von Ihering (p. 524) did not reach the coast of Chile until the Pleistocene Period. Thus it seems manifest that during practically the whole of the Tertiary Era there was no Humboldt current sweeping northward along the west coast of South America, as it does at present. On the contrary, there is sufficient evidence to show that whatever current there existed flowed in the opposite direction.

This investigation has resulted in two very important results, viz., firstly, the demonstration that the Humboldt current formerly did not exist, and secondly, that its absence must have been caused by profound differences in the conditions of land and water from those now prevailing. Of the nature of these changes I have foreshadowed already enough to enable anyone to reconstruct them. When the currents issued from the Caribbean Sea into what is now the Pacific, they must have been faced by land westward and northward. They could only have flowed southward. But the land which' lay south-westward between Central America and the Galapagos islands extended probably far southward, parallel to

* Ihering, H. von, “Mollusques fossiles de l'Argentine," pp. 514-516.

† Ortmann, A. E., "Tertiary Invertebrates of Sta. Cruz," p. 320. 
the present coast. How far it reached will be more fully discussed in the subsequent chapters. It may only comparatively recently have subsided. May not the remarkable circumstance, alluded to by Dr. Bigelow, ${ }^{*}$ that to the south-west and west of the Humboldt current the sea is almost entirely devoid of surface as well as bottom life, be due to this cause?

* Bigelow, H. B., “ Albatross Expedition-Medusae," p. 222. 


\section{CHAPTER XIII}

\section{NORTHERN STATES OF SOUTH AMERICA}

The great continent of South America (Fig. 18), with its roughly triangular shape, is not much smaller than its northern relative. The basis of the triangle facing northward is bounded by the Caribbean Sea, and the two other sides by the Atlantic and Pacific Oceans respectively. There is a very general impression that the west coast of South America is mountainous, the remainder being a vast plain. This is not quite correct. A northern continuation of the long chain of the Andes skirts also the southern shores of the Caribbean Sea, while to the south-east of it lies the highland of Guiana and further south the Brazilian highland. The two eastern highlands-that of Guiana and Brazil-are broken into two parts by the Amazon valley. The space between these eastern highlands and the Andes is occupied by the central lowlands. We might say, therefore, that the three great natural regions of South America are the eastern highlands, the central lowlands and the western Cordillera. The Amazon, Orinoco and La Plata-the three great streams -all drain eastward.

The main part of the continent has a tropical climate. Sub-tropical and temperate conditions prevail in the south. The climate of the Brazilian region is exceptionally favourable for a luxuriant development of the fauna and flora, whereas certain parts of what Dr. Wallace called " the Chilean sub-region " are arid, and inimical to expansion and specific differentiation of animals and plants.

Although our acquaintance with the fauna, flora and geology of this vast continent is naturally much less complete than that of North America or Europe, we possess unmistakable evidences of the fact that South America has undergone considerable alterations in the distribution of land and 


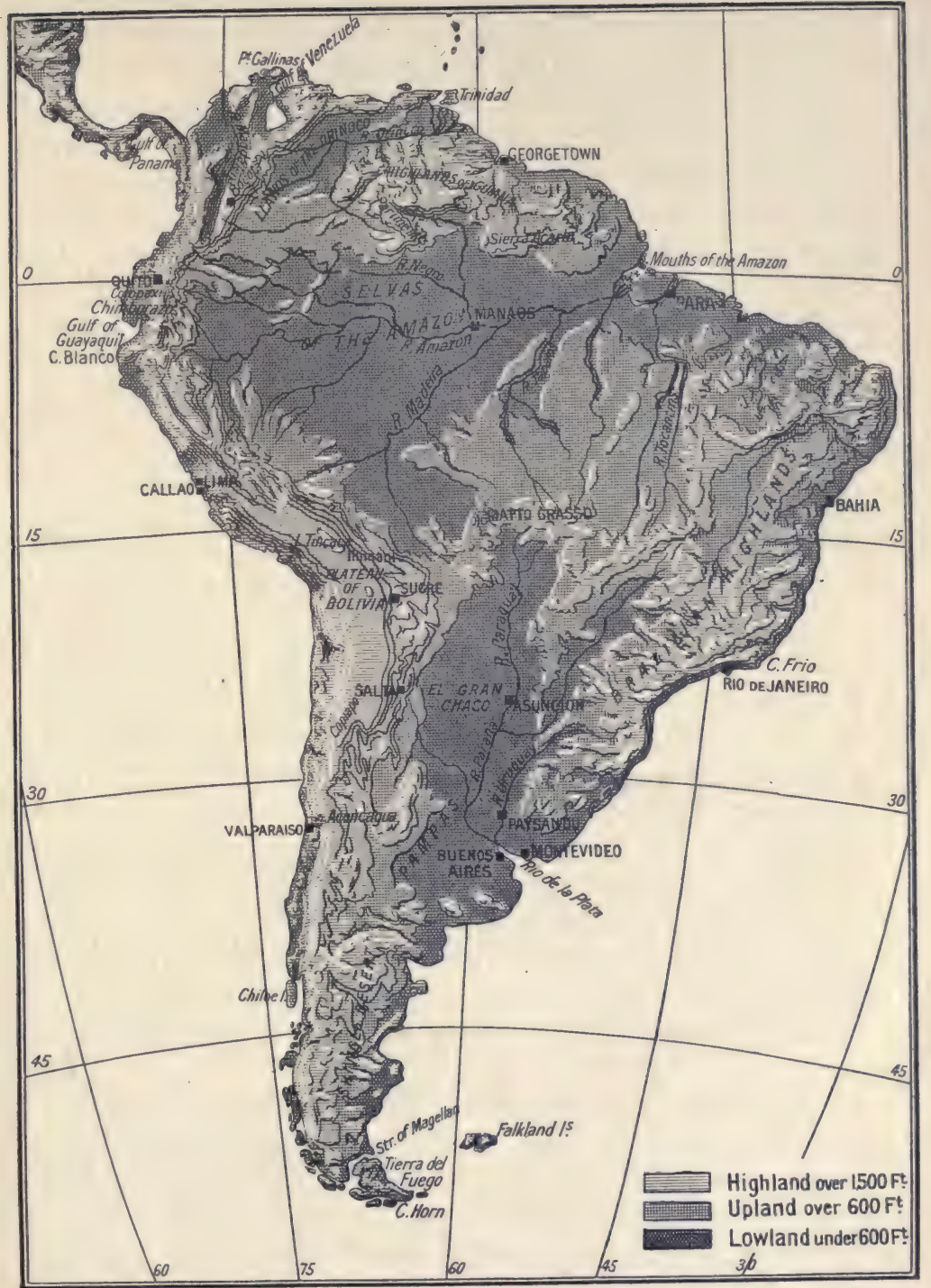

FrG. 18.-Map of South America. (Reproduced from Meiklejohn`s Oroscopic Map, by permission of Messrs. Meiklejohn \& Son.) 

water since the close of the Mesozoic Era. The testimony is of a threefold character. It is founded on our knowledge of geology, of palaeontology, and of the geographical distribution of living animals and plants. Richness, as Dr. Wallace observed, combined with isolation, is the predominant feature of neotropical zoology. Nevertheless, he thinks that early. during the Tertiary Era, the zoological differences between the Nearctic and Neotropical, that is to say, between the North and South American regions, were probably even more radical than they are now. South America, he argues, was then a huge island or group of islands - a kind of Australia of the New World-chiefly inhabited by the imperfectly organised group of edentate mammals. Dr. Wallace * believes, moreover, that there must have been one or more ancient land connections between the two continents, perhaps in Eocene or Miocene times, admitting ancestral types of monkeys and the members of the camel-tribe (Llamas) from the north to South America.

Dr. Wallace's opinions, expressed thirty-five years ago, were founded entirely on the distribution of living animals. Rapid strides have been made since that time in our knowledge of the fauna of South America. The geology of certain districts is being worked out. Botanists have made great progress in mapping out the distribution of plants, while the most astonishing discoveries have been disclosed principally among the past inhabitants of the continent. Thus we are now in a very different position from that of Wallace, when he pronounced upon the physical changes of South America during the past, on the strength of his zoological knowledge.

We are particularly indebted to Dr. von Ihering's researches on the fauna and flora of South America, which he conducted during many years of devoted labour, that our information on the main features of distribution has advanced so rapidly. During his long residence in southern Brazil he collected, and is still collecting, data bearing principally on the question of the geological history of the continent; and since his scattered papers have recently been reprinted in

* Wallace, A. R., "Distribution of Animals," II., p. 58 . 
book form we are better able to appreciate the advances in our knowledge that are due to his investigations. His researches were not confined to recent zoology. He has also dealt with the subject from a palaeontological point of view, and has even subjected the main features of the flora to a detailed revision. All the same, he acknowledges that there are several important problems connected with the geological history of South America for which no satisfactory solution has as yet been suggested. More than twenty years ago, Dr. von Ihering announced that the close relationship of the Brazilian with the African fresh-water mussels implied the former existence of a land connection between South America and Africa. But, whereas America as a whole is one of the richest regions for fresh-water mussels in the world, Chile and Peru are among the poorest. While east of the Andes there is a luxuriant fauna of fresh-water mussels largely related to that of Africa, we find only the genus Unio (in its wide sense) represented on the western slope of the mountains. Dr. von Ihering explains this and other similar facts by the supposition that in the east and the west there were originally similar faunas, but while eastern South America obtained a rich stock of immigrants across the land bridge from Africa, the great mountain chain of the Andes, which was then commencing to rise, prevented any further influx westward. Considering that the fresh-water mussels (Unionidae) are well represented even in Jurassic deposits, Dr. von Ihering* recognised that the geographical distribution of these mollusks may be utilised to advantage as indicators of very ancient, especially Mesozoic, conditions of land and water.

In the course of his studies the same author came to the conclusion that from the Cretaceous to the end of the Pliocene Periods, South America must have been completely separated from North America. A real South American continent existed only since Oligocene times. It then consisted of two parts united by the narrow isthmus of the newly formed Andes. He named these two old original constituents of South America "Archiguiana" and "Archiplata." The former comprised the highlands of Guiana and Venezuela,

* Thering, H. von, "Archhelenis and Archinotis," p. 79. 
the latter the remainder of South America, the two parts being separated by a broad ocean except for a narrow western land bridge. Each of these great islands had its own peculiar fauna and flora, but Archiguiana must have been connected by land with Africa until Oligocene times, and Archiplata with New Zealand and Australia during the Mesozoic Era.

With the gradually increasing knowledge of palaeontology Dr. von Ihering's original ideas naturally became subject to various modifications. Thus in a map representing the conditions of land and water during the Eocene Period, and published in 1907 (Fig. 17), not Archiguiana but Archiplata is connected by land with Africa and also India, the whole of this ancient continent being called "Archhelenis." Archiplata is still joined at this time to Australia by means of the antarctic continent "Archinotis," while Arehiguiana is united with the West Indies and parts of Central America into a large land-mass which stretched forth westward to the Sandwich islands, and was called "Pacila." Quite recently the same author brought forward testimony in favour of a Miocene land bridge between Central America and eastern Asia. I have already alluded to it in the previous chapter. Dr. von Thering now tells me that he will shortly publish a revised palaeogeographical map in the "Neues Jahrbuch für Mineralogie und Geologie," in which these features are indicated.

The same problem, studied from the point of view of the distribution of fresh-water crabs and crayfishes, led Dr. Ortmann * to somewhat different conclusions. At the end of the Mesozoic Era he recognises the existence of the island of Brazil, which had previously been connected with Africa, while Guiana was still joined to western North America on the one hand and Africa on the other. The independent Chilean tract of land was connected with Australia by means of the supposed antaretic continent (Fig. 15). At the commencement of the Tertiary Era South America had assumed its present shape, except for an elongated bay extending inland from the Atlantic Ocean into the valley of the Amazon. In

* Ortmann, A. E., “Distribution of Decapods," pp. 379-381. 
the south it was still joined to the Antarctic Continent, which had then become separated from Australia. In the north it had lost its land connection with North America, which it did not regain until later Tertiary times.

To a certain extent the views of the two authors agree, at any rate, in the assumption that the continent of South America is composed of several originally independent landmasses, one of which was joined to Africa. The most striking difference in their opinions, apart from the geological period during which the various elements are supposed to have become fused together, lies in Dr. Ortmann's conception of three totally distinct land-masses, while Dr. von Ihering only recognises two. Nevertheless, even the latter acknowledges the faunistic division of his "Archiplata" into a northern and southern portion, although his nomenclature is apt to be somewhat confusing. Dr. von Ihering informs us (p. 177) that the old Archiplata fauna has no close relationship to that of the rest of South America.

A third contribution to the geological history of South America is furnished by another group of fresh-water animals, namely, the fishes. The tropical American fresh-water fauna, having its centre of greatest diversity in the middle Amazon basin, says Professor Eigenmann,* is attenuated northward till it reaches the vanishing point just on the borders of the United States. Southward it extends to somewhere south of Buenos Aires. The Patagonian and North American faunas are entirely different from the tropical American fauna and from each other. The results of his studies are that the existing distribution of the fresh-water fishes can only have been brought about by the supposition that tropical America in early Tertiary times consisted of two land areas ("Archiguiana" and "Archamazona "), separated by the lower valley of the Amazon, which was submerged by the sea. There was a land-mass between Africa and South America, possibly. joining Guiana and tropical Africa. But this connection, he urges, must have ceased to exist before the origin of the present genera, and even before that of some of the families.

* Eigenmann, C. H., “Freshwater Fishes of South America," pp.;517 -528 . 
Several other writers have discussed the theory of former land bridges between South America and Africa and between South America and other continents without dealing with the geological history of South America itself. Their views will be presented later on.

The only author who, to my knowledge, has treated the subject under review from a purely palaeontological standpoint is Dr. Ameghino. His views were brought forward in several important technical papers. As they may have undergone slight modification in the course of time, I prefer to quote his opinions from a recent semi-popular account. It may be mentioned that Dr. Ameghino's * theories are founded on the known distribution of fossil mammals. North of the Equator, he says, there was, at the end of the Mesozoic Era, a vast ocean containing many. islands. In the south lay a great continent, united in the east with Africa and in the south with Australia and New Zealand by way of an antarctic land bridge. Gradually, in early Tertiary times, the northern islands became fused and joined to the southern land-mass, while Australia was disconnected. During all this time North and South America remained entirely separated. Mammals, however, were able to pass from the latter continent through Africa into Europe, and across a land bridge in northern latitudes to North America. The sea, which had covered the Andean region in Mesozoic times, disappeared early in the Tertiary Era, but certain bays of the Pacific Ocean still remained and extended eastward to the far side of the Andes. During the Eocene Period the Atlantic Ocean advanced from the south, covering part of Argentina and practically separating Brazil from the rest of the continent, while the former land connection with Africa ceased to exist. Towards the end of the Oligocene Period the "Archhelenis" land bridge once more rose to the surface for a brief period and then finally subsided entirely, save for a few scattered islands.

It would have been particularly valuable to obtain Professor Osborn's opinions on the geological evolution of South America. We possess only his palaeogeographical maps

* Ameghino, Fl., “Geología de la República Argentina," pp. 9-16. 
founded upon the distribution of fossil mammals. It is surprising that in these maps South America in late Cretaceous and basal Eocene times, is represented as almost precisely what it is to-day, except that it is continued southward across an antarctic continent to Australia. In the middle Eocene, South America differs only in so far as a long bay of the Atlantic has entered the Amazon valley. There are no indications of any land bridges at that time, South America being completely isolated from all other continents. During the Oligocene Period it still remained so, but the sea made further inroads on the Amazon valley, it encroached on the valley of the Paraná river and flooded a large part of Argentina, reducing southern Chile to a few islands. It is only in Miocene times, according to Professor Osborn,* that South America became divided into two parts by a broad gulf extending from the Atlantic to the Pacific across the Amazon valley.

Geologists, except Dr. Katzer and Professor de Lapparent, $\uparrow$ have as a rule dealt with the problem in a less comprehensive manner. The ideas of the latter differ from the authors cited in so far as the main permanent land-mass at the end of the Mesozoic Era in South America was confined, in their opinion, to the east. They suppose the highlands of Guiana, eastern and southern Brazil to have been united. All the rest of the continent was then under water. At the commencement of the Eocene Period, according to Professor de Lapparent, Central America had come into existence, but disappeared again shortly after, while a broad marine channel stretched from the Pacific to the Atlantic between northern Chile and Argentina. Dr. Katzer's views are somewhat similar. $\mathrm{He}$ dces not believe in the Atlantic Ocean having invaded South America from the east. In the beginning of the Mesozoic Era the area of archaean rocks and later palaeozoic deposits of Guiana and Brazil formed a large connected land-mass. In Upper Jurassic times, he says, the old land connection between South America and South Africa on the one hand, and between South America and Australia, still existed. An old

* Osborn, H. F., "Age of Mammals" Maps, pp. 64, 137, 183 and 24é.

† Lapparent, A. de, "Traité de Géologie," 4th ed., pp. 1376 and 1455. 
ocean strait extended from the north side of Guiana across Venezuela and Colombia to Peru during the Cretaceous Period. During all this time, and even in early Tertiary times, the waters from the old eastern land continued to drain westward towards the Pacific. The persistent rise of the newly formed Andean mountain chain resulted at first in the formation of a vast lake covering the entire lowlands of the Amazon valley area. Eventually, in Miocene times, according to Dr. Katzer, * the drainage was reversed, with the result that the Amazon river flowed for the first time into the Atlantic Ocean. Concurrently North and South America became united through the Central American land bridge.

Professor Koken's $†$ palaeogeographical maps were constructed as the outcome of a combination of geological and palaeontological studies. South America, he remarks, had already assumed its present shape and form in Cretaceous times, though it did not extend so far west as at present except in Ecuador and Colombia. It was separated from all other continents but Africa. In early Tertiary times South America became entirely isolated. Argentina and southern Chile were largely flooded by the sea, while a long gulf filled the whole valley of the Amazon as far east as the Andes.

Dr. Arldt, $\$$ who included the distribution of living animals and plants as well as palaeontology within the sphere of his studies, gives a series of highly complex maps which cannot readily be described. His conception is that South America in Lower Cretaceous times was somewhat like that described by Professor Koken, viz., an extension of land eastward as far as Africa and a simultaneous submergence of the west coast. Towards the end of the Mesozoic Era, that is to say at the end of the Cretaceous Period, a complete change in the conditions of land and water supervened. South America was then divided into two parts by an interoceanic connection across the Amazon valley. The northern portion, consisting of Colombia, Ecuador and Guiana, is supposed to have extended westward across the Galapagos islands as far as the Sandwich

\footnotetext{
* Katzer, F., “Geologie des Amazonengebietes,” pp. 239-262.

† Koken, E., “ "Die Vorwelt,” Maps 1 and 2.

$\ddagger$ Arldt, J., “Entwicklung der Kontinente," Maps 19 and 20.
} 
islands, thus forming a great peninsula of land which likewise was joined to lower California and western Mexico. The southern part of South America was then still united by a narrow land bridge with Africa, while the western side of it now became joined to a great belt of land extending right across the Pacific Ocean to New Zealand and Australia. In early Tertiary times South America became separated from North America and the Sandwich islands, while the two sections of the continent fused in the west. The African and Australian land connections still persisted in a modified form.

We can gather from all these expressions of opinion as to the past geological history of South America that there is comparatively little general agreement on the subject. Some points, however, seem to be fairly well established. All authorities concur in the belief that the Eastern highlands of Guiana and Brazil have been land surfaces since the beginning of the Secondary Era, at any rate, and on these, therefore, we ought to find relicts of a Mesozoic fauna. All the writers quoted also agree that at some time or other during the Tertiary Era there was either a complete interoceanic connection along the Amazon valley or a long gulf of the ocean extending for some distance inland. Yet there is an important difference of opinion as to whether this gulf belonged to the Atlantic or the Pacific Ocean. But since most of the writers contend that the central portion, at any rate, of the Andes is made up largely of Jurassic and Cretaceous marine deposits, while the eastern parts of South America were land in Mesozoic times, it seems more reasonable to assume, with Dr. Katzer, that the Pacific Ocean extended eastward as far as the archaean highlands of Brazil and eventually retreated so as to leave only a Pacific gulf on the site of the existing upper Amazon valley. In view, however, of the fact that the Pacific Ocean must have been completely shut out from South America by the western belt of land above alluded to, it was really the waters of the Atlantic Ocean which flooded western South America as far east as the highlands of Brazil (compare Fig. 14).

Several of the authors cited recognise a faunistic relationship between Australia as well as between Africa and South 
America, and some contend that Chile has been wholly or partially above the surface of the ocean since very early geological times. As Professor Suess * has pointed out, the extreme south of the continent is composed of a peculiar and probably very ancient system of rocks. This Patagonian mountain chain is quite independent of the Andes, of which it does not form a continuation. Further north in Chile it lies outside or westward of the Andes, constituting the coast Cordillera.

Still further north, in Peru, only fragments of this Cordillera are recognisable here and there close to the coast, while in Ecuador the ancient coast Cordillera again appears to be more clearly represented. There is some evidence, therefore, of the existence of a very old land-mass not only on the eastern but also on the western side of the continent. And it seems as if the Mesozoic rocks forming a large part of the Andes had been deposited in a great trough along the eastern shores of this ancient land. When the Andes were subsequently raised, the older western land presumably subsided, leaving only here and there along the coast some traces of its former existence.

Let us now pursue this subject from a purely zoogeographical point of view, and endeavour to utilise groups with whose distribution we are fairly well acquainted, in elucidating the more obscure points in the geological history of northern South America. Groups of animals of which we have reason to believe that they are very ancient, possibly of Mesozoic age, will be best for this purpose. Such a one for example is that of the Onychophora (Protracheata). It contains creatures caterpillar-like in appearance, with a beautifully soft skin and unjointed limbs. Internally they contain air-tubes so characteristic of insects ; at the same time, their excretary organs resemble those of worms. These very primitive features, taken together with a wide and most discontinuous distribution, have always caused these creatures to be looked upon as survivors or relicts of very remote geological ages. Formerly they were all classified under the genus Peripatus. In recent years many new forms have been discovered and subjected to careful study, with the result that

* Suess, E., “ Antlitz der Erde," I., pp. 666-690. 
quite a number of genera are now recognised. The most exhaustive account of these remarkable creatures is, no doubt, the monograph recently published by Professor Bouvier. He divides the group into seven genera, of which Peripatus is confined to tropical and sub-tropical America and tropical Africa, and Opisthopatus to Chile and South Africa. This is a most astounding discovery. That a group of these creatures found in tropical South America should be more closely related to another occurring in tropical Africa than to that of Chile, and that the latter should exhibit a more intimate affinity with South African forms than with tropical American ones, is of great zoogeographical interest. Professor Sedgwick, * however, does not share Professor Bouvier's opinion with regard to the intimate relationship supposed to exist between the tropical South American and tropical African, and between the Chilean and South African groups. He thinks they are perfectly distinct from one another. On the other hand, he agrees with Professor Bouvier in the recognition of a group of Onychophora, limited to tropical and sub-tropical America, as distinct from the Chilean group. And this is really the principal point I wish to draw attention to.

Professor Bouviert claims that the Andean species of Peripatus are the most primitive members of the whole family. $\mathrm{He}$ believes that the ancestral stock inhabited a former Pacific continent, and that their immediate descendants took refuge on the eastern and western land areas when their original habitat vanished. The whole genus Peripatus, as defined by Professor Bouvier, I may mention again, is found from Mexico in the north, throughout Central America, the West Indies and South America as far south as Bolivia. The Chilean species belongs, according to the same authority, to the distinct genus Opisthopatus.

The genus Peripatus is readily divisible into two sections, the Andean and the Caribbean one. The twelve species belonging to the former all inhabit the Pacific side of the Andes, except Peripatus eiseni and Peripatus goudoti, which live in Mexico nearly two thousand miles north-westward of the other

* Sedgwick, A., “Distribution of Onychophora," pp. 383-406.

† Bouvier, E. L., “ Onychophores," I., pp. $64-79$. 
members of the Andean group. This discontinuous distribution is a very noteworthy fact, for it cannot be explained by the supposition that some member of this Andean group may still exist and have been overlooked in the intermediate vast tract of country, because many specimens of Peripatus have been discovered in Costa Rica, Nicaragua and Panama, all belonging to the Caribbean group. Accidental dispersal, such as marine currents, cannot be invoked as being responsible for this distribution. It is due, in my opinion, to a former direct land connection between western Mexico or Guatemala and some part of the west coast of South America. That the mountain system of Guatemala suddenly terminates at the edge of the Pacific, and that it formerly had a westward continuation, has been alluded to, and I have mentioned also several cases of discontinuous distribution that I thought were due to the existence of an ancient land, more or less independent of Central America. The newt Spelerpes is one of these. Its headquarters seem to be in Mexico. A few occur in Guatemala, Costa Rica and Chiriqui. Further south we meet with the genus again in Colombia, Ecuador and northern Peru, but nowhere else in South America. The tortoise Chelydra rosignoni occurs in Guatemala. It is absent from the rest of Central America, yet in Ecuador we find an isolated colony. Another tortoise, Geoemyda punctularia, inhabits Guatemala and Mexico. Southward it is only known from Ecuador, Colombia, Venezuela and further east. The geckolike genus Eublepharus is probably an exceedingly ancient one, its range being most peculiar and strikingly western. One species occurs in California, another in Mexico, still another in Panama, and lastly one in Ecuador. All the remaining species, which show great resemblance to the American ones, are confined to southern Asia. We probably have to deal in this case with a persistent type which throughout many geological periods has retained the same characters and has died out in the still existing land fragments of the ancient Pacific continent, whence it originally spread east and west after its subsidence. There are numerous other examples, particularly among plants, implying that the land which I deseribed as lying westward of Central America once touched the South American continent, probably near 
Ecuador (compare Fig. 14). As this western belt of land was in direct communication with the West Indies by way of Central America, it follows that the West Indies and Ecuador were able to enter into a faunistic exchange. Many instances might be quoted showing this relationship between the West Indies, Central America and western South America, or between parts of these areas. The headquarters of the snake-like limbless amphibians, known as Coecilia, are in Ecuador. From there they have spread eastward through Guiana to Brazil, and northward through Colombia as far as Panama. No species is actually known to occur in Central America beyond Panama. I alluded to the family Anguidae on several occasions, those generally limbless lizards to which the so-called glass-snake belongs. One genus with well-developed limbs (Diploglossus), inhabits chiefly the principal islands of the West Indies, viz., Cuba, Haiti and Jamaica. In Central America it occurs in Guatemala and Costa Rica, while in South America it inhabits only Ecuador and Brazil, having apparently spread into the latter state from the west.

Attention has been drawn to the fact that while the fauna and flora of the Galapagos islands are principally Central American and West Indian in character, they also are related to those of western South America. A mere fragment only of the animals and plants that passed across the lands of which these islands formed part could have been preserved there. Thus the Streptaxidae, a family of carnivorous snails almost restricted in America to the southern continent, do not occur in the Galapagos islands, although a few species have penetrated to Guatemala, and one even to Haiti. The genus Martinella is peculiar to Ecuador, whereas two other genera, viz., Guestieria and Systrophia appear to have spread from an Ecuadorian centre of dispersal to Peru, Colombia and Bolivia.

A most interesting and important case of discontinuous distribution is that of Clausilia, a genus of snails which I mentioned when dealing with the origin of the West Indian fauna (p. 272). I then stated the reasons for my belief that Clausilia had travelled across the mid-Atlantic land bridge from southern Europe to the West Indies rather than by a 



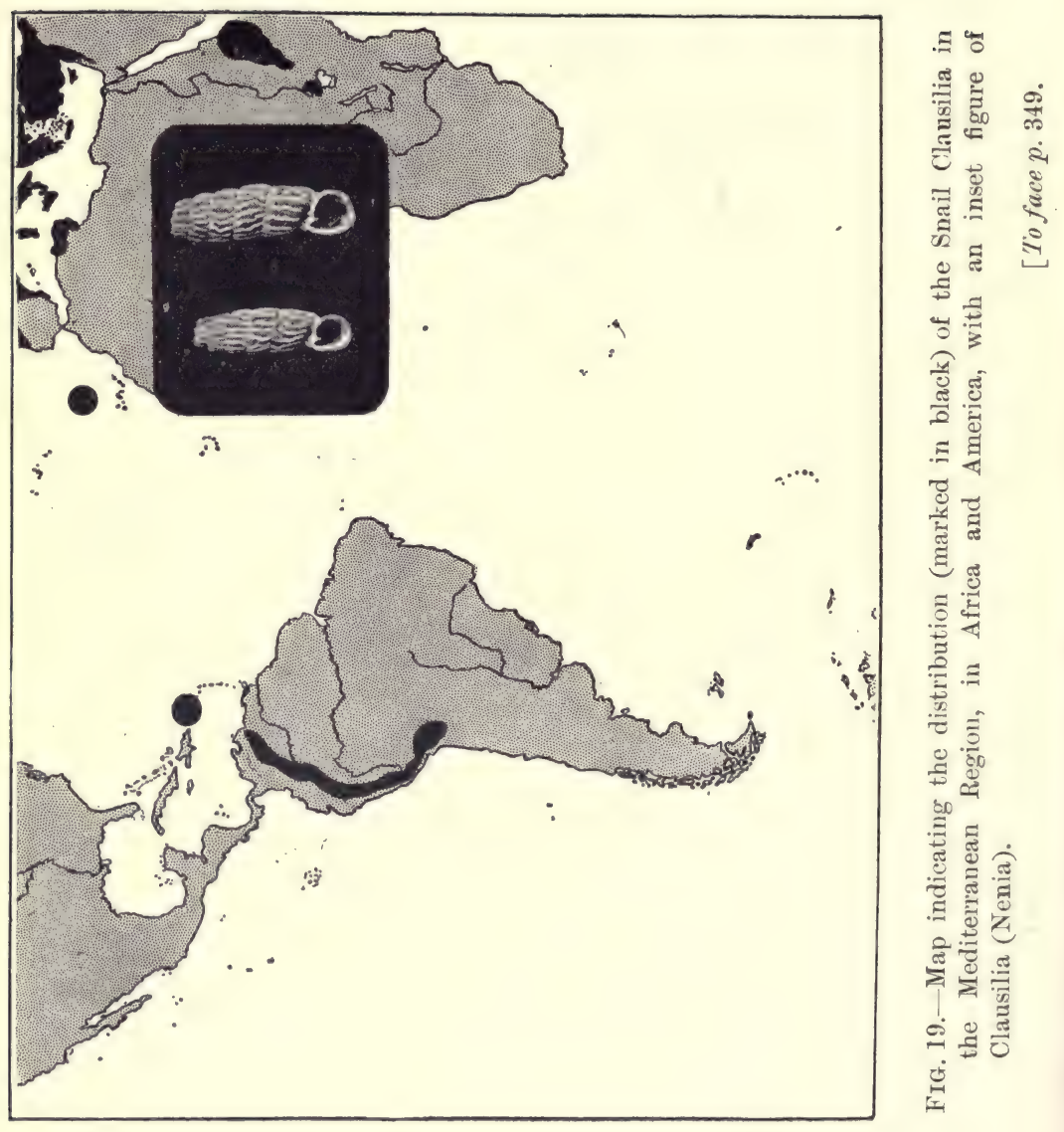


land connection between eastern Asia and Central America as suggested by Dr. von Ihering.* The American species all belong to the sub-genus Nenia, being extremely like the Pyrenean Clausilia pauli. So far only a single species is known from the West Indies, while the genus has not yet been discovered in Central America (Fig. 19). No trace of Clausilia, either recent or fossil, has been met with in North America or in northern Asia. If we assume that Clausilia passed across the Atlantio Ocean to the West Indies and thence to South America, it should have traversed Central America. It may still be found in Guatemala, or it may recently have become extinct. At any rate, I think it passed from Central America to the western or Pacific land bridge connecting Guatemala with Ecuador. The latter state, together with northern Peru, must be looked upon as the centre of dispersal of the South American species of Clausilia. Over fifty Clausilias are now known from South America. $\dagger$ A few are found northward of Ecuador as far as the province of Bogotá in Colombia. The great mass, however, is confined to the highlands of Ecuador and Peru. South of Bolivia the genus is unknown. Is there any possible explanation for the presence of this isolated colony of mountain snails in western South America except by migration on a former land connection from Europe or eastern Asia? A dispersal of the ancestral Clausilia in early Tertiary times to South America by means of either land bridge is possible, but I greatly favour the Atlantic one (compare Fig. 14). It also explains the presence of a species of Clausilia in Portorico better than the other theory.

Besides this instance of discontinuous distribution, we more over have a large number of others exhibiting ancient relationship between the faunas of the west coasts of North and South America. These will be more fully dealt with when we come to the consideration of the Chilean fauna. I may only mention one example, that of the three very closely related genera of scorpions, Hadrurus, Hadruroides and Caraboetonus. The first inhabits California, having spread from there

* Thering, H. von, "Verbreitung der Heliciden," p. 450.

+ Boettger, O., "Die Nenia Arten." 
into the adjoining state of Arizona. The second lives in Ecuador and Peru. The third is only met with in Chile and southern Peru. They all are entirely confined to the west coasts. A somewhat more distant relationship exists between the centipede Newportia of the West Indies and Central and South America, and Plutonium, which is confined to Sardinia and Corsica. This affinity implies the presence of a former mid-Atlantic land bridge between the Mediterranean and Antillean Regions and between the latter and northern South America.

My principal aim, in alluding to the fauna of Ecuador and the adjoining areas, was to point out the more important features of the former as an ancient land-mass somewhat independent from the rest of South America, and the affinity of its animal inhabitants with those of Central America, the Antilles and even southern Europe. The antiquity of the region can be demonstrated by many examples. Even birds show it clearly. Among one hundred and eighteen genera of humming-birds (Trochilidae) known to science, Androdon, Eutoxeres, Damophila, Urochroa, Phaeolaema, Agapeta, Ionolaema, Eugenia and others are quite confined to this region.* Among mammals I need only mention the remarkable discovery by Mr. Oldfield Thomas $\dagger$ of Caenolestes. This small rat-like mammal inhabits Ecuador and the province of Bogotá in the adjoining State of Colombia. It is, therefore, quite confined to northwestern South America. The only other known genera of the family Epanorthidae were found in the Santa Cruz deposits of Argentina. The presence of a still living member of this otherwise extinct family is of considerable interest. Even more important is the fact that Caenolestes is the only living American herbivorous marsupial mammal more nearly related to the kangaroo of Australia than to the American representatives of the order-the opossums.

The only South American representative of the family of bears (Ursidae) known as the spectacled bear (Tremarctos ornatus), on account of the yellow rings surrounding its eyes,

* Hartert, E., "Trochilidae."

† Thomas, O., "On Caenolestes." 
is confined to the Andes between Colombia and Chile, that is to say, altogether to western South America. This range suggests that the bears are not originally a South American family, otherwise we might expect their having a wider distribution. The only alternative is that they migrated from some other part of the world to the part of South America where they still maintain themselves. Dr. von Ihering * argued that the ancestors of the South American bear originally came from Asia, and that they wandered across on a Miocene land connection which united eastern Asia with Central America without touching North America. In that case they would be older than the North American bears which, according to Professor Osborn, + belong to the much later Pleistocene Eurasiatic invasion. As a matter of fact, the geological history of the bears in America has never received the careful attention it deserves. Bears, it is well known, are entirely absent from Africa south of the Sahara, that is to say, from what is known as the Ethiopian Region, and no fossil remains of any members of the family have ever been discovered there. Hence it is unlikely that Africa was the source of the Ursidae or that they invaded South America by means of a direct land bridge from that continent as suggested by Dr. Ameghino.f The absence of bears from the whole of eastern South America indicates, moreover, that bears have made their entry from the west. The bears of South and North America are not closely related. They appertain to different genera. A fossil bear (Arctotherium vetustus), belonging to a genus closely related to or identical with Tremarctos, has been recorded by Dr. Ameghino from the Entrerios deposits of Argentina which are of Miocene age. It would appear on that account as if Dr. von Ihering's suggestion that the South American bears were older than the North American ones, and had quite an independent Asiatic origin, was borne out by palaeontological evidence. Since Arctotherium also occurs fossil in some Pleistocene beds of North America it must have spread northward in recent times and subsequently have become extinct there.

* Thering, H. von, "Geschichte der Südamer. Raubtiere," p. 179.

† Osborn, H. F., "Age of Mammals," p. 438.

I Ameghino, Fl., "Tetraprothomo argentinus," p. 230. 
Among living bears the nearest relation of the Andean species seems to be the Malayan bear (Ursus malayanus) inhabiting the Malay peninsula and neighbouring countries. But the European Miocene Ursus boeckhi and the Pliocene Ursus etruscus are members of the same group, and it appears to me possible that the South American Tremarctos and the Ursus malayanus groups may have had a common ancestor which passed from southern Europe to South America by way of the mid-Atlantic land bridge and the Antilles in Oligocene times.

Although tapirs have a much wider range in South America than bears, their American distribution also suggests that, like the bears, they are immigrants either from Europe or Asia. Their general range is in so far comparable to the distribution just cited as the only living tapirs are confined to South America and southern Asia. Tapirs are often alluded to as among the most striking and familar instances of what is called "discontinuous distribution." But we know a good deal more of the geological history of tapirs than of bears. Of the two South American tapirs the smaller one is confined to the Andes between Colombia and Peru, while the other (Tapirus americanus) has probably spread eastward from a western centre of dispersal, for it occurs from eastern Peru to Brazil, Venezuela, Guiana and to northern Argentina. Two other tapirs live in Central America. The genus is only known fossil from Pleistocene South American deposits, and it might appear as if it were a recent immigrant from North America. But in the latter continent only a single fossil species (Tapirus haysi) has been discovered, and that likewise in Pleistocene beds. Professor Osborn asserts that a tapir, undistinguishable from the living South American species (Tapirus americanus), invaded North America together with Mylodon and Megatherium in Pleistocene times. I am not aware of any reliable osteological characters distinguishing the living South and Central American species. If there are such, Professor Osborn's * statement may possibly refer to one of the latter. Still, it is quite evident that the genus Tapirus could not have come across any Bering Strait land connection in Pleistocene times and have travelled to Argentina before

* Osborn, H. F., "Age of Mammals," p. 472. 
the end of the Pleistocene Period, nor does Professor Osborn suggest such a mode of origin. The problem, therefore, still remains unsolved. Mr. Earle* pointed out that tapir-like creatures or tapiroids arose about the same time in Europe and North America. In the light of more recent researches it would appear that the Eocene Systemodon and Isectolophus are confined to North America, while the European tapiroid remains belong to the related family Lophiodontidae. The true tapirs, to which the American genera belong, do not make their appearance in Europe until the Oligocene Period. According to Professor Osborn, $\uparrow$ the existing Malayan tapir is almost identical with the Pliocene tapir of southern Europe (T. arvernensis), and I cannot help thinking that the genus Tapirus has evolved in the Mediterranean region from American ancestors much earlier than is generally supposed, the modern tapirs having spread west and east from this centre of dispersal at a time when the mid-Atlantic land bridge was still in existence.

If we pass from Ecuador southward along the chain of the Andes, we meet with a number of new forms of animal life, all of which are more or less confined to this great mountain range. In certain districts in Peru at high altitudes there are immense colonies of curious little squirrel-like rodents with very large ears and grey fur of extreme softness. Like the prairie-dogs and other North American rodents, these chinchillas, as they are called, live in burrows. There is a larger kind, too, which has still longer ears and great black whiskers, differing sufficiently from Chinchilla to deserve recognition as the distinct genus Lagidium. Both genera inhabit exclusively the high mountains between Peru and Chile. A third member of the same tribe, the viscacha, lives on the plains of Argentina, and will be more fully described later on. These three genera included in the family Viscaciidae (Lagostomidae) have, to judge from their distribution, probably originated from one or more western ancestors. But Dr. Ameghino $\ddagger$ has described quite a number of genera

* Earle, C., "Fossil Mammalia of Europe," p. 115.

† Osborn, H. F., "Age of Mammals," p. 315.

$\ddagger$ Ameghino, Fl., "Formations sédimentaires," p. 428.

L.A. 
obviously of the same family from the Patagonian and Argentine Eocene, Oligocene, Miocene and Pliocene beds, so that it would seem, as he indeed suggests, as if South America had been the original home of the family. Professor Schlosser quite agrees that these are the undoubted ancestors of the still existing South American genera, but he thinks that Dr. Ameghino is mistaken about the age of the South American deposits in which these rodents occur. He believes them to be not earlier than Miocene, while more primitive ancestors of these rodents are to be found in European Oligocene beds. The Theridomyidae of Europe which, according to Professor Schlosser, have given rise to Chinchilla and its relatives, are more primitive in structure than the latter and nearly allied to them. The same writer acknowledges that other groups of mammals also entered South America from Europe, although he does not give us the least clue as to the means they employed in doing so. Whether Chinchilla and its relations are descended from European ancestors, or whether the European Theridomyidae have been derived from South America, is really comparatively immaterial to our present enquiries. The important point at issue is the recognition, by such an authority as Professor Schlosser,* that the two continents have had a faunistic interchange about Oligocene times in which North America took no part.

Ecuador possesses such a number of quaint archaic forms of animal life that I have scarcely been able to give a general sketch even of the main features of the fauna, but before dealing with the causes that produced them I must mention one more instance. It is the most noteworthy perhaps of the whole deer-tribe, namely, the little pudu (Pudua mephistopheles). No larger than a hare, this tiny creature, with its simple unbranched spike-antlers, reminds us of some of the early progenitors of the deer-tribe. The genus Pudua has two species, both entirely confined to western South America, like the bear and Chinchilla. One of these lives in the mountains of Ecuador, the other in Chile and on the island of Chiloë. I need not repeat the remarks made in an earlier chapter 742.

* Schlosser, M., “Tullberg's System der Nagethiere," pp. 741- 
(pp. 107-112), when I argued that the South American deer had not originated in North America, as is generally assumed, but in South America from European ancestors.

I venture to think that most palaeontologists will agree with my contention, which is by no means a new one, that there is quite a remarkable affinity between the living western South American groups of mammals and thase of the early European Tertiaries. It is my interpretation of the causes which produced this striking feature that will not so readily commend itself. The faunas of the West Indies and Central America form the chief difficulty to the acceptance of my theory. I acknowledge that comparatively few traces remain in these countries of the vast migration that swept across them. In the West Indies, I presume, the subsequent submergence must have destroyed the principal part of the original fauna, while Central America in its present form did not exist at the time when the mid-Atlantic land bridge spanned the ocean. Competition with newer arrivals, moreover, must have been very keen, so that Central America became unfitted for the survival of European relict forms. This explanation does not appear altogether satisfactory. But the crux of the problem is North America. By what possible system of land bridges can western South America have received part of its fauna from Europe and have exchanged certain groups in return without North America having become affected? This seems all the more puzzling considering that I drew special attention in Chapter IX. to the conspicuous faunistic relationship between southern Europe and California. The faunas of western North America and western South America as a whole are strikingly different, and yet I have indicated certain points of resemblance, especially between some of the more ancient members of the two faunas. If we supposed the midAtlantic land bridge of early Tertiary times to have been connected at first with both western North America and western South America, while disconnected at all other points with these continents, certain very ancient points of resemblance between the two continents and with Europe might thus receive a satisfactory explanation. If the same land bridge had then become entirely separated from North America, remaining united with South America, the faunistic 
interchange would have continued only between Europe and South America. If the land bridge had then become disconnected with South America, and joined to western North America, while the Antilles were submerged, the latest European emigrants would have taken refuge in California as the last remnants of the old land sank into the Pacific. That something of this kind actually took place I feel convinced, although the details of these events must be founded largely on geological studies which unfortunately are as yet insufficiently known. My own knowledge, moreover, of the geological features of the regions alluded to is only fragmentary. Nevertheless, the little I have been able to gather does not tend to contradict the general scheme of the theories I now suggest.

In later Cretaceous times a broad sea, as I have pointed out on several occasions, separated western from eastern North America, while the Pacific Ocean flooded a large portion of the western States, so as to leave only a comparatively narrow strip of land between the two seas. The Cretaceous deposits can be traced all along the Pacific coast as far almost as the extreme tip of Lower California. Here they suddenly stop. The Cretaceous sea evidently did not cover the interesting Cape Region of Lower California nor any part of western Mexico. There are reasons for the belief that even at this time the western part of the coast ranges of California were not submerged, thus suggesting the existence of another land-mass to the west of the Californian Sea. This land may have been connected with the Cape Region of Lower California, and thus with Mexico. By the end of Cretaceous time, says Professor Smith,* the subsidence and erosion of the western part of the continent had almost established a connection between the Pacific Gulfs in California and Oregon and the old Mediterranean Sea in the Mississippi valley. The intervening isthmus was covered by extensive marshes. Professor Smith tells us that the geographical conditions remained the same in Eocene times as in the Upper Cretaceous, except that the sea encroached still further on the land. Now it is precisely at this time that we notice a striking affinity

"Smith, J. Perrin, “Geological History of California," pp. 347-348. 
between the western mammalian fauna of North America and those of Europe on the one hand and South America on the other. Since south-western North America was then practically isolated and separated from the remainder of North America by great ocean belts, how can we imagine these European and South American affinities to have been brought about? Surely only by some land connection that lay to the south. I suggest that it was from western Mexico that these earliest mammals invaded south-western North America. Then followed a time when the Gulf of Mexico and the Pacific Ocean probably communicated with one another, thus separating the supposed mid-Atlantic land bridge from North America. Professor Smith speaks only of a temporary connection between the oceans, accounted for by the occurrence in Oregon, as well as in California, of the Atlantic marine mollusk Venericardia planicosta. Before the Miocene Period this Atlantic connection had ceased, and the faunas of the later Tertiary were wholly of the Pacific type, continues Professor Smith.* He does not allude to Oligocene deposits, but it is not long since that these were recognised at all outside Europe. At any rate, after the Eocene follows a time during which the Pacific recedes from the west coast, thus giving full opportunities for an invasion of animals from the theoretical western land. We may suppose that this corresponded with the Oligocene Period and with the time when, as Professor Osborn tells us, there was a re-establishment of the faunal resemblance of south-western North America with Europe. Possibly Chile, which was connected at an earlier period with this same western belt of land, became separated from it. This again was succeeded by a period of marine transgression in the west. Even northern Mexico was largely covered by the sea, as well as both sides of Lower California and a large portion of western California. All this time western South America must have risen gradually above the sea, and I presume that certain fragments of land, like Peru, became joined to the long peninsula which stretched far southward running parallel with the newly formed west coast of South America. Thus while North America no longer

* Smith, J. Perrin, “Geological History of California,” p. 348. 
received its quota of European emigrants, they found suitable accommodation on the newly-formed land of north-western South America. The mid-Atlantic land bridge now ceased to exist, and far-reaching geographical changes supervened almost everywhere. Owing possibly to the extensive subsidences in the Pacific Ocean, the land that I assume to have occupied part of the eastern Pacific, was gradually reduced in size. But, being no longer tenanted by the more vigorous and more advanced European types, South American forms now commenced to occupy this land, thus first reaching the Antilles and then North America as it again became fully connected with the western land. Central America in its present shape had not yet come into existence. Not long ago it was thought that the Central American isthmus must have been first utilised as a highway at the beginning of the Pliocene Period, and that then the great edentates began to pour into North America. Now the surprising evidence has come to hand that true edentates of the Megalonyx type occur in the Middle Miocene Mascall beds of Oregon. Dr. Matthew writes to inform me that the Megalonyx remains only doubtfully belong to this horizon. Professor Osborn, * on the other hand, believes in the discovery, and expresses the opinion that it tells in favour of my theory of the former existence of a western land connecting North and South America independently of Central America. Still, he points out that it is inconsistent with the fact that other animals did not pasis south or north.

Let us examine some of the other new arrivals in North America in Miocene times, and endeavour to trace their geological history. One of the most noteworthy of these is the first appearance in North America of elephants (Mastodon). Since Dr. Andrews' $†$ surprising discoveries in northern Africa were published, Africa is generally looked upon as the original home of elephants, the earliest form being Moeritherium, from which later on Palaeomastodon and its more modern relations arose. The first of the latter was the Mas-

* Osborn, H. F., "Age of Mammals," pp. 289-292.

† Andrews, C. W., "Tertiary Vertebrates of the Fayúm," pp. xvixviii. 
todon called Trilophodon on account of the three transverse rows of cusps on its intermediate grinding teeth. Now Trilophodon arrived in Europe and in North America at about the same time during the Miocene Period. Professor Osborn assumes that these mammals came from Asia, although we possess no evidence of their having reached the northern or eastern parts of that continent. We might be tempted to invoke a direct land connection between Africa and South America in Oligocene times, but, as we shall see later on, that connection must have disappeared at a still earlier period. However, these and other problems will be considered in the next chapter.

Several important zoogeographical features of western and northern South America still remain to be considered. Special researches among the Cretaceous rocks and their fossils in Peru have shown that during Lower Cretaceous time, that is to say, towards the latter part of the Mesozoic Era, the greater part of the country was buried deeply beneath the ocean. From Bolivia and Chile, even as far south as the Strait of Magellan, Lower Cretaceous deposits have been discovered. North of Peru they occur in Colombia and Venezuela. The most surprising circumstance connected with these South American beds, however, is the great number of species that are either identical with or closely allied to, such as occur in the Cretaceous deposits of north Africa, the south of France, Switzerland and the neighbouring countries.* More than sixty years ago D'Orbigny already drew attention to this fact, and argued from it that a land connection across the midAtlantic must have enabled species to cross the ocean by. travelling along a continuous shore-line. On the other hand, scarcely any affinity exists between the Cretaceous of Venezuela and that of Mexico or Texas, thus clearly implying the presence of a land barrier between these two areas. The old highland of Guiana east of Venezuela was long ago a peninsula of the archaean highlands of Brazil in the south. There is reason to believe that the great mountain chain of the Andes gradually emerged out of this sea. During this process some of the newly-formed islands probably became attached

* Paulcke, W., “Kreideformation in Südamerika,” pp. 305-308. 
to parts of pre-existing western lands. All through Tertiary time the mountains must have continued to rise, though our knowledge of later geological history is still meagre. We know that Tertiary marine deposits occur in the Orinoco valley, and it is likely that a narrow marine channel still separated northwestern South America from the rest of the continent during the earlier part of the Tertiary Era. The Amazon valley no doubt was at that time a bay of the Pacific; still, I am unaware of any geological or zoogeographical evidence for Professor Osborn's supposition that north and middle South America were completely divided in Miocene times by a wide sea. That the Orinoco and Amazon valleys were in communication with one another for a long time is shown by the fact that one of the species of manatees (Trichechus inunguis) and the freshwater turtle Podocnemis expansa are confined to the upper portions of these two great rivers. A most surprising confirmation of the theory that an ocean bay extended to the neighbourhood of the Andes has been discovered near the small town of Pebas, on the upper Marañon, more than twenty degrees of longitude west of the mouth of the Amazon. Professor: Boettger described deposits from this locality containing typically brackish water mollusks which could only have lived in the neighbourhood of the sea. He naturally came to the conclusion that the Atlantic then had invaded the Amazon valley so as to extend near to the foot of the Andes. But Dr. Katzer's view, already alluded to, according to which the Amazon drainage only changed eastward in later Tertiary times, appears to me to agree better with the zoogeographical features of eastern South America. Professor Boettger* looked upon the Pebas beds as being of Oligocene, possibly Eocene age. The fresh-water fish fauna of the Pacific slopes of southern Ecuador still exhibits such affinity to that of the Amazon that the Ecuador mountains could only have had a slight elevation until comparatively recent geological times. Hence we may assume that the Pacific extended to the neighbourhood of Pebas when these brackish water beds were laid down.

An interesting zoogeographical demonstration of the

* Boettger, O., "Die Tertiärfauna von Pebas," p. 503. 
gradual elevation and consequent slow change of the marine character of an ancient lagoon is afforded by Lake Titicaca on the borders of Peru. This lake, with a length of eighty miles, lies in a mountain valley over 12,000 feet above sealevel, and occupied not long ago a much larger area. To suppose that this region should have risen from sea-level to such a height, and still preserve the remnants of an ancient marine fauna dating back to the period when it was a gulf of the Pacific, would seem a very bold theory. Professor Suess,* indeed, expresses the opinion that the presence of a marine fauna in Lake Titicaca cannot be regarded as a sufficient proof of the theory that the lake was at sea-level within recent geological times. I quite concur with Professor Suess in so far as the assumption of a recent elevation is concerned, but we have reason to believe that certain ancient forms of animal life, particularly among aquatic groups, have transmitted their specific characters unchanged to their modern descendants. It is conceivable, therefore, and even possible, that the striking affinity of the fauna of Lake Titicaca to that of the Pacific coast may have been preserved, although the actual junction of the lake with the sea took place perhaps as far back as early Tertiary times. The theory of the recent elevation was first mooted by Mr. A. Agassiz, $†$ owing to the discovery in the lake of eight species of the marine amphipod Allorchestes, one of which (A. dentatus) differs but slightly from a form still inhabiting the Strait of Magellan. That fact alone might be attributable to accidental dispersal, although the enormous difference in height between the sea and the lake, and the circumstance of there being eight different species of Allorchestes, would be difficult to explain on that theory. But besides this marine crustacean ather members of a marine fauna have been shown to exist in Lake Titicaca, and thus the case against accidental dispersal has assumed a stronger position. The fish fauna consists of a catfish (Pigidium rivulatumi), belonging to a genus which is very widely distributed all over South America, and several species of Orestias. The latter genus is quite confined to Lake Titicaca, and since

* Suess, E., "Antlitz der Erde," I., p. 693.

† Agassiz, A., "Lake Titicaca," p. 287. 
its nearest relations are all marine forms, its ancestors, as Professor Eigenmann * remarks, could only have entered the area when it was still a gulf of the sea.

In the Eocene Period "Archiguiana," as Dr. von Thering named the ancient highland of Guiana and eastern Venezuela, was supposed by this writer to have been isolated from the highland of Brazil. And, indeed, the mountain plateau of Guiana contains a very large number of archaic and most peculiar types, some of which seem to spread westward into Venezuela and Colombia rather than into Brazil. Yet the great majority of these ancient forms of Guiana also occur southward in eastern Brazil. One of the most noteworthy birds, the hoatzin (Opisthocomus hoatzin), whose young climb about among the branches of the trees by means of well-developed claws on their wings, and which have been placed into a distinct order by themselves, range southward as far as Bolivia. The chatterers (Cotingidae) comprising some of the mosit ornate and peculiar birds of South America, are almost equally divided between Brazil and Guiana. The familiar umbrella bird (Cephalopterus ornatus), the bell bird (Casmorhynchus niveus), the bald-headed crow (Gymnocephalus calvus), and the cock-of-the-rock (Rupicola crocea), all belong to genera which have spread westward from Guiana rather than into Brazil. In all these cases we have to determine what was the original centre of dispersal. The singular genus of snails Ampullaria probably spread across South America from a Brazilian centre, and so did the fresh-water crab (Pseudothelphusa) and the whole family of fishes called Cichlidae. The snail Strophocheilus, the fresh-water mussel Unio, the archaic arthropod Peripatus, the family of tortoises Cinosternidae and others, have apparently entered Brazil from the north and west. As I shall endeavour to show in the next chapter, many of the forms that have spread from the Brazilian highlands have near relations in Africa, while among the northern and western immigrants into Brazil scarcely any have succeeded in crossing the Atlantic area to Africa.

* Eigenmann, C. H., “Freshwater Fishes of South America," p. 521. 


\section{CHAPTER XIV}

\section{EASTERN SOUTH AMERICA}

When we consider that Brazil covers an area larger than that of the whole of Europe, merely the roughest outlines of the general zoological features of that vast country can be attempted in a work of this nature. The highlands of Brazil, as I have mentioned already, are confined to the east, being surrounded by the ocean on one side and by a continuous tract of lowlands on the others. It is believed that the mountains were once continuous with those of Guiana right across the present mouth of the river Amazon. The whole of the area between the two great highlands of Brazil and Guiana is drained by the mighty Amazon, whose waters exceed in quantity that of any river in the world. The Paraguay and its tributary the Paraná drain the southwestern parts of Brazil. Practically the whole of the country lies in the tropics. The combined influence of high temperature and abundance of moisture thus produces that exuberance of animal and plant life which is so characteristic of Brazil. The great tropical forests are truly bewildering in the wealth and variety of their vegetation, and it is here that we realize more than anywhere else the keen struggle for exist. ence as applied to plants and animals. In their constant efforts to reach the light, and in their endeavour to obtain a full share of it, the trees crowd and press upon one another until the weaker succumb. In their turn they are invaded again by others, while hosts of enemies, parasitic plants and climbers, twine round and strangle the less sturdy long before they succeed in attaining their object. We are thus presented with a scene of savage warfare among plants. It is less evident among animals. But the ringing sound of the multitude of voices issuing out of the forest reminds the traveller that in this teeming profusion of nature there must be an acute 
struggle for life among animals as well as among plants. And yet, except birds, insects and lizards, animals do not appear to be present in unusually large numbers. The large class of mammals, which elsewhere form such a conspicuous feature of a fauna, seem almost to be absent. This is largely due to the fact that Brazil is really poor in terrestrial mammals. Those that do inhabit the country are chiefly of arboreal habits, and thus escape attention. Mr. Bates* believes that the South American fauna has been slowly adapted to an arboreal life, and that extensive forests must always have existed since the region was first peopled by mammalia.

Among these arboreal mammals the family of the capuchin monkeys (Cebidae), whose unusually prehensile tail gives them peculiar facilities for climbing, are the most noteworthy. They range all over tropical America, being most abundant in the dense forest regions of Brazil. In some monkeys, like the howlers (Mycetes), the end of the tail underneath is devoid of hair, and thus acts with even greater efficiency than in capuchins (Cebus). The sakis (Pithecia) and squirrel-monkeys,(Chrysothrix) have non-prehensile tails. The spider monkeys, with their long limbs and long prehensile tail, are the most admirably adapted creatures for a purely arboreal life. A second family (Hapalidae) includes the smallest of all monkeys, the marmosets. Mostly very active little squirrellike creatures, with arboreal habits, they are almost confined to Brazil and north-western South America. In many respects these two families of South American monkeys are closely related to one another, whereas they differ from the Old World species, especially in their dentition. Since no members of the Cebidae and Hapalidae have ever been found fossil outside South or Central America, it is believed that they form a branch distinct from the Old World monkeys, having had a separate origin from lemur-like creatures. Dr. Ameghino has described quite a number of lemuroid remains from the Cretaceous of Patagonia, and he maintains that these early forerunners of monkeys and man originated in the ancient vast territories of southern South America. I am fully aware that

* Bates, H. W., "Naturalist on the Amazons," p. 32. 
the views of Dr. Ameghino* as to the age of these beds have received a considerable amount of adverse criticism. Still, if we assume the correctness of his arguments and the former existence of a land bridge between South America and Africa, these lemuroid mammals might have passed from Patagonia, as Dr. Ameghino supposes, to Africa and thence to Europe, and lastly, from there to North America. I do not think that this was the history of events. One distinct branch may have travelled from Patagonia to Chile, and thence direct to North America by a western land connection (compare Fig. 14), which I have already mentioned and which will be further discussed in the next chapter. From North America it may have passed into Europe by the mid-Atlantic land bridge. I doubt whether arseparate branch reached Africa from South America by a land bridge, which Dr. Ameghino contends joined these two continents. However, it is this very problem of the zoological affinity between South America and Africa and its origin which will be dealt with in this chapter.

What we have to consider principally, therefore, is whether there are really such affinities between the living faunas of the two continents as to make it probable that the latter were once connected with one another by land. The capuchin and marmoset families, which are quite confined to South and Central America, have probably originated there in the remote past and have not been able to pass into any other continent. All we know of their immediate ancestry is that in the Eocene deposits of Patagonia a new family of monkey-like creatures arose, possessing certain marks of resemblance to the two recent South American families. They were named "Homunculidae" by Dr. Ameghino. As these also are quite unknown outside South America, it would appear as if Patagonia had become isolated during the course of the Eocene Period from the rest of the world. We certainly have no evidence of any Tertiary land connection between the southern portions of South America and Africa from the distribution of monkeys.

Another typically Brazilian arboreal mammal is the sloth, which lazily and cautiously moves from branch to branch

* Ameghino, Fl., "Formations sédimentaires de Patagonie," p. 289. 
supported by the long claws of its toes. Two genera of this edentate mammal are known, viz., Bradypus and Choloepus, both of them confined to South and Central America; and, like the monkeys, absent from Argentina, Chile and Patagonia. In spite of their absence from the latter country, it is there, according to Dr. Ameghino, that we find the earliest traces of the sloth-tribe in the Eocene beds. The Eocene Entelops and Trematherium have been placed into the same family with the modern sloths. Certain sloth-like remains have even been traced back to the Upper Cretaceous of Patagonia. Sloths of the arboreal type have not been found fossil outside South America. The remains of a supposed sloth (Bradytherium) were discovered by $\mathrm{Mr}$. Grandidier ten years ago on the island of Madagascar. According to Dr. Smith Woodward they belong to a lemur, yet there are so many other points of affinity between South America and Madagascar that a former direct land connection between the two regions has been suggested. I return to this subject more fully in the next chapter.

In a previous chapter (p. 70) I explained that, although all American porcupines are arboreal in distinction to the Old World species which live on the ground, only the South and Central American forms have prehensile tails. This gives them greater facilities for dispersal in Brazil, and greater protection from their enemies. These South American porcupines agree in their general range with the monkeys and the sloths, and like them are absent from the southern states of South America, although their ancestral home was seemingly in Patagonia. Some species of Coëndu are known from the Brazilian caves, still, the centre of origin lay manifestly further south.

Of the pouched or marsupial mammals we have noticed that the opossum has a wide range in North America. In Central and South America the same North American species (Didelphys marsupialis) occurs widely distributed. Such an enormously extensive range must be due to the fact of its being a persistent mammalian type. The genus, or one closely related to it, certainly was already represented in the Lower Eocene of North America and the Upper Eocene of France. Only one genus of these marsupial mammals occurs 
in North America. From South America three others are known. The general range of the family Didelphyidae points to South America as the centre of dispersal. Although the genus Didelphys or Peratherium has been met with in the Eocene of North America and France, while it first appears in South America in the Miocene Period, if Dr. Ameghino is correct, the earliest member of the family (Proteodidelphys) occurs in the Lower Cretaceous beds of Patagonia. Even if we look upon these beds, with Professor Osborn, as really of Eocene age, the more primitive characters of Proteodidelphys point to South America as the ancestral home of the family, and on this continent no doubt the genus Didelphys has originated and not in south-eastern Asia, as suggested by Mr. Lydekker.* I think the geological history of the opossums, though dating further back than that of the South American monkeys, followed much upon the lines of the groups just considered, at any rate, they seem to have entered Brazil about the same time.

Among the birds of South America we have precisely similar examples, except that in their case we know unfortunately very little of their past history from palaeontological evidence. The wonderful family of humming birds (Trochilidae) is comparable in distribution with the opossums, in so far as it ranges all over South and Central Americla. It has in all likelihood entered North America in later geological times. Not a single species of humming bird is known beyond the confines of America. It is of importance to note that of the one hundred and eighteen genera admitted by Dr. Hartert, $\uparrow$ the great majority are confined to the west coast. Some of them inhabit Chile, others Peru, Bolivia, Ecuador, Colombia, Central America and Mexico. A few (Oreotrochilus) live at enormous heights, up to 20,000 feet. Others are limited in their range to the Antilles and Brazil. Only the single genus Avocettula, with one species, is peculiar to Guiana. This seems to suggest that the family originated in western South America, and has only gradually spread eastward on the mainland. The West Indian area no doubt was

* Lydekker, R., “Geographical History of Mammals," p. 112.

$\dagger$ Hartert, E., "Trochilidae," 
invaded by the humming birds in earlier times from the west, since several very distinct genera with well marked characters have originated there. The humming birds constitute a sharply defined family, whose nearest relatives are the treeswifts (Macropteryx) of southern Asia and western Polynesia. The common ancestors of these two groups may possibly have inhabited part of the supposed ancient Pacific continent, and may have diverged from it east and westward when it subsided. As Dr. Wallace* aptly remarks, no naturalist can study in detail this single family of birds without being profoundly impressed by the vast antiquity of the South American continent, its long isolation from the rest of the land surface of the globe, and the persistence through countless ages of all the conditions requisite for the development and increase of varied forms of animal life.

The chatterers (Cotingidae) which have already been alluded to as comprising some of the most beautiful and noteworthy of American birds, are almost confined to South and Central America and the West Indies. Only a few species enter North America in Mexico. The curious toucans (Rhamphastidae) with their huge bills and strange texture and coloration of their plumage, as well as several other families, are restricted to South and Central America and have no near relations in the Old World.

If South America had been connected by land with Africa in later Tertiary times, we should expect, at any rate, such mobile creatures as birds and also butterflies to indicate by their distribution the former existence of such a land bridge. Among the most conspicuous butterflies in the Brazilian forests, Mr. Bates mentions the Heliconiidae, which are readily recognisable by their long narrow black wings, variously ornamented with white, crimson and yellow dots or stripes. Yet the family is almost purely South American. A single species only (Heliconius charitonia) passes into Mexico. $\dagger$

The Morphidae likewise range from Argentina to Mexico, some of the larger species, with their dazzling metallic

* Wallace, A. R., "Distribution of Animals," II., p. 9. † Stichel, H., and H. Riffarth, "Heliconiidae." 
colours, being characteristic of the Brazilian forest fauna. The family is unknown in the Old World, but, as in the case of the humming birds, we have closely allied groups (Amathusidae, etc.) in western Polynesia and southern Asia, so that the Morphidae or their ancestors may possibly have entered South America, as so many other groups have done, from the west.

The large and mostly active lizards belonging to the family Teiidae are spread all over South America, ranging northward as far as California and Texas and through the West Indies. They appear to have only extended their range into North America in comparatively late geological times, although they are known from early Tertiary deposits in South America. Nevertheless the Teiidae are quite unknown in the Old World. Instances of that kind might easily be cited from every group of vertebrates and invertebrates.

Yet although these examples seem to show that the faunistic community between South America and Africa is so slight as not to necessitate the hypothesis of a former land connection between these continents, we possess other very striking features of distribution which are strongly opposed to such a conclusion. I may draw attention again to the most remarkable fact, pointed out by Professor Bouvier,* that the genus Peripatus is peculiar to America, with the single exception of Peripatus tholloni of West Africa. All the other Peripatus-like creatures have been proved by Professor Bouvier to belong to different genera or groups.

During his travels in the Amazon region, Mr. Bates discovered a curious archaic spider-like creature, which was named Cryptostemma westermanni. More recently the same species has been recorded from Sierra Leone and from the Cameroons in West Africa. Those who allege that accidental dispersal is responsible for such cases of distribution, probably accept the discovery of Cryptostemma westermanni on both sides of the Atlantic as a notable instance of the facility with which species are wafted across the ncean. But we must remember that there are thousands of species of animals and plants inhabiting the coasts of West Africa and

* Bouvier, E. L., "Monographie des Onychophores," I., p. 91. 
Brazil that are specifically and generically distinct from one another, although more fitted for accidental dispersal across the ocean than Cryptostemma is. The instances of such specific or generic identity of animals and plants, in fact, are scarce. Moreover, Cryptostemma is the single survivor that has yet been brought to light of the otherwise extinct order Meridogastra, which occupies a somewhat intermediate position between the true spiders and what are called " harvestmen."* For this reason it must, like Peripatus, be looked upon as an exceedingly ancient relict member of our fauna.

Let us take another group of apparently very ancient animals, the worm-like and limbless coecilians, which live underground. Dr. Boulenger $\dagger$ tells us that of the genus Dermophis three species are found in Central and South America, one in West Africa and another in East Africa, and that the genus Herpele is confined to Gaboon in West Africa and Panama. Dr. Sarasin argues that the dispersal of Herpele at any rate dates from pre-Cretaceous times. It seems possible, therefore, that these few archaic creatures indicating faunistic relationship between South America and Africa, have obtained their present range during some very remote geological period, when the conditions of land and water were entirely different from what they are at present, and that they are not to be regarded as instances of accidental dispersal across the Atlantic. The suggestion that South America and Africa were once united by land is not a new one. It has been made, as we have learnt, by various authorities on entirely different grounds. Considering the contradictory nature of the evidence, however, the problem requires close scrutiny.

I have already stated that Dr. Ameghino had expressed the opinion, based on the evidence of the fossil mammals, that South America and Africa were joined by a land bridge during the whole of Upper Cretaceous times. During the Eocene Period this land connection, he thinks, became more restricted or narrowed down, while it still persisted incompletely as a chain of islands, until middle Miocene times. Dr. Ame-

* Karsch, F., “ Über Cryptostemma," pp. 25-29.

+ Boulenger, G. A., "Synopsis of apodal Batrachians," pp. 404-409. 
ghino's * arguments in favour of this union of South America and Africa are not founded on any palaeontological resemblance between these two continents, but rather on the affinity of the fossil mammals of South America to those of Europe, Asia and North America. Since I have shown that until about Oligocene times southern Europe was connected by land with western South America, by way of the West Indies and part of Central America, there does not seem to be any necessity for a second land bridge further south in order to account for the mammalian affinities existing between South America and Europe as well as Asia and North America. Professor Osborn does not recognise the existence of any former land bridge during the age of mammals between South America and the Old World except by way of North America.

Mr. Lydekker $\dagger$ argues that the only marked community between the Ethiopian and Neogaeic(South American)faunas as regards mammals, relates to the hystricomorphous rodents, but he thinks this community is a very marked one and diffcult to explain on any other hypothesis than that of a land connection between the two areas. The Hystricomorpha are a section of the rodent mammals, well distinguished by morphological characters from the other sections of that order. It is of the greatest importance to note that this hystricomorphous section is now confined to Africa and America, with the exception of a couple of genera which range into southern Europe and Asia. The centre of distribution is no doubt South America. If they had passed from there to Africa, we should expect them to be found in Brazil and western Africa. Let us examine the two closely related families of Octodontidae and Ctenodactylidae, which are included in the section Hystricomorpha. The first is confined to South America, the other to Africa. Of the former it is the sub-family Octodontinae which is nearest related to the Ctenodactylidae, and almost entirely confined to Argentina and the west coast of South America. Only a few species like Ctenomys brasiliensis and Ct. minutus really enter Brazil. The extinct species are all but one confined to

* Ameghino, F., "Formations sédimentaires," pp. 281-287.

† Lydekker, R., "History of Mammals," p. 127. 
Argentina. It seems manifest, therefore, that the ancestral members of this sub-family have travelled along the west coast of South America probably from a southern centre of dispersal. We find no trace of them in Central America or the Antilles, but it is in North Africa where we meet with Ctenodactylus with its peculiarly modified inner toes. Here in the Mediterranean region, and not in Africa proper, must have been the Old World centre of dispersal, for we find the allied extinct genus Pellegrinia in the Pleistocene of Sicily, and Ruscinomys in the Pliocene of southern France. A recent relation of Ctenodactylus (Massoutiera) has passed southward towards the Senegal. The main branch, however, has apparently invaded eastern Africa from the Mediterranean region, giving rise to the genera Pectinator, Thryonomys and Petromys. Only a single species (Thryonomys swinderianus) has gained the west coast of Africa. Of the sub-family Echimyinae, which largely inhabits Brazil, Africa possesses no near relations. The only African family of the hystricomorphous rodents, that of the Cape jumping hares (Pedetidae), occupies a more isolated position, its exact relationship being still somewhat obscure. But in any case, I fail to deduce sufficient evidence from the distribution of these hystricomorphous rodents, in favour of a direct land connection between South America and Africa, although there must have been one between the Mediterranean region and western South America by way of the West Indies and Central America (see p. 280 and Fig. 14).

Apart from the cape jumping hares (Pededitae), there are in South Africa certain mammals which indicate a distant relationship with South American ones. The peculiar piglike African edentate Orycteropus occurs in Africa, while another edentate, the pangolin (Manis), inhabits Africa and the Indian region. Dr. Tullberg thought that these and other features implied that south-western Africa must have been joined by land to South America during a time when the former was completely severed from the rest of Africa. But even this land bridge ceased to exist, according to Professor Tullberg,* at the beginning of the Tertiary Era, at latest in

* Tullberg, T., “System der Nagetiere,” p. 498. 
Eocene times. He thought that south-western Africa later on became united with eastern Africa, thus enabling some of these ancient mammals of South American origin to spread northward towards Europe and eastward into Asia. But both the Manidae and the Orycteropidae are represented in the Eocene deposits of southern Europe, while the genus Orycteropus lived in Samos and on the mainland of Greece in Miocene times. Moreover, neither Manis nor Orycteropus are confined to southern Africa. Both are distributed north-eastward as far as Kordofan and Senaar. It seems more likely, therefore, that these edentates, like the hystricomorphous rodents just alluded to, have originated in the Mediterranean region from South American ancestors and have spread southward subsequently.

The same problem has also been discussed by Dr. Andrews* as the result of his remarkable discoveries of fossil mammals in the Fayúm of Egypt. All the Carnivora he found there belonged to that archaic group known as the "Creodonta." He argues that the presence of these creodonts in Africa would account for the existence of the "Sparassodonta" in Pata. gonia, if we assumed that during the remote period when these ancient groups originated, Africa and South America had been joined to one another by land. He also brings forward another testimony in support of his suggestion, which I shall deal with later on. As for the Creodonta, they are so amply represented in the early Tertiaries of both North America and Europe, that the assumption of a mid-Atlantic land bridge is sufficient to explain their presence in these continents as well as in Egypt, while Patagonia must have had some land connection with North America in late Cretaceous or early Eocene times.

The distribution of birds does not give us many definite suggestions as to former land connections between South America and Africa. The range of the parrots (Psittacidae), however, points to an affinity between these continents. A more striking example seems to be that of the ostrich and rhea. The former inhabits exclusively Africa and Arabia, the other Argentina and Brazil. Hence we might be tempted to

*Andrews, C. W., "Tertiary Vertebrates of the Fayúm," p. xxii. 
explain their present range by a direct land bridge between the two continents. The American ostrich (Rhea) is only known fossil from superficial deposits, but the ostrich (Struthio) occurs in the Miocene or Lower Pliocene of the Siwaliks of India and of the island of Samos. Since the ostrich once lived in the Mediterranean region, it is possible that the common ancestor of the two families may have utilised the mid-Atlantic land bridge to travel from the Old World to the New or vice versa.

The reptiles and amphibians, as Dr. Blanford * has pointed out, indicate a much more pronounced faunal relationship between South America and Africa than the birds or mammals do. Professor Pfeffer $\dagger$ endeavoured to explain this very ingeniously by the assumption of a former sub-universal, or almost universal, distribution and a subsequent extinction on the northern continents. He admits that some form of land bridge was necessary, of course, yet almost all intercontinental communication must have passed, according to his views, across a Bering Strait land bridge. $\mathrm{He}$ quotes a number of instances of groups which are now confined to the southern hemisphere, but have once also extended to the northern continents, and because they have done so he contends that they must have had a sub-universal distribution. All those examples which are not found fossil in the northern hemisphere are nevertheless supposed to have had a similar range and to have gained their present southern distribution in different countries by wandering from one to the other almost by way of the North Pole and then south again. Nothing but a careful general study of existing distribution can convince us of the fallacy of such an assumption.

Let us take, for instance, the family of fresh-water tortoises, the Pelomedusidae. It is confined to Africa, including Madagascar, and South America. Curiously enough, one of the genera of this family, viz., Podocnemis at present inhabits only northern South America and Madagascar. But, as Professor Pfeffer tells us, the genus is known as far back as

* Blanford, W. T., "Anniversary Address," pp. 70--71.

+ Pfeffer, G., “Zoogeographische Beziehungen,” pp. 417-418. 
the Cretaceous of Patagonia and New Zealand, the Eocene of Egypt, England and India, and the Miocene of Egypt and Malta. The faunistic relationship between Patagonia and New Zealand will be explained later on, yet it has by no means been produced by a sub-universal distribution. The only fossil occurrence of Podocnemis we know of from Africa is that from Egypt, and even that, with Malta and England, is rather suggestive of a radiation from a Mediterranean centre. The dispersal from an originally Patagonian birthplace may have taken place westward to New Zealand and northward along the ancient land connection, which I described as extending by way of Central America to southern Europe. It is important to bear in mind this very peculiar case of faunistic relationship between South America and Madagascar, exclusive of the African continent, because similar instances are met with among many groups of animals and plants. I have already alluded to one, and it was first suggested by Dr. H. O. Forbes, I think, that this range was due to a former direct land connection between Patagonia and Madagascar.

I drew attention in a former chapter (p. 173) to the members of the family Amphisbaenidae as furnishing, on account of their subterranean habits, important evidences of former changes of land and water. I may mention again that they are limbless, wormlike liazrds, and that many of them live underground in ants' nests. They are not liable, therefore, to accidental dispersal. Their distribution is most interesting. They inhabit mostly Africa and South America. A few occur in the West Indies and the Mediterranean region. Some have even spread into the southern States of North America, and we possess a few remains from Oligocene deposits. Otherwise we know nothing of their past history. We might suppose that some early member of this family had spread across the mid-Atlantic land bridge to the Mediterranean region and thence colonised Africa with Amphisbaenidae. But in this instance such a land bridge cannot help us, because the genus Amphisbaena occurs in Africa and South America, while the Mediterranean region is inhabited by the genus Blanus. The latter, no doubt, may owe its origin to a migration across this mid-Atlantic land bridge, still we can scarcely imagine that, coming from 
the north, and after having given rise to Blanus in southern Europe, the American ancestor reverted again to Amphisbaena when it reached Africa. Amphisbaena, moreover, is represented in Brazil by about a dozen species, some of which are very closely allied to those of Sierra Leone and Liberia in West Africa. If we attribute such a range to a former sub-universal distribution, as Professor Pfeffer suggests, then practically all animals with a wide southern range must at some time or other have passed through North America and Asia or Europe to raach their present habitats, and for such an assumption we have no palaeontological evidence. I think a case of this kind, as Dr. Blanford remarks, implies a former land connection between South America and Africa. We possess among the Amphisbaenidae an even more striking example of faunal relationship between these two continents. There are two species of Anops, one of which (Anops kingi) ranges from Brazil to Argentina, while the only other species (A. africanus) is confined to West Africa.

Of particular interest are the skinks (Scincidae), as I explained (p. 124) that this family must be of very great antiquity. Some of the genera certainly date back to Mesozoic times. Now, while skinks are abundant in North America, the southern continent is almost entirely free from these lizards. Those that live there, at any rate, belong to a genus distinct from the northern one. Southern Asia and Africa are the headquarters of this large family. Only the single genus Mabuia has spread into South America. Mabuia occurs principally in southern Asia, Madagascar and Africa. A few species are known from the Cape Verde islands on the west coast of Africa, while one (Mabuia punctata), very closely allied to them, has been met with on the island of Fernando de Noronha off the east coast of South America and also in Guiana. Three species are found in Brazil. A couple have passed northward penetrating into Central America and one even to the Greater Antilles. We have clear evidence here of a former land connection between West Africa and South America and of its having been utilised by the skink, Mabuia, in traversing the Atlantic in a westward direction.

The worm-like amphibian Dermophis has not yet been 
noticed in eastern South America, but to judge from the circumstance that one species lives in east Africa, another in west Africa, a third in Ecuador, and a fourth in Central America, according to Dr. Boulenger, ${ }^{*}$ we may conclude that the genus will probably turn up in Guiana.

The frogs and toads are divided into two groups, one of which (a very small one) contains those that are devoid of a tongue, while all others possess this useful organ. The tongueless toads are generally looked upon as the most primitive of the tailless amphibians. Three genera of these creatures are known to science, two (Xenopus and Hymenochirus) inhabiting Africa south of the Sahara, the other (Pipa) eastern South America. The only member of the last genus is the remarkable Surinam toad (Pipa americana) whose skin on the back of the female is provided with pits in which the eggs are placed and the young undergo their whole metamorphosis. These tongueless toads (Aglossa) are not known as fossils. We have thus to conjecture the origin of their dispersal from their present distribution which is highly suggestive of a former direct land bridge between Africa and South America. This view is considerably strengthened by the fact that the West African Hymenochirus is in several respects more closely related to Pipa than to Xenopus.

The toothless frogs (Dendrobatidae) appear at first sight to be typical examples of a group which has obtained its present range by means of a former land bridge between South America and Africa. They occur only in northern South America, in west Africa and Madagascar, a discontinuous distribution which betokens antiquity, and which is not unknown among other animals and plants. Yet Dr. Gadow $\dagger$ argues that the Old World and New World genera were evolved independently from toothed frogs, that this is, in fact, a case of convergence. It may be so, but his arguments are by no means convincing.

I may once more be permitted to draw attention here to the opinion long ago expressed by Dr. Gill $\ddagger$ that fishes are

* Boulenger, G. A., "Synopsis of apodal Batrachians," p. 404.

† Gadow, H., "Amphibia and Reptiles," p. 272.

$\ddagger$ Gill, T., " Principles of Zoogeography," pp. 29-30. 
among the best indicators of past continental changes, and that the relations of the several southern continents as to their ichthyio faunas can be best understood by the assumption that, at some remote epoch or epochs, there was distribution of land and water which eventually permitted an emigration and immigration of types from one into another. Dr. Günther * enunciated similar views. He thought that the existence of so many similar forms of fishes on both sides of the southern Atlantic supported the supposition that they are the descendants of a common stock which had its home in a region now submerged under some intervening part of the ocean. Since the days when these two great authorities pronounced upon this subject, the ichthyology of both Africa and South America has become better known, and new light has been thrown on the relationship between the various groups of fishes. We can deal with the problem now in the light of the latest researches. Dr. Boulenger has made a special study of the African fish fauna, while Mr. Regan and Professor Eigenmann have paid particular attention to the ichthyology of South America. In his interesting address to the British Association on the distribution of African fishes Dr. Boulenger mentions Protopterus as the most noteworthy fish of Africa. In some respects it approaches the amphibia. It possesses a double lung as well as gills, and is able to live for a long period in dried mud. Anatomically there are many characters in which it differs from almost all other fishes. Its only living relation, Lepidosiren of Brazil, is very similar in form and so closely allied that the two are placed into the same family Lepidosirenidae. Professor Pfeffer $†$ contends that since this family is represented in the Permian and Trias of western North America, in the Trias of India and South Africa, in the Cretaceous of Patagonia and the Trias and Jurassic of Europe it must have had a universal distribution. Hence he argues that the occurrence of Protopterus in Africa and of Lepidosiren in South America can have no significance in supporting the theory of a former land connection between these two continents. But recent

* Günther, Albert, "Study of Fishes," p. 233.

† Pfeffer, G., “Zoogeographische Beziehungen,” p. 433. 
researches have shown that these extinct forms all belong to the genus Ceratodus, that all are members of the family Ceratodidae.* The only fossil member of the Lepidosirenidae is Protopterus libycus of Egypt. There is really no reason, therefore, as Dr. Boulenger $\uparrow$ puts it, why the latter family should not have passed from one of the two continents into the other when they were connected by land.

Another striking feature of the South American fresh-water fish fauna is the extraordinary number and variety of forms of the Characinidae, unquestionably, according to Dr. Boulenger, one of the most lowly and generalised groups of exclusively fresh-water teleosts. They are likewise abundantly represented in western and central Africa, yet not a single genus is common to both continents. Hence Dr. Boulenger $\ddagger$ concludes that it is quite legitimate to explain the distribution of this family by the assumption of a land bridge connecting Africa and South America about the end of the Cretaceous Period.

A similar argument is used by Mr. Regan $\S$ to account for the large fresh-water family Cichlidae (compare Fig. 12) in these two continents, except that he is of opinion that the land bridge was still in existence in early Eocene times.

Professor Eigenmann || states that there is no known means by which these two families could have crossed the existing gap between Africa and South America. There has been no exchange of species in recent times, for there is no species or genus common to the two continents. The South American and African elements of these two families must have been derived from some intermediate land-mass, or must have travelled from one continent to the other over a land bridge. That this connection must have been obliterated before the Tertiary Era is evidenced, he remarks, by the fact that the Tertiary deposits of Taubaté and Paraná include existing genera, and that many South American families of fishes

* Goodrich, E. S., "Cyclostomes and Fishes," p. 258.

+ Boulenger, G. A., "Distribution of African Fishes," p. 5.

$\ddagger$ Boulenger, G. A., "Distribution of African Fishes," p. 6.

§ Regan, T., "Fishes of Central America," p. xiv. 526.

II Eigenmann, C., "Fishes of South and Middle America," pp. 525- 
which are absent from Africa have arisen in South America from the Characinidae and Siluridae since the separation of the two continents.

Dr. von Ihering's early recognition of the importance of fresh-water faunas as an aid to the palaeogeographical studies of the Palaeozoic and Mesozoic Eras, has led to very remarkable results. Some of these I have indicated already. His noteworthy discovery that some of the fresh-water bivalves of South America have a "lasidium" larva, while all the Unionidae possess a "glochidium," placed the family Mutelidae into quite a different position. The Mutelidae are a family essentially South American and African, demonstrating clearly, as Dr. von Ihering * admits, the existence of a land connection between South America and Africa during the Mesozoic Era.

The family Achatinidae includes some of the largest and most conspicuous land-snails, Achatina achatina growing to a length of seven inches. Their distribution, which is well known, indicates an African centre of evolution. The early members of the family are unknown and should be looked for in mid-Mesozoic deposits, according to Dr. Pilsbry. $\dagger$ The same authority believes that some of the sections of the Achatinidae migrated to South America before the interruption of the land connection across the tropical Atlantic. Dr. Pilsbry, who in his earlier volumes condemns the practice of throwing hypothetical bridges across the oceans, now almost takes it as a matter of course that Africa and South America were once united by land. The mollusks, as most other groups of animals, yield facts of distribution that are quite unexplainable by the theory of accidental dispersal, and many of those who at first were firm believers in the immutability of our ocean basins, have entirely changed their opinions after a careful study of zoogeography. It is the smaller kinds of the Achatinidae which show the affinity between the two continents most clearly. Thus the genus Subulina is confined to Africa and tropical America while Opeas and Pseudopus have spread to other parts as well.

* Therino, H. von, "Archhelenis and Archinotis," pp. 125-145.

$\dagger$ Pilsbry, H. A., " Manual of Conchology," Vol. XVIII., p. vi. 
It is now fifty years since Mr. Andrew Murray* first directed attention to the fact that the beetle fauna of Old Calabar in West Africa presented certain affinities with that of South America. He even then suggested that some sort of communication must once have existed between these two regions of the earth. A few years later he returned to the same problem, expressing the opinion that this communication consisted of an actual land bridge of which the only remaining vestiges are the islands of Ascension, St. Paul's, St. Helena and Tristan da Cunha.†

Great stress is also laid on this remarkable relationship between the southern continents by Professor Kolbe, $\ddagger$ but he explains it by the assumption of a land bridge far to the south of the Equator.

Dr. Packard § was good enough to inform me some years ago that the distribution of the Lepidoptera was distinctly in favour of the theory of a former union between South America and Africa. He alluded in particular to a family of moths known as the Saturnidae, stating that their general range confirmed the view arrived at from other sources, that perhaps at the close of the Cretaceous Period and through the early part of the Tertiary Era the two continents were connected with one another by land.

The importance of the fresh-water crabs in the solution of problems of this nature has been emphassised, as I mentioned before, by Dr. Ortmann, \| who showed that the west African Potamoninae are geographically most closely approached by the South American Potamocarcininae, and that this suggested a former union of these regions. This land bridge in its full extent, he thinks, existed during the Jurassic and in early Cretaceous time. In the middle of the Cretaceous Period the southern Atlantic advanced northward and gradually invaded the east coast of South America extending as far as the Amazon valley. Guiana still remained joined to West Africa during the remainder of the Cretaceous Period, and was not

* Murray, A., "Coleoptera of Old Calabar," pp. 453-454.

† Murray, A., "Coleopterous Faunae," p. 15.

† Kolbe, H. J., “ Die Coprophagen Lamellicornier,” p. 503.

§ Packard, A. S., "Larval Forms of Moths," p. 280.

|| Ortmann, A. E., "Distribution of Decapods," pp. 350-351. 
finally destroyed until early Tertiary times (compare Figs. 15 and 20). Quite recently, however, Dr. Ortmann * argued that this "Archhelenis" of Dr. von Ihering must have sunk beneath the waves of the ocean by the end of the Mesozoic Era.

Some time ago Mr. Pocock $†$ pointed out that the scorpions of the genus Opisthacanthus were confined to tropical Africa, Madagascar and South America. Our knowledge of the distribution of scorpions has increased considerably since he wrote his essay, but the range of Opisthacanthus has not been greatly extended. It occurs in west, east and south Africa and Madagascar, while it reappears on the opposite side of the Atlantic in Colombia and the island of Haiti. It is not known from either Brazil or Guiana and may possibly have become extinct there. On the other hand, Damon, one of the Tarantulidae, occurs in west and east Africa and from Brazil to Patagonia. Professor Kraepelin $\ddagger$ assumes that because the African Damon variegatus in a specifically identical form actually inhabits South America, it must have been introduced into the latter continent, yet in another place he urges that several of the centipedes (Scolopendridae) probably maintained their specific characters from archaic times to the present day. Like some of the species of Otocryptops, Rhysida and Scolopendra and the curious arachnid Cryptostemma, Damon variegatus may possibly represent one of these ancient species which has retained its morphological characters unchanged since Mesozoic times.

The numerous examples, cited above, indicate that there exists a perfectly recognisable faunistic relationship between tropical Africa and tropical South America. Nevertheless this relationship rarely extends to genera and species. If so it is confined to forms like Anops, Mabuia, Subulina, Opisthacanthus, Cryptostemma and others, of which there is reason to believe that they are extremely ancient types. From some cause or other they may have retained their specific or generic characters throughout a series of geological ages. The faunas of Africa and South America as a whole are thoroughly dis-

* Ortmann, A. E., "Tertiary Archhelenis," p. 242.

+ Pocock, R. I., "Distribution of Arachnida," p. 229.

$\ddagger$ Kraepelin, K., "Scorpiones and Pedipalpi,” p. 240. 


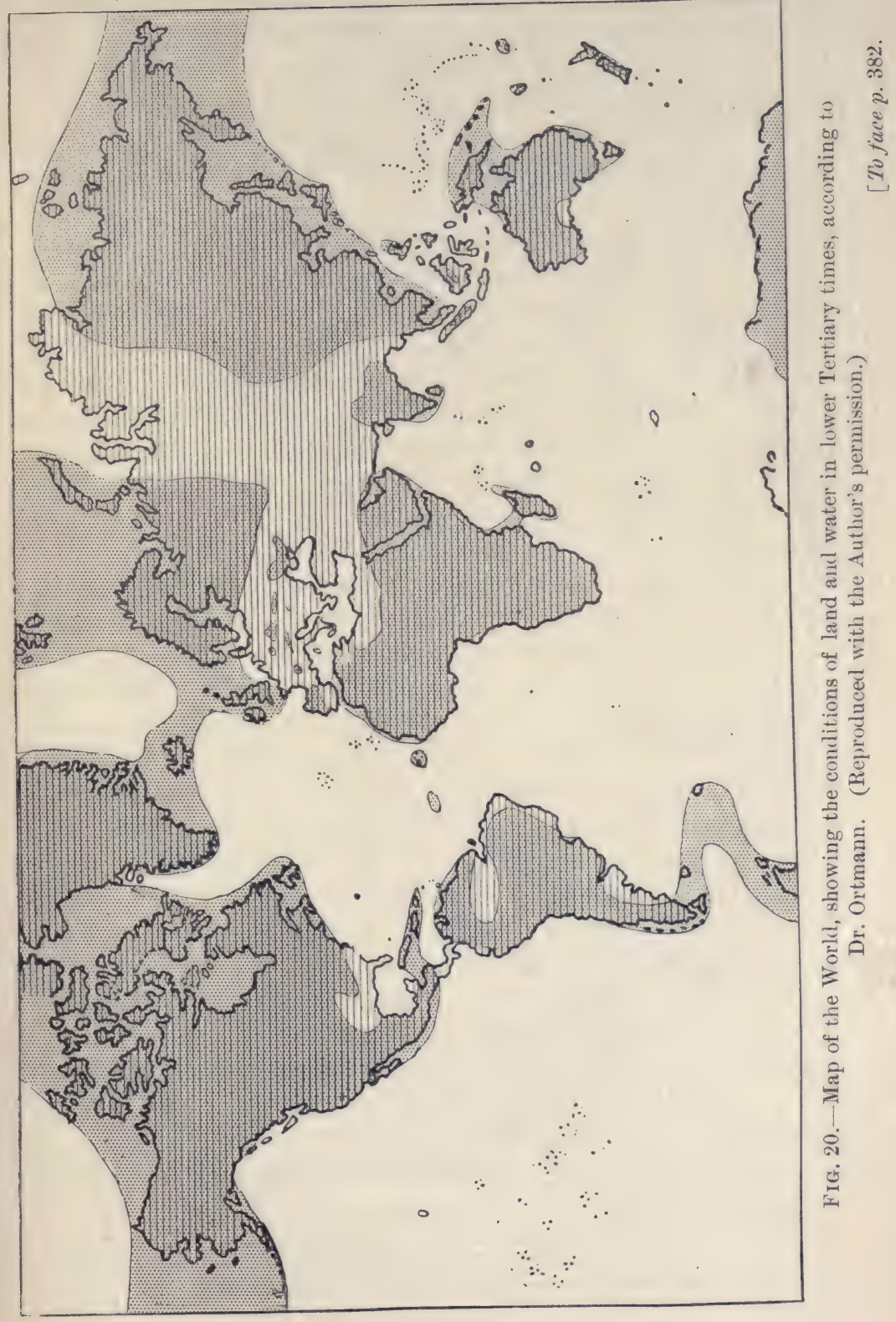



tinct. All the more modern families of these continents show scarcely any traces of relationship to one another. Consequently we must conclude with Dr. Ortmann and several other authors who have definitely expressed themselves on the geological age of the former land bridge between South America and Africa, that the latter ceased to exist before Tertiary times.

Dr. von Ihering* did not limit his studies in South America to the fauna, he likewise urged, contrary to the opinion held by most botanists, that the floras of South America and Africa pointed unmistakably to the existence of his "Archhelenis." His arguments were so convincing that Professor Engler $\dagger$ adopted his views after a very careful and critical examination of the problem from a botanical aspect. He acknowledged that for a long time he had looked upon the theory of a former land connection between South America and Africa with scepticism, chiefly on account of the great intervening ocean depths and the marked endemism in the flora of the two continents. After discussing the various means of accidental dispersal, and eliminating those plants which might possibly owe their presence in both continents to some of the known modes of occasional transport, he was impressed by the circumstance that there was still a residuum of species, genera and families which must have had another origin. He urged that the distribution of the Strelitzioidae, whose fruits cannot be dispersed by wind, also that of some of the water plants of Africa, which have very near relations in South America, and others might be accounted for by the supposition of the former existence of a series of large islands in the Atlantic Ocean separated by narrow channels. All the same he prefers a complete land bridge between the two continents.

Dr. Arldt $\ddagger$ discusses the problem in a very effectual manner both from a biological and a geological point of view. Like Dr. Ameghino, however, he is led to the conclusion that even in early Tertiary times South America was still directly joined

* Thering, H. von, "Das Neotropische Florengebiet."

$\dagger$ Engler, A., "Floristische Verwandtschaft zwischen Afrika and Amerika," pp. $50-51$.

$\ddagger$ Arldt, Th., "Entwicklung der Kontinente," p. 451. 
to Africa, whereas I favour the theory that such a connection could only have persisted indirectly by way of the Antilles and southern Europe.

It has been urged that if a land bridge had once existed between Brazil and west Africa we ought to find some traces of sedimentary rocks on the few islands that are scattered about in the intermediate area, like Fernando de Noronha, St. Paul's, St. Helena, Ascension and Tristan da Cunha, whereas all these are believed to be composed of volcanic rocks. Professor Schwarz, ${ }^{*}$ nevertheless, affirms that although Ascension consists of volcanic rock the substratum is granitic. St. Paul's island, he thinks, is mainly metamorphic in structure, and there are signs of its having been subjected to considerable earth movements. Continental types of rocks occur on Tristan da Cunha. Consequently Professor Schwarz concludes that these Atlantic islands furnish some geological testimony for the belief in a Mesozoic Continent in the position of the southern Atlantic lasting until the beginning of the Tertiary Era.

The island of Fernando de Noronha lies about two hundred miles east of Cape San Roque on the coast of Brazil. Since its discovery in 1503 both the original fauna and flora of the island have been laid waste by early settlers, so that only vestiges of these are left. The splendid trees that once clothed the island are gone and with them probably the greater part of the fauna. A mammal, at any rate, existed on Fernando de Noronha when it was discovered, but it has quite vanished. Mr. Ridley, who visited Fernando de Noronha in 1887, noticed that quite a number of species of animals and plants had evidently been introduced by human agency. Many others, he thinks, have been transported to the island from the mainland by winds, although he noted that the smaller birds and a large proportion of the smaller insects are endemic. A few, he remarks, may possibly have been brought over on the feet of wading birds. There still remains a small group of indigenous species which are difficult to account for, on the hypothesis of accidental distribution. The subterranean lizard

* Schwarz, E. H. L., "Land-connection between Africa and uth America," pp. 81-90. 
Amphisbaena ridleyi, for example, is peculiar to the island, its nearest relation living in the West Indies. The skink (Mabuia punctata) occurs on the island as well as in British Guiana. The snail Bulimulus ridleyi, as I have already pointed out (p. 176), is the only living representative of the Oligocene group of species which once inhabited Florida. There are, moreover, two species of Opeas identical with West Indian forms, while a Pupa seems closely allied to a Cuban species. The single fresh-water species (Planorbis noronhensis) is endemic. The noteworthy relationship with the Antilles is also noticeable among the plants as well as among the marine forms living on the shores of the island. As might be expected, this is attributed by Mr. Ridley* to the action of sea-currents. No other theory of the origin of the fauna and flora of Fernando de Noronha than that of accidental dispersal by wind or waves ever occurred to him. Yet both Mabuia and Amphisbaena are genera which, as I have shown, can be cited with some justification as evidences of the existence of a former land connection between South America and West Africa. And these, with a gecko of enormously wide range, constitute the only members of the reptilian fauna. Why should these ancient reptiles inhabit Fernando de Noronha and not any of the more modern groups? This and other pertinent criticisms of Mr. Ridley's theory have also been urged by Dr. von Ihering, $\dagger$ who shows, especially from a botanical point of view, that accidental dispersal has not played a very important part in the origin of the island flora. On the contrary, he maintains that it is part of the ancient Archhelenis which once united South America and Africa.

The small island of Trinidad, not to be confounded with the island of the same name in the West Indies, lies much further south, and about seven hundred miles east of the coast of Brazil. It is now uninhabited, though for a time it contained a small colony of settlers who left a few goats and pigs on the island, which continued the destruction of the native fauna and flora commenced by their late masters. The ground

* Ridley, H. N., "Zoology of Fernando Noronha," pp. 473-502.

† Thering, H. von, "Fernando de Noronha," p. 6.

L.A. 
moreover, is riddled with the burrows of myriads of land crabs, which have aided the domestic animals, to the best of their ability, in this work. Trinidad seems to have been densely wooded formerly with tree ferns, palms, etc., whereas living trees are now confined to the mountain tops. Among the ferns collected on the island by Dr. Copeland * there was one (Asplenium compressum) hitherto only observed in St. Helena. Of the fauna nothing appears to be known.

Ascension island lies in about the middle of the southern Atlantic. When Darwin visited the island during his famous voyage round the world, he found little there of interest. A principal mound in the centre looks as if it were the parent of the lesser volcanic cones studded round the island. The surface is parched and barren, and everything presents a scene of utter desolation. Yet not only is Ascension island inhabited, the scanty pasture has even been made serviceable for a number of sheep, goats and cows. Ascension stands on a submarine bank about two hundred miles in length. It is probable on that account that the existing island only represents the last remnant of a cluster of volcanic cones which rose high above the surrounding land. The surviving fauna and flora are extremely poor. Many of the species, like the centipede Scolopendra morsitans, are almost cosmopolitan in their range, a few also occur in Africa or South America. But no effort has as yet been made to conduct a thorough zoological and botanical survey of the island, and it is to be hoped that this will be accomplished before all traces of the ancient relicts that might still occur have been superseded by recent importations. At any rate, nothing of any importance can be gathered from the little information we possess. $\dagger$

St. Helena, like Ascension island, is wholly volcanic in structure, and being, moreover, surrounded by depths up to 17,000 feet, Dr. Wallace claims that we ought to be satisfied as to its being a true oceanic island and as to its owing none of its peculiarities to a former union with any continent or other distant land. But, as I have pointed out once before, the existence of such a great depth of the ocean does not prove that it

* Copeland, R., "Insel Trinidad," pp. 274-277.

† Günther, A., and others, "Collection made in Ascension Island." 
always was so. Geological evidence, says Professor Suess,* does not prove, nor even point to, a permanence of the great depths, at least in the oceans of the Atlantic type. No longer can we, therefore, subscribe to Dr. Wallace's statement that St. Helena is necessarily what he calls a "true oceanic island." The island was densely covered with a luxuriant forest vegetation when it was discovered in the year 1501 . Human occupation has almost wholly destroyed this indigenous vegetation, and with it no doubt the greater part of the fauna. The rich soil, no longer protected by the covering vegetation, has been swept away by tropical rains, leaving a vast expanse of bare rock or sterile clay. Fortunately the fauna and flora of St. Helena have received greater attention. than those of Ascension, and although a mere fragment only of what originally inhabited this area, it allows us to draw some conclusions as to their origin. There are neither mammals, amphibians nor reptiles on the island. The only indigenous bird is a small plover (Aegialitis sanctae-helenae), closely allied to a species found in South Africa. Among the invertebrates the beetles in particular have been carefully studied by $\mathrm{Mr}$. T. V. Wollaston. $\dagger$ Out of two hundred and three species collected on the island, he considers one hundred and twentynine to be indigenous. Only one of these is found elsewhere. These species belong to thirty-nine genera, of which no less than twenty-five are peculiar to St. Helena, most of them being weevils (Rhynchophora). Since the greater number of weevils are woodborers, we conclude from this fact alone that the island once possessed a luxuriant forest vegetation. Many of the beetles show no close affinity with any existing insects. A small number only are more or less remotely related to European and South African species. These features imply, as Dr. Wallace truly remarks, that the beetle fauna of the island is extremely ancient, dating back to at least the Miocene age. Dr. Wallace acknowledges that at present the marine currents flow towards St. Helena from the region of the Cape of Good Hope; nevertheless he contends that in former geological periods the currents may

* Suess, E., "Are Ocean Depths Permanent?" p. 186.

† Wollaston, T. V., "Coleoptera Sanctae Helenae." 
have varied, and that drift-wood might have been carried to the island from different directions. Great alterations of wind, he thinks, were probable during the Glacial Epoch, so that these two most potent agencies in the accidental transport of species may have varied very much during the periods in which the island received its colonists from other countries. Of course, Dr. Wallace* firmly adheres to the belief that all animals and plants found on the island owe their existence there to some means of occasional transport.

Thirty species of bugs (Hemiptera) have been recorded by Dr. White from St. Helena, of which five have certainly, and one probably, been introduced. This leaves twenty-six species indigenous to the island. Of the twenty-one genera of Hemiptera eight are peculiar to St. Helena, but the general distribution of these insects was so little known at the time that Dr. White was unable to trace their affinities, except that most of them have a wide range, and several are known from Miocene deposits. Only one genus (Megarhaphis) has distinctly African affinities. Dr. White $†$ argues from the general aspect of the fauna and flora, from the non-existence of mammals and reptiles, from the large number of endemic species, and from the great depth of the surrounding sea, that St. Helena at no time could have been joined by land with Africa or South America. A careful consideration of all the known facts led him to believe that the colonists did not arrive all in a body, but that colonisation was spread over a considerable period. He rejects the theory of a continuous land surface, contending that the fauna and flora arrived from the north in the direction of the Cape Verd islands. Steppingstones in the shape of islands, now disappeared, may have existed formerly, thus facilitating dispersal, whilst the marine currents were probably reversed.

Mr. Pickard-Cambridgef informs us that forty-four species of spiders are known from the island, some of them being also found in Europe, and two in Egypt. The rest are endemic, but most of them show European relationship. In a former

* Wallace, A. R., "Island Life," pp. 294-303.

+ White, F. B., "Hemiptera of St. Helena," pp. 446-460.

$\ddagger$ Pickard-Cambridge, O., "Spiders of St. Helena," p. 210. 
ncte he recorded two scorpions (Lychas maculatus and L. americanus). These have since been shown to be both forms of Isometrus maculatus, a cosmopolitan species of the tropical and sub-tropical zone. In Europe it occurs only in the south of Spain.*

The total number of land-shells indigenous to St. Helena is estimated by Mr. Smith as amounting to twenty-seven species. With regard to their origin, he likewise rejects the theory of a possible land connection of the island with either Africa or South America, or, indeed, any other land surface. All the same, he points out that there is a greater resemblance between the molluscan fauna of St. Helena and South America than was recognised by previous observers. It is especially a species resembling the exclusively Brazilian genus Tomigerus that seemed to Mr. Smith to point to South America as the likely source of some of the indigenous species. He does not feel tempted to probe further into this mystery, for he exclaims, "How they were transmitted is a hopeless problem to solve, and although drift-wood, carried by oceanic currents, is doubtless answerable for a good deal in the way of distribution the subject must apparently ever remain one of mere speculation." Nevertheless Dr. Kobelt $\uparrow$ regards it as highly probable that this molluscan fauna is the last remnant of that of an ancient Mesozoic continent.

About half of the species of the snails of St. Helena are now extinct and occur only in a sub-fossil condition. Hyalinia cellaria, H. alliaria and a few others, along with Amalia (Milax) gagates are supposed to have been introduced with plants. It is quite possible that some of them were brought to St. Helena in that manner, still it is very remarkable that the only slug thus conveyed should be one of our rarest British species, and the one which has the widest range of all slugs. It occurs in California, New Zealand, and other remote localities, while none of our common Arions, Agriolimaces or Limaces have found their way to the island. I am fully convinced that Amalia gagates is one of the most ancient of our European terrestrial species, as I explained in a previous

* Pickard-Cambridge, O., "Spiders and Scorpions of St. Helena," p. 544.

† Kobelt, W., "Zoogeographische Stellung von St. Helena," p. 201. 
chapter (p. 213), and that it might well form part of the indigenous fauna of the island. There are twelve species, some of which greatly resemble Polynesian forms, as $\mathrm{Mr}$. Smith pointed out, and, indeed, Dr. Pilsbry has placed them provisionally with Endodonta, a genus otherwise confined to Australia and Polynesia. There are three species of Succinea, a genus which seems to be particularly unfit for transport on drift-wood, while the most striking members of the snailfauna are a species of Bulimus, seven species of Bulimulus, and one provisionally placed by Mr. Smith* in the South American genus Tomigerus.

More recently, Dr. Pilsbry demonstrated that these apparently bulimoid snails are really members of the family Achatinidae, and that they all belong to the genus Chilonopsis. Since all the nearest relations of Chilonopsis are African. genera, the affinity of this group is with Africa rather than with South America. But the great antiquity of Chilonopsis is indicated by the fact that Trichodina, to which it is closely allied, has a most remarkably discontinuous range, occurring only on some islands off the coast of West Africa and on the Comoro islands in East Africa. Chilonopsis, moreover, is more primitive than the genera of the large African Achatinidae, and Dr. Pilsbryt expresses the opinion that it, as well as the related genera, originated from a common ancestor which lived in Mesozoic times, when Africa and South America were united by land. None of the species have any affinity with South African ones, as was supposed to be the case among the Hemiptera.

Although Dr. White's Megarhaphis has now been shown to belong to Macrorhaphis, a genus confined to Africa, two species have since been taken in west Africa. The supposed slight affinity of the St. Helena bugs to those of the Cape has therefore entirely disappeared. As regards the pronounced European element in the St. Helena insect fauna, it is probably to a large extent of American origin. The beetle Zophobas morio lives, outside St. Helena, only in west Africa, Central and South America and

* Smith, E. A., "Land-shells of St. Helena," pp. 259-269.

† Pilsbry, H., "Manual of Conchology (Pulmonata)" (2), Vol. XVII., pp. $171-173$. 
the Antilles, while all other members of the genus are American. The only relation of the bug Metacanthus concolor of St. Helena occurs in Europe, whereas the three most closely allied genera inhabit America. The genus Nysius has a world-wide range, and is known from American Miocene deposits. Cardiastethus occurs in Europe as well as in St. Helena, but the genus is mostly American, and from there ranges across the Pacific to New Zealand. Nabis capsiformis occurs in southern Europe, and also all over Africa and America, while the genus has a world-wide range. The allied Vernonia of St. Helena has near relatives in the West Indies and the western Pacific region. Salda is a distinctly northern genus, although a few species reappear far southward of the others in Chile, New Zealand and St. Helena. That such a range implies great generic antiquity is evident, and, indeed, Salda is known in several species from the lower Oligocene.

Of the Curculionidae which are so largely represented in the fauna of St. Helena, and which Dr. Wallace thought might be of Miocene age, many recent genera are now known from the Lower Oligocene and they are probably much older even than that, for, according to Dr. Handlirsch, over two hundred species are now known from Oligocene deposits. The genus Homalota which Dr. Wallace fancied was exclusively European, is represented in the Oligocene of North America. Philonthus, Xantholinus and Oxytelus occur in the American Miocene and European Lower Oligocene. The supposed European genera of insects inhabiting St. Helena are thus mostly groups of very widie range, or such of which we actually possess palaeontological evidence of their having existed since early Tertiary times.

However ancient the insect fauna may be, remarks Dr. Wallace, the flora must be more ancient still. Of the fifty truly indigenous flowering plants, about forty are peculiar to St. Helena, and of twenty-six ferns, about ten. The relationship of this flora is mainly African, according to Sir Joseph Hooker, whereas Mr. Bentham maintains that the Compositae have their affinities for the most part with South America. Sixteen species of ferns are common to St. Helena 
and other countries. Dr. Wallace, ${ }^{*}$ however, acknowledges that specific identity among ferns does not necessarily imply a recent origin. According to Professor Engler $\dagger$ the five endemic genera are somewhat related to American ones, whereas some species of Pelargonium, Mesembryanthemum, Wahlenbergia and Oteospermum must have originated in Africa.

Dr. von Ihering $\ddagger$ discusses all the various modes of dispersal, by birds, winds and ocean currents, in connection with the origin of the flora of St. Helena, and rejects them as quite inefficient. In his opinion, only a land connection with Africa and South America could have produced the flora.

Although St. Helena is surrounded by great ocean depths, and possesses neither mammals, reptiles nor amphibians, we cannot assume, as Dr. Wallace has done, that the whole fauna and flora owe their origin to accidental dispersal by birds, winds and ocean currents. If such were the case, there is no reason why these modes of transport should not have been equally effective in Pliocene and Pleistocene times than in the older geological periods, and why there should not be many species differing but slightly from American or African ones. Everything, on the other hand, points to the animals and plants being almost all of extreme antiquity. We have either to suppose, therefore, that during some very remote period the modes of transport alluded to were far more efficient than they are now, or that St. Helena was connected by land with South America and Africa. For many reasons, already fully discussed in this chapter, the latter hypothesis appears to me the only one that is at all probable. If we assume that there was such a land bridge, it is quite possible that the actual volcanic area now forming St. Helena was not in existence, but originated after portions of the land connection had already subsided. A mere remnant of the fauna and flora would eventually have taken refuge on the rock of St. Helena, whilst the surrounding country disappeared beneath the floods. Whether in early Tertiary, or even in later Tertiary times, there was a short and independent land bridge between

* Wallace, A. R., "Island Life," pp. 305-307.

$\dagger$ Engler, A., "Entwicklungsgeschichte der Florengebiete," II., p. 179.

$\ddagger$ Thering, H. von, "Das neotropische Florengebiet," p. 50. 
St. Helena, Ascension island, the Cape Verd islands, the Canaries and Madeira, is a matter which must be left to future observations. Certain faunistic features appear to be in favour of such a theory.

Tristan da Cunha is almost as large as St. Helena. It lies considerably further south, being bleak and inhospitable in the extreme, owing to its proximity to the northern boundary of the antarctic ice-drift. The flora is quite different from that of St. Helena, as it possesses antarctic affinities. The genera Nertera, Uncinia and Acaena inhabiting antarctic America, New Zealand or Australia occur here also. It has Lomaria alpina, in common with South America, Kerguelen island, New Zealand and Australia, while Spartina arundinacia occurs in Tristan da Cunha and St. Paul, and is related to a South American species.* The most remarkable member of the fauna is the genus Tristania which, with its two species, is confined to the island. It is related to the snail Opeas which inhabits both Africa and South America.

Almost three hundred miles further south there is still another volcanic island, of which scarcely anything was known until it was visited by Dr. Bruce, the leader of the Scottish National Antarctic Expedition. First called "Diego Alvarez " according to Dr. Brown, $\dagger$ its name was later on changed to "Gough island." The island differs from some of the other islands referred to, in being densely covered with vegetation, which is similar in character to that of Tristan da Cunha. While showing the same general affinities, Diego Alvarez seems to have a stronger American element than the islands forming the Tristan da Cunha group. The land birds comprising two species of bunting (Nesospiza) and a gallinule (Porphyriornis) are peculiar to the island, but related to species living on Tristan da Cunha.

To briefly review the results of our studies so far, it appears highly probable that Brazil was entirely separated from western South America in Mesozoic and part of Tertiary times, but was connected with the highland of Guiana across the mouth of what is now the Amazon river, which flowed

* Engler, A., "Entwicklungsgeschichte der Florengebiete," II., p. 159.

† Brown, R. N. R., "Diego Alvarez," pp. 9-10. 
westward. During part of secondary times eastern Brazil was most likely united by land with West Africa. During the Cretaceous age already, the southern Atlantic rapidly advanced northward, invading eastern Brazil, so that the land bridge then joined only northern South America and a small tract of West Africa. In Eocene times the southern trans-Atlantic land connection had ceased to exist, yet the South American continent must have extended still far eastward of its present coast-line. Eastern Brazil continued to receive new additions to its fauna from the northern States of South America: while its area extended gradually westward. When Brazil finally became joined to Argentina a faunistic interchange took place, although Brazil and Chile remain to the present day two fundamentally distinct countries. 


\section{CHAPTER XV}

\section{ARGENTINA AND CHILE}

Aцтнолян the natural southern boundaries of Brazil appear to be the great river Plate and the Paraguay river (Fig. 18), the two smaller republics of Uruguay and Paraguay are interposed between Brazil and this river system, while Argentina has also claimed a large slice of territory on the northern side of it. As we proceed southward from eastern Brazil the mountains gradually pass into hills which again are replaced by gently undulating plains. Magnificent pasture lands abound in Uruguay, accompanied by a mild and healthy climate, so that the country is well adapted for the staple industry, which consists in raising horses and cattle. The spurs of the eastern highlands of Brazil are still recognisable in the northern provinces of Argentina, where they are covered by extensive forests of algaroba, cedar and other trees, thus greatly adding to the natural resources of that wealthy country. The surface of the remainder of the great Argentine Republic is largely occupied by somewhat monotonous tracts of low and nearly level land, here and there relieved by small groups of mountain ranges which seem mostly to have some connection with the foothills of the Andean mountain chain. The whole of western Argentina again is very mountainous and well wooded. The highest summit of the Andes, Aconcagua (23,080 feet), actually lies in Argentine territory. Beyond the crest of this immense mountain chain, occupying an elongated narrow strip of country along the shores of the Pacific Ocean, lies the Republic of Chile. The upheaval of the Cordillera of the Andes, separating the two states, must have been the result of movements of the earth's crust which occurred long after the formation of the rocks composing the range.

With these alterations in the topography and climate as 
we proceed southward, the fauna and flora gradually undergo a complete change. On leaving the forest, monkeys, sloths and other animals, bound to an arboreal life, are replaced by new types, unknown in Brazil, such as the Patagonian hare and vizcacha. A very characteristic faunistic feature of the Argentine "pampas," as the humid grassy country is called, is the presence there of the American representative of the ostrich. This rhea is quite absent from the vast forests of Brazil. In the northern parts of that country, however, where we again meet with grass lands, this flightless bird reappears as a memento of the times when north and south were joined by continuous prairies. We thus have some noteworthy instances of discontinuous distribution suggesting a former period when the drying up of vast lakes, perhaps, may have given rise to grass lands, which enabled certain southern types to push northward. Other Argentine animals, such as the coypu (Myocastor coypus), one of the largest of the rodent tribe, have apparently invaded Brazil in more recent times, for they have only entered the southern and western provinces. To those unacquainted with the past history of South America it must come as a matter of surprise that the only ungulate which is noticed in these vast pampas of Argentina is a deer, closely related to the true North American deer (Odocoileus virginianus) and its allies. I have expressed my belief above (p. 111) that the true American deer owe their origin to one or more ancestors which passed into South America directly from Europe, and it is important to note that the centre of dispersal of the various groups in South America lies in the western states. Only a couple of species are peculiar to Brazil. All the others are more or less confined to the western states. Even the distribution of the South American wolves led Dr. von Ihering * to the similar conclusion that these animals entered the continent from the west.

Mr. W. H. Hudson $†$ gives us a vivid idea of the life in the pampas of Argentina, the striking poverty of its fauna as compared with Brazil, and all the more characteristic features

* Thering, H. von, “Südamerikanische Raubtiere,” p. 162.

†.Hudson, W. H., "Naturalist in La Plata." 
of that remarkably fertile country, which has lately become a centre of attraction, not only from a point of view of agriculture, but as a treasure-house of palaeontological records.

Argentina must have undergone very notable physiographical and climatic changes within the Tertiary Era. As Dr. White * has pointed out, the whole of the coast-line from Rio de Janeiro southward appears to present evidences of submergence. Rivers, bays and islands exhibit an aspect of drowning similar to that shown by the rivers and bays of Nova Scotia, Cape Breton and Newfoundland; and the amount of coastal depression seems to increase southward, judging by borings for harbour works at Rio de Janeiro and at Pelotas.

The presence of terrestrial and fresh-water deposits to a depth of nearly a thousand feet below the city of Buenos Aires implies, as Dr. Ameghino $\uparrow$ remarks, that here also the continent extended formerly much further eastward. The same author contends, in fact, that the whole of the southern Atlantic is of Tertiary age. I am not prepared to concur in this view, but it can scarcely be doubted that Argentina had in later Tertiary times at any rate a much greater area than at present.

It is now more than twenty years since Dr. Ameghino first made known to the world that an extraordinary wealth of animal life once tenanted the vast plains of Argentina. Not only in early Tertiary deposits; even in late Mesozoic beds were found the bones of mammals belonging to many different groups. The origin of life, at least of the higher animals, was always looked for in the north. Dr. Ameghino's discoveries, which certainly rank among the most noteworthy that have ever been made in palaeontology, riveted attention for the first time to the southern hemisphere. No wonder that Dr. Ameghino $\ddagger$ in his enthusiasm pronounced Argentina to be the original home of all the mammals of the world.

* White, I. C., "Relatorio final de estudos das minas," p. 3.

† Ameghino, Fl., " Formations sédimentaires, p. 29.

$\ddagger$ Ameghino, Fl., "South America as the Source of Mammalia," p. 260. 
Naturally his views gave rise to a considerable amount of discussion and criticism among geologists and palaeontologists; and many visited the scenes of these startling discoveries. Almost all of them felt convinced that Dr. Ameghino had wrongly interpreted the age of the deposits alluded to. They thought that the fossiliferous beds described must be much more recent than Dr. Ameghino supposed, and that at any rate South America was certainly not the source of all the mammalia. One of the richest of the deposits exposed in different parts of Patagonia, especially in the region of the Santa Cruz river, and hence spoken of as the "Santa Cruz beds," is considered by Dr. Ameghino as of Upper Eocene and Lower Oligocene age. Almost all other authorities believe them to belong to the Miocene. The latter view seems to be strengthened by the results of the study of the marine shells contained in beds of similar age which were pronounced by Dr. Ortmann * to be of Miocene Age. As Professor Scott + expresses the opinion that Dr. Ortmann has clearly demonstrated the Miocene age of the Santa Cruz beds, I should like to direct attention to a more recent work dealing with this problem. Its author, Dr. von Ihering, $\$$ has made a special study for many years past of the marine mollusks of South America. Hence his opinion is of particular value. After a long and careful study of a larger series of fossil mollusks than was available before, he came to the conclusion that the marine Cretaceous deposits of Patagonia pass very gradually into those of the next formation, which is the one described by Dr. Ortmann, the latter scarcely containing five per cent. of living species. $\mathrm{He}$ is inclined on that account to agree with Professor Ameghino as to the Eocene and Oligocene age of these marine beds, and thus indirectly with his general scheme of correlation. Dr. von Ihering's arguments appear to me more convincing than those of Dr. Ameghino's opponents, and I shall therefore adhere to the latter's nomenclature of the Argentina deposits. Not only. has Dr. von Ihering adopted Dr. Ameghino's views, they

* Ortmann, A. E., "Princeton University Expedition," Vol. IV., p. 317 .

† Seott, W. B., "Mammalian fauna of Santa Cruz," p. 241.

$\ddagger$ Thering, H. von, "Mollusques fossiles de l'Argentine," p. 95. 
have partially been accepted also by Dr. Roth,* who has personally studied the problems on the spot.

As regards the mammalian remains contained in the Santa Cruz terrestrial beds, Professor Scott $\uparrow$ was greatly struck by the strangeness of the assemblage. Not a single genus occurs in any part of the northern hemisphere. Some of the orders even of mammals are distinct from those of the northern faunas. Thus the beds have yielded no carnivores, no modern groups of ungulates nor elephants, while the rodents all belong to the section Hystricomorpha. The place of the carnivores was taken by carnivorous marsupials, somewhat resembling the Tasmanian wolf (Thylacinus). Numbers of small plant-eating marsupials, of which Caenolestes (see p. 350) is an interesting survival, likewise occur. One of the largest, most varied and most characteristic elements of the Santa Cruz fauna are the edentates. They are represented by the Dasypoda or armadillos, the greater part of whose skin is strongly ossified, the scutes forming a great shield over the body, and by the Glyptodontia and the Gravigrada. The last two groups are now extinct. The glyptodonts resembled armadillos, except in so far as the bony scutes were joined into a solid mass like the shield of tortoises, while the Gravigrada or ground sloths were extraordinarily varied and numerous. Only a single genus (Necrolestes) of Insectivora has been obtained in the Santa Cruz beds, as already alluded to (p. 246). At present this order is quite unknown in South America. The ungulates belong to the extinet groups Toxodontia, Astrapotheria and Litopterna. The toxodonts were represented by the genus Nesodon which somewhat resembled a rhinoceros in shape and had similar teeth. Of the second group very little is as yet known, while the Litopterna are the most remarkable of all the hoofed animals. Without being in any way related to the horse-tribe, certain genera have paralleled the structure of the horse-foot in a most wonderful way, giving the latter a striking and deceptive resemblance to that of the ancient Hipparion. The animals afford, indeed, as Professor Scott remarks, one of the most

* Roth, S., "Sedimentablagerungen in Patagonien."

† Scott, W. B., "Mammalian fauna of Santa Cruz," pp. 242-247. 
remarkable and instructive examples of convergent development among mammals. Finally the Santa Cruz beds contain the remains of monkeys of South American type. The earliest traces of mammalian remains in Patagonia were supposed to have been found together with the bones of dinosaurs. Since these reptiles are characteristic of the Mesozoic Era, the statement that they were contemporaneous with rather advanced types was at first treated with little credence, especially as the actual deposits were not examined by Dr. Ameghino* but by his brother. Dr. Roth, however, has since re-examined the localities in question and has met with mammalian remains partly mixed with those of dinosaurs, and partly resting actually below the latter, so that there is scarcely any doubt as to the correctness of the original observation. The mammals belong to peculiar mastodon-like ungulates, having been placed in the order Pyrotheria which is now extinct and quite confined to Patagonia. Others, such as Notostylops, belong to the Toxodontia above alluded to.

I think there is a general agreement now that, at any rate at the dawn of the Tertiary Era, a number of rather specialized groups of mammals lived in Patagonia, and, although some of them became extinct, others continued to inhabit the country until recent geological times. A few of the largest edentates, like the giant ground sloth Megatherium, which was about the size of an elephant, and is supposed to have dragged down trees in order to feed on the leaves, rather than climb up like its modern diminutive relation the tree-sloth, still roamed about the country in Pleistocene times. $\dagger$ A few years ago the dried skin, with hair still attached to it, of a huge creature was discovered in a cave in southern Patagonia, near the boundary between Argentina and Chile. It proved to belong to the ground sloth Neomylodon, now known as Grypotherium listai.f Later on, the bones of the animal were disinterred, along with those of an extinct horse and a large carnivore. Traces of a fire were also noticed and an enclosure with cut hay. From these evi-

* Ameghino, Fl., "Formations sédimentaires," p. 80.

† Lankester, Ray, "Extinct Animals," p. 172.

$\ddagger$ Moreno, F. P., and A. Smith Woodward, "Neomylodon listai." 
dences of man's presence, along with the remains of the ground sloth, it was concluded that the cavern was an old corral in which the ground sloths had been kept and tended by some primitive human race.*

The survival of many of such large creatures until recent geological times implies that, as in the northern hemisphere, there must have been ample food available in Argentina during the Pliocene and Pleistocene Periods to nourish these mammals, the climatic conditions having since become more varied and unfavourable. Compared with the Santa Cruz edentates, the less ancient groups were mostly larger.

In spite of the fact that the fossil mammalian fauna of Argentina presents so many features pointing to long isolation, the relationship of certain forms to those found in far distant regions is of extreme interest and importance from a zoogeographical point of view, as elucidating the geological history of the South American continent. The diversity in shape and character between the Santa Cruz armadillos (Dasypoda), for example, is very notable, according to Professor Scott, $\dagger$ no less than three families and seven genera having been described so far. And yet a genus of armadillo (Metacheiromys) makes its appearance in the Middle Eocene beds of western North America. Dr. Wortman's theory that the edentates were of North American origin, having subsequently spread to South America, has not been adopted by any later authors. Dr. Wortman assumed that their earliest appearance in South America did not antedate the Santa Cruz epoch, whereas Professor Scott points out that they also occur in the oldest known Tertiary and possibly even preTertiary deposits of Patagonia, and that there is every. appearance of their having been indigenous in that region. It is, in fact, generally assumed now that South America was the original home of the edentates. If it is correct, as I have endeavoured to show, that Central America has only come into existence in comparatively recent geological times, and that the whole continent of South America in the dawn of the Tertiary Era consisted of several distinct masses, Patagonia

* Woodward, A. Smith, "Grypotherium listai," p. 64.

† Scott, W. B., "Princeton Expedition to Patagonia," Vol. V., p 7.

L.A.

D D 
at that time must have had a direct land connection with western North America almost independently of the rest of South America (Fig. 14). At a still earlier stage there was even a more marked affinity between Patagonia and southwestern North America; and from this Professor Osborn concluded that the northern and southern continents were connected by land. But the points of resemblance are not alone with Patagonia and south-western North America. Professor Gaudry * expressed his astonishment at the striking faunistic relationship between the Patagonian Notostylops fauna on the one hand, and the faunas of the Torrejon in New Mexico and Cerney in France on the other. That a land bridge, disconnected at certain intervals, extended between western North America and southern Europe I have urged again and again in the preceding chapters; and it should be borne in mind how, even in these remote times, special facilities existed for the passage of species from Europe to the extreme south of South America, which no doubt were taken advantage of by several groups then inhabiting the Old World.

Until recently it was thought that North and South America could have had no land connection subsequently to these early. events until the end of the Miocene or the beginning of the Pliocene Periods. Professor Osborn, $\dagger$ however, has shown that there is now evidence for the existence of true edentates of the Megalonyx type in the Mascall beds of Oregon, which are of Middle Miocene age. During the Miocene Period Central America in its present shape had not yet come into existence. Hence we may assume that even in Miocene times there was a land connection between western North America and some portion of South America by means of a route which, as I argued, lay to the west of that continent.

The rodents of the Santa Cruz fauna, as previously mentioned, all belong to the section Hystricomorpha. They are very closely allied, according to Professor Scott, to recent South American genera. Yet all are extinct and many of them have left no successors. Nevertheless, though the Santa Cruz rodents are more primitive, the skull structure is nearly

* Gaudry, A., "Fossiles de Patagonie," p. 105.

+ Osborn, H. F.,." "The Age of Mammals," p. 289. 
the same as in the recent ones. There is reason to believe, says Professor Scott,* that several of the genera represent the direct ancestors of existing forms. Viscacha was probably derived from Prolagostomus, Dolichotis from Schistomys, Erethizon and Coendu from Steiromys. As regards the latter, it is interesting to note that it resembles the recent Erethizon more than it does the modern South American genera of the same family. It seems to me probable, therefore, as I have already suggested (pp. 69-71), that the South American and North American tree porcupines originated from two distinct branches of ancestral Steiromys-like rodents, thus favouring the view I advocated of a direct land connection between Patagonia and south-western North America. That the genus Erethizon, to which all the North American porcupines belong, should not be known from pre-Pleistocene deposits presents, no doubt, a difficulty to the acceptance of this theory, but its ancestors may have remained on the last remnants of the land which once existed westward of North and South America until compelled to leave that land in Pliocene times, when it finally subsided.

The Santa Cruz fauna likewise reveals an affinity with the fauna of Australia and Tasmania. The Patagonian marsupials are referable to three families, remnants of which survive in widely separated parts of the world. The Thylacinidae, now confined to Tasmania, where the Tasmanian wolf represents the family, formerly inhabited both Patagonia and Australia. As we might expect, the Santa Cruz thylacines are of a more primitive type than the Tasmanian wolf, but Professor Sinclair expects that the common ancestor of these two will probably be found among the marsupials occurring in still older Patagonian deposits. The opossums (Didelphyidae), among which Microbiotherium is the best known, are met with in several genera in the Santa Cruz beds. The Cretaceous Proteodidelphys suggests, as I have already mentioned, that South America must be looked upon as the original home of the family whence some members passed into North America and Europe. I have briefly alluded to the occurrence in Ecuador

* Scott, W. B., "Princeton Expedition," Vol. V., pp. 384-386 and p. 413. 
of the marsupial Caenolestes and to its being the only living member of the extinct family Epanorthidae. In the Santa Cruz beds this and another family of herbivorous marsupials are represented by several genera. Professor Sinclair * inclines to the belief that the South American Epanorthidae and the Australian phalangers have had common ancestors. From all these facts he concludes that a land connection between Patagonia and the Australian region must have existed not later than the close of the Cretaceous Period or the beginning of the Tertiary Era, and that the interchange of marsupials may have been effected between the two continents at this time.

Of all the similarities between the South American and Australian extinct faunas none perhaps is more striking, remarks Dr. Smith Woodward, $\uparrow$ than the essential identity of the extinct Miolania in the two regions. He thinks there can be no doubt that this creature was a truly terrestrial or marsh chelonian. The theory of a former land connection between South America and Australia seemis, therefore, to receive weighty support from the new discovery of this curious reptile.

It has also been urged that the Patagonian fossil fauna indicates traces of an affinity with South Africa. Professor Scott, $\ddagger$ with some hesitation, expresses the opinion that the resemblance of the solitary Patagonian insectivore Necrolestes to the golden mole Chrysochloris of South Africa may be due to genetic relationship. It is significant, in view of the early Tertiary faunistic relationship of Patagonia and western North America, to note that certain creatures resembling the golden moles made their appearance in North America in Oligocene and Lower Miocene times. I have had occasion to allude to Xenotherium and Arctoryctes already (p. 246). The affinities between these various forms are not very marked. At any rate, it would be unsafe to draw any conclusions as to the existence of a former direct land bridge between Patagonia and South Africa from the presence of Necrolestes in the Santa Cruz deposits.

* Sinclair, W. J., "Marsupial Fauna of Santa Cruz," pp. 76-81.

$\dagger$ Woodward, A. Smith, "Extinct Reptiles from Patagonia," p. 182.

I Scott, W. B., "Princeton Expedition," Vol. V., p. 379. 
Professor Tullberg's* reference to a pre-Tertiary land bridge between South America and south-west Africa is not very definite. From his remarks it is not clear that he is in favour of the existence of an independent connection far to the south of the one I discussed in the last chapter.

These are among the more important results derived from the study of the fossil fauna of Argentina as to the affinities presented by this part of South America to the more distant parts of the world. We have still to consider the faunistic kinship between Argentina and the neighbouring states of South America. Dr. von Ihering $\dagger$ pointed out long ago that, whereas America as a whole is the richest part of the world in the variety of genera and species of fresh-water mussels, Chile and Peru belong to the poorest districts, since, at any rate west of the Andes, only the genus Unio occurs. Similarly Ampullaria and many other typically American fresh-water genera are absent from Chile. On the other hand, the Unios of Chile are most of them nearly related to those of the La Plata region. Dr. von Thering $\ddagger$ concludes from these very peculiar zoographical features that, while the whole of southern South America (Archiplata) formed a united land-mass in Secondary times, the elevation of the Andes afterwards prevented a faunistic interchange between the two districts. The freshwater crustacea tell us a very similar story. The fresh-water crayfish Parastacus is met with in eight species in South America. § None of them occur north of southern Brazil, although several of the Chilean species are closely related to Brazilian ones. The fresh-water crab Aeglea laevis, no doubt an exceedingly ancient form and the only representative of the family Aegleidae, lives in identically the same species on both sides of the Andes. The absence of almost all the leading genera of Brazilian fishes from Chile and Patagonia, $\|$ emphasises the noteworthy distinctness in the fresh-water fauna of the two regions. On the other hand, Patagonia and Chile present traces of a relationship, as I intend to show later on,

* Tullberg, Tycho, "S5stem der Nagetiere," p. 495.

† Ihering, H. von, "Verbreitung der Ampullarien," p. 106.

† Thering, H. von, "Archhelenis and Archinotis," p. 57.

§ Ortmann, A. E., "Distribution of Decapods," pp. 292-296.

|| Eigenmann, C., "Freshwater Fishes of Patagonia," pp. 227-229. 
with western North America, with southern Africa and with New Zealand and Australia.

As we ascend the Andes from northern Argentina, we meet with a familiar animal which we generally associate with Peru and its inhabitants, namely, the llama. The llama is only a domestic animal. But its wild ancestor the huanaco (Lama huanachus) still exists plentifully in the Andes of Peru and Chile, as well as in the plains of Patagonia. Its western distribution, like that of the bear, some of the deer and many vertebrates and invertebrates, is thus very marked and demands an explanation. For the benefit of those who may be unacquainted with the pedigree of this creature I may mention that the huanaco and its domesticated relations the llama and alpaca, are essentially camels in structure. There are certain differences in the teeth, the huanaco being without a hump and smaller than the camel, while the head is more like that of a sheep. But the shape and structure of the skull and bones and the general anatomy are very similar in the huanaco and camel, implying that they have descended from the same ancestor. The occurrence of the camels in Asia and of the llamas in South America is a case of widely discontinuous distribution of two related genera and thus points to an ancient origin. The geological history of the family is of the greatest interest. The first member of the camel tribe makes its appearance in Argentina in a deposit known as the Lower Pampean, which Dr. Ameghino considers of Pliocene age, though some authorities think it is more recent. Here occurs Palaeolama, an extinct ancestor of the huanaco. In the upper portions of the same deposit the remains of quite a number of llama-like creatures have been discovered such as Protauchenia, Hemiauchenia, Stilauchenia and Mesolama, as well as the huanaco itself. That is about all we know of the past history of these camel-like animals of South America. The fact that no members of the family are known from earlier deposits than Pliocene, and that the extinct genera are nearly related to the living one, suggests that the ancestors of the huanaco were not originally native to South America but invaded the continent from elsewhere. Africa and Europe no longer were connected with South America. North America is thus the only possible source whence the ancestral huanacos 
or llamas could have originated. And that is precisely what happened, as already mentioned (p. 86). Towards the latter end of the Eocene Period there appeared four genera in western North America, all of which exhibit decidedly camel-like characters, and Professor Osborn* believes that one of these, the diminutive Protylopus, may possibly represent the most remote ancestor of the grand American phylum of camels. Other genera occur in Oligocene and Miocene beds of North America. During the latter period camels had apparently spread in great herds over the continent. It is thus probable that they then extended their range to other parts of the world. Some of them, like Pliauchenia, had assumed llama-like characters, and as the,western Pacific landbelt was then in communication with California the ancestors of the South American llamas were able to pass southward. According to Professor Osborn llamas survived in North America until Pleistocene times. They were then becoming extinct in the eastern States, lingering on in California where the great sabre-tooth tiger no doubt stalked them. In the Siwalik beds of northern India camels first appear in the Pliocene, as in South America, and it is generally assumed that the ancestors of the Old World camels crossed over to Asia by the Bering Strait land bridge. But as it was probably in Miocene times that these early camels wandered westward from North America, the Bering Strait land bridge had not yet come into existence. They must have utilised the more southern bridge, which I think replaced it in earlier Tertiary times (Fig. 16).

Recently we have received clear proof of a migration of mammals from Asia to North America, which I think must have taken place across the same Pacifie land bridge. One of the most remarkable discoveries among the many noteworthy ones in North American palaeontology is that by Dr. Matthew and Mr. Cook $\dagger$ of Asiatic antelope remains in western Nebraska. The American invasion by true Asiatic antelopes was brilliantly and amply confirmed, according to Professor Osborn, by Mr. Merriam's discovery in Nevada.

* Osborn, H. F., "Age of Mammals," p. 170.

† Matthew, W. D., and H. J. Cook, "Pliocene Fauna from Nebraska." 
Rather earlier arrived in North America the mastodons, and no doubt by the same Pacific land connection. They invaded the continent from Asia and remained until Pleistocene times, being thus ca-existent with the early races of man in America. That they travelled beyond North America, penetrating far into the southern continent, has been clearly demonstrated. A large number of apparently distinct forms have been described from South America, most of them, as we should expect, from the west coast, though it is very doubtful if more than a few species lived there. Dr. Nordenskiöld thinks that Mastodon chilensis, M. bolivianus and M. andium all belong to one species. In North America, as in Europe, both the trilophodont and tetralophodont types of mastodon have been discovered, that is to say, animals which possessed intermediate molar teeth with either three or four ridges. In the South American Mastodon andium, at any rate, the molars are in the transition stage between the trilophodont and tetralophodont types. These extinct elephants made their first appearance in Argentina in the Lower Pampean deposits. Since they had thus penetrated so far south in early Pliocene times they must have left North America before Central America had come into existence. They could only have wandered southward along the southern continuation of the Pacific land bridge and have entered the South American continent from the west during the time the bridge was joined to the latter. Dr. Nordenskiolld * argues that, having no more efficient competitors in South America, the mastodon probably lived longer there than in North America.

Hitherto the theory has been quite generally accepted that the invasions of animals from North America to the southern continent, during later Tertiary and Pleistocene times, took place across the narrow isthmus of Central America as soon as its formation was completed. Some doubts have latterly been raised as to the nature of the barrier which prevented the interchange of the two faunas in the earlier portion of the Tertiary Era. Yet until the discovery of gravigrade sloth remains in the Miocene Mascall beds of Oregon was announced by Professor Sinclair, the assumption seemed perfectly justi-

* Nordenskiöld E., "Säugetier-fossilien des Tarija Tals," pp. 14-25. 
fied, from all available data, that North and South America became joined at the commencement of the Pliocene Period. It was supposed that the advance of northern types, such as the mastodon and hosts of others, towards the southern continent must have coincided with the opening up of the new land of Central America. The occurrence of edentate remains in North American Miocene deposits upsets this theory, because, if mammals were able to reach North America from the south during the Miocene Period, northern species must have had equal facilities for invading South America at this time. If there is geological evidence that Central America was not available as a safe land bridge between North and South America in Miocene times, some other land connection must have united the two continents. When I advanced the theory of the former existence of a Pacific land bridge between North and South America, westward of Central America, ${ }^{*}$ I was unaware of Professor Sinclair's interesting discovery among the Mascall beds of Oregon. My theory was largely founded on zoogeographical data-on curious instances of discontinuous distribution of ancient groups in North and South America. Professor Osborn $†$ regards my theory as inconsistent with the fact that the Pacific land bridge should only have been used by these gravigrade sloths. If such a land connection really existed why was it not more extensively used ? I think it was used by other animals, such as the mastodons and the ancestors of the llamas to pass southward, and by the ancestors of the North American tree porcupines in entering North America.

Since I wrote my essay on the problem of a former land connection, other than the Central American one, between North and South America, I have had opportunities of studying the subject more at my leisure. I find that the affinity existing between south-western North America and the extreme south of South America among some of the more ancient groups of animals is greater than I thought. Let us examine this curious relationship between the two widely separated faunas a little more closely. I explained

* Scharff, R. F., "Early Tertiary Land-connection."

† Osborn, H. F., "Age of Mammals," p. 292. 
(p. 120) that the mammals inhabiting Patagonia and southwestern North America in late Mesozoic and early Tertiary times indicated the existence of a direct land bridge between these two areas. But the Patagonian land-mass must have included Chile or such parts of it as were then above sealevel. We know very little of the past fauna of Chile. If, as I endeavour to prove, a portion of our living fauna is of great antiquity, some animals should reveal unmistakable signs of this early affinity of Chile with that of south-western North America. I imagine, as previously stated, that the early Tertiary land bridge connected Chile directly with western Mexico and California. Hence we might expect that not only Chile and Patagonia, but the outlying islands of California, as well as the Galapagos islands, ought to show a faunistic relationship with one another.

I have already alluded to the fact that three groups of the snail Bulimulus inhabiting Chile and Peru, the Galapagos islands and Lower California are very similar in their narrow elongated shape, so that they were formerly considered to be very closely related. Dr. Pilsbry* is now of opinion that this similarity in appearance is not any evidence of near relationship but a special parallel modification of different Bulimulus stocks, or, as we might say, a case of convergence. He attributes these cases to be products of similar environments. Yet is the environment of Chile really so similar to that of the Galapagos islands or Lower California? Climatically and geologically I should think there must be a good deal of difference between these districts.

The relationship between the western North American snail fauna and that of western and south-western South America is well illustrated by the distribution of the genus Epiphragmophora. This is a group of snails entirely confined to Central America and the Pacific borders of North and South America. It is important to note also that the majority of the snails inhabiting the islands off the coast of California belong to this genus. Cerros, Guadelupe, Santa Barbara, San Clemente and other islands all have their peculiar species of Epiphragmophora. Now the most interesting point about

* Pilsbry, H. A., "Manual of Conchology (Pulmonata)," X., p. 126. 
the members of this genus is their astonishing resemblance, as mentioned before, to certain species of the European group Helicigona, including the well-known Arianta arbustorum. Some of the American shells are externally so much like the latter that they were placed into the same genus until recently. Dr. Pilsbry,* however, maintains that the European Helicigona differ anatomically from Epiphragmophora, and that the two should be placed in quite distinct groups. Even on anatomical grounds opinions may differ very radically, for Dr. von Ihering claims that the American Epiphragmophora and the members of the group Helicigona are genetically connected. After careful examinations of the European Arianta arbustorum and the Argentine Epiphragmophora tucumanensis he could perceive no noteworthy anatomical difference between the two, and placed them both into the same genus. If Dr. von Ihering's $\uparrow$ observations are correct, this is another example of the same extraordinary relationship between European and west American forms that I have had occasion to point out in previous chapters. Occasionally this relationship manifests itself only in Europe and south-western North America. In other cases it exists simply between European and western South American forms. In this case both the American western centres are related to the European centre of dispersal. It clearly illustrates, as stated before, that Europe was once joined to a mid-Atlantic land bridge which communicated directly with a belt of land lying to the west of America. On the disappearance of the latter many of the animals inhabiting that belt of land took refuge in the western parts of America and still persist there.

Epiphragmophora, all the same, does not clearly reveal the special affinity that exists among the older forms of animal life of south-western North America and southern South America. The wingless insects known as "bristle tails "(Thysanura) are generally looked upon as a very ancient group. Among these the genus Japyx, which is easily recognisable by its forceps-like tail-appendage, has a noteworthy distribution. Japyx solifugus occurs in the Mediterranean region,

* Pilsbry, H. A., "Manual of Conchology (Pulmonata)," IX., p. 195.

† Thering, H. von, "System der Heliciden," p. 422. 
whence it has spread as far north as southern Germany. Several other species are peculiar to southern Europe and Madeira. One Japyx is found in India. Across the Atlantic Japyx subterraneus has been observed in the Mammoth Cave of Kentucky, while a second species (Japyx saussurei) inhabits only Mexico and Chile.*

The curious scorpion-like Koenenia, the only genus of the order Palpigradi, is confined, as already mentioned, to southern Europe, Texas and Chile. As far as America is concerned, it is limited in its range to the two regions alluded to. The family of spiders, Mecicobothriidae, according to Mr. Pocock, $\dagger$ occurs only in the western States of North America and in Argentina, the genus Hexura being found in the former and Mecicobothrium in the latter part of America.

The ancestral form of the evidently very ancient family of earthworms, Megascolecidae, seems to be Notiodrilus. This genus is met with in America only in Mexico, Guatemala, Chile, Argentina, Patagonia, Tierra del Fuego and the Falkland islands, while another genus, namely, Kerria, inhabits Lower California and southern South America, being absent from the intermediate area. The slug Philomycus has a wide range in North America, occurring in Mexico, Guatemala and Costa Rica, and then turns up again far away to the south in Chile. Similarly the salamander Plethodon, which in North America inhabits principally the western States, is found in a single district in South America, namely, in Argentina. There are a large number of similar examples among such forms of insects that we have reason to believe date back to at least early Tertiary times. The best known example, perhaps, is that of the common northern genus Carabus. In Mexico there are still two species. Neither in Central America, nor in northern nor middle South America has it been discovered, while in Chile and Tierra del Fuego there are nine species. That the latter are now considered sufficiently distinct to be placed into the separate genus Ceroglossus does not alter the fact that they are closely related to northern Carabi, whereas they have no affinity at all with

* Karsch. F., "Neue Fundorte von Japyx," p. 154.

† Pocock, R. I., "Geographical Distribution of Spiders," p. 346. 
any South American forms. The genus of Tenebrionidae Apocrypha is quite confined to California and Chile. That all these instances indicate the existence of a former direct land connection between Chile and California, independent of the rest of South America, as I have explained before, is indicated by another example derived from the same family of beetles. The three closely allied genera Arthrocomus, Stomion and Eurymetopon occur respectively in Chile, the Galapagos islands and California.

Under this heading also comes an instance of distribution which had not hitherto been noted and which was pointed out by Mr. MeLachlan.* He remarked that the family Limnophilidae, a family of insects the larvae of which manufacture those cases of twigs and straws, so abundant in northern ponds and ditches, is not known to occur south of Mexico, except in Chile and the Falkland islands.

It was Dr. Wallace, $\dagger$ I believe, who first drew attention, as already noted in a previous chapter (p. 235), to the remarkable fact that a large number of European and North American genera, such as the butterfly Argynnis and the running beetle Carabus, reappeared far south of the tropics in Chile, Argentina and Tierra del Fuego. I also alluded to his explanation of the manner in which this surprising phenomenon had been brought about. He was under the impression that this migration across the tropics had been effected mainly during successive Glacial Epochs, when the mountain range of the isthmus of Panama, if moderately increased in height, might have become adapted for the passage of northern forms, while storms would often carry insects from peak to peak over intervening forest lowlands or narrow straits of sea. Improbable as this theory may appear, it might still be defended as long as we had to deal merely with the occurrence in southern South America of a few northern insects. But the phenomenon is, as we have seen, a much more widespread one. It applies to earthworms, slugs, salamanders and even mammals, and it is evidently the result of a dispersal which occurred long before the Glacial Epoch.

* McLachlan, R., "Insect Fauna of Chile," p. 162.

† Wallace, A. R., "Geographical Distribution," Vol. II., p. 45. 
It took place, in fact, in very remote times, probably during the dawn of the Tertiary Era; and only such forms as were capable of preserving their specific and generic characters till the present day clearly reveal their northern origin.

The flora of the New World, as I remarked in the paper just referred to, retains even more pronounced traces of that curious relationship between the south-western areas of its two continents.* As among the fossil mammals so do we find also among the fossil plants, a remarkable affinity in late Mesozoic deposits between species from Argentina and from western North America. Professor Berry tells us that in mid-Cretaceous times seventy-five per cent. of the known plants of Argentina were characteristic types of the Dakotagroup flora of North America. During a period of geological history when a large section of the existing western part of South America was under water, there was this extraordinary similarity between two regions lying at such a great distance from one another. Professor Berry justly argues that the surprising affinity of these floras to one another points to a community of origin. In these ancient plant deposits of Argentina all the familiar northern genera such as Lirio dendron, Liquidambar, Cinnamomum and Sassafras are met with. Even Platanus, Populus, Quercus and other modern genera are represented. No wonder that Professor Berry $\dagger$ came to the conclusion that a geographical connection must have existed between North and South America during midCretaceous times. During Cretaceous and early Tertiary times the genus Sequoia, to which the Californian red-wood and big-trees belong, likewise ranged from North America to Chile. And it is now held by many botanists that the fossil Sequoia langsdorfi is identical with the still living big-tree (Sequoia gigantea) of California. We possess no fossil testimony of the occurrence of the smaller deciduous plants in those remote times, but to judge from the fact that many of the Mesozoic genera of trees still survive to the present day, certain persistent deciduous species presumably did so too. $\mathrm{Mr}$. Engelhardt $\neq$ records a number of plant remains from the

* Scharff, R. F., "Early Tertiary Land-connection," pp. 523-526.

+ Berry, E. W., "Mid-Cretaceous Geography," p. 510.

† Engelhardt, H., "Tertiärpflanzen von Chile," p. 635. 
west coast of Chile which he considers to be of early Tertiary age. Of these the greater portion, he thinks, belongs to still existing species, though he hesitates, in the absence of further evidence, to adopt the recent specific names. At any rate, almost all are very closely related to species now living in the West Indies, Central America and Brazil.

There exists a very widespread assumption that no species of animals or plants survive to this day from the Mesozoic Era. As our knowledge of fossil animals increases, instances accumulate of very close resemblance of Mesozoic species of mollusks to those now living, while some genera certainly date back to Palaeozoic times, so that we can no longer place implicit faith in the old traditional belief. My own conviction is that many species of the less highly organised groups of animals have survived unchanged even from those remote times to the present day. We know that certain species of plants such as Sequoia langsdorfi, and some of the Unios among animals, have remained practically unaltered throughout a series of geological ages. It seems equally possible that others of whose geological history we know nothing have likewise done so.

Professor Asa Gray and Sir Joseph Hooker* long ago directed attention to the unexpected feature that many genera, and even species of North American plants, recur in the distant regions of southern South America. More recently Professors Engler, $\dagger$ Bray and Hackel have dwelt on this remarkable phenomenon, and have speculated on the problems connected with it. The flora of the Rocky Mountains, including the Sierra Nevada Mountains above the transition zone, and the mountains of Chile and Argentina, though separated from one another by a stretch of some ten degrees of latitude of moist tropical country, abound in northern genera of plants, such as Ranunculus, Anemone, Geranium, Spiraea, Geum, Rubus, Saxifraga, Vaccinium, Gentiana, Hieracium and others. The greater number of such plants occurring in the southern continent are endemic, pointing to long-continued isolation. Yet certain species even of the Rocky

* Gray, Asa, and J. Hooker, "Vegetation des Rocky Mountain Gebietes," p. 292.

† Engler, A., " Entwicklungsgeschichte der Florengebiete," II., p. 256. 
Mountain arctic alpine region reappear in the extra-tropical Andes, being, so far as is known, wholly absent from the Mexican Mountains as well as from the tropical Andes. Among these Professor Bray mentions particularly Gentiana prostrata, Trisetum subspicatum, Primula farinosa and its variety magellanica, Draba incana, Alopecurus alpinus, Saxifraga caespitosa, Polemonium microcanthum and Collomia gracilis. Dr. Stapf kindly drew my attention to another instance, namely, to the occurrence on the mountains of Argentina, at a height of 10,000 feet, of the typically arctic genus of grasses Phippsia. The similarity in the flora of the two regions is by no means confined to mountain forms. Some species of the western plains of North America also reappear in the extreme south of South America. Thus the monotypical saxifrage Lepuropetalon, a peculiar and somewhat abnormal genus, grows in damp low-lying meadows in Texas. Yet far south on the coast of Chile the same species, Lepuropetalon spathulatum is to be met with.

A few of these plants may possibly have been casually introduced from the northern locality to the southern. But in most cases, Professor Bray* thinks, we have to deal with forms which were connected by a remote ancestry, and which flourished at a time and under conditions permitting a more general distribution.

What these conditions were like he does not venture to suggest, but a direct land bridge between western North America and Chile probably existed, as I suggested, in late Cretaceous and early Tertiary times. To it, I think, the relationship of the floras of these two widely separated areas to one another, is mostly due. Whether many species of plants have persisted to the present day from such remote times we do not know. Some no doubt have, and, as already stated, others, among them those alluded to, may have done so. A large portion of this old western land, with its mixture of a southern and northern fauna and flora, evidently remained above sea-level until a much later geological period. The evidence derived from certain relict land-areas of this Pacific land belt clearly shows that a

* Bray W. L., "Relations of North American Flora," pp. 709-716. 
southern flora passed over them, for of course southern plants penetrated northward just as animals did. Mr. Sereno Watson,* for example, in referring to the flora of the small island of Guadalupe off the west coast of California, remarks that the presence of so many South American types suggests that this, and the similar element which characterises the flora of California, may be due to some other connection between these distant regions than the one now existing. He expresses the opinion, too, that all the peculiarities in the western floras of both continents had a common origin in an ancient flora which prevailed over a wide, now submerged area, and of whose character the former are the partial exponents.

As regards the question whether the northern plants growing in Chile and Argentina can really be regarded as indigenous or introduced, Professor Hackel has recently dealt with this problem from a new point of view. He shows that the species which are either identical with European or North American plants, or such as may be considered as varieties or sub-species of them, increase rather than diminish as we go further south. Thus he records fifty-one plants from southern Patagonia and Tierra del Fuego belonging to this group, which he regards as undoubtedly indigenous to these countries. Thirty others may possibly have been introduced by man. Professor Hackel thinks that their southward advance could only have taken place step by step on a land surface. If these plants had passed across Central America and along the Andes, we should find relict colonies of the species, or at least their modified descendants, scattered on their route of migration. Only very few of such occur in Bolivia, Peru and Ecuador, and these have the appearance of having reached these localities from the south rather than from the north. When we examine the composition of this remarkable flora in the Magellan district, we notice, according to Professor Hackel, $\uparrow$ that the majority of the species belong to the grasses (Gramineae) and the sedges (Cyperaceae). The dicotyledons only comprise fifteen species. This he believes

* Watson, Sereno, "Flora of Guadalupe Island," p. 112.

† Hackel, E., "Flora der Magellansländer," pp. cxi-cxv. 
to be due to the greater antiquity of the grasses and sedges, and he argues in favour of an ancient direct land connection, long since disappeared, on which the slow southward advance of these forms took place, the identical species having preserved their specific characters throughout a long series of ages. This is precisely the conclusion I have come to in regard to many species of animals of very wide range, contrary to the view generally held that most of such forms are to be regarded as human importations scattered throughout the world by commerce.

I have mentioned on several occasions that California extended considerably further westward in former times, and that the numerous little islands such as Guadalupe, Cerros, Santa Catalina, Santa Rosa and others are the visible remains of that ancient Pacific land belt. The fact that they are inhabited by fourteen species and varieties of reptiles and amphibians* not known from the mainland, suggests that the islands have been separated from the latter since at any rate pre-Glacial times.

Now on the coast of Chile we have similar evidence of a westward extension of land in former times. The tiny deer known as the "pudu" occurs in Chile and Chiloë island. Its only near relative lives in Ecuador. The small mouse-like mammal Acodon brachyotis of Chiloë island and the Chonos archipelago is peculiar to these islands, and so are many other species of the lower groups of animals. There is, in fact, quite a considerable assemblage of animals and plants on these islands, indicating a former westward extension of the mainland. Even the far distant Juan Fernandez island, which lies five hundred miles from the mainland, possesses a peculiar species of humming-bird (Eustephanus fernandensis) and no doubt other indigenous forms of animal life. It is situated on the tract of the old land belt which I believe to have once extended from the west coast of southern Chile to south-western North America, and from there eastward to Europe (Fig. 14). In early Tertiary times already parts of this old land bridge had disappeared, so that Chile and south-

* Denburgh, J. van, "Reptiles and Amphibians of Pacific Coast Islands," p. 4. 



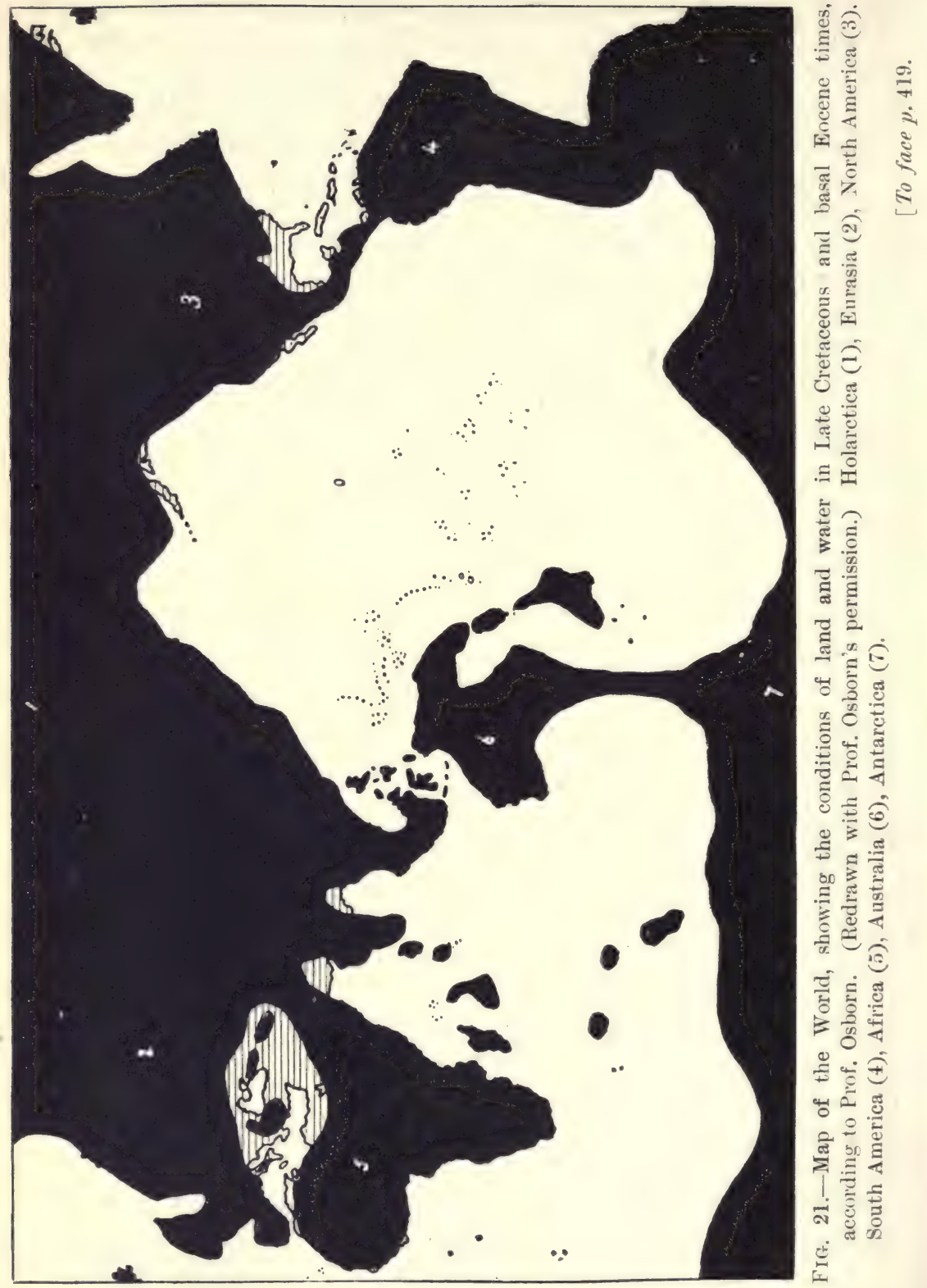


western North America became disconnected. Yet the eastern shores of the great peninsula, which long afterwards stretched southward from the west coast of California, joined the continent of South America further north, probably in Ecuador and Peru (Fig. 16). Animals and plants arriving from the north, like the mastodon above alluded to, no longer reached Chile directly, though still able to enter South America by this second route, which added many new forms to the fauna of the continent.

This is all I have to say on the origin of the faunistic and floristic relationships between southern South America and North America as well as Europe. I have also referred above to a kinship existing between the Santa Cruz fauna of Argentina and the living fauna of Australia. This is a problem of even greater interest than that just discussed. At any rate, the testimony in its favour has converted many of those who had hitherto looked upon great changes in the disposition of continents and ocean basins during the Tertiary Era as altogether visionary speculations. 'Some, like Professor Osborn,* who contends that the Atlantis hypothesis is highly improbable, regard the hypothetical reconstruction of a great southern continent (Fig. 21) uniting South America with Australia as one of the greatest triumphs of recent biological investigation. The theory of the former land connection between southern South America and New Zealand or Australia has been discussed from almost every point of view, so that we possess at present quite an extensive literature on the subject. A few years ago Dr. Ortmann summarised the more important papers dealing with this subject, but many other essays have since been published throwing further light on this fascinating problem. The great majority of those who have endeavoured to account for the undoubted faunistic or floristic affinities of southern South America and the Australian region have come to the conclusion that it is due to the existence of a former antarctic continent. A few, however, argue that there was a more direct land connection between the two areas across the southern Pacific, while some believe that the resemblance in the fauna and flora of the countries referred to has

* Osborn, H. F., "Age of Mammals," p. 75. 
arisen partly by accidental dispersal and partly by migration through the existing continents, when they were united by short temporary land bridges in the far north.

Sir Joseph Hooker seems to have been the first to formulate the theory of a former land connection of southern lands from the occurrence of identical species of plants in widely. separated areas. The first to mention an antarctic continent in this connection was Professor Ruetimeyer. This was twenty years later, in 1867. Six years elapsed after that until Professor F. W. Hutton again brought forward the theory, expressing his belief in the former existence of an antarctic land-mass and its union with the southern extremities of the present continents. A few years later Dr. Gill declared himself in favour of a large continental mass embracing Africa, South America and Australia, his views being based on the geographical distribution of fishes. The fact that Dr. Wallace repudiated the opinions expressed by his predecessors need not be taken too seriously. Since his great work on the geographical distribution of animals was issued, facts have been brought to light which are so overwhelmingly in favour of some kind of continuous land connection between South America and the Australian region that he could not at the present day assert, as he did then, that the affinities alluded to are mostly due to accidental dispersal across the ocean, aided by the presence of an antarctic land-mass unattached to other continents. Professor Hutton subsequently abandoned his theory of a land-bridge between the two regions by way of an antarctic continent in favour of a land connection right across the South Pacific towards the end of the Mesozoic Era.*

In the year 1891, an important contribution to the subject was published by Dr. von Ihering. $t$ He points out that the species of fresh-water Unio from New Zealand and adjoining countries have their nearest allies exclusively in Chile and southern Brazil, and that the fresh-water crayfishes (Parastacidae) show the same character. The conclusions he derives from these and other facts are that the southern portions 140.

* Ortmann, A. E., "Origin of Antarctic Faunas and Floras," pp. 139-

† Thering, H. von, "Relations between New Zealand and South America," p. 442. 
of South America (Archiplata) extended southward in form of a South Pacific antarctic continent, which kept this area in communication with the Pacific continent during the whole of Mesozoic times (Fig. 17). From the latter became separated first a number of Polynesian islands, then New Zealand and finally Australia and New Guinea. Dr. von Ihering deals with the same problem in several of his papers, some of which have now been reprinted in his recent work entitled "Archhelenis and Archinotis."* After giving a brief review of the main features pointing in favour of a former antarctic continent connecting the Australian region with South America, Professor Jacobi $\dagger$ expresses himself in favour of the theory. A great deal of additional evidence in support of the same view was collected by Dr. H. O. Forbes. $\ddagger$ He cites many examples among birds, the southern pikes (Galaxiidae), which occur in Chile, Patagonia, the Falkland islands and New Zealand, the family Cystognathidae among amphibians, and numerous plants, as illustrating the intimate affinity existing between the faunas of the Australian and South American regions. He also traces a faunistic relationship between these regions and the Madagascar area, and concludes that all these southern land-masses were once joined to an antarctic continent. It is easy enough to vaguely describe such a land connection. Dr. Forbes was not satisfied to do this. $\mathrm{He}$ was the first to give a map clearly indicating how he conceived that all the areas referred to were united with one another.

Mr. Beddard $\S$ briefly discussed the problem in 1895 . While criticising Dr. Forbes' evidence in so far as it relates to the struthious birds and penguins, he admits that there are very strong arguments in favour of a former land connection between Patagonia and the Australian region, particularly when we take into consideration the distribution of earthworms.

As Mr. Hedley aptly remarks, "we may compare the shattered biological monuments of Tasmania and South

* Thering, H. von, "Archhelenis and Archinotis."

† Jacobi, A., "Biogeographische Gebiete," pp. 204-207.

t Forbes, H. O., "The Chatham Islands."

§ Beddard, F. E., "Zoogeography," pp. 161-172. 
America to the broken columns found by Oriental travellers in the ruined and deserted cities of a vanished civilisation. And as an archaeologist may restore from such fragments the fallen temples or disused aqueducts, so may a naturalist trace the missing arches of life that once spanned the gap." $\mathrm{Mr}$. Hedley * favours the theory of a direct land connection in Mesozoic or early Tertiary times between Tasmania and Tierra del Fuego across the South Pole, while New Zealand then reached sufficiently near this antarctic land without joining it, to receive by flight or drift many animals and plants. He thinks the faint affinity of Antarctica to Africa would be explicable on the supposition that before either America or Australia had united with the former, Africa had already broken away from it.

A very memorable discussion on this question took place during the fourteenth annual meeting of the American Society of Naturalists in Philadelphia. Reviewing the geology of the antarctic regions, Professor Heilprin $\uparrow$ stated that in its relation to the other continents there was reason to believe that Antaretica, whether as a continent or in fragmental parts, had a definite connection with one or more of the land-masses lying to the north, and that the suspicion could hardly be avoided that such connection was, if with nothing else, with New Zealand (and through it with Australia) and Patagonia. The facts of palaeontology are best explained, according to Professor Scott $\ddagger$ on the assumption that the antarctic land-mass has at one time or another been connected with Africa, Australia and South America, all of which once radiated from the South Pole, just as North America and Eurasia now do from the North Polar area.

Although Professor Britton $\S$ cited many examples of astonishingly close relationship between plants of Australia, southern South America and South Africa, it is unnecessary in his opinion to invoke as an explanation a former land connection across the antarctic region.

Arguing from the geographical distribution of the fishes,

* Hedley, C., "Surviving Refugees in Austral Lands," pp. 3-6.

† Heilprin, A., “Geology of Antarctic Regions," pp. 306-307.

† Scott, W. B., "Antarctica Palaeontology," p. 310.

$\S$ Britton, N. L., "Origin of Antarctic Flora," p. 311. 
reptiles and anıphibians, Dr. Gill* maintained that the evidence in favour of a former antarctic continental area is strong, and, in view of the affinities of the species of the now distant regions, the conclusion is logical that the time of disruption was not remote in a geological sense.

So far as existing mammals and birds are concerned, said Dr. Allen, $\dagger$ there seemed to be very slight need for calling in the aid of a former antarctic continent to explain their present distribution. The distribution of marsupials alone among mammals gave a hint of a possible former land connection between South America and Australia.

Mr. Ancey $\ddagger$ gives a valuable contribution to the subject at issue, founded on the distribution of the terrestrial mollusks. The results of his enquiries are that the evident relationship of the faunas of South America and the Australian region can be satisfactorily explained by the assumption of a former antarctic continent uniting these land areas.

As the antarctic problem has been widely discussed from an ornithological standpoint, and since Dr. Forbes and Professor Milne-Edwards have based their theories of former land connections largely on the past and present range of the flightless ratite birds, it is right to mention that Professor Burckhardt $\S$ disagrees entirely with their conclusions. $\mathrm{He}$ does not dispute the possibility of former antarctic land connections, especially between New Zealand and South America. But he does not consider that the flightless giant birds of the southern hemisphere can in any way be regarded as furnishing evidence in favour of the theory of a former antarctic continent.

From a zoogeographical point of view, inconspicuous groups of invertebrates, such as the earthworms, are of far greater value than birds are. When the older writers discussed the antarctic problems we knew as yet practically nothing of their distribution. Within recent years several zoologists have made a special study of this group, and have found that earthworms are of the greatest value in the study:

* Gill, Th., "Fishes, Reptiles and Amphibians of the Antaretic," p. 315.

† Allen, J. A., "Birds and Mammals of the Antaretic," p. 317.

$\ddagger$ Ancey, C. F., "Faunes malacologiques australes," p. 27.

§ Burckhardt, R., "Problem des antarktischen Schöpfungscentrum." 
of palaeogeography. Professor Benham, moreover, has the advantage of residing in New Zealand, so that his views on these problems are of peculiar interest. To the south of New Zealand, between the latter and the antarctic regions, there are two groups of islands, viz., the Auckland and Macquarie islands. Now it is a specially noteworthy fact, remarks Professor Benham, that the species of earthworms from Macquarie island, and those occurring in the Auckland islands, are more nearly allied to South American and South African species than to those of the mainland of New Zealand. The evidence derived from the distribution of earthworms is, according to Professor Benham,* strongly in favour of the theory that New Zealand, South America and South Africa were once connected with one another by land.

A study of the fresh-water crayfishes yields an even more remarkable testimony in support of the same view, at least of the theory that New Zealand and southern South America were connected by land. Dr. Ortmann points out that the family of crayfishes known as Parastacidae is confined to Australia, including Tasmania, New Zealand, southern South America and Madagascar. This family has thus an extremely. discontinuous range and must be of great antiquity. Dr. Ortmann + believes that the Parastacidae existed in Australia in Upper Cretaceous times and thence spread by a land connection into Antarctica, from which Parastacus reached Chile. Subsequently Parastacus extended its range to Argentina and southern Brazil. Madagascar, he thinks, was not connected with the Antarctic Continent, and received its fresh-water crayfishes by another route. Besides this affinity in the freshwater crayfishes of the Australian region and temperate South America, there are other crustaceans showing similar features. $\mathrm{Mr}$. Geoffrey Smith $\div$ tells us that one of the commonest plankton organisms in the mountain lakes and tarns of Tasmania is the copepod crustacean Boeckella. Now this genus nowhere spreads into the tropics, yet reappears in New Zealand and southern South America.

* Benham, W. B., "Geographical Distribution of Earthworms," pp. $329-335$.

† Ortmann, A. E., “Distribution of Decapods," p. 340.

† Smith, Geoffrey, "Naturalist in Tasmania," p. 137. 
Professor Kolbe contributes a careful review of the subject from the point of view of the beetles (Coleoptera). After illustrating the intimate relationship that exists between southern South America and the Australian region, by means of the distribution of some of the Carabidae, Lucanidae, Scarabaeiidae, Buprestidae, Elateridae and other families of beetles, he comes to the conclusion that an Antarctic Continent must have existed in early Tertiary times. Professor Kolbe* believes that this continent was joined to the southern parts of South America, New Zealand and Australia, and that some genera passed from the latter to America, whilst others travelled in the opposite direction. Although the affinities of South Africa and Madagascar with South America and Australia are much less pronounced, Professor Kolbe nevertheless urges that these countries, too, were to some extent connected by land with the Antarctic Continent.

Dr. Arldt $\uparrow$ recently gave us an excellent summary of the most striking points in favour of the theory that southern South America and the Australian region were once connected by means of an Antarctic Continent. The theory meets with his entire approval, but he concurs with Professor Hutton and others in the belief that a second means of communication between Australia and South America was furnished by a mid-Pacific land bridge.

Finally, Professor Chilton $\ddagger$ reviewed the problem from the point of view of New Zealand and the neighbouring subantarctic islands and their fauna and flora. His conclusions are strongly in favour of a former land connection by way of the Antarctic Continent between South America and New Zealand.

I have still to state my own opinion on this subject. That there was some kind of a direct land connection between Chile and New Zealand and Australia appears to me obvious. The strongest arguments in its favour are supplied by the distribution of the fresh-water mussels and the fresh-water crayfishes. The genus Diplodon, one of the Unionidae, inhabits

* Kolbe, H., "Coleopteren der Magalhaensischen Sammelreise," pp. 19 - 30 (compare also "Die Südpolarkontinenttheorie ").

† Arldt, Th., "Bedeutung der Antarktis," p. 370.

$\ddagger$ Chilton, C., "Biological Relations of Sub-antarctic Islands," p. 806. 
the rivers of western and southern South America. No living Diplodon has ever been discovered in Central or North America, where other Unionidae are found in the greatest profusion. No Diplodon has ever been discovered fossil either in Central or North America, although a great many fossil Unionidae are known to science. Hence it seems certain that Diplodon has never lived north of its present habitat. Yet in New Zealand, in Tasmania and Australia this genus reappears. Further north in Asia it has never been met with. Some zoologists are of opinion that affinities such as the one alluded to can be interpreted by the supposition of a former sub-universal distribution and a subsequent extinction in all but the present habitats. We do not possess a shadow of any. evidence for such a belief, in so far as the range of the freshwater mussel Diplodon is concerned.

Let us take the second case, that of the fresh-water crayfishes. Crayfishes are abundant in the streams of North America and Asia, but they all belong to the family Potamobiidae, while southern South America is inhabited by quite a different family, the Parastacidae. Crayfishes of the latter family are again met with on the other side of the Pacific, but only in the extreme south, in New Zealand, Tasmania and Australia. Neither of these instances can be due to convergence, nor to a passage from one continent to the other by way of the northern continents. A direct land bridge becomes absolutely essential, yet this need not necessarily have lain in the direction of the antarctic regions. Its position might have been further north, as suggested by Professor Hutton,* although the latter has more recently revised his theories, in so far as he now advocates two south Pacific land bridges, instead of a single one as previously maintained. In 1905 he announced that, having reconsidered his former conclusions, he believed that an Antarctic Continent existed in Jurassic times which connected South America with New Zealand and South Africa. He thinks that this continent sank in the Cretaceous Period, Antarctica never having since been connected with northern lands. Subsequently, either during Cretaceous or early. Tertiary times, a Pacific Continent must have united

* Hutton, F. W., “Ancient Antarctica," p. 245. 
New Zealand with Chile, which, as he maintains, ceased to exist at the close of the Eocene Period.

Certain geological features no doubt point to a former westward extension of Chile. Dr. Burckhardt* showed that in western Chile there are enormously thick deposits of porphyritic conglomerates which become more attenuated and composed of lighter sandy material as we proceed eastward. Hence he argues that these deposits were laid down on an ancient shore-line of a vast western land-mass of which the existing coast cordillera of Chile is the last remnant. He advocates, in fact, nothing short of what we might call a Pacific Continent which lay mainly to the westward of Chile. That land formerly extended in that direction I have endeavoured to demonstrate from purely faunistic evidence, but I believe that it was part of a great circum-Pacific belt of land which stretched mainly northward, communicating from time to time with Central America and the Antilles, and also with Mexico and western California, and then eventually bending across to eastern Asia in a great loop and thus joining New Guinea, Australia and New Zealand. That Central America and western North America must have been thus connected by land with the Australian region has been urged above on several occasions when dealing with the North American fauna. It might be argued that if such a northern land connection once existed, uniting Chile with the Australian region, there would no longer be any necessity for postulating an antarctic land bridge. Professor Dahl has recently taken up this attitude, illustrating his adverse criticism against the antarctic theory by means of the distribution of spiders. He does not adopt, of course, my view of a northern semicircular land belt because this theory has never before been published and is entirely my own. His contention is that the continents and oceans have remained within the lifetime of the present fauna what they are now, that is to say, within the more recent geological periods, except that the great landmasses were joined in the north. A powerful centre of dispersal existed in the arctic regions, according to Professor Dahl.t

* Burckhardt, C., "Traces d'un ancien continent," pp. 186-190.

+ Dahl, F., "Die Verbreitung der Spinnen." 
and from it streamed forth practically all life, which eventually reached the most southern tips of the continents. We thus not only find there the oldest forms congregated together, according to Professor Dahl, but these would naturally resemble one another in all the southern parts of the continents. It is a simple theory, and at first sight, as I mentioned before, when discussing the similar views of Dr. Haacke, it seems to put before us the solution of all the problems of dispersal. in a satisfactory manner. No one, however, who has taken the trouble to read this book, can for a moment, I venture to think, perceive any justification for holding such a belief as that of Professor Dahl's. There may possibly have been such a centre of dispersal as that suggested, but it was long before any geological records existed. Any forms of animal life that we are aequainted with show clearly and unmistakably that there have been scores of great centres of dispersal in the world, and that from them streamed forth new forms in every available direction. Northern animals advanced southward and southern forms northward, aided, no doubt, by the everchanging conditions of climate and the gradual evolution of oceans and continents.

To return to the question at issue, let us examine what light the marine fauna throws on the problem. The geographical distribution of the elephant seal (Macrorhinus leoninus), which occurs on the shores of southern South America, of the antarctic lands, of New Zealand and Tasmania, will not contribute much to its solution, but some of the invertebrates are of more importance. The Eocene beds of Patagonia, as well as those of New Zealand, contain several species of marine mollusks common to both, such as Cucullaea alta, Scalaria rugulosa and Turritella ambulacrum. Other Patagonian species, for example, Brachydontes magellanica, Turritella patagonica and Crepidula gregaria only appear in New Zealand in later deposits. Besides these species the older Tertiaries of the two countries have a large number of genera common to both. Dr. von Ihering * thus concludes with considerable justification that the geographical conditions during early Tertiary times must have been favourable for a dis-

* Thering, H. von, “Mollusques Fossiles de L'Argentine,” p. 499. 
persal of marine mollusks between Patagonia and New Zealand. It is interesting to note that, whereas this faunistic interchange took place between Patagonia and New Zealand, the early Tertiary Chilean fauna exhibits scarcely any traces of relationship with that of New Zealand.

If the ancient land connection between southern South America and New Zealand had been a westward extension of the coast of Chile, we should expect a greater resemblance between the old Tertiary fauna of the latter country and New Zealand than between Patagonia and New Zealand. The evidence derived from the Eocene mollusks of Patagonia and New Zealand is, therefore, in favour of a southern land connection by way of the antarctic regions. I cannot believe that an Antarctic Continent, in the sense of Forbes or Osborn, could have existed at that time. If the affinity of the marine faunas of Patagonia and New Zealand was due to a continuous shore-line between the two countries, Chile must have extended southward beyond Tierra del Fuego and then have curved across to New Zealand in a great loop. The Patagonian fauna spread to New Zealand on the south side of the latter. Hence the South Polar region must have been largely. covered by sea at that time. At any rate, I believe in the former existence of two land connections between Chile and New Zealand, one by way of North America and eastern Asia, the other directly across the South Polar area.

This leads us to the third problem connected with that extraordinarily interesting region of southern South America, namely, its direct affinities with the anntarctic regions, and incidentally with South Africa and Madagascar. The southern tip of Tierra del Fuego bends eastward. At its eastern extremity lies Staten island, and beyond it the great Burdwood Bank. North of the latter, at no great distance, are situated the Falkland islands. Nowhere is there a greater depth of water than a hundred fathoms between the latter anid the mainland. Consequently all this presumably was once part of South America.

The Falkland islands cover an area of about half the size of Ireland, lying three hundred and fifty miles east of Patagonia. The country consists of undulating moorland, with an abundance of peaty soil yielding an ample supply of wiry 
grass with a growth of bushes here and there. As Darwin pointed out long ago, almost the whole of the islands are composed of sedimentary rocks, such as clay-slate arid sandstone, while the hills are formed of white granular quartz. Darwin* considered the sandstone of Silurian age, whereas Mr. Newton, $\uparrow$ who has recently examined the fossils brought back by Dr. Bruce, shows that they belong to the Devonian Period, many of them being identical with South African species of similar age.

No clue, however, can be obtained from the geological features as to the age of the islands, or, as we might say, the time when the latter became separated from the mainland. We are thus obliged to seek for information from the existing animals and plants. Mr. Vallentin's $\ddagger$ account of the fauna and flora only deals with the general features, such as a casual visitor might notice. He informs us that no indigenous mammals occur on the Falkland islands, as the peculiar wolf (Canis antarcticus) which once lived there is now extinct. It is still customary to connect this Falkland island wolf with some of the inainland species, although Mr. Lydekker $\S$ pointed out long ago that it differs markedly from all the dogand wolf-like creatures (Canidae) of South America, being closely allied to the North American coyote (Canis latrans). Dr. von Ihering || places it, along with the coyotes, into the sub-genus Lyciscus, whereas the remaining South American species of the family belong to Chrysocyon, Carcinocyon and other genera. Neither of these writers dwell upon the causes of this altogether extraordinary range. Are we to regard this as an instance of convergence? I scarcely think that any mammalogist will maintain such a view. And yet how are we to account for the fact of the existence in these remote islands of a mammal whose nearest relatives are all confined to North America? It is an extremely interesting problem. I have alluded to the noteworthy fact more than once that Chile, and even Tierra del Fuego and Argentina, exhibit a very surprising

* Darwin, C., "Journal of Researches," p. 142.

+ Newton, E. T., "Fossils from Falkland Islands," p. 251.

士 Vallentin, R., "Voyage to the Falklands," p. 352.

§ Lydekker. R., "Geographical History of Mammals," p. 140.

|| Thering, H. von, "Verbreitung d. Südamerik. Raubtiere," p. 153. 
faunistic relationship with western North America, but this affinity seems to be confined to very ancient groups of vertebrates and invertebrates. I ventured to allude to the North American porcupines as being possibly the descendants of Steiromys, which I suggested had utilised the early Tertiary land connection from Chile to Mexico or California. Steiromys, however, is long since extinct. If we suppose the coyotes to have taken advantage of that land connection in early Tertiary times, we might assume a member of that early fauna to have succeeded in surviving in these lonely islands until recent times. But the difficulty in accepting such an hypothesis is that it would give the coyotes a much longer ancestry than any palaeontologist would care to admit. Nevertheless it is the only theory I can suggest. Another question that occurs to me is-If the wolf was the only mammal inhabiting the Falkland islands, what did it live on? Wolves are carnivorous, as everyone knows, usually feeding on smaller mammals. Yet Darwin states that it is the only quadruped native to the islands; he adds, however, in a footnote, "I have reason to suspect there is also a field mouse." This is probably a species of Reithrodon or some allied genus. Still this mouse-like creature could scarcely have constituted the sole food of such a large animal as the wolf. In all likelihood, some larger rodent existed on the islands and may have become extinct before the advent of man. The wolf soon after this event shared the same fate.

An examination of the earthworm fauna, which is probably of very great antiquity, reveals the fact that there are living on the Falkland islands two species of the genus Noteodrilus ( $\mathrm{N}$. bovei and $\mathrm{N}$. falclandicus) which otherwise is confined to South and Central America, New Zealand, Australia, Cape of Good Hope, Madagascar and several of the antarctic islands. A second genus, viz., Chilota, which is represented on the Falkland islands by Chilota daleti, inhabits only southern South America and the Cape of Good Hope, with the exception of a single species living on the Cape Verd islands. The third genus, Yagansia, has not yet been found on the Falkland islands. It is almost peculiar to Chile and Argentina. Only one species of Yagansia has been met with in South Africa.*

* Michaelsen, W., "Verbreitung d. Oligochaeten," p. 74. 
Thus there appears to be a distinct faunistic affinity between southern South America as a whole, including the Falkland islands, and New Zealand, as well as South Africa and Madagascar. I have already alluded to Professor Bouvier's * remarkable discovery of the Peripatus of Chile being more closely allied to that of South Africa than to those of the rest of South America, so that he now places the South African and Chilean species into the genus Opisthopatus, while all the rest remain in the old genus Peripatus. I have likewise drawn attention to the fact that the family of fresh-water crayfishes Parastacidae occurs only in southern South America, the Australian region and Madagascar. Professor Kolbe $†$ argued long ago that the manifold faunistic affinities of South America and Madagascar were largely due to an immigration into the latter of American forms from the south by means of antarctic land connections. Lastly, there are relationships even among the marine forms of Patagonia and South Africa which seem to demand the existence of a former direct land connection between these areas, although Dr. Ashworth $\ddagger$ would join the latter to an Antaretic Continent. When the faunas of Madagascar and South Africa become better known, it will be possible to follow these clues with greater success. That these affinities are altogether of the nature of convergences, as some authorities would have us believe, is, I think, inadmissible. If they are due to the existence of former antarctic land connections, we may be sure that they, are of very great antiquity, possibly far beyond the limits of the Tertiary Era.

Stimulated largely by these zoogeographical problems, the antarctic regions have within recent years received a greater share of public attention than hitherto. Thus expeditions have been fitted out from Belgium, France, Germany, England and Scotland in order to endeavour to throw light on some of these mysteries. Interesting results in connection with the theories of a former land connection between South America and Madagascar were obtained, particularly by the Scottish Antarctic Expedition. Returning northward

* Bouvier, E. L., " Monographie des Onychophores," pp. 64-65.

† Kolbe, H. J., "Zoogeographische Elemente in Madagascar," p. 173.

‡ Ashworth, J. H., " Arenicolidae of South Africa," p. 23. 
from the South Polar regions, Dr. Bruce took a series of soundings proving that the South Atlantic rise extended a thousand miles further south than was previously known. Now Dr. Bruce believes that this comparatively shallow water area extends westward to the Sandwich group (not to be confounded with the Sandwich islands in the Pacific Ocean), and eastward to Bouvet island. By demonstrating the presence of a long ridge of about three hundred miles in breadth between Madagascar and Bouvet island to the Sandwich group, with a forked connection towards the South Orkneys and the antaretic regions on the one hand, and the Falkland islands and Tierra del Fuego on the other, Dr. Bruce * has made a valuable addition to our knowledge of the zoogeographical affinities referred to.

Professor Carpenter, $\uparrow$ who described the Collembola brought back from the South Orkney islands by the Scottish antarctic Expedition, concludes that these minute insects support the view of the former existence of extensive land tracts south of the American continent. It may be mentioned incidentally that sedimentary rocks have now been discovered not only in the South Orkney islands by Dr. Pirie, but also in the island of South Georgia.

A very important contribution to the subject of the antarctic problem is that by Dr. Enderlein. He deals with the geographical distribution in the South Polar regions of insects as a whole. Chile, Tierra del Fuego, the Falkland islands and South Georgia all belong, according to him, to Dr. von Ihering's "Archiplata" region, while the Auckland isles, Campbell islands and the Macquarie islands are grouped as part of New Zealand. The former has a large number of endemic genera of insects. Dr. Enderlein regards the family Thynnidae as one of the most valuable supports in favour of a former land connection between Archiplata and the whole Australian region, all the females of this family of Hymenoptera being wingless. These insects are confined to the Australian region and southern South America. Numbers of similar instances are cited. After quoting all the recorded

* Bruce, W. S., "Survey of South Atlantic," p. 10.

† Carpenter, G. H., "Collembola from South Orkneys," p 479.

L.A. 
insects from the antarctic regions, Dr. Enderlein comes to the conclusion that the existing features of distribution are best explained by means of Dr. Simroth's pendulation theory. That theory is founded on the supposed pendulation or shifting of the poles in the course of time. As the South Pole gradually travelled northward, the present antarctic regions would have slowly moved into more favourable climatic regions, and have thus become habitable for such temperate animals and plants as were able to reach them. When the Pole once more moved back towards its present position, the antarctic fauna and flora would again have endeavoured to regain suitable climatic regions by any other land connections then available. In this manner it is perfectly conceivable how, by a combination of serviceable land connections and a shifting Pole, the present geographical distribution of the animals and plants alluded to could have been brought about. We need not imagine the former existence of a huge continent from which long peninsulae projected, simultaneously joining all the southern continents with one another. More slender land bridges uniting one continent after another during successive geological ages with an antarctic land-mass would be sufficient. Dr. Enderlein supposes that probably towards the end of Cretaceous or in Eocene times the antarctic "HeardMarion," area was connected by land with Madagascar and indirectly with South Africa. Tierra del Fuego extended beyond the Falkland islands, South Georgia, South Orkneys and Shetlands to Antarctica about the same time, and also, perhaps during the Oligocene and Miocene Periods. Australia was joined to the same area in Oligocene or Miocene times. Dr. Enderlein,* on the other hand, believes New Zealand to have been completely isolated from all other regions since the Eocene Period.

The theory appears simple and plausible, and if it should be proved that the Poles shift their position to the extent assumed by Professor Simroth, it would explain the causes of some of the great movements of animal life in a satisfactory manner. Nevertheless, we cannot, as Dr. Enderlein acknowledges, dis-

* Enderlein, Günther, "Biologische Bedeutung der Antarktis," pp. 333-350. 
pense with land connections, and he rejects the theories of accidental dispersal as quite inapplicable to the solution of the antarctic biological problems. For my own part, I think that changes of land and water, combined with warm currents in the Polar regions, would likewise explain the same phenomena in a satisfactory manner, and I prefer to adopt the latter view until we possess more definite information as to evidence on which the pendulation theory is founded.

I have endeavoured in this work to show how the gradual evolution of our continents and the former changes of land and water can be demonstrated by a study of the geographical distribution of living animals and plants. Whenever possible I have taken advantage of our palaeontological and geological knowledge in furtherance of this object, and I venture to think that I have succeeded in unravelling some intricate problems of the palaeogeography of America. Indirectly I have thus been able to indicate the manner in which North and South America became populated, and the extent to which these continents took part in supplying animals and plants to other regions of the world. 



\section{BIBLIOGRAPHY}

Principal Works consulted in the Preparation of this Volume

Adams, A. Leith. "Field and Forest Rambles, Notes and Observations on the Natural History of Eastern Canada." London, 1873.

ADAMs, C. C. "South-Eastern United States as a Centre of Geographical Distribution of Flora and Fauna." Biol. Bull. Vol. III., pp. 115-131. 1902.

ADAMs, C. C. " Post-Glacial Origin and Migrations of the Life of the North-Eastern United States." Journal of Geography, Vol. I., pp. 303-310 and pp. 352-357. 1902.

ADAMs, C. C. "The Post-Glacial Dispersal of the North Americnn Biota." Biol. Bull., Vol. IX., pp. 53-71. 1905.

Agassiz, A. "Hydrographic Sketch of Lake Titicaca." Proc. Amer. Acad. Arts and Sciences, Vol. III. (N.S.), pp. 283-292. 1876.

Agassiz, A. "Reports on the Dredging Operations off the West Coast of Central America to the Galapagos, to the West Coast of Mexico, and in the Gulf of California, carried on by the U.S. F'ish Commission Steamer Albatross." Bull. Mus. Comp. Zool. Harvarel, Vol. XXIII., pp. 1-89. 1892.

Agassiz, A. "A Reconnaissance of the Bahamas and of the Elavated Reefs of Cuba in the Steam Yacht Wild Duck." Bull. Muts. Comp. Zool. Harvard, Vol. XXVI., pp. 1-203. 1894.

Agassiz, A. "The Elevated Reef of Florida, with Notes on the Geology of Southern Florida by L. S. Griswold." Bull. Mus. Comp. Zool. Harvard, Vol. XXVIII. (Geol. Ser.), pp. 29-62. 1896.

Agassiz, L. "Notice of a Collection of Fishes from the Southern Bend of the Tennessee River in the State of Alabama." American Journ. of Science and Arts, Vol. XVII. (2), pp. 297-308 and 353369. 1854 .

Alcock, A. "Description of and Reflections upon a New Species of Apodous Amphibian from India." Ann. and Mag. Nat. Hist. (7), Vol. XIV., pp. 267-273. 1904.

Allen, Glover M. "Mammals of the West Indies." Bull. Mus. Comp. Zool. Harvard, Vol. LIV., pp. 175-263. 1911.

Allen, J. A. "The Geographical Distribution of the Mammalia, 
considered in relation to the Principal Ontological Regions of the Earth, and the Laws that govern the Distribution of Animal Life." Bull. U.S. Geological Survey, Vol. IV., pp. 313-377. 1878.

Allen, J. A. "On a Small Collection of Mammals from the Galapagos Islands.” Bull. Amer. Mus. Nat. Hist., Vol. IV., pp. 47 $-50.1892$.

Allen, J. A. "The Geographical Distribution of North American Mammals." Bull. Amer. Mus. Nat. Hist., Vol. IV., pp. 199-243. 1892.

Allen, J. A. "The Geographical Origin and Distribution of North American Birds, considered in relation to the Faunal Areas of North America." The Auk. (N.S.), Vol. X., pp. 97-150. 1893.

Allen, J. A. "The Origin and Relations of the Floras and Faunas of the Antarctic and adjacent Regions. Birds and Mammals." Science (N.S.), Vol. III., pp. 317-320. 1896.

AlıLeN, J. A. "The Mountain Caribou (Rangifer montanus) of North British Columbia." Bull. Amer. Mus. Nat. Hist., Vol. XIII., pp. 1-18. 1900.

Allen, J. A. "The Musk Oxen of Arctic America and Greenland." Bull. Amer. Mus. Nat. Hist., Vol. XIV., pp. 69-86. 1901.

Allen, J. A. "A Preliminary Study of the South American Opossums of the Genus Didelphis." Bull. Amer. Mus. Nat. Hist., Vol. XVI., pp. 249-279. 1902.

Allen, J. A. " Mammals collected in Alaska and Northern British Columbia by the Andrew J. Stone Expedition, 1902." Bull. Amer. Mus. Nat. Hist., Vol. XIX., pp. 521-567. 1903.

Allen, J. A. "Report on the Mammals collected in North-Eastern Siberia by the Jesup North Pacific Expedition." Bull. Amer. Mus. Nat. Hist., Vol. XIX., pp. 101-184. 1903.

Allen, J. A. "Mammalia of Southern Patagonia." Zoology, Part I. Rep. Princeton Univ. Exped. Patagonia, Vol. III., pp. 1120. 1905.

Allen, J. A. "Notes on Solenodon paradoxus, Brandt." Bull. Amer. Mus. Nat. Hist., Vol. XXIV., pp. 505-517. 1908.

Alston, E. R. "Mammalia Centrali-Americana." 240 pp. London, 1879-1882.

Ameghino, Fl. "South America as the Source of the Tertiary Mammalia." (Translated from "La Argentina al través de las últimas épocas geológicas.”) Natural Science, Vol. XI., pp. 256-264. 1897.

Ameghino, Fl. "Les formations sédimentaires du Cretacé supérieur et du Tertiaire de Patagonie." Anal. Mus. Nacional de Buenos Aires (3), Vol. VIII., pp. 1-568. 1906.

Ameghino, FL. "Notas preliminares sobre el Tetraprothomo argentinus, un precursor del hombre del Mioceno superior de Monte Hermoso." Anales del Museo Nacional de Buenos Aires (3), Vol. IX., pp. $105-240.1908$.

Amegnino, Fu. "Geologia, Paleogeografia, Paleontologia, Antropologia de la República Argentina." Estudo publicado en el Número 
de la Nación del 25 de Mayo de 1910 (Edicion del autor), pp. 1-26. 1910.

Ameghino, Fl. "Otra nueva especie extinguida del gênere Homo." Congreso Cientifico Int. Americano, Buenos Aires, pp. 1-6. 1910.

Ancey, C. F. "Considérations sur les faunes malacologiques des parties australes du globe." Journal de Conchyliologie, Vol. XLIX., pp. 12-33. 1901.

ANDERSEN, KNud. "A List of the Species and Sub-species of the Genus Rhinolophus, with some Notes on their Geographical Distribu. tion." Ann. and Mag. Nat. Hist. (7), Vol. XVI., pp. 648-662. 1905.

Andreae, A. "Binnenconchylienfauna d. Miocäns von Oppeln in Schlesien." Mitt. a. d. Roemer Museum in Hildesheim (3 parts). 1902-1904.

Andrews, C. W. "A Descriptive Catalogue of the Tertiary Vertebrata of the Fayúm, Egypt." London, 1906.

APPELL, F, A. "Report on Norwegian Fishery and Marine Investigations." Vol. II., Part 1, pp. 83-93. 1909.

ARLdt, Th. "Über den Parallelismus der Küsten von Südamerika." Mitt. des Vereins f. Erdkunde. Leipzig, 1901.

ARLDT, Тн. "Die Entwicklung d. Kontinente \& ihrer Lebewelt." Leipzig, 1907.

ARLDT, TH. "Die Ausbreitung einiger Arachnidenordnungen (Megalomorphen, Skorpione, Pedipalpen, \&c.)." Archiv f. Naturgeschichte. 74 Jahrg. 1 Bd., pp. 389-458. 1908.

ARLdT, TH. "Die Bedeutung d. Antarktis in der Entwicklung d. Erde \& ihrer Lebewesen." Zeitschrift “ Himmel \& Erde," Vol.. XXII., pp. 354-372. 1910.

ARNOLD, RALPH. "The Palaeontology and Stratigraphy of the Marine Pliocene and Pleistocene of San Pedro, California." Mem. Calif. Acad. Sc., Vol. III. ' 1903.

Arnold, Ralph. "The Tertiary and Quaternary Pectens of California." U.S. Geol. Survey Prof. Paper 47. 1906.

Asнworth, J. H. "The Arenicolidae of South Africa, including an account of Arenicola loveni, Kinberg." Annals of the South African Museum, Vol. XI., (Part I.), pp. 1-26. 1911.

Ashworth, J. H. "MS. Catalogue of the Chaetopoda in the British Museum. Part I. Arenicolidae.

Austaut, J. L. "Les Parnassiens de la faune paléarctique." Leipzig, 1889.

Austen, E. P. "Catalogue of the Coleoptera of Mount Washington." Proc. Boston Nat. Hist. Soc., Vol. XVI., pp. 265-276. 1873 -1874 .

Batley, Vernon. "Revision of the American Voles of the Genus Microtus." North American Fauna No. 17. Washington Govt. Print. Off. 1900.

BALL, JoHN. "Notes of a Naturalist in South America." London, 1887. 
Bangs, Outram. "A List of the Mammals of Labrador." American Naturalist, Vol. XXXII., pp. 489-507. 1898.

Bangs, Outram. "The Land Mammals of Peninsular Florida and the Coast Region of Georgia." Proc. Boston Soc. Nat. Hist., Vol. XXVIII., pp. 157-235. 1899.

Bangs, Outram and T. S. Bradlee. "The Resident Land Birds of Bermuda." The Auk (N.S.), Vol. XVIII., pp. 249-257. 1901.

BANks, N. "The Arachnida of Florida." Proc. Acad. Nat. Sc. Philadelphia, Vol. LVI., pp. 120-147. 1904.

Barbour, Thomas. "Batrachia and Reptilia from the Bahamas." Bull. Mus. Comp. Zool. Harvard, Vol. XLVI., pp. 55-61. 1904.

Barbour, Thomas. "A Note regarding the Chinese Alligator." Proc. Acad. Nat. Sc. Philadelphia, pp. 464-467. 1910.

Barbour, Thomas. " Notes on the Herpetology of Jamaica." Bull. Mus. Comp. Zool. Harvard, Vol. LII., pp. 273-301. 1910.

Barrett-Hamilton, G. E. H. "On Some Skins of the Variable Hare.” Proc. Zoological Soc. London, pp. 87-92. 1900.

Barrett-Hamilton, G. E. H. and I. L. Bonhote. "On Two Subspecies of the Arctic Fox (Canis lagopus)." Ann. and Mag. Nat. Hist. (ser. 7), Vol. I., pp. 287-289. 1898.

Bates, H. W. "The Naturalist on the River Amazon" (5th ed.). London, 1879.

Baur, G. “Das Variiren der Eidechsen-Gattung Tropidurus auf d. Galapagos Inseln.” Biol. Centralblatt, Vol. X., pp. 475-483. 1890. Baur, G. "On the Origin of the Galápagos Islands." American Naturalist, Vol. XXV., pp. 217-229 and 307-326. 1891.

BaUR, G. "New Observations on the Origin of the Galápagos Islands, with Remarks on the Geological Age of the Pacific Ocean." American Naturalist, Vol. XXXI., pp. 661-680 and 864-896. 1897.

BedDard, F. E. " A Text-book of Zoogeography." Cambridge, 1895.

BEDdaRD, F. E. "The Former Northward Extension of the Antarctic Continent.” Nature, Vol. LIII., p. 129. 1896.

Belt, TH. "The Naturalist in Nicaragua." London, 1874.

BenHaM, W. B. "The Geographical Distribution of Earthworms and the Palaeogeography of the Antarctic Regions." Report 9th Meet. Australian Assoc., pp. 319-343. 1902.

BENHAM, W. B. "Report on Olichaeta of the Subantarctic Islands of New-Zealand." From "Subantarctic Islands of New-Zealand," pp. 251-292. 1909.

Berry, E. W. "A Note on Mid-Cretaceous Geography." Science (N.S.), Vol. XXIII., pp. 509-510. 1906.

Berry, E. W. "Contributions to the Pleistocene Flora of North Carolina." Journal of Geology, Vol. XV., pp. 338-349. 1907.

Bigelow, Henry B. "The Medusae." Reports on the Scientifio Results of the Albatross Expedition to the East Pacific. Mem. Mus. Comp. Zool. Harvard, Vol. XXXVII., pp. 1-243. 1909.

Blaisdell, Frank E. "A Monographic Revision of the Coleoptera 
belonging to the Tenebrionidae Tribe Eleodiini, inhabiting the United States, lower California and adjacent Islands." Bull. U.S. Nat. Mus., Vol. LXIII., 524 pp. 1909.

BuAnd, TH. "On the Geographical Distribution of the Land Shells of the West India Islands." Annals Lyceum Nat. Hist. Soc. New York, Vol. VII., pp. 1-35. 1861.

Blanford, W. T. "Address delivered at the Anniversary Meeting of the Geological Society of London." Proc. Geol. Soc. London, pp. 13-80. 1890.

Böse, E. and F. Toula. "Zur jung-tertiären Fauna von Tehuantepec.” Jahrb. d. K.K. Geol. Reichsanst. Wien, Vol. LX., pp. 215276. 1910.

Bofttaer, O. "Die Tertiärfauna von Pebas am oberen Marannon." Jahrb. d. K.K. Geol. Reichsanst. Wien, Vol. XXVIII., pp. 485-504. 1878.

Boettger, O. Referat über "Baur's differentiation of species on the Galapagos Islands, \&c." Zool. Centralblatt, Vol. II., pp. 461463. 1895.

Boettaer, O. Noch einmal "Die Verwandtschaftsbeziehungen d. Helix-arten aus d. Tertiär Europas." Nachrichtsbl. d. d. Malak. Gesellsch. 41 Jahrg., pp. 97-118. 1909.

BoETtGer, O. "Bestimmungsschlüssel und Literaturnachweise f. die bis jetzt bekannten Nenia-Arten." Nachrichtsbl. d. d. Malak. Gesellsch. 41 Jahrg., pp. 162-183. 1909.

BoettGer, O. "Weitere Mitteilungen über Nenia -Arten." Nachrichtsblatt d. d. Malak. Gesellsch., 42 Jahrg., pp. 73-79. 1910.

Born, PaUl. "Zoogeographisch-carabologische Studien." Entomol. Wochenblatt, Vol. XXV., pp. 1-68. 1908.

Boulenger, G. A. "Catalogue of the Batrachia Salientia S. Ecaudata in the Collection of the British Museum" (2nd ed.) London, 1882.

Boulenger, G. A. "Catalogue of the Batrachia Gradienta S. Caudata and Batrachia Apoda in the Collection of the British Museum " (2nd ed.). London, 1882.

Boulenger, G. A. "Catalogue of the Lizards in the British Museum” (Nat. Hist.). Vols. I.-III. (2nd ed.). London, 18851887.

Boulenger, G. A. "Catalogue of the Chelonians, Rhynchocephar lians and Crocodiles in the British Museum" (Nat. Hist.)(new ed.). London, 1889.

Boulenger, G. A. "Catalogue of the Snakes in the British Museum.” (Nat. Hist.), 3 vols. London, 1893-1896.

Boulenger, G. A. "A Synopsis of the Genera and Species of Apodal Batrachians, with Descriptions of a New Genus and Species (Bdellophis vittatus)." Proc. Zool. Soc. London, pp. 401-414. 1895.

Boulenger, G. A. "The Distribution of African Freshwater Fishes." (Address to the Zool. Section of the Brit. Ass. Adv. Science). Reprint. 1905. 
Bouvier, E. L. “Monographie des Onychophores." (In two parts). Paris, Ann. Sc. Nat. (8 and 9), Vol. I., pp. 1-383 and Vol. V., pp. 61-318. 1905-1907.

Brandegee, T. S. "Flora of the Cape Region of Baja California." Proc. Calif. Acad. Sc. (2), 'Vol. III., pp. 108-182; additions, pp. 218-227. 1890-1892.

Brauer, A. "Die arktische Subregion. Ein Beitrag z. geegr. Verbreitung der Thiere." Zool. Jahrd. (Abth. f. Syst.), Vol. III., pp. 189-308. 1887.

BraY, W. L. "Relation of the Vegetation of the Lower Sonoran Zone in North America to the Arid Zones of Chile and Argentina." Botanical Gazette, Vol. XXVI., pp. '121-147. 1898.

Bray, W. L. "The Relations of the North American Flora to that of South America." Science (N.S.), Vol. XII., pp. 709-716 1900 .

Brehm, Vincenz. "Die Entomostraken der Danmark-Expedition." From "Danmark Ekspeditionen til Grönlands Nordöstkyst, 1906 -1908," Vol. V., pp. 305-317. 1911.

Brendel, F. "Notes on the Flora of Florida." American Naturalist, Vol. VIII., p. 449. 1874.

Britton, N. L. "The Origin and Relations of the Floras and Faunas of the Antarctic and adjacent Regions." (Botany.) Science (N.S.), Vol. III., pp. 310-311. 1896.

Brooks, A. H. "The Geography and Geology of Alaska." Washington (Prof. Pap. Geol. Surv.). 1906.

Brown, A. E. "The Variations of Eutaenia in the Pacific Subregion." Proc. Acad. Nat. Sc. Philadelphia, pp. 286-297. 1903.

Brown, A. E. "Texas Reptiles and their Faunal Relations." Proc. Acad. Nat. Sc. Philadelphia, Vol. LV., pp. 543-558. 1903.

Brown, A. E. "Postglacial Nearctic Centres of Dispersal for Reptiles." Proc. Acad. Nat. Sc. Philadelphia, Vol. LVI., pp. 464474. 1904.

Brown, A. E. "The Zoology of North American Big Game," (in "American Big Game and 'its Haunts," by George Bird Grinnell), pp. 52-98. New York, 1904.

Brown, Barnum. "The Conard Fissure, a Pleistocene Bone, Deposit in Northern Arkansas." Memoirs American Museum of Natural History, Vol. IX., Part IV., pp. 157-208. 1908.

Brown, RoBert. "On the Mammalian Fauna of Greenland." Proc. Zool. Soc. of London, pp. 330-362. 1868.

Brown, R. N. RuDmose. "Diego Alvarez or Gough Island (Scottish Antarctic Expedition)." Scottish Geogr. Mag., Aug. 1905.

Bruce, W. S. "Scottish National Antarctic Expedition. Bathymetrical Survey of the South Atlantic Ocean and Weddell Sea." Scottish Geogr. Mag., Aug. 1905.

Bruce, W. S. "Polar Exploration." London, 1911.

Budde-Lund, G. "Crustacea Isopoda Terrestria," Part I., p. 319. Kj申benhavn, 1885. 
Budde-Lund, G. "Revision of Crustacea Isopoda Terrestria,"I. "Eubelum," Kj申benhavn, 1899. II. "Spherilloninae." III. "Armadillo." 1904.

BURCKHARDT, C. "Traces géologiques d'un ancien Continent pacifique." Revista do Museo de la Plata, Vol. X., pp. 179-192. 1902. Burckhardt, R. " "Das Problem d. antarkt. Schöpfungscentr. v. Standtpunkt d. Ornithologie." Zool. Jahrb. (Abth. f. System.), Vol. XV., pp. 499-536. 1902.

Calnert, Th. T. " The Composition and Ecological Relations of the Odonate Fauna of Mexico and Central America." Proc. Acad. Nat. Sc. Philadelphia, Vol. LX., pp. 460-491. 1908-1909.

Camerano, Lorenzo. "Ricerche intorno alle renne delle isole Spitzberghe." Memorie della R. Acad. delle Science di Torino (2), Vol. LT., pp. 159-240. 1902.

Carpenter, G. H. "Nearctic or Sonoran?" Natural Science, Vol. V., pp. 53-57. 1894.

Carpenter, G. H. Collembola from the South Orkney Islands." Proc. R. Soc. Edinburgh, Vol. XXVI., pp. 473-483. 1905-1906.

Carthaus, E. "Die klimatischen Verhältnisse der geologischen Vorzeit vom Präcambrium an bis zur Jetztzeit, \& ihr Einfluss auf d. Entwicklung der Haupttypen des Tier \& Pflanzenreiches." Berlin, 1910.

Caton, J. D. "The Antelope and Deer of America" (2nd ed.). 1881.

CaUdell, A. N. "The Phasmidae or Walking Sticks of the United States." Proc. U.S. Nat. Mus., Vol. XXVI., pp. 863-885. 1903.

Chamberlin, RalpH V. "Revision of North American Spiders of the Family Lycosidae." Proc. Acad. Nat. Sc. Philadelphia, Vol. LX., pp. 158-318. 1908.

Chamberlin, T. C. and R. D. Salisbury. "Geology-Earth History" 3 vols. London, 1906.

Chapman, F. M. "Notes on Birds and Mammals near Trinidad, Cuba, with Remarks on the Origin of West Indian Bird Life." Bull. Amer. Mus. Nat. Hist., Vol. IV., pp. 279-330. 1892.

Chapman, F. M. "A Revision of the Genus Capromys." Bull. Amer. Mus. Nat. Hist., Vol. XIV., pp. 313-323. 1901.

CHILton, Сн. "The Biological Relations of the Subantarctio Islands of New Zealand," ex. "The Subantarctic Islands af New Zealand," Vol. II., pp. 793-807. 1909.

Cockerell, T. D. A. "The Fossil Fauna and Flora of the Florissant (Colorado) Shales." Univ. of Colorado Studies, Vol. III., pp. 157-176. 1906.

CoE, W. R. "The Anatomy and Development of the Terrestrial Nemertean Geonemertes agricola of Bermuda." Proc. Boston Nat. Hist. Soc., Vol. XXXI., pp. 531-570. 1904.

Coe, W. R. and B. W. Kunkel. "Studies on the California Limbless Lizard Aniella." Trans. Connect. Acad. Sc., Vol. XII., pp. 349 -403. 1907. 
Coleman, A. P. "Glacial and Interglacial Deposits near Toronto." Journal of Geology, Vol. III., pp. 622-645. 1895.

Conwentz, H. "Zur Verbreitung des Moschusochsen in Nord-ost Grönland." Verh. d. Gesellsch, f. Erdkunde, Berlin, Vol. XXVII., pp. 427-432. 1900 .

Cooke, Wells W. "Some New Facts about the Migration of Birds." Year Book of Dept. of Agriculture, U.S.A., pp. 371-386. 1903.

Cooke, A. H., A. E. Shipley, and F. R. C. Reed. "Molluses, Brachiopods (Recent) and Brachiopods (Fossil)." Cambridge Natural History, Vol. III. London, 1895.

Cooper, J. G. "On Land and Freshwater Shells of Lower California." Proc. Calif. Acad. Sc. (2), Vol. III., pp. 99-103, 207-217, and 338-344. 1890-1892.

Core, E. D. "Check List of the North American Batrachia and Reptilia, with a Systematic List of the Higher Groups, and an Essay, on Geographical Distribution." Washington, 1875.

Cope, E. D. "Notes on the Geographical Distribution of the Batrachia and Reptilia in western North America." Proc. Acad. Nat. Sc. Philadelphia, pp. 10-35. 1883.

Cope, E. D. "The Batrachia of North America." Bull. U.S. National Museum. Washington, 1889.

Cope, E. D. "The Crocodilians, Lizards and Snakes of North America." Rep. U.S. Nat. Mus. for 1898, pp. 153-1270. 1900.

Copfland, Ralph. "Ein Besuch a. d. Insel Trinidad im südatlantischen Ocean." Abhandl. Naturw. Ver. Bremen, Vol. VII., pp. $269-280$.

Credner, R. "Die Reliktenseen"-I. Theil. Petermanns Mitteil. Ergänzungsheft 86. II. Theil. Ergänzungsheft 89. 1887-1888.

Cunningham, Robert O. "Notes on the Natural History of the Straits of Magellan and West Coast of Patagonia." Edinburgh, 1871.

DAHL, Fr. "Die Landfauna von Bermuda." Plankton-Expedition d. Humboldt—Stiftung, Leipzig, Vol. I., pp. 105-112. 1892.

DAHL, Fr. "Die Verbreitung der Spinnen spricht gegen eine frühere Landverbindung der Südspitzen unsrer Kontinente." Zool. Anzeiger, Vol. XXXVII., pp. 270-282. 1911.

DaLL, W. H. "On the Marine Faunal Regions of the North Pacific (Introductory Note to Clark's Report on Hydroids)." Proc. Acad. Nat. Sc. Philadelphia, pp. 205-208. 1876.

DALL, W. H. "A Subtropical Miocene Fauna in Arctic Siberia." Proc. U.S. National Mus., Vol. XVI., pp. 471-478. 1893.

DaLL, W. H. "Land Shells of the Genus Bulimulus in Lower California, with Description of several New Species." Proc. U.S. National Museum, Vol. XVI., pp. 639-647. 1893.

DALL, W. H. "Insular Landshell Faunas, especially as illustrated by the Data obtained by Dr. G. Baur in the Galapagos Islands." Proc. Ac. Nat. Sc. Philadelphia, pp. 395-459. 1896.

DALL, W. H. "Contributions to the Tertiary Fauna of Florida." 
Trans. Wagner Free Institute of Philadelphia, Vol. III., Parts IV. -VI., pp. 571-1654. 1898.

DALL, W. H. "Additions to the Insular Land-shell Faunas of the Pacific Coast, especially of the Galapagos and Cocos Islands." Proc. Nat. Sc. Philadelphia, pp. 88-106. 1900.

DALL, W. H. "Land and Freshwater Mollusks of Alaska." Ex. Harriman Alaska Expedition, Vol. XIII., pp. 1-171. 1905.

DALL, W. H. "On the Relations of the Land and Freshwater Mollusk Fauna of Alaska and 'Eastern Siberia." Popular Science Monthly, pp. 362-366. 1905.

Dall, W. H. "On Climatic Conditions at Nome, Alaska, during" the Pliocene." American Journal of Science (4), Vol. XXIII., pp. 457 -458. 1907.

DaLL, W. H. "Report on a Collection of Shells from Peru, with a Summary of the Littoral Marine Mollusca of the Peruvian Province." Proc. U.S. National Museum, Vol. XXXVII., pp. 147294. 1910.

Dali, W. H. and G. 'D. Harris. "Correlation Papers-Neocene." Bull. U.S. Geol. Survey No. 84, pp. 1-349. 1891.

Daly, Reginald A. "The Geology of the north-east Coast of Labrador." Bull. Mus. Comp. Zool. Harvard, Vol. XXXVIII., pp. 205 -270. 1900-1903.

Darwin, Charles. "Journal of Researches into the Natural History and Geology of the Countries visited during the Voyage of H.M.S. Beagle round the World" (3rd ed.). London, 1889.

Dawson, J. W. "The Canadian Ice Age." 1893.

Dawson, J. W., D. T. Penhallow and others. "Canadian Pleistocene Flora and Fauna." Report British Association, Bradford, pp. 328-339. 1900.

Denburgh, J. van. "A Review of the Herpetology of Lower California : Reptiles." Proc. Calif. Acad. Science (2), Vol. V., pp. 77-162. 1895.

Denburgh, J. van. "The Reptiles and Amphibians of the Islands of the Pacific Coast of North America from the Farallons to Cape S. Lucas and the Revilla Gigedo Islands." Proc. Calif. Acad. Sc. (3), Zool., Vol. IV., pp. 1-4. 1905.

Denburgh, J. van. "Preliminary descriptions of Four New Races of Gigantic Land Tortoises from the Galapagos Islands." Proc. Calif. Acad. Sciences (4), Vol. I., pp. 1-6. 1907.

Denburgh, J. van. "The Snakes of the Galapagos Islands." Proc. Calif. Acad. Sc. (4), Vol. I. (In the Press.)

Depéret, Charles. "L'évolution des mammifères tertiaires." Comptes Rendus de L'Académie d. Sciences, Paris, Vols. CXLCXLVIII. 1905-1909.

Depéret, Charles. "The Transformations of the Animal World." London, 1909.

Dickerson, Mary C. “The Frog Book." New York, 1906. 
Diederich, Franz. "Die geographische Verbreitung der Elstern." Ornis (Separatabdruck), pp. 1-54. 1889.

Dilg, CaRL. "Beiträge zur Kenntniss der Morphologie \& postembryonalen Entwicklung des Schädels bei Manatus inunguis." Gegenbaur's Morphologisches Jahrbuch, Vol. XXXIX., pp. 83-145. 1909.

Ditmars, R. E. "The Reptile Book." New York, 1907.

Dollfus, A. "On West-Indian Terrestrial Isopod Crustaceans." Proc. Zool. Soc. London, pp. 388-400. 1896.

Drasche, R. von. "Ửber paläozoische Schichten auf Kamtschatka \& Luzon." Neues Jahrb. f. Mineralogie, Geologie \& Palaeontologie, pp. 265-269. 1879.

Drude, O. "Pflanzengeographische Anhaltspunkte für das Bestehen einer Landbrücke zwischen Grönland \& West Europa zur Eiszeit." Ausland, 56 Jahrg., pp. 325-329. 1883.

Drude, O. "Handbuch d. Pflanzengeographie." Stuttgart, 1890.

DryGaLSKI, E. voN. "Grönland Expedition der Gesellschaft für Erdkunde in Berlin.” Berlin, Vol. I. 1897.

DuERDEN, J. E. "Contributions to the Natural History of Jamaica." Journal Instit. Jamaica, Vol. II., pp. 263-275. 1896.

DyaR, H. G. "Papers from the Harriman Alaska Expedition : Lepidoptera." Proc. Washington Acad. Sc., Vol. II., pp. 487-501. 1900.

Dyar, H. G. " A List of North American Lepidoptera." Bulletin U.S. National Museum (No. 52). 1902.

Earle, Charles. "Notes on the Fossil Mammalia of Europe." Part VI. "Remarks on the Fossil Tapiroids of France." American Naturalist, Vol. XXXII., pp. 115-116. '1898.

Eckel, E. C. and T. C. Paulmier. "Catalogue of New York Reptiles and Batrachians." Bull. New York State Mus., pp. 356388.1902.

Eigenmann, C. H. "A Case of Convergence." Science, Vol. XIV. (N.S.), pp. 280-282. 1899.

Eigenmann, C. H. "Freshwater Fishes of Western Cuba." Bull. U.S. Fish Commission, Vol. XXII., pp. 211-236. 1902.

Eigenmann, C. H. "The Freshwater Fishes of South and Middle America." Popular Science Monthly, pp. 515-530. 1906.

Eigenmann, C. H. "The Freshwater Fishes of Patagonia, and an Examination of the Archiplata-Archhelenis theory." Reports Princeton Expedition, Vol. III., Part II., pp. 225-374. 1909.

EIsen, G. "Explorations in the Cape Region of Baja California in 1894, with References to Former Expeditions of the California Academy of Sciences." Proc. Calif. Acad. Sc. (2), Vol. V., pp. 733 $-775.1895$.

Elliot, D. G. "Check List of Mammals of the North American Continent, the West Indies and the Neighbouring Seas." Field Columbian Mus. Pub., Zool. Series, Vol. VI. 1905.

Elwes, H. J. "Geographical Distribution of Butterflies." (Presid. Address), Trans. Entom. Soc. London, pp. liii.-lxxxiv. 1894-1895. 
Emerson, Ellen T. "General Anatomy of Typhlomolge rathbuni." Proc. Boston' Nat. Hist. Soc., Vol. XXXII., pp. 43-76. 1905.

Emerton, J. H. "A Comparison of the Spiders of Europe and North America." Proc. Boston Soc. Nat. Hist. Soc., Vol. XIX., pp. 68-72. 1877.

Emerton, J. H. "The Common Spiders of the United States." Boston, 1902.

Emery, C. "Beiträge z. Kenntniss d. nordamerik. Ameisenfauna (Schluss)." Zool. Jahrb. (System.), Vol. VIII. (earlier part in Vol. VII.), pp. 633-682. 1893.

Enderlein, Günther. "Die biologische Bedeutung d. Antarktis \& ihrer Faunengebiete, mit besond. Berücksichtigung d. Insektenwelt." Deutsche Südpolar Exped., Vol. X., (Zool. Vol. II.), pp. 323 $-360.1909$.

Engelhardt, H. “Úber Tertiärpflanzen von Chile." Abh. Senekenb. Naturf. Gesellsch." Vol. XVI., pp. 629-692. 1891.

ENGLeR, A. “Versuch einer Entwicklungsgeschichte d. extratrop. Florengebiete d. nördl. Hemisphäre." Vol. I. Leipzig, 1879. Do. “d. südl. Hemisphäre,” Vol. II. Leipzig, 1882.

Engler, A. "Über floristische Verwandtschaft zwischen dem tropisch. Afrika und Amerika, sowie über die Annahme eines versunkenen brasilianisch-äthiopischen Continents." Sitz. d. preuss. Akad. d. Wissensch. (Phys. Math. Cl.), Vol. VI., pp. 180-231. 1905 .

Evermann, B. W. "List of Species of Fishes known to occur in the Great Lakes or their Connecting Waters.". Bull. U.S. Fish Comm., pp. 95-96. 1901.

Evermann, B. W. and W. C. Kendall. "An Annotated List of the Fishes known to occur in the St. Lawrence River." Report of the Commissioner U.S. Comm. of Fish and Fisheries, Part 27, pp. 227240. 1902.

Evermann, B. W., Barton Warren, 'and E. L. Goldsborough. "A Check List of the Freshwater Fishes of Canada." Proc. Biol. Soc. Washington, Vol. XX., pp. 89-120. 1907.

Faxon, W. "A Revision of the Astacidae." Memoirs Mus. Comp. Zoology, Harvard, Vol. X. 1885.

Feilden, H. W. "Notes on the Glacial Geology of Arctic Europe and its Islands." Quart. Journ. Geol. Soc., Vol. LII., pp. 52-65. 1896.

Feilden, H. W. and C. E. DE Rance. "Geology of the Coasts of the Arctic Lands." Quart. Journ. 'Geol. Soc. London, Vol. XXXIV., pp. 556-567. 1878.

Flower, W. H. and R. LYDEKKER. "An Introduction to the Study of Mammals." London, 1891.

Forbes, H. O. "The Chatham Islands: Their Relation to a former Southern Continent." R. Geogr. Soc. (Suppl. Papers), Vol. III., pp. 1-33. 1893.

Frazer, Persifor. "History of the Caribbean Islands from a 
Petrographic Point of View." Proc. 'Acad. Nat. Sc. Philad., Vol. LV., pp. 396-400. 1903.

GADOW, Hans. "Amphibia and Reptiles." Cambridge Natural History, Vol. VIII. London, 1901.

GaDow, HaNS. "The Distribution of Mexican Amphibians and Reptiles." Proc. Zool. Soc. London, Vol. II., pp. 191-244. 1905. Gardiner, F. "Coleoptera of the White Mountains." Psyche, Vol. II., pp. 211-213. 1879.

Garman, H. "On the Origin of the Cave Fauna of Kentucky." Science, Vol. XX., pp. 240-241. 1892.

Garman, S. "The Reptiles of Bermuda." Ex. Contributions to the Natural History of the Bermudas. Bull. U.S. Nat. Museum, No. 25, pp. 285-303. 1884.

Garman, S. "The Reptiles of the Galapagos Islands." Bull. Essex. Institute, Vol. XXIV., pp. 73-87. 1892.

Gaudry, Albert. "Fossiles de Patagonie." Annales de Paléontologie, Vol. I., pp. 1-42. 1906.

GEIKIE, A. "Text-book of Geology." 1882.

GeIKIE, James. "The Great Ice Age" (3rd ed.). London, 1894.

Gidley, J. W. "Tooth Characters and Revision of the North American Species of the Genus Equus." Bull. Amer. Mus. Nat. Hist., Vol. XIV., pp. 91-142. 1901.

Gidley, J. W. "Revision of the Miocene and Pliocene Horses of North America." Bull. Amer. Mus. Nat. Hist., Vol. XXIII., pp. 865 -934. 1907.

Gidley, J. W. "Fossil Raccoon from a California Pleistocene Cave deposit.” Proc. U.S. Nat. Mus., Vol. XXIX., pp. 553-554. 1906.

Gidley, J. W. "Description of Two New Species of Pleistocene Ruminants of the Genera Ovibos and Boötherium." Proc. U.S. Nat. Mus., Vol. XXXIV., pp. 681-684. 1908.

GrLL, T. "The Principles of Zoogeography." Proc. Biol. Soc. Washington, Vol. II., pp. 1-39. 1884.

GILL, T. "The Origin and Relations of the Floras and Faunas of the Antarctic and adjacent Regions. Vertebrata of the Land, Fishes, Batrachia and Reptiles." Science (N.S.), Vol. III., pp. 314 -317. 1896.

GiLl, T. "A Remarkable Genus of Fishes-the Umbras." Smithsonian Miscell. Coll., Vol. XLV., pp. 295-305. 1904.

Gill, T. and J. F. Bransford. "Synopsis of the Fishes of Lake Nicaragua." Proc. Acad. Nat. Science Philad., pp. 175-191. 1877.

Gilmore, C. W. "Smithsonian Exploration of Alaska in 1907 in Search of Pleistocene Fossil Vertebrates." Smithsonian Miscell. Coll., Vol. LI., pp. 1-38. 1908.

Girard, M. “Note sur l'Entomologie de l'Amérique du Nord, considerée spécialement au point de vue des éspèces identiques et analogues à celles d'Europe." Ann. Soc. Ent. de France (4), Vol. VIII., pp. 287-296. 1868. 
Goodrrch, E. S. "Cyclostomes and Fishes." Treatise on Zoology by Ray Lankester, Part IX. 1909.

Gould, Augustus. "Remarks on Mollusks and Shells" (Ex. U.S. Explor. Exped., Vol. XII.). Edin. New Phil. Journ., Vol. LVI., pp. $74-80.1854$.

GrabaU, A. W. "Guide to the Geology and Palaeontology of the Niagara Falls and Vicinity." Bull. Buffalo Soc. Nat. Sc., Vol. VII., pp. 1-284. 1901.

Granger, Walter. "A Revision of the American Eocene Horses." Bull. Amer. Mus. Nat. Hist., Vol. XXIV., pp. 221-264. 1908.

Granger, Walter. "Tertiary Faunal Horizons in the Wind River Basin, Wyoming, with Descriptions of New Eocene Mammals." Bull. Amer. Mus. Nat. Hist., Vol. XXVIII., pp. 235-251. 1910.

Grant, Madison. "The Caribou." 7th Ann. Report New York. Zool. Soc., pp. 1-24. 1902.

Grant, Madison. "The Moose." 7th Report Forest, Fish and Game Comm., State of New York, pp. 225-238. 1903.

Grant, Madison. "The Origin and Relationship of the Large Mammals of North America." 8th Ann. Report Now York Zool. Soc., pp. 1-30. 1904.

Grant, Madison. "The Rocky Mountain Goat." 9th Ann. Report New York Zool. Soc., pp. 6-36. 1905.

Gray, Asa. "Observations upon the Relations of the Japanese Flora to that of North America and other parts of the North Temperate Zone." Mem. Amer. Acad. Science, Vol. VI. 1859.

Gray, Asa. "Sequoia and its 'History." Scientific Papers of Asa Gray, Vol. II., pp. 142-164. 1889.

Grax, Asa and JosepH Hooker. "Die Vegetation des Rocky Mountain Gebietes, \& ein Vergleich derselben mit der anderer Welttheile." Engler's Botanische Jahrbücher, Vol. II., pp. 256-296. 1882.

Greene, Edward LeE. " Nates on the Botany of Sta. Cruz Island." Bull. Cal. Acad. Sciences, Vol. II., pp. 377-418. 1887.

Gregory, J. W. "The Relations of the American and European Echinoid Faunas.” Bull. Geol. Soc. America, Vol. III., pp. 101108. 1891.

Gregory, J. W. "Contribution to the Palaeontology and Physical Geology of the West Indies." Quart. Journ. Geol. Soc., Vol. LI., pp. 255-312. 1895.

GRENFELL, WILFReD T. and others. "Labrador, the Country and the People." New York, 1910.

Grosse, Franz. "Die Verbreitung d. Vegetationsformationen Amerikas im Zusammenhang mit den Klimatischen Verhältnissen." Jahresber d. Achten Realschule zu Berlin, pp. 1-26. 1899.

Grote, A. R. "The Effect of the Glacial Epoch upon the Distribution of Insects in North America." Ann. and Mag. Nat. Hist. (4), XVI., pp. 440-442. 1875.

Grote, A. R. "On the Allied Species of Nootuidae inhabiting 
Europe and North America." Buffalo Soc. Nat. Sc., Vol. II., Part II. and Part IV. 1875.

GüNther, A. "Deseription of the Living and Extinct Races of Gigantic Land-Tortoises." Phil. Trans. Royal Soc., Vol. CLXV., pp. 251-284. 1876.

Günther, A. "Account of the Zoological Collections made during the Visit of H. M. S. Petrel to the Galapagos Islands." Proc. Zool. Soc. London, pp. 64-93. 1877.

GÜNTHER, A. "An Introduction to the Study of Fishes." Edinburgh, 1880 .

GÜNTHER, A. and E. SMith, and others. "Report on a Collection made by T. Conry in Ascension Island." Ann. and Mag. of Nat. Hist. (5), Vol. VIII., pp. 430-440. 1881.

Gulick, Addison. "The Fossil Landshells of Bermuda." Proc. Acad. Nat. Sc. Philadelphia, Vol. LVI., pp. 406-425. 1904.

Guppy, H. B. "Observations of a Naturalist in the Pacific between 1886-1899." 2 vols. London, 1903-1906.

Guppy, R. J. L. "Notes on West Indian Geology, with Remarks on the Existence of an Atlantis in the Early Tertiary Period, and Descriptions of some New Fossils from the Caribbean Miocene." Geological Magazine, pp. 496-501. 1867.

Guppy, R. J. L. "The Geological Connexions of the Caribbean Region." Trans. Canadian Institute, Vol. 'VIII., pp. 373-391. 1909.

HaACKe, W. "Der Nordpol als Schöpfungszentrum der Landfauna." Biol. Centralblatt, Vol. VI., pp. 363-370. 1887.

HaAcke, W. and W. Kuhnert. "Das Thierleben der Erde." 3 vols. Berlin, 1901.

HaCKeL, E. "Über die Beziehungen der Flora der Magellansländer zu jener d. nördl. Europa und Amerika." Mitteil. naturw. Verein Steiermark (Botan. Sekt.), pp. cx.-cxv. 1905 (1906).

Hamilton, John. "Catalogue of the Coleoptera Common to North America, Northern Asia and Europe" (2nd ed.). Trans. Amer. Entom. Soc., Vol. XXI., pp. 345-416. 1894.

Handlirsch, Anton. "Die fossilen Insekten und die Phylogenie der rezenten Formen." Wien, 1906.

Handlirsch, Anton. "Über Relikte." Verhandl. K. K. Zool. Bot. Gesell. Wien., pp. 183-207. 1909.

Handlirsch, Anton. "Die Bedeutung d. fossilen Insekten f. d. Geologie." Mitt. d. Geologisch. Gesell. Wien., pp. 503-522. 1910.

Hansen, H. J. " On six species of Koenenia, with remarks on the order Palpigradi." Entomol. Tidskrift., Vol. XXII., pp. 193-240. 1901.

Harrison, Alfred H. " In Search of a Polar Continent." London, 1908.

Harshberger, J. W. "The Comparative Age of the different Floristic Elements of eastern North America." Proc. Ac. Nat. Sc. Philadelphia. Vol. LVI., pp. 601-615. 1904. 
HARshberger, J. W. "The Plant Formations of the Bermuda Islands." Proc. Acad. Nat. Sc. Philadelphia, Vol. LVII., pp. 695704. 1905.

Harshberger, J. W. "Original Centers Concerned in North American Plant Distribution." Proc. Acad. Nat. Sc. Philadelphia, p. 2. 1905 .

Hart, Henry Chichester. "On the Botany of the British Polar Expedition 1875-1876." Journal of Botany, pp. 1-43. 1880.

Hartert, ERnst. "Trochilidae." Tierreich. 9th Lief. Berlin, 1900.

HaUg, E. "Les géosynclinaux et les Aires Continentales." Bull. Soc. Geol. France (3), Vol. XXVIII., pp. 617-711. 1900.

$\mathrm{H}_{\mathrm{AY}}, \mathrm{O}$. P. "Bibliography and Catalogue of the Fossil Vertebrata of North America." Bull. U. S. Geol. Survey, No. 179. 1902.

HaY, O. P. "The Fossil Turtles of North America." Carnegie Institution, Washington D.C. 1908.

HaY, O. P. "The Geological and Geographical Distribution of some Pleistocene Mammals." Science (N.S.), Vol. XXX., pp. 890893. 1909.

HaY, O. P. "On the Changes of Climate following the Disappearance of the Wisconsin Ice-sheet." From "Die Veränderungen des Klimas seit der letzten Eiszeit," pp. 371-374. Stockholm, 1910.

Hayes, C. W. and M. R. Campbell. "The Relation of Biology to Physiography." Science (N.S.), Vol. XII., pp. 131-133. 1900.

HeDLEy, C. "The Range of Placostylus, a Study in Ancient Geography." Proc. Linn. Soc. New South Wales (2), Vol. VII. 1892.

HeDLey, C. "Considerations on the Surviving Refugees in Austral Lands of Ancient Antarctic Life." Proc. R. Soc. New South Wales, Vol. XXIX., pp. 278-286. 1895.

HeDley, C. "A Zoogeographical Scheme for the Mid-Pacific" Proc. Linn. Soc. New South Wales, pp. 391-417. 1899.

HeILPRIN, A. "The Geographical and Geological Distribution of Animals." London, 1887.

HeIlprin, A. "Explorations on the West Coast of Florida." Trans. Wagner Free Institute of Science, Philadelphia, Vol. I. 1887.

HeIlprin, A. "The Bermuda Islands." Philadelphia, 1889.

HeILPRIN, A. "The Origin and Relations of the Floras and Faunas of the Antarctic and adjacent Regions." Science (N.S.), Vol. III., pp. $305-320.1896$.

Heli.er, Edmund. "Papers from the Hopkins Stanford Galapagos Expedition, 1898-1899. Reptiles." Proc. Washington Acad. Science, Vol. V., pp. 39-98. 1903.

HelLer, E. "Mammals of the Galapagos Archipelago." Proo. Calif. Acad. Sc. (3), Vol. III., pp. 233-250. 1904.

Hemsley, W. B. "Botany of Mexico and Central America." Vol. IV. Biologia Centrali-Americana. London, 1886-1888. 
Hemsley, W. B. "Insular Floras.” Science Progress, Vol. V., pp. 286-303, VI. (A), pp. 374-383, VI. (B.). 1896.

HeRshey, O. H. "The Geology of the Central Portion of the Isthmus of Panama." Bull. Dep. Geology, Univ. California, Vol. II., pp. 231-267. 1901.

Heyden, L. von, E. Reitter und J. Weise. "Catalogus Coleopterorum Europae." Editio secunda. Paskau, 1906.

Heynemann, D. F. "Die Geographische Verbreitung der Nacktschnecken." Abh. Senckenb. Naturf. Gesellsch., Frankfurt, Vol. XXX. 1905.

Hill, R. T. "The Geological 'History of the Isthmus of Panama and portions of Costa Rica." Bull. Mus. Comp. Zoology, Harvard, Vol. XXVIII., pp. 151-285. 1898.

Hill, R. T. "The Geology and Physical Geography of Jamaica, Study of a Type of Antillean Development." Bull. Mus. Comp. Zoology, Harvard, Vol. XXXIV., pp. 1-256. 1899.

Hinton, Martin A. C. "On the Fossil Hare of the Ossiferous Fissures of Ightham, Kent, and on the recent Hares of the Lepus variabilis Group." Sc. Proc. Royal Dublin Soc., Vol. XII. (N.S.), pp. 225-265. 1909 .

Hгтснсоск, С. H. "Remarks upon the Distribution of Animals and Plants in New Hampshire, forming Chapt. 17 of Hitchcock and Huntingdon's Geology of New Hampshire." Vol. I. 1874.

HoldHaus, K. "Biogeographische Argumente für die Existenz eines pazifischen Kontinents." Verh. K. K. Zool.-Bot. Gesellsch. Wien, pp. 258-260. 1907.

Hollick. Arthur. "Plant Distribution as 'a Factor in the Interpretation of Geological Phenomena with Special Reference to Long Island." Trans. N. York Acad. Sc., Vol. XII., pp. 189-202. 1893.

Hollister, N. "A systematic Synopsis of the Muskrats." North American Fauna No. 32 (U. S. Department of Agriculture, Biological Survey). 1911.

Hooker, J. D. "Outlines of the Distribution of Arctic Plants." Trans. Linnean Soc. London., Vol. XXIII., pp. 251-348. 1860.

Hooker, J. D. "The Distribution of the North American Flora." Proc. R. Institution of Great Britain, London, pp. 568-580. 1878.

Hornaday, W. T. "The Extermination of the American Bison, with a Sketch of its Discovery and Life History." Ann. Rep. Smithson. Inst., pp. 367-548. 1887.

Hornaday, W. T. "Notes on the Mountain Sheep of North America." 5th Ann. Rep. New York Zool. Soc., pp. 77-122. 1901.

HorvítH, G. "Les relations entre les faunes hémipterologiques de l'Europe et de l'Amérique du Nord." Annales Historico-Naturales Musei Nationalis Hungarici, Vol. VI., pp. 1-14. 1908.

How ARD, L. O. "The Agency of Man in the Distribution of Species." Science (N.S.), Vol. VI., pp. 382-398. 1897.

HowortH, H. H. "The Mammoth and the Flood." London, 1887. 
HowoRtH, H. H. "Did the Mammoth Live before, during, or after the Deposition of the Drift?" Geological Mag. (Dec. III.), Vol. IX., pp. 250-267. 1892.

HoworTH, H. H. “Ice or Water ?” 2 Vols. London, 1905.

Hudson, W. H. “The Naturalist in La Plata." London, 1892.

HuLL, E. "Submerged Terraces and River Valleys Bordering the British Isles." Trans. Victoria Institute, Vol. XXX. 1897.

Hutton, F. W. "On the Origin of the Fauna and Flora of New Zealand." Ann. Nat. Hist. (5), Vol. XIII., pp. 425-448. 1884.

Hutton, F. W. "The Origin of the Fauna and Flora of New Zealand" (Part II.), Ann. and Mag. Nat. Hist. (5), Vol. XV., pp. 77-107. 1885.

Hutron, F. W. “Ancient Antarctica." Nature, Vol. LXXII., pp. $244-245.1905$.

Ihering, H. von. "Die Geograph. Verbreitung d. Ampullarien im Südlichen Brasilien." Nachrichtsbl. d. Deutsch. Malak. Gesell., 23 Jahrg., pp. 93-109. 1891.

IHERING, H. voN. "Die Insel Fernando de Noronha." Globus., Vol. LXII., pp. 1-6. 1891.

IHERING, H. von. " On the Ancient Relations between New Zealand and South America." Trans. New Zealand Inst., Vol. XXIV., pp. 431 $-445.1891$.

IHERING, H. von. "Anodonta und Glabaris (a study in Ancient Geography." Zool. Anzeiger., Vol. XIV., pp. 474-484, and Vol. XV., pp. 1-5. 1891-1892.

IHERING, H. voN. "Das Neotropische Florengebiet und seine Geschichte." Engler's Botan. Jahrbücher., Vol. XVII., pp. 1-54. 1893.

IHERING, H. von. "Najaden von S. Paulo und die Geograph. Verbreitung d. Süsswasserfaunen von Süd-Amerika." Archiv f. Naturgesch., pp. 45-140. 1893.

Ihering, H. von. "Les Mollusques Fossiles du Tertiaire et du Crétacé Supérieur de l'Argentine." Anales del Museo Nacional de Buenos Aires, Vol. XIV., pp. 1-611. 1907.

Ihering, H. von. "Archhelenis und Archinotis." Leipzig, 1907.

IHERING, H. voN. "Die Entstehungsgeschichte der Fauna der Neotropischen Region." Verh. K. K. Zool.-Botanisch. Gesellsch. Wien, pp. 282-302. 1908.

IhERING, H. von. " System und Verbreitung der Heliciden." Verh. K. K. Zool.-Botanisch. Gesellsch. Wien, pp. 420-455. 1909.

IHERING, H. von. "Systematik, Verbreitung und Geschichte d. Südamerikanischen Raubtiere." Arch. f. Naturgesch. 76 Jahrg., Vol. I., pp. 113-179. 1910.

JACOBI, A. "Lage und Form biogeograph. Gebiete." Zeitschr. d. Gesellsch. f. Erdkunde zu Berlin, Vol. XXXV., pp. 147-238. 1900 .

JoHansen, A. C. "On the Hypotheses of the Sinking of Sea-beds, based on the occurrence of dead Shallow-water Shells at great 
Depths in the Sea." Videnskab. Meddelelser Nat. Foren. Kjфbenhavn, pp. 393-435. 1902.

Johnson, Charles W. "On the Distribution of Helix hortensis in North America." Nautilus, Vol. XX., pp. 73-80. 1906.

JoLY, J. "Radioactivity and Geology" London, 1909.

Jones, J. M. "Recent Observations in the Bermudas." Nature, Vol. VI., p. 262. 1872.

Jordan, D. S. "Guide to the Study of Fishes." 2 Vols. Westminster, 1905.

Jordan, D. S. and B. W. Evermann. "The Fishes of North and Middle America." Bull. U. S. Nat. Mus. No. 47 (4 parts). 18961900.

Junk, W. and S. Schenkling. "Coleopterorum Catalogus." Berlin, 1910-1911.

Karsch, F. Über Cryptostemma, Guér. als einzigen recenten Ausläufer d. fossilen Arachnoideen-Ordnung d. Meridogastra." Berlin. Ent. Zeitschr., Vol. XXXVII., pp. 25-32, und 64. 1893.

Karsch, F. "Neue Fundorte für Japyx." Berlin. Ent. Zeitschr., Vol. XXXI., p. 154.

Katzer, F. "Grundzüge der Geologie des unteren Amazonengebietes.” Leipzig, 1903.

Kennard, A. S. and B. B. Woodward. “The extinct Postpliocene Non-marine Mollusca of the South of England." South-Eastiern Naturalist, pp. 1-11. 1905.

Kirby, W. F. “A Synonymic Catalogue of Orthoptera." 3 vols. London, 1904-1910.

KnopF, AD. “The probable Tertiary Land Connection between Asia and North America." Bull. Dept. of Geology. Univ. California, Vol. V., pp. 413-420. 1910.

KoвeLt, W. "Das Verhältniss d. Europäischen Land-Molluskenfauna zur Westindisch-Centralamerikanischen." Nachrichtsbl. d.d. Malakoz. Gesellsch., Vol. XIX., pp. 145-148. 1887.

KовеLт, W. "Die zoogeograph. Stellung d. Insel St. Helena." Geograph. Zeitschr., Vol. II., pp. 199-203. 1896.

Kobelt, W. "Cyclophoridae" (ex. Tierreich). 'Berlin, 1902.

Koken, ERnst. "Die Vorwelt und ihre Entwicklungsgeschichte." Leipzig, 1893.

Kolbe, H. J. “Zoogeographische Elemente in der Fauna Madagaskar's." Sitzungsber. Gesell. naturf. Freunde. Berlin, pp. 147181. 1887.

Kolbe, H. J. “ "Die geographische Verbreitung der Neuroptera und Pseudoneuroptera der Antillen." Arch. f. Naturgesch. Jahrg. 54, pp. 153-176. 1888.

KolBE, H. J. " U̇ber die Lebensweise und die geogr. Verbreitung d. coprophagen Lamellicornier." Zool. Jahrb. System. Suppl. 8, pp. 475-594. 1905.

KoLBE, H. J. "Coleopteren (Hamburger Magalhaensische Sammelreise)." Hamburg, 1907. 
Kolbe, H. "Die Südpolarkontinenttheorie nebst Bemerkungen über tiergeographische Verhältnisse a. d. Südhemisphäre." Naturwiss. Wochenschrift (N. F.) Vol. VIII. 1909.

KowarziK, Rudolf. "Der Moschusochs und seine Rassen." Fauna Aretica, Vol. V., pp. 89-126. 1909.

Kraepelin, Karl. “Scorpiones et Pedipalpi." (Tierreich Iief. 8). Berlin, 1899.

Kraepelin, K. "Revision der Scolopendriden." Mitt. aus d. Naturhist. Museum in Hamburg, Jahrg. XX., pp. 1-276. 1903.

Kraepelin, K. "Die geographische Verbreitung der Scolopendriden." Zool. Jahrbücher. Suppl., Vol. VIII. (Festschrift Möbius), pp. 167-194. 1905.

Krishtafovitch, N. J. "Sur la dernière Période Glaciaire en Europe et dans l'Amérique du Nord, en rapport avec la question de la cause des Périodes Glaciaires en général." Bull. Soc. Belge de Géologie, Vol. XXIV., pp. 292-305. 1910.

LAMPLUGH, G. W. "On British Drifts and the Interglacial Problem" (Address to the Geological Section). British Association, York. Reprint 1906.

LANKester, E. RaY. "Extinct Animals." London, 1905.

Lapparent, A. DE. Traité de Géologie " (4th ed.). Paris.

LeChe, Wilhelm. "Zur Entwicklungsgeschichte d. Zahnsystems d. Säugetiere. II. Teil Die Familien d. Centetidae, Solenodontidae \& Chrysochloridae." Zoologica (49), Vol. XX. 1907.

Lecoq, H. "Des Glaciers et des Climats." Paris, 1847.

Lethierry, L. and G. Severin. "Catalogue général des Hémiptères." 3 vols. Bruxelles, 1893-1896.

LINELL, M. L. "On the Coleopterous Insects of the Galapagos Islands." Proc. U.S. National Mus., Vol. XXI., pp. 249-268. 1898.

Lobley, J. Logan. "The American Fauna and its Origin." Trans. Victoria Institute, Reprint. 1908.

Lönnberg, E. "Taxonomic Notes about Palaearctic Reindeer." Arkiv fôr Zoologi, Upsala \& Stockholm., Vol. VI., pp. 1-18. 1909.

Lovén, S. L. "UUber einige Crustaceen." Zeitschrift f. Naturwissenschaft, Halle, Vol. XIX., pp. 34-68. 1862.

LUCAS, F. "The Fossil Bison of North America." Proc. U.S. Nat. Mus., Vol. XXI., pp. 755-771. 1899.

Lucas, F., TH. GILL and others. "Discussion of the Question on former Land Connections between Asia and North America." Science (N.S.), Vol. XIII., pp. 307-308. 1901.

LydekKer, R. "Catalogue of the Fossil Mammalia in the British Museum." (Nat. Hist.), 5 parts. London, 1885-1887.

LydeKKer, R. "A Geographical History of Mammals." Cambridge, 1896.

LYDEKKER, R. "The Deer of all Lands, a Natural History of the Cervidae." London, 1898.

LyDEKKer, R. “Wild Oxen, Sheep and Goats of all Lands, Living and Extinct," London, 1899. 
Lyon, Marcus WARD. "Classification of the Hares, and their Allies." Smithson, Miscell. Coll., Vol. XLV., pp. 321-447. 1903.

MacFarlane, R. "Notes on Mammals collected and observed in northern Mackenzie river district, north-west territories of Canada, with remarks on explorers and explorations of the far north." Proc.

U. S. National Museum., Vol. XXVIII., pp. 673-764. 1905.

McLaCHLAN, R. "On some peculiar points in the Insect Fauna of Chile.” Nature, Vol. XVII., p. 162 and p. 260. 1878.

Macloskie, George. "Character and Origin of the Patagonian Flora." Rep. Princeton Expedition to Southern Patagonia, Vol. VIII., Part II., pp. 945-960. 1903-1906.

MadDren, A. G. "Smithsonian Exploration in Alaska in 1904, in search of Mammoth and other Fossil Remains." Smithson. Miscell. Coll., Vol. XLIX., pp. 1-117. 1905.

Major, C. I. Forsyth. "On fossil and recent Lagomorpha." Trans. Linnean Soc. (2) Zool., Vol. VII., pp. 433-520. 1898.

Marsh. O. C. "Introduction and Succession of Vertebrate Life in America." 1877.

Martens, E. von. “Mollusca Centrali-Americana." London, 1890 $-1901$.

Marx, George. "A contribution to the knowledge of the Spider Fauna of the Bermuda Islands." ' Proc. Acad. Sc. Philad., pp. 98101.1889.

Matthew, W. D. “A Horned Rodent from the Colorado Miocene, with a revision of the Mylagauli, Beavers and Hares of the American Tertiary." Bull. Amer. Mus. Nat. Hist., Vol. XVI., pp. 291-310. 1902.

Matthew, W. D. "Fossil Chrysochloridae in North America." Science (N.S.), Vol. XXIV., pp. 786-788. 1906.

Matтhew, W. D. "Hypothetical Outlines of the Continents in Tertiary Times.” Bull. Amer. Mus. Nat. Hist., Vol. XXII., pp. 353 -383. 1906.

Matthew, W. D. "A Lower Miocene Fauna from South Dakota." Bull. Amer. Mus. Nat. Hist., Vol. XXIII., pp. 169-219. 1907.

Matthew, W. D. "Osteology of Blastomeryx and Phylogeny of the American Cervidae." Bull. Amer. Mus. Nat. Hist., Vol. XXIV., pp. 535-562. 1908.

Matthew, W. D. "The Carnivora and Insectivora of the Bridger Basin, Middle Eocene." Memoirs Amer. Mus. Nat. Hist., Vol. IX., pp. 291-567. 1909.

Matтhew, W. D. "On the Skull of Apternodus and the Skeleton of a new Artiodactyl." Bủll. Amer. Mus. Nat. Hist., Vol. XXVIII., pp. 33-42. 1910.

MátThew, W. D. "On the osteology and relationship of Paramys, and the affinities of the Ischyromyidae." Bull. Amer. Mus. Nat. Hist., Vol. XXVIII., pp. 43-71. 1910.

Matthew, W. D. and H. J. Coок. "A Pliocene Fauna from W. Nebraska." Bull. Amer. Mus. Nat. Hist., Vol. XXVI., pp. 361-414. 1909. 
MeEK, S. E. "Distribution of the Freshwater Fishes of Mexico." Amer. Naturalist, Vol. XXXVII., pp. 771-784. 1903.

Meek, S. E. "Synopsis of the Fishes of the Great Lakes of Nicaragua." Field Columbian Museum (Zool.), Vol. VII., pp. 97132. 1907.

Merian, P. “Die Bedeutung d. Araneen für die Tiergeographie." Zürich, 1910.

MerRIaM, C. H. “The Geographical Distribution of Life in North America." Proc. Biol. Soc. Washington, Vol. VII., pp. 1-64. 1892.

Merriam, C. H. "Revision of the Lemmings of the Genus Synaptomys.” Proc. Biol. Soc. Washington, Vol. X., pp. 55-64. 1896.

Merriam, C. H. "Revision of the Coyotes, or Prairie Wolves." Proc. Biol. Soc. Washington, Vol. XI., pp. 19-33. 1897.

Merriam, C. H. "The Prairie Dog of the Great Plains." Year Book Dept. Agriculture, pp. 257-264. 1901.

MerRiam, JoHn C. "The occurrence of Strepsicerine Antelopes in the Tertiary of North-Western Nevada." Bull. Dept. Geology. Univ. California., Vol. V., pp. 319-330. 1909.

Merrill, G. P. "On the Geology and Natural History of the Peninsula of Lower California." Rep. U.S. National Mus., pp. 969 -994. 1895.

Michaelsen, W. "Die Lumbriciden-fauna Nord Amerikas." Abh. d. Naturw. Ver. Hamburg. (Reprint), Vol. XVI. 1900.

Michaelsen, W. "Die Geographisohe Verbreitung der Oligochaeten." Berlin, 1903.

Miller, G. S. "On a collection of Small Mammals from the New Hampshire Mountains." Proc. Boston Nat. Hist. Soc., Vol. XXVI.. pp. 177-197. 1895.

Mili.er, G. S. "Key to the Land Mammals of North-Eastern North America." Bull. New York State Museum, Vol. VIII., pp. 59 $-160.1900$.

Miller, Loye Holmes. Pavo calífornicus, a Fossil Peacock from the Quaternary Asphalt Beds of Rancho la Brea." Bull. Dept. Geology. Univ. California, Vol. V., pp. 285-289. 1909.

Milne-Edwards, A. "Sur les ressemblances qui existent entre la faune des îles Mascareignes, et celles de certaines îles de l'Océan pacifique austral." Ann. d. Sc. Nat. Zool. (8), Vol. II., pp. 117136.1896.

Mörch, O. A. L. "On the Land and Freshwater Mollusca of Greenland." American Journal of Conchology, pp. 24-46.

Moreno, F. P. and A. Smith Woodward. "On a portion of Mammalian Skin, named Neomylodon listai from a Cavern near Consuelo Cove, Patagonia." Proc. Zool. Soc. London, Vol. I., pp. 144 -156. 1899.

MöschleR, H. B. “Die Nordamerika und Europa gemeinsam angehörigen Lepidopteren." Verh. K. K. Zool.-Bot. Ges. Wien, pp. 273 $-320.1884$. 
Monse, E. S. “The Gradual Dispersion of certain Mollusks in New England.” Bull. Essex Inst., Vol. XII., pp. 171-176. 1880.

Murray, A. "On the Geographical Relations of the Coleoptera of Old Calabar." Trans. Linn. Soc., Vol. XXIII., pp. 449-455. 1862 .

Murray, A. "The Geographical Distribution of Mammals." London, 1866.

Murray, A. "On the Geographical Relations of the Chief Coleopterous Faunae.” Proc. Linn. Soc. (Zool.), Vol. XI., pp. 1-89. 1870.

Nansen, F. "The bathymetrioal features of the North Polar Seas, with a discussion of the Continental Shelves, and previous oscillations of the Shore-line." Norwegian North Polar Expedition, Vol. IV., pp. 1-231. 1904.

Nathorst, A. G. "Beiträge d. Polarforschung zur Pflanzengeographie d. Vorzeit in 'Nordenskiöld's Studien \& Forschungen.'" pp. 221-288. Leipzig, 1885.

Nathorst, A. G. "Kritische Bemerkungen über d. Geschichte d. Vegetation Grönland's." Engler's Botanische Jahrbücher., Vol. XIV., pp. 183-220. 1892.

Nehring, A. "Über Tundren \& Steppen d. Jetzt \& Vorzeit (mit besonderer Berücksichtigung ihrer Fauna)." Berlin, 1890.

NeLson, E. W. "The Rabbits of North America" (North American Fauna No. 29). U.S. Dept. of Agriculture, Washington. 1909.

Nelson, E. W., L. Stejneger, etc. " Natural History of the Tres Marias Islands, Mexico." U.S. Dept. of Agriculture (Division of Biological Survey). North American Fauna No. 14. 1899.

NewTon, E. T. "Notes on Fossils from the Falkland Islands brought home by the Scottish Antarctic Expedition in 1904." Proc. R. Phys. Soc. Edinburgh, Vol. XVI., pp. 248-257. 1906.

Nordenskiöld, A. E. von. "Studien \& Forschungen veranlasst durch meine Reisen im hohen Norden." Leipzig, 1885.

NordenskröLd, E. "Über die Säugetierfossilien des Tarija Tals, Südamerika. 1. Mastodon andium." K. Svenska Vetensk-akad. Handlinger. Vol. XXXVII., pp. 1-30. 1902-1903.

Ortmann, A. E. "The Theories of the Origin of the Antarctic Faunas and Floras." American Naturalist, Vol. XXXV., pp. 139142. 1901.

Ortmann, A. E. “Tertiary Invertebrates." Reports of the Princeton University Expedition to South Patagonia, Vol. IV., Part II., pp. 45-332. 1902.

Ortmann, A. E. "The Geographical Distribution of Freshwater Decapods, and its bearing upon Ancient Geography." Proc. Amer. Philos. Soc., Vol. XLI., pp. 267-400. 1902.

Ortmann, A. E. "The Mutual Affinities of the Species of the Genus Cambarus, and their Dispersal over the United States." Proc. Amer. Philos. Soc., Vol. XLIV., pp. 91-136. 1905.

Ortmann, A. E. "Tertiary Archhelenis." American Naturalist., Vol. XLIV., pp. 237-242. 1910. 
Ortmann, A. E. "A Monograph of the Najades of Pennsylvania." Memoir Carnegie Museum, Vol. IV., pp. 279-347. 1911.

Osborn, H. F. "The Rise of the Mammalia in North America." Studies from the Biol. Labs. of Columbia Coll. (Zool.), Vol. I., pp. 1-45. 1893.

Osborn, H. F. "Faunal Relations of Europe and America during the Tertiary Period." Ann. N. York Acad. Sc., Vol. XIII., pp. 46 -56.1900 .

Osborn, H. F. "American Eocene Primates, and the supposed Rodent family. Mixodectidae." Bull. Amer. Mus. Nat. Hist., Vol. XVI., pp. 169-214. 1902.

Osborn, H. F. " An Armadillo from the Middle Eocene (Bridger) of North America." Bull. Amer. Mus. Nat. Hist., Vol. XX. 1904.

Osborn, H. F. "New Oligocene Horses." Bull. Amer. Mus. Nat. Hist., Vol. XX., pp. 167-179. 1904.

Osbonn, H. F. "Ten Years Progress in the Mammalian Palaeontology of North America." Extr. d. Comptes rendus du 6me Congr. Int. d. Zoologie de Berne. (1904.) 1905.

Osborn, H. F. "The Causes 'of Extinction of Mammalia." American Naturalist, Vol. XL., pp. 769-795 and 829-859. 1906.

Osborn, H. F. "Cenozoic Mammal Horizons of Western North America." Bull. U.S. Geological Survey No. 361. Appendix by W. D. Matthew. "Faunal Lists of the Tertiary Mammalia of the West." 1909.

Osborn, H. F. "The Age of Mammals in Europe, Asia and North America." New York, 1910.

OsGood, W. H. "Scaphoceros tyrelli, an extinct Ruminant from the Klondike Gravels." Smiths. Miscell. Collections, Vol. XLVIII., pp. 173-185. 1907.

Osgood, W. H. "A Revision of the Mice of the American Genus Peromyscus." North American Fauna No. 28, Washington, pp. 1285. 1909.

OsGood, W. H. "Biological Investigations in Alaska and Yukon Territory." North American Fauna No. 30, Washington, pp. 1-96. 1909.

PACKARD, A. S. “The Labrador Coast." New York, 1891.

PACKaRD, A. S. "The Origin of the Subterranean Fauna of North America." American Naturalist, Vol. XXVIII., pp. 727-751. 1894.

Packard, A. S. "On the Larval Forms of several Exotic Ceratocampid moths." Psyche, Vol. IX., pp. 279-280. 1901.

Pagensteaher, A. "Die Lepidopteren d. Nordpolargebietes." Jahrb. Nassau. Ver. f. Naturk., Vol. L. 1897.

Pagenstecher, A. "Die Lepidopteren d. Hochgebirges." Jahrb. Nassau. Ver. f. Naturk., Vol. LI., pp. 89-178. 1898.

Pagenstecher, A. "Die Lepidopteren-fauna der Antillen." Jahrb. Nassau. Ver. f. Naturk., Vol. LX., pp. 91-102. 1907.

Pagenstecher, A. "Die Geographische Verbreitung d. Schmetterlinge.". Jena, 1909. 
Paulcke, W. “Ủber die Kreideformation in Südamerika \& ihre Beziehungen zu anderen Gebieten." Neues Jahrb. Min. Geol. Pal. Beil., Vol. XVII., pp. 252-312. 1903.

Penhallow, D. P. "Contributions to the Pleistocene Flora of Canada.” Proc. \& Trans. R. Soc. Canada (II.), Vol. II., Section IV., pp. $59-77.1896$.

Penhallow, D. P. "Contributions to the Pleistocene Flora of Canada.” American Naturalist, Vol. XLI., pp. 443-452. 1907.

Peschel, O. "Neue Probleme der Vergleichenden Erdkunde." Leipzig, 1883.

Petersen, W. “Die Lepidopteren-fauna des arktischen Gebietes v. Europa, und die Eiøzeit." Beitr. z. Kenntniss d. russ. Reiches 3 Folge., Vol. IV., pp. 1-141, 1888.

Pfeffer, G. “Die zoogeographischen Beziehungen Südamerikas, betrachtet an den Klassen d. Reptilien, Amphibien und Fische." Zool. Jahrb. (System.) Suppl. VIII., Jena, pp. 407-442. 1905.

Pickard-Cambridge, O. "Notes on some Spiders and Scorpions from St. Helena.” Proc. Zool. Soc. London, pp. 531-544. 1869.

Pickard-Cambridge, O. "On the Spiders of St. Helena." Proc. Zool. Soc. London, pp. 210-227. 1873.

Pickard-Cambridge, O. "Arachnida Araneidea." Biologia Centrali-Americana. London, 1889-1900.

Pilsbry, H. A. "Nomenclature and Check-list of North American Land Shells.” Proc. Acad. Nat. Sc. Philadelphia, pp. 191-210. 1889.

Pilsbry, H. A. “Manual of Conchology (Tryon's) Pulmonata." Vol. IX. (Guide to the Study of Helices). 1894.

Pilsbry, H. A. “Bulimulidae.” In Manual of Conchology (Pulmonata), Vols. X-XIII. 1895-1900.

Pilsbry, H. A. " Phylogeny of the genera of Arionidae." Proc. Malac. Soc. London, Vol. III., pp. 94-104. 1898.

Pilsbry, H. A. "The Genesis of Mid-Pacific Faunas." Proc. Acad. Nat. Sc. Philadelphia, pp. 568-581. 1900.

Pilsbry, H. A. "Air Breathing Mollusks of the Bermudas." Trans. Connecticut Acad., Vol. X., pp. 491-509. 1900.

Prlsbry, H. A. "Geological and Zoogeographic Data bearing on Urocoptidae." Manual of Conchology (Pulmonata), Vol. XVI., pp. xx.-xxiv. 1904.

Pilsbry, H. A. "Origin of the Tropical Forms of the Land Molluscan Fauna of Southern Florida." Proc. Acad. Nat. Sc. Philadelphia, Vol. LIX., p. 193. 1907.

Pilsbry, H. A.' and J. H. Ferris. " Mollusca of the South-Western States." Proc. Acad. Sc. Philadelphia, Part I., Vol. LVII., pp. 211 -290 ; Part II., Vol. LVIII., pp. 123-175 ; Part III., Vol. LXI., pp. 495-516; Part IV., Vol. LXII., pp. 45-147, 1905-1910.

Pilsbry, H. A. and E. G. VanatTa. "Revision of the North American Slugs: Ariolimax and Aphallarion." Proc. Acad. Nat. Sc. Philadelphia, pp. $339-350 ., 1896$.

Pirie, J. H. Harvey. (Scottish Antarctic Expedition). "Deep- 
Sea Deposits of the South Atlantic Ocean and Weddell Sea." Scottish Geograph. Mag., pp. 1-5. 1905.

Pocock, R. I. "Report upon the Myriopoda of the Challenger Expedition, with remarks upon the Fauna of Bermuda." Ann. \& Mag. Nat. Hist. (6), Vol. XI., pp. 121-142. 1893.

Pocock, R. I. "Scorpions and their Geographical Distribution." Natural Science, Vol. IV., pp. 353-364. 1894.

Pocock, R. I. "The Geographical Distribution of the Arachnida of the Orders Pedipalpi and Solifugae." Natural Soience, pp. 213231. 1899.

Рососк, R. I. "On the Geographical Distribution of Spiders of the Order Mygalomorphae.” Proc. Zool. Soc. London, Vol. I., pp. 340 -368. 1903.

Poppius, B. “Die Coleopteren des Arktischen Gebietes.” Fauna Arctica, Vol. V., Part.I., pp. 291-447. 1910.

Pourtalès, L. F. DE. "Hints on the Origin of the Flora and Fauna of the Florida Keys." American Naturalist, Vol. XI., pp. 137 -144. 1877.

Preble, E. A. "Revision of the Jumping Mice of the Genus Zapus." North American Fauna No. 15, U.S. Dept. Agriculture, pp. 1-42. 1899.

Preble, E. A. "Biological Investigation of the Hudson Bay Region." U.S. Dept. of Agriculture, Division Biol. Survey. Washington. North American Fauna No. 22. 1902.

Preble, E. A. "A Biological Investigation of the AthabaskaMacKenzie Region.” North American Fauna No. 27. Washington, 1909.

Putnam, F. W. "Remarks on the Mammoth Cave and some of its Animals." Bull. Essex Institute, Vol. VI., pp. 191-200. 1874.

Quackenbush, L. S. "Notes on Alaskan Mammoth Expedition of 1907 and 1908." Bull. American Mus. of Nat. Hist., Vol. XXVI., pp. 87-130. 1909.

Rathbun, Mary J. "A Contribution to the Knowledge of the Freshwater Crabs of America. The Pseudothelphusinae." Proc. U.S. Nat. Mus., Vol. XXI., pp. 507-537. 1898.

Rathbun, Mary J. "Decapod Crustaceans of North-West Coast of North America." Harriman Alaska Expedition, Vol. X., pp. 1212. 1904.

Rathbun, Mary J. "The Stalk-eyed Crustacea of Peru and the Adjacent Coast." Proc. U.S. Nat. Mus., Vol. XXXVIII., pp. 531620. 1910 .

Regan, C. Tate. "Biologia Centrali-Americana. Pisces." Part CXCIX. 1906-1908.

Rehn, James A. G. "On the Orthoptera of Bermuda." Proc. Acad. Nat. Sc. Philadelphia, Vol. LXII., pp. 3-11. 1910.

ReHN, J. A. G. and M. Hebard. "A Contribution to the Knowledge of the Orthoptera of S. and C. Florida." Proc. Acad. Nat. Sc. Philadelphia, Vol. LVII., pp. 29-55. 1905. 
Reiche, Karl. "Grundzüge d. Pflanzenverbreitung in Chile." Vegetation d. Erde, Vol. VIII. 1907.

RHOADS, S. N. "Synopsis of the Polar Hares of North America." Proc. Acad. Nat. Sc. Philadelphia, pp. 351-376. 1896.

Rice, William North. "The Geology of Bermuda." Ex. Jones and Goode's Contrib. to the Nat. Hist. of the Bermudas. Bull. U.S. Nat. Museum, No. 25, pp. 1-32. 1884.

RICHARDSON, HaRRIET. "The Marine and Terrestrial Isopods of the Bermudas, with Description of new Genera and Species." Trans. Connecticut Acad., Vol. XI., Part I., pp. 277-310. 1901-1902.

RICHARDSON, HaRRIET. "Monograph on the Isopods of North America.” Bull. U.S. National Museum, No. 54. 1905.

Ridgway, R. "Birds of the Galapagos Archipelago." Proc. U.S. Nat. Mus., Vol. XIX., pp. 459-667. 1897.

Ridgway, R. "The Birds of North and Middle America." Bull. U.S. Nat. Museum, No. 50, 4 parts. 1901-1907.

Ridley, H. N. "Notes on the Zoology of Fernando Noronha." Journal Linnean Soc. London, Zool., Vol. XX., pp. 473-570. 1890.

Robbins, W. W. and T. D. A. Cockerell. "Notes on two Slugs of the Genus Veronicella." Proc. U.S. National Museum. Vol. XXXVI., pp. 381-384. 1909.

Robinson, B. L. and J. M. Greenman. "On the Flora of the Galápagos Islands, as shown by the collection of Dr. G. Baur." American Journal of Science (3), Vol. I., pp. 135-149. 1895.

Roosevelt, TH. "Wilderness Reserves (American Big Game and its Haunts)," pp. 23-51. 1904.

Rörig, A. "Phylogenie des Cervidengeweihes." Verh. d. 5 ten Int. Zool. Congresses. Berlin, 1901 ; pp. 538-543. 1902.

Rörig, A. "Das Wachstum d. Geweihes v. Capreolus vulgaris." Roux, Arch. f. Entw.-Mech. d. Organismen, Vol. XXV., pp. 423430. 1908 .

Rosehdahl, C. O. “Die Nordamerikanischen Saxifraginae \& ihre Verwandtschaftsverhältnisse in Beziehung z. ihrer geogr. Verbreitung." Engler's Bot. Jahrb. Beiblatt, Vol. XXXVII., pp. 1-87. 1905.

Rотн, S. "Beitrag zur Gliederung der Sedimentablagerungen in Patagonien \& der Pampasregion." Neues Jahrb. f. Mineralogie \& Geologie, Vol. XXVI., pp. 92-150. 1908.

Rothschild, W. and E. Hartert. "A Review of the Ornithology of the Galapagos Islands." Novitates Zool. Tring., Vol. VI., pp. 85 $-205.1899$.

Rothschild, W. and E. Hartert. "Further Notes on the Fauna of the Galapagos Islands." Novitates Zool. Tring., Vol. IX., pp. 373 -448. 1902.

Russell, I. C. "North America." London, 1904.

Ruthren, Alex. G. "A Collection of Reptiles and Amphibians from Southern New Mexico and Arizona." Bull. Amer. Mus. Nat. Hist., Vol. XXIII., pp. 483-604. 1907. 
Ruthren, Alex. G. "Faunal Affinities of the Prairie Region of North America." American Naturalist, Vol. XLII., pp. 388-393. 1908.

Ruthinen, Alex. G. "Variations and Genetic Relationships of the Garter Snakes." Bull. Smithsonian Institution. U.S. Nat. Mus. No. 61. 1908.

RydberG, P. A. "Composition of the Rocky Mountain Flora." Science (N. S.), Vol. XII., pp. 870-873. 1900.

Salvin, O. "On the Avifauna of the Galapagos Archipelago." Trans. Zool. Soc. London, Vol. IX., pp. 447-510. 1877.

Salvin, C. and F. D. Godman. "Aves Centrali-Americanae."

4 Vols. London, 1879-1904.

Sarasin, F. "Über die Geschichte der Tierwelt von Ceylon." Zool. Jahrbücher (System. Suppl. 12, Part I.). 1910.

Sarasin, F. "Die Fauna der Galapagos Inseln." Verhandl. d. Schweizer. Naturf. Gesellschaft 93 Jahresvers, Vol. I., pp. 292-294. 1910.

ScharfF, R. F. “Étude sur les mammifères de la région holarctique et leurs relations avec des régions voisines." Mém. de la Soc. Zool. de France, Vol. VIII., pp. 436-474. 1895.

ScharFF, R. F. "The History of the European Fauna." London, 1899.

ScharfF, R. F. "Some Remarks on the Atlantis Problem." Proc. R. Irish Acad., Vol. XXIV. (Sect. B.), pp. 268-302. 1903.

ScharfF, R. F., G. CofFey and others. "The Exploration of the Caves of Kesh, Co. Sligo." Trans. R. Irish Acad. (Sect. B.), Vol. XXXII., Part IV., pp. 171-214. 1903.

SchaRfF, R. F. "European Animals: their Geological History. and Geographical Distribution." London, 1907.

ScharfF, R. F. "On an early Tertiary Land-connection between North and South America." American Naturalist, Vol. XLVIII., pp. 513-531. 1909.

SCHARFF, R. F. "On the Evidences of a Former Land-bridge between Northern Europe and North America." Proc. R. Irish Academy, Vol. XXVIII. (Sect. B.), pp. 1-28. 1909.

Schlosser, M. "Uber die Beziehungen der ausgestorbenen Säugetierfaunen und ihr Verhältniss zur Säugetierfauna der Gegenwart." Biologisches Centralblatt, Vol. VIII., pp. 582-631. 1888.

Schlosser, M. “Über Tullberg's System d. Nagethiere nebst Bermerkungen über die fossilen Nager \& die während d. Tertiärs existirenden Landverbindungen." Centralbl. f. Mineralogie. Geol. \& Palaeont., pp. 705-713 und 737-748. 1902.

Sснмітт, P. "Über die Verbreitung d. Fische im Nördl. Stillen Ocean \& die damit zusammenhängenden zoogeogr. Probleme." Comptes rendus 6me Congrès Int. Zoologie, Berne, pp. 561-572. 1904.

SchUChert, C. "Paleogeography of North America." Bull. Geol. Soc. of America, Vol. XX., pp. 427-606. 1910. 
Schwarz, E. A. "The Coleoptera of Florida." Proc. Amer. Phil. Society, Vol. XVII., pp. 353-472. 1878.

Schwarz, E. A. "Coleoptera common to North America and other Countries.". (Presid. Address), 1890. Proc. Entom. Soc. Washington, Vol. I., pp. 182-194. 1890.

Schwarz, E. A. "Papers from the Harriman Alaska Expedition. Coleoptera." Proc. Washington Acad. Sc., Vol. II., pp. 523-537. 1900 .

Schwarz, E. H. L. "The Former Land Connection between Africa and South America." Journal of Geology, Vol. XIV., pp. 81 -90. 1906.

Sclater, W. L. and P. L. Sclater. "The Geography of: Mammals." London, 1899.

Scotт, W. B. "The Origin and Relations of the Floras and Faunas of the Antarctic and Adjacent Regions. Antarctica Palaeontology." Science (N.S.), Vol, III., pp. 307-310. 1896.

Sсотт, W. B. "Mammalia of the Santa Cruz Beds." Report of the Princeton Expedition to Patagonia, 1896-1899, Vol. V. 1903 $-1905$

Sсотт, W. B. "The Mammalian Fauna of the Santa-Cruz Beds of Patagonia." Comptes rendus 6me Congr. Int. Zoologie. Berne, pp. 241 $-247.1905$.

Scudder, S. H. " The Distribution of Insects in New Hampshire." Forming Chapt. XII. of Hitcheock and Huntingdon's Geology of New Hampshire, Vol. I. 1874.

ScUdder, S. H. "The Tertiary Insects of North America." Washington Govt. Press. 1891.

SEDGwick, A. "Relation between the Geographical Distribution and the Classification of the Onychophora." Quart. Journ. Mic. Sc., Vol. LII., pp. 379-406. 1908.

Seton, E. Thompson. "Life Histories of Northern Animals." 2 vols. London, 1910.

SEWard, A. C. "Fossil Plants as Tests of Climate." London, 1892.

SHALER, N. S. "Nature and Man in America." London, 1892.

Sharpe, R. B. and others. "Catalogue of Birds in the British Museum" (Nat. Hist.). 27 vols. London, 1874-1895.

ShimeK, B. "Helicina occulta. Say." Proc. Acad. Sc. Davenport, Iowa, Vol. IX., pp. 173-180. 1904.

SiebenRock, F. "Synopsis d. rezenten Schildkröten." Zool. Jahrbücher (System, Suppl. 10), pp. 427-618. 1909.

Simpson, C. T. "On the Relationships and Distribution of the North American Unionidae, with notes on the West Coast Species." American Naturalist, Vol. XXVII., pp. 353-358. 1893.

Simpson, C. T. "On some Fossil Unios and other Freshwater Shells from the drift at Toronto, Canada : with a review of the distribution of the Unionidae of N. E. North America." Proc. U. S. Nat. Mus., Vol. XVI., pp. 591-595. 1893. 
Srmpson, C. T. "Distribution of the Land and Freshwater Mollusks of the West Indian Region, and their evidence with regard to past changes of Land and Sea." Proc. U.S. National Mus., Vol. XVII., pp. 423-450. 1894.

Simpson, C. T. "On the Mississippi Valley Unionidae found in the St. Lawrence and 'Atlantic Drainage Areas." American, Naturalist, Vol. XXX., pp. 379-384. 1896.

Simpson, C. T. "On the Evidence of the Unionidae regarding the former course of the Tennessee and other Southern Rivers." Science (N.S.), Vol. XII., pp. 133-136. 1900.

Srmpson, C. T. "Synopsis of the Naiades, or pearly Freshwater Mussels." Proc. U.S. Nat. Mus., Vol. XXII., pp. 501-1044. 1900.

Sтмroth, H. "Die Nacktschneckenfauna d. russischen Reiches." K. Akad. d. Wissensch. St. Petersburg. 1901.

Sтмrotн, H. “Die Pendulationstheorie.” Leipzig, 1907.

Sinclatr, W. J. "The Marsupial Fauna of the Santa Cruz Beds." Proc. Amer. Phil. Soc., Vol. XLIX., pp. 73-81. 1905.

SkottsberG, C. "Some Remarks upon the Geographical Distribution of Vegetation in the colder Southern Hemisphere." Ymer., pp. 402-427. 1905.

Smith, Edgar A. "On the Land-Shells of St. Helena." Proc. Zool. Soc. London, pp. 258-270. 1892.

Smith, Eugene A. "On the Geology of Florida." American Journal of Science, (3), Vol. XXI. pp. 292-309. 1881.

Smith, Geoffrex. "A Naturalist in Tasmania." Oxford, 1909.

Smith, J. Perrin. "Periodic Migrations between the Asiatic and the American Coasts of the Pacific Ocean." American Journal of Science (4), Vol. XVII., pp. 217-233. 1904.

Smith, J. Perrin. "Salient Events in the Geological History of California." Science (N.S.), Vol. XXX., pp. 346-351. 1909.

Snodgrass, R. E. and E. Heller. "Papers from the HopkinsStanford Galapagos Expedition, 1898-1899. Birds." Proc. Washington Acad. Sciences, Vol. V., pp. 231-372. 1904.

Sollas, W. J. "Funafuti-The Study of a Coral Atoll." Natural Science, Vol. XIV., pp. 17-37. 1899.

Speight, R. "Petrological Notes on Rocks from Kermadec Islands, with some geological evidence for the existence of a sub-tropical Pacific Continent." Trans. \& Proc. New Zealand Institute, Vol. XLII., pp. 241-254. 1909.

Spencer, J. W. "The high Continental Elevation preceding the Pleistocene Period." Bull. Geol. Soc. of America, Vol. I. 1890. Also in Geol. Mag. (N.S.), Dec. 2, Vol. VII., pp. 208-213. 1890.

Spencer, J. W. "Reconstruction of the Antillean Continent." Bull. Geol. Soc. America, Vol. VI., pp. 103-140. 1895.

Spencer, J. W. "Submarine valleys off the American Coast and in the North Atlantic." Bull. Geol. Soc. America., Vol. XIV., pp. 207-226. 1903. 
Spencer, J. W. "The Falls of Niagara." Dept. of Mines, Geol. Survey Branch, Canada. Ottawa, 1907.

Spencer, J. W. "Note on the Discovery by Prof. de la Torre, of Fossil Mammals in Cuba." Geological Mag. (N.S.), Dec. V., Vol. VII., pp. 512-513. 1910.

Spethmann, Hans. "Der Aufbau der Insel Island." Centralblatt $\mathrm{f}$. Mineralogie, Geologie und Paläontologie. (Separatabdruck), pp. 1-16. 1909.

Standfuss, M. “Handbuch der palaearktischen Gross-Schmetterlinge.” Jena, 1896.

Staudinger, O. and H. Rebel. "Catalog d. Lepidopteren d. palaearktischen Faunengebietes." 2 Theile, (3 Aufl.) 1901.

Stearns, R. E. C. "Report on the Mollusk Fauna of the Galapagos Islands, with descriptions of new species." Proc. U.S. Nat. Mus., Vol. XVI., pp. 353-450. 1893.

Stebbing, T. R. R. “A History of Crustacea." London, 1893.

STEHLIN, H. G. "Geschichte des Suiden-gebisses." Abhandl. d. Schweiz. palaeontol. Gesellsch., Vol. XXVI., I. 1899.

Steindachner, F. "Die Schlangen und Eidechsen d. Galapagos Inseln." Verh. K. K. Zool.-Bot. Gesellsch. (Festschrift.), pp. 301330.1876.

Stejneger, L. "Batrachians and Reptiles of South Patagonia." Reports Princeton Univ. Exped. Patagonia, 1896-1899, Vol. III., Part II., pp. 211-224.

STEJNEGER, L. "Scharff's History of the European Fauna." American Naturalist, Vol. XXXV., pp. 87-116. 1901.

Stejneger, L. "The Herpetology of Porto Rico." Annual Report of the Smithsonian Institution, pp. 553-724. 1902.

Stejneger, L. "A resumé of the geograph. distrib. of the discoglossoid toads, in the light of ancient land connections." Bull. Amer. Geogr. Soc., Vol. XXXVII., pp. 91-93. 1905.

SteJNeger. L. "The Birds of the Genus Cinclus, and their Geographical Distribution." Smithsonian Miscell. Collections, Vol. XLVII., Part IV,, pp. 421-430. 1905.

SteJNEger, L. "Herpetology of Japan and Adjacent Territory." Bull. Smithson. Inst. U.S. Nat. Mus., pp. 1-575. 1907.

Stewart, Alban. "A Botanical Survey of the Galapagos Islands." Proc. California Acad. Sciences (4), Vol. I., pp. 7-288. 1911.

Stichel, H. and H. Riffarth. "Heliconiidae." Das Tierreich 22 Lief. 1905.

Strmpson, A. "On the Deep Water Fauna of Lake Michigan." American Naturalist, Vol. IV. 1870.

Stoli, O. "Zur Zoogeographie der landbewohnenden Wirbellosen." Berlin, 1897.

Stone, W. and W. E. Cram. "American Animals." New York, 1905.

Strand, E. "Die Arktischen Araneae, Opiliones \& Chernetes." Fauna Arctica, Vol. IV., Part III., pp. 433-478. 1906. 
Streber, H. "Revision d. Unterfamilie d. Orthalicinen." Mitt. a. d. Naturh. Mus. Hamburg., Vol. XXVI., pp. 1-191. 1909.

SuEss, E. " Das Antlitz der Erde." 3 vols. (third volume in two parts). Wien, 1892-1909.

SuEss, E. "Are great Ocean Depths permanent?" Natural Science, Vol. II., pp. 180-187. 1893.

Thоmas, OLDFIELD. "On Caenolestes, a still existing survivor of the Epanorthidae of Ameghino, another representative of a new family of recent Marsupials." Proc. Zool. Soc. London, pp. 870878.1895.

Toll, Eduard von. "Die fossilen Eislager \& ihre Beziehungen zu den Mammuthleichen." Mém. l'Acad. Imp. St. Pétersbourg (7), Vol. XLII., No. 13, pp. 1-86. 1892.

Toula, Franz. "Eine jungtertiäre fauna von Gatun am Panama Kanal.” Jahrb. d. K. K. Geol. Reichsanst. Wien., Vol. LVIII., pp. 673-760. 1909.

TCHERSKI, J. D. “Wiss. Resultate der zur Erforschung der Janaländer \& der Neusibirisch. Inseln ausgesandt. Expedition." IV. Abth. Mém. Acad. Imp. St. Pétersbourg (7), Vol. XL., pp. 1-511. 1893.

Transeau, E. N. "On the Geographical Distribution and ecological relations of the Bog Plant Societies of northern North America." Botanical Gazette, Vol. XXVI., pp. 401-420. 1903.

Tristram, H. B. "The Polar Origin of Life, considered in its bearing on the Distribution and Migration of Birds." Ibis (5), Vol. V., pp. 236-272. 1887.

Trotter, Spencer. "The Geological and Geographical relations of the Land-bird Fauna of North-Eastern America." Auk., Vol. XXVI., pp. 221-233. 1909.

Trouessart, E. L. "Catalogus Mammalium tam viventium quam fossilium.” II. vols. Berlin, 1898-1899. Supplementum, 19041905.

Trouessart, E. L. “Faune des Mammifères d'Europe." Berlin, 1910.

True, F. W. "A Revision of the American Moles." Proc. U.S. National Museum, Vol. XIX., pp. 1-111. 1896.

Tullberd, Trcho. "Über das System der Nagethiere." Nova Acta Reg. Soc. Sc. Upsala (3), pp. 1-514. 1898.

Ulbrich, Eberhard. “Über d. system. Gliederung und geographische Verbreitung d. Gattung Anemone." Engler's Botan. Jahrbücher., Vol. XXXVII., pp. 172-334. 1906.

UphaM, WarRen. "Marine Shells and Fragments of Shells in the Till near Boston." Proc. Boston Soc. Nat. Hist., Vol. XXIV., pp. 127-141. 1890.

VALLENTIN, RUPERT. "Notes by a Naturalist of his Voyage to the Falklands and back, with remarks on the Fauna and Flora of those Islands." J. R. Cornwall Inst., Vol. XIV., pp. 339-364. 1901.

Vanatta, E. G. "Bermuda Shells." Proc. Acad. Nat. Sc. Philadelphia, Vol. LXII., pp. 664-672. 1911. 
VANhöffen, ERnst. "Die Fauna and Flora Grönlands." Grönland-Expedition d. Gesellsch. f. Erdkunde Berlin, 1891-1893, Vol. II., pp. 1-383. Berlin, 1897.

Vaughan, Thomas Wayland. "A Contribution to the Geologio History of the Floridian Plateau." Publication 133, Carnegie Institution, Washington, pp. 99-185. 1910.

VERRILL, A. E. "On the comparison of the Coral Faunae of the Atlantic and Pacific coasts of the isthmus of Darien, as bearing on the supposed former connection between the two Oceans.". American Naturalist, Vol. III. 1869.

Verrill, A. E. “The Bermuda Islands." Trans. Connecticut Acad. Sc., Vol. XI., pp. 413-956. 1902, and Vol. XII., pp. 45-348. 1904-1907.

WALKer, Bryant. "The Origin and Distribution of the Land and Freshwater Mollusca of North America." 1st Rep. Michigan Academy, pp. 43-61. 1900.

WALKER, BRyANT. "The Distribution of Margaritana margarifera in North America." Proc. Malacol. Soc. London, Vol. IX., pp. 126-145. 1910.

WaLlace, A. R. "The Geographical Distribution of Animals." 2 vols. London, 1876.

WALLACE, A. R. "Island Life." 2nd ed. London, 1892.

Walther, JoHannes. “ UỦber den Bau der Flexuren an den Grenzen der Kontinente." Jenaische Zeitschr. f. Naturwissensch., Vol. XX., pp. 243-278. 1887.

WARMING, E. Über Grönland's Vegetation." Engler's Botanische Jahrbücher, Vol. X., pp. 346-409. 1888-1889.

Watson, Sereno. "On the Flora of Guadalupe Island, Lower California." Proc. American Academy of Arts and Sciences, Vol. III. (N.S.), pp. 105-112. 1876.

WEBER, MAx. "Der indo-australische Archipel, und die Geschichte seiner Thierwelt." Jena, 1902.

Webster, F. M. "Wind and Storms as Agents in the diffusion of Insects.” Amer. Nat., Vol. XXXVI., pp. 795-801. 1902.

WHEeLER, W. M. "The Ants of the Bahamas, with a list of the known West Indian species." Bull. Amer. Mus. Nat. Hist., Vol. XXI., pp. 79-135. 1905.

Wheeler, W. M. "The North American Ants of the Genus Dolichoderus.” Bull. Amer. Mus. Nat. Hist., Vol. XXI., pp. 305 -319. 1905.

WheELER, W. M. "The North American Ants of the Genus Liometopum." Bull. Amer. Mus. Nat. Hist., Vol. XXI., pp. 321 $-333.1905$.

Wheeler, W. M. “The Ants of the Bermudas." Bull. Amer. Mus. Nat. Hist., Vol. XXII., pp. 347-352. 1906.

WHEELfe, W. M. "Honey Ants, with a revision of the American Mrrmecocysti." Bull. Amer. Mus. Nat. Hist., Vol. XXIV., pp. 345 $-397.1908$. 
WHITE, C. A. "Certain phases in the Geological History of the North American Continent, biologically considered." Proc. Biol. Soc. Washington, Vol. II., pp. 41-66. 1885.

White, C. A. "The Ancestral Origin of the North American Unionidae." Smiths. Miscell. Coll., Vol. XLVIII., pp. 75-88. 1905.

White, F. B. "Contributions to a knowledge of the Hemipterous Fauna of St. Helena, and speculations on its Origin." Proc. Zool. Soc., pp. 444-477. 1878.

W HITE, I. C. "Relatorio final do commissâo de estudos das minas de carvâo de pedra do Brazil." Rio de Janeiro, 1908.

WhITFIELD, R. P. "Remarks on and descriptions of new Fossil Unionidae from the Laramie Clays of Montana." Bull. Amer. Mus. Nat. Hist., Vol. XXIII., pp. 623-628. 1907.

WhiтNey, J. D. "The Climatic Changes of later Geological Times." Mem. Mus. Comp. Zool. Cambridge, Mass., Vol. VII., pp. 1-394. 1882.

WILSER, L. "Der nordische Schöpfungsherd." Zeitschr. f. d. Ausbau d. Entwicklungslehre., Vol. III., pp. 121-138. 1909.

Winge, Herluf. " "Gr $\phi$ nlands Pattedyr." Meddelelser om Gronland, Vol. XXI., pp. 319 -521. Kjфbenhavn, 1902.

WoLf, Tн. "Die Galapagos Inseln." Verhandl. Gesellsch. f. Erdkunde, Berlin, Vol. XXII., pp. 246-265. 1895.

Wollaston, T. V. "The Coleoptera of St. Helena." Ann. \& Mag. Nat. Hist., pp. 1-61. 1869 ; and Suppl., pp. 396-413. 1871. Wollaston, T. V. "Notes on the Lepidoptera of St: Helena." Ann. \& Mag. Nat. Hist. (5), Vol. III., pp. 1-56. 1879.

Woodward, A. S. "Outlines of Vertebrate Palaeontology for Students of Zoology." Cambridge, 1898.

WOODWARD, A. S. "On some remains of Grypotherium (Neomylodon) listai \& associated Mammals from a Cavern near Consuelo Cove, Patagonia." Proc. Zool. Soc. London, pp. 64-79. 1900 (Part I.).

Woodward, A. S. "On some extinct Reptiles from Patagonia of the genera Miolania, Dinilysia and Genyodectes." Proc. Zool. Soc. London, pp. 169-184. 1901 (Part I.).

WoodWARD, S. P. "A Manual of the Mollusca" (3rd ed.). London, 1875, with appendix by Ralph Tate.

Wortman, J. L. "Psittacotherium, a member of a new and primitive sub-order of Edentata." Bull. Amer. Mus. Nat. Hist., Vol. VIII., pp. 259-262. 1896.

Wright, G. F. and W. Upham. "Greenland Icefields, and Life in the North Atlantic." London, 1896.

Zittel, K. A. von. "Handbuch der Palaeontologie." 5 vols. München, 1876-1893. 


\section{N DE X}

$\Delta$

Acanthonyx petiverii, 333

Accidental distribution, of butterflies, 116,117 ; of snakes, 130 ; as applied to Bermuda, 192, 194 ; of freshwater fishes, 232 ; in Antilles, 265 ; of animals and plants in Galapagos islands, 300, 301, 306, 309

Achatellina, 308

Achatina achatina, 380

Achatinidae, 380, 390

Acodon brachyotis, 418

Actoniscus ellipticus, 190

ADAMS, life in Alaska during Glacial Epoch, 34, 35 ; southward retreat of fauna and flora during Ice Age, 35, 37, 38 ; centres of dispersal in south-east and south-west, 174 ; “ biotic preserves," 174

Adelopoma, 257, 273 ; stolli, 257 ; martensi, 257

Aegialitis sanctae-helenae, 387

Aeglea laevis, 405

Aegleidae, 405

Aestrelata phaeopygia, 302

Agapeta, 350

Agarista, 214

Aqassiz, A., subsidence of Bahamas, 185 ; origin of Galapagos islands, 296 ; ocean floor off Panama, 332, 333; relict fauna in Lake Titicaca, 361

Aanssiz, L., faunistic isolation of New England, 56, 57

Aglossa, 377

Agonostomus, 290 ; monticola, 290

Agraulis, 179

Agrotis exclamationis, 214

Alaska, description of, 74, 75 ; Glacial Epoch in, 76, 81 ; "black muck" deposits, 79 ; fauna in Pleistocene,
78-81 ; mammalian fauna, 91,92 ; flora, 92,93

Alberta, game preserves in, 119

Alces, americanus, 32 ; bedfordiae, 32 ; machlis, 32 ; gigas, 92

ALCoOK, dispersal of Coeciliidae, 251

Allen, G. M., mammals of West Indies, 282

Allen, J. A., species of reindeer, 5 ; species of musk-ox, 7, 8;' polar origin. of life, 23 ; Glacial Epoch, views on, 34 ; Bering Strait land-bridge, 85 ; American mammalian types in Asia, 85 ; opossums, 182 ; specific distinctions of Solenodon, 282 ; mammalia of Galapagos, 298, 299 ; affinities of antarctic lands, 423

Alligator, 179, 180, 319 ; mississippiensis, 179 ; sinensis, 180

Allorchestes dentatus, 361

Alsophis, 288

Alston, mammals of Central America, 248

Alytes, 204

Amalia, wide distribution of, 213, 214, 389 ; howstoni, 213 ; gagates, 213 ; ponsonbyi, 214 ; pectinata, 214

Amathusidae, 369

Amazon River, 363

Amblyopsidae, 164-166

Amblyopsis spelaeus, 165

Amblyrhiza, 267 ; inundata, 285

Amblyrhynchus, 302 ; cristatus, 304

Amblystoma, 136, 137 ; tigrinum, 136, 137; persimile, 137; jeffersonianum, 137

AMEGHINo, tree-porcupine in Santa Cruz beds, 71 ; deer in upper Miocene of Argentina, 109 ; affinities of Phlaocyon, 151, 152; southern origin of edentates, 244 ; South America 
as source of Tertiary mammalia, 244,397 ; ancestral types of coypu, 283 ; Cuban cave man, 285; geological history of South America, 341 ; origin of American bears, 351 ; origin of Viscaciidae, 353, 354; lemuroid remains in Patagonia, 364, 365; South Atlantic land-bridge, 365, 370,371 ; sloth remains, 365 ; opossum remains, 367 ; freshwater deposits of Buenos Aires, 397 ; discoveries of Tertiary fauna, 397, 398; ancestors of huanaco, 406

Ameiurus cantonensis, 89

Ameiva, 288

American animals in Asia, 85, 86

Amia calva, 163

Amiidae, 163

Amphibians, in Hudson Bay region, 37 ; relationships of east American and Asiatic, 135-137; relationship of American and south European, $137,138,172$; rarity of, in southwestern States, 204

Amphibulima, 271

Amphicyclotus, 257, 268

Amphipyra pyramidea, 214

Amphisbaena, 288, 375 ; ridleyi, 385

Amphisbaenidae, 173, 202, 288, 375

Amphiuma means, 172

Ampullaria, origin in Brazil, 362 ; absent from Chile, 405

Anadenulus, 212

Anadenus, 213

Anarta, melanopa, 22, 36 ; leucocycla, 22 ; lapponica, 22

ANCEY, southern distribution of mollusks explained by Antarctic continent, 423

Anchitherium, 148

ANDERSEN, geographical distribution of bats, 299

Andes, flora related to that of Rocky Mountains, 104

ANDREAE, Atlantic land-bridge in Miocene times, 272 ; distribution of Adelopoma, 257

ANDREws, fossils of the Fayúm in Africa, 358, 373 ; land connection between South America and north Africa, 278, 373
Androdon, 350

Anemone, origin and distribution of, 114

Anguidae, 202, 281, 347, 348

Anguis, 281

Anniella, 202

Anniellidae, 202

Anodons on Pacific slope of North America, 162

Anodonta, marginata, 52 ; kennicotti, 52 ; pepiniana, 52

Anops, 376; kingi, 376; africanus, 376 Anosia archippus, 117

Antarctic continent, 419-426

Ants, in Bermuda, 189 ; in south-western States, 215-217

Antilles, characteristics of fauna, 261; geology and form of islands, 262, 264,286 ; past geography as shown by mollusks, $265-271$; affinities of fauna, 265-278; affinities explained by land-bridge, 274 ; mammalian fauna, 282-285; birds of, 289 ; summary of geological development, 292-294; Bahamas, 288, 289 ; Cuba, 261, 262, 285, 290, 291 ; Jamaica, 284, 288 ; Portorico, 288

"Antillean continent," 237, 241

Antilocapra americana, 112

Antilocafridae, 112, 113

Antlers of deer, development of, 108, 111, 112

Aphallarion, 212

Aplexa hypnorum, 72

Aplodontia, 228

Apocrypha, 413

"Apollo" butterflies, 90, 91

APPELL $\phi F$, opposition to subsidence theory of Faröe Bank, 17, 18

Archaean land-mass in West Indian region, 177

Arctia quenselii, 36 ; caja, 214

Arctoryctes, 246, 404

Arctotherium vetustus, 351

Arenicola marina, 16

Argentina, 395, 396 ; geological bistory of, 397 ; former climate, 401 ; connections with North America, 402, 403 ; with Australia, 403, 404

Argynnis, 235, 413 ; chariclea, 22 ; polaris, 22 
ARLDT, connection between Asia and North America, 97 ; Archaean rocks on oceanic islands, 277 ; reptiles and mollusks in Galapagos islands, 314 ; land-connection to Galapagos islands, 316 ; parallelism of Pacific islands, 327 ; former geographical conditions of South America, 343, 344 ; on Atlantic land-bridge, 383 ; connection between South America and Australian region, 425

Armadillo in Bridger deposits, 244 ; in Santa Cruz beds, 399, 401 ; in North America, 401

Armadillo (Isopod), 309

ARNOLD, climate of Pleistocene Period, 94-96

Arthrocomus, 413

Arvicola (see Microtus and Pitymys). Ascaphus, 204

Ascension island, 396

Ashmunella, 206

AsHWORTH, distribution of marine shore forms, 16 ; marine worms of Patagonia and south Africa, 432

Asiatic types in America, 83-91, earlier and later migrations, 317320 ; route of ancient Tertiary migration, 328, 329 ; antelopes in America, 407

Astacus (see Potamobius).

Astrapotheria, 399

Atalapha (see Lasiurus).

Ateles vellerosus, 250

Athabasca - Mackenzie region, fauna and flora of, 58-73

Atherina evermanni, 290

Atlantic islands, origin of, $383-393$

Atlantic States, effect of moist climate on vegetation, 167

Atophyrax, 201

Auckland island, earthworms of, 424

Austaut, Asiatic origin of Apollo butterflies, 90

Avocettula, 367

“Axolotl," 137

\section{B}

Bahamas, raccoon in, 181 ; effect on Gulf Stream by elevation of, 185 (See Antilles.)
BAILEY, distribution of Microtus, 28

BANGS, mammals of Labrador, 28 ; water-vole of Florida, 182

Bangs and BRADleE, Bermudan birds, 188

BANKs, scorpions of Florida, 179

BARBOUR, on alligators, 180 ; Jamaican reptiles and amphibians, 288 ; Bahama reptiles and amphibians, 288

BARRETT - HAMILTON, external characters of arctic hare, 9

BARRETT - HaMILTON and BonHote, varieties of arctic fox, 11

Bartonius, 177

Bassaricyon, 249

Bassariscus, 201

BATES, antiquity of forests in South America, 364; on Heliconiidae, 368; discovery of Cryptostemma, 369

BAUR, on Galapagos islands, 296 ; Troxidurus, 311; harmonic and disharmonic faunas, 311-313; theory of origin of Galapagos, 312 ; accounts for peculiarities of flora, 315 ; on Indo-Pacific continent, 323

Bear, black, 28 ; barren-ground, 61 ; in Alaska, 80 ; spectacled, 350

Beavers, extinct in Alaska, 80 ; in lower Pleistocene, 153

BEDDARD, connection between Patagonia and the Australian region, 421

Beetles, distribution of running, 20 ; in Scarboro' Heights deposit, 43 ; of Rocky Mountains, 117, 118 ; of south - western States, 215 ; of Old Calabar, 381 ; of St. Helena, 387

BELT, connection of Atlantic and Pacific Oceans, 239 ; birds of Central America, 250

BENHAM, faunistic affinities of New Zealand, 424

BENTHAM, floral affinities of St. Helena, 391

Berendtia, 206

Bermuda, 183, 184 ; geology of, 184, 186 ; comparison with Bahamas, 185; flora and fauna, 186-194; affinities of fauna, 190

BERRY, Pleistocene climate, 175 ; midCretaceous floral affinities, 414 
Bigelow, Pacific medusae, 240 ; absence of surface forms in parts of Pacific, 335

Big-horn, Kamchatkan, 85, 104, 105; Rocky Mountain, 104, 105

BINNEY, distribution of Helix hortensis, 14

Birds, geographical distribution of, 61; of Nova Scotia, 56; of Mackenzie Region, 61; of Rocky Mountains, 113 ; of Galapagos islands, 301, 302; of Bermuda, 188, 189 ; of Central America, 250, 251; of West Indies, 290; of South America, 367-369

Bison, range and history of, $65-67$; in Gulf plains, 145

Bison, bison, 65; sivalensis, 66 ; alleni, 66 ; 80 ; scaphoceras, 66 ; crassicornis, 67,80 ; priscus, 67 ; occidentalis, 80

Blaisdell, Tenebrionidae, 215

BLANFORD, permanence of ocean basins, 277 ; on volcanic islands, 297 ; relationship of reptiles and amphibians of South America and Africa, 374, 376

Blanus, 375, 376

Blaps, 215

Blastocerus, 111

Blastomeryx, 110, 112

Blue-bird in Bermuda, 188

Boas, distribution of, 203

Boeckella, 424

Boettaer, Tertiary Helices, 193 ; Helicidae, affinities of, 206 ; on Adelopoma, 257 ; Atlantic Miocene land-bridge, 272 ; connection between Galapagos and Central America, 313 ; Clausilia of South America, 349 ; Tertiary fossils in Amazon valley, 360

Boidae, 203

Boltenia, 272

Bombinator, 204

BonHOTE (see BARRETT-HAMILTON).

Boötherium, 154; bombifrons, 80, 154 BorN, distribution of running beetles in North America, 20

Böse and Toula, fossils of Isthmus of Tehuantepec, 238 ; affinities of Pacific and Atlantic faunas, 241
BouleNGER, distribution of Lygosoma, 125 ; on Tropidonotus, 129 ; affinities of $E m y s, 134$; distribution of Coecilians, 370 ; distribution of Dermophis, 377 ; African fishes, 378, 379. Bourguignat, identity of European and American Clausilia, 272

BOUVIER, distribution of Onychophora, 346,369 ; distribution of Peripatus, 432 Bow-fin in Mississippi basin, 163

Brachionycha nubeculosa, 214

Brachydontes magellanica, 428

Brachylagus, 226

Brachylophus, 207

Brachymeles, 126

Brachypodella, 267

BradleE (see Bangs).

Bradypus, 366

Bradytherium in Madagascar, 366

Brandegee, Californian flora, 208

Bransford (see Gill).

BRAUER, arctic fauna, 6

BraY, plants common to Andes and Rocky Mountains, 104 ; floral affinities of North and South America, 415,416

Brazil, 363 ; summary of geological history, 393-394

BREHM, crustacea of Greenland, 19

BRENDEL, on Florida plants, 167

Bridger deposits of Wyoming, 102, 143, 163, 229, 244

Britton, Flora of Antaretic continent, 422

BRooke, structural characters of Cervus canadensis, 68

BrooKs, great range of climate in Alaska, 74 ; geology of Alaska, 84 Brotulidae, 290

Brown, A. E. dispersal of reindeer, 5 ; North Atlantic land-connection, 25, 222 ; Rocky Mountain sheep, 104, 105; origin of Oreamnos, 106; variation of garter-snakes, 128 ; origin of rattle - snakes, 131 ; centres of dispersal, 174

Brown, B., age of Potter Creek deposits, 29 ; Conard fissure, 61, 64, 70,87 ; remains of mule-deer from Conard fissure, 108 ; Symbos and Scaphoceros, 155 
Brown, R., similarity of Greenland and European reihdeer, 4 ; arctic hare, 9

Brown, R. N. R., on Diego Alvarez, 393

Brows, S., Bermudan flora, 187

Bruce, fossils from Falkland islands, 430 ; soundings in southern Atlantic, 433

Buckleyia, 256, 268

Budde-Lund, on the Pacific Continent, 320

Budorcas, 106

Buffalo (see Bișon).

Bufo, absence from Jamaica, 288

Bugs of St. Helena, 388, 390

Bulimus, 390

Bulimulidae, 269-271, 273

Bulimulus, 176, 206 ; of Lower California, 208 ; on ancient Pacific land, 209, 210 ; of Galapagos, 306-308 ; of St. Helena, 390; common to Chile, Galapagos, and California, 410 ; forms not easily distinguishable, 269, 270 ; americanus, 270 ; ridleyi, 270,385

Bunting on Diego Alvarez, 293

Bufrestidae, 425

BurckhardT, C., on Pacific continent, 427

BURCKHARDT, R., distribution of flightless birds, 423

Burdwood Bank, 429

Butterflies, dispersal of, 115 ; of south - western States, 214; of Antilles, 289 ; of Florida, 179

\section{C}

Cactornis, 301

Caenolestes in Santa Cruz beds, 350, 404 ; in Ecuador, 350

California, geological history, 198200 ; Cape Region of, 199, 207 ; fauna and flora of Cape Region, 207, 208 ; relationship with Europe, 211; geology of Cape Region, 329, 330, 356 ; Cape Region a part of Pacific land-belt, 331 ; animals common to Chile, 333, 410, 412, 413

Californian islands flora, 210 ; peculiar species of Epiphragmophora,
410 ; relicts of Pacific land-belt, 418

Calvert, dragon - flies of Central America, 258

\section{Camarhynchus, 301}

Cambaroides, 218-220

Cambarus, place of origin, 177,178 ; dispersal of, 218-220 ; primaevus, 220 ; сubensis, 291, 292 ; mexicanus, 291

Camel, ancient migrations, 86 ; fossil in North America, 153 ; camel-like animals of America, origin of, 406, 407

Camelidae, 86, 116, 406

Camelus, 153

Camerano, cranial differences in reindeer, 5 ; varieties of reindeer, 34

Campbell (see Hayes).

Campylaea, 206

Canadian forest region, fauna of, $63-$ 67

Cancer amphiaetus, 93, 94

Canidae, an ancient family, 149, 150

Canis, 149, 150 ; occidentalis albus. 61 ; latrans, 149, 430 ; dingo, 150; antarcticus, 430, 150 ; tonggerana, 150

Capreolus, resemblance to American deer, 111

Caprolagus, 225

Capromeryø, 113

Capromys, 282; columbianus, 283

Carabidae, 425

Caraboctonus, 349, 350

Carabus, supposed accidental distribution, 20 ; peculiar distribution in North and South America, 235, 236, 412,413 ; catenulatus, 20 ; nemoralis, 20 ,

Carcharhinus nicaraguensis, 241

Carettochelyidae, 135

Carcinocyon, 430

Cardiastethus, 391

Cardinal, in Bermuda, 188, 189

Cardinalis bermudianus, 189

Caribbean Sea, a gulf of the Pacific, 241, 332

Caribou, derivation of name, 3 ; " barren-ground," 3, 5, 27, 58 ; "wood-land," 3, 5 ; " mountain," 5 
Carnivores, Cretaceous ancestors, 149

Carpenter, Sonoran region, 196, 197 ; Collembola from South Orkneys, 433

Carpodacus, 56

Carthaus, sea-water formerly more salt, 276

Cascade Mountains, 103

Casmorynchus niveus, 362

Castor, extinct in Alaska, 80

Castoroïdes, 153, 285, 286

Cat-bird, in Bermuda, 188, 189

Cat-fish, 89, 361

Caton, likeness of wapiti and reddeer, 68

Catostomus rostratus, 89

Caudell, on Phasmidae, 158

Cebidae, 364

Cebus, 364

Celestus, 281

Centetidae, 246, 282

Central America, faunal problems, 233, 234 ; geological features, 237, 238; date of formation, 152 ; time of submergence, 241,242 ; elevated in Pliocene Period, 243; flora and fauna, 247-257; affinity with Europe, 257 ; general affinities of, 259,260

Centrurus, gracilis, 178 ; carolinianus,

178 ; margaritatus, 178 ; hent $z i, 178$

Cephalopterus ornatus, 362

Cexolis, 175, 176

Cercoleptes flavus, 151, 248, 249

Ceroglossus, 413

Certhia, 56

Certhidea, 315

Cervalces, 32

Cervidae, origin of, 109-111

Cervulus, 111

Cervus, origin of, 68 ; canaäensis, 67 -69 ; distinct from American deer, 107,108

Chamberlin, T. C., and Salisbury, glaciation of Nova Scotia, 41; interglacial phases, 45 ; ice dispersion from Keewatin centre, 46, 76, 77

Chamberlin, R. V., North American Lycosidae, 36

Chamops, 127

Chapman, origin of Antillean fauna, 290
Characinidae, 379, 380

Chauliodes, 289

Chelonians of north-eastern States, 134

Chelydridae, 134, 251, 319, 320

Cholydra, serpentina, 134 ; rosignonii, 135

Chile, 395 ; occurrence of northern forms, 234 ; species in common with California, 333, 334 ; poverty of freshwater fauna, 405 ; distribution of mammals, 406 ; species in common with California and Galapagos, 410 ; western extension of, 427 Chilean islands, 418

Chilonopsis, 390

CHiltoN, Antarctic continent, 425

Chinchilla, 353, 354

Chipmunk, 63

Choanopoma, 176

Choloexus, 366

Chologaster, 165

Chondropoma, 175

Chorophilus nigritus, 31

Chrosomus erythrogaster, 50

Chrysemys, 132

Chrysochloridae, 245, 246, 404

Chrysocyon, 430

Chrysothrix, 364

Chub, silver, in drift area, 51

Cichlidae, 234, 290, 362, 379

Cinclus, origin of, 113

Cinosternidae, 362

Cistudo, 134

Citellus, general range of, 60 ; parryi, 61,85 ; douglasi, 61 ; tridecemlineatus, 61 ; buxtoni, 85 ; osgoodi, 92; nebulicola, 92 ; beringensis, 92 ;

barrowensis, 92 ; stonei, 92

Clausilia, range and geological history, 272,273 ; discontinuous distribution of, 348,349 ; pauli, 272, 349

Clemmys, guttata, 132 ; marmorata, 133,222 ; leprosa, 133, 222 ; insculpta, 133 ; morrisiae, 133

Coati, of western origin, 249

Cochlicopa lubrica, 72

COCKERELL, distribution of Helix hortensis, 14 ; Florissant shales of Miocene Age, 118; Florissant shales, 200 (See Robbins.) 
Cocornis, 301

COE, land-nemertean in Bermuda, 191

CoE and KUNKEL, Californian limbless lizard, 202

Coecilians, 251, 252, 370

Coeciliudae, geological history, 251, 252,348

Coendidae, 71

Coendu, migrations of, 70,71 ; in Brazil, 366 ; origin of, 403

Colias, in Rocky Mountains, 117 ; in southern South America, 235; nastes, 22

Coleoxtera of South America related to those of Australia, 425

Collembola from South Orkneys, 433

Coleman, fossil plants as tests of climate, 43 ; Canadian Pleistocene flora, 44

Columbigallina bermuãiana, 188 ; fasserina, 188

Conard Fissure, fauna of, 61, 64, 70, 107, 108, 153

Condylura cristata, 142

Conepatus, 201

Conolophus, 304

Conoryctes, 244

Conulus, 306, 308 ; fabricii, 21

Conuropsis carolinensis, 159, 172

Conurus, 172

Conwentz, distribution of musk-ox, 7 CooK (see MatTHEw).

Cooks, A. H., operculate land-mollusks, 57

Cooke, W. W., bird migration, 168

COOPER, Californian mollusks, 208

COPE, varieties of bison, 66 ; Felis hillianus, 107 ; distribution of ground-lizard, 124 ; mud-puppy of eastern States, 136 ; eastern and western types of snakes, 173 ; Sonoran region, 196 ; fossil voles, 224 ; fossils of Puerco formation, 244

Copeland, flora of Trinidad, 396

Corals, fossil, of Barbados with Mediterranean affinities, 278

Corydalis, 289

Cosoryx, 112

Cotingidae, 362, 368

Cougar, vast range of, 106, 107
Coville, land-bridge between Asia and North America, 83

Coyote, distribution in North America, 149,150 ; related to Falkland Island wolf, 430, 431

Coypu, distribution and ancestry, 282, 283,396

Crabs, distribution of freshwater, 25๊ ; of Cuba, 291; of coast of Chile, 333 ; of southern South America, 405

Cragin, fossil species of Nemorrhaedus, 106

Crayfish, freshwater, distribution of, 217,218 ; of south-western States, 218 ; of Cuba, 291; of South America, 405 ; of Chile and New Zealand, 420, 424, 426

Credner, fauna of relict lakes, 49

Creodonta, 373

Crepidula gregaria, 428

Crocidopoma, in Antilles, 256, 268

Crocodilus americanus, 180, 181

Crotalus, 131, 253 ; horridus, 131 ; terrificus, 131, 253

Crow in Bermuda, 188 -

Crustacea, of the Great Lakes, 48, 49 ; blind, of Cuba, 291

Cryptostemma westermanni, 369, 370, 382

Cryftobranchus, 83 ; allegheniensis, 135 ; japonicus, 135

Ctenodactilus, 372

Ctenodactylidae, 371

Ctenomys, brasiliensis, 371 ; minutus, 371

Ctenosaura hemilopha, 207

Ctenucha, 214

Cuba, poverty of mammalian fauna, 261,262 ; cave fauna, 285, 290 ; fishes, 290, 291

Cubaris, pisum, 179 ; galapagoensis, 309

Cucullaea alta, 428

Cupiennius sallei, 178

Curassows in Central America, 250

Curculionidae, 391

Cyclophis, 130, 319 ; aestivus, 130

Cyclophoridae, 256, 257, 268

Cyclura, 207

Cylindrellidae (see Urocoptidae).

Cynomys, 148, 149; ludovicianus, 148 
Cyprinids, 50

Cyrtotoma, 256, 268

Cystognathidae, 421

\section{D}

Dace, red-bellied, in drift area, 50

DAHL, distribution of spiders, 191 ; arctic centre of dispersal, 427,428

DALL, Helix hortensis in Pleistocene clays, 14 ; temperature of Pliocene seas, 16 ; land between Asia and North America, 83 ; fauna of northeast Pacific, 93 ; subsidence in Alaska in Pleistocene times, 96; marine gravels at Nome, 94; climate during Tertiary Era, 94-97; on Helicina, 158; geological history of Florida, 176 ; mollusks of Florida, 176 ; Californian Bulimulus, 208; Galapagos islands, 296 ; importance of accidental distribution, 306, 307 ; Alaskan leaf-bed, 318, 319; Miocene mollusks of Penjinsk, 319 ; marine faunal provinces, 333,334

DALL and HARRIS, Miocene change of Gulf Stream, 186

DALY, geology of Labrador, 41

Damon variegatus, 382

Damophila, 350

Darien, isthmus of (see Central America).

DARwIN, Galapagos islands, 295-297 ; human importations, 298 ; birds and lizards of Galapagos, 301-303; flora of Galapagos, 310 ; subsidence of Pacific Ocean, 321, 322, 331 ; Ascension island, 386 ; description of Falkland islands, 430, 431

Dasychira roseii, 36

Dasypoda, 399, 401

Dasyuridae, 183

Dawson, G., foraminifera in Glacial clays, 47

Dawson, J. W., Pleistocene flora and fauna of Canada, 44, 53 ; foraminifera in Canadian Pleistocene clays, 47 ; views on Glacial Epoch, 98

DAviD, atoll boring at Funafuti, 321

Deer, origin of, 109-111
DenBURGH, Van, lizards of Lower California, 207 ; reptiles of Galapagos, 305 ; reptiles and amphibia of Californian islands, 418

\section{Dendrobatidae, 377}

DEPÉRET, pedigree of horse, 147 ; original home of fossil horses, 148; centres of origin, 227 ; Miocene and Pliocene migrations, 230 ; age of Central America, 243

Dermatemydidae, 236, 251

Dermatemys mawi, 251

Dermophis, 370, 376

DE SÉLYs, Pitymys from St. Gothard, 223

Devisia mythodes, 135

Diapheromera femorata, 158

Dibelodon, 231

DICKERSON, amphibians of Hudson Bay region, 31

Dicrocerus, 111

Dicrostonyx, torquatus, 9-11 ; hudsonius, $11,27,60$

Diäelphyidae, 229, 367, 403

Didelphys, 182, 183 ; marsupialis, 182, 283,366

DIEDERICH, distribution of magpies, 88 Diego Alvarez island, 393

DiLG, anatomy of manatees, 279,280

Dinosaurs, 400

Dione, 179

Diplocardia, 174

Diplocynodon, 180

Diplodon, 425, 426

Diploglossus (see Celestus).

Diplommatininae, 257

Dipodomys, 201

Dippers, distribution of, 113

Discoglossidae, 204

Discoglossus, 204

DITMARs, Sceloporus undulatus, 126 ; remarks on rattle-snakes, 131 ; remarks on terrapins, 132 ; habits of snapping turtles, 134

DODGE, description of bison herd, 65

Dog, wild, of Australia, 150 ; of Java, 150

Dolichonyx oryzivorus, 301

Dolichotis, 403

D'ORBIGNY, mid-Atlantic land-bridge, 359 
Dragon - flies of Florida, 178; of Central America, 258; of Antilles, 289

Drasche, boundaries of Pacific, 328

Drift-deposit in North America, 4043 ; absence of, in Labrador, 41

Dromicus, biserialis, 304 ; chamissonis, 304

Drygalski, v., coast lands in Greenland never glaciated, 18

Drymaeus, 175 ; dominicus, 176, 270; dormani, 270

\section{E}

EARLE, tapiroids in Europe and America, 353

Earthworms, in Florida, 174 ; affinity of North and South American, 412; importance of, in zoogeography, 423 , 424 ; of Falkland islands, 431

Echimyinae, 372

Echinoids, fossil of America and Europe, 278

ECKel and PaUlmier, reptiles of New York, 123, 127

Ecuador, an ancient land-mass, 350 ; fauna of, 354

Edentates, range of, 152, 153, 156 ; origin of, 244, 245 ; in Santa Cruz beds, 399

Eglandina, 175

Eraenmann, on blind fishes, 165 ; freshwater fishes of Central America, 253 ; affinities of Cuban fishes, 291; geological history of South America, 340 ; Orestias, 362 ; land-bridge between Africa and South America, 379 ; Patagonian fishes, 405

Eisen, Cape Region of Lower California, 330

Elateridae, 425

Eleodes, 118

Elodinae, 215

Elephants, remains on Pribilof islands, 78 ; fossil in North America, 153, 200, 230, 231, 358, 359

Elephas, primigenius, 80 ; columbi, 83,
87,153 ; antiquus, 87 ; meridionalis, 87 ; imperator, 87,153

El.Liot, black musk-ox, 7

Emerson, Texas subterranean newt, 136

EMERTON, affinity between spiders of America and Europe, 23

EMERY, honey ants, 216 ; Formira in America, 216

Emydidae, 134

Emys, distribution of, 51, 132-134; blandingi, 51, 132; orbicularis, 51

Enallagma, 178

ENDERLEIN, insects of south Polar regions, 433, 434 ; former antarctic land-connection, 435

Endodonta, 306, 308, 390 ; helleri, 308

Engelmardt, fossil plants of Chile, 414,415

ENGLER, affinities of flora of Asia and North America, 93 ; plants common to Andes and Rocky Mountains, 104 ; affinities of western American plants, 139,140 ; origin of Florida plants, 168 ; land-bridge between South America and Africa, 383 ; St. Helena flora, 392 ; Tristan da Cunha flora, 393 ; floral affinities of North and South America, 415

Entelops, 366

Eohippus, 147, 228

Epanorthidae, 350, 404

Epihippus, 147

Exilobocera, 255, 291

Epiphragmophora, 206, 212, 410 ; tucumanensis, 411

Erebia, 117

Erethizon, 71, 366, 403 ; dorsatus, 27, 69 ; epixanthum, 70

Eryx, 203

Eublepharus, 347

Euceratherium, 154

Euchirotes, 207 ; biporus, 202, 203

Euconulus fulvus, 72

Eugenia, 350

Eumeces, 123-126 ; quinquelineatus, 123, 189 ; latiscutatus, 189 ; longirostris, 189

Eurymetopum, 413 
Eustephanus fernandensis, 418

Eutenia sirtalis, 127

Eutoxeres, 350

Evermann (see Jordan).

Evotomys, 29 ; ungava, 27 ; protens, 27 ; wrangeli, 92 ; dawsoni, 92 ; orea, 92

\section{F}

Falkland islands, geology of, 429,430 ; fauna and flora, 431

Faröe Bank, shells dredged off, 17

Faxon, crayfish, 218, 220

Faxonius, 177

Felis, concolor, 107 ; hillianus, 107

Fernando de Noronha, 384, 385

Ferris, mollusca of south - western States, 206

Fiber, obscurus, 56, 64; zibethicus, 64, 92 ; spathulatus, 64, 92 ; annectens, 64.

Feilden and de Rance, banded lemming in Greenland, 11; glaciomarine deposits, 47

Florida, flora of, 167 ; relation to Antilles, 168 ; former geological conditions, $168-172$; fauna of, 175 -182 ; majority of faunal elements non-tropical, 181, 182 ; course of Gulf Stream across, 185

Florissant Shales, insects and plants of, 118,200

Flying squirrel, distribution of, 63

Foraminifera, in boulder clay, 41

Forbes, relationship of Madagascar and South America, 375 ; Antarctic continent, 421

Forest region of North America, fauna of, 31,63

Formica, cineria, 216 ; rufibarbis, 216

Fox, arctic, 11, 27 ; red, 27 ; Newfoundland, 56

Frazer, Archaean land mass in Caribbean Sea, 177

Frogs, near Hudson Bay, 31 ; Florida tree, 173 ; in South America, 377

Funafuti, boring coral reef at, 321, 322

Furlong, Euceratherium in Californian cave, 154
GADOw, affinities between reptiles of Madagascar and America, 126 ; distribution of salamanders, 137, 138 ; distribution of Scaphiopus, 205 ; age of genus Spelerpes, 221; home of Coeciliidae, 251, 252 ; geological history of Antilles and Central America, 287 ; origin of Galapagos tortoises, 313; on Dendrobatidae, 377

Gaeotis, 271

Galapagos islands, origin of fauna and flora, $295-317$

Galaxiidae, 421

Galeoscoptes bermudianus, 189

Gallinula galeata, 188

Gallinule, Florida, 188 ; on Diego Alvarez, 393

Ganodonta, 244

Ganoid fishes, of Mississippi, 88, 89, 163,164

Gardiner, beetles of White Mountains, 37

GaRMan, H., on blind fishes, 165

Garman, S., Bermudan skink, 189 ; reptilian fauna of Galapagos, 303

Garnieria, 273

Gastrodonta, 193

GAUDRY, affinity of Patagonian extinct fauna with that of New Mexico and France, 402

Gecko in Galapagos islands, 303

Geckonidae, 303, 304

GEIKIE, A., on permanence of ocean basins, 274, 276

GEIKIE, J., Greenland in Ice Age, 18 ; inter-glacial phases, 45 ; gigantic glaciers in Ice Age, 69

Geoemyda punctularia, 347

Geomalacus, 213

Geonemertes agricola, 191

Geospiza, 315

Gidley, Pleistocene species of Equus, 146, 147 ; on fossil raccoon, 152

" Gila-monster," 201

GILL, distribution of mud-minnows, 51 ; land-bridge between Asia and America, 83, 88; fishes, as indicators of changes of land and water, 377, 
378 ; southern continental land connections, 420, 423

Gill and Bransford, fishes of Nicaragua, 240

Gilmore, Pleistocene deposits in Alaska, 79, 80

GiRARD, moths common to Canada and Europe, 22

Glacial Epoch, survival of life in Greenland during, 18-25; elevation of land in, 14, 42, 98 ; cause of, 15, 99,318 ; mild climate in northern latitudes, 19, 24, 43-46, 81, 154157 ; effects of, on animals and plants, $37-45$; survival of species in drift area, $36,40,41,52$; in Newfoundland, 41, 55; in Nova Scotia, 56 ; not caused by diminution of temperature, 76,156 ; in Alaska, 76-79, 81 ; in Siberia, 81, 82 ; its influence on fauna and flora, 175 ; inter-glacial epochs, 45

Glandina, fossil in Florida, 171 ; in Europe, 271, 272

Glaresis, 215

Glauconia, dulcis, 203 ; humilis, 203

Glauconiidae, 203

Glutton in Labrador, 27

Glyptodontia, 399

Glyptotherium, 153

Gnathocerus maxillosus, 215

Goat-antelopes, 106

Goat, Rocky Mountain, 104-106

Godman and Salvin, researches on the fauna and flora of Central America, 246 ; Central American insects, 258

Gonatodes, 304

Goodrich, on Ceratodidae, 379

Gophers, distribution of, 60

Gough island (see Diego Alvarez).

Gould, Pacific continent, 321

GrabaU, geological history of Great Lakes, 54, 55

Grandala, 188

GrandidIER, on Bradytherium, 366

Granger, on Eocene horses, 147

Grant, varieties of reindeer, 3 ; northern land-connections, 25 ; range of moose, 32 ; Rocky Mountain goat, 105

Gravigrada, 244, 399

L.A.
GraY, affinities of flora of Asia and America, 92, 139 ; Rocky Mountain flora, 103 ; North and South American plants, 415

GrEENE, flora of Californian islands, 210,329

Greenland, flora and fauna, 3-22 ; land-connections, 12, 13, 30 ; survival of species in Pleistocene times, $18-21$; former climate, 19 ; affinities with Labrador, 42

Greenman (see Robinson).

Gregory, elevation of Florida, 170 ; junction of Atlantic and Pacific, 239, 241, 242 ; land - connection between North and South America, 264 ; abysmal deposits in Barbados and Cuba, 277; on fossil seaurchins, 278 ; on fossil corals, 278

GrENFELL, description of Labrador, 27

GroTe, noctuids common to Europe and North America, 22; effect of Glacial Epoch on range of butterflies, 38, 39

Ground-dove, in Bermuda, 188

Gryllus bermudensis, 189

Grypotherium listai, 400

Guadalupe, flora of, 417

Guatemala, flora of, 247

Guestieria, 348

Guiana, as centre of dispersal, 362

"Gulf Plains," 144

Gulf Stream, course in Tertiary times, 185,186

Gulick, Bermudan fossil mollusca, 193

Gulo luscus, 27, 61

Gunther, Central American fishes, 240 ; reptilian fauna of Galapagos, 303 ; land isopod from Galapagos, 309 ; distribution of fishes, $\mathbf{3 7 8}$; fauna of Ascension, 386

Guppy, H. B., on Pacific continent, 324-326 ; mangrove formation, 333

GUPPY, R. J. L., mid-Atlantic landbridge, 278

Gymnocephalus calvus, 362

H

HaACKe, Polar origin of life, 23, 428 HACKEL, affinities of North and South American floras, 415, 417 
Hadruroides, 349, 350

Hadrurus, 349, 350

Halichoerus, 280

HANDLIRSCH, on fossil insects, 118, 158, 391 ; fossil Liometopum, 216

HANSEN, distribution of Koenenia, 217

Hapalidae, 364

Haplarmadillo, 190

Haplophora, 258

Hare, range of, 224-226 ; aretic, 9, 10 ; fossil of England, 10 ; Irish, 10 ; in Mackenzie Region, 59; Cape jumping, 372, 373 ; Patagonian, 396

HARRIS (see DALL).

Harrison, Mackenzie River, 58

HARSHBERGER, effects of Glacial Epoch on flora, 39, 40 ; flora of Florida, 168, 169 ; Bermudan flora, 187

HARTERT, on humming-birds, 350, 367

Hartert (see Rothschild).

HATCHER, on American palaeontology, 102

HaUG, on Pacific continent, 327

HAY, origin of fossil turtles, 133, 134, 251 ; climate of Pleistocene Period, $154-156$

Hayes and CaMpBell, change of river courses, 162, 163

Hebard (see ReHN).

HEDLEY, north Atlantic land-connection, 30 ; Placostylus, 209 ; Pacific land-connections, 323, 324 ; antarctic land-connection, 421, 422

HEILPRIN, origin and migration of animals, 97 ; Bermuda islands, 186; Antarctic continent, 422

Helicidae, 193, 205, 212

Helicigona, 212, 411

Helicina, 192, 306, 308 ; chrysocheila, 157 ; orbicula, 157 ; occulta, 157, 158 ; convexa, 192, 193

Heliconiidae, 368

Heliconius, 179 ; charitonia, 368

Helix, hortensis, distribution of, 13, $14,39,141$; in Labrador, 30 ; in Pleistocene clay of Maine, 39 ; imbricata, 193

"Hell-bender," 135, 319

HELLER, mammalia of Galapagos, 299; reptiles of Galapagos, 303, 304; geological age of Galapagos, 305
Heller (see Snodgrass).

Heloderma, 202

Hemiauchenia, 406

Hemiptera, common to Europe and America, 89, 90 ; of St. Helena, 388

Hemphillia, 212

Hemsley, Bermudan flora, 187 ; Central American and Mexican floras, $246-248$; on origin of Galapagos islands, 315

Heros, tetracanthus, 290 ; nigricans, 290 Herpele, 370

HERSHEY, ancient land west of Panama, 331

Hesperarion, 212

Hesperomys, 298

Hexura, 412

Hill, orogenic movement in Antilles, 171; geology of Panama, 236-238; east coast of America in pre-Cretaceous times, 263, 264; sunken land west of Central America, 331 Hinton, origin of arctic hare, 10

Hipparion, 148

Hoatzin, 362

Hodomys, 201

Holdiaus, on Pacific continent, 324

Holliok, east American flora, 140, 141

HoLlister, on musk-rats, 64

Holosfira, 206

Homalota, 391

Homo cubensis, 285

Homunculidae, 365

HOOKER, survival of plants in Greenland, 17; Rocky Mountain flora, 103 ; Asiatic floral element in North America, 139 ; floral affinities of St. Helena, 391 ; former antarctic landconnections, 420

HORNADAY, extermination of bison, 65; habits of Rocky Mountain sheep, 105

"Horned-toad," great antiquity of, 202

Horses in America, extinction of, 146; geological history, 146, 148, 228

HorvatH, Hemiptera common to Europe and North America, 89, 90

HowARD, spread of species by agency of man, 65

Howorth, level of land in Pleistocene times, 15 ; temperate climate in 
Arctic regions, 19 ; mild climate during Glacial Epoch, 46; Foraminifera in glacial clays, 47; water as agent in formation of glacial deposits, 77 ; past climate of Siberia, 81 ; range of mammoth, 86

Hor, on Mysis relicta in Lake Michigan, 48

Huanaco, distribution of, 406

Hudson, on pampas of Argentina, 396, 397

Hudson Bay region, 31-36 ; invaded by waters of Arctic Ocean, 47

HuLL, pre-Glacial elevation of land, 14

Humboldt Current, striking Galapagos islands, 294, 300 ; did not exist during Tertiary Era, 334, 335

Humming-birds, range of, 250, 367, 368

Hutia in Antilles, 282

Hutton, on Pacific land-connections, $322,420,426$

HUXLEY, on cray-fish, 218

Hyalinia, radiatula, 72 ; nitidula, 72 ; cellaria, 389 ; alliaria, 389

Hyalinia (see Vitrea).

Hyla gratiosa, 173

Hymenochirus, 377

Hymenoptera, wingless of Australia and South America, 433

Hyracotherium, 147

Hystricidae, 71

Hystricomorpha, 371-373 ; in Santa Cruz beds, 399, 402

\section{I}

Iguanavus, 127

Iguanidae, 126, 202, 207, 304, 305

IHERING, v., affinities of Phlaocyon, 151, 152; origin of Procyonidae, 152 ; dispersal of mollusks, 161 ; on Mutelidae, 161 ; range of Helicidae, 205, 206, 212; distribution of Unionidae, 254; Archhelenis, 274; on origin of Galapagos islands, 313 ; Pacific Continent, 322 ; fossil marine mollusks of South America, 334 ; researches in South America,
337 ; freshwater mussels of Brazil and Africa, 338 ; palaeogeography of South America, 339, 340; distribution of Clausilia, 349 ; origin of South American bear, 351 ; South America in Eocene Period, 362; land-connection between Africa and America, 380 ; flora of South America, 383; Fernando de Noronha, 385 ; flora of St. Helena, 392 ; dispersal of wolves, 396 ; distribution of freshwater mussels in South America, 405; on age of Santa Cruz beds, 398 ; relationship of west American and European shells, 411 ; faunistic affinities of Chile and New Zealand, 420, 421 ; dispersal of marine mollusks, 428 , 429 ; affinities of Falkland island wolf, 430

Insectivora, of eastern States, 141, 142 ; of Bridger deposits, 143 ; of south-western States, 201 ; of Santa Cruz, 399

Insects from Antarctic regions, 433, 434

Ionolaema, $\mathbf{3 5 0}$

Ischyromidae, 228

Isectolophus, 353

Isometrus maculatus, 389

\section{$\mathbf{J}$}

JACOBI, connection between Australia and South America, 421

Japyx, 411 ; solifugus, 411 ; subterraneus, 412 ; saussurei, 412

JOHANSEN, subsidence of land tested by marine shells, 17

JoHnson, distribution of Helix hortensis, 14

JoLY, on permanence of ocean basins, 275,276

JoNes, submarine deposits in Bermuda, 184

JORDAN and EVERMANN, origin of

North American blind fishes, 165

Jordan, Central American fishes, 240

Juan Fernandez island, 418 
K

Kangaroo-rats of western States, 201

KaRsCH, on Cryptostemma, 370 ; distribution of Jaxyx, 412

KATZER, geology of South America, $342-344,360$

Keewatin ice-sheet, 73,77

KenNaRd and Woodward, post-Pliocene mollusca, 21

Kerria, 208, 412

Kessleria, 88

Kingsleya, 255

Kinkajou in Mexico, 248

KNOPF, land-connections between Asia and North America, 84, 319

Koenenia, 412 ; draco, 217 ; mirabilis, 217 ; wheeleri, 217

Koken, geology of South America, 343

Kolbe, distribution of Enallagma, 179 ; distribution of beetles, 215 ; Antillean dragon-flies, 289 ; South Atlantic land-bridge, 381 ; antarctic land-connection as shown by beetles, 425,432

KoBeLt, Helicidae, 206 ; distribution of Cyclophoridae, 257, 268 ; affinities of European and Antillean molluscan faunas, 271 ; zoogeograpby of St. Helena, 389

KowARZIK, structure of musk-ox, 7, 8 ; musk-ox of Mackenzie region, 59 ; the genus Ovibos, 154

KraEPeLIN, Scolopendridae from California and southern Europe, 217 ; distribution of Damon variegatus, 382

Krishtafovitor, North Atlantic landconnections, 25

KUNKeL (see Cos).

"Kuroshiwo" current, 94, 95, 318

I

Labrador, 26, 27 ; flora and fauna, 26-31; connection with Greenland, 30 ; affinities with White Mountains, 42

Lachesis, 131
Lagopus, 62 ; albus, 62 ; rupestris, 62 ; leucurus, 62 ; scoticus, 62 ; mutus, 62 ; hyperboreüs, 62

Lagidium, 353

Lagomorxha, 224-226

Lagostomidae (see Viscacidiae).

Lakes, Great, of North America, invaded by the sea, 47 ; fauna of, 49 , 50 ; geological history of, 50,54

Lama huanachus, 406

LAMPLUGH, on inter-glacial epochs, 45

Lampsilis, 254; borealis, 52 ; superiorensis, 52

Land-connection, north Atlantic (between Scotland, Greenland, and Labrador), $12-25,30$; mid-Atlantic (between southern Europe and West Indies), 203, 271-281, 293, 294, 309 ; mid-Atlantic (between southern Europe and south-western North America), 110, 114, 120, 164, 173, 203, 204, 211-230, 366-380 ; south Atlantic (between eastern South America and west Africa), $110,282,338-340,366-385,389$, 390, 392, 394; south Atlantic (between Patagonia, South Africa, and Madagascar), 344, 372, 375, 404, 405, $429-433$; north Pacific (Bering Strait), 5, 12, 28, 29, 32, 61-71, 82 -97, 115 ; north Pacific (between western North America and eastern Asia), 202, 318-329, 407, 408 ; Pacific belt (between North and South America westward of Central America), 71, 245, 246, 254, 316, 317, $329-335,347,356-358,401-403$, 408-418, 431 ; Antarctic (between Patagonia and Chile, and Australia and New Zealand) 339-342, 403, 404, 419-429, 433-435; Atlantic (between Bermuda and West Indies), 183, 205

Land-nemertean in Bermuda, 191

LANKESTER, on extinct animals, 400

LAPPARENT, geology of South America, 342

Lasiurus, 299 ; brachyotis, 299 ; semotus, 300

LECHE, origin and age of Centetidae, 282 
LECOQ, glaciers produced by high temperature, 45

LEIDY, American palaeontology, 102

Lemming, arctic, 9, 11 ; in Mackenzie region, 60

Lemming-voles, 15 ; range of, 28

Lemmus, 60 ; trimucronatus, 60 ; minusculus, 60,92 ; nigripes, 60 , 92 ; leтmus, 60

Leonia, 272

Lepidoptera of Greenland, 22 ; of White Mountains, 36; of Alaska, 90, 91 ; of Rocky Mountains, 115 ; of Antilles, 289

Lexidosiren, 378

Lepidosirenidae, 378, 379

Lexidosteus, 163, 164, 290 ; osseus, 163, 164; tropicus, 164; tristoechus, 290

Leporidae, 224-226

Leptinaria (see Tornatellina).

Leptomeryx, 110

Leptotherium, 113

Lextotrichus granulatus, 190

Lepus, 225, 226 ; variabilis, 9 ; bangsi, 56 ; othis, 92 ; poadromus, 92

Lerma River, fish fauna of, 232

Letourneuxia, 213

Lichanura, 203 ; trivirgata, 203, 207

Liguus, 175 ; fasciatus, 176

Limnaea, vahli, 21; holbolli, 21 ; palustris, 2 ; stagnalis, 72 ; truncatula, 72

Limnolagus, 225, 226

Limnophylidae, 413

Linopodes, 258

Liometopum, 216 ; apiculatum, 216 ; microcephalum, 216 ; lindgreeni, 216

Liofelma, 204

Liopeltis vernalis, 130

Liparis, 307

Lithobius, provocator, 189 ; bermudensis, 189

Litopterna, 399

Littorina littorea, 16

Lizards, scarcity of, in eastern States, 123 ; abundance in western States, 196 ; Bermudan, 189 ; in California, 207 ; in Galapagos, $302-304$; in South America, 369 ; blue-tailed, 123, 125; burrowing, 202, 203 ; swift, 123 ; ground, 124 ; limbless, 202

Llama, 406

LOBLEY, north Atlantic land-connection, 25

LOCARD, on Clausilia, 272

LÖNNBERG, structure of reindeer, 4

Loxhiodontidae, 353

Lovén, marine relicts in freshwater lakes, 48

Loxia, 56

Loxocemus bicolor, 320

Loxomylus, 267

Lucainidae, 425

LuCAs, fossil bisons of North America, 66; land-connection, Asia and North America, 83 ; fossil sheep in Nicaragua, 105

Lucifuga subterraneus, 290

Lumbricus castaneus, 39

Lutra degener, 56

Lychas maculatus (see Isometrus).

Lyciscus, 430

LYDEKKER, varieties of reindeer, 3,4 ; musk-ox from Greenland, 7 ; extinct bison, 67 ; relationship of wapiti to Siberian maral, 68 ; origin of American deer, 109, 110 ; age of Falkland islands, 151 ; origin of opossums, 183, 367 ; origin of Central America, 243; affinity between African and American faunas, 371 ; Falkland island wolf, 430

Lygosoma laterale, 124, 125, 319, 320 Lynx subsolanus, 56

LYON, on hares and their allies, 225

\section{M.}

Mabuia, 376 ; punctata, 376, 385

MACFARLANE, mammals of north-west, 58

Mackenzie River, 58

Macroclemmys temminckii, 135

Macrofteryx, 368

Macrorhafhis, 390

Macrorhinus leoninus, 428

Macquarie islands, éarthworms of, 424

MadDren, life in Alaska during Pleistocene times, 78,79 
Magellan flora, affinities of, 417, 418

Magpies, distribution, 87, 88

MaJor, Forsyth, meadow-voles, 224 ; on Lagomorpha, 224; on fossil Lexoridae, 225, 226

Malacoclemmys centrata, 132

Mammoth in Alaska, $78-80,87$; in Siberia, 82

Manatees on both sides of Atlantic, 279,280

Manculus, 172

Manidae, 373

Manis, 372

Mantisfa, 289

Maral deer, 68

Margaritana margaritifer, distribution of, $34,37,51,52,55$; on Pacific. slope of North America, 162

Marmoset, 364

Marsh, fossil bison, 66 ; progenitors of Cervidae, 110

Marsupials, geological history of, 182, 183, 366 ; affinities of Patagonian, 403

Marten in Newfoundland, 56

Martens, mollusca of Central America, 256

MARx, Bermudan spiders, 191

Massoutiera, 372

Mastodon, 70, 87, 153, 358 ; advent in America, 408, 409 ; americanus, 80 ; chilensis, 408 ; bolivianus, 408 ; andium, 408

MaTTHEW, land-connection between Asia and North America, 84 ; ancestry of Odocoileus, 110 ; insectivores of middle Eocene, 143 ; Eocene and Miocene carnivora, 149 -151 ; junction of Florida and Cuba, 171; Lagomorpha, 226 ; fossil rodents, 228 ; Apternodus, 246 ; fossil edentate in Cuba, 285 ; Mascall beds of Oregon, 358

MatTHew and Cook, antelope remains in Nebraska, 407

McLaCHLAN, distribution of Limnophilidae, 413

Mecicobothriidae, 412

MEeK, Lerma River fishes, 232 ; Nicaraguan fishes, 240

Megalobatrachus, 135
Megalocnus, 293

Megalomastoma, 269

Megalomys (see Moschophoromys).

Megalonyx, 70,87 ; in Miocene of North America, 152, 153 ; in drift area, 156 ; in Pliocene of Texas, 235 ; in Oregon, 358

Megarhaphis, 388, 390

Megascolecidae, 412

Megatherium in Patagonia, 400

Meleagris, galloparo, 159

Meridogastra, 370

Meristhus scrobinula, 321

Merriam, C. H., on Synaftomys, 28 ; destruction of life in Glacial Epoch, 34 ; prairie fauna, 148, 149 ; fauna of southern Florida, 175 ; Sonoran region, 196, 197

Merriam, J. C., Asiatic antelopes in America, 407

MeRriLL, on Lower California, 207

Merycodontinae, 112

Merycodus, 112

Mesohippus, 147

Mesolama, 406

Metacanthus concolor, 391

Metacheiromys, 401

Metoponorthus sexfasciatus, 190

Mexico, eastern, relationship of fauna, 198 ; geological history, 199, 200; relicts in west, 232 ; flora of south, 247

Miacidae, 149-151

MiCHAELSEN, distribution of earthworms, 431

Microbiotherium, 403

Microphrys platysoma, 333

Microsauri, 304

Microtus, range of, 28-64 ; enixus, 27,28 ; pennsylvanicus, 27,28 ; terraenovae, 56 ; operarius, 92 ; unalascensis, 92 ; kadiacensis, 92 ; yakutatensis, 92 ; sitkensis, 92 ; innuitus, 92 ; abbreviatus, 92 ; alleni, 182

Milax (see Amalia).

MrLLeR, mammals of White Mountains, 37 ; meadow-voles, 224

MILNE-EDWARDs, on antarctic problem, 423

Miohippus, 147 
Miolania, 404

Mississippi, fishes of, $88,89,163$; drainage area, 144 ; description of its course, 160

Mites of Central America, 258

Moeritherium, 358

Mole, 142 ; star-nosed, 142 ; fossil, 143 ; golden, 245, 246, 404

Mole-mice, 201

Mole-shrew, 201

Mollusks, land and freshwater, in Hudson Bay Region, 37 ; slow dispersal, 52 ; as illustrating geographical changes in North America, $51-54$; common to Alaska and Asia, 83 ; of Florida, 175 ; of Bermuda, 191-194; of south-western States, 205, 206 ; of Central America, 256, 257; of Antilles, 265-274; of St. Helena, 389, 390 ; marine, absence of from relict lakes, 49 ; Pacific, affinity to English Crag species, 96 ; of West Indies and Mediterranean, 278 ; of western South America, 333, 334 ; common to Patagonia and New Zealand, 428

Monachus, albiventer, 280 ; tropicalis, 280

Monkeys, distribution of, 249, 250 ; in Santa Cruz beds, 400 ; capuchin, 364 ; squirrel, 364 ; sakis, 364 ; spider, 364 ; howlers, 364

Moose-deer, 32, 33, 80, 92 ; former range, 33 ; absent from Newfoundland, 56 ; in Mackenzie region, 67 Möror, mollusks of Greenland, 21

Moreno and Woodward, Neomylodon listai, 400

Morphidae, 368, 369

Morse, discovery of Helix hortensis, 15 ; dispersion of European species on American shores, 16

Moschophoromy8, desmaresti, 284 ; luciae, 284

Moseley, on Bermudan flora, 187

Mouse, red-backed, 29 ; jumping, 29 ; in Galapagos, 297

Mud-minnows in drift area, 51

" Mud-puppy," 136

MurraY, A., origin of Galapagos fauna, 311 ; on beetles common to Asia and America, 321 ; on south Atlantic land-bridge, 381

Murray, J., on coral reefs, 327

Mus, sylvaticus, 24 ; galapagoensis, 297 ; decumanus, 298 ; rattus, 298

Musk-ox, present and former range, $6-9$; variations of, 7 ; place of origin, 7,8 ; remains within drift area, 43 ; in Mackenzie region, 59 ; in Alaska, 78, 80

Musk-rat, 64, 153

Mussels, freshwater, $51-55$; importance of their distribution, 160162 ; of Central America, 254 ; affinity between African and Brazilian, 338 ; of South America, 405

Mustela, atrata, 56 ; kenaiensis, 92 ; arcticus, 92

Mutelidae, 168, 380

Mycetes, 364

Mylodon, 70, 153, 235

Myocastor coypus, 283, 396

Myrmeocystus, melliger, 216 ; mexicanus, 216

Myomarphus cubensis (see Megalocnus).

Myopotamus (see Myocastor).

Mysis, distribution and origin, 48 ; relicta, 48 ; oculata, 48

\section{$\mathrm{N}$}

Nabis capsiformis, 391

NANSEN, pre-glacial elevation of land, 14

Nasua, rufa, 249 ; olivacea, 249

NATHORST, on musk-ox, 7 ; effects of Glacial Epoch on arctic flora, 17

Natrix (see Tropidonotus).

"Natural Science," anonymous writer on origin of reindeer, 4

Nebria gyllenhali, 24

Necrolestes, 246, 399, 404

Necturus maculatus, 136

NEHRING, relationship of Cervus canadensis, 68

NeLson, external features of Greenland hare, 9; distribution of rabbits, 226 ; Tres Marias islands, 330 
Nelsonia, 201

Nemorrhaedus, 83, 106

Nenia (see Clausilia).

Neocyclotus, 268

Neofiber, 64, 182

Neomylodon (see Grypotherium).

Neotomodon, 201

Nexhila, clavipes, 190 ; clavata, 191

Nesodon, 399

Nesolagus, 225

Nesomimus, 301, 315

Nesopelia, 301

Nesoryzomys, indefessus, 299 ; narboroughi, 299

Nesospiza, 393

Neuroptera of Florida, 178 ; of Central America, 258; of Antilles, 289

Neürotrichus, 321 ; gibbsi, 201

Newfoundland, survival of fauna from pre-glacial times, 41 ; geological history, 55 ; fauna of, 56

Newportia, 350

Newton, Falkland island fossils, 430

Nicaragua, Lake, fauna of, 240

Nicoletiella, 258

Nome, marine gravels at, 97

Nonionina depressula, 47

North-Eastern States, reptiles, 123135 ; amphibians, 135-139 ; flora, 139-141; mammals, 141-143

NordenskiöLD, on Mastodons, 408

Notiodrilus, 412 ; bovei, 431 ; falclandicus, 431

Notiosorex, 201

Notostylops, 400-402

Notropis, cornutos, 50 ; atherinoides, 50

Nova Scotia, land-bird fauna, 56

Nycterinus, 215

Nysius, 391

\section{O}

Ocean floor, composition of, between America and Galapagos, 332

Oceanodroma cryptoleucura, 302

Ochotona collaris, 92

Octodontidae, 371

Odocoileus, origin of, 107-110, 396; hemionus, 107 ; virginianus, 108, 396 ; columbiamus, 108, avius, 109
Odonata, 258

Oeneis semidea, 36,38

Oleacinae, 272

"Olm," 136

Oniscus asellus, 39

Oniticellus, 215

Onychodectes, 244

Onychomys, 201

Onychophora, 345-347, 432

Oxeas, 380, 385, 393

Ophisaurus, distribution of, 281 ; ventralis, 173, 221 ; apus, 173, 221

Oxisthacanthus, 382

Opisthopatus, 346,432

Opossum, range, 182 ; past history, 229 ; in West Indies, 283 ; in South America, 366 ; in Santa Cruz beds, 403

Oppenheim, on Helicidae, 206

Oreamnos, origin of, 106 ; kennedyi, 92 ; montanus, 105

Oreohelix, 206

Oreotrochilus, 367

Orestias, 361, 362

Orthalicinae, 270, 273

OrtManN, distribution of Cambarus, 177 ; distribution of freshwater crayfishes, 217-220; Central American crabs, 239, 240 ; freshwater crabs, 255 ; land - bridge between Mexico and Cuba, 291 ; development of Central America and Antilles, 292 ; origin of Galapagos, 314 ; Miocene marine fauna of Peru, 334; geological history of South 'America, 339,340 ; south Atlantic landbridge, $381-383$; on Ihering's Archhelenis, 382 ; on age of Santa Cruz beds, 398 ; Chilean crayfishes, 405 ; on Antarctic continent, 419, 420, 424 Orycteropidae, 373

Orycteropus, 372

Oryctolagus cuniculus, 225

Oryzomys, range of, 284 ; victis, 284; antillarum, 284; galaxagoensis, 299; bauri, 299 ; nelsoni, 299

OsBorn, connection between North and and South America in Cretaceous times, 71, 227 ; connection between Asia and North America, 84, 319 ; dispersal of camels, 86 ; distribu- 
tion of fossil elephants, 87 ; origin of Cervidae, 110 ; middle Miocene fauna, 112 ; fossil-beds of western America, 119, 120 ; faunal phases in North America, 120-122 ; cause of extinction of species, 146 ; Oligocene horses, 147 ; Lower Pleistocene mammals, 153 ; mammal horizons, correlation of, 226, 227 ; Eocene $\checkmark$ affinities between Europe and North $\lambda$ America, 228; Oligocene affinities Abetween Europe and America, 229, 230, 294, 357 ; on Miocene and Pliocene faunas, 230, 231; origin of Central America, 243 ; armadillo in Eocene beds of North America, 244; dispersal of manatees, 279 ; geological evolution of South America, 341,342 ; origin of North American bears, 351 ; tapirs in North America, 352, 353 ; Miocene edentates in North America, 358, 402, 409 ; Miocene sea in Amazon valley, 360 ; Eocene deposits in Patagonia, 367 ; on absence of land-connection between South America and Old World, 371 ; ancestors of camels, 407 ; Antarctic continent, 419

OsGooD, reindeer in Alaska, 5 ; on Scaphoceros, 155

Ostriches, present and former range, 373,374

Otocryftops, 382

Otostomus (see Drymaeus).

Otter, in Newfoundland, 56 ; in Pleistocene deposits, 153

Ovibos, distribution, 6-9, 86 ; ancestry, 154, 155 ; moschatus mackenzianus, 59

Ovis, nivicola, 85, 86, 105 ; borealis, 86 ; canadensis, 104 ; scaphoceras, 105 ; cavifrons, 155

Oxystyla undata, 176

Oxytelus, 391

\section{P}

Pacific continent, evidence for the former existence of, $321-328$; probable subsidence before Tertiary Era, 328
Pacific land-belt, theory of, 409, 410, $427-429$; southern faunistic affinities explained, 426

Pacific islands, geological formation of, 322,326

PACKARD, Labrador fauna and flora, 27 ; subterranean faunas, 165; South Atlantic land-bridge, 381

Paddle-fish in Mississippi, 88, 89

Pagenstecher, affinities of Greenland lepidoptera, 22 ; lepidoptera of Rocky Mountains and Europe, 117 : butterflies of Florida, 179 ; Californian butterflies and moths, 214 ; on Antillean lepidoptera, 289

Palaemonetes, 291

Palaeolagus, 226

Palaeolama, 406

Palaeomastodon, 358

Palaeomeryx, 112

Palpigrada, 217

Panama, isthmus of, geology of, 236, 237 ; date of submergence of, 238 ; sunken land westward of, 331

Pangolin, 372

Panolopus, 281

Panopeus bermudensis, 333

Paramylodon, 153

Parascalops breweri, 142

Parastacidae, 420, 424, 426, 432

Parastacus, 405

Pardosa groentandica, 36

Parnassius, range of genus, 90, 91; nomion, 90 ; sminthus, 90 ; thor, 90 ; clodius, 90 ; clarius, 90

Paroxya bermudensis, 189

Parrot, Florida, 159, 172 ; in Central America, 250 ; showing affinity between Africa and America, 373

Parus, 56

Patagonia, fossil fauna of, 398-404; land-connection with western North America, 402; affinities to south Africa, Australia, and New Zealand, $405-416$

Patula, solitaria, 72 ; striatella, 72

PAULCKE, cretaceous deposits in South America, 359

Paulmier (see Eckel).

Peccary in North America, 153, 156

Pectinator, 372 
Pedetidae, 372, 373

Pellegrinia, 372

Pelobates, 204 ; syriacus, 221

Pelobatidae, 204, 221

Pelodytes, 221

Penhallow, Pleistocene flora of

Canada, 43, 44

Pentalagus, 225

Peratherium, 367

Perch, absent from western States, 198

Percidae, 198

Peripatus, range and origin of, 345$347,362,432$; eiseni, 346 ; goudoti, 346 ; tholloni, 369

Permanence of ocean basins theory, 214-232, 272-281, 321-333

Perodipus, 201

Peromyscus, maniculatus, 27 ; sitkensis, 92

Peru, geological history of, 359 ; poverty of freshwater fauna, 405

PESCHEL, meaning of term "relict lake," 49

Petersen, Polar centre of distribution for butterflies and moths, 22

Petromys, 372

Pezzotettix, glacialis, 36; borealis, 36 ; frigida, 36

PFEFfer, sub-universal distribution of species, 374,375 ; distribution of Lepidosirenidae, 378

Phaeolaema, 350

Phasmidae, 158

Philomyous, 412

Philonthus, 391

Philoscia, bermudensis, 190 ; couchi, 190

Philyra pisum, 93

Phlaocyon, 151, 152

Phoca, 280

Phragmatobia fuliginosa, 214

Phrynosoma, 127, 202

Phyllodactylus tuberculosus, 304

Pica, rustica, 87 ; nutalli, 88

Pickard-Cambridge, Central American spiders, 258; spiders of $\mathrm{St}$. Helena, 388, 389

pigidium rivulatum, 361

Pike, as evidence of old land-connection of America with Asia, 83; "bony," 89 ; in Mississippi, 163, 164
PilsBRY, mollusks of Florida, 175, 176 ; mollusks of Bermuda, 191193 ; on eastern and western faunal provinces, 198 ; family Helicidae, 205, 206, 212 ; on Arionidae, 212, 213 ; on Urocoptidae, 267, 268 ; geological history of Antilles, 267 ; on groups of Bulimulus, 270, 307 ; on Pacific continent, 322,323 ; distribution of Achatinidae, 380 ; mollusca of St. Helena, 390 ; Chilonopsis, 390 ; convergence among Bulimuli, 410 ; Helicigona and Arianta, 411

"Pine-barren" flora, 140, 141

Pinicola, 56

Pipa americana, 377

PIRIE, sedimentary rocks in South Orkneys, 433

Pitymys, range implying great antiquity, 223, 224 ; incertus, 223 ; quasitor, 224 ; pinetorum, 224 ; nemoralis, 224

Placostylus, 209, 307

Plagiodontia, 282, 283

Plagiola, 254

Planorbis, nathorsti, 21 ; arcticus, 21 ; noronhensis, 385

Plants, as tests of climate, 43,175 ; in Pleistocene beds, 44; of Rocky Mountains, 114 ; common to eastern States, Japan and Himalayas, 139 ; affinity in mid-Cretaceous times between Argentina and Dakota, 414 ; common to Rocky Mountains, and southern South America, 415

Platatherium, 113

Platygonus, 153

Plectocyclotus, 268

Plekocheilus, aurissileni, 269 ; aulacostylus, 269

Plestiodon, 123

Plethodon, 412 ; cinereus, 31

Pleurodonte, 272

Pliauchenia, 153, 407

Plover of St. Helena, 387

Plutonium, 350

Pocook, myriopods of Bermuda, 189 ; distribution of scorpions, 382 ; on affinity between western North America and Argentina, 412 
Podocnemis, distribution of, 374, 375 ; expansa, 360

Poeciliidae, 166

Poecilozonites, 192, 193

Polar origin of life, 23, 24, 427, 428

Polygyra, 198, 205 ; monodon, 31

Polyodon spathula, 88

Pomadasis grandis, 241

Pontoporeia, hoyi, 49 ; filicornis, 49

Popprus, distribution of arctic Coleoptera, 21

Porcellio Farvicornis, 190

Porcupine, Canadian, 27, 69, 431 ; South American, 366, 403

Porites, 239

Porxhyriornis, 393

Port Kennedy cave fauna, 153

Potamobiidae, 218-220, 426

Potamobius, 218-220

Potamocarcininae, 381

Potamoninae, 255, 381

Potos, 249 (See also Cercoleptes.)

Potter Creek cave fauna, 61, 153

Prairie-dog, 148

"Prairie-plains," 144

Prairie-wolf, 148

Praticolella, 175

PrEBLE, distribution of Zapus, 29 ; on Hudson Bay region, 31 ; report on Athabasca-Mackenzie region, 58

Prenolepis kincaidi, 189

Primates in North American Eocene beds, 228, 230

Proboscidea, 230

Procafromys geayi, 283

Procellariidae, 302

Procyon, lotor, 151 ; simus, 152 ; maynardi, 181, 249

Procyonidae, 151, 152, 181, 249

Prolagostomus, 403

Prong-horn, range and ancestry of, 112, 113

Prophysaon, 212

Prorastomus veronensis, 280

Proscalops, 143

Protauchenia, 406

Proteidae, 136

Proteocordylus, 135

Proteodidelfhys, 367, 403

Proteus anguineus, 136

Protopterus, 378 ; libycus, 379
Protracheata (see Onychorhora).

Protylopus, 407

Psexhurus gladius, 89

Pseudobranchus lateralis, 172, 173

Pseudoneuroptera of Antilles, 289

Pseudothelphusa, 255, 362 ; colombiana, 256 ; americana, 291 ;

terrestris, 291 ; affinis, 291

Pseudopus, 380

Psittacidae, 373

Psittacotherium, 244

Ptarmigan, willow, 62 ; rock, 62

Pterosphenus, 278

Pudu, 354 ; in Chile, 418

Pudua mephistopheles, 354

Puma, 106, 107

Pupa in Galapagos islands, 306, 308 ;

in Fernando de Noronha, 385;

hoppei, 21 ; muscorum, 72 ; armifera, 72 ; holzingeri, 72

Putnam, fauna of Mammoth Cave, $x$ 164,165

Putorius, pygmaeus, 85 ; rixosus, 85

Pyrameis, atalanta, 214; cardui, 214

Pyrotheria, 400

\section{Q}

QUACKRNBUSH, mammoth. remains in Alaska, 80

Quesal, 250

R

Rabbits, affinities and ancestry of, 225 , 226

Raccoon, 151, 181, 249, 283

Raccoon-fox, 201

Rana, pipiens, 31 ; palustris, 31 ; cantabrigiensis, 31 ; septentrionalis, 31

Rance, de (see Frilden).

Rangifer, tarandus, 3 ; spitsbergensis, 3 ; caribou, 3 ; stonei, 5 ; osborni, 5 ; montanus, 5, 92 ; terrae novae, 56 ; arcticus, 59

Rat on Galapagos islands, 298, 299

RATHBUN, distribution of Pacific crustacea, 93, 94; freshwater crabs of Central America, 255 ; crabs of Peru, 333 
Red-deer, origin of, 68

Red-fin in drift area, 50

REGAN, on bony-pikes, 164 ; Central American Cichlidae, 234 ; land-connection between South America and Africa, 379

Regulus, in Nova Scotia, 56 ; dispersal, 114, 115 ; cuvieri, 115 ; satrapa, 115 ; calendula; 115

REHN and HeBARD, Bermudan Orthoptera, 189 ; Orthoptera of Florida, 179

Reindeer, forms of, 3, 4 ; original home, 4, 5; extinct Irish, 12 ; in Iceland, 12 ; former range in Europe and America, 6, 35 ; in Newfoundland, 55

Reithrodon, 431

Relict lakes, explanation of term, 49 Rhamphastidae, 250, 368

Rhea, 373, 374, 396

Rhinema floridana, 173

Rhineura, 203

Rhinocerotidae, 229

RHOADs, structure of Greenland hare, 9

Rhopalomesites, 178

Rhynchophora, 387

Rhynchopsittacus, 172

Rhysida, 382

RICE, geology of Bermuda, 184

Rice-rats, in Antilles, 284, 285 ; in Galapagos, 298

RICHARDSON, isopods of Florida, 179 ; isopods of Bermuda, 190

RIDaway, birds of Galapagos, 301

Ridley, on Fernando de Noronha, 384, 385

RiffaRth (see Stichel).

RobBins and Cockerell, on Veronicella, 194

Robinson and Greenman, flora of Galapagos islands, 314, 315

Rockall Bank, shallow water species dredged near, 17

Rocky Mountains, 100-104 ; plants of in Southern Andes, 414-418

Roe-deer, affinity with American deer, 111

Romerolagus, 226

RöIG, affinity of American deer, 111
RotH, fauna of Santa Cruz beds, 399, 400

ROTHSCHILD and HARTERT, birds of Galapagos islands, 302

Roosevelt, land reserves in Rocky Mountains, 118, 119

Rumina decollata, 192, 273

Rupicapra, 106

Rupicola crocea, 362

Ruscinomys, 372

Russeld, extent of American ice-sheet, 33 ; former drainage of Mississippi, 54 ; description of Rocky Mountains, 102; absence of trees in prairies, 145

RUTHVEN, prairie forms of animal life, 145 ; origin and varieties of garter-snakes, 128, 222

RÜTIMEYER, on Antaretic continent, 420

RYDBERG, antiquity of Rocky Mountain flora, 103

\section{S}

Salamander, giant, 135, 136 ; tiger, 136, 137 ; blunt-nosed, 136

Salamandridae, 136, 137

Salda, 391

Salisbury (see Chamberlin).

Salvin and Godman, birds of Central America, 250 ; insects of Central America, 258

Salvin, birds of Galapagos islands, 301

SANDberger, on Tertiary mollusks, 176 ; on Helicidae, 206

Santa Cruz fossil beds, 246, 398-404

SARASIN, on age of Coeciliidae, 251 ; on age of Typhlopidae, 252, 288; origin of Galapagos, 313 ; dispersal of Herpele, 370

Saturnidae, 381

Sauresia, 281

Scalaria rugulosa, 428

Scalops aquaticus, 142

Scapanus, 201

Scaphiopus, 204, 220 ; holbrooki, 205

Scaphirhynchus, 83 ; platyrhynchus, 88

Scaphoceros tyrelli, 155

Scarabaeidae, 425 
Sceloporus undulatus, 123, 126, 127

Schistomys, 403

ScHLOSSER, origin of reindeer, 4 ; on value of zoogeographical evidence, 120,223 ; geological age of $\nabla i s-$ caciidae, 354

Sснмірт, fish fauna of northern Sea of Japan, 94

ScHUCHERT, palaeogeography of California, 198 ; palaeogeography of North America, 228-231 ; on Central America, 237, 238 ; antiquity of Bahamas, 264, 293

Schwarz, Coleoptera of Florida, 178 geology of Ascension, 384

Scincidae, 123, 124, 189, 376

Sciuropterus, sabrinus, 63, 64 ; yukonensis, 63,92

Sclater, W. L., and P. L. Sclater, distribution of seals, 280

Scoliopterix libatrix, 214

Scolopendra morsitans, 382, 386

Scolopendridae, 382

Scorpions in Florida, 178 ; of western America, 349, 350 ; of St. Helena, 389

Scotr, on Cervalces, 32 ; Steiromys an ancestor of Erethizon, 71 ;Necrolestes, 246, 404; on Santa Cruz fauna, 398-404; origin of edentates, 401; Antarctic continent, 422

Seals, distribution of, 280 ; " elephant," 428

Sea-urchins, fossil, of West Indian and Mediterranean areas, 278

SEDGwICK, distribution of OnychoFhora, 346

Semotilus corforalis, 51

SETON, mountain caribou, 5, 6 ; range of moose, 32 ; range of wapiti, 67

SEWARD, fossil plants as tests of climate, 43

SHALER, effect of warm current on Polar regions, 99 ; former elevation of Florida, 169

Sharpe, birds of Bermuda, 188, 189

Sheep, range of in America, 6 ; extinct, in Alaska, 80 ; in English Forest Bed, 85 ; in Nicaragua, 105 SHIMEK, on Helicina, 158
Sialis bermudianus, 188

Siberia, fauna of, in Glacial times, 82

Siebenrock, distribution of turtles, 132

Siluridae, 380

SIMPson, distribution of Unionidae, 52,54 ; sub-divisions of Unionidae, 254 ; geological history of Florida, 177 ; Antillean molluscan fauna, 265 $-267$

Simpulopsis, 270

SimrotH, on Arionidae, 213 ; mode of dispersal of Amalia, 214; origin of Bulimulidae, 273 ; pendulation theory, 434

Sinclatr, discovery of Euceratherium, 154 ; Santa Cruz fossil beds, 403, 404 ; Miocene beds in Oregon, 408, 409

Siren lacertina, 173

Sistrurus, 131

Sitta, 56

Skinks, 123, 189, 376

Skunks, western, 201

Sloth, in Brazil, 365, 366 ; ground, 244 ; giant ground, in North America, 153, 156; in South America, 400; gravigrade, remains in Oregon, 408

SmiтH, Edgar A., mollusca of St. Helena, 389, 390

SмiтH, Eugene A., elevation of Florida, 170

SmitH, G., Mysis relicta in Lake Superior, 48

Smitr, Geoffrey, faunistic affinity of Tasmania and South America, 424 SмIтH, J. P., similarity of marine faunas of Japan and America, 96 ; geology of California, 199, 356, 357 ; northern marine faunas, 318

Snakes in eastern North America, 127 ; garter, 127, 128, 222 ; rough green, 130, 197 ; smooth green, 130 197 ; rattle, 131, 253, 352 ; burrowing, 252, 253 ; glass, 173, 221, 281 ; blind, 203

SNODGRASS and HELLER, birds of Galapagos, 302

Solenodon, paradoxus, 282 ; cubanus, 282 
Solenodontidae, 282

Sollas, coral-boring at Funafuti, 321

"Sonoran" region, 196

Sonorella, 206

Sorex, tundrensis, 92 ; glacialis, 92 ; pribilofensis, 92

South America, northern animals in, 235 ; climate and fauna, 336, 337 ; past geography, 338-345, 359, 360 ; faunistic affinities of, 344-350 ; affinity with European Tertiary fauna, 355; relationship with Madagascar, 375 ; affinity with Africa, 368-383

South Orkney islands, 433

South - Western States, 196 ; as original home of eastern forms, 197 ; gradual desiccation of, 200204 ; affinity with Europe, 205-231.

Sparassodonta, 373

SPEIGHT, geology of mid-Pacific islands, 327

Spelerpes, age of genus, 172, 221, 246; in Antilles, 281 ; in South America, 347; orizabensis, 137; leprosus, 137; chiropterus, 137 ; fuscus, 138, 221; infuscatus, 281

SPENCER, pre-Glacial elevation of land, 14, 15 ; drainage of Great Lakes in pre-Glacial times, 54 ; elevation and submergence of Florida, 169, 170 ; Cuban cave fossils, 285 ; West Indian land-bridge, 286 ; Antillean continent, 293

Spermophilus (see Citellus).

$X$ SpethmanN, land-bridge between Europe and Greenland, 18

Sphaeroniscus, 190

Sfherilloninae, 320

Sphingidae, 117

Spider, silk, in Bermuda, 190, 191; spiders of Central America, 258; of St. Helena, 388, 389

Sxinus, 56

STANDFUSS, affinities of Vanessa, 91

STAPF, arctic grasses found in Argentina, 416

Staten island, 429

Stearns, on Galapagos islands, 291 ; accidental dispersal, 300, 306 ; mollusca of Galapagos, 305
Stebing, on Cambaroides, 218

Steiromys, 71, 403

SteJNeGer, on origin of reindeer, 5 ; range of ptarmigan, 62 ; landbridge between Asia and North America, 83 ; distribution of Cinclus, 113 ; distribution of groundlizard, 124 ; on Tropidonotus, 129 ; discoglossoid toads, 204 ; Antillean reptiles and amphibia, 288

Stenamma westwoodi, 215

Stenogyridae, 192

STEWART, botany of Galapagos, 315, 316

St. Helena, fauna, affinities of, 386391 ; flora, 391, 392

STICHEL and RIFFARTH, on Heliconiidae, 368

Stilauchenia, 406

Strmpson, Mysis relicta in Lake Michigan, 48

SToLL, mites of Guatemala, 257, 258

Stomion, 413

STRAND, distribution of arctic spiders, 21

STREBEL, on Orthalicinae, 270

Streptaxidae, 348

Strobilops labyrinthica, 31

Strobilus, 272

Strophocheilus, 362

Struthio, 374

Sturgeon, shovel-nosed, 88

Stygicola dentatus, 290

Subulina, 272, 380

Succinea, in Galapagos, 306, 308 ; in St. Helena, 390; groenlandica, 21, 24 ; bermudensis, 192,193 ; barbadensis, 192

" Suckers," 89

Suess, ancient land "Laurentia," 26 ; absence of land-connection with Asia in Pliocene times, 84 ; great Pliocene subsidence of land, 195 ; Cape Region of California, 199 ; north Atlantic land-bridge, 229, 231 ; distinctness of Central America from North and South, 237, 261 ; Antillean mountain system, 263 ; permanence of ocean basins, 276,387 ; Galapagos islands a continuation of American mountain 
chain, 297 ; ancient western rocks in South America, 345 ; elevation of Lake Titicaca, 361

"Swift " lizard, 123, 126, 127

Sylvilagus, 225

Symbos, 153-155 ; tyrelli, 80

Symbranchus marmoratus, 290

Synaptomys, innuitus, 27 ; sphagnicola, 37 ; cooperi, 28 ; wrangeli, 92 ; dalli, 92

Systemodon, 228, 353

Systrophia, 348

\section{$\mathrm{T}$}

Talpa ouropaea, 142

Talpidae, 142, 143

Tamias caniceps, 92

Taxiridae, 228, 352, 353

Taxirus, americanus, 352 ; haysi, 352 ; arvernensis, 353

Tarantulidae, 382

Tayassus tetragonus, 156

TCHERSKI, wapiti deer and Siberian maral, 68 ; conditions of climate in Siberia in Glacial Epoch, 82 ; fossil mammals in Siberia, 86

Teanopus, 201

Tehuantepec, isthmus of, 236

Teiidas, 369

Tenebrionidae, 215, 413

Tennessee river, alteration of its course illustrated by distribution of shells, 62

Teonoma saxamans, 92

Terrapene putnami, 134

Terrapin, 132

Testudo, 315

Tetrabelodon, 231

Thamnophis, 128, 222 ; sirtalis, 127

Theatops erythrocephalus, 217

Theridomyidae, 354

Tномas, on meadow-voles, 224 ; discovery of Caenolestes, 350

Thryonomys swinderianus, 372

Thylacinidae, 399, 403

Thylacinus, 399

Thynnidae, 433

Thysanophora hypolepta, 192, 193
Thysanura, 411, 412

Tierra del Fuego, faunistic affinity of, $429-431$

Tillodontia, 244

Titicaca, Lake, 361

Tiger, sabre-tooth, 153, 200

Tityus floridanus, 178

Toads, in south-western States, 204 ; spade-foot, 205, 220 ; tongueless, 377 ; Surinam, 377

Todies, 289

Toditae, 289

ToLL, fossil mammals in Siberia, 82

Tomigerus, 389, 390

Tomocyclus, 269

Tornatellina, 306 ; chathamensis, 308

Tortoises, land and freshwater, in drift area, 51; geological history of, 132, 222,236 ; in Central America, 251 ; of Galapagos islands, 302, 303, 312, 313 ; of Africa, Madagascar, and South America, 374

Toucans, 250, 368

Toula, Tertiary fauna of Gatun, 238 ;

Tertiary fauna of Panama, 243

Towodontia, 399

Transead, bog plant societies, 34

Tree-frog, Florida, 173

Tree-swifts, 368

Tremarctos ornatus, 350,351

Trematherium, 366

Tres Marias islands, 330

Tribolonotus, 126

Trichechus, manatus, 279 ; inunguis, 279, 360 ; senegalensis, 279

Trichodina, 390

Trichoniscidae, 190

Triglopsis thompsoni, 49

Trilophodon, 259

Trinidad island, flora, 385, 386

Tristan da Cunha, flora and fauna, 393

Tristania, 393

Tristram, polar origin of life, 23, 24

Trochilidae, 250, 367

Trogon, resplendens, 250 ; gallicus, 250

Trogonidae, geological history of, 250

Tropidonotus, range and age of, 128 , 129,222 ; validus, 222 ; viferinus, 222 
Tropidurus, 304, 315

TrotTER, origin of land-bird fauna of Nova Scotia, 56

Truncatella, 176

Tudorella, 272

TULLBERG, dispersal of Microtus, 28 ; origin of meadow-voles, 223 ; on South Atlantic land-bridge, 372, 373, 405

Tundral fauna and flora, 35

Turkey, in North America, 159

Turritella, ambulacrum, 428 ; patagonica, 428

Turtle, spotted, 132 ; diamond-back, 132 ; semi-box, 132 ; box, 134 ; snapping, 134 ; alligator snapping, 135

Tylos, latreilli, 179, 190 ; niveus, 179, 190

Typhlichthys subterraneus, 165

Tyxhlomolge rathbuni, 136

Tyy hlopidae, 252, 253

Tyxhlops, tenuis, 253 ; lumbricalis, 288

\section{U}

ULBRIOH, distribution of Anemone, 114 Umbra, limi, 51 ; krameri, 51

Umbridae, 51

Unio luteolus, 162

Unionidae, distribution of, 161, 198, 254, 405; on Pacific slope of North America, 162 ; groups of, 254 ; on west of Andes, 338 ; of Chile and New Zealand, 420

UPHAM, elevation of north-eastern North America, 41 ; elevation of Lake Region, 54, 55

Urania leilus, 117

Urochroa, 350

Urocoxtidae, 176, 206, 266

Uropoda, 258

Uropodias bermudensis, 190

Urotrichus, 321

Ursidae, 350

Ursus, americanus, 28 ; richardsoni, 61 ; middendorffi, 92; kidderi, 92 ; dalli, 92 ; eulophus, 92 ; kenaiensis, 92 ; emmonsi, 92 ; malayanus, 352 ; boeckhi, 352 ; etruscus, 352

Uta, 127

Utah, lakes of, 103

\section{V}

VALLENTIN, Falkland islands, 430

Vanatta, Bermudan freshwater shells, 194 ; on Arionidae, 212

Vanessa, distribution of, 91 ; cardui, 117 ; antiopa, 214

VANHOFFEN, survival of life in Greenland during Glacial Epoch, 19

Varicella, 175

Vadghan, geology of Florida, 171

Venericardia planicosta, 199, 357

Vernonia, 391

Veronicella, in southern Florida, 176 ; schivelyae, 192, 194 ; moreleti, 194

VERRILL, Mysis relicta in Lake Superior, 48 ; geology of Bermuda, 184, 185 ; Bermudan flora, 187 ; Bermudan spider, 190 ; Central American corals, 239

Vertigo, ovata, 72 ; ventricosa, 72

Vireo, bermudianus, 188 ; noveboracensis, 188

Viscacha, 353, 403

Viscaciidae, 353, 403

Vitrea, 306, 308

Vitrina, angelicae, 21 ; limpida, 72

Voles, range of, 28 ; meadow, 223, 224 ; Jalapa meadow, 224

Vulpes, lagopus, 11 ; deletrix, 56 ; kenaiensis, 92 ; rribilofensis, 92 ; beringensis, 92

\section{W.}

WALKER, distribution of Margaritana, 51 ; North American mollusca, 73 ; mollusca of Florida, 177

WALLACE, age of fauna and flora of New Zealand, 125; age of Australian fauna, 150; Falkland island wolf, 151 ; Bermudan fauna 
due to accidental dispersal, 183, 184, 188, 189 ; Central American fauna, 233,234 ; appearance of southern forms in North America, 234; northern element in South America, $235,236,259,413$; Antillean fauna, 261 ; Galapagos islands, 296, 298, 309 ; permanence of ocean basins, 274-277 ; faunal characteristics of South America, 336, 337 ; antiquity of continent of South America, 368 ; St. Helena an oceanic island, 386, 387 ; fauna and flora of St. Helena, 388, 391, 392

Walther, on Pacific coast lines, 328 Wapiti deer, distribution and origin, $67-69$

Water-vole of Florida, 182

WATson, flora of Californian islands, 417

Weasel, 85

WEBER, origin of Australian dog, 151

WeBster, dispersal of butterflies and moths, 116

West Indies (see Antilles).

WHEELER, Bermudan ants, 189 ; honey-ants, 216 ; Liometopum, 216

White, C. A., on American Unionidae, 161

WHiтE, F. B., Hemiptera of St. Helena, 388, 390

WHIте, I. C. on geology of Argentina, 397

White Mountains, fauna and flora, 35 -37; relationship with Labrador and Greenland, 42; with Rocky Mountain flora, 103

WhITFIELD on fossil Unionidae, 161

WHITNEY, temperate climate in Glacial Epoch, 19, 45, 46 ; climatic conditions necessary to a Glacial Epoch, 75,76 ; glaciation of Rocky Mountains, 102

Wilser, Polar continent as origin of life, 23

Winge, on aretic hares, 9

WINKLEY, distribution of Helix hortensis, 14

WoLf, Galapagos islands, 296 ; flora of Galapagos, 309, 310
Wolf, arctic, 11 ; barren-ground, 61 ; in Alaska, 61 ; Falkland island, 150, 430, 431 ; in South America, 396 ; Tasmanian, 399, 403

Wollaston, beetles of st. Helena, 387

Wolverine, 61

Wood-chuck, 63

Wood-lice, 179, 190, 309

Wood-rats, 201

WOODWARD, A. S., Grypotherium listui, 401 ; Miolania, 404 ; on Prorastomus, 280 ; on Bradytherium, 366. (See also Moreno.)

WOODWARD, B. B., distribution of marine mollusks, 16 (See also KENNARD.)

Woodward, S. P., on Atlantic landbridge, 272

Worm-lizard, 173

WorTMAN, North American origin of Ganodonta, 244 ; origin of edentates, 401

Wren, golden-crested, 114

Wriaht, J., Foraminifera in boulder clay, 47

Wright, G. F., and UphaM, survival in Greenland of musk-ox, 8 ; elevation of northern lands in Pliocene times, 15

Wyoming, game preserve in, 119

X

Xantholinus, 391

Xenomys, 201

Хепория, 377

Xenotherium, 246, 404

$\mathbf{Y}$

Yagansia, 431

Yellowstone Park, 118

\section{$\mathbf{Z}$}

Zapus, hudsonius, 27, 29 ; setchuanus, 29

Zonitoides nitidus, 72

Zophobas morio, 390 BRADBURY, AGNEW \& CO. LD., PRINTERS, LONDON AND TONBRIDGE. 





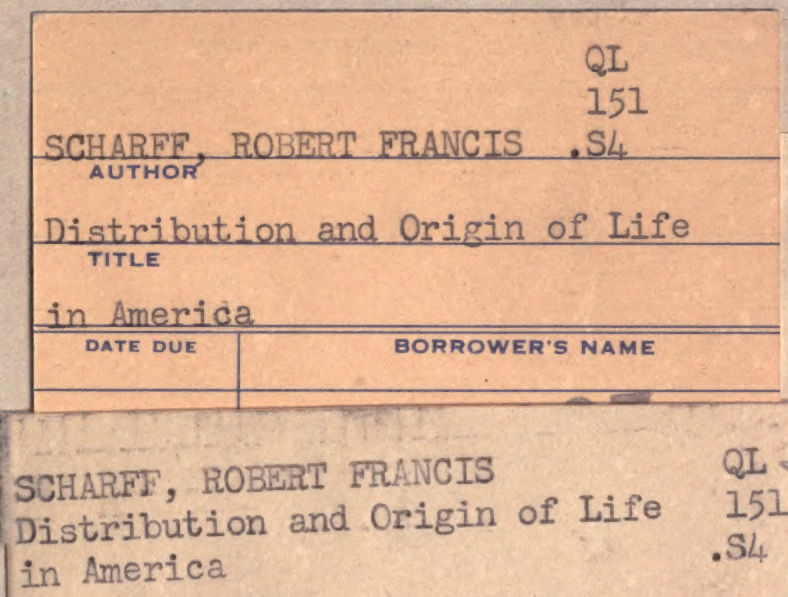


